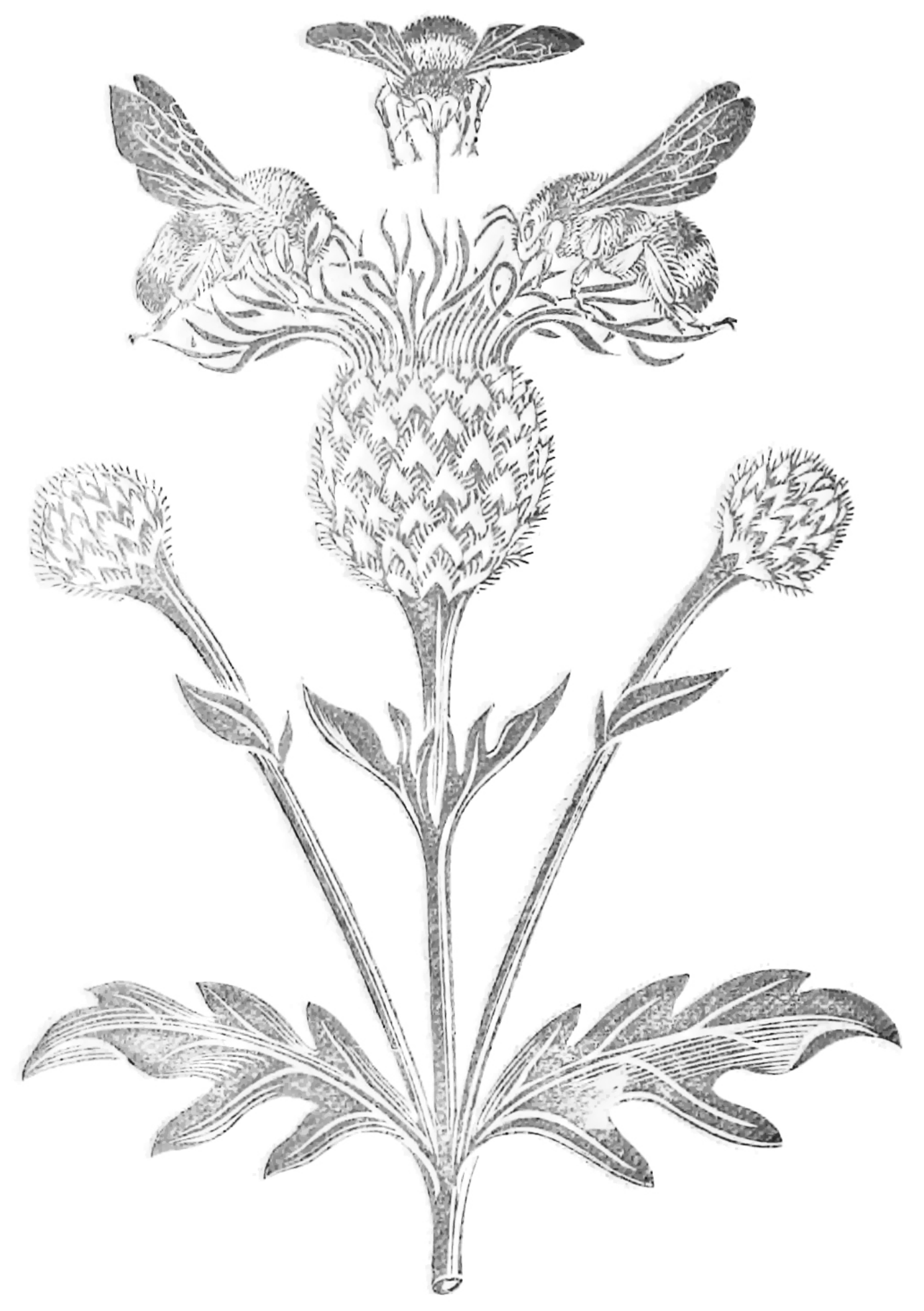

\title{
Bombus terrestris chegará ao Brasil? Um estudo preditivo sobre uma invasão em potencial
}

Figura da capa do livro The Humble-Bee: Its life-history and how to domesticate it de F.W.L. Sladen, 1912 
Universidade de São Paulo

André Luis Acosta

Bombus terrestris chegará ao Brasil?
Um estudo preditivo sobre uma invasão em potencial

Will Bombus terrestris reach Brazil?

A predictive study about a potential invasion

Orientador: Prof. Dr. Antônio Mauro Saraiva 
Universidade de São Paulo

\author{
André Luis Acosta
}

Bombus terrestris chegará ao Brasil?

Um estudo preditivo sobre uma invasão em potencial

\author{
Versão corrigida
}

\title{
Will Bombus terrestris reach Brazil?
}

A predictive study about a potential invasion

Tese apresentada ao Instituto de Biociências da Universidade de São Paulo para obtenção do título de Doutor em Ecologia

Área de Concentração:

Ecologia de Ecossistemas Terrestres

Orientador: Prof. Dr. Antônio Mauro Saraiva 


\section{Ficha Catalográfica}

Acosta, André Luis

Bombus terrestris chegará ao Brasil? Um estudo preditivo sobre uma invasão em potencial

Will Bombus terrestris reach Brazil? A predictive study about a potential invasion

Número de páginas:

Tese (Doutorado) - Instituto de Biociências da Universidade de São Paulo. Departamento de Ecologia.

1. Palavra-Chave Principal: Bombus terrestris;

2. Palavra-Chave Secundária: polinizador invasor;

3. Palavra-Chave Secundária: modelos ecológicos

I. Universidade de São Paulo. Instituto de

Biociências. Departamento de Ecologia.

\section{Comissão Julgadora}

Dra. Márcia de Fátima Ribeiro

Dra. Betina Blochtein
Dr. Jean Paul Walter Metzger

Dra. Luisa M. G. Rodrigues Carvalheiro

Dr. Antônio Mauro Saraiva

Presidente da Comissão Julgadora 
Para a Sofia 
Nem todos alienígenas são extraterrestres Haja vista o caso da Bombus terrestris!

Acosta, A.L. em Viagens mentais durante a escrita da Tese 
Agradeço, primeiramente, aos meus pais, Almir e Helena, que sempre apoiaram as minhas decisões e me incentivaram a tomar minhas próprias decisões, mas, sobretudo, sempre fizeram o máximo para que eu pudesse concretizá-las, inclusive esta, que me faz escrever este agradecimento e tornar-me o primeiro doutor da família.

Agradeço a minha mulher, Janyssa, que trilha o mesmo caminho que eu há 17 anos, ou seja, durante metade de toda minha existência neste planeta, batalhando para superar as dificuldades do mundo, mas também sentimos juntos todas as felicidades que, na verdade, são felizes por que estamos juntos.

Agradeço imensamente a minha filha, Sofia, pois deu a mim um novo significado para a vida, mudando as minhas perspectivas e desejos para o futuro. Entre tantas mudanças, hoje, eu não apenas desejo "salvar o planeta" para o bem da natureza e seus animaizinhos e plantinhas, os quais eu estimo muito, mas para que ela possa ter um mundo melhor pela frente, um planeta seguro, bonito e saudável pra viver.

Agradeço ao meu orientador, Dr. Saraiva, por ser o maior exemplo de respeito e equilíbrio que eu já tive no ambiente acadêmico. Quantas vezes, em meus momentos de ansiedade, mostrou-me várias alternativas e perspectivas mais otimistas e promissores que eu não era capaz de vê-las; mostrando-me que além do oriente, há o ocidente, o norte e o sul.

Agradeço à Dra. Vera (Imperatriz-Fonseca) por ter me acolhido em seu mundo, este belíssimo mundo dos polinizadores, e por ter aberto o meus olhos para a extrema importância das abelhas para a natureza e a para humanidade, eu jamais teria conhecido a Bombus terrestris se a Dra. Vera não tivesse me apresentado, ou seja, esta Tese não existiria!

Agradeço a Dra. Cris (Giannini) pela disponibilidade incondicional para ajudar, pelos momentos quebrando a cabeça para tentar desvendar os mistérios da natureza através dos números, pela extrema habilidade em transformar textos dramáticos e barrocos em ciência clara e objetiva e, claro, pelos cafezinhos da tarde enriquecidos por discussões filosóficas.

Agradeço ao Dr. Jean Paul Metzger e a Dra. Luisa Carvalheiro, que além de excelentes pessoas são excepcionais cientistas; ambos contribuíram com importantes sugestões que aprimoraram muito esta Tese. Também agradeço a CPG, representada pelo coordenador Dr. Jean Paul, devido à compreensão da necessidade de maior tempo para aumentar a qualidade deste trabalho.

Ressalto também meu respeito e gratidão aos meus antigos orientadores, que primeiramente me acolheram na USP tão logo regressei do exterior, que me ensinaram muito ao longo do ano que estivemos juntos, e apoiaram incondicionalmente a minha decisão de partir da evolução e ecologia humana para ecologia de ecossistemas, o Dr. Rui Sereni Murrieta e o Dr. Walter Alves Neves.

Aos colaboradores e amigos, que contribuíram e se dispuseram em alguma ou várias partes desta pesquisa, eu os agradeço igualmente, por isso os cito alfabeticamente:

Dra. Astrid Kleinert; Dra. Betina Blochtein; Dra. Carolina Laura Morales; Dr. Charles Fernando dos Santos; Sr. Dulphe Pinheiro Machado Neto; Dr. Carlos Eduardo Pinto; Dr. Guaraci Duran Cordeiro; Dr. Hayo Velthuis; Dra. Isabel Alves dos Santos; Dra. Rosana Halinski; Dr. Jesus Aguirre-Gutierrez; Dr. Leandro Reverberi Tambosi; Dr. Lucas Alejandro Garibaldi; Sra. Maria da Gloria (Bá); Dra. Marina Albertman; Sr. Otávio Jardim; Dra. Paola Marchi; Sr. Paulo Cesar Fenandes; Sr. Paulo Francisco Conrad; Dr. Paulo Nogueira Neto; Dr. Ricardo Hideki Nonaka; Dr. Rodolfo Jaffé; Dra. Sheina Koffler.

Agradeço a FAPESP, que acreditou no projeto e financiou este pesquisa.

Por fim, agradeço aos meus grandes e incondicionais amigos canídeos, sempre presentes, receptivos e bem humorados, a Pi e o Zé. 


\section{Título}

Bombus terrestris chegará ao Brasil? Um estudo preditivo sobre uma invasão em potencial.

\section{Resumo}

A abelha Bombus terrestris é um eficiente polinizador, prestando importantes serviços ecossistêmicos na Europa e adjacências, onde é nativa. Suas colônias têm sido criadas em larga escala para polinização agrícola, as quais são comercializadas internacionalmente, inclusive em países fora de sua área de ocorrência natural. Deliberada ou acidentalmente a espécie tem sido introduzida em ambientes alóctones, em muitos casos tornando-se invasora. Quando invasora, a espécie é um potencial vetor de doenças e um competidor com outras abelhas; vários impactos têm sido relatados em áreas invadidas ao redor do mundo. Na América do Sul, a espécie foi inicialmente introduzida em ambientes naturais no Chile, mas rapidamente a invasão se espalhou; atualmente é encontrada ocupando ambientes naturais na Argentina. A elevada capacidade invasiva da espécie e a alta velocidade de sua expansão, conforme tem sido relatada por pesquisadores, levantou a possibilidade de a espécie alcançar o Brasil por meio de corredores ambientais favoráveis que se conectam com áreas já invadidas, gerando preocupações sobre potenciais impactos aos sistemas naturais e agrícolas. Esta pesquisa empregou uma abordagem interdisciplinar, integrando uma variedade de métodos analíticos oriundos de diferentes áreas da ecologia e os mais avançados recursos de sistemas de informações geográficas para detectar globalmente as áreas susceptíveis à invasão por Bombus terrestris, considerando-se também as mudanças climáticas. Para o sul da América do Sul foram identificados os corredores de invasão que poderão permitir a espécie se espalhar e alcançar o Brasil a partir de locais invadidos conhecidos. Para o Brasil, foram identificados os municípios mais vulneráveis à entrada da espécie, e também aqueles que estão na rota de expansão da invasão Brasil adentro. Para os municípios brasileiros, por sua vez, foram verificadas as culturas agrícolas e as espécies de Bombus nativas que a invasora poderá interagir ao longo da rota de invasão potencial. Com estas informações foram apontadas áreas prioritárias, subsidiando o planejamento de monitoramento e ações de controle do processo de invasão, mas também medidas preventivas e mitigadoras de impactos ambientais e econômicos após a invasão, caso venha a ocorrer. 
Title

Will Bombus terrestris reach Brazil? A predictive study about a potential invasion.

\begin{abstract}
The bee Bombus terrestris is an efficient pollinator, providing important ecosystem services in Europe and surrounding areas, where it is a native species. Their colonies have been reared in large-scale for agricultural pollination, which are internationally traded, including for countries outside its native range. The species has been deliberately or accidentally introduced into nonnative environments, becoming invasive in many cases. When invasive, the species is a potential vector of diseases and competes with other bees for resources; many impacts have been reported in invaded countries around the world. In South America, the species was introduced in natural environments of Chile at first, but the invasion was quickly spread; nowadays it is found living in natural environments of Argentina. The high invasiveness of the species and the high speed of its invasive expansion, as has been reported by researchers, raised the possibility of the species reach Brazil through suitable environmental corridors that are connected with areas already invaded, raising the concerns about potential impacts to natural and agricultural systems. An interdisciplinary approach was used in this research, composing a variety of analytical methods from different areas of ecology and applying the most advanced resources of geographic information systems to detect areas susceptible to invasion by Bombus terrestris at global scale, considering also climate change. For the southern South America, the corridors of invasion that could allow the spreading of the species and that potentially reach Brazil were identified. For Brazil, the most susceptible municipalities for the entrance of the species have been identified, and also those that are on the route of expansion inside the country. For Brazilian municipalities, crops and native species of Bombus which the invasive species can interact with along the potential invasion route were verified; with this information, priority areas were identified, supporting the planning of monitoring and control actions of the invasion process, but also preventive and mitigating measures of environmental and economic impacts after the invasion, if it eventually occurs.
\end{abstract}


Capítulo 1. Bombus terrestris: A espécie, o problema e o porquê do estudo.

1.1. A espécie

1.2. Área de ocorrência nativa

1

1.3. Ciclo de vida e reprodução

1.4. Nidificação e alimentação

1.5. Serviços de polinização

1.6. Perspectiva histórica: da observação à domesticação

1.7. Perspectiva econômica: da domesticação à comercialização

1.8. Difusão global de colônias industrializadas

1.9. Invasão global por Bombus terrestris

1.10. Bombus terrestris na América do Sul

1.11. O porquê de um estudo preditivo sobre uma invasão potencial

Capítulo 2. Fundamentação teórica para o método de modelagem ecológica 20

2.1. Introdução à modelagem ecológica computacional 20

2.2. Definição da premissa conceitual fundamental do método $\quad 22$

Capítulo 3. Método de obtenção e seleção de dados e ferramentas de modelagem

3.1. Seleção de ferramentas para modelagem de Adequabilidade de Habitat 33

3.2. Obtenção de dados de ocorrência das espécies $\quad 39$

3.3. Avaliação e consolidação dos registros para a base de dados 48

3.4. Obtenção de dados ambientais digitalizados $\quad 52$

3.5. Revisão geral das camadas ambientais, alguns critérios e ajustes 55

\begin{tabular}{cc} 
Capítulo 4 - Modelo global de susceptibilidade à invasão de Bombus terrestris & 72 \\
\hline 4.1. Worldwide Alien Invasion: A methodological approach to forecast the potential spread & 73
\end{tabular}

of a highly invasive pollinator

4.2. Projeção do modelo de susceptibilidade para cenários climáticos futuros 124

Capítulo 5. Bombus terrestris chegará ao Brasil? 146

5.1. A ciência por detrás da Ecogeografia 146

5.2. Justificativa e objetivos da análise ecogeográfica 151

5.3. Metodologia 152

5.3.1. Construção da base de dados $\quad 152$

5.3.2. Caracterização ecogeográfica de Bombus terrestris 153

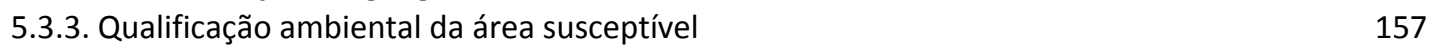

5.3.4. Conectividade ambiental na área susceptível à invasão na América do Sul 160

5.3.5. Municípios brasileiros na rota de invasão de Bombus terrestris 164

5.3.6. Abelhas Bombus nativas na rota de invasão de Bombus terrestris no Brasil 167

5.3.7. Potenciais interações com as culturas agrícolas no Brasil 169

5.3.8. Repercussões das mudanças climáticas na rota de invasão no Brasil 170

5.3.9. Integração dos dados para a avaliação da progressão invasiva de B. terrestris no Brasil 170

5.4. Resultados e Discussões 172

5.4.1 Caracterização Ecogeográfica de Bombus terrestris $\quad 173$

5.4.2. Corredores de invasão para Bombus terrestris na América do Sul 190

5.4.3. Por onde Bombus terrestris entrará no Brasil 199

5.4.4. A potencial progressão da invasão no Brasil $\quad 201$

5.4.5. Áreas prioritárias para o monitoramento e ações após invasão no Brasil 209

Capítulo 6. Observações da paisagem rio-grandense e ações práticas $\quad 213$

6.1. Observações in loco nas "portas de entrada” de Bombus terrestris no Brasil 214

6.2. Campanha de monitoramento 219

Capítulo 7. Conclusões gerais da pesquisa $\quad 224$

Referências Bibliográficas $\quad 227$

$\begin{array}{lr}\text { Anexos } & 242\end{array}$

Publicações relevantes desenvolvidas ao longo desta pesquisa 259 
Capítulo 1. Bombus terrestris: A espécie, o problema e o porquê do estudo.

\subsection{A espécie}

Os indivíduos da espécie Bombus terrestris (L. 1758) possuem grandes dimensões físicas dentre as espécies de abelhas e são popularmente conhecidos em países de língua portuguesa como mamangavas (no Brasil também mamangaba) ou abelhão (em Portugal, Macau e nos $P A L O P s^{1}$ ). No Brasil, mamangava também pode se referir às abelhas dos gêneros Xylocopa, Centris e outras espécies de abelhas grandes, mas no âmbito científico as mamangavas (inglês: Bumblebees; francês: Bourdons; alemão: Hummeln; castelhano: Abejorro) se referem exclusivamente às abelhas do gênero Bombus.

Foram descritas até o momento cerca de 250 espécies de mamangavas (Williams, 1998; Michener, 2007; Rasmont et al., 2008) e são reconhecidas atualmente nove subespécies de Bombus terrestris: $B$. terrestris terrestris (Latreille, 1758); $B$. terrestris africanus (Krüger, 1956); B. terrestris audax (Harris, 1780); B. terrestris calabricus (Krüger, 1958); B. terrestris canariensis (Pérez, 1895); B. terrestris dalmatinus (Dalla Torre, 1882); B. terrestris lusitanicus (Krüger, 1956); B. terrestris sassaricus (Tournier, 1890); B. terrestris xanthopus (Kriechbaumer, 1870).

As mamangavas da tribo Bombini (Latreille, 1802) são organismos considerados primitivamente eusociais, tendo em vista a capacidade de uma rainha fecundada poder fundar sozinha uma nova colônia e também devido à menor especialização da divisão de trabalho, que é geralmente ligada ao tamanho das abelhas e não ao polietismo etário, como nas abelhas altamente eusociais das tribos Apini (ex: Apis mellifera, popularmente conhecida como abelha melífera europeia) e Meliponini (ex: Tetragonisca angustula, popularmente conhecido como jataí) (Michener, 1974, Shpigler et al., 2013).

Dentro do grupo das abelhas (subgrupo Anthophila; superfamília Apoidea), assim como dentre as espécies abrangidas pelo gênero Bombus (tribo Bombini, família Apidae), a Bombus terrestris é uma das espécies que apresentam indivíduos com maior tamanho corporal, sendo ela a maior abelha do gênero Bombus em seu ambiente nativo (Bumblebee.org, 2015).

As dimensões corporais dentre indivíduos adultos de Bombus terrestris poderão diferir entre populações, entre colônias e mesmo entre indivíduos de uma mesma colônia, conforme a disponibilidade de recursos na área de distribuição, a idade da colônia, a dedicação da rainha e das operárias nos cuidados da prole durante o estágio larval e, ainda, conforme o tipo de atividade desempenhada pelos indivíduos na colônia (Cnaani et al., 1994; Spaethe e Weidenmüller, 2002; Shpigler et al., 2013). Em média a rainha possui entre 2 e 2,8 centímetros de comprimento (Figura C1-1), já as operárias são um pouco menores, em média entre 1,5 e 2,0 centímetros e os machos, em média, entre 1,4 a 1,8 centímetros (Figura C1-2).

A variação de tamanho nas operárias de uma mesma colônia (polimorfismo de tamanho) tem relação direta com o tipo de atividade que elas desempenham. Os indivíduos que se dedicam às atividades internas da colônia, por exemplo, cuidando da prole e da manutenção do ninho, são menores do que aqueles que trabalham fora da

\footnotetext{
${ }^{1}$ PALOP: Países Africanos de Língua Oficial Portuguesa - a sigla se refere aos países africanos colonizados por Portugal e que permaneceram com o Português como língua oficial.
} 
colônia, e demandam menor quantidade de energia no desempenho de suas funções (Cumber, 1949; Free, 1955; Heinrich, 2004). Já as operárias que forrageiam são maiores e consomem grande quantidade de energia, pois fazem várias viagens de flor em flor, voam velozmente, e carregam grande quantidade de peso extra ao trazerem recursos para a colônia. Além disso, as abelhas que saem da colônia requerem energia para regular sua temperatura corporal e superar adversidades ambientais, especialmente quando trabalham em dias mais frios, ventosos, nublados e até mesmo chuvosos. Entretanto, abelhas Bombus terrestris também são favorecidas pela grande quantidade de pelos que possuem em seu abdômen e pela habilidade de vibrar sua musculatura para gerar calor, aspectos que auxiliam em sua tolerância ao frio (Heinrich e Heinrich, 1983; Spaethe e Weidenmüller, 2002; Shpigler et al., 2013).

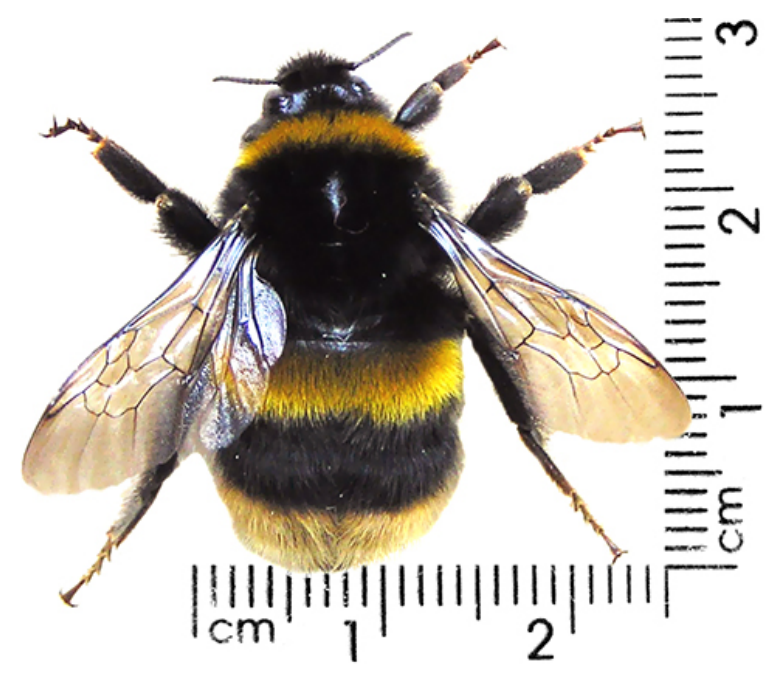

Figura C1-1. Escala de referência do tamanho da rainha de Bombus terrestris. Fonte: RX Wildlife, 2011.
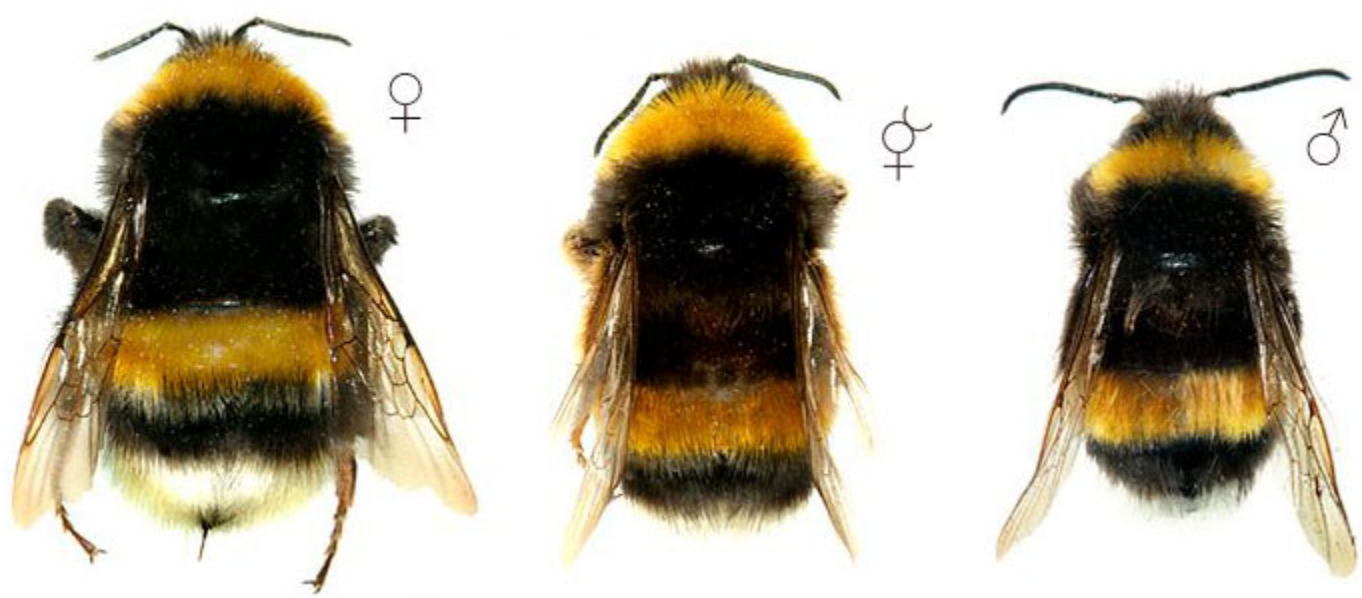

Figura C1-2. Comparação entre tamanhos de indivíduos (rainha, operária e macho) de Bombus terrestris de uma mesma colônia. Fonte: Josef Dvorák, 2009. 


\section{2. Área de ocorrência nativa}

A zona de distribuição natural de Bombus terrestris é bastante ampla, ocupando grande parte da área ocidental da região paleártica (Rasmont et al., 2008). Portanto, abrange quase todo o continente europeu (incluindo as ilhas mediterrâneas, ilhas britânicas no Atlântico Norte e ilhas no Mar do Norte) com exceção do extremo norte da península escandinava. Também se distribui no extremo oeste da Rússia, nas llhas Canárias no Atlântico e em países africanos que possuem litoral no mar Mediterrâneo, como o Marrocos, a Turquia, a Algéria e a Tunísia. (Kruger, 1954, 1956; Loken, 1973; Pekkarinen et al., 1981; Ne'eman e Dafni, 1999, McClay, 2005; Winter et al., 2006; Dafni et al., 2010).

A amplitude das variações ambientais existente na área de ocorrência nativa de Bombus terrestris é impressionante, sugerindo que a espécie possui elevada capacidade de tolerância fisiológica. Factualmente, suas operárias foram observadas forrageando ou se deslocando sob condições usualmente adversas para outras abelhas, como durante chuva, em dias com ventos fortes e em temperaturas inferiores a $10^{\circ} \mathrm{C}$ e superiores a $32^{\circ} \mathrm{C}$ - inclusive, estas características são adversas para Apis mellifera, uma das espécies de abelha com maior distribuição global (Heinrich, 1979; Kuusik et al., 2002; Winter et al., 2006, Coppée, 2010; Dafni et al., 2010).

\subsection{Ciclo de vida e reprodução}

Bombus terrestris, na maior parte de sua área de ocorrência nativa, apresenta um ciclo de vida anual, portanto, univoltino. No entanto, já foi detectado que em algumas regiões mais quentes ela poderá apresentar ciclos polivoltinos (Rasmount et al, 2005).

Na maior extensão de sua área nativa, a rainha já acasalada hiberna quando as condições ambientais se tornam progressivamente mais adversas com a aproximação do inverno, regressando à atividade após alguns meses, durante a primavera (Beekman et al., 1998; Ings et al., 2005).

Seu ciclo de vida é subdividido em três fases principais:

1) Uma fase solitária: em que a rainha constitui a colônia gerando as primeiras proles. Sendo a espécie monogínica, uma única rainha fecundada é totipotente, portanto, capaz de formar sozinha uma nova colônia completa, a qual pode alcançar o número de 500 indivíduos rapidamente (Buttermore, 1997; Alaux et al., 2005; Hayo Velthuis com. pess.). Nesta fase, durante o dia, a rainha solitária busca todo tipo de recurso necessário à construção de seu pequeno ninho, que é feito em cavidades préexistentes, normalmente em buracos no solo escavados por outros animais, por exemplo, ninhos de roedores abandonados.

2) Uma fase ergonômica: quando a população cresce, gerando a força de trabalho necessária para o progresso da colônia. Nesta fase a rainha se dedica primariamente à produção de operárias. Porém, há uma importante diferenciação no desenvolvimento das operárias: as larvas melhor alimentadas tornar-se-ão operárias grandes e trabalharão fora da colônia buscando recursos; aquelas menos alimentadas serão pequenas e permanecerão na colônia desenvolvendo trabalhos internos. Este controle é feito pela rainha, mas poderá ser influenciado pela disponibilidade de recursos no ambiente circundante à colônia (Pereboom et al., 2003). 
Conforme o primeiro grupo de operárias emerge, elas substituem a rainha no trabalho de forragear, e esta última permanece no ninho ovipositando e gerindo os cuidados com as larvas, contando também com trabalho das operárias internas da colônia. Tão logo o desenvolvimento da colônia alcance um estágio ideal, dá-se a transição para a fase de geração de indivíduos reprodutivos, sendo que o momento desta transição é normalmente mediado pela rainha (Duchateau e Velthuis, 1988; Beekman, et al., 1998).

3) A fase reprodutiva é principalmente caracterizada pela produção de fêmeas reprodutivas, pois os machos poderão ser gerados em momentos anteriores ou posteriores. Como em todos os himenópteros, Bombus terrestris é haplodiplóide, portanto os machos possuem apenas metade da informação genética (haplóide) que as rainhas e as operárias, pois são gerados de ovos não fecundados. Já a rainha e as operárias são oriundas de ovos fecundados (diplóides), tendo ambas, portanto, o potencial de gerar machos. Por conta disso, poderá haver um conflito reprodutivo entre a rainha e as operárias, bem como entre as operárias, pelo parentesco com o macho a ser gerado. Este conflito ocorre em curto período durante a fase reprodutiva e é conhecido como "fase competitiva" (Trivers e Hare, 1976; Mehdiabadi et al., 2003; Alaux et al., 2004, 2005, 2007).

Enquanto está ovipositando ovos fertilizados, a rainha inibe a oviposição das operárias por meio da secreção de feromônios que são produzidos em suas glândulas mandibulares; durante esta fase, a rainha é a única fêmea desempenhando esta função na colônia (Bloch e Hefetz, 1998). Ao longo do tempo a concentração destes feromônios diminui progressivamente, bem como o efeito da castração química, consequentemente, as operárias começam a ovipositar ovos que darão origem à machos.

Portanto, apenas a rainha é responsável pela produção de fêmeas, mas a produção de machos será garantida pela rainha e pelas operárias. Esta fase competitiva também é caracterizada pela oofagia mútua, ou seja, a rainha ingere ovos colocados por operárias e as operárias fazem o mesmo com os ovos da rainha (Cnaani et al., 2000; Allaux et al., 2004).

Os machos abandonam o ninho logo que emergem de suas células, o que não acontece com as rainhas virgens, também denominadas fundadoras. Estas saem da colônia, mas retornam, até que em determinado momento elas são atraídas por feromônios sexuais exalados por machos, e então são fecundadas (Coppée et al., 2011). Cada rainha virgem é inseminada por apenas um macho (monandria); com isso, o ciclo reprodutivo volta a se repetir.

\subsection{Nidificação e alimentação}

Bombus terrestris requer cavidades pré-existentes para construir seu ninho, portanto, depende da disponibilidade deste recurso no ambiente para nidificar.

Em seu ambiente nativo, as rainhas demonstram preferências por nidificar em cavidades no solo escavado por roedores ou aves (Goulson, 2010), daí vem a origem de terrestris em seu nome cientifico. Todavia, poderá alternativamente nidificar também em cavidades encontradas em troncos, entre rochas em muros, cavidades na base de touceiras e buracos em barrancos (Kells e Goulson, 2003). 
Havendo a existência de recursos adequados e suficientes, Bombus terrestris poderá ocupar ambientes urbanos, assim como o faz em ambientes selvagens e rurais (agrícolas). Neste contexto, Chapman et al. (2003), que estudaram 96 colônias de Bombus terrestris em parques urbanos no Reino Unido, ressaltaram a importância de parques arborizados e floridos para a conservação das mamangavas, levando em consideração que nestes parques havia abundante quantidade e variedade de recursos florais e de locais de nidificação para as abelhas. Ainda neste caso específico, eles perceberam que Bombus terrestris ocorria em maior densidade em áreas urbanas e suburbanas do que nas áreas agrícolas próximas.

Bombus terrestris é uma mamangava que possui probóscide curta relativamente ao seu tamanho corporal (4.5-6.5 mm; Dafni et al., 2010) - estrutura que lhe permite obter por meio de sucção o néctar das flores (que será chamada de língua a partir daqui). Por conseguinte, seus indivíduos exploram adequadamente flores cuja corola é compatível com o tamanho de sua língua, permitindo-lhe alcançar a fonte de néctar via abertura frontal (Ranta e Lundberg, 1980). Embora sua língua seja curta em relação às outras mamangavas, é maior que a de muitas outras espécies de abelhas, inclusive a da Apis mellifera, algo que amplia a quantidade de tipos florais usufruídos por ela perante as demais espécies de abelhas.

Todavia, quando Bombus terrestris não é capaz de acessar recursos de flores com corolas longas, ela poderá perfurar a base da corola para alcançar o recurso contido no seu interior. Obviamente, este tipo de exploração alternativa danifica a flor, podendo levá-la à queda prematura, antes mesmo de ser polinizada; como consequência, a fecundidade da planta poderá ser prejudicada, resultando na redução da produção de frutos. Esta atividade pode ser classificada como "roubo" ou "pilhagem" de recursos florais, devido à ausência de troca, por parte da abelha, do serviço de polinização pela contrapartida do néctar provido pela planta, mas também devido ao dano causado à planta (Fussell e Corbet, 1992). Ademais, os buracos deixados na flor facilitam a entrada de outros insetos, como alguns sirfídeos que secundariamente também roubam recursos - neste caso o pólen - pois também não são polinizadores (Olesen et al., 1998). No entanto, estes orifícios podem ainda permitir a entrada de formigas em busca de néctar e também de outros organismos prejudiciais às plantas (Inouye, 1980). O consumo de néctar por este meio ilegítimo reduz a disponibilidade deste recurso para outras abelhas que também o usam sem danificá-lo. Dentre elas estão os polinizadores efetivos, que contribuem com serviços de polinização para a planta e são recompensados com recursos necessários à sua sobrevivência e de sua colônia (Inouye, 1980; Stout et al., 2000). Não obstante, alguns pesquisadores abordam que o roubo de néctar não é sempre prejudicial às plantas, mas que em alguns casos muito específicos esta atividade poderá ser considerada uma relação interespecífica mutualística (Mallof e Inouye, 2000).

A alta capacidade de aprendizado da espécie (Stout et al., 1998) habilita-a a um rápido desenvolvimento de novas estratégias para a exploração de recursos florais que a abelha ainda não havia explorado, aspecto que the permite utilizar uma grande diversidade de tipos de flores para obter recursos (Dafni et al., 2010). Assim, Bombus terrestris é altamente polilética (generalista) e conhecida por polinizar centenas de espécies de plantas com variadas características florais, mas demonstra particular preferência por plantas que possuem grande quantidade de pequenas flores próximas 
umas das outras (incluindo inflorescências) (Heuschen et al., 2005; Leadbeater e Chittka, 2007).

Alguns trabalhos também têm demonstrado que a espécie poderá ter preferências em termos de colorações das flores usadas como recurso favorito. Apesar de haver variações entre populações, de uma forma geral, Bombus terrestris demonstra ter preferência por flores com cores próximas ao azul e ao violeta (aquelas que refletem mais a frequência ultravioleta) e depois próximas ao vermelho (Gumbert, 2000; Chittka et al., 2004). Esta preferência pode ser inata, decorrente de processos adaptativoevolutivos, mas também é influenciada por aprendizagem, pois os indivíduos são capazes de memorizar a cor daquelas flores que lhes provêm recursos mais atrativos e abundantes, e optam por elas dentre flores com outras cores (Gumbert, 2000; Chittka et al., 2004).

\subsection{Serviços de polinização}

Bombus terrestris é uma excelente polinizadora de várias espécies de plantas selvagens e agrícolas, mas é notavelmente eficiente em plantas que possuem anteras poricidas (Velthuis e Cobb, 1991; Free, 1993; Proctor et al., 1996; Morandin et al., 2001a, b; Velthuis e van Doorn, 2006). A maior eficiência de polinização em um determinado tipo floral não reduz a importância nem a dimensão dos serviços ecossistêmicos de polinização prestados pela espécie. Estima-se que existam cerca de 20 mil espécies de plantas (aproximadamente, 400 gêneros e 65 famílias) que liberam pólen exclusivamente por meio de anteras poricidas (Buchmann, 1983; De Luca e VallejoMarín, 2013; De Luca et al., 2013). Nesta quantia estão compreendidas diversas espécies de elevada importância para a segurança alimentar humana; dentre elas, por exemplo, as espécies da família Solanaceae, que provê alimentos como o tomate (Solanum lycopersicum), a batata (Solanum tuberosum), a berinjela (Solanum melongena), as pimentas e os pimentões (gênero Capsicum); mas também plantas com outros usos, como algumas dos gêneros Petunia e Brunfelsia (ex: manacá-de-cheiro), por exemplo.

A velocidade de visitação desempenhada pelas operárias de Bombus terrestris é notável; um único indivíduo é capaz de visitar de 20 a 50 pequenas flores por minuto (Chittka et al., 2004; Dafni et al., 2010). Além disso, a área de ação de Bombus terrestris durante a atividade de forrageamento supera à das abelhas do gênero Apis, o que é vantajoso quando visto sob a perspectiva da prestação de serviços de polinização em áreas extensas, pois resulta no maior alcance no fluxo genético entre plantas. Ademais, devido ao grande tamanho corporal, uma operária de Bombus terrestris extrai recursos florais em quantidade superior a uma operária de outras espécies de abelhas de menor porte que compartilham os mesmos recursos, por exemplo, a Apis mellifera, aprimorando o potencial de sucesso na transferência de pólen entre distintos indivíduos da mesma espécie de planta (Proctor et al., 1996; Goulson, 2003; Wolf e Moritz, 2008; Goulson, 2010).

Sob circunstâncias adequadas de disponibilidade de recursos, Bombus terrestris habitualmente forrageia próxima à sua colônia, em média 800 metros, e raramente ultrapassando dois quilômetros. Havendo recursos adequados e em cota suficiente nos arredores de sua colônia, a relação entre tempo de cada trajeto (rapidez nas idas e vindas entre colônia e flores) e o gasto energético durante o forrageamento (menor distância, menor consumo energético) é mais favorável se a atividade decorrer nas 
proximidades (Walther-Hellwig e Frankl, 2000; Darvill et al., 2004; Knight et al., 2005; Wolf e Moritz, 2008). Entretanto, em condições de escassez de recursos, ela poderá ultrapassar os 10 quilômetros em cada trajeto (Wolf e Moritz, 2008).

Goulson e Stout (2001) demonstraram empiricamente que operárias foram capazes de retornar aos seus ninhos de origem quando soltas em distâncias superiores a $9,8 \mathrm{~km}$. Considerando também que neste experimento as abelhas foram capturadas próximas à colônia e levadas a esta distância em caixas escuras, sem possibilidade de visualizar o trajeto feito, Bombus terrestris demonstrou ainda ter uma eficiente capacidade de navegação, bem como uma alta velocidade de voo, superando 15,7 quilômetros por hora. Também é sugerido pelos autores que a abelha possa se deslocar para distâncias muito superiores em caso de extrema necessidade.

Bombus terrestris tem se mostrado superior em competir por recursos com as abelhas do gênero Apis em nível de indivíduo, principalmente devido ao maior tamanho físico, ao manejo mais robusto das flores e, em especial, à capacidade de fazer a polinização por vibração. Já em nível de colônia, Apis poderá superar a Bombus terrestris, não apenas devido ao maior número de indivíduos por colônia, mas também por conta do mais avançado sistema de comunicação entre indivíduos (Buchmann, 1983; Westerkamp, 1991; King e Buchmann, 2003; Wolf e Moritz, 2008).

A polinização por vibração (sônica) ou buzz pollination é uma habilidade não compartilhada por todas as espécies de abelhas - na verdade, é uma peculiaridade de poucas. Até o momento este tipo de polinização foi observado em abelhas de 7 famílias e cerca de 50 gêneros dentre os Apoidea (Hymenoptera). Notavelmente, ocorre em todas as espécies do gênero Bombus ${ }^{2}$. Mesmo a Apis mellifera, que é globalmente reconhecida como uma espécie polinizadora altamente eficiente e utilizada na agricultura para este fim, não apresenta esta habilidade. As abelhas que possuem esta habilidade são capazes de desviar a atuação de seus músculos torácicos, que são primariamente dedicados ao voo, para gerar uma vibração de alta frequência em seu corpo (podendo superar 400 pulsos por segundo) que é transmitida às anteras poricidas da flor por meio de sua mandíbula, cabeça e parte ventral de seu abdômen. A ressonância transmitida às anteras rompe as microestruturas que fixam o pólen dentro das cápsulas poricidas, expelindo-os sobre a abelha por uma fenda na base da cápsula. Possivelmente, os grãos de pólen desprendidos são atraídos ao corpo da abelha por meio de forças eletrostáticas em seus pelos (De Luca et al., 2013; De Luca e VallejoMarín, 2013). Uma vez "banhada" com o pólen, a abelha coleta uma porção deste recurso transferindo-o de seu abdômen para suas pernas posteriores; o restante mantém-se sobre o corpo da abelha e parte será transmitida para o estigma de outra flor da mesma espécie de planta, efetivando-se a polinização. Somando-se a isso, ArceoGómes (2011) e seus colaboradores sugerem que a polinização por vibração, além de liberar pólen das anteras de uma primeira planta visitada, poderá favorecer também a chegada do pólen no estigma de uma segunda, gerando um benefício complementar que favorece diretamente o aumento das chances de fecundação cruzada nas plantas.

Este eficiente e importante serviço ecossistêmico provido pela Bombus terrestris à natureza e à agricultura obviamente chamou a atenção de pessoas interessadas em

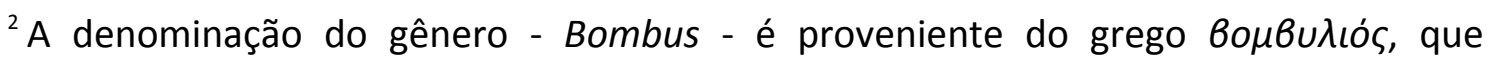
lexicamente é interpretado como abelhão zumbidor [decorrente do som emitido ao vibrar a flor] (Sladen, 1912).
} 
obter algum domínio sobre colônias da espécie para usufruir controladamente deste eficiente tipo de polinização em produções agrícolas, bem como capitalizá-lo, assunto este que é abordado a seguir.

\subsection{Perspectiva histórica: da observação à domesticação}

O relato mais antigo encontrado sobre Bombus, talvez até tratando-se de Bombus terrestris, está escrito na obra de Aristóteles, História dos Animais, escrita por volta de 350 antes da era cristã.

Sabe-se que atualmente Bombus terrestris vive naquela região da Grécia, e seguramente já estava lá muito antes de Aristóteles, mas pelo menos outras 22 espécies de mamangavas também se distribuem pela região (Anagnostopoulos, 2005). Provavelmente, jamais se poderá afirmar que a espécie citada no trabalho de Aristóteles se refere especificamente à espécie estudada, sendo que as primeiras descrições da espécie (Apis terrestris, 1758; por Carolus Linnaeus) e do gênero (Bombus, 1802; por Pierre André Latreille) ocorreriam após cerca de dois milênios.

Todavia, as características descritas por Aristóteles em muito se assemelham as apresentadas pelas abelhas Bombus terrestris. Os fragmentos da obra que se referem às mamangavas foram livremente traduzidos do inglês, da versão traduzida do grego por D'Arcy Wentworth Thompson (Aristotle, 350 AEC).

"Existem nove variedades [de insetos que constroem colônias], dentre os quais seis são sociais: a abelha (bee); a abelha rainha (king-bee); o zangão (drone bee), a vespa anual (annual wasp) e, além destas, o Anthrene (ou hornet) [vespão] e o Tenthredo (ou ground-wasp) [hoje, moscas Tenthredinidae]; e três são solitárias: a pequena ninfa (smaller siren), de cor parda; a grande ninfa, preto e salpicado [pontos pretos?!]; e a terceira e maior de todas, que é chamada de Humble-bee." \{Parte 40\}

"As Humble-bees produzem seus jovens sob rochas, diretamente no chão, com um par de células ou um pouco mais; nestas células encontra-se uma 'tentativa' de mel [no sentido de pouco], e de um tipo pobre [baixa qualidade]." \{Parte 43\}.

"Existe uma espécie de Humble-bee que constrói um ninho em forma de cone de argila em pedra ou em situação semelhante [substrato], diluindo a argila com algo parecido com saliva. E este ninho ou colmeia é extremamente espesso e duro; na verdade, dificilmente se pode quebrá-lo para abri-lo usando-se um cravo. Aqui [na Grécia] os insetos depositam seus ovos, e larvas brancas são produzidas envoltas em uma membrana preta. Além da membrana foi encontrada alguma cera no favo; e esta é uma cera de tonalidade muito mais pálida que a cera encontrada no favo das abelhas [referindo-se às abelhas melíferas]." \{Parte 24\}.

Dando-se um salto de mais de 2200 anos - infelizmente, pulando outros trabalhos relevantes neste espaço de tempo; notavelmente o de Newman (1851), que detalhou comportamentos das mamangavas durante "horas de lazer de quatro ou cinco verões da [sua] juventude" (Habits of the Bombinatrices; Newman, 1851) - outro renomado estudioso utilizou-se da observação das mamangavas para fundamentar algumas de suas hipóteses biológicas. Estas, conjuntamente com outras hipóteses, culminaram em uma das mais fundamentais bases da teoria evolutiva.

Charles Darwin em sua renomada obra - A origem das espécies (1859) - ressaltou a importância da polinização feita por abelhas, mas discriminando a importância das mamangavas para determinadas plantas em relação às outras abelhas. Segundo suas 
palavras [livremente traduzidas]: "Eu percebi, por meio de experimentos, que as mamangavas são quase indispensáveis para a fertilização do amor-perfeito (Viola tricolor), já que outras abelhas não visitam essa flor. Descobri também que as visitas de abelhas são necessárias para a fertilização de alguns tipos de trevo; por exemplo, vinte cabeças de trevo holandês (Trifolium repens) renderam 2290 sementes, mas de outras vinte cabeças, protegidas das abelhas, nem uma foi produzida." (Darwin, 1859).

Também, com base em observações de mamangavas, Darwin descreve um cenário que se contextualiza precisamente com uma das principais bases teóricas do que se conhece hoje como redes de interações ecológicas.

"As mamangavas sozinhas visitam o trevo vermelho, visto que outras abelhas não conseguem alcançar o néctar. Por conta disso podemos inferir como altamente provável que, se todo o gênero das mamangavas se tornar extinto ou muito raro na Inglaterra, o amor-perfeito e o trevo vermelho se tornariam muito raros, ou desapareceriam totalmente. O número de mamangavas em qualquer cidade depende, em grande parte, do número de ratos do campo, os quais destroem seus favos e ninhos; [...] agora, como é de amplo conhecimento, o número de ratos é largamente dependente do número de gatos; [...] por isso, é bastante credível que a presença de um felino em grande número em uma cidade pode determinar, por meio de intervenção, inicialmente dos camundongos e depois das abelhas, a frequência de certas flores naquela cidade." (Darwin, 1859).

Um pouco após Darwin, o mais robusto e detalhado trabalho científico publicado foi escrito por Frederic William Lambert Sladen, em 1912, abordando diversos aspectos da biologia de Bombus terrestris (morfológicos, fisiológicos e comportamentais), mas também das mamangavas de uma forma geral.

Em seu trabalho intitulado Humble-Bee (Sladen, 1912), o autor formalizou cientificamente, de forma bastante consistente, técnicas para a domesticação e criação de mamangavas em cativeiro, as quais foram referências para tantas outras pesquisas que o sucederam nesta temática, bem como foram bases teóricas que contribuíram com o posterior sucesso prático na domesticação e produção de colônias em larga escala.

Dentre tantas contribuições, Sladen propôs um modelo de caixa racional de criação, ressaltando as diferenças cruciais em relação àquelas caixas usadas para a criação das abelhas melíferas, as quais deveriam ser precisamente consideradas para o sucesso de uma casa artificial para mamangavas; a caixa de criação foi denominada por ele de Sladen's Humble-bee House.

Sladen, também relatou um fato que possivelmente foi o primeiro transporte de Bombus para fora de seu ambiente nativo, para fins de polinização agrícola, algo que culminou na introdução de duas espécies na Nova Zelândia. Segue a tradução do trecho: "Foi descoberto que na Nova Zelândia o trevo vermelho (red clover) não produz sementes espontaneamente. Então, em novembro e dezembro de 1884, uma quantidade de rainhas foi enviada da Inglaterra para Nova Zelândia, que resultou em duas espécies, Bombus terrestris e Bombus ruderatus, se tornarem estabelecidas lá, e o trevo vermelho agora produz uma abundante cultura de sementes." (Sladen, 1912).

Inequivocamente, as rainhas foram levadas da Inglaterra para Nova Zelândia de navio, via grande extensão oceânica, em uma longa viagem iniciada no período do inverno na Europa (novembro e dezembro, segundo Sladen). Estes aspectos sugerem que as rainhas já estavam inseminadas e possivelmente estavam em diapausa, bem como elas devem ter sido cuidadosamente manejadas e preservadas para a viagem, 
evidenciando que na época já havia conhecimento suficientemente avançado sobre a biologia destas espécies para viabilizar tal feito.

\subsection{Perspectiva econômica: da domesticação à comercialização}

Em meados do século $X X$, pesquisadores desenvolveram técnicas eficientes de atração e aprisionamento de rainhas em domicílios artificiais, o que foi um importante passo para a fase de manejo e produção artificial de colônias para aplicações agrícolas (ex: Jordan, 1936; Hasselrot, 1952, 1960; Fye e Medler, 1954; Holm, 1960, 1966).

Mas a produção e a comercialização de colônias em larga escala, de fato, iniciaram-se no final da década de 1980, após o veterinário belga Dr. Roland De Jonghe, quase que casualmente, descobrir a existência de viabilidade e o grande valor do uso de colônias de Bombus terrestris para polinizar tomateiros cultivados no confinamento de estufas.

Até aquele momento as flores dos tomates em estufa eram polinizadas manualmente, vibrando-se as plantas três vezes por semana, e este trabalho gerava gastos superiores a 10 mil Euros por hectare de cultivo por ano, com base em dados da Holanda (Ravestijn e Nederpel, 1988). Em outros países europeus a polinização manual do tomateiro também era feita, mas, além disso, em alguns casos as plantas também eram tratadas com hormônios, algo que gerava gastos ainda superiores.

Produtores e pesquisadores perceberam que a eficiência da polinização por mamangavas dentro das estufas, comparada à polinização manual, era muito superior, e os tomates apresentavam melhor sabor, maior tamanho, maior quantidade de sementes e melhor qualidade visual, aumentando consideravelmente seu valor de mercado (Imperatriz-Fonseca, 2004; Velthuis e Van Doorn, 2004).

Ainda, outra vantagem na perspectiva da produção é que as abelhas confinadas não podem optar por usar recursos de outras plantas, pois estão restritas aos recursos florais das plantas confinadas no mesmo ambiente. Este aspecto resulta em máximo aproveitamento do potencial de polinização. Todavia, há custo para a colônia, pois esta não obtém todos os recursos e nutrientes necessários para seu desenvolvimento, sendo necessário que o produtor supra esta necessidade. As abelhas confinadas também deixam de desempenhar papéis ecológicos no ambiente natural, como o do fluxo genético das plantas por meio da polinização cruzada, e sua própria reprodução também é restrita ou totalmente suprimida nestas condições.

$\mathrm{Na}$ época, por conta da massiva difusão entre os produtores europeus das vantagens do uso de mamangavas nas estufas, especialmente dentre os produtores de tomates, a demanda por colônias cresceu imediatamente. Porém, a maioria dos produtores rurais pouco ou nada sabia sobre as abelhas. No entanto, aqueles que já tinham o domínio sobre o processo de obtenção de rainhas e domesticação de colônias em casas artificiais viram uma excelente oportunidade de negócios.

Neste contexto, o Dr. De Jonghe, em 1985, na Bélgica, fundou em sua garagem a primeira empresa dedicada à venda de colônias para suprir este mercado em crescimento, a empresa foi denominada BIOBEST. Durante seus experimentos, De Jonghe desenvolveu uma técnica para anular a diapausa da rainha já inseminada (Velthuis e Van Doorn, 2006), obrigando-a a trabalhar e iniciar sua colônia, mesmo que seu anseio fosse continuar em "sono profundo". Esta foi uma grande vantagem econômica, pois agora as mamangavas trabalhariam no ambiente controlado da estufa o 
ano todo, sem interrupções fenológicas, e a construção de colônias podia ser iniciada no momento desejado.

Subsequentemente, muitas outras empresas foram fundadas na Europa almejando suprir esta lucrativa demanda por colônias industrializadas de polinizadores. Até mesmo empresas que já trabalhavam no setor agrícola ampliaram sua oferta de produtos incluindo colônias nos itens disponíveis à venda. Por exemplo, a holandesa Koppert, que estava no mercado de controle biológico para agricultura desde 1967, começou a produzir colônias em 1989 (Velthuis e Van Doorn, 2006).

No fim desta mesma década, colônias de Bombus terrestris já eram comercializadas em 15 países europeus. Pouco tempo depois a espécie já era exportada para muitos outros países, inclusive para fora da sua área de distribuição nativa.

Entre 1988 a 1990 as colônias custavam em torno de 200 Euros cada, mas a polinização com mamangavas ainda era mais barata do que a polinização manual. Em 2004, as colônias já custavam bem menos, cerca de 60 Euros, e foram comercializadas mais de 850 mil colônias de Bombus terrestris naquele ano (Velthuis e Van Doorn, 2004). Dois anos após, em 2006, um milhão de colônias já eram produzidas anualmente; atualmente a cota deve ser muito superior, ainda mais perante a intensa redução global de polinizadores, especialmente no hemisfério norte, por conta do Distúrbio do Colapso de Colônias (do inglês: Colony Collapse Disorder, CCD).

Em 2010, a BIOBEST teve uma receita líquida de 27,6 milhões de dólares (USD) e empregava 350 funcionários (Azure, 2012). Além da sua sede na Bélgica, já tinha escritórios no Canadá, França, México, Turquia e Espanha, mas já distribuía seus produtos (que incluem químicos e organismos de controle biológico) em mais de 50 países (Azure, 2012). Já a Koppert, por exemplo, dentre seus escritórios em 60 países, possui duas unidades no Brasil, mas aqui não vendem colônias (Unidade Piracicaba Macrobiológicos; Unidade Itapetininga - Microbiológicos). Segundo Velthuis e Van Doorn (2004), em épocas de alta produção, a Koppert vende mais de 10 mil colônias por semana aos produtores.

Estas empresas, em relação à polinização industrializada, lucram também com os produtos de suporte às colônias, como nutrientes e alimentos. Por exemplo, em 2004 foram vendidos três milhões de quilogramas de xarope de açúcar (Figura C1-3) como o BIOGLUC $^{\circledR}$ (Velthuis e Van Doorn, 2004; BIOBEST, 2015).

As colônias comercializadas não são permanentes, possuem tempo de vida útil definido para cada tipo, tamanho e preço de caixa comercializada, em geral, em torno de 4 a 8 semanas, sendo necessária a aquisição permanente de novas colônias para a manutenção do serviço de polinização (BIOBEST, 2015).

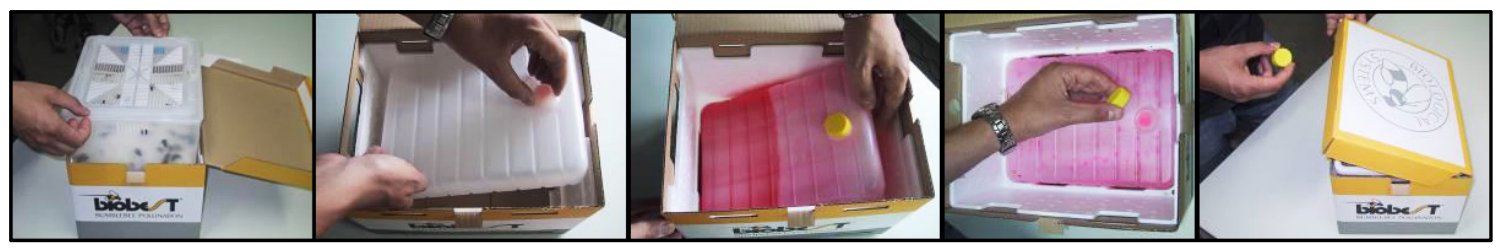

Figura C1-3. Sequência de substituição do compartimento de xarope de açúcar BIOGLUC $^{\circledR}$ das colônias industrializadas de Bombus terrestris da empresa BIOBEST. Fonte: Guidelines for the Use of Biobest Bumblebee Hives (B. terrestris) de autoria de Paco Lozano Rubio. 
Atualmente, cerca de 30 empresas multinacionais trabalham neste setor, com instalações de criação de colônias em pelo menos 19 países (Tabela C1-1).

Tabela C1-1. Países onde há instalações de criação de Bombus terrestris (Velthuis e van Doorn, 2006; AHGA, 2008; Aron 2005).

\begin{tabular}{ll}
\hline Países & Empresas \\
\hline Alemanha & STB-Biocontrol \\
Bélgica & Biobest, BIP \\
Canadá & Apidol, Biobest, Global Horticulture, Groupe Hort. Ledoux \\
China & Beijng Yong-An-Xin Biological Pollination CO. \\
Coréia do Sul & Sesil Corporation, Yae-cheon Ind., Mr. Lee \\
Eslováquia & Koppert \\
Espanha & Agrobio, Biobest \\
Estados Unidos & Koppert \\
França & GTICO, GIE Lacroix, Biobest, Biotop \\
Holanda & Bunting Brinkman Bees, Biopol, Koppert \\
Israel & Bio-Bee, Yad Mordechai \\
Itália & Agriapi \\
Japão & Api Company, Cats Agrisystems \\
Marrocos & Biobest \\
México & Koppert, Biobest \\
Noruega & Bombus Pollinering, Norbol, Pollinering Service \\
Nova Zelândia & Zonda, Biobees \\
Rússia & Cinco pequenas empresas \\
Turquia & Bunting Brinkman Bees, Biobest, Koppert \\
\hline
\end{tabular}

Os negócios relacionados à polinização agrícola são multimilionários. Isso decorre do imenso benefício econômico resultante do aprimoramento da polinização que se reflete diretamente na quantidade e qualidade dos produtos agrícolas, que neste caso, são multibilionários. Por exemplo, o valor da receita em um ano dos tomates produzidos em estufas por meio da polinização por mamangavas foi estimado, em 2006, em cerca de 12 bilhões de Euros (AHGA, 2008). Mas as mamangavas também são usadas como polinizadores em muitas outras culturas, tanto em estufa como em ambientes abertos, Tabela C1-2.

Tabela C1-2. Principais plantas agrícolas polinizadas por Bombus terrestris (Velthuis e Van Doorn 2004, 2006; Biobest, 2015).

\begin{tabular}{ll}
\hline Abacate & Melancia \\
Abóbora & Melão \\
Abobrinha & Mirtilos \\
Alho-poró & Morango \\
Batata & Oxicoco \\
Berinjela & Pepinos (comum, japonês, Gherkin) \\
Cebola & Pera \\
Cenouras & Pimentas e Pimentões (vários tipos) \\
Kiwi (comum e Kiwi Berry) & Repolho \\
Maçã & Tomates (tipos grande e Cherry) \\
\hline
\end{tabular}




\subsection{Difusão global de colônias industrializadas}

Devido ao aprimoramento dos processos de armazenamento de colônias em caixas de criação portáteis, colônias de mamangavas podem ser hoje compradas por telefone, transportadas por avião e recebidas por correio em quase todo o mundo.

As caixas, por exemplo, da BIOBEST, são externamente de papelão grosso, com uma fina camada interna de isopor, auxiliar no isolamento térmico, e um compartimento removível e arejado de plástico no interior, onde está a colônia. Embaixo do compartimento plástico está o recipiente com xarope de açúcar ao alcance das abelhas por um orifício. Na parte lateral da caixa há uma porta selada de papelão, que é aberta apenas no momento de liberação das abelhas, e logo atrás desta porta há dois diferentes orifícios de acesso: um orifício permite a entrada das abelhas para o interior da colônia e a saída para o exterior (Figura C1-4. A). Já o outro orifício permite apenas a entrada das abelhas para o interior, mantendo-as retidas (Figura C1-4. B e C). Esta entrada retentora é útil quando é necessário transportar a colônia, lidar com as plantas sem a presença das abelhas e trocar o recipiente vazio de xarope de açúcar tingido de vermelho (Figura C1-3), cujo nível pode ser acompanhado por um orifício na lateral da caixa.

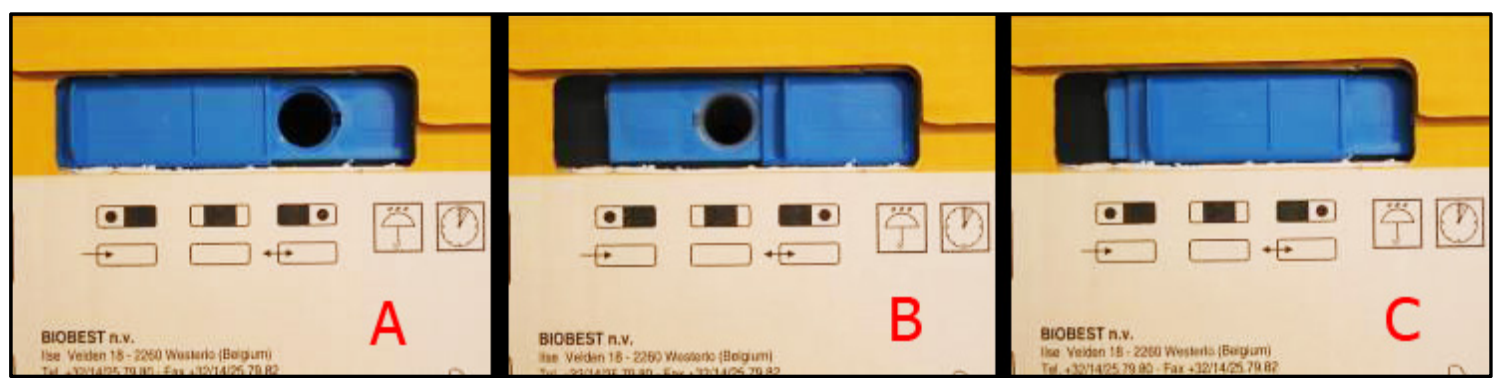

Figura C1-4. Tipos de acesso à colônia: A) Nesta opção as abelhas têm acesso livre do interior ao exterior da colônia durante o desempenho de seus serviços; B) As abelhas entram, mas não são capazes de sair de dentro da colônia; C) As abelhas ficam retidas no compartimento plástico do interior, quando necessário reabastecer xarope de açucar ou transportá-las. Fonte: Guidelines for the Use of Biobest Bumblebee Hives (B. terrestris) de autoria de Paco Lozano Rubio.

Além das avançadas técnicas de criação e manejo de colônias, a tecnologia agregada nas caixas de criação é de fundamental importância para o sucesso do comércio internacional de colônias. Ao longo de anos de aprimoramentos, as empresas alcançaram caixas/colônias praticamente livres de manutenção (apenas recebendo xarope), com dimensões perfeitas para cada espécie, estruturação interna adaptada para a manutenção e limpeza que é feita pelas próprias abelhas, sistemas de ventilação com nível controlável de fluxo de ar dependendo da temperatura do ambiente (Figura C1-5. B), materiais isolantes térmicos e anuladores de eletrostática, baratos e não tóxicos para abelhas. Até mesmo as cores externas e internas da caixa foram trabalhadas pensando-se na melhor eficiência da colônia.

De forma similar a uma indústria de montagem de carros em série, as colônias são produzidas sequencialmente em seções de fábrica. Na Figura C1-5 (A) vê-se a seção de montagem das caixas da BIOBEST. Na Figura C1-5 (C) pode-se perceber que as estufas de cultivo, neste caso de tomate, fogem à noção comum de tamanho de 
estufas, as quais são gigantescas e requerem grande quantidade de colônias. $O$ número de colônias é determinado pela área de cobertura da polinização, o tipo da cultura que a requer, e a quantidade de abelhas em cada tipo de caixa.

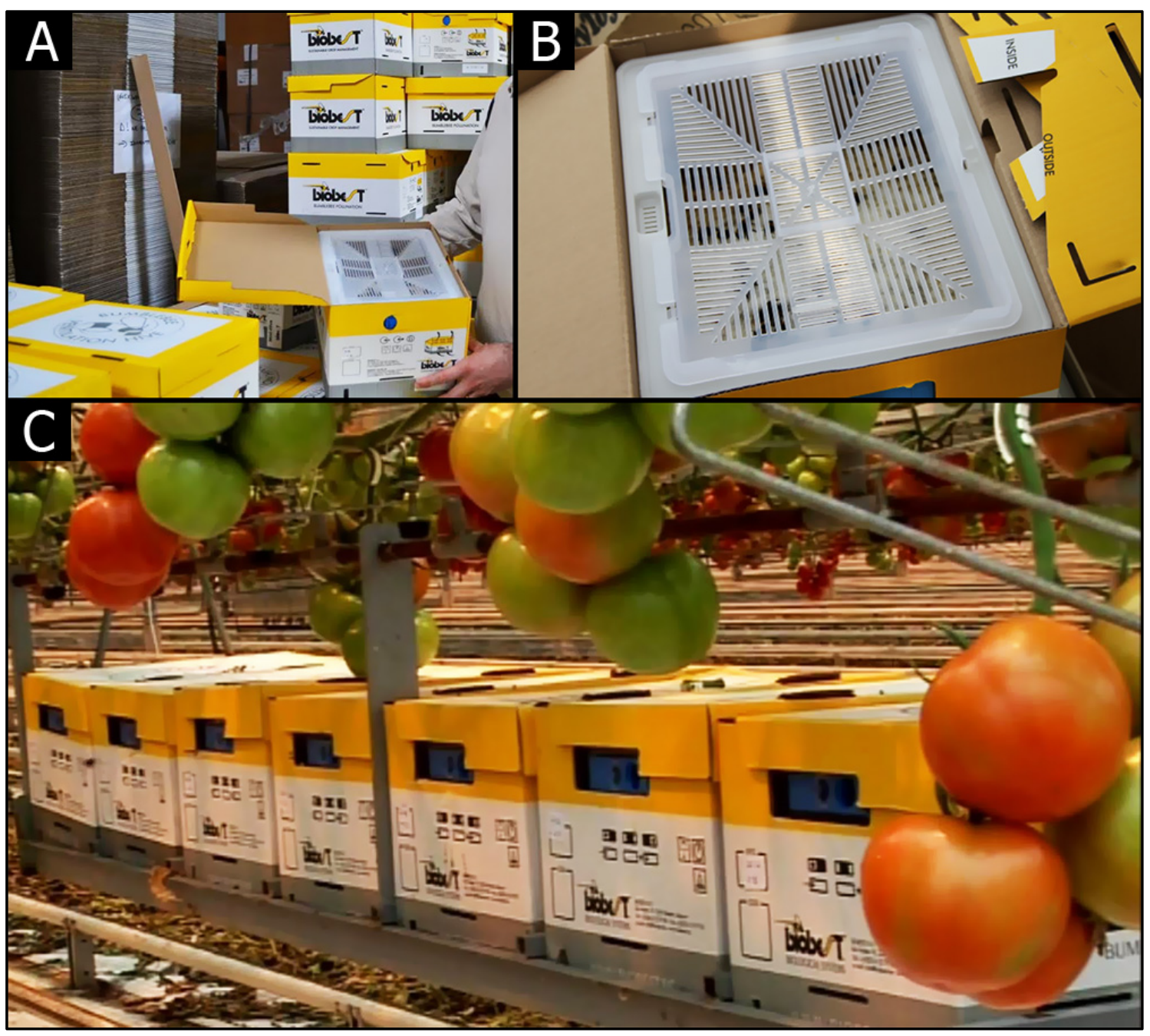

Figura C1-5. A) Área de montagem das caixas de criação da BIOBEST; B) Estrutura de ventilação das colônias em caixas artificiais; C) Colônias de Bombus terrestris em estufa de produção de tomates. Fontes: Francisco Lozano-Rubio, ledauphine.com.

\subsection{Invasão global por Bombus terrestris}

Devido à facilidade de compra, transporte e às fracas restrições e fiscalizações da importação de polinizadores, nas duas últimas décadas a comercialização e exportação de Bombus terrestris tornaram-se ainda mais intensas e, simultaneamente, as repercussões dos aspectos negativos associados à sua introdução em locais onde não são nativas (Winter et al., 2006; Dafni et al., 2010; Howlett e Donovan, 2010). Muitos países, perante essa situação estão tomando medidas coercitivas e restritivas a fim de evitar a introdução da espécie em seus territórios, notadamente a Austrália, o Canadá, os Estados Unidos, o México e o Japão, países que já publicaram atos oficiais de restrição à importação da espécie (Goka, 2006; Velthuis e van Doorn, 2006; Winter et al., 2006). 
A introdução de Bombus terrestris em sistemas naturais e agrícolas nos quais a espécie não é nativa promove competição com as espécies locais, bem como impactos no equilíbrio dos sistemas ecológicos e agrícolas já estabelecidos (Goulson et al., 2008).

Alguns destes aspectos foram identificados recentemente na ilha de Hokkaido (Japão), onde ocorreu um intenso declínio do número de colônias da espécie nativa Bombus hypocrita sapporoensis devido à competição com Bombus terrestris por locais de nidificação (Inoue et al., 2008) e devido à capacidade da invasora em usurpar colônias de abelhas nativas matando suas rainhas (Kearns et al., 1998).

Também no Japão, o aumento do número de colônias invasivas de Bombus terrestris tem gerado efeito direto na redução da aptidão reprodutiva das espécies de mamangavas nativas por meio de cruzamentos interespecíficos, produzindo proles não viáveis (Kanbe et al., 2008; Kondo et al., 2009). Além de impactos às abelhas, Kenta et al. (2007) demonstraram que a espécie invasora poderá levar a reduções na taxa de frutificação de algumas plantas nativas no Japão.

Em Israel, Dafni e Schmida (1996) observaram que a Bombus terrestris iniciava seu forrageio mais cedo do que as outras abelhas e esgotava o néctar de várias flores, reduzindo drasticamente o recurso compartilhado com outras abelhas $e$, consequentemente, excluindo geograficamente outras espécies. Adicionalmente, os autores perceberam que as abelhas solitárias eram quase totalmente excluídas de algumas plantas por conta do comportamento territorialista agressivo que a Bombus terrestris, fisicamente mais robusta, exibia frente às abelhas nativas da região (Dafni e Shmida, 1996; Ruz, 2002).

Conforme já citado, Bombus terrestris foi inicialmente introduzida na Nova Zelândia em 1884 para polinização do trevo-vermelho (Sladen, 1912), e se espalhou rapidamente, em uma taxa de cerca de 90 km por ano (MacFarlane e Gurr 1995; Buttermore, 1997). Hoje, esta invasora é a abelha mais frequentemente encontrada visitando flores naquele país (Hanley e Goulson, 2003; Lye et al., 2010).

Não se sabe seguramente como a espécie chegou à Tasmânia (ilha adminstrada pela Austrália). Semmens et al. (1993) relataram, pela primeira vez, ter visto colônias da espécie na Tasmânia em 1992, e sugeriram que sua invasão provavelmente teve origem a partir de abelhas trazidas da Nova Zelândia. Sua velocidade de invasão foi menor naquela ilha, estimada em aproximadamente 12,5 $\mathrm{km}$ por ano (Buttermore, 1997), mas mesmo assim nota-se a alta capacidade de expansão invasiva da espécie. Segundo Buttermore (1997), os indivíduos de Bombus terrestris encontraram fortes barreiras bióticas em sua invasão na Tasmânia por conta dos hábitos predatórios das aves australianas, algo que pode ter reduzido sua velocidade de expansão.

Além de Bombus terrestris causar uma grande variedade de impactos às espécies nativas e agrícolas, poderá favorecer também outras espécies invasoras. Por exemplo, Sladen (1912) relatou que o trevo-vermelho - planta que também foi introduzida na Nova Zelândia - não produzia sementes adequadamente neste país, e após a introdução da abelha começou a produzir grande quantidade de sementes, refletindo-se na maior taxa de reprodução e expansão desta espécie de planta invasora. Stout et al. (2002) também encontraram relação direta entre a invasão de Bombus terrestris na Tasmânia com o aumento na produção de sementes da leguminosa Lupinus arboreus, que também é invasora na ilha e foi favorecida pela presença da abelha. 
Evidentemente, não se pode omitir que a invasão de Bombus terrestris, em alguns casos específicos, poderá beneficiar algumas espécies de plantas agrícolas, afinal, a abelha é uma excelente polinizadora, especialmente para as plantas com anteras poricidas. No entanto, se pode inferir com alguma segurança que o balanço entre os potenciais benefícios econômicos (para alguns produtores de algumas culturas agrícolas) e os conhecidos malefícios para as espécies nativas e, inclusive, para algumas culturas agrícolas, não justificaria introduções deliberadas, haja vista o número e a variedade de impactos ambientais causados pela espécie em ambientes invadidos, conforme foram relatados (ex: MacFarlane e Gurr 1995; Dafni e Shmida, 1996; Buttermore, 1997; Ruz, 2002; Stout et al., 2002; Hanley e Goulson, 2003; Kenta et al., 2007; Goulson et al., 2008; Inoue et al., 2008; Kanbe et al., 2008; Kondo et al., 2009; Lye et al., 2010; Arbetman et al., 2013; Aizen et al., 2014). Ademais, deve-se ressaltar que os indivíduos de Bombus terrestris em ambientes invadidos são potenciais vetores de doenças e parasitas exóticos, tanto para outras abelhas como para as plantas selvagens e agrícolas que elas visitam (Velthuis e van Doorn, 2006; Winter et al., 2006; Goulson et al., 2008; Plischuk e Lange, 2009).

\subsection{Bombus terrestris na América do Sul}

O histórico da presença de Bombus terrestris no continente sul americano tem início no Chile, a partir de 1982 (Morales, 2007), mas se intensificou no fim da década de 1990, quando a importação da espécie foi autorizada pelo "Servicio Agrícola y Ganadero de Chile - SAG". Na época, essa importação estava de acordo com as regras internacionais estabelecidas pelo "Behaviour Code for the importation and liberation of exotic agents for biological control" como parte das políticas internacionais praticadas pela Organização das Nações Unidas para Agricultura e Alimentação - FAO (Ruz, 2002).

As primeiras colônias foram importadas de Israel e distribuídas em diferentes localidades do Chile, e eram principalmente dedicadas à polinização de culturas de abacate e tomate em estufa (Ruz e Herrera, 2001; Molet et al., 2009; Aizen et al., 2014). Considerando que uma rainha inseminada pode gerar sozinha uma colônia inteira, em poucos meses várias colônias se estabeleceram em ambientes naturais daquele país.

Segundo Ruz (2002), é provável que a Bombus terrestris tenha inicialmente se expandido para zonas mais ao sul do Chile, distribuindo-se por áreas previamente ocupadas por duas outras espécies de Bombus, especialmente nas áreas de ocorrência da espécie nativa Bombus dahlbomii.

A invasão de Bombus terrestris no Chile foi muito bem sucedida (na perspectiva da espécie), mas sua velocidade de expansão estimada não foi tão grande quanto à observada na Nova Zelândia (90 km/ano), mas superior à da Tasmânia (12.5 km/ano), alcançando cerca de 20 km/ano (300 km em 15 anos; Ruz, 2002).

Em pouco tempo cruzou a fronteira com a Argentina por meio de caminhos de baixa altitude através dos Andes. Em 2006 foram avistadas as primeiras colônias naquele país, onde não há relatos formais de importação de Bombus terrestris (Torreta et al., 2006; Morales, 2007). No início de 2009 foram registrados 111 indivíduos de Bombus terrestris (76 machos, 36 operárias e duas rainhas) nas proximidades de San Carlos de Bariloche (Plischuk e Lange, 2009), sugerindo a boa adaptação ambiental da 
espécie invasora no sul da América do Sul, e indicando que sua expansão invasiva possivelmente continuará a crescer.

Recentemente, Carolina Morales e colaboradores (Morales et al., 2013), demonstraram a veloz expansão invasiva da espécie na Argentina, que em apenas 5 anos tornou-se a abelha do gênero Bombus mais abundante e com ampla distribuição na região, parcialmente substituindo a espécie nativa Bombus dahlbomii. Os autores relataram que no vale Challhuaco (Patagônia), onde já há décadas ocorria a presença de outra Bombus invasora, a Bombus ruderatus, em apenas dois anos após a detecção de Bombus terrestris, a espécie nativa $B$. dahlbomii desapareceu do local.

Impactos da presença invasiva de Bombus terrestris também estão sendo relatados em culturas agrícolas na América do Sul. A produção de framboesas na Patagônia tem sido prejudicada por conta de danos que a espécie causa em suas flores durante forrageio, prejudicando a fertilização da planta ao danificar estruturas reprodutivas da flor, e consequentemente, reduzindo a taxa de frutificação (Aizen et al., 2014).

Conforme as evidências providas por esses trabalhos, Bombus terrestris possui alto poder de competição (especialmente de exclusão), o qual supera o de muitas espécies de abelhas, inclusive espécies de seu próprio gênero. Mas também pode estar eliminando geograficamente outras abelhas, colônias e populações por conta de doenças carregadas em seu corpo e transmitidas para as outras abelhas, direta ou indiretamente, por meio da contaminação de plantas (Arbetman et al., 2013).

Alguns trabalhos publicados sugerem que a Bombus terrestris pode ter sido importada para o Uruguai em 1995 (Hingston et al., 2002; Imperatriz-Fonseca 2006; AHGA, 2006; Morales et al., 2007; Dafni et al., 2010), e poderá estar expandindo sua invasão em ambientes naturais e agrícolas. Contudo, nada foi encontrado que confirme sua presença neste país por meio de observação e coleta de organismos; mas a falta de segurança quanto à presença de Bombus terrestris no Uruguai poderá decorrer também da baixa frequência de levantamentos sistemáticos em campo sobre abelhas, o que poderia diminuir as chances da eventual constatação da invasão.

No Brasil também não há relatos da invasão de Bombus terrestris até o momento, mas deve-se ter cautela em afirmar que a espécie não está presente.

\subsection{O porquê de um estudo preditivo sobre uma invasão potencial}

A Natureza sofre uma infinidade de tipos de impactos degradantes, que atuam em diferentes escalas e decorrem principalmente das formas através das quais a humanidade desenvolve suas atividades e explora o ambiente para sua sobrevivência e lazer. Ao se assumir uma perspectiva global, estes impactos podem ser abrangidos por três principais grupos de pressões ubíquas sobre a biodiversidade:

1) A destruição e fragmentação de sistemas ecológicos (ex: habitat ${ }^{3}$, ecossistemas, biomas, paisagens) que decorrem das atividades não sustentáveis de exploração, sobrexplotação de recursos (ex: madeira, minérios, água) e a supressão dos sistemas naturais, a fim de tornar o solo disponível para o desenvolvimento de

\footnotetext{
${ }^{3}$ Nesta pesquisa optou-se pelas normas do Novo Acordo Ortográfico (2015) para a grafar a palavra latina habitat, que passou a ser classificada como substantivo de dois números, assim, não há o acréscimo de " $\mathrm{s}$ " no plural (habitats).
} 
atividades produtivas, exploratórias e de ocupação humana (ex: plantações, pastagens, cidades);

2) As alterações climáticas, que estão intimamente ligadas às emissões de poluentes químicos, especialmente os gases intensificadores do efeito estufa, mas também aos desmatamentos, queimadas e as alterações da paisagem como, por exemplo, a substituição de florestas por pastagens;

3) O transporte de organismos intencionalmente entre sistemas ecológicos distantes e semi-isolados (ex: biopirataria, plantas ornamentais), dissimuladamente (ex: água de lastro em navios) ou, em menor frequência, inadvertidamente (ex: aranhas exportadas em caixas de bananas), conduzindo a eventos de invasão por espécies exóticas que impactam a biodiversidade e a sociedade humana.

Dentre estes três grupos, as invasões por espécies exóticas têm sido especialmente no Brasil - pouco consideradas nos meios políticos, na academia e principalmente nos veículos midiáticos. Não obstante, a frequência dos eventos de invasão é crescente em todo o planeta, e são raros os planos de ação para evitá-los, monitorá-los e mitigar seus impactos.

Frequentemente, quando uma espécie invasora é detectada pela primeira vez, sua ocupação invasiva já se expandiu e as populações já se tornaram estabelecidas no ambiente não nativo; neste estágio, erradicar a espécie invasora e/ou controlar seus impactos torna-se uma tarefa extremamente complexa, custosa e, na maioria das vezes, ineficaz. Por outro lado, prever a susceptibilidade de áreas a novos eventos de invasão por espécies exóticas poderá prover subsídios consistentes para o desenvolvimento de medidas preventivas e restritivas, bem como ações de controle, levantamento e monitoramento do processo invasivo. Tudo indica, pela lógica mais trivial, que tentar evitar e se preparar para um evento de invasão é a forma mais inteligente, eficiente e barata para reduzir impactos ambientais, sociais e econômicos. Obtendo-se inspiração nesta lógica e considerando o fato de que uma espécie altamente invasiva e conhecida por gerar impactos em vários países está invadindo o sul da América do Sul neste momento - a Bombus terrestris - tornou-se necessário pesquisar sobre a possibilidade desta espécie alcançar o Brasil. Adicionalmente, mapear os caminhos potenciais que os indivíduos desta espécie invasora poderão usar para chegar ao nosso país a partir de locais já invadidos e que são relativamente próximos.

Certamente esta pesquisa não pretende oferecer a resolução definitiva para esta questão complexa e que evolui com o tempo, mas apresentar uma base de conhecimentos sobre esta invasão, difundir informações sobre a problemática para a sociedade brasileira, mas também prover subsídio metodológico e, em parte, conceitual, para outras pesquisas que também envolvem espécies invasoras. 


\subsection{Objetivos}

O objetivo precípuo desta pesquisa é responder a pergunta: Bombus terrestris chegará ao Brasil? Para se alcançar esta resposta, se definiu uma sequência de objetivos específicos:

- Mapear globalmente os habitat adequados para Bombus terrestris com base nas características topoclimáticas de sua área de ocorrência nativa; pois habitat adequados que são externos à sua distribuição natural são potencialmente susceptíveis a eventos de invasão se a espécie alcançá-los ou neles for introduzida.

- Identificar as repercussões das mudanças climáticas para as áreas susceptíveis à invasão de Bombus terrestris com base em estimativas de diferentes cenários de mudança para um futuro próximo.

- Caracterizar ecogeograficamente Bombus terrestris em escala global, analisando as afinidades e tolerâncias ambientais da espécie, comparando entre áreas de ocorrência nativa e invasivas, e subsidiando os resultados com base na literatura.

- Mapear para a América do Sul a potencial progressão invasiva da espécie a partir de localidades já reportadas como invadidas no Chile e na Argentina, considerando que os indivíduos invasores poderão se deslocar através de corredores ambientais favoráveis por meio de sucessivas colonizações, podendo permitir que a espécie alcance o Brasil.

- Identificar os municípios brasileiros fronteiriços com o Uruguai que potencialmente serão os primeiros a serem invadidos pela espécie por meio de sua expansão invasiva natural que, para propósitos práticos, compreendem a denominada "porta de invasão" de Bombus terrestris no Brasil.

- Mapear os trajetos e corredores potencialmente mais propícios ambientalmente para o deslocamento da espécie em seu processo de invasão dentro do Brasil, bem como apontar as cidades brasileiras vulneráveis que estão ao longo deste caminho.

- Identificar no Brasil a produção de culturas agrícolas com as quais Bombus terrestris é conhecida por interagir e que são cultivadas nestes municípios brasileiros vulneráveis.

- Quantificar o potencial de interação entre a espécie invasora e as espécies do gênero Bombus que são nativas nestes municípios brasileiros vulneráveis.

- Com base nas informações obtidas pelas conclusões dos objetivos anteriores, apontar áreas prioritárias para o monitoramento, desenvolvimento de estudos científicos, ações de controle do processo de invasão e mitigação de impactos à agricultura e às espécies de Bombus nativas no Brasil. 


\section{Capítulo 2. Fundamentação teórica para o método de modelagem ecológica}

Este capítulo contextualiza a modelagem ecológica computacional em suas aplicações e aponta sua utilidade a esta pesquisa. Mas também argumenta sobre o que implica o resultado destes modelos para uma espécie: o seu nicho, a sua área de distribuição, ou a adequabilidade do seu habitat.

\subsection{Introdução à modelagem ecológica computacional}

Conforme a sociedade humana evolui tecnologicamente, novas e mais robustas ferramentas se tornam disponíveis e são aplicadas na pesquisa científica, permitindo a ampliação e o aprofundamento dos conhecimentos sobre os fenômenos naturais.

Infelizmente, muitos dos grandes avanços tecnológicos na história humana decorreram durante corridas armamentistas e foram desenvolvidos em ambientes militares; todavia, com o tempo tornam-se progressivamente disponíveis às pessoas que fazem melhor uso delas.

Dentre tantos produtos e serviços hoje já bem conhecidos e difundidos, como o forno micro-ondas ${ }^{4}$, o GPS $^{5}$ e a Internet ${ }^{6}$, outras tecnologias de origem bélica, como as imagens de satélite, os supercomputadores, as avançadas lógicas e algoritmos computacionais, permitiram a emergência e o rápido desenvolvimento de áreas científicas que usam estes recursos como ferramentas de estudo: este é o caso das Ciências de Informações Geográficas (ex: Goodchild, 1997; Longley et al., 2015).

As Ciências de Informações Geográficas estão inseridas em um campo de estudo fundamentado na obtenção, armazenamento, processamento, análise e interpretação de todos os tipos de informações que possam ser dimensionadas no espaço geográfico. Para tanto, pesquisas nesta área requerem o uso de Sistemas de Informações Geográficas ou, como usualmente são chamados, GIS (acrônimo, em inglês, de Geographic Information System). GIS são sistemas digitais que agregam a mais alta tecnologia disponível na obtenção de dados (ex: imagens aéreas e de satélite multiespectrais, drones, torres de fluxo, estações e balões meteorológicos, bóias oceânicas, data loggers, GPS), no armazenamento e processamento de dados (ex: supercomputadores individuais, agregados e distribuídos: cluster, cloud computing, servidores de armazenamento) e na análise de dados (ex: algoritmos e lógicas) (Goodchild, 1997).

Ao longo das duas últimas décadas, os GIS foram progressivamente integrados ao conjunto de ferramentas aplicadas no estudo ecológico, aprimorando em grande medida a eficiência e a velocidade de processos analíticos, bem como a precisão e abrangência dos estudos que requerem dimensionamentos geoespaciais, como é o caso da Modelagem Ecológica Computacional.

Modelos, de uma forma geral, podem ser descritos como representações de uma realidade concreta ou mesmo, abstrata. Por exemplo, um modelo poderá

\footnotetext{
${ }^{4} \mathrm{O}$ efeito de aquecimento por micro-ondas foi descoberto por Percy Spencer em 1946 quando desenvolvia testes de radares para uma empresa de sistemas de defesa.

${ }^{5}$ Global Positioning System - GPS: Sistema de Posicionamento Global, que foi desenvolvido em um projeto militar liderado pelo engenheiro Bradford Parkinson em 1995.

${ }^{6}$ Advanced Research Projects Agency Network - ARPANET: Projeto militar de rede que desenvolveu o primeiro protocolo de controle e transmissão de dados (Transmission Control Protocol - TCP) que veio a se tornar o sistema de dados utilizado na Internet (Internet Protocol - IP).
} 
representar um objeto, como uma miniatura que retrata a forma de um automóvel em escala reduzida; ou também um comportamento, como um modelo de moda e estilo, que reproduz padrões visuais e comportamentais estereotipados, ainda; poderá ser uma referência processual a ser seguida, como um modelo de negócios para uma empresa.

Já a modelagem ecológica trata de representações gráficas, matemáticas e argumentativas de um determinado fenômeno natural, que pode ser, por exemplo, comportamental (ex: modelos de divisão de trabalho em insetos sociais; Beshers e Fewell, 2001), espaço-temporal (interações entre abelhas e recursos florais em larga escala espacial; Giannini et al., 2013), físico (ex: incompatibilidade de caracteres morfológicos em interações planta-inseto; Anderson et al., 2010), químico (ex: proteínas relacionadas à comunicação química de insetos; Pelosi et al., 2006) e muitos outros. Estes fenômenos representados podem estar ligados a fatores intrínsecos ou extrínsecos (ou ambos) de organismos individuais, espécies, populações, comunidades e ecossistemas, por exemplo. Contudo, também podem ser modelos generalizados e teóricos, que representam uma fração de algo que transpassa muitas espécies, e não necessariamente é restrito a um determinado espaço e tempo, por exemplo, os modelos predador-presa de Lotka-Volterra (referência inicial: Lotka, 1910).

Quando se acopla o elemento computacional geoespacial (SIG) à modelagem ecológica, dá-se maior poder analítico ao estudo dos fenômenos naturais, permitindo ampliar a gama e a quantidade de dados que podem ser simultaneamente analisados, assim como permite ampliar a resolução e extensão destes dados. Por conseguinte, pode-se dizer que aprimora o estudo ecológico na compreensão da dinâmica e estruturação dos fenômenos naturais no espaço e no tempo, mas também reduz imensamente o tempo dos processos analíticos, a mão de obra e os custos no desenvolvimento de estudos em ampla escala geográfica.

A modelagem ecológica computacional como área de pesquisa está em pleno crescimento e em contínuo aprimoramento. De forma bastante diversificada e ampla, tem contribuído com a resolução de questões teóricas e na geração de subsídios científicos para ações práticas no âmbito de vários setores sociais. Ainda assim, o desenvolvimento de novos métodos analíticos e novas formas de uso é necessário, bem como novas aplicações práticas são promissoras para guiar ações de mitigação de impactos e conservação de espécies e habitat.

Os estudos em modelagem ecológica computacional têm provido resultados robustos e de extrema aplicabilidade prática, os quais tem sido empregados, por exemplo, para a conservação de espécies raras ou ameaçadas (Araújo e Williams, 2000; Engler et al., 2004; Brito et al., 2009), estimativa de impactos das mudanças climáticas em espécies (Peterson et al., 2002; Oberhauser e Peterson, 2003; Siqueira e Peterson, 2003; Thomas et al., 2004; Pearson et al., 2006; Araújo et al., 2006; Araújo et al., 2008; Wiens et al., 2009; Giannini et al., 2013) avaliação do potencial invasivo de espécies exóticas (Peterson et al., 2003; Peterson e Robins, 2003; Peterson et al., 2006a), deteç̧ão de possíveis rotas de disseminação de doenças infecciosas e (Costa et al., 2002; Peterson et al., 2006b; Levine et al., 2007); determinação de áreas prioritárias para conservação (Ortega- Huerta e Peterson, 2004; Chen, 2009).

As ferramentas de modelagem ecológica computacional, bem como os conceitos ecológicos que as envolvem, são úteis a esta pesquisa por permitem 
detectar globalmente os ambientes adequados para Bombus terrestris em áreas não nativas, portanto, que poderão estar susceptíveis a novos eventos de invasão.

Estas ferramentas permitem o delineamento geoespacial e auxiliam na caracterização dos compartimentos ecogeográficos cuja conjunção de fatores ambientais é favorável à presença da espécie. Estes compartimentos ecogeográficos são quase sempre detectados com base nas ocorrências nativas da espécie, por isso também poderão denotar o seu nicho, a sua área de distribuição, bem como a adequabilidade do habitat. Embora estes três aspectos sejam eventualmente usados como sinônimos de uma mesma característica ecológica, eles devem ser diferenciados conceitualmente; algo que se buscou fazer adiante.

\subsection{Definição da premissa conceitual fundamental do método}

Há muito tempo os naturalistas já buscavam - e encontravam - padrões ambientais estreitamente relacionados às áreas de distribuições das espécies. Esta busca e suas respostas também são axiais nos estudos biogeográficos e um dos principais fundamentos da disciplina Ecologia.

Porém, o primeiro uso da palavra nicho em uma publicação científica abarcando estes aspectos em um termo generalizado costuma ser atribuído a Joseph Grinnel por conta de seu artigo: The niche-relationships of the California Thrasher, publicado em 1917 na revista Auk. Ele descreve neste trabalho que uma espécie de ave (California Thrasher; Toxostoma redivivum) possui um alcance geográfico notavelmente restrito, e que esta restrição de distribuição provavelmente é relacionada ao tênue ajustamento de vários aspectos fisiológicos e psicológicos (sic) da ave em relação à estreita faixa das condições ambientais da área. Ao concluir suas descobertas, nos dois últimos parágrafos, ele cita as três únicas vezes que a palavra nicho aparece no corpo do texto, e cunha o termo ao associá-lo à dependência da espécie à cobertura vegetacional (do chaparral californiano) e a sua adaptação em estrutura física e "temperamento" ao ambiente em que vive. Ressaltou, ainda, que não há duas espécies estabelecidas em uma mesma fauna que possuam as mesmas relações de nicho.

Grinnell via o nicho de uma espécie como sendo uma unidade comportamental espacialmente restrita pelos limites fisiológicos e morfológicos da espécie perante os fatores físicos do ambiente. Ele disse em um trabalho posterior que [o nicho é] "A unidade de distribuição final ou máxima (ultimate) dentro da qual cada espécie é mantida por suas limitações estruturais e instintivas" (Grinnell, 1928).

Um pouco depois, Charles Sutherland Elton em seu livro Animal Ecology (1927), contribuiu com uma definição diferente, descrevendo que o nicho de um animal é o seu local (ou posição) no meio biótico decorrente de suas relações com o alimento (presas) e seus inimigos (predadores). Elton também descreve exemplos do que ele considera o nicho para algumas plantas e animais, atribuindo ao termo nicho a funcionalidade do organismo na estrutura e organização de sua comunidade.

Georgii Frantsevich Gause, nesta mesma linha, acresceu que um nicho "indica o local em que uma dada espécie ocupa em uma comunidade, ou seja, quais são os seus hábitos, alimentação e modo de vida" (Gause, 1934). Posteriormente, no livro The Ecology of Animals (1950), Elton reforça o complemento de Gause utilizando quase as 
mesmas palavras: "O nicho significa o modo de vida e, sobretudo, o modo de alimentação de um animal" (Elton, 1950).

Ou seja, Elton e Gause viam o nicho como sendo o papel desempenhado pela espécie em sua comunidade, portanto ambos consideraram as interações bióticas, mas que apenas poderiam ocorrer num espaço ambientalmente adequado, portanto, uma limitação extrínseca à espécie (Pullian e Waser, 2011).

Entretanto, pesquisadores que entendiam e definiam nicho de forma ainda diferente, especialmente no que concerne à funcionalidade da espécie na comunidade, questionaram os autores anteriores. Lee Raymond Dice (1952) refutou os conceitos de Elton e Gause dizendo que o termo nicho não inclui, exceto indiretamente, qualquer consideração sobre as funções que uma espécie desempenha na comunidade. Dice e outros (ex: Van Valen, 1960; Root, 1967) possuíam uma interpretação de nicho que se aproximava às definições atualmente mais aceitas; de que o nicho é essencialmente o conjunto de todos os requisitos de uma espécie.

Root (1967) sugeriu, pela primeira vez, a multidimensionalidade do nicho, na qual cada dimensão corresponde a um requisito para a espécie. Van Valen (1971) separava nicho em dois componentes principais: um que envolvia os recursos (bióticos e abióticos) de que a espécie dependia, e o outro que envolvia a resistência da espécie à predação e ao parasitismo. Dezenas de outros autores discutiram, argumentaram, complementaram e redefiniram o conceito de nicho conforme suas formas de entender o que a palavra deveria abranger conceitualmente, mas também seguindo linhas de raciocínio determinadas por relações políticas e acadêmicas no meio científico.

Assim, desde Grinnel, a conceituação de nicho é uma das mais controversas e inconclusivas discussões ecológicas. Todavia, analogamente a Constatino I no ano 325, que alcançou o consenso entre os religiosos de sua época, pacificando-os e unificandoos ao combinar conceitos de Deus e de Jesus num único pacote: a bíblia romana, George Evelyn Hutchinson, descrito como o pai da ecologia moderna pelos seus pares, fez algo similar em seu tempo com o conceito de nicho, capturando elementos convergentes, transformando-o em um conceito sólido, conciso e abrangente.

Fundamentalmente, a definição de nicho para Hutchinson é "um hipervolume n-dimensional" (Hutchinson, 1944; modificado em Hutchinson, 1957). Obviamente, Hutchinson aprofundou e detalhou bastante seu conceito, mas esta frase é o eixo nuclear de sua lógica, que pode ser entendida assim: o nicho compreende o conjunto de todos os " $n$ " (numeráveis) fatores ambientais que afetam a espécie em seu ambiente, bem como todos aqueles fatores dos quais a espécie depende para sobreviver e perpetuar-se no ambiente (Hutchinson, 1944; 1957; 1967). Mas, deve-se ressaltar que para Hutchinson (1957), o nicho é um atributo da espécie (intrínseco) e não do ambiente. Portanto, diverge neste sentido às versões de Grinnel e Elton (Colwell e Rangel, 2009; Pullian e Waser, 2011).

A definição de Hutchinson para nicho é generalizada, dimensionada e equacionada; pode-se calcular o nicho contanto que as dimensões consideradas possam ser detectadas (a priori) e medidas. Mas também pressupõe, pelo menos fundamentalmente, que todas as dimensões são indistintamente influentes quando presentes no nicho da espécie e as outras, externamente ao nicho, são direta ou indiretamente irrelevantes. 
Cada uma destas dimensões ligadas à presença da espécie no espaço geográfico pode ser, pelo menos em teoria para todos os casos, graficamente representada por meio de eixos. Estes eixos possuem escalas que representam a variação (métrica) de cada fator ambiental considerado. Os extremos desta variação por cada fator são determinados pelos limiares de tolerância do organismo, ou seja, é o intervalo na variação total do fator ambiental em que o organismo é encontrado. Sendo o nicho hutchinsoniano um atributo da espécie, estas escalas tratam, de certa forma, dos limites fisiológicos dos indivíduos da espécie, mas também da sua capacidade de adaptação ao ambiente. A representação gráfica de todos estes " $n$ " eixos ( $n$-fatores influentes), ajustados em suas respectivas escalas perante as faixas de tolerância da espécie seria, portanto, multidimensional e mostraria o hipervolume.

Em um estudo hipotético de um nicho bidimensional de uma espécie, considerando, por exemplo, extremos da temperatura média e precipitação anual, o hipervolume seria uma área plana, o qual seria representado em um gráfico cartesiano como um quadrado ou um retângulo (Figura C2-1). No caso de três dimensões, acrescendo-se extremos de altitude, por exemplo, teríamos um gráfico tridimensional que mostraria uma forma geométrica hexaédrica representando o hipervolume. Eventualmente um cubo ou um paralelepípedo. Se considerarmos centenas ou milhares de dimensões, o hipervolume não poderia ser efetivamente representável em um mundo tridimensional (omitindo-se o tempo, neste caso), mas se poderia pensar, assumindo uma perspectiva subjetiva, que se assemelharia a uma bolha tortuosa flutuando em um espaço multidimensional.

Hutchinson também ressaltou a importância de se distinguir os fatores ambientais em dois tipos: as variáveis dinamicamente interativas, denominadas por ele como variáveis bionômicas (recursos ou fatores bióticos), que são limitadas em quantidade e acesso, e cujas espécies podem competir entre elas para seu usufruto; e aquelas que não são diretamente interligadas, denominadas variáveis cenopoéticas (condições ou fatores abióticos), que são ilimitadas ou não consumíveis, portanto, segundo ele, não geram competição (Hutchinson, 1978).

Seguindo suas predefinições quanto aos tipos de variáveis, Hutchinson fracionou o nicho em dois compartimentos que se sobrepõem. O primeiro ele denominou como nicho fundamental, que é o espaço mais amplo em que a população é capaz de persistir devido à combinação de faixas de variação adequadas dos fatores cenopoéticos. Todavia, as espécies não ocupam de fato esse espaço amplo, devido às interações negativas com outras espécies, especialmente considerando-se a exclusão decorrente de competição interespecífica. O segundo compartimento foi denominado de nicho realizado, o qual é um espaço contido na dimensão do nicho fundamental, frequentemente bem menor, e onde há a conjunção dos fatores abióticos e bióticos que variam em faixas adequadas à permanência da espécie, e dos quais ela necessita para sobreviver. Neste compartimento é presumido que a espécie seja competitivamente dominante. 


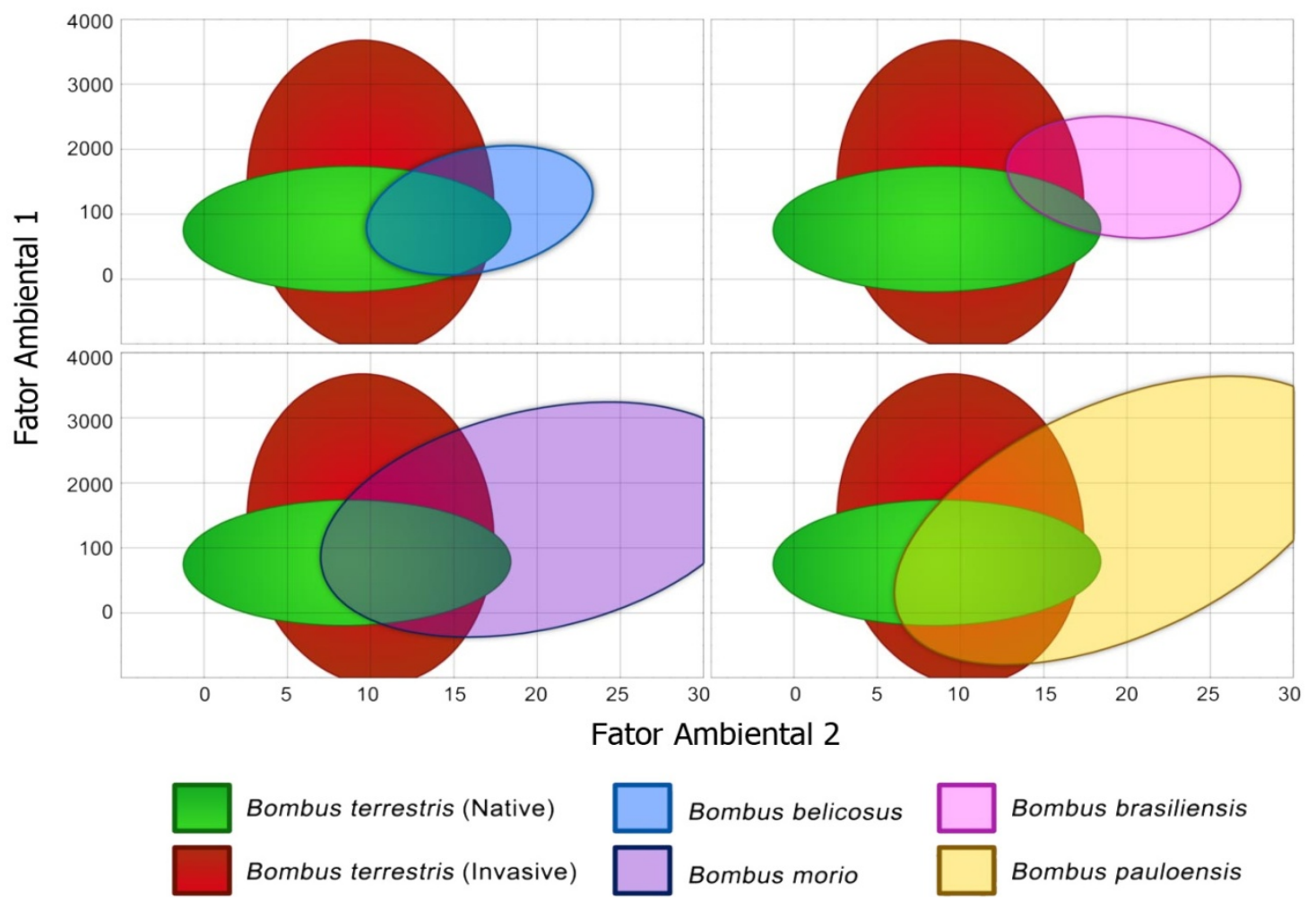

Figura C2-1. Representações gráficas do nicho hutchinsoniano bidimensional das espécies estudadas. Embora os gráficos considerem dados reais das espécies, seu uso aqui é apenas para ilustrar nichos bidimensionais com uso de elipses suavizadas com intervalos de confiança de $95 \%$.

Devido a certas similaridades entre o conceito de nicho de Hutchinson com alguns dos conceitos de habitat (ou biótopo) (Patten e Auble, 1981; Colwell e Rangel, 2009; Chase e Myers, 2011), os "defensores do nicho" começaram a incluir habitat em suas conceituações de nicho para evidenciar a diferença entre ambos.

Pode-se perceber, por exemplo, a tentativa de Aarssen (1984) em distinguir habitat dentre as três compartimentações do nicho que ele propôs; que segue a mesma linha de Hutchinson. Conforme descrito por ele: "O nicho disponível é um local 'real' (ou conjunto de locais) na natureza que corresponde a uma fração do nicho potencial da espécie [...]. Este [nicho disponível] é grosseiramente equivalente ao habitat e representa o espaço real onde a espécie poderá teoricamente deixar descendentes se não houver interações bióticas com outras espécies. O nicho realizado (pós-interativo), finalmente, é um 'local real' na natureza onde a espécie poderá deixar descendentes apesar da contínua interação com outras espécies".

Tomando o conceito de Begon (2006) como sólido, por ser amplamente aceito, habitat é uma referência do lugar do organismo e não se restringe necessariamente a um determinado tipo ou grupo de fatores ambientais. Assim, cada habitat poderá conter muitos nichos diferentes.

A definição de habitat não carrega o mesmo peso conceitual que o nicho possui, e não se faz necessário referir-se aos " $n$ " de fatores ambientais considerados. Habitat poderá referir-se ao lugar físico espacialmente mais restrito quando se trata de uma única espécie, de forma que provenha uma referência efetiva do lugar onde ela vive. Também poderá ser tão amplo quanto necessário para abarcar várias formas de vida dentro dele, quando se trata de várias espécies ou grupos maiores. Assim, o boto- 
cor-de-rosa vive na América do Sul, nos domínios da floresta tropical chuvosa da Amazônia, mas seu habitat são os rios da bacia Amazônica. Já a Amazônia é habitat de várias espécies de peixes, aves, mamíferos e do boto-cor-de-rosa.

Mais recentemente, com o aprimoramento e difusão das ferramentas aplicadas para o desenvolvimento de Modelos de Nicho Ecológico ou de Distribuição de Espécies, a conceituação de nicho ganhou nova energia. O conceito foi reajustado para abranger as novas perspectivas de uso, mas também compreender aspectos relacionados à genética, evolução, fisiologia, paleogeografia, dentre outros. Neste momento também se faz necessário distinguir e particularizar os termos distribuição geográfica e adequabilidade de habitat do contexto conceitual de nicho.

Uma das abordagens mais sólidas dedicadas à diferenciação de nicho e distribuição geográfica foi escrita por H. Ronald Pullian (2000), contrapondo aspectos do nicho de Hutchinson com elementos da teoria da dinâmica de metapopulações. Ele exemplifica que numa situação de dinâmica populacional do tipo fonte e dreno é esperado que as espécies não estivessem sempre restritas dentro do compartimento de seu nicho. Afinal, os habitat que drenam indivíduos (onde morrem mais do que nascem), os quais são supridos pelos habitat fonte (onde nascem mais do que morrem), potencialmente estão externos às variações ambientais mais adequadas à espécie, portanto, externos ao compartimento em que a espécie é capaz de se perpetuar por meio da reprodução. Os indivíduos alcançam estes habitat externos ao seu "nicho" por processos migratórios e, embora estes locais não sejam ambientalmente perfeitos como se presume o nicho, eles são capazes de habitá-los. Se houver um permanente afluxo de indivíduos da fonte para o dreno, a espécie estará permanentemente presente.

Pullian também discute que locais ambientalmente similares ao nicho da espécie podem nunca ser alcançados devido a limitações de dispersão da espécie e sua história natural, algo como "nichos vazios" de uma espécie. Estas considerações sugerem que uma espécie poderá distribuir-se externamente ao domínio de seu nicho e, em outros casos, não se distribuir por todo o domínio de seu nicho, evidenciando que nicho e distribuição devem ser vistos como perspectivas diferentes da abrangência geográfica de uma espécie.

Jorge Soberón (2007, 2010), nesta mesma linha, incluiu a componente mobilidade em seu quadro conceitual de distribuição geográfica da espécie, representando-a em um diagrama que chamou de BAM (Biótico-Abiótico-Mobilidade; Figura C2-2. A). De forma aparentemente contraditória, o fator mobilidade poderá se expressar como limitante da abrangência geográfica da distribuição de uma espécie perante seu "nicho hutchinsoniano", mas também poderá ampliar a área potencial de distribuição para além do domínio de seu "nicho hutchinsoniano". Mesmo que em uma determinada área a conjuntura dos fatores ambientais seja adequada à espécie, se não houver a mobilidade que Ihe permita alcançar este local, ela não se distribuirá sobre ele. Por outro lado, se houver a abrangência da mobilidade sobre uma extensa área que contém zonas ambientais inadequadas, a espécie poderá se distribuir por elas em determinado momento, mas só permanecerá se houver contínuo fluxo de indivíduos a partir de uma população fonte "imersa em nicho hutchinsoniano" e conectada pela mobilidade.

Cinco anos após a primeira versão do BAM, Towsend Peterson e Jorge Soberón (Peterson e Soberón, 2012) reformularam o diagrama, ajustando-o ao contexto da 
modelagem para ampla escala geográfica. Consideraram que nestas dimensões os fatores bióticos podem ser difusos e não limitantes para a espécie, ou podem se manifestar em resoluções tão finas que não sejam perceptíveis quando os fenômenos estudados se manifestam em resoluções mais grosseiras, portanto, a componente biótica nestes casos poderia ser "colocada de lado" (Figura C2-2. B).
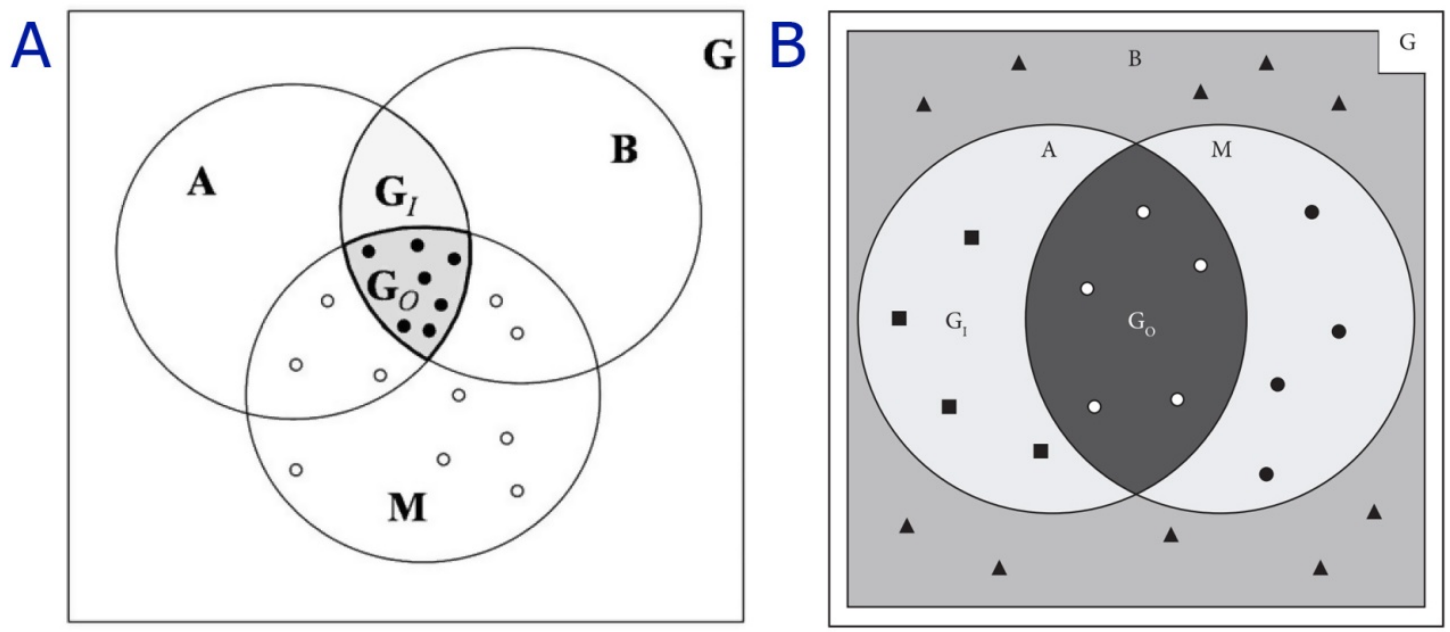

Figura C2-2. Diagramas de BAM representando em grandes círculos os fatores ambientais principais: $A$ (abióticos), B (bióticos) e $M$ (mobilidade). G é a abrangência da área considerada na análise; $\mathrm{G} 0$ a região geográfica onde a espécie de fato ocorre (pontos preenchidos em preto na Figura $A$ são populações do tipo fonte e em branco na Figura B são presenças). No BAM do quadro $A, G 1$ representa a conjunção de fatores bióticos e abióticos favoráveis, portanto uma área que poderia ser ocupada pela espécie, mas que ela não a alcança, pois a mobilidade (M) é desfavorável; já os pontos abertos representam as populações do tipo dreno, onde a espécie também se distribui em determinados momentos, pois há mobilidade, mas a conjunção de fatores não é perfeitamente adequada ( $A, B)$. No BAM do quadro $B$, a componente biótica (B) é desconsiderada, portanto a espécie tem o potencial de ocupar toda a área $(A)$, mas ela apenas se distribui pela área G0, pois não é capaz de alcançar a área G1 devido à falta de mobilidade; os pontos quadrados representam ausências relacionadas à falta de mobilidade; os pontos circulares pretos representam ausências devido à falta de adequabilidade dos fatores abióticos; os pontos triangulares são ausências devido à falta de mobilidade e dos fatores abióticos adequados (Soberón, 2007, 2010; Peterson e Soberón, 2012).

A área de distribuição de uma espécie é definida por vários autores como uma expressão complexa de sua ecologia e história evolutiva, determinada por diversos fatores que operam com diferentes intensidades em diferentes escalas (Brown, 1995; Brown e Lomolino, 2006; Soberón, 2005; Gaston, 2003; Pearson e Dawson 2003). Segundo estas definições, para caracterizar a distribuição de uma espécie devem ser abrangidos os fatores do nicho hutchinsoniano, a capacidade de dispersão dos indivíduos da espécie (como ressaltado por Pullian e Soberón), mas também aspectos pregressos que atuaram na espécie para sua atual posição no espaço geográfico, ou seja, processos evolutivos e a história natural da espécie e dos seus ambientes (ex: glaciações, isolamento geográfico, especiação).

Da mesma forma, estes aspectos também deverão estar considerados na detecção da distribuição potencial da espécie, pois este potencial também está condicionado aos elementos inerentes à distribuição real. Externamente à vulgarização do termo distribuição e dentro do mundo conceitual da ecologia, a distribuição de uma 
espécie significa mais do que pontos de ocorrência sobre uma área, portanto, a distribuição potencial também carrega este peso conceitual.

O nicho hutchinsoniano, mesmo combinado com a mobilidade, retrata um cenário imediato - uma "fotografia" das afinidades e limitações de uma espécie perante os fatores ambientais e sua capacidade de dispersão. Mas não captura, exceto indiretamente, os processos que há muito tempo atuam na espécie e atuaram nos seus antepassados, moldando e redefinindo a sua ocupação geográfica, a qual se manifesta hoje em uma determinada configuração geoespacial.

Estes e outros aspectos geraram discussões quanto às terminologias frequentemente usadas em trabalhos que empregam ferramentas de modelagem para identificar áreas ambientalmente adequadas e que são acessadas (ou acessíveis) pelas espécies com base no cruzamento de registros de ocorrências e variáveis ambientais. Estes tipos de estudos são, na maioria das vezes, denominados Modelagem de Nicho Ecológico (Ecological Niche Modeling; Peterson, 2006) e Modelagem de Distribuição de Espécies (Species Distribution Modeling; Guisan et al., 2000), com menor frequência também são referidos como Habitat-based Metapopulation Models (Akçakaya, 2000); Resource Selection Functions (Boycee-McDonald, 1999; Manly et al., 2002) e Gradient Analysis (Austin e Cunningham, 1984). Não se adentrará nas discussões terminológicas quanto à melhor denominação do método/ferramenta, pois não há consenso. Para maior abrangência sobre o assunto, um trabalho recente poderá ser consultado, no qual o autor do presente trabalho também é coautor (Giannini et al., 2012).

Para se diferenciar adequabilidade de habitat relativamente ao nicho e a distribuição da espécie não se faz necessário aprofundamento teórico, tampouco há grandes divergências envolvidas na definição e uso do termo. A adequabilidade de um habitat é identificada por meio da matemática do nicho hutchinsoniano, portanto é o hipervolume $n$-dimensional, mas o " $\mathrm{n}$ " é bem mais restrito. Todavia, a diferença fundamental está no foco dos termos. Enquanto o nicho na conceituação de Hutchinson é uma particularidade da espécie (espécies possuem nichos, não ambientes), a adequabilidade do habitat é detectada para a espécie (ambientes/habitat possuem adequabilidade). Pode-se dizer que um modelo de adequabilidade de habitat é uma aplicação operacional (prática) do nicho ecológico conceitual (Hirzel e Lay, 2008).

Embora a lógica de Hutchinson seja aplicada na detecção da adequabilidade de habitat - permitindo combinar " $n$ " fatores mensuráveis - a expressão geoespacial e interpretação ecológica se enquadram melhor no conceito de nicho grinnelliano, conforme argumentado por Soberón (2007) com base em Grinnell (1917): o nicho grinnelliano é "definido fundamentalmente (mas não exclusivamente) por variáveis cenopoéticas e condições ambientais em larga escala, que são relevantes para entender propriedades ecológicas e geográficas das espécies que se manifestam em escalas menos finas".

A adequabilidade e a inadequabilidade de um habitat poderão ser representadas em níveis contínuos ou categóricos (discretos), mas um limiar divide as faixas de adequabilidade e de inadequabilidade. Na abrangência do habitat adequado, a taxa de crescimento populacional da espécie é pressuposta ser sempre positiva $(r>0)$, mas este valor positivo reduzirá a partir do ótimo ambiental em direção à zona limite do habitat adequado (Figura C2-3). Em determinada conjuntura de fatores ambientais (em suas escalas de variação combinadas), o crescimento populacional torna-se zero 
$(r=0)$; neste limiar acaba a faixa de adequabilidade. A partir de $r=0$, em sentido oposto ao ótimo ambiental, o crescimento populacional torna-se negativo. Nesta faixa $(r<0)$ a espécie só estará presente devido à emigração de indivíduos das populações abrangidas pelo habitat adequado. $\mathrm{O}$ " $r$ " negativo continua crescendo até alcançar um determinado limiar em que já não haverá mais indivíduos da espécie, pois a conjuntura dos fatores inadequados é tão desfavorável ao ponto de limitar a presença da espécie em nível fisiológico (Figura C2-3). A linha divisória entre o crescimento populacional positivo e negativo, ou seja, a isolinha de crescimento populacional líquido igual a zero, delineia a forma geométrica da área entre habitat adequado e inadequado para a espécie.
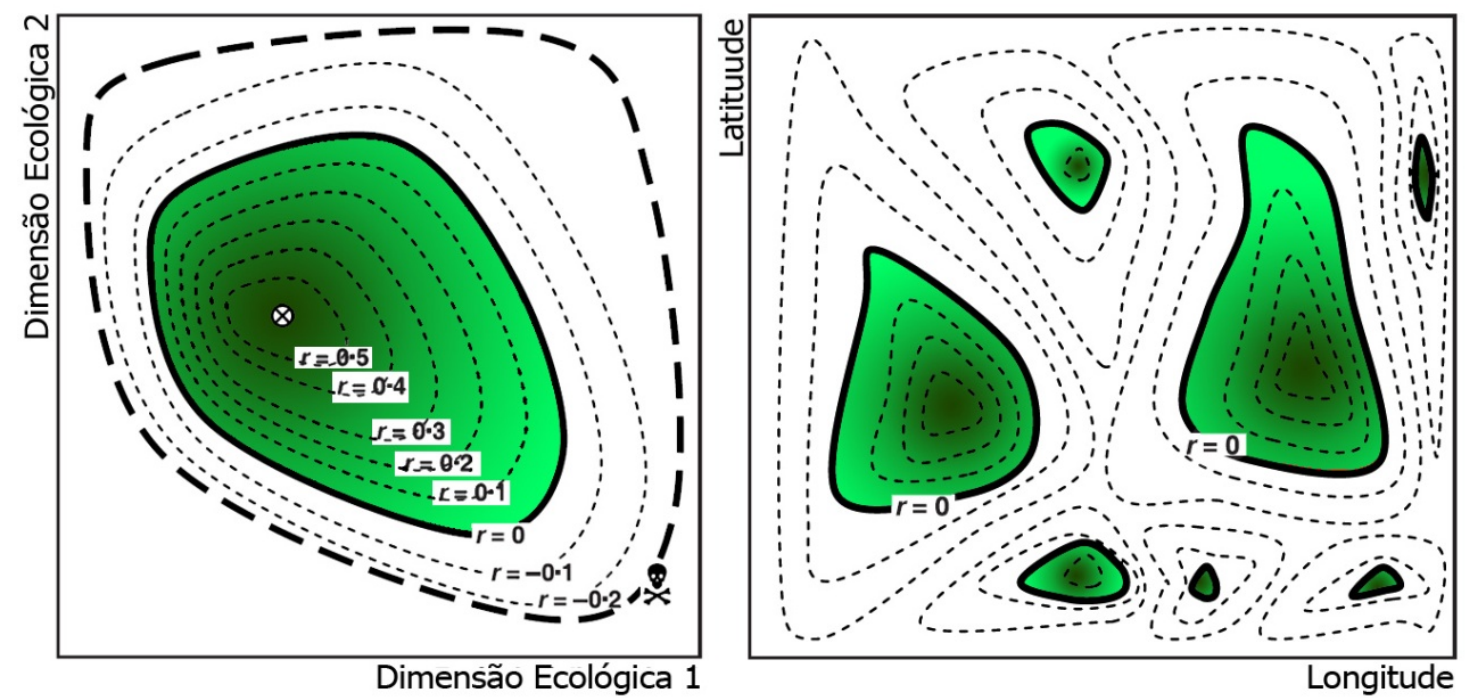

Figura C2-3. Representação do nicho ecológico em um espaço ambiental bidimensional (quadro à esquerda) e sua relação com a distribuição das espécies no espaço geográfico (quadro à direita). As isolinhas (tracejadas) conectam os pontos de igual faixa da taxa de crescimento per capita para a espécie $(r)$. A área verde representa o nicho grinnelliano (à esquerda), e sua manifestação espacial (à direita), o habitat adequado. $O$ gradiente em verde representa a variação desde o ótimo de adequabilidade (ponto com cruz à esquerda) até o limite da faixa de adequabilidade (verde mais claro). A isolinha contínua e mais espessa é o limiar entre adequabilidade e inadequabilidade, onde o crescimento populacional é zero; externamente a esta linha, o crescimento populacional torna-se negativo, e onde decorre a faixa de tolerância da espécie aos fatores ambientais. A linha espessa e tracejada (à esquerda) mostra o limiar de morte para os indivíduos, portanto além desta linha a espécie não é mais encontrada por não tolerar fisiologicamente as condições do ambiente (adaptado de Hirzel e Lay, 2008).

Espécies praticamente nunca estão isoladas de outras espécies ${ }^{7}$, bem como nunca estão isoladas de interações com os elementos físicos de seus ambientes. Os fatores bióticos (como competição, predação, parasitismo, mutualismo) podem restringir a ocupação geográfica de uma espécie em uma área de habitat

\footnotetext{
${ }^{7}$ Podem ser consideradas exceções organismos microscópicos que vivem em diapausa por milênios congelados em permafrost, em meteoros ou em outros planetas - eles não estão mortos e não estão interagindo com outras espécies. Também, alguns organismos que sobrevivem exclusivamente capturando recursos de fontes geotérmicas em zonas abissais, que interagem com o ambiente e com outros de sua espécie, mas não necessariamente interagem diretamente com outras espécies.
} 
abioticamente adequado por algum tempo. Todavia, os fatores bióticos não são necessariamente limitantes, e a probabilidade de existência de um fator biótico plenamente limitante para uma espécie é baixa (ex: uma doença fulminante, um predador extremamente eficiente e ubíquo na área).

Determinados fatores bióticos podem se expressar como barreiras que dificultam o crescimento populacional e desaceleram a expansão espacial de uma espécie, mas podem ser transponíveis ao longo do tempo. Por exemplo, a invasão de Bombus terrestris na Tasmânia, conforme relatado por Buttermore (1997), poderá ter sofrido efeitos de uma forte barreira biótica devido à presença de aves predatórias australianas, o que reduziu sua velocidade de expansão invasiva. Mas, hoje, a espécie é uma das abelhas mais frequentemente avistadas nesta ilha.

Por outro lado, os fatores abióticos quase sempre são limitantes, dependendo apenas de suas variações ambientais, e podem determinar a ausência de uma espécie em certas áreas durante certo tempo. Um mesmo fator abiótico, como a precipitação, por exemplo, poderá ser favorável, desfavorável e limitante, dependendo da sazonalidade e intensidade de suas variações em uma área, assim como da tolerância/intolerância da espécie a estas variações.

Indivíduos poderão se adaptar ao longo do tempo às condições abióticas que variam externamente ao seu ótimo ambiental ou, até mesmo, às condições que se tornem gradualmente desfavoráveis, mas apenas se a mudança ambiental for lenta o suficiente para ser compensada pela velocidade de adaptação da espécie às novas condições ambientais que progressivamente se apresentarem. Isto é especialmente válido no caso de microrganismos ou organismos cujos ciclos de gerações ocorrem rapidamente e a taxa de mutação é elevada. Portanto, as variáveis bióticas são altamente relevantes em estudos detalhados, em menor escala geográfica e resolução mais fina. Porém, para isso, é imprescindível haver dados de interação com alta qualidade e que sejam representativos perante a dimensão da área estudada, bem como sejam significativos para responder à(s) questão(ões) ecológica(s) ou fenômeno(s) estudado(s). Dados como estes são raramente disponíveis ou são muito difíceis de obter (Soberón, 2007). Já quanto às variáveis abióticas, há uma vasta quantidade de dados disponíveis (ex: clima, solo, topografia) em alta resolução, e muitas delas em extensão global.

Em um modelo de adequabilidade de habitat alimentado por variáveis abióticas, o nível de segurança é maior na negação do que na afirmação da adequabilidade. Ou seja, áreas detectadas como inadequadas são muito mais seguras para se afirmar a ausência da espécie do que áreas detectadas como adequadas para se afirmara presença. Isto decorre do fato que na dimensão geográfica detectada como adequada poderão existir fatores limitantes que não são conhecidos e (ou) que não foram considerados no modelo. Mas uma vez que uma faixa de variação de um fator abiótico é limitante e foi detectada em uma área, dificilmente a espécie poderá transpor este fator e fundar populações permanentemente nesta área sem a reposição contínua de indivíduos providos por uma população fonte. Se mais de um fator limitante, ou escalas de variações limitantes de mais de um fator, se sobrepuserem em uma área, maior será a inviabilidade desta área para a espécie. E dependendo dos limiares extremos destes fatores, a área poderá ser ambientalmente fatal para indivíduos. 
Em um trabalho relativamente recente, no qual o autor do presente trabalho é coautor (Brito et al., 2009), foi detectada uma faixa extremamente estreita delimitando habitat adequados dos inadequados para uma espécie de raposa africana, a Vulpes pallida, com menos de $1 \mathrm{~km}$ em algumas zonas. A espécie se distribui no Sahel, que é um sistema de transição entre o Sahara e a Savana. Devido a efeitos geográficos, especialmente deslocamento de dunas, a transição deste sistema vegetacional para o solo exposto e arenoso do Sahara é brusca, bem como a variação dos fatores abióticos, que mudam drasticamente. Durante o dia, a temperatura no Sahara na distância de 500 metros do Sahel, difere em mais de $10^{\circ} \mathrm{C}$. O Sahel possui vários arbustos, herbáceas e algumas árvores, o que gera sombreamento, reduzindo a incidência e reflexão da radiação solar, tornando o ambiente menos quente, menos ventoso e perceptivelmente mais úmido. Esta grande diferença ambiental expressa em uma estreita faixa geográfica é suficiente para separar um local potencialmente mortal de outro adequado para uma espécie.

Há muitos outros exemplos de transições abióticas bruscas, que tornam um habitat adequado imediatamente em inadequado e vice-versa, às vezes em questão de centímetros. Podem ser citadas como exemplo as faixas termoclinas e quimioclinas de salinidade (halóclina) e pH em corpos d'água; faixas intertidais litorâneas; e até mesmo a direção de um tronco em relação ao sol para liquens. Estes efeitos bem conhecidos demonstram o poder dos fatores abióticos na determinação da presença, mas, especialmente da ausência de espécies em determinados locais, algo não tão evidente (e não tão previsível e mensurável) quando se tratando de fatores bióticos.

$\mathrm{Na}$ detecção de áreas susceptíveis à invasão com base na identificação e delineamento geográfico da adequabilidade de habitat perante fatores abióticos - tal como o objetivo nuclear deste trabalho - deve-se assumir que: os espaços ecogeográficos delineados como habitat adequados, mas que não possuem ou nos quais não se conhece a distribuição da espécie invasora, serão considerados susceptíveis para serem invadidos se indivíduos da espécie os alcançarem por dispersão natural ou se forem levados para lá deliberada ou indeliberadamente. Ainda, os espaços geográficos delineados como habitat adequados, que em alguma parte de sua abrangência possuam registros de presença invasiva da espécie, irão sugerir a dimensão espacial potencial para a expansão invasiva da espécie a partir destas localidades já invadidas.

Para se alcançar o objetivo nuclear da presente pesquisa, os aspectos listados abaixo foram considerados como não necessários (e em alguns casos, impossíveis) de serem considerados:

1) identificar e medir os " $n$ " fatores bióticos e abióticos envolvidos na presença de Bombus terrestris para caracterizar seu nicho hutchinsoniano de forma plena;

2) identificar os limiares de tolerância fisiológica dos indivíduos da espécie perante variações nos fatores ambientais (como a temperatura) em ambiente laboratorial controlado (faixas de melhor aptidão e limiar de morte);

3) medir a capacidade de dispersão da espécie para incluir mobilidade às considerações sobre o nicho;

4) identificar populações/habitat fonte e dreno em campo para isolar os nichos realizados/efetivos daquelas áreas em que a espécie está presente exclusivamente por conta de sua mobilidade; 
5) levantar e analisar aspectos evolutivos, adaptativos e de história natural para caracterizar sua distribuição geográfica real e estimar a distribuição potencial.

A detecção da adequabilidade de habitat para Bombus terrestris por meio de modelagem ecológica computacional considerando fatores abióticos é um meio prático e efetivo, conceitualmente subsidiado, para mapear as áreas susceptíveis e insusceptíveis à invasão em escala global. Para tanto, investigou-se o melhor método de modelagem atualmente disponível, o qual se ajustaria adequadamente ao contexto e às demandas analíticas da pesquisa, mas que também permitisse ajustes de parâmetros e aprimoramentos de processos de cálculo em busca de resultados mais precisos para estudos de invasão em larga escala espacial - assuntos que estão abordados nos próximos capítulos. 


\section{Capítulo 3. Método de obtenção e seleção de dados e ferramentas de modelagem}

Este capítulo trata fundamentalmente de três aspectos: o critério de seleção da ferramenta para a modelagem da adequabilidade de habitat, justificando os motivos de a ferramenta ter sido escolhida; do levantamento e seleção das fontes de registros de ocorrência das espécies-alvo e a filtragem e consolidação destes registros em base de dados; também, da obtenção e seleção dos dados ambientais em formato digital e os ajustes que foram feitos.

Os resultados da concretização destes tópicos não são, de fato, os resultados analíticos da pesquisa, mas do progressivo desenvolvimento de uma etapa fundamental que antecede a metodologia analítica, que é a obtenção e seleção da ferramenta-base de análise e das variáveis (dependentes e independentes) que serão usadas ao longo de todo o estudo para se alcançar os objetivos da pesquisa. Tendo isso em consideração, não se dissociou os procedimentos de seus produtos; eles foram mantidos integrados ao longo do texto, conforme melhor se ajustaram em uma descrição linear e progressiva tratando do desenvolvimento desta etapa.

\subsection{Seleção de ferramentas para modelagem de Adequabilidade de Habitat}

A primeira e mais fundamental tarefa que precedeu o desenvolvimento dos modelos de adequabilidade de habitat foi a identificação da ferramenta de modelagem capaz de compreender os objetivos analíticos da pesquisa e prover predições de habitat adequados de forma biologicamente consistente e matematicamente mais precisa quanto possível.

Para tanto, foi necessário investigar na literatura as ferramentas de modelagem que foram usadas em contextos similares aos objetivos analíticos desta pesquisa e proveram resultados robustos. Mas, para evitar a inventariação e inspeção desnecessária de publicações que não contribuiriam com o método, foram usados filtros para restringir a busca. Primeiramente, um filtro geral foi elaborado: "Serão selecionados para avaliação os aplicativos, algoritmos e técnicas aplicadas em modelagem ecológica computacional com maior frequência pela comunidade científica e que constem em publicações de revistas indexadas". Essencialmente, as ferramentas mais citadas.

Após este primeiro filtro, outros adicionais foram definidos para refinar a listagem de ferramentas presentes no conjunto de publicações inicialmente selecionadas: "Dentre as ferramentas mais citadas, serão avaliadas e qualificadas as técnicas e ferramentas conforme os seguintes atributos:

1) nível de ajuste aos propósitos analíticos - serão preferidas as técnicas e ferramentas que melhor se enquadrem aos objetivos analíticos e que tenham sido utilizadas em contextos similares;

2) nível de aceitação no âmbito científico - serão preferidas as técnicas e ferramentas que possuam publicações ressaltando suas qualidades por meio de comparações e avaliações criteriosas;

3) nível de atualização - serão preferidas as ferramentas mais modernas, completas e com contínuo desenvolvimento de versões; 
4) nível de divulgação e popularização no âmbito científico - serão preferidas as ferramentas e técnicas mais citadas e discutidas em grupos virtuais, cursos, seminários e disciplinas;

5) nível de aprimoramento por meio de colaboração livre entre pesquisadores serão preferidas as ferramentas cujas versões de atualização relevem as opiniões e experiências de seus usuários".

Também, se considerou favorável, mas não limitante, que as ferramentas possuam código aberto (Open Source), de forma que os algoritmos possam ser lidos, permitindo o entendimento profundo de sua lógica funcional e analítica. Este aspecto também permite que os parâmetros gerais e específicos possam ser livremente modificados, possibilitando o melhor ajuste do código para suas aplicações. Algumas ferramentas são pré-compiladas e possuem uma interface GUI (Graphical user interface) específica e fixa para entrada de dados e ajuste de parâmetros, o que limita as opções de configuração. Além disso, sua lógica (via código) não é livremente acessível.

A seguir estão brevemente descritas as avaliações de ferramentas que não foram selecionadas para a avaliação prática (teste de modelagem), pois não compreenderam em quantidade ou qualidade suficiente os atributos desejados. Todavia, foram pré-selecionadas e merecem nota por abrangerem pelo menos em parte algum atributo. As ferramentas que não apresentaram condições mínimas ao longo dos filtros e qualificações, não foram abordadas.

O período definido para contabilizar a quantidade de citações por ferramenta foi de janeiro de 2012 até o momento da avaliação, em setembro de 2013, portanto, aproximadamente 21 meses. A base "indexadora" de publicações científicas utilizada foi Scopus (Scopus, 2013).

\section{Desktop GARP (DG)}

O pacote DG (Stockwell e Peters, 1999) foi muito usado no passado, mas é exclusivamente executado em aplicativo fechado, sem acesso direto à lógica de modelagem e com restrições nos ajustes de parâmetros. Ademais, o desenvolvimento e a atualização de versões cessaram em 23/06/2005, tornando o pacote obsoleto. De janeiro de 2012 até o momento da avaliação apenas uma publicação usou esta ferramenta (período referido doravante como "21 meses").

\section{ModEco (ME)}

O pacote ME (Guo e Liu, 2010), embora tivesse uma última versão relativamente recente na época da avaliação (22/11/2011), não havia sido utilizado em pesquisas científicas nos 21 meses com base no Scopus. Também é um aplicativo fechado, com acesso restrito à lógica analítica e para modificações de parâmetros de entrada.

\section{Biomapper (BM)}

O pacote Biomapper (Hirzel et al., 2004) ainda era utilizado em análises ecológicas na época. Este pacote fora citado seis vezes em pesquisas científicas nos 21 
meses (Scopus, 2013). O algoritmo nuclear do Biomapper é denominado Ecological Niche Factor Analysis (ENFA), que basicamente detecta as escalas de variação dos fatores ambientais mais recorrentes na área empírica de uma espécie por meio de uma Análise de Componentes Principais (PCA). Sua lógica é conhecida e bastante simplificada, o que poderia ser visto como favorável; todavia é executado em aplicativo fechado e com limitações nas configurações de parâmetros. Sua última versão era defasada, pois havia sido compilada em 11/02/2009.

\section{OpenModeller (OM)}

O pacote OM (Muñhos et al., 2009) continua a ser utilizado em pesquisas ecológicas, mas com pouca frequência. Naqueles 21 meses fora citado apenas 3 vezes. Possuía uma versão recente na época de avaliação, compilada em 25/07/2012.

Este pacote inclui bom número de algoritmos de modelagem e recursos de análises. Possui código aberto e licença pública, todavia, é executado em aplicativo fechado e compilado em plataforma de linguagem $\mathrm{C}++$. Portanto, por exemplo, ajustes de parâmetros não previstos na interface original GUI demandarão do pesquisador conhecimento profundo nesta linguagem para escrever as modificações no código e, subsequentemente, compilar o programa inteiro para então executar os modelos.

Devido a alguns dos colaboradores desta presente pesquisa no âmbito da Escola Politécnica (USP) estarem envolvidos com o desenvolvimento desta plataforma (OpenModeller, 2012), mas também pela extrema facilidade de seu uso e grande opção de algoritmos, o OM foi intensivamente testado em diferentes circunstâncias.

Este pacote é facilmente aplicável para uso educacional, devido à simplicidade de processos e à disposição intuitiva dos botões que geram ações passo a passo para o desenvolvimento de modelos. Seus algoritmos de modelagem naquela época eram exclusivamente de aprendizado de máquina (Machine Learning) e de envelopes climáticos, não disponibilizando algoritmos de regressão como GAMs (Generalized Additive Models) e GLMs (Generalized Linear Models), por exemplo. Estas lógicas de regressão têm sido relatadas na literatura como de bom desempenho analítico para grandes bases de dados, gerando ótimos resultados preditivos (ex: Aguirre et al., 2013 e citações contidas nele).

Os testes de modelagem com o OM evidenciaram que quando se usava dados de entrada em pequena quantidade (poucas ocorrências) e de menor tamanho (baixa resolução e extensão das camadas climáticas), os algoritmos geravam ótimos resultados. Os habitat adequados eram extremamente coerentes com os conhecimentos publicados sobre as espécies estudadas e com elevados índices de avaliação matemática (AUC - ROC; Fawcett, 2006). Mas quando a massiva quantidade de registros de Bombus terrestris e as camadas em escala global eram usadas, rapidamente o uso da memória do computador chegava ao limite, levando a plataforma e em alguns casos também o computador ao travamento. Aparentemente, o software naquela época não era capaz de compartimentar adequadamente o uso da memória RAM (Random Access Memory) e/ou fragmentar os processos de cálculo, ou ainda, estabelecer um limiar máximo de segurança ao acesso dos recursos computacionais dedicados ao aplicativo, de forma que permitisse rodar os modelos sem empilhar processos indefinidamente, conduzindo o computador ao travamento pela indisponibilidade de memória para o sistema operacional. 
Houve a oportunidade de testar a implementação do OM em código paralelizado em ambiente $\mathrm{R}$ rodado em cluster computacional, mas problemas ocorreram na transferência dos dados de entrada para o servidor (que são bastante grandes) e não foi possível concretizar a avaliação. Havia o desejo de comparar seus resultados com o de outros pacotes, especialmente como uma contribuição para os desenvolvedores que poderiam usar estes resultados para aprimorar a ferramenta. Infelizmente, os travamentos inviabilizaram a modelagem para Bombus terrestris, e o pacote não foi utilizado nesta pesquisa.

As ferramentas que estão descritas a seguir atendem às condições desejadas em quantidade e qualidade suficiente, e foram testadas com os dados provisórios de Bombus terrestris ${ }^{8}$, todavia, uma delas foi desconsiderada e os motivos também estão apontados.

\section{MAXENT, DISMO, BIOMOD2}

O MAXENT (Máxima Entropia) (Phillips et al., 2006) é um aplicativo fechado e compilado em linguagem JAVA, algo que poderia ser um ponto para sua exclusão imediata. Todavia, o algoritmo de modelagem executado pelo aplicativo nuclear maxent.jar - recebe instruções externas (data/parameters input) e retorna os resultados (model/analysis output) de forma interativa com a plataforma de execução de instruções em linguagem " $R$ " ( $R$ Development Core Team, 2011).

Pode-se enviar grande diversidade de parâmetros e massiva quantidade de dados para o arquivo JAR, o qual irá rodar o modelo de Máxima Entropia e retornar seus resultados para a mesma plataforma. Portanto, a limitação da interface é superada por esta característica interativa com a plataforma de linguagem $R$.

Sua lógica analítica é conhecida e bastante estudada no âmbito da modelagem, algo que também ultrapassa a barreira de se poder ler o código em linguagem JAVA (propriedade da Oracle Inc.), pois boa parte dele está criptografada.

O MAXENT é o algoritmo/aplicativo mais citado em estudos que envolvem modelagem ecológica. De janeiro de 2012 até o momento de avaliação havia 410 citações no Scopus (2013). Sua atualização é contínua e tem sido muito bem classificado em pesquisas que avaliam desempenho e qualidade de resultados comparativamente com distintos algoritmos/lógicas. Nesta pesquisa, apenas o núcleo de processamento do MAXENT- cuja lógica de modelagem ecológica é inspirada na segunda lei da termodinâmica - a entropia - será utilizado para a modelagem, mas não sua interface original de entrada de dados e configuração de parâmetros (GUI).

O DISMO (Hijmans et al., 2010, 2011) e o BIOMOD2 (Thuiller, 2003) são pacotes de algoritmos de modelagem ecológica computacional executados exclusivamente por meio do ambiente de processamento em linguagem de programação " $R$ ". Esta linguagem é amplamente utilizada para análises estatísticas em todas as áreas do conhecimento, e sua aplicação e aceitação está em franco crescimento dentre os biólogos; portanto, merece atenção.

\footnotetext{
${ }^{8}$ Os dados utilizados nos testes foram obtidos exclusivamente via busca em uma base de dados na internet (GBIF) em caráter provisório, sem filtros de qualidade e continham apenas cerca de $30 \%$ da quantidade de registros em relação ao montante total utilizado nesta pesquisa. Mais detalhes estão disponíveis adiante neste capítulo.
} 
Apesar de ser necessário algum conhecimento de sintaxe da linguagem e noções de lógica de programação para ser possível rodar as análises, a execução de comandos em "R" por meio de scripts e com o suporte de pacotes de códigos prémontados torna o uso desta linguagem bastante simples quando comparado com a maioria das outras linguagens de programação.

A linguagem $R$ é uma versão de livre acesso da linguagem " $\mathrm{S}$ ", e conta com a acoplagem de semântica da linguagem Scheme, principalmente quanto ao formato (Lisp-1) e flexibilidade das funções (de primeira classe). Sua estrutura funcional é composta por camadas de funções sobre funções, que desenvolvem tarefas mais simples e que demandam menor processamento, mas quando o cálculo é pesado e as tarefas são complexas, 0 " $R$ " interage com códigos escritos em linguagens mais robustas e íntimas com os recursos computacionais como o C, C++ e Fortran.

É uma linguagem de programação interpretada, portanto não requer compilação de código a cada rodada. O script envia as informações para o interpretador, e este faz a tarefa de calcular e processar os dados em tempo real e interativamente com o computador.

Sua simplicidade de uso não reduz a qualidade e a diversidade dos recursos analíticos disponíveis por meio de acesso livre e gratuito de uma vasta variedade de pacotes. A plataforma $\mathrm{R}$ e seus pacotes possuem a premissa de serem desenvolvidos exclusivamente com licença pública e código aberto.

São inúmeras as vantagens de se desenvolver análises e modelos em " $\mathrm{R}$ ". Uma delas é agregar todos os processos de cálculo e avaliação dentro de um mesmo ambiente; até mesmo gráficos e mapas podem ser gerados e exportados em vários formatos por meio da plataforma (ex: JPG, PNG, PDF).

Além disso, o " $R$ " possui integração com outros softwares de uso difundido entre pesquisadores, por exemplo, o Statistica (Statsoft Inc., 2015) e o Excel (Microsoft Inc., 2015), por meio de pacotes de interação (ex: DCOM-R; Statcom, 2015). Também, há uma infinidade de pacotes de interação e exportação compatibilizando o " $R$ " com Sistemas de Informações Geográficas (GIS) de terceiros, simplificando e aprimorando as análises geoestatísticas e geoespaciais. Na verdade, o " $R$ " também é um Sistema de Informações Geográficas bastante robusto e sofisticado.

Outro benefício do " $R$ " é a capacidade de sua plataforma acessar alta taxa de recursos de processamento disponíveis no computador de forma controlada, e a possibilidade de serialização e paralelização das tarefas com uso de pacotes dedicados a isso como o snowfall (Jochen Knaus; The Comprehensive $R$ Archive Network), que acelera muito o processamento de grande quantidade de dados e tarefas.

Os dois pacotes " $R$ " de modelagem, BIOMOD2 e DISMO, possuem atualizações contínuas e desenvolvimento colaborativo por meio de grupos virtuais. Também possuem vasta variedade de algoritmos de modelagem (Tabela C3-1). O BIOMOD2 contém ao todo 10 algoritmos, um a mais do que o DISMO (9), e compartilham cinco. Os algoritmos exclusivos do BIOMOD2 possuem lógicas muito mais avançadas do que os algoritmos exclusivos do DISMO. Havia interesse em comparar as implementações dos algoritmos comuns em ambos e verificar qual proveria melhores resultados usando o mesmo princípio lógico. Por exemplo, comparar os modelos GLM gerados por cada pacote com os mesmos dados de entrada. Todavia, o pacote DISMO não havia sido citado nos 21 meses em pesquisas científicas indexadas no Scopus, já o BIOMOD2 fora citado 22 vezes. Desta forma, o BIOMOD2 e o MAXENT (executado 
através do BIOMOD2 via plataforma "R") foram selecionados para a realização dos modelos de adequabilidade de habitat.

Tabela C3-1. Algoritmos incluídos no BIOMOD2 e no DISMO

\begin{tabular}{|c|c|c|}
\hline Nomes dos Algoritmos & BIOMOD2 & DISMO \\
\hline Generalized Additive Models & $\checkmark$ & $\checkmark$ \\
\hline Generalized Boosted Models * & $\checkmark$ & $\checkmark$ \\
\hline Generalized Linear Models & $\checkmark$ & $\checkmark$ \\
\hline Maximum Entropy & $\checkmark$ & $\checkmark$ \\
\hline Random Forests & $\checkmark$ & $\checkmark$ \\
\hline Artificial Neural Networks & $\checkmark$ & $\cdot$ \\
\hline Classification Tree Analysis & $\checkmark$ & $\cdot$ \\
\hline Flexible Discriminant Analysis & $\checkmark$ & $\cdot$ \\
\hline Multivariate Adaptive Regression Splines & $\checkmark$ & $\cdot$ \\
\hline Surface Range Envelops (similar ao Bioclim) & $\checkmark$ & $\cdot$ \\
\hline Bioclim (similar ao Surface Range Envelops) & $\cdot$ & $\checkmark$ \\
\hline Domain & $\cdot$ & $\checkmark$ \\
\hline Mahalanobis & $\cdot$ & $\checkmark$ \\
\hline Support Vector Machines & $\cdot$ & $\checkmark$ \\
\hline
\end{tabular}

O BIOMOD2 pode gerar modelos utilizando até dez algoritmos simultaneamente em uma mesma tarefa de modelagem, sendo que nove são acessados por meio da integração com outros pacotes em linguagem " $R$ ", e um deles, o MAXENT, é executado por meio de interação (envio e recebimento de dados e parâmetros) com o aplicativo nuclear externo de mesmo nome, escrito em JAVA.

Cada algoritmo usa sua lógica particular para desenvolver seus modelos (referências sobre as lógicas usadas por cada algoritmo podem ser consultadas no Capítulo 4), mas todos recebem dois tipos de informações do BIOMOD2: o primeiro tipo são os dados das variáveis dependentes e independentes e o segundo, os parâmetros que definem o processo de modelagem e que serão usados pelos algoritmos para executar os modelos. Porém, há dois tipos principais de parâmetros: os parâmetros gerais, usados por todos os algoritmos igualmente, por exemplo, a fração de particionamento das ocorrências em subconjuntos de teste e treino; e os parâmetros específicos, que ajustam cada algoritmo individualmente conforme as necessidades particulares de cada um para gerar seus modelos; por exemplo, parâmetros de calibragem, ponto de parada das iterações, a profundidade e complexidade lógica do cálculo.

Os algoritmos usados pelo BIOMOD2 podem ser executados separadamente por meio de suas próprias implementações em distintos pacotes (ex: mda, glm, randomforest), mas as vantagens de rodá-los dentro de um único e integrativo pacote decorrem principalmente dos seguintes aspectos:

1) Em uma abordagem multi-modelos, pode-se enviar os mesmos $\mathrm{N}$ subconjuntos de presenças aleatoriamente particionados para treinar e testar os modelos, e os mesmos $\mathrm{N}$ conjuntos de pseudo-ausências que podem ser definidos ou gerados aleatoriamente. $O$ envio de dados em condições idênticas para cada algoritmo (e/ou rodada de modelagem) elimina hipóteses de vieses relacionados a ajustes e seleções diferenciadas nos dados de entrada, 
especialmente quando são aleatoriamente gerados/fracionados de forma automatizada pelo próprio pacote;

2) Avaliar e comparar modelos de forma padronizada em uma mesma tarefa de modelagem, pois as mesmas métricas, calibragens e parâmetros de avaliação são compartilhados entre as várias rodadas de modelagem. Assim, as avaliações (ex: ROC, TSS, KAPPA) mantém a equivalência métrica entre modelos gerados por distintos algoritmos e entre modelos gerados por diferentes rodadas do mesmo algoritmo;

3) Desenvolver $\mathrm{N}$ rodadas de modelagem com $\mathrm{N}$ algoritmos em um mesmo ambiente de aplicativo, o que aprimora a eficiência no uso de recursos computacionais, encadeando e serializando processos analíticos e reduzindo as redundâncias de arquivos usados e gerados (input e output);

4) Maior eficiência no processo de modelagem, tendo em vista que uma vez que os dados e parâmetros estão pré-definidos a modelagem decorre de forma automatizada e sequencial, não a obrigatoriedade do acompanhamento permanente do processo, disponibilizando tempo ao pesquisador para executar outras tarefas;

5) Padronização dos resultados armazenados em arquivos (nomes e extensões de arquivos, padrões de exibição dos resultados), que facilitam a organização, comparação e interpretação dos dados, reduzindo a probabilidade de erros posteriores ao processo de modelagem;

6) Os parâmetros específicos para cada algoritmo já estão calibrados previamente, ou seja, cada algoritmo foi testado, comparado e ajustado no BIOMOD2 de forma que os parâmetros originais alcançam resultados com qualidades equivalentes entre distintos algoritmos (são comparáveis) e precisos para a maioria das aplicações. Na verdade, estes parâmetros continuam sendo aprimorados por meio do compartilhamento de experiências entre usuários em grupos virtuais, e os ajustes e correções são difundidos por meio das atualizações do pacote.

\subsection{Obtenção de dados de ocorrência das espécies}

Para a construção da base de registros de ocorrências das espécies-alvo foram levantados inicialmente os principais tipos de fontes que poderiam ser exploradas na obtenção deste tipo de dado, encontrando-se cinco tipos principais, conforme segue:

A) Inventariação de registros armazenados em museus e coleções biológicas;

B) Obtenção de registros por meio de coleta de espécimes em campo;

C) Extração de coordenadas em formato numérico da literatura científica;

D) Estimação das coordenadas geográficas de mapas publicados em literatura científica;

E) Obtenção de dados por meio do estabelecimento de colaborações com pesquisadores;

F) Inventariação de dados primários de fontes não científicas.

Todos os tipos de fontes de dados e meios de obtenção foram explorados nesta pesquisa e proveram dados que contribuíram com o estudo. Adiante, cada tipo será abordado e seus resultados conjuntamente apresentados. 


\section{A) Inventariação de registros armazenados em museus e coleções biológicas}

A inventariação de dados já coletados provê grande quantidade de registros rapidamente, mas sua qualidade deve ser cuidadosamente avaliada por potencialmente conter registros de baixa qualidade que podem prejudicar a qualidade geral dos dados. Os registros de coleções e museus podem apresentar identificação incorreta ou imprecisa da espécie, que pode também decorrer do armazenamento inadequado, com a troca dos códigos de identificação. Algumas de suas coordenadas podem estar mal definidas em termos de padrões numéricos, levando a erros de geoposicionamento (ex: apontando lagos para uma espécie terrestre), ou ter baixa precisão de georreferenciamento $\left(-25^{\circ},-40^{\circ}\right)$, omitir ou apresentar sistemas de coordenadas mal definidas (Graus decimais, Grau 'minuto' segundo", UTM) e não exibir o sistema geodésico (ex: SAD69, WGS84, SIRGAS 2000). Alguns registros podem ser grosseiramente georreferenciados com o uso das coordenadas de cidades ou regiões onde foram coletados, e considerando que no Brasil temos municípios maiores que países inteiros - por exemplo, a área do município de Altamira no Pará cobre quase duas vezes a área de Portugal - o georreferenciamento por município poderá ser inútil para análises geoespaciais.

Atualmente já não é necessário que o pesquisador se desloque para cada museu e para cada coleção biológica quando sua necessidade é obter registros de presenças georreferenciadas de espécies, pois é crescente a disponibilidade deste tipo de dado em portais de internet dedicados precisamente a isso. Estes portais interligam bases de dados distribuídas de museus e coleções em todo o mundo por meio de serviços web (web services) e disponibilizam os dados aos usuários via website. Também agregam ferramentas de busca personalizada, filtragem, ordenamento e avaliação de qualidade dos dados. Por meio dos dados disponíveis nestes portais é possível obter informações que auxiliam no julgamento de cada registro, por exemplo, o nome do coletor e do identificador do espécime, o ano de coleta, a instituição e o código da coleção onde o espécime está depositado, o tipo de georreferenciamento, o padrão das coordenadas e muitos outros dados qualitativos.

O maior portal global de dados georreferenciados atualmente é o GBIF (Global Biodiversity Information Facility; GBIF, 2013), com cerca de 527 milhões de registros (março de 2015) de aproximadamente 1,4 milhões de espécies confirmadas pelo Catalogue of Life (COF, 2013). Também temos um portal brasileiro, o speciesLink (SPL, 2013), com cerca de 5,7 milhões de registros georreferenciados para aproximadamente 103 mil espécies (março de 2015).

Durante o processo de busca por fontes virtuais de registros de ocorrência, diversos portais foram encontrados e verificados. Uma parte destes trata especificamente de determinados organismos ou ecossistemas, por exemplo, o Biofresh Data Portal (BDP, 2013) que disponibiliza dados sobre espécies de água doce, também o Ocean Biogeographic Information System (OBIS, 2013) que disponibiliza dados para organismos marinhos. Outros são regionalizados, por exemplo, o Nature Serve (NS, 2013) que disponibiliza dados sobre a biodiversidade nos Estados Unidos e Canadá e o NaturData (ND, 2013) que trata da biodiversidade em Portugal. Também foi possível observar que uma razoável parte destas bases de dados estava interligada ao GBIF, e seus dados poderiam ser obtidos diretamente deste portal (GBIF, 2013). 
As bases de dados selecionadas para a obtenção de presenças de abelhas do gênero Bombus foram o GBIF (GBIF, 2013), speciesLink (SPL, 2013), The National Biodiversity Network (NBN, 2013) e Discover Life (DL, 2013). Estas quatro bases de registros foram escolhidas por proverem a maior quantidade de dados georreferenciados das espécies-alvo e que continham, para cada registro, dados adicionais que permitiam o julgamento de sua qualidade. Também são provedores com alta aceitação pela comunidade científica global, em constante aprimoramento e com ferramentas mais criteriosas para lidar com os registros. Por exemplo, o GBIF permite filtrar, durante a busca, os registros com coordenadas questionáveis (With NO known coordinate issues), excluindo registros que não foram avaliados em termos de coerência geográfica, ou que foram reportados por pesquisadores como incoerentes, ou ainda com padrões de dados numéricos e geográficos inconsistentes.

\section{B) Obtenção de registros por meio de coleta de espécimes em campo}

A obtenção de registros em campo na área de ocorrência nativa de Bombus terrestris seria financeiramente inviável e não era imprescindível. Os recursos destinados a esta pesquisa não seriam suficientes para uma amostragem que contribuísse significativamente com as análises, tendo em vista a imensa dimensão de ocorrência nativa da espécie, mas principalmente também perante a massiva quantidade de dados obtidos pelos meios virtuais, que supriu com alta qualidade as necessidades neste quesito (detalhes no item 3.3 deste capítulo).

Já a obtenção de registros de ocorrências invasivas da espécie, especialmente na área de maior interesse, a América do Sul, aprimoraria grandemente a qualidade da análise. Para tanto, foi planejado um estudo em campo com a observação da espécie em atividade (ex: interações da invasora com espécies nativas de plantas e abelhas) e coleta (cujos indivíduos seriam identificados e curados no país de origem) na região de San Carlos de Bariloche (Argentina) Esta região, onde a espécie invasora está em franca expansão invasiva, compreende o extremo norte da ocorrência conhecida da espécie América do Sul até este momento, portanto, a mais próxima ao Brasil. Este estudo em campo obteve suporte acadêmico do Prof. Dr. Lucas Alejandro Garibaldi (Universidad Nacional de Río Negro - UNRN; Bariloche, Argentina) e com a colaboração das especialistas sobre o processo invasivo de Bombus terrestris na Argentina, com diversas publicações sobre o assunto, Dra. Carolina Laura Morales (Universidad Nacional del Comahue) e Dra. Marina Arbetman (Universidad Nacional del Comahue). Entretanto, a coleta não pode ser realizada devido a atrasos na liberação de recursos financeiros. No entanto, uma imprescindível coleta em campo no Brasil foi concretizada, compreendendo três objetivos principais:

1) Averiguar a presença de Bombus terrestris na área ambientalmente adequada à espécie no Brasil em faixa próxima à fronteira com o Uruguai;

2) Coletar indivíduos das espécies do gênero Bombus nativas no Brasil que se distribuem pela mesma área;

3) Observar os recursos ambientais quanto à disponibilidade, tipo e potencial de uso por Bombus terrestris tendo como base na observação das atividades das outras abelhas nativas grandes (gêneros Bombus e Xylocopa). Os resultados deste último objetivo estão abordados no Capítulo 6 , quando se trata das observações e percepções gerais sobre o ambiente susceptível à invasão. 
A coleta em campo no sul do Estado do Rio Grande do Sul (RS) ocorreu durante o período de $24 / 10$ a $08 / 11$ de 2013 , compreendendo a primavera, que é um período de alta disponibilidade de recursos florais para as abelhas.

Para a melhor definição do trajeto e dos pontos de amostragem, foi feito um modelo preliminar ${ }^{9}$ de adequabilidade de habitat para delinear as áreas ambientalmente mais adequadas para Bombus terrestris na América do Sul, as quais também podem ser consideradas susceptíveis à invasão. Foram inicialmente estimados nove pontos de coleta, os mais equidistantes quanto possível, que cobriam a área susceptível à invasão no Brasil que foi detectada, mas também acompanhando a linha de fronteira com o Uruguai. Para a atribuição geoespacial dos pontos de coleta também foram consideradas as estradas e vias de acesso que permitiam alcançar as áreas mais próximas à fronteira, as quais foram verificadas por meio do aplicativo Google Earth (Google Inc., 2015).

Todavia, quando em campo, dois pontos não puderam ser acessados, pontos $F$ e $\mathrm{H}$ na figura C3-1, por conta da impossibilidade de circulação nas estradas de acesso. Estes pontos foram substituídos, respectivamente, pelos pontos E e G (Figura C3-1). O ponto $B$, inicialmente estimado no Uruguai, era de grande interesse, pois estava localizado a oeste da Lagoa Mirim, que poderia atuar como uma potencial barreira ao deslocamento da espécie invasora, dessa forma, a probabilidade de se encontrar Bombus terrestris neste ponto uruguaio seria maior do que na margem oposta, no lado brasileiro. Infelizmente, este ponto não pôde ser acessado devido ao carro usado na coleta ser oficial (IB-USP) e não poder cruzar fronteiras sem autorização prévia do governo federal, de forma que foi necessário substituí-lo pelo ponto $A$. $O$ ponto $D$ foi substituído pelo ponto $C$, que logisticamente era mais acessível e ambientalmente equivalente, sem comprometer a cobertura do terreno.

Durante o trajeto o GPS (Montana 650; Garmin, 2013) permanecia conectado a um notebook com o aplicativo OziExplorer (Des Newman, 2013) de forma que se podia acompanhar em tempo real e com visão ampla a área percorrida por meio de imagens aéreas (Google Earth; Google Inc., 2015), malhas municipais (IBGE, 2010), camadas de cobertura de solo (Arino et al., 2010), malha de estradas do TrackMaker (Geo Studio, 2013) e a camada do modelo preliminar. Isso permitiu que os pontos previamente planejados pudessem ser alcançados com máxima eficiência, bem como auxiliou na melhor seleção dos pontos de coleta substitutos, dando-se especial atenção àqueles locais que continham focos de vegetação, em oposição às imensas áreas com monoculturas.

Além dos cinco pontos previamente planejados e que foram alcançados (em coloração verde no mapa, Figura C3-1), e além dos outros quatro substitutos (não alcançados, em branco, e substitutos, em laranja), três outros pontos foram vistoriados (em amarelo): um ponto no município de Dom Pedrito-RS, devido a uma grande faixa de vegetação herbácea ricamente florida na beira da estrada; um ponto em Santana do Livramento - RS, em uma larga faixa de mata ciliar com algumas plantas herbáceas e arbustivas floridas; e um ponto na cidade de Herval-RS, devido à presença de fragmentos de vegetação florestal próximos uns dos outros e de razoáveis dimensões, que possuíam muitas flores, especialmente de um tipo de maracujá selvagem.

\footnotetext{
${ }^{9}$ O modelo preliminar seguiu método e parâmetros descritos no Capítulo 4, mas neste caso a geração de pseudo-ausências foi inteiramente aleatória e a seleção de modelos utilizou apenas a métrica TSS. Para mais detalhes consultar o Capítulo 4 considerando as exceções aqui descritas.
} 


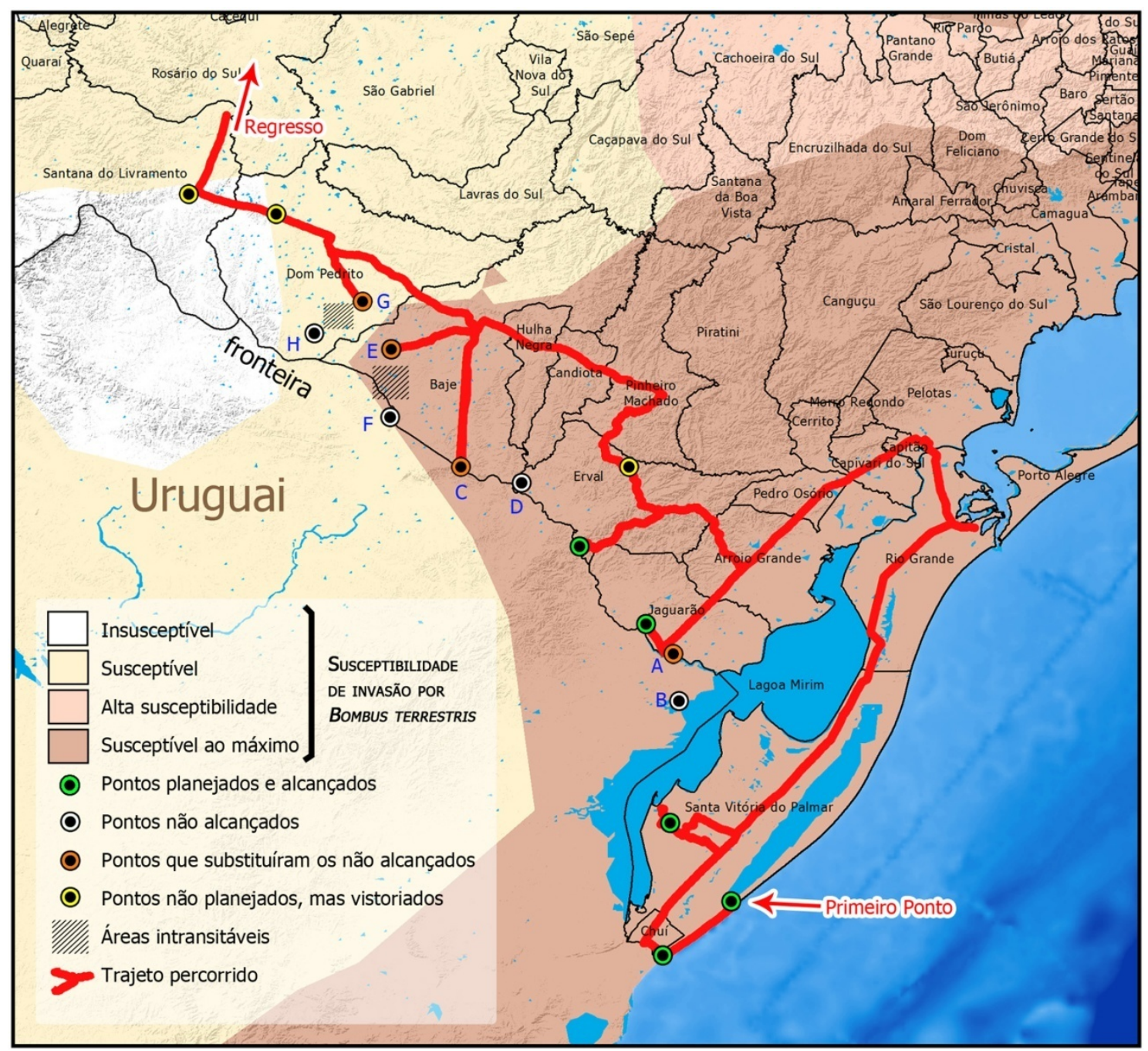

Figura C3-1. Trajeto de levantamento em campo (linha vermelha) e pontos de coleta. Em verde estão pontos do planejamento inicial e que foram efetivados. Em laranja estão os pontos não planejados, mas que foram amostrados em substituição daqueles não efetivados, em branco. Em amarelo são os pontos previamente não planejados, mas que foram inventariados extraordinariamente. Os hachurados em preto referemse às zonas que estavam inacessíveis e inviabilizaram o acesso aos dois pontos de coleta previamente planejados.

A coleta seguiu parâmetros flexíveis de vistoria em cada um dos 12 pontos amostrados, mas sempre cobrindo a dimensão de pelo menos $1 \mathrm{Km}^{2}$ (medida por GPS) em cada um deles por meio de trajetos em zigue-zague sobre a área circundante à coordenada geográfica de cada ponto. Cada ponto foi inventariado por cerca de 6 horas, iniciando-se a vistoria pela manhã, às 9:00 horas, com pausa entre as 12:00 e 14:00 horas. Foram priorizados os focos de elementos ambientais com maior quantidade de recursos úteis às abelhas, como flores, locais de nidificação, etc. Se na localidade precisa do ponto previamente definido não havia recursos (como aconteceu no primeiro ponto de coleta, pois estava atribuído sobre a faixa de areia da praia), buscava-se áreas mais próximas a ele que continham recursos aparentes (a partir deste primeiro ponto, em apenas cerca de 600 metros, uma faixa de restinga com recursos florais abundantes foi encontrada, com várias abelhas forrageando). 
No trajeto destacado em vermelho na figura C3-1 foram percorridos mais de $2500 \mathrm{Km}$, tendo em vista que além do caminho percorrido para se alcançar cada ponto, em muitos casos a conexão de um ponto com outro demandava voltar pelo mesmo caminho para acessar uma via que permitisse alcançar o próximo ponto. Durante vários momentos ao longo do trajeto foram feitas verificações visuais rápidas em moitas e arbustos floridos em beira de estrada durante alguns minutos em busca da presença de Bombus terrestris e das outras Bombus.

Embora as condições ambientais não estivessem ótimas para atividade externa das abelhas durante a maior parte do tempo e ao longo do trajeto, com temperaturas relativamente baixas (entre 10 e $26^{\circ} \mathrm{C}$ ), vento forte e contínuo, e alguns momentos de chuva, foi possivel obter seis novas ocorrências de abelhas nativas do gênero Bombus: 3 Bombus pauloensis (atratus), 1 Bombus bellicosus e 2 Bombus morio.

Deve-se ressaltar, já a partir deste momento, que não foi encontrado qualquer indivíduo de Bombus terrestris na área durante o período de levantamento. Apesar de não ter sido confirmada a presença da espécie invasora no Brasil, o levantamento feito não permite assegurar a sua ausência. Para tanto, levantamentos frequentes seriam necessários, especialmente em melhores circunstâncias ambientais e em maior quantidade de pontos de amostragem.

Como esta pesquisa não requer dados de abundância, pois para os métodos de análise a confirmação pontual da presença da espécie na área já é suficiente, apenas as abelhas de grandes dimensões físicas foram capturadas por meio de rede entomológica (Figura C3-2). Ao se capturar e observar um indivíduo na rede entomológica, quando havia indicações claras de que ele não pertencia ao gênero Bombus, ele era solto. Porém, quando houve dúvida sobre o gênero ou quando havia certeza de que pertencia ao gênero Bombus, o espécime foi coletado.

Ao todo, doze indivíduos foram coletados durante o trajeto, sendo que seis foram identificados como pertencentes ao gênero Bombus, como já citado. Todos os indivíduos foram curados conforme os padrões internacionais de coleções entomológicas e permanecerão depositados na Coleção Entomológica Paulo Nogueira Neto (CEPANN-IB/USP).

As abelhas pertencentes ao gênero Bombus foram identificadas pelo próprio pesquisador com o auxílio de um pesquisador experiente em identificar abelhas deste grupo: o Dr. Guaraci Duran Cordeiro. Quanto às outras abelhas, pôde-se assegurar por meio de características diagnósticas que não pertencem ao gênero Bombus, mas suas identificações específicas requerem confirmação por taxonomista. 


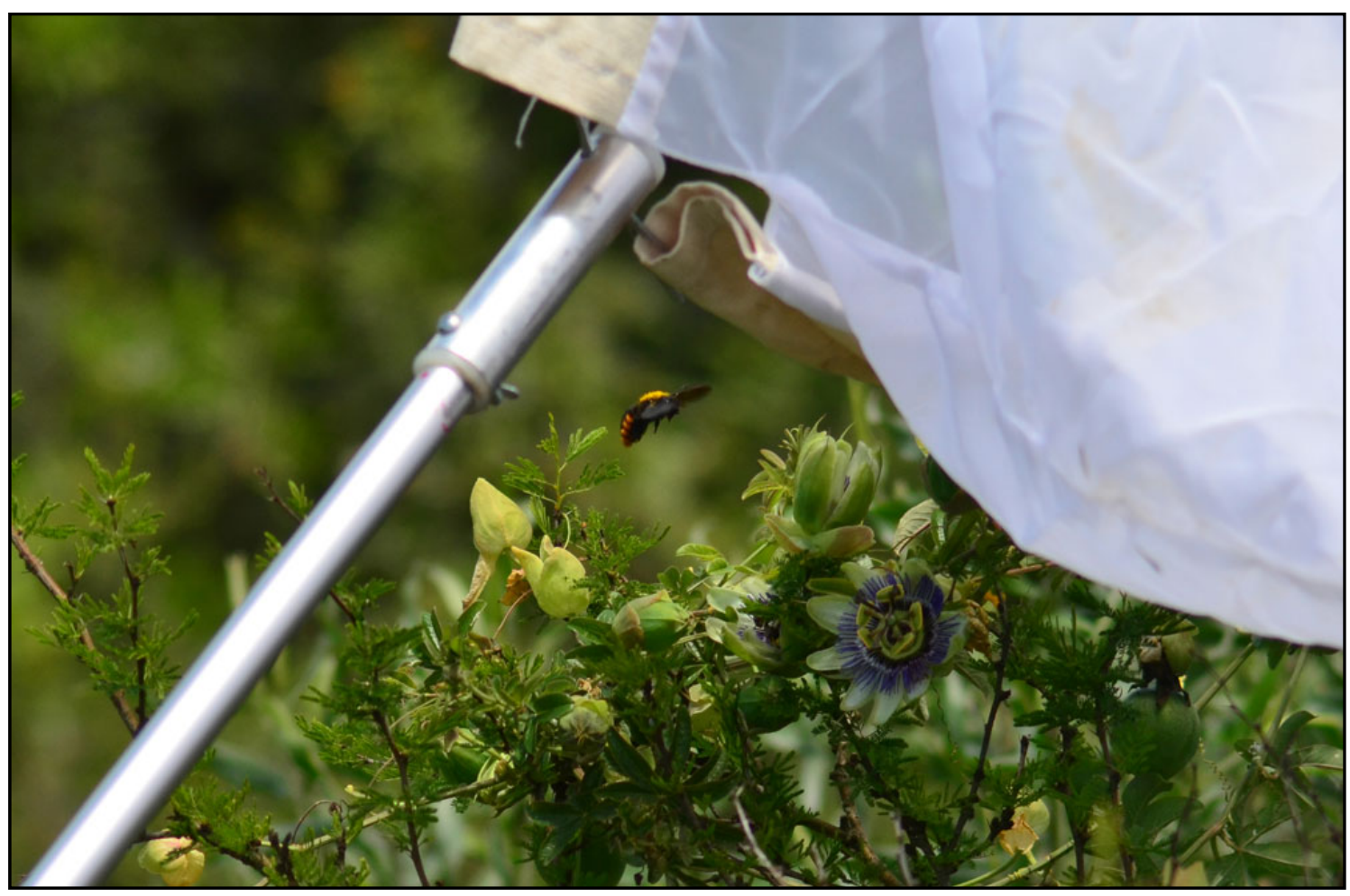

Figura C3-2. Procedimento de coleta com uso de rede entomológica.

\section{C) Extração de coordenadas em formato numérico da literatura científica}

Este procedimento ocorreu simultaneamente com o subsequente (item D) e envolveu o levantamento de publicações por meio de uma grande variedade de "indexadores" de publicações científicas, nomeadamente, Sciencedirect (2013), SpringerLink (2013), Scopus (2013), Scielo (2013), ISI Web of Knowledge (2013).

As buscas focaram-se no nome científico das espécies e foi necessária a inspeção visual de uma grande quantidade de trabalhos, seguindo-se seleção e extração de dados de cada uma delas. Uma vez que um conjunto de publicações foi selecionado, pois continham indícios de material útil e que podiam contribuir com registros e informações sobre as espécies, cada publicação foi qualificada por meio de avaliação com relação ao tipo de veículo de difusão. Por exemplo, se eram publicações nacionais ou internacionais, se eram revistas bem conceituadas com alto fator de impacto (JCR, 2013) ou com aparente boa qualidade, embora pouco conhecidas. Durante as inspeções, as publicações foram fracionadas em três tipos: 1) com dados numéricos de coordenadas; 2 ) sem dados numéricos de coordenadas, mas com mapa exibindo as posições geográficas; 3 ) com registros com referência de localidades, mas sem dados numéricos nem mapas. O segundo e terceiro tipo foram separados e o processo está detalhado no próximo item (D). As publicações com dados numéricos foram processadas conforme a exposição das coordenadas no texto.

Quando as coordenadas estavam em tabelas dentro de arquivos do tipo PDF (Portable Document Format; ISO, 2008) não bloqueados por senha para evitar a cópia, elas foram selecionadas, copiadas e diretamente transferidas para uma planilha. Quando o arquivo estava bloqueado, as coordenadas foram manualmente digitadas na planilha. Em ambos os casos procurou-se referências quanto ao tipo de coordenada geográfica, mas na maioria das publicações esta informação não estava explícita ou 
mesmo não existia. Quando não havia indicações, por meio de inspeção visual presumiu-se um tipo e um padrão de coordenadas (ex: WGS84), e então os registros foram exibidos em ArcGIS (ESRI, 2010) conjuntamente com as malhas políticoadministrativas do GADM (Global Administrative Areas; GADM, 2012) e do IBGE (Instituto Brasileiro de Geografia e Estatística; IBGE, 2010). Foram procuradas referências de municípios para cada registro ao longo do corpo do texto; os registros cujas coordenadas casavam com o município declarado no corpo do texto, validavam, ao menos parcialmente, o padrão de coordenadas presumido.

Quando além das coordenadas numéricas havia também mapas exibindo-as, estas imagens foram importadas para dentro do ArcGIS e georreferenciadas com a ferramenta Georeferecing tool, de forma que os registros pudessem ser cruzados com os pontos no mapa, também validando o padrão presumido. Quando os registros não combinavam, presumia-se um novo padrão de coordenadas e repetia-se o processo. Não houve casos de insucesso neste processo.

D) Estimativa das coordenadas geográficas de mapas publicados em literatura científica

Nos casos de artigos que não continham coordenadas numéricas, mas possuíam mapas exibindo as ocorrências, foi necessário extrair o mapa do arquivo original e georreferenciá-lo. O procedimento envolve o uso de três aplicativos: o primeiro é o Adobe Acrobat Pro (Adobe, 2005) que permite editar o arquivo PDF e exportar a figura do mapa na resolução original, o qual é transferido para o segundo aplicativo; o Adobe Photoshop CS4 (Adobe, 2005). Neste, todas as informações desnecessárias são apagadas e o fundo do mapa é selecionado e excluído, deixando-se apenas os pontos dos registros, pontos de referência (ex: localização de sede de reservas ambientais, sedes municipais), os contornos (ex: lagos, tipos de vegetações) e as linhas (ex: grades geográficas, trópicos, estradas) que são imprescindíveis para o georreferenciamento. O mapa com fundo transparente em formato PNG de 24 bits (Portable Network Graphics; ISO, 2004) e com apenas as informações úteis foi primeiramente importado para o Google Earth (Google Inc., 2015) com uso da ferramenta Add Image Overlay e ajustado aos elementos geográficos exibidos pelo software (contorno municipal, locais, corpos d'água, etc.). Quando o mapa combinava precisamente com o contexto do fundo, as coordenadas dos pontos foram extraídas. Nos casos em que o mapa não pode ser precisamente ajustado no Google Earth, devido a diferenças na projeção cartográfica, foi necessário importá-lo para o ArcGIS e georreferenciá-lo com a ferramenta Gereferencing Tool com uso de camadas auxiliares (ex: contorno de municípios). O processo consumiu bastante tempo, mas contribuiu com dados imprescindíveis para as análises, principalmente as ocorrências invasivas de Bombus terrestris.

E) Obtenção de dados por meio do estabelecimento de colaborações com pesquisadores

Por meio de contatos e estabelecimento de parceiras é possível obter registros ainda não publicados que ampliam a abrangência geográfica da espécie estudada, pois, os pesquisadores tendem a fazer levantamentos em locais que ainda não foram 
previamente vistoriados. Mas, além disso, especialistas nas espécies ou nos grupos estudados podem prover importantes informações e sugestões para o estudo, de uma forma geral. Assim, através do estabelecimento de contatos foram obtidos 8 novos registros pertencentes à base de dados da Profa. Dra. Betina Blochtein da Pontifícia Universidade Católica em Porto Alegre - RS para as espécies de Bombus nativas no sul do Brasil. Mas, além disso, foi possível consolidar uma parceria que auxiliou no desenvolvimento de outras etapas fundamentais da pesquisa, que estão descritas no Capítulo 6.

\section{F) Inventariação de dados primários de fontes não científicas}

Dados primários são informações que ainda não foram trabalhadas e retrabalhas, portanto estão em sua forma primária (bruta) desde a obtenção. Provedores deste tipo de dado se enquadram em uma grande variedade de fontes, desde fotografias georreferenciadas das espécies (ex: flickr.com, panoramio.com), impressos de propaganda que exibem informações sobre organismos, até coletas e observações desenvolvidas por apaixonados por determinados grupos biológicos e hobbistas, como observadores de aves e colecionadores de borboletas, por exemplo. As fontes de dados primários não científicos devem ser questionadas a priori, e só poderão ser usadas se houver muita segurança por parte do pesquisador que as informações de fato são confiáveis e imprescindíveis.

A seleção de fontes deste tipo de dado iniciou-se pela busca indiscriminada na internet de tudo que se referia às espécies estudadas, tomando como base seus nomes científicos e populares. Logo no início foram encontrados problemas evidentes de identificação, sugestões de nomes das espécies que não casavam com a imagem (abelha errada), fotografias geoposicionadas de uma espécie em locais nunca relatados com a presença da mesma, e assim por diante. Devido à insegurança em relação a esses dados e ao fato de não serem imprescindíveis, decidiu-se não usar essas fontes primárias nesta pesquisa, com apenas uma exceção, o projeto de monitoramento participativo Seiyou Busters no Japão. Esse projeto é liderado por pesquisadores da Universidade de Tóquio em colaboração com National Institute of Informatics (NII, 2012), e creditado pelo National Institute for Environmental Studies (NIES, 2012). Todas estas instituições estão ligadas ao governo do Japão.

Essencialmente este é um projeto de ciência cidadã, no qual aos sábados e domingos um grupo de pessoas com tempo livre (a maioria formada por não cientistas) circula pela ilha de Hokkaido no Japão em busca da espécie invasora Bombus terrestris, e capturam imagens e as coordenadas dos locais de avistamento de indivíduos da espécie. As coordenadas são transferidas para a base de dados em seu site oficial (www.seiyoubusters.com) e os participantes planejam conjuntamente por meio da rede social Twitter (twitter.com/seiyoubusters) e outras redes sociais, as regiões aonde irão ao próximo fim de semana, de forma que possam se encontrar no local e planejar a cobertura mais adequada da área, mas também para fazer "piquenique" e conversarem. A cada ano os pesquisadores líderes do projeto compilam os dados e publicam um relatório denominado Seiyou Status, e isto tem acontecido desde 2010.

Tendo em vista a existência de treinamento dos coletores por pesquisadores da universidade, inclusive com a divulgação de cartilhas de identificação para serem 
levadas ao campo, mas também devido à revisão dos dados coletados por especialistas, esta fonte de dados pode ser considerada segura e foi usada. Foram baixadas as ocorrências de Bombus terrestris no ano de 2012, provendo um bom número de registros para a ilha de Hokkaido.

\subsection{Avaliação e consolidação dos registros para a base de dados}

Uma vez que todas as fontes tinham sido inventariadas e seus dados coletados, as planilhas individuais foram importadas para ArcGIS (ESRI, 2010) e combinadas em uma única camada (shapefile) de pontos. Colunas foram geradas para discriminar a espécie, as fontes dos dados, as coordenadas e outros dados relevantes para cada registro individual (correspondentes às linhas). As ocorrências de Bombus terrestris foram cruzadas com a malha de fronteiras político-administrativas do Global Administrative Areas (GADM, 2012) de forma a identificar os países onde cada registro se localizava. Com base na literatura (consultar Capítulo 4), estas ocorrências foram discriminadas em dois grupos quanto ao tipo de ocorrência reportada: nativa ou invasiva (Figuras C3-3 e C3-4). Na figura C3-5 pode-se verificar o total de registros por fonte de dados para as espécies nativas do gênero Bombus que se distribuem no sul do Brasil. As referências das publicações vistoriadas que proveram dados de ocorrência de Bombus terrestris podem ser consultadas no material suplementar (S.1) do Capítulo 4.1.

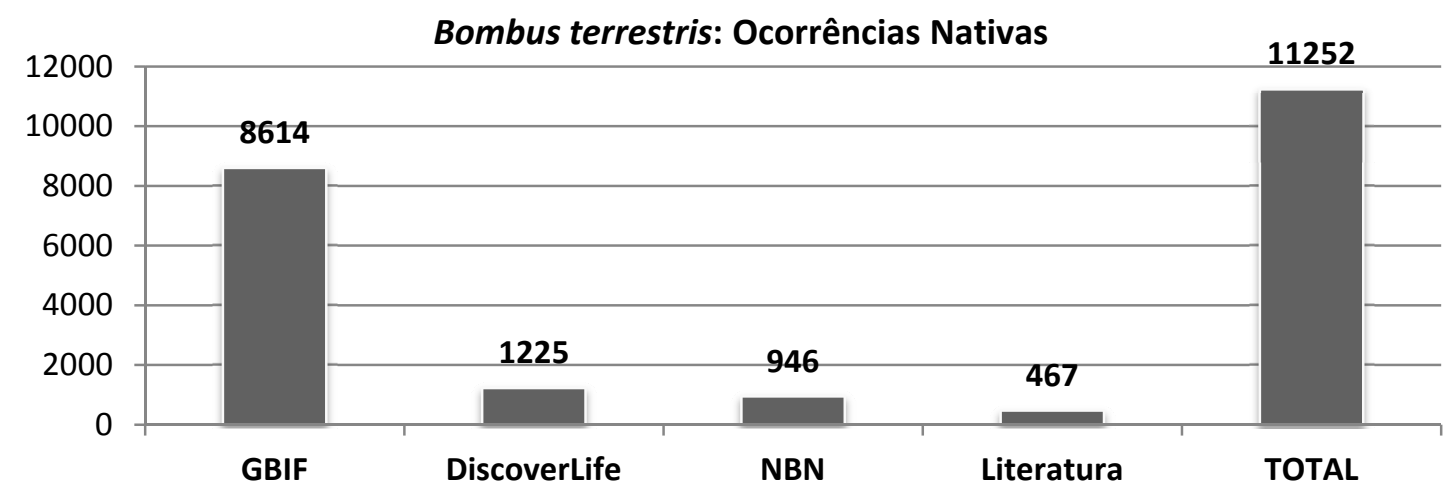

Figura C3-3. Dados brutos de Bombus terrestris em ambiente nativo.

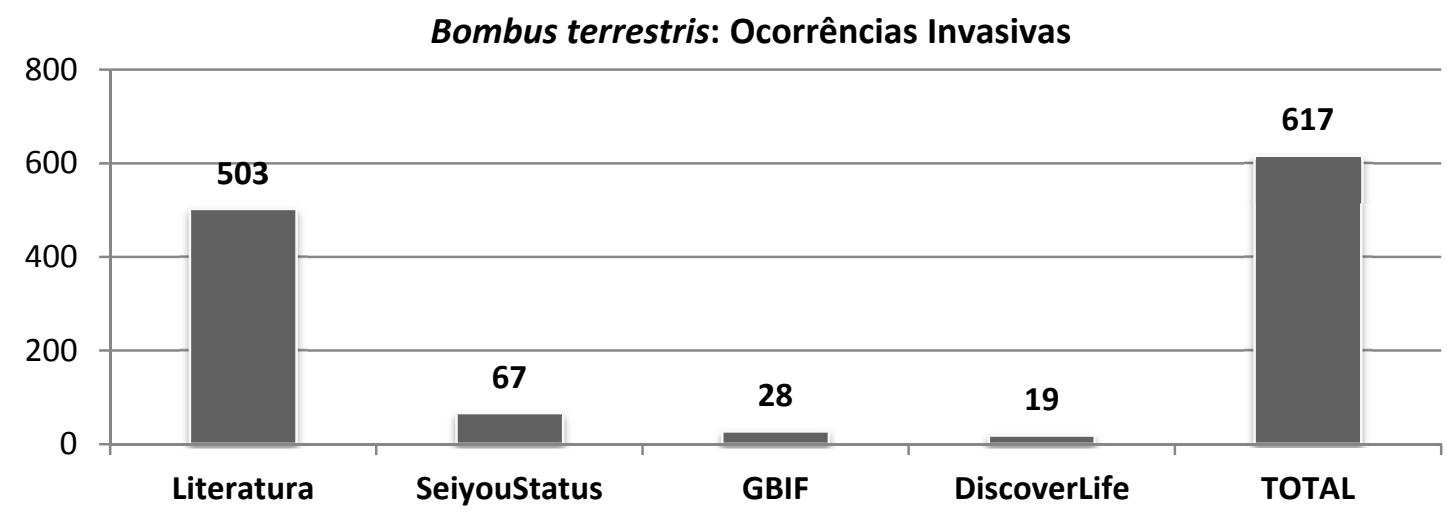

Figura C3-4. Dados brutos de Bombus terrestris em ambiente invadido. 


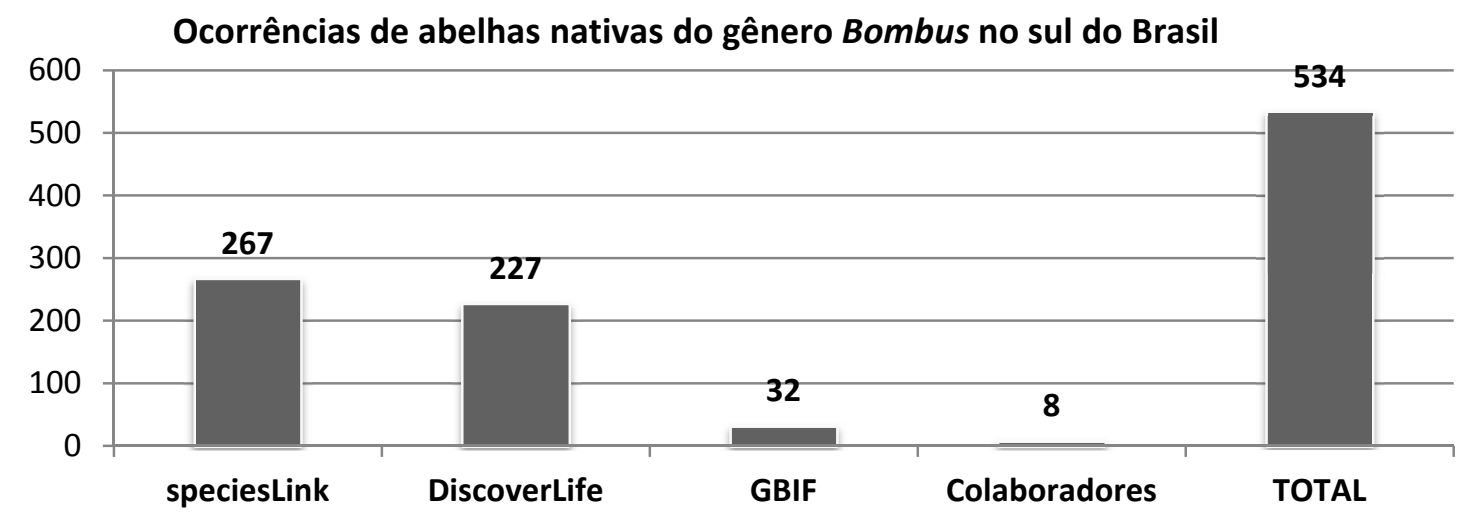

Figura C3-5. Dados brutos das espécies de Bombus que se distribuem no sul do Brasil: B.brasiliensis; B.bellicosus; B. morio; B.pauloensis (B.atratus).

As principais análises usadas nesta pesquisa podem ser prejudicadas pelo acúmulo de dados sobre as mesmas unidades geográficas das camadas ambientais, podendo reduzir a qualidade dos resultados se esta influência não for previamente anulada.

No caso da modelagem, os valores de cada variável ambiental que coincidam espacialmente com as presenças da espécie só poderão ser repetidos nos casos em que as posições de diferentes indivíduos da espécie ocorram sobre diferentes unidades espaciais que, por um acaso, exibem o mesmo valor ambiental. $\mathrm{O}$ acúmulo de valores repetidos resultante do empilhamento de registros sobre as mesmas unidades espaciais (células das camadas ambientais) gera artificialmente maior peso estatístico para um determinado valor ou intervalo de uma mesma variável ambiental, ou ainda, maior peso para uma variável ambiental em relação às outras variáveis. Porém, este acúmulo não corresponde à maior preferência da espécie por estas características ambientais mais recorrentes, mas apenas a um viés de amostragem.

No caso da análise ecogeográfica, o número de indivíduos reportados em uma mesma localidade poderia ser uma informação útil, pois se poderia sugerir que a maior porcentagem de presença em determinado espaço acontece devido aos valores ambientais mais favoráveis que são apresentados à espécie em comparação com outros locais com menor porcentagem. Mas se deve considerar que, perante a diversificada origem dos registros de ocorrência na base de dados, o acúmulo de registros na abrangência de uma mesma unidade espacial (ex: células com 10 x $10 \mathrm{~km}$ ) poderá decorrer de uma mesma coleta feita por armadilhas, que capturam vários indivíduos em um mesmo ponto. Ou por distintas coletas feitas em diversos momentos, por diferentes pesquisadores com variáveis métodos e esforços de amostragem. Ademais, o acúmulo de registros sobre diferentes unidades ambientais também não decorrem de métodos uniformemente padronizados de coleta e esforços amostrais. Portanto, estes dados repetidos não indicam, de fato, a abundância ecológica e não sugerem a maior preferência da espécie para determinados valores ambientais.

A repetição irreal de valores ambientais modifica as tendências centrais da distribuição dos dados (mediana e percentis), enviesando a definição dos intervalos ambientais mais favoráveis à espécie. Para eliminar este viés foi necessário tornar binária a presença/ausência da espécie por unidade espacial de valor das camadas 
ambientais. Para tanto, foi necessário gerar em ArcGIS (ESRI, 2010) uma camada (shapefile) matricial (fishnet) com células quadradas e contíguas compreendendo a extensão global e com dimensões celulares idênticas as das camadas ambientais ( 5 minutos de arco; detalhes no item seguinte). Por meio das funções spatial join e field calculator, as células da matriz que coincidiam geoespacialmente com pelo menos um registro de indivíduos recebeu o valor "1", aquelas que não coincidiam receberam valor " 0 ".

As coordenadas dos centroides das células da camada matricial binária foram extraídas e com elas foi gerada uma nova base de ocorrências, mas que agora contém valores binários " 1 " indicando presença e " 0 " indicando a "potencial" ausência ou pseudo-ausência (Figura C3-6).

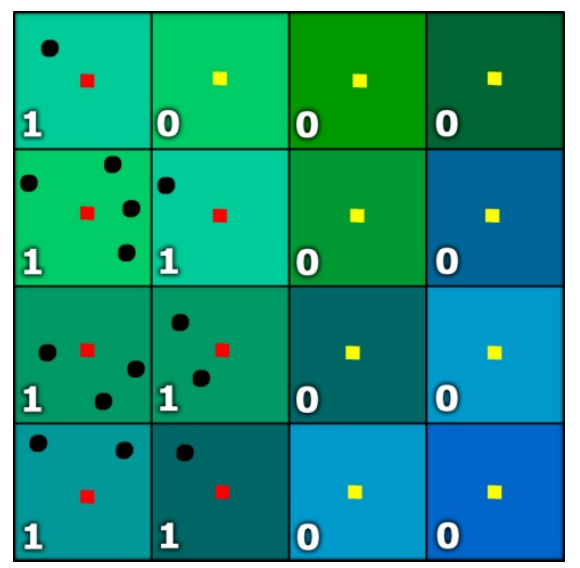

Figura C3-6. Esquema gráfico do procedimento de "binarização" dos registros de ocorrência. As células da matriz binária que coincidiam com um ou mais registros da espécie (os pontos pretos) receberam valor binário " 1 ", aquelas sem registros coincidentes receberam " 0 ". Após este procedimento, foram extraídas as coordenadas dos centroides celulares (os pontos quadrados), os quais carregaram consigo a latitude, a longitude e o valor binário 1 (pontos quadrados em vermelho) e binário 0 (pontos quadrados amarelos) para a construção da nova base de ocorrências. As cores das células exibem a variação de uma camada ambiental hipotética evidenciando a perfeita sobreposição entre a matriz binária (quadrículas em preto) e as células das camadas ambientais (as cores). Embora ocorra um sutil deslocamento do geoposicionamento das ocorrências dentro da abrangência celular, isto em nada interfere na análise, pois as camadas proveem apenas um único valor ambiental por célula.

A filtragem dos dados de ocorrência após a "binarização" é imprescindível para garantir a qualidade das análises. O primeiro passo foi a exclusão das presenças que coincidiam geoespacialmente com a classe referente aos corpos d'água (ex: oceanos, mares, rios, lagos) da camada de cobertura de solo Globcover 2009 (detalhes sobre as camadas estão no item seguinte), tendo em vista a abelha não ocupar ambientes aquáticos. Em seguida, as ocorrências que se posicionavam fora da abrangência das camadas ambientais também foram excluídas, pois não proveriam valores ambientais para as análises. Para esta filtragem foi utilizada a camada de temperatura média anual (Bio 1; Tabela C3-2) como referência espacial (Hijmans et al., 2005).

O processo de avaliação também requer o julgamento por inspeção visual dos geoposicionamentos incoerentes ou duvidosos das ocorrências, tendo como subsídio o conhecimento disponível sobre a espécie. Por exemplo, foram encontradas e excluídas duas ocorrências de Bombus terrestris posicionadas em zonas muito áridas e quentes do Sahara. Outros registros que estavam posicionados em países onde não havia relatos na literatura (Referências no Capítulo 4) sobre a ocorrência nativa ou invasiva da espécie também tiveram seus registros excluídos, como por exemplo, as ocorrências nos Estados Unidos. Os extremos máximos e mínimos na análise 
ecogeográfica são muito sensíveis à falta de precisão dos dados, por exemplo, um único ponto incorreto de Bombus terrestris no Sahara elevará o extremo máximo de temperatura adequada para toda a espécie para valores erroneamente altos.

Após o procedimento descrito acima, a base de dados estava ajustada, filtrada e pronta para as análises. Isso se deu com a perda de uma expressiva quantidade de registros, mas com um significativo acréscimo de qualidade. As figuras C3-7 e C3-8 exibem a quantidade de registros na base de dados após avaliação, respectivamente para a Bombus terrestris e para as espécies do gênero Bombus que ocorrem no sul do Brasil.

A figura C3-9 permite verificar geoespacialmente a cobertura dos registros de ocorrência de Bombus terrestris após filtragem em escala global. Considerando-se a grande quantidade de registros, que inviabilizaria a adequada verificação visual das localidades de ocorrência da espécie no espaço geográfico se os pontos fossem exibidos com grandes dimensões no mapa. Foi calculado o total de pontos coincidentes em cada país, permitindo a melhor verificação da cobertura das ocorrências. Para auxiliar a referência geoespacial dos tipos de ocorrências (nativas e invasivas) e suas regiões específicas, atribuiu-se identificações para quatro quadros que abrangem as ocorrências da espécie em diferentes regiões do planeta (Figura C39). O quadro denominado de "EU" abrange as ocorrências da espécie em sua área nativa, o quadro denominado "JP" abrange as áreas invadidas no Japão, o quadro "NZT" abrange as áreas invadidas na Nova Zelândia e na Tasmânia (Austrália) e o quadro "SA" abrange a área focal mais importante do trabalho, a região do cone sul da América do Sul, que cobre as localidades invadidas neste continente, mas também uma grande área adjacente que poderá ser invadida pela espécie. Estes quadros serão usados ao longo de toda a pesquisa como referência geoespacial das diferentes áreas focais de estudo.

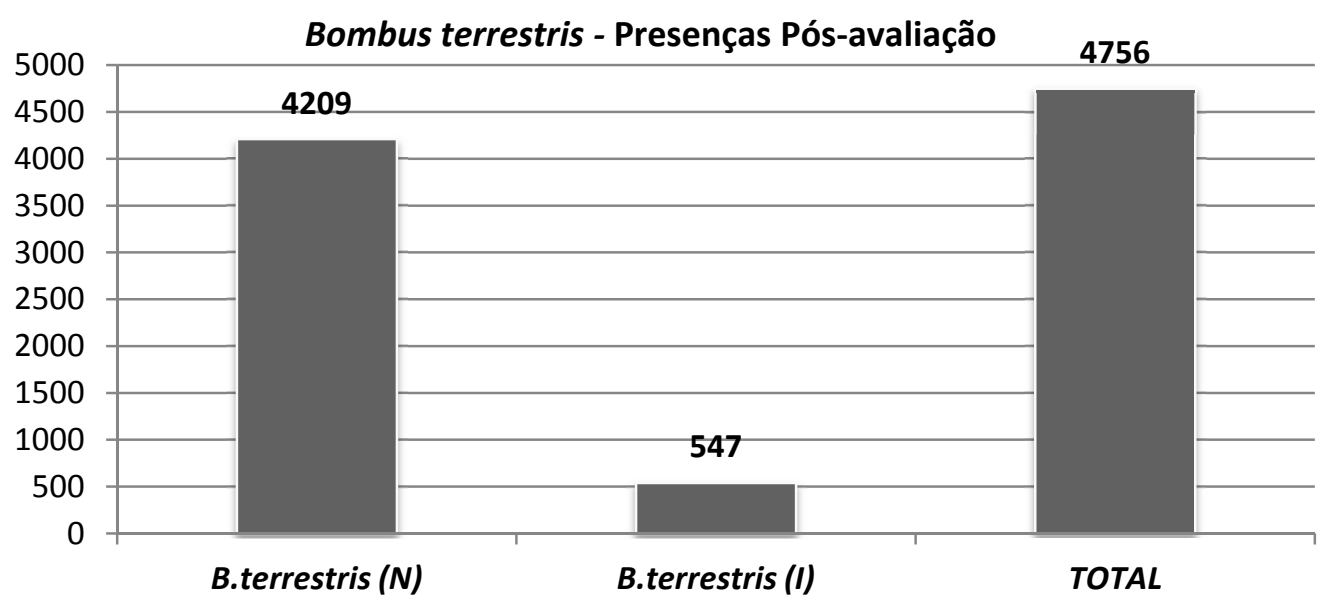

Figura C3-7. Quantidade de registros de presença de Bombus terrestris em área de ocorrência nativa (N) e invasiva (I) após avaliação. 


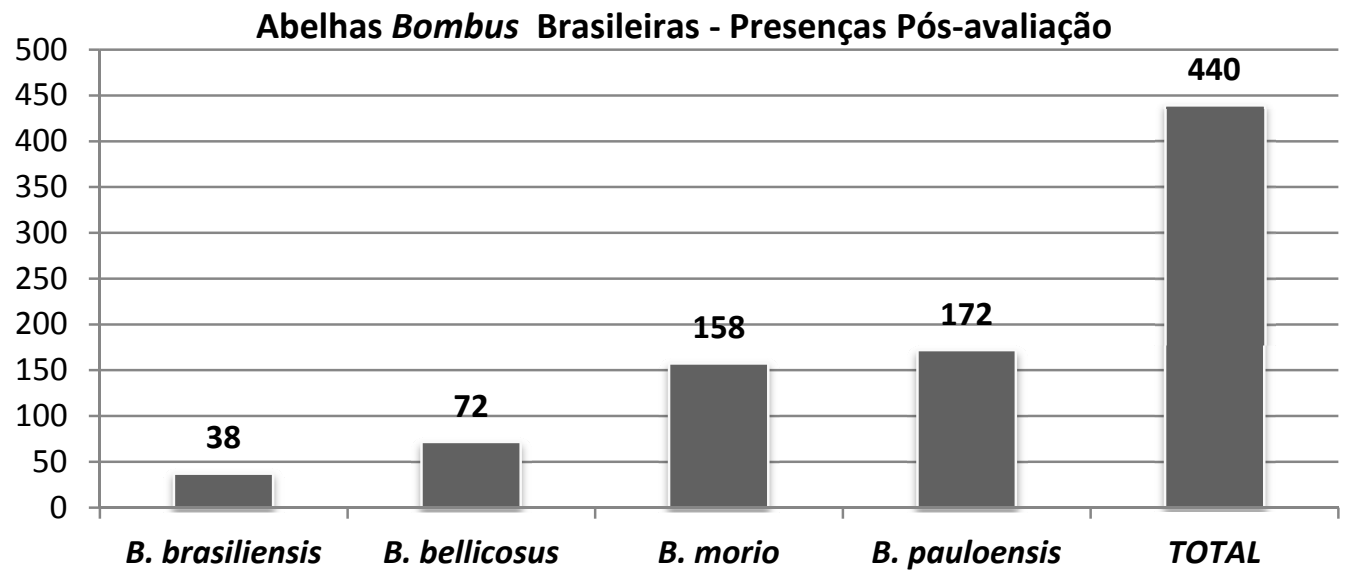

Figura C3-8. Quantidade de registros de presença das espécies nativas do gênero Bombus que ocorrem no sul do Brasil após avaliação.

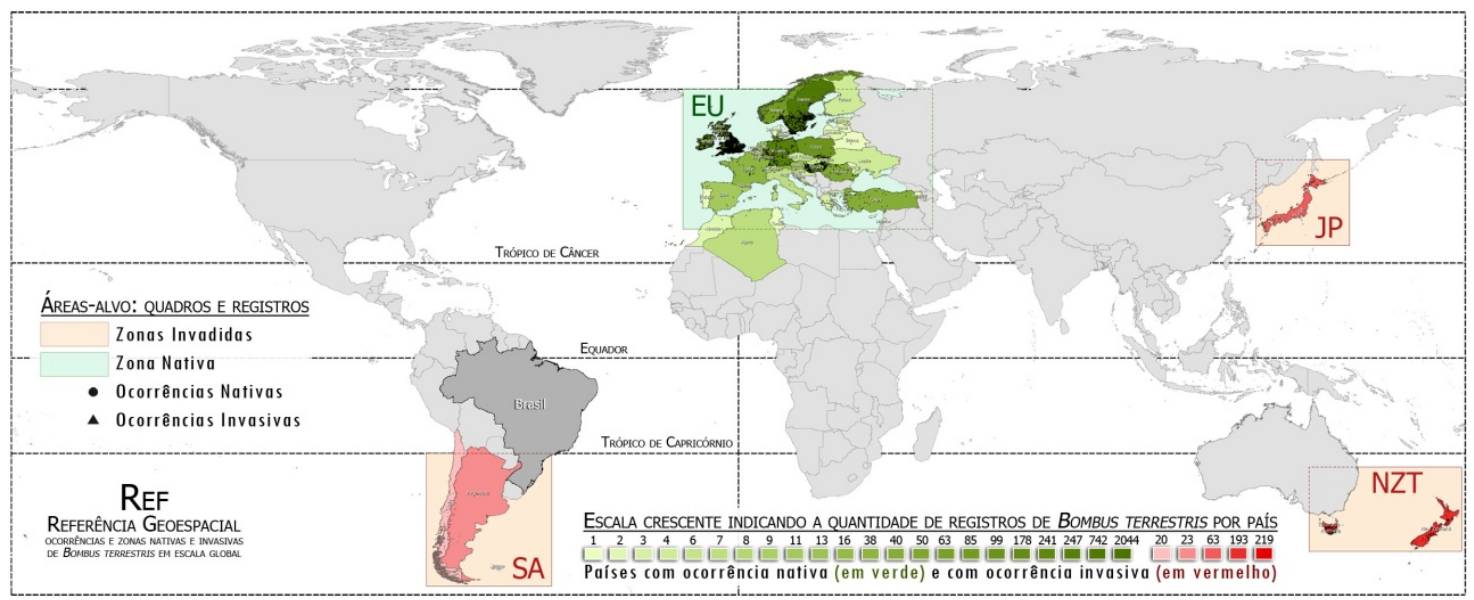

Figura C3-9. Referência geoespacial da cobertura dos registros de ocorrências de Bombus terrestris em escala global e as quatro áreas focais evidenciadas pelos quadros: SA, EU, JP e NZT.

\subsection{Obtenção de dados ambientais digitalizados}

A obtenção das variáveis mais adequadas é essencial para aumentar a precisão dos modelos de adequabilidade de habitat (Hirzel e Lay, 2008; Guisan et al., 2000; Manly et al., 2002). Conforme já abordado, os fatores abióticos são os mais significativos em análises que consideram uma ampla dimensão espacial para explicar aspectos ecológicos que se manifestam em resolução menos fina (Soberón, 2007, 2010; Peterson e Soberón, 2012).

Os fatores abióticos são categorizados em três tipos de variáveis: a bioclimática (ex: precipitação, temperatura, índices bioclimáticos), a geofísica (ex: relevo, elevação, aspecto, radiação) e a edáfica (ex: tipo de solo, $\mathrm{pH}, \%$ de carbono). Para Bombus terrestris, que é um organismo terrestre e altamente móvel, a conjuntura de determinadas variações bioclimáticas e geofísicas exercem maior influência em sua ocupação espacial do que as edáficas, as quais são particularmente mais influentes em organismos sésseis ou que utilizam o solo diretamente como recurso, tais como as plantas, os fungos do solo e os organismos subterrâneos, como alguns anelídeos, por exemplo. 
A Bombus terrestris requer solo para nidificar, portanto este é um aspecto relacionado a um fator edáfico. Todavia, a influência das características do solo neste caso está apenas indiretamente relacionada à espécie, pois não são seus indivíduos que escavam as cavidades para a construção da colônia, mas outras espécies pertencentes ao grupo das aves e dos roedores, por exemplo. A rainha já acasalada se enterra no solo para a diapausa, no entanto, as informações edáficas disponíveis em formato digital (ex: HWSD, 2009) não incluem características da superfície do solo que possam ser relacionadas com alguma preferência da espécie neste sentido, tendo em vista a superficialidade do seu hibernáculo. As camadas superficiais do solo sofrem intemperismos de forma permanente (ação do sol, vento, neve, chuva) que alteram sua composição e estrutura em relação às camadas mais profundas. Também não há dados disponíveis sobre a serapilheira, que poderá ser bastante espessa em ambientes nativos da espécie, como nas florestas de coníferas onde o solo poderá ser coberto por uma espessa e compacta camada de folhas aciculares entrelaçadas, e que poderá ser usado pela espécie como um abrigo para a diapausa (Sladen, 1912).

Dentre as características geofísicas, o elemento topográfico que pode ser considerado altamente influente para a espécie é a altitude, especialmente em termos de limitação à sua ocorrência em determinadas escalas elevadas. Isso se dá não apenas por conta da menor concentração de oxigênio em altas altitudes (que prejudica os processos metabólicos), e da menor densidade do ar (que prejudica a atividade de voo), mas também por conta das temperaturas mais baixas, do excesso de vento e da menor disponibilidade de recursos para forrageamento, hibernação e nidificação.

A angulação e a irregularidade do relevo poderão ter também alguma influência micro-climática nos indivíduos e especialmente nas colônias. Por exemplo, se a face do solo é voltada para um determinado ponto cardeal, ela receberá maior ou menor incidência solar, aquecendo mais ou menos a colônia neste local em determinado período do ano. Mas, nada foi encontrado nas publicações sobre a espécie que subsidiasse o estabelecimento desta relação.

O clima pode ser considerado de elevada influência para Bombus terrestris bem como para praticamente todos os organismos do planeta -, pois além de influenciar na fisiologia dos indivíduos, influencia a conjuntura de organismos existentes nos ambientes ocupados pela espécie e, consequentemente, na disponibilidade de potenciais recursos (ex: alimentação e nidificação) e interações (ex: plantas, predadores, doenças).

Tendo este aspectos supracitados em consideração, foram selecionados quatro conjuntos de camadas climáticas para o desenvolvimento das análises, dentre os quais, dois grupos que consideram o clima atual (variações e médias mensais e anuais dos cinquenta anos entre 1950 e 2000) e dois que consideram duas diferentes estimativas para o clima na década de 2050 (Tabela C3-2).

As camadas bioclimáticas e climáticas em cenário atual e uma camada de altitude foram obtidas do Worldclim (Hijmans et al., 2005), que disponibiliza as camadas climáticas de mais alta qualidade até o momento, e todas na resolução de 5 minutos de arco, que é equivalente a células de aproximadamente $10 \times 10 \mathrm{~km}$ quando próximas ao equador. Uma das camadas bioclimáticas exibindo a Variação Anual da Precipitação em cenário atual (Bio20; Tabela C3-2) foi gerada pela subtração das bioclimáticas dos extremos de precipitação BIO13 e BIO14. 
As camadas de cenários climáticos futuros foram obtidas do Climate Change, Agriculture and Food Security por meio de seu portal de dados (CGIAR-CCAFS, 2015). Suas características e referências metodológicas gerais são as seguintes: Método de downscaling do tipo DELTA; cenários de concentrações RCP 4.5 e 6.0 para a década de 2050; modelo desenvolvido em 2015 pelo Goddard Institute for Space Studies da National Aeronautics and Space Administration (NASA); em extensão global com exceção do continente Antártico e ilhas em latitudes mais a sul do que $60^{\circ}$; também em resolução de 5 minutos de arco, que equivale a células aproximadamente de 10×10 km quando próximas ao equador (Tabela C3-2). O processo de seleção das fontes de camadas futuras - dentre a grande variedade disponível - está descrito no próximo item.

Para a modelagem de adequabilidade de habitat foram usadas oito camadas climáticas atuais (Bio 2, Bio5, Bio7, Bio13, Bio14, Bio15, Bio18, Bio19) e as mesmas oito variáveis respectivas foram extraídas dos dois conjuntos de camadas de clima futuro e usadas na projeção do modelo de adequabilidade de habitat para potenciais climas futuros (RCP 4,5 e 6,0). A camada de altitude (Alt; Tabela C3-2) foi usada tanto na projeção atual como nas futuras, pois sua variação é indiferente nesta faixa temporal, entre 2000 e 2050. Os motivos da seleção destas variáveis dentre o conjunto total está descrito no método do Capítulo 4, sobre a modelagem.

Para as análises ecogeográficas foram usados os conjuntos integrais de camadas climáticas e bioclimáticas em cenário atual, mais a altitude e outras duas camadas adicionais:

A) Camada de aridez global anual Global Aridity Index foi obtida do Consultative Group on International Agricultural Research - Consortium for Spatial Information (CGIAR-CSI, 2015) na resolução de 30 segundos de arco, com células correspondendo aproximadamente $1 \times 1 \mathrm{~km}$ (Zomer et al., 2008). Esta camada foi usada para identificar as afinidades e tolerâncias de Bombus terrestris aos ambientes mais secos ou úmidos do planeta;

B) Camada de tipologias de cobertura de solo Globcover 2009 obtida da European Space Agency (ESA) na resolução de 10 segundos de arco, com células correspondendo aproximadamente a 300x300metros (Bontemps et al., 2010). Esta camada foi usada para caracterizar os tipos de cobertura de solo (notavelmente a vegetação) mais frequente nas áreas de ocorrência de Bombus terrestris.

Como as camadas adicionais possuem resolução maior que as camadas climáticas selecionadas, foi necessário ajustá-las por meio da redução de suas resoluções originais para 5 minutos de arco por meio de reamostragem em ArcGIS (ESRI, 2010). Para a redução de resolução da camada de aridez, que contém variação contínua, usou-se a mediana (aggregate function) dos valores das células originais (30 segundos de arco) que eram cobertas pela a abrangência das células climáticas maiores ( 5 minutos de arco). Para a camada de cobertura de solo, que é categórica (discreta), considerou-se o valor mais frequente (resample function - majority) nas células menores (Globcover) que são abrangidas pelas células maiores (climáticas; 5 minutos de arco). A camada de cobertura de solo também foi utilizada em sua resolução original (300×300 metros) na geração de uma camada de resistência ambiental para análise de conectividade, os detalhes estão descritos no capítulo 5 . 
Tabela C3-2. Lista das variáveis ambientais em formato de camadas (raster) usadas nas análises quanto ao tipo de variável, sua sigla de referência, nome da variável e origem.

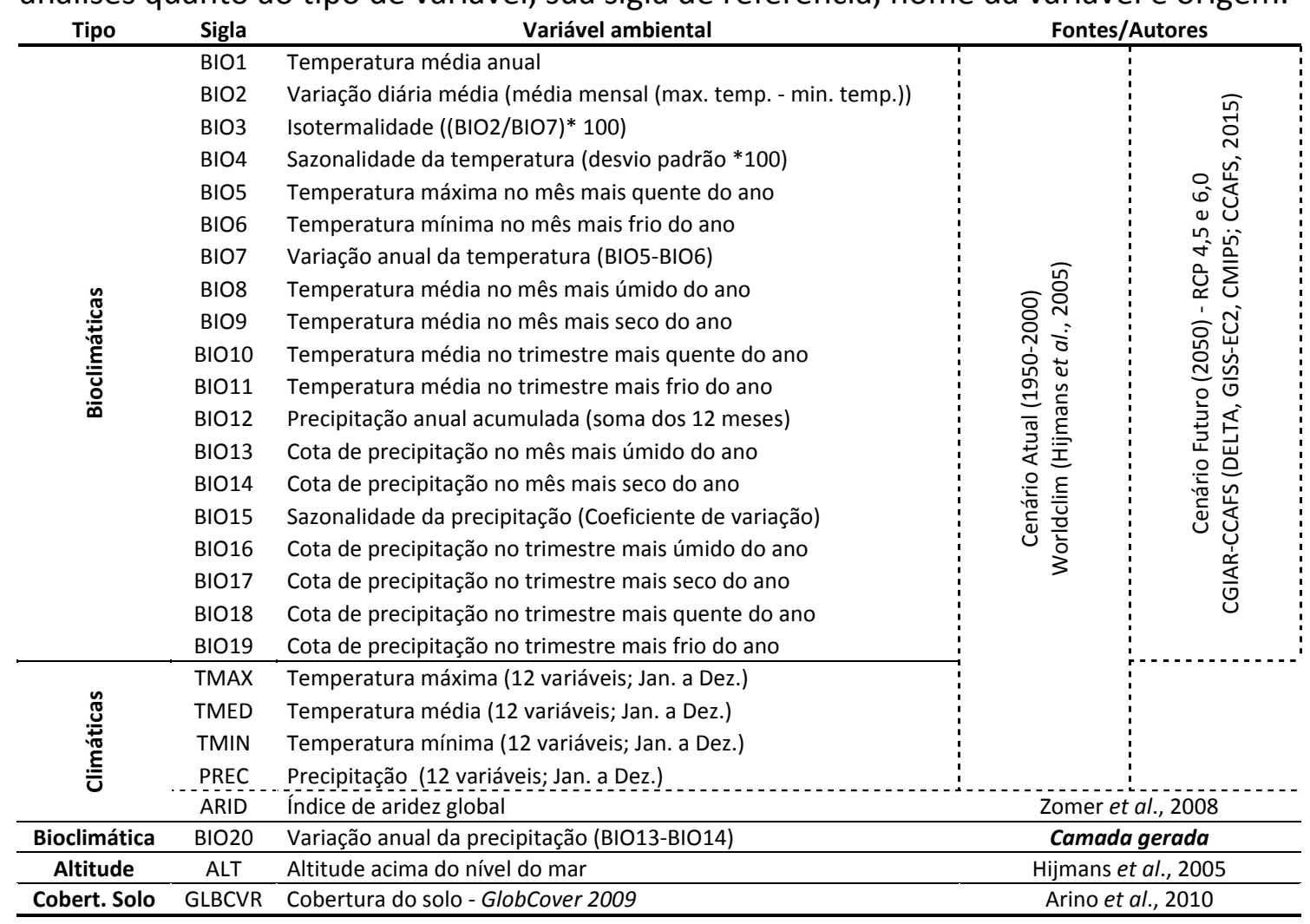

\subsection{Revisão geral das camadas ambientais, alguns critérios e ajustes}

Para a interpretação da relação existente entre o ambiente e a ocupação de uma espécie é necessário obter previamente conhecimentos sobre o significado das variáveis ambientais, e quando necessário, as variáveis devem ser ajustadas aos propósitos do estudo (Hirzel e Lay, 2008; Guisan et al., 2000; Manly et al., 2002).

Nesta seção foi feita uma breve descrição sobre a origem dos dados ambientais, como estas camadas ambientais foram feitas e os aspectos geoespaciais mais marcantes da variação de seus dados, provendo uma perspectiva geral da estrutura e significado destas variáveis. Também está descrito o critério utilizado para a seleção da instituição fonte e período das camadas ambientais (modelo) projetadas para cenários futuros de mudanças climáticas e o procedimento feito para aprimorar a classificação da camada de cobertura de solo para melhor adequá-la ao escopo da análise ecogeográfica.

\section{Camada de Altitude}

Os dados de altitude foram obtidos por meio de emissores e receptores de ondas de rádio fixados em ônibus espacial durante a Shuttle Radar Topography Mission (SRTM; JPL-NASA, 2015). A obtenção de dados segue a mesma lógica de funcionamento de radares convencionais, no qual uma fonte emite uma onda que colide com um objeto distante e retorna no sentido oposto, sendo captada por um receptor. O tempo de viagem é medido e sugere a distância entre o emissor/receptor e o ponto em que a onda colidiu e foi refletida. Mas difere de um radar convencional 
devido à existência de um segundo emissor/receptor na extremidade de uma haste fixada no ônibus espacial distante do primeiro em 60 metros. Por meio desta técnica, chamada de interferometria, é possível comparar as ondas captadas simultaneamente pelas duas antenas, aumentando consideravelmente a resolução dos dados. Quanto menor for o tempo de trajeto da onda entre o ônibus espacial e um ponto de superfície da Terra, maior será a altitude. Para calibrar a escala métrica, basta-se apontar o radar para altitudes conhecidas na Terra, que foram previamente medidas com equipamentos de precisão ao nível do solo. O tempo dos trajetos nestas altitudes conhecidas são parâmetros de conversão da escala tempo para a escala distância.

Esta missão topográfica (SRTM) coletou massiva quantidade de dados (cerca de $80 \%$ da superfície), mas é quase impossível cobrir completamente toda a superfície da Terra. As lacunas de informações, bem como correções de vieses relacionados, por exemplo, à curvatura terrestre e ao efeito Doppler na onda do radar, são feitos por meio de séries de modelagens em Sistemas de Informações Geográficas (ex: digital elevation model - DEM, digital terrain model - DTM).

O padrão geral da variação da camada de altitude em escala global na resolução de 5 minutos de $\operatorname{arco}^{10}$ exibe que a maior parte da superfície seca do planeta possui elevações relativamente baixas (mediana de 353 metros) e que as altitudes entre média e alta (entre 1500 e 3000 metros) estão concentradas em determinadas regiões do planeta, como no sul da África, na Ásia, na Groenlândia e no oeste da América do Norte. As zonas de cordilheiras com montanhas extremamente altas (> 3000 mil metros) são ainda mais restritas espacialmente, notavelmente as maiores cadeias montanhosas do planeta se concentram nos Andes, no Himalaia e em parte da Groenlândia (ex: Watkins Range), outras cordilheiras como os Alpes, Apeninos, Atlas, Bálcãs, Pirineus, Cáucaso e Urais são pouco perceptíveis nesta escala, pois também cobrem relativamente pequenas dimensões espaciais.

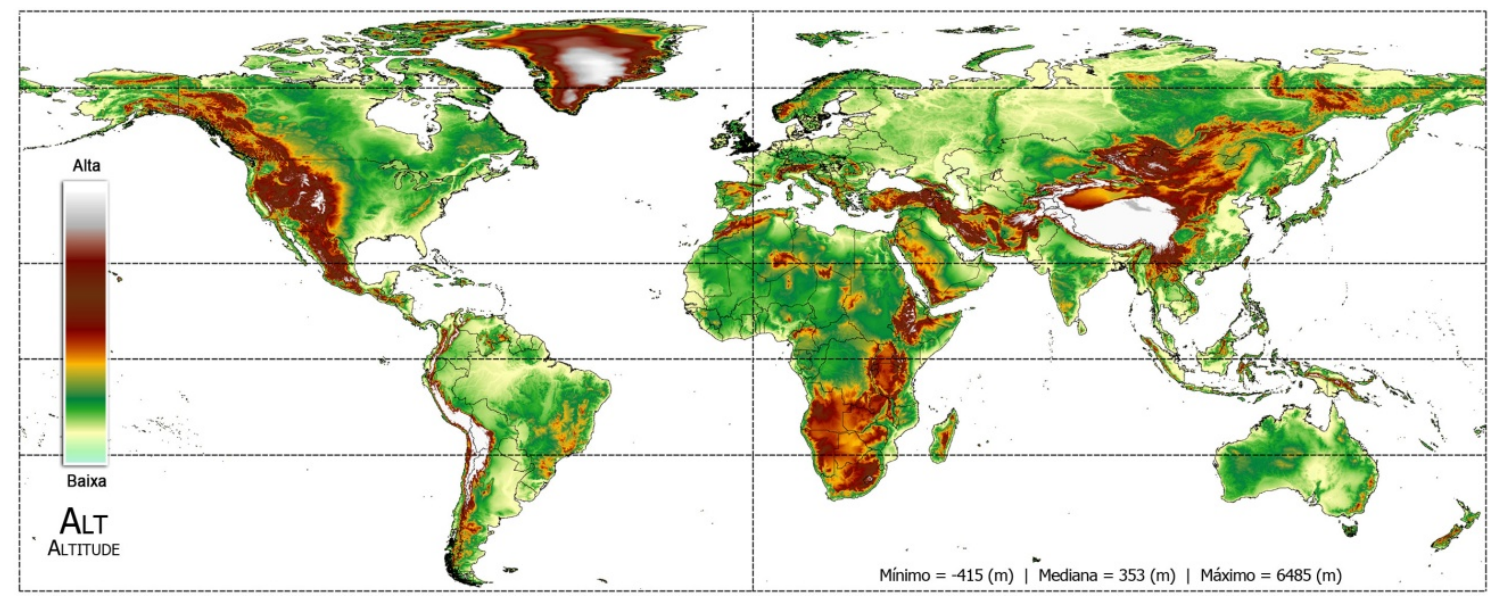

Figura C3-10. Variação da altitude global em escala colorimétrica contínua.

\footnotetext{
${ }^{10}$ Deve-se considerar que a resolução das variáveis ambientais utilizadas $(10 \times 10 \mathrm{~km})$ poderá reduzir ou aumentar os valores extremos reais para algumas delas, algo notável no caso das máximas altitudes, que frequentemente ocorrem em zonas pontuais (picos de montanhas); uma montanha como o Monte Everest exibe seu extremo de altitude ( 8.848 metros) em um espaço menor que $10 \times 10 \mathrm{~km}$, portanto o valor predominante na célula que o abrange (6.485 metros) e não o máximo valor apresentado na cobertura da célula.
} 
Camadas climáticas

Os dados usados na construção das camadas climáticas (temperatura e precipitação) são obtidos por meio de estações meteorológicas espalhadas pelo planeta (Figura C3-11). Da mesma forma que ocorre com os dados de altitude, há muitas lacunas espaciais de informações (coloração em verde claro na figura C3-11) e distorções a serem preenchidas e corrigidas, visando obter uma cobertura espacialmente uniforme da variação do clima em toda a superfície do planeta. Para tanto, são usados métodos de interpolação (Hijmans et al., 2005). A interpolação permite estimar valores dentro destas lacunas com base nos valores conhecidos em suas áreas limítrofes. Basicamente, se no ponto 1 o valor é 10 e no ponto 3 o valor é 20, no ponto 2 - que está no centro entre 1 e 3 e tem valor desconhecido - o valor será estimado pela interpolação em 15. Esta estimativa dependerá também da distância entre os pontos, mas, fundamentalmente, do que existe entre estes pontos conhecidos que poderia influenciar na variação da temperatura e precipitação e, portanto, no clima. Neste ponto, é utilizada a informação da camada de altitude. Por padrão aceito pela Organização Mundial de Meteorologia (Hanna et al., 1982; Barry e Chorley, 1987), a cada 100 metros de aumento na altitude há a redução de $0.65^{\circ} \mathrm{C}$ na temperatura média. Considerando duas estações meteorológicas em mesma altitude, distantes em $10 \mathrm{~km}$ e ambas mostram $20^{\circ} \mathrm{C}$ de temperatura média, a temperatura estimada no topo de uma montanha a 1000 metros acima das estações e no meio do caminho entre elas será de $13.5{ }^{\circ} \mathrm{C}(=20-1000 / 100 * 0.65)$. Portanto as camadas de temperatura contém, integradas aos seus valores, a variação da altitude.

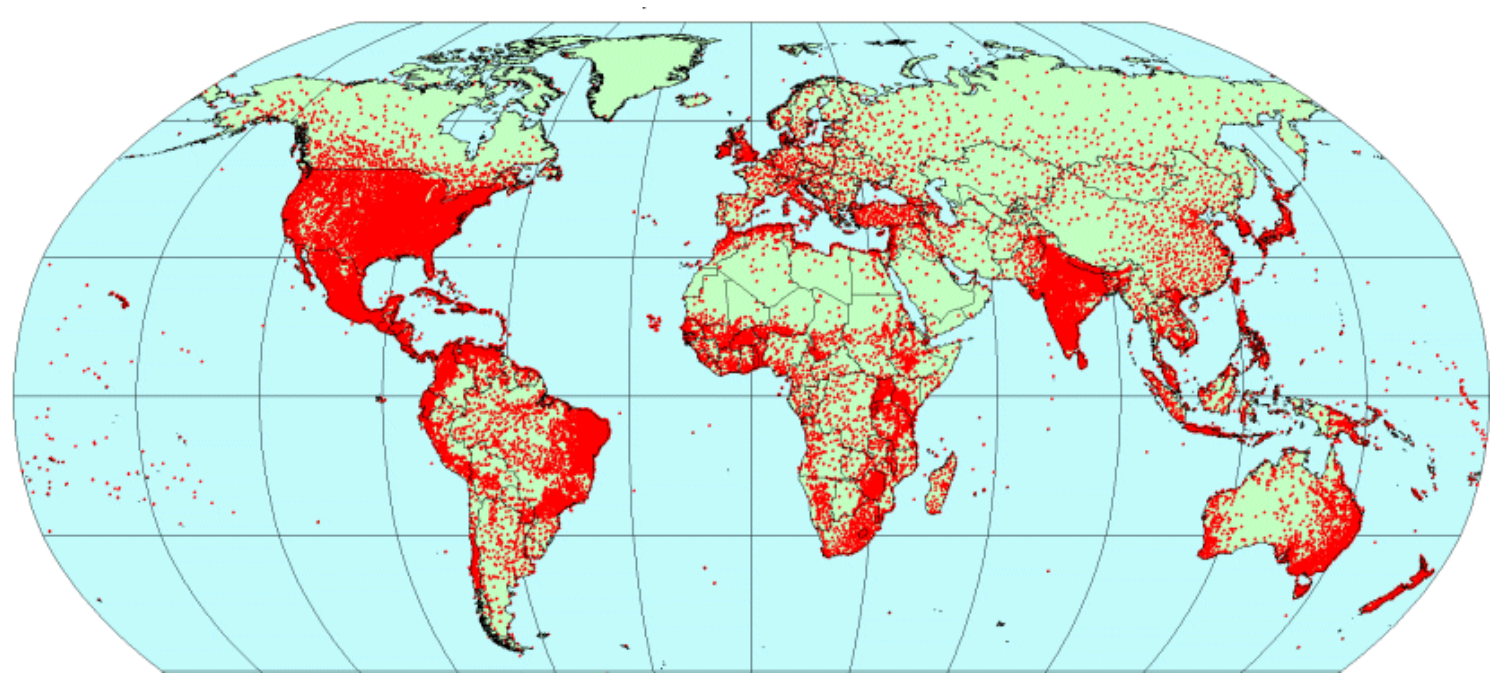

Figura C3-11. Estações meteorológicas (pontos em vermelho) que proveram dados para a construção das camadas de precipitação (Hijmans et al., 2005).

De forma similar à temperatura, a altitude também afeta a precipitação. Quando uma massa de ar carregada de água desloca-se por uma planície e em um determinado momento encontra-se com montanhas, a massa é empurrada para cima, onde há temperaturas mais baixas e valores de pressão atmosférica diferentes do ambiente em que estava se deslocando anteriormente. Esta mudança ambiental brusca induz a condensação e a descarga da água na forma de chuva, logo acima das primeiras montanhas. Um típico e extremo exemplo deste efeito orográfico na 
precipitação é a relação existente entre a Floresta Amazônica de um lado, o Deserto do Atacama do outro, com uma cordilheira separando estes dois ambientes e tornando-os drasticamente diferentes em termos de umidade. Portanto, as camadas de precipitação contêm a variação da altitude integrada aos seus valores, porém de forma diferente das camadas de temperatura.

Devido ao fato de todas as camadas climáticas possuírem as variações da altitude integradas aos seus valores, poderá ocorrer colinearidade entre variáveis nos modelos que usam regressão como lógica preditiva. Também, poderá elevar artificialmente a importância de variáveis altamente correlacionadas entre si na explicação/interpretação de um modelo de adequabilidade de habitat, sobrevalorizando determinadas faixas ambientais devido à variação conjunta e em escala proporcionalmente similar de mais de uma camada ambiental, quando altamente correlacionadas. Desta forma, deve-se ter cautela na seleção de variáveis independentes a fim de evitar estes vieses que prejudicam a análise.

As camadas de precipitação e temperatura são geradas em séries temporais (horas, dias, meses) permitindo também a geração de camadas climáticas derivadas que exibem tendências, extremos e sazonalidades temporais na variação. Por exemplo, ao subtrair as máximas temperaturas no mês mais quente do ano das mínimas temperaturas no mês mais frio do ano se obtém a variação anual da temperatura. Estas camadas derivadas são denominadas bioclimáticas, pois são especialmente úteis na relação e explicação de dinâmicas e aspectos biológicos.

Pode-se observar que as camadas que exibem médias e extremos de temperatura, a Bio 1, Bio 5, Bio 6, Bio 10 (Figura C3-12) e Bio 11 (Figura C3-13) expressam um padrão geral similar de variação de seus valores, em que os ambientes quentes estão predominantemente nas zonas tropicais e os mais frios nas zonas temperadas e polares. Os extremos mensais (Bio 5, Bio 6) e trimestrais (Bio 10 e Bio11) são especialmente úteis para identificar os limites de tolerância térmica de uma espécie. Já a média anual (Bio 1), auxilia na identificação das zonas de maior afinidade térmica da espécie.

As camadas Bio4 (desvio padrão da variação da temperatura; unidade em ${ }^{\circ} \mathrm{C}^{*} 100$ ) e Bio 7 (largura da variação entre temperaturas no mês mais frio e mais quente do ano) compartilham similaridades entre si na expressão geográfica de suas variações (Figura C3-12). Estas camadas evidenciam a variação da temperatura ao longo do ano, que é diretamente relacionada à variação do ângulo de incidência da radiação solar no zênite. Ou seja, nas zonas tropicais (e quanto mais próximo ao equador), menor será a variação do ângulo do trajeto do sol no céu ao longo das estações, resultando em menor variação térmica entre verões e invernos. Já nas zonas temperadas (e quanto mais próximo aos polos), maior será a variação térmica ao longo das estações, com invernos rigorosos e verões quentes ou amenos. Deve-se ter atenção que estas escalas são relativas (Bio 4 e Bio 7), de forma que um lugar sempre frio, cujas temperaturas do verão são parecidas com as do inverno, os valores nestas variáveis serão baixos. Por exemplo, na Islândia (em azul na Bio 4 e Bio 7), que é uma ilha relativamente sempre fria e com baixa variação térmica entre estações, o valor da escala para ambas as variáveis é similar ao valor apresentado para a floresta Amazônica (também em azul na Bio 4 e Bio 7), que é um local sempre quente com baixa variação térmica anual. 
A Bio 2 (Figura C3-12) exibe a diferença entre a máxima e a mínima temperatura de cada mês multiplicada pela soma destas variações em todos os meses dividido por 12 (a média anual das diferenças). Ou seja, é uma aproximação, em média anual, da variação da temperatura ao longo de um dia. Esta camada permite identificar locais onde, durante o dia as temperaturas são altas e durante a noite, são baixas algo mais comum em ambientes áridos, de forma que os desertos possuem alto valor nesta variável. Mas, permite também discriminar as zonas mais úmidas, como as florestas tropicais, e os locais litorâneos com alta influência da maritimidade (contribuição dos oceanos na umidade e precipitação devido à evaporação), pois a alta umidade atmosférica e a proximidade com grandes massas de água gera um efeito buffer térmico, que suaviza a variação térmica do ambiente devido à água esfriar mais lentamente que o solo (Trenberth, 2010).

A camada Bio 3 (Figura C3-12), que exibe a isotermalidade, é relativamente similar ao inverso das escalas de Bio 4 e Bio 7. Esta variável evidencia a amplitude da oscilação da temperatura durante o dia relativamente à largura da variação entre o mês mais quente e mais frio do ano; sua unidade é expressa em porcentagem ${ }^{11}$. É calculada pela divisão da Bio 2 (variação térmica diária) pela Bio 7 (variação térmica anual). Assim, quanto mais próximo ao Equador, mais altos serão os valores, e quanto mais próximo aos polos, mais baixos serão os valores. Assim, um local com valor 100 (\%) significará que a variação da temperatura ao longo das 24 horas do dia é tão baixa quanto à variação anual da temperatura, então, em zonas sob a linha do Equador.

As camadas Bio 8 e Bio 9 (Figura C3-12) indicam a variação da temperatura média nos dois períodos (trimestres) que exibem as cotas mais extremas de precipitação no ano, respectivamente, a estação mais chuvosa (Bio 8) e mais árida do ano (Bio 9). Elas permitem entender a distribuição das chuvas na estação mais fria (que pode ser no inverno) e mais quente do ano (que pode ser no verão). Pode-se observar que o padrão de chuvas é globalmente bastante variável em relação à variação térmica, por exemplo, no extremo sul da América do Sul, na Nova Zelândia e na Tasmânia a precipitação é maior no inverno (Bio 8, temperaturas baixas em azul). Já na Índia e no norte da Austrália, por exemplo, o período mais chuvoso ocorre no verão.

As variáveis Bio 12 (milímetros de chuva acumulados no ano), Bio 13 ( $\mathrm{mm}$ de chuva acumulado no mês mais chuvoso) e Bio 16 ( $\mathrm{mm}$ de chuva acumulados no trimestre mais chuvoso), embora possuam escalas diferentes entre si, expressam padrões muito similares de variação (Figura C3-13). Elas exibem as altas cotas de precipitação nas zonas tropicais, nas zonas influenciadas pela maritimidade e naquelas influenciadas por fluxos de massas atmosféricas úmidas em escala global. Nas zonas tropicais, a precipitação é maior especialmente por conta da intensa radiação solar que aumenta a evaporação oceânica, e da influência da Zona de Convergência Intertropical que retém e acumula as massas de vapor d'água nestas faixas adjacentes ao equador. As zonas de alta precipitação externas aos trópicos, como no nordeste da China, sudeste da Austrália (e Tasmânia), Nova Zelândia, Japão, sudoeste do Chile, noroeste dos Estados Unidos e Canadá recebem alta precipitação por conta da Zona de Convergência do Pacífico Sul, das correntes do Alasca, da Califórnia, de Kuroshio, de Oyashio e de outros fluxos.

\footnotetext{
${ }^{11} \mathrm{~A}$ unidade de Bio 3 pode ser considerada porcentagem pois é calculada pela razão entre a Bio 2 (escala dia) e Bio 7 (escala ano) multiplicada por 100. Na literatura há divergências quanto a sua unidade efetiva (USGS, 2012; CCAFS, 2015).
} 
TEMPERATURA MÉDIA ANUAL Mínimo $=-27.4\left({ }^{\circ} \mathrm{C}\right) \mid$ Mediana $=8.7\left({ }^{\circ} \mathrm{C}\right) \mid$ Máximo $=31.6\left({ }^{\circ} \mathrm{C}\right)$

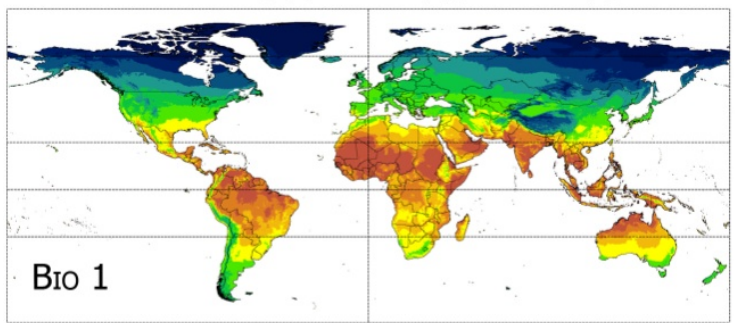

VARIAÇÃO DIÁRIA MÉDIA

Mínimo $=0.9\left({ }^{\circ} \mathrm{C}\right) \mid$ Mediana $=11\left({ }^{\circ} \mathrm{C}\right) \mid$ Máximo $=21.3\left({ }^{\circ} \mathrm{C}\right)$

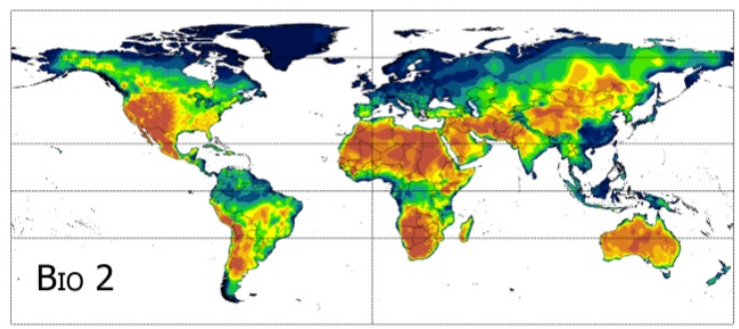

ISOTERMALIDADE

Mínimo $=8(\%) \mid$ Mediana $=32(\%) \mid$ Máximo $=96(\%)$

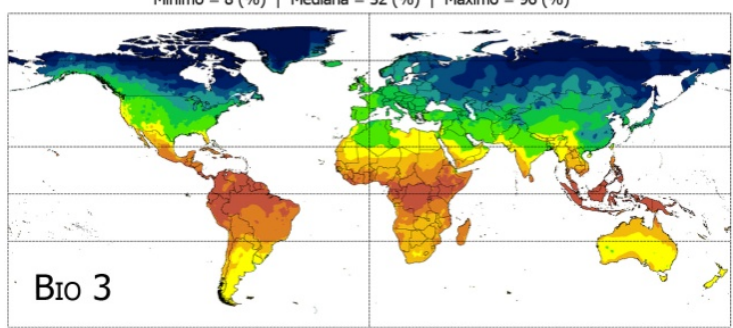

SAZONALIDADE DA TEMPERATURA

Minimo $=0.72\left({ }^{\circ} \mathrm{C}\right) \mid$ Mediana $=80.88\left({ }^{\circ} \mathrm{C}\right) \mid$ Máximo $=226.92\left({ }^{\circ} \mathrm{C}\right)$

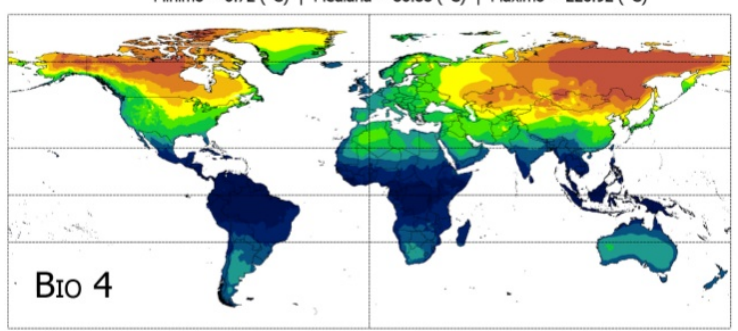

TEMPERATURA MÁXIMA NO MÊS MAIS QUENTE DO ANO Minimo $=-7.3\left({ }^{\circ} \mathrm{C}\right) \mid$ Mediana $=27.1\left({ }^{\circ} \mathrm{C}\right) \mid$ Maximo $=48.9\left({ }^{\circ} \mathrm{C}\right)$

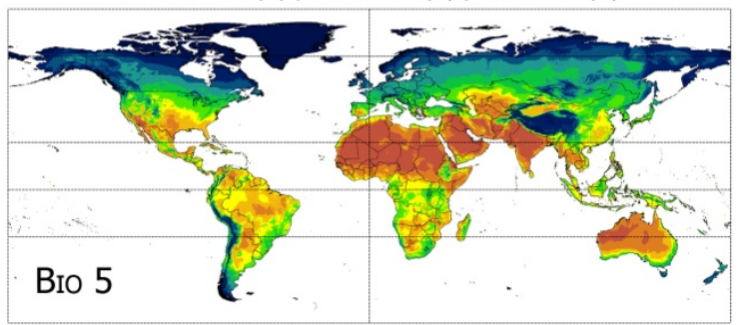

TEMPERATURA MÍNIMA NO MÊS MAIS FRIO DO ANO Mnimo $=-55.5\left(^{\circ} \mathrm{C}\right) \mid$ Mediana $=-7.6\left({ }^{\circ} \mathrm{C}\right) \mid$ Máximo $=25.8{ }^{\circ} \mathrm{C} C$

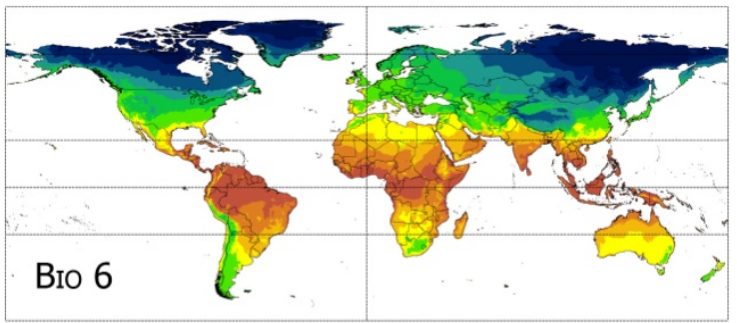

VARIAÇÃO ANUAL DA TEMPERATURA

Minimo $=5.3\left({ }^{\circ} \mathrm{C}\right) \mid$ Mediana $=34.3\left({ }^{\circ} \mathrm{C}\right) \mid$ Máximo $=72.5\left({ }^{\circ} \mathrm{C}\right)$

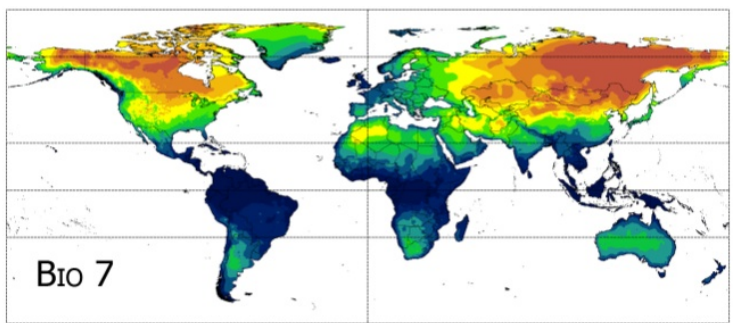

TEMPERATURA MÉDIA NO MÊS MAIS ÚMIDO DO ANO Minimo $=-27.3\left({ }^{\circ} \mathrm{C}\right) \mid$ Mediana $=15.8\left({ }^{\circ} \mathrm{C}\right) \mid$ Máximo $=37.6\left({ }^{\circ} \mathrm{C}\right)$

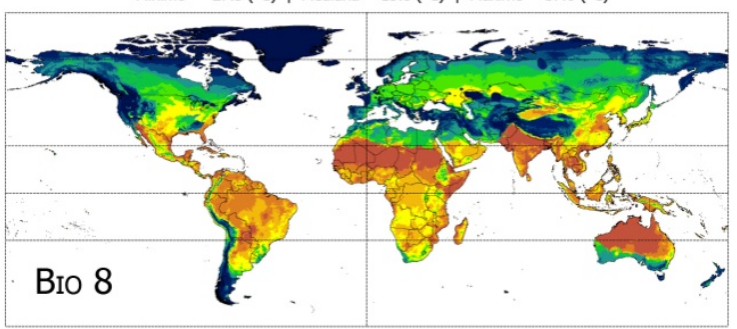

TEMPERATURA MÉDIA NO MÊS MAIS SECO DO ANO Minimo $=-49.1\left(^{\circ} \mathrm{C}\right) \mid$ Mediana $=3.7\left({ }^{\circ} \mathrm{C}\right) \mid$ Máximo $=36.5\left({ }^{\circ} \mathrm{C}\right)$

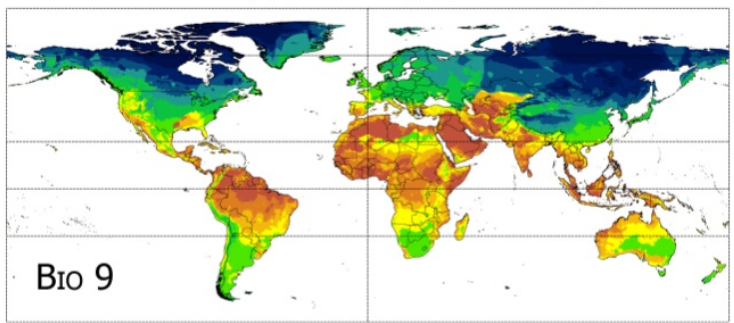

TEMPERATURA MÉDIA NO TRIMESTRE MAIS QUENTE DO ANO Minimo $=-11.4\left({ }^{\circ} \mathrm{C}\right)$ | Mediana $=19.6\left({ }^{\circ} \mathrm{C}\right) \mid$ Máximo $=38.1\left({ }^{\circ} \mathrm{C}\right)$

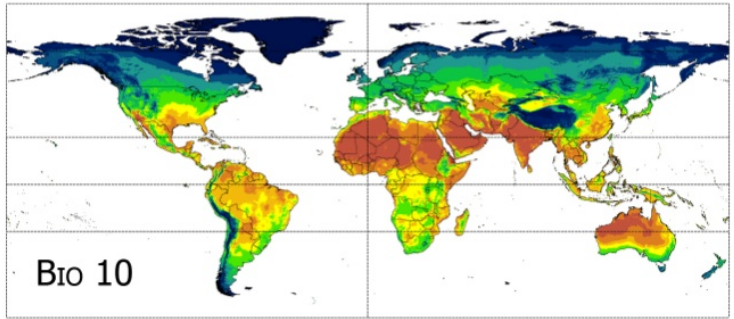

\section{LEGENDA \\ CAMADAS BIOCLIMÁTICAS \\ (Cada cor representa um decil da escala total)}

Bio 1 a BIO 11

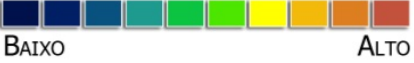

Bio 12 a Bio 20

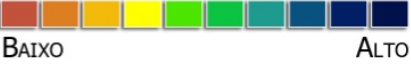

Figura C3-12. Camadas bioclimáticas Bio 1 a Bio 10. A variação contínua de cada variável foi categorizada por decis, e o gradiente de cor é invertido entre variáveis de precipitação e temperatura para prover uma variação colorimétrica mais intuitiva. 
TEMPERATURA MÉDIA NO TRIMESTRE MAIS FRIO DO ANO Mínimo $=-49.7\left({ }^{\circ} \mathrm{C}\right) \mid$ Mediana $=-1.9\left({ }^{\circ} \mathrm{C}\right) \mid$ Máximo $=28.9\left({ }^{\circ} \mathrm{C}\right)$
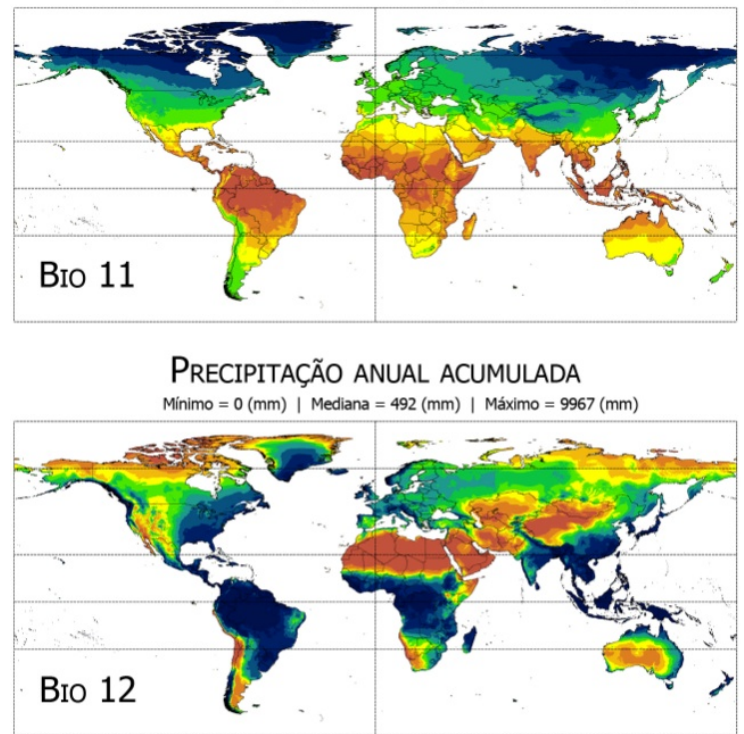

COTA DE PRECIPITAÇ̃̃O NO MÊS MAIS ÚMIDO DO ANO Mínimo $=0(\mathrm{~mm}) \mid$ Mediana $=78(\mathrm{~mm}) \mid$ Máximo $=2198(\mathrm{~mm})$

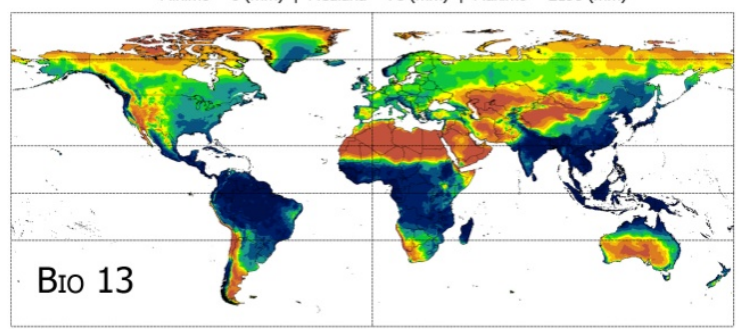

COTA DE PRECIPITAÇ̃̃̃O NO MÊS MAIS SECO DO ANO
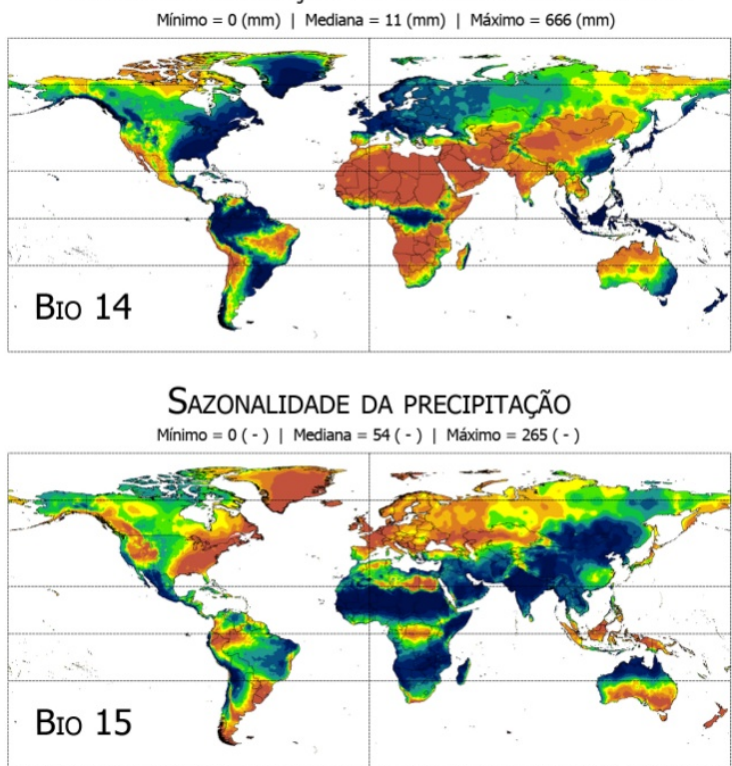

PRECIPITAÇ̃̃O NO TRIMESTRE MAIS ÚMIDO DO ANO Mínimo $=0(\mathrm{~mm}) \mid$ Mediana $=209(\mathrm{~mm}) \mid$ Máximo $=5691(\mathrm{~mm})$

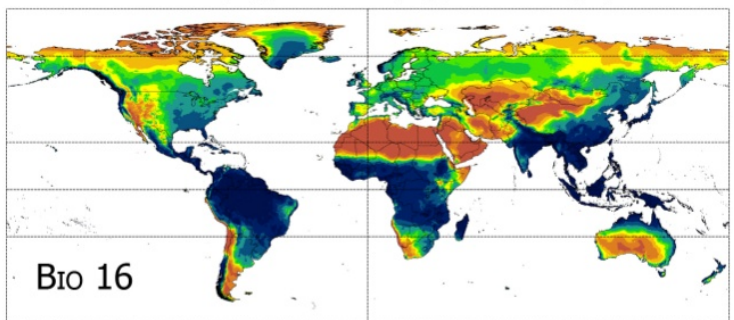

Precipitação No tRIMESTRE MAIS SECO dO ANO

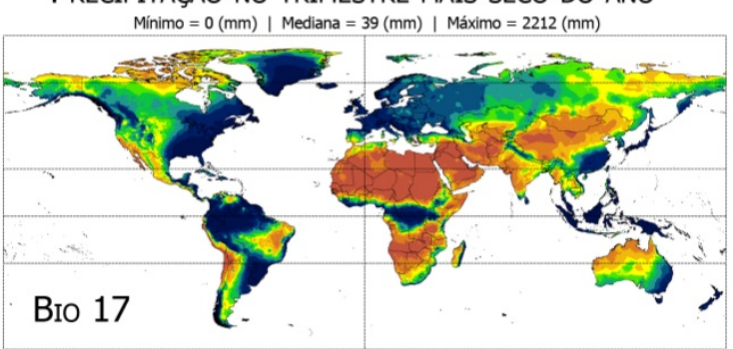

PRECIPITAÇ̃̃o NO TRIMESTRE MAIS QUENTE DO ANO

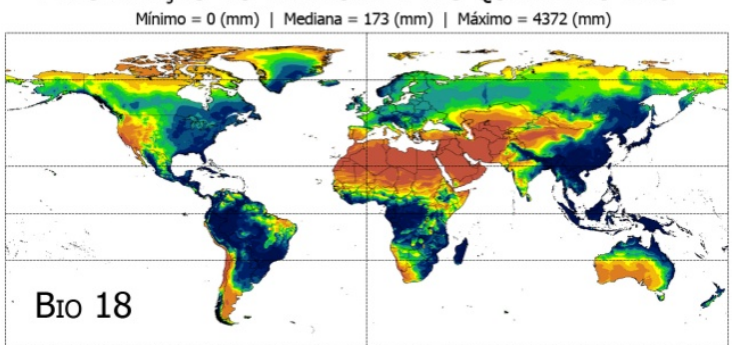

PRECIPITAÇ̃̃O NO TRIMESTRE MAIS FRIO DO ANO
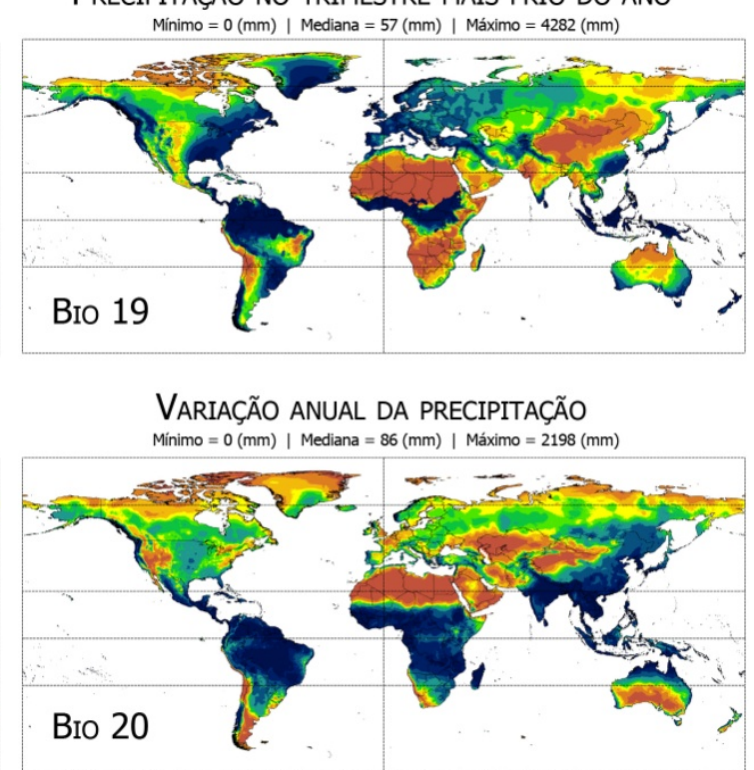

\section{LEGENDA \\ CAMADAS BIOCLIMÁTICAS \\ (Cada cor representa um decil da escala total)}

Bio 1 a Bio 11

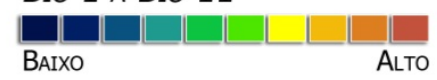

Bio 12 a Bio 20

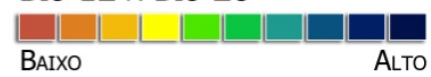

Figura C3-13. Camadas bioclimáticas Bio 11 a Bio 20. A variação contínua de cada variável foi categorizada por decis, e o gradiente de cor é invertido entre variáveis de precipitação e temperatura para prover uma variação colorimétrica mais intuitiva. 
As correntes oceânicas também influenciam as precipitações na área continental, como a corrente do Golfo que aumenta a precipitação no leste dos Estados Unidos, no sul da Groenlândia e no oeste Europeu. Pode-se perceber que os desertos ficam bastante evidentes pela baixa precipitação mesmo nos períodos mais chuvosos do ano. Ressaltando também que os locais com mais alta precipitação do planeta estão localizados na Colômbia, Índia, Indonésia, Birmânia, no extremo sul do Chile e em Papua Nova Guiné, com precipitações superiores a 5000 mm/ano, enquanto as zonas mais chuvosas da Amazônia possuem em média 3000 mm/ano.

A Bio 14 ( $\mathrm{mm}$ de chuva acumulados no mês mais seco) e a Bio 17 ( $\mathrm{mm}$ de chuva acumulados no trimestre mais seco) exibem, de forma bastante similar entre elas, as zonas com nenhuma ou com precipitação muito baixa em relação às zonas que, mesmo nestes períodos mais secos do ano, ainda apresentam alguma ou altas cotas de precipitação (Figura C3-13). Por exemplo, os locais que são extremamente secos no período de menor precipitação do ano (Bio 14 e Bio 17) incluem o semiárido brasileiro, praticamente toda a Índia e as florestas tropicais africanas com demarcada exceção das equatoriais no norte do Congo, Gabão e Camarões. Estas variáveis são importantes na detecção dos limiares de tolerância das espécies à baixa precipitação, que poderá ser um fator limitante em muitos casos.

A sazonalidade da precipitação, Bio 15 , exibe a variabilidade das cotas de precipitação ao longo do ano (Figura C3-13). Esta variável é calculada pela razão entre o desvio padrão da precipitação total mensal e o total médio mensal da precipitação (coeficiente de variação) e não possui unidade específica (CCAFS, 2015). Os valores mais altos (em azul) exibem as zonas onde há alta irregularidade pluviométrica enquanto que os valores mais baixos (em vermelho) onde há maior uniformidade na precipitação ao longo do ano. Esta escala é relativa, então uma mesma cor (valor) poderá evidenciar igualmente áreas muito secas e muito úmidas, mas que variam de forma similar no curso do ano. Para verificar a amplitude da variação (em termos de intervalo absoluto) entre os extremos da precipitação no ano foi necessário criar a variável Bio 20 (Figura C3-13) por meio da subtração dos mínimos valores de precipitação no ano dos máximos valores de precipitação no ano (Bio 13 menos Bio 14). Estas variáveis (Bio 14 e 20) sugerem importantes aspectos ecogeográficos, pois a oscilação pluviométrica ao longo do ano exerce forte influência sobre as espécies, mas a variável Bio 20 revela oscilação pela sua magnitude, enquanto a sazonalidade relativiza a oscilação perante a média anual. Por exemplo, na cidade de São Paulo (logo abaixo do trópico de Capricórnio e próximo ao litoral na Figura C3-13), a precipitação mínima no mês menos chuvoso é $40 \mathrm{~mm}$ (Bio 14) e a máxima no mês mais chuvoso é $235 \mathrm{~mm}$ (Bio 13); portanto, a Bio 20 exibe o valor $195 \mathrm{~mm}$, ou seja, cerca de 83\% de redução na precipitação entre o período seco e chuvoso. Já o valor da sazonalidade (Bio 15; Figura C3-13) é 58, que é um valor útil em termos comparativos entre áreas, apesar de não ser um valor quantitativo prático.

As Bios 18 e 19 (Figura C3-13) são variáveis "irmãs" das Bios 8 e 9 (Figura C312). Enquanto as últimas (Bios 8 e 9) permitem identificar o valor da temperatura média em períodos (trimestres) extremos de precipitação (mais chuvoso e mais seco do ano), as primeiras (Bios 18 e 19) permitem identificar o valor da precipitação acumulada nos períodos (trimestres) onde ocorrem os extremos de temperatura (mais quente e mais frio do ano). Elas permitem também entender a distribuição das chuvas nas estações verão e inverno, mas cada par com enfoques diferentes. A Bio 18 pode 
auxiliar na localização de áreas cujas cotas de precipitação no período estão intimamente ligadas à carga de vapor decorrente da evapotranspiração (chuvas de verão). Já a Bio 19 pode evidenciar (indiretamente), em zonas bastante frias, a carga de água por meio da precipitação em forma de neve, a qual é geralmente contabilizada como chuva por meio do cálculo do equivalente de água em neve (WMO, 2013).

As variáveis mensais de temperatura mínima, média e máxima (TMIN, TMED, TMAX, Tabela C3-2) e as mensais de precipitação (PREC) não serão detalhadas, afinal não exibem complexidades de interpretação e, de certa forma, estão expressas nas variáveis bioclimáticas. Neste trabalho, estas 48 camadas foram usadas na análise ecogeográfica de Bombus terrestris, que foi abordada no Capítulo 5.

\section{Camada de Aridez}

A variável do índice de aridez global (Figura C3-14) indica a relação entre a disponibilidade de precipitação (precipitação média anual) perante a demanda atmosférica local por água (média anual do potencial de evapotranspiração). Ou seja, evidencia os locais do planeta em que a atmosfera tem maior/menor potencial de remover água da superfície e de seus componentes (evaporação dos corpos d'água, evapotranspiração dos solos e plantas) e que, ao mesmo tempo, recebem maior/menor carga de água por meio da chuva (Zomer et al., 2008). Essencialmente, exibe as zonas mais áridas e mais úmidas do planeta, bem como as variações intermediárias entre estes extremos.

A camada de aridez global difere das bioclimáticas (ex: Bio 18) devido à inclusão de um terceiro tipo de variável, que é radiação solar extraterrestre, ou seja, a radiação que chega ao topo da atmosfera antes de passar por filtragem espectral pelas nuvens e refração através de gases e vapores atmosféricos (GAGPET, 2012). Os valores mais baixos de sua escala sugerem ambientes mais secos, e os mais altos, os mais úmidos; não possui uma unidade específica, mas a escala contínua pode ser categorizada com base na classificação da UNEP (1997) em áreas hiperáridas, áridas, semiáridas, subúmidas e úmidas (GAGPET, 2012; UNEP, 1997).

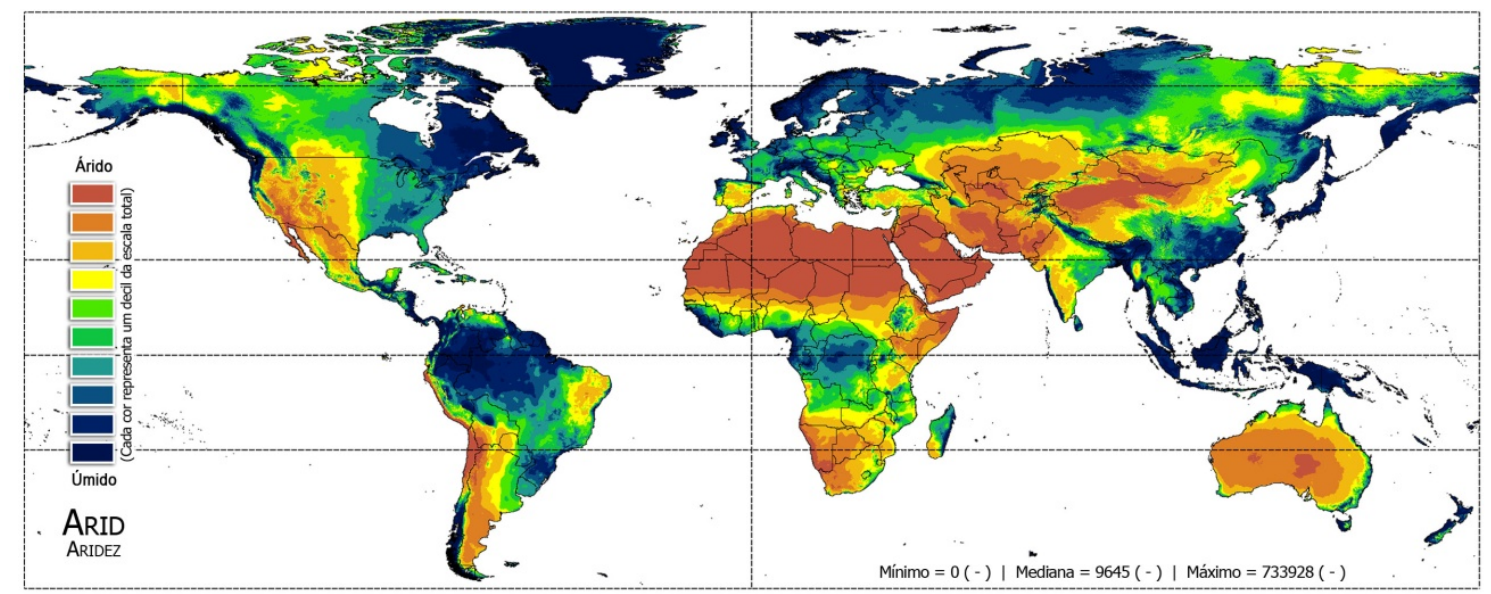

Figura C3-14. Índice de Aridez Global com a variação contínua categorizada por decis.

Pode-se verificar na figura C3-14 que o índice de aridez exibe que são igualmente úmidas as florestas tropicais e algumas regiões polares, algo que difere das bioclimáticas que exibem extremos e o total de precipitação anual (Bio 12, 13 e 16; 
Figura C3-13). Por exemplo, na Índia, praticamente todo seu território apresenta elevadas cotas de chuva para estas variáveis bioclimáticas (Bio 12, 13 e 16), mas, de uma forma geral, exibe um índice de aridez mediano a baixo perante a escala total, ou seja, indicando aridez (Figura C3-14), mas com peculiar exceção da estreita faixa oeste do país que é diretamente afetada pelas monções. Outro aspecto interessante é que a península Ibérica apresenta um índice de aridez similar ao semiárido brasileiro.

\section{Camada de cobertura de solo}

As informações utilizadas para gerar a camada de cobertura de solo Globcover são provenientes de sensoriamento remoto de imagens capturadas de cinco espectrômetros instalados no satélite europeu Envisat (ESA, 2015). Estes espectrômetros são como câmeras fotográficas, mas que não capturam uma imagem inteira a cada disparo; na verdade são câmeras dotadas de espelhos móveis que capturam sequências de filetes de imagens do planeta, de forma similar ao escâner de papel. Seus sensores são capazes de capturar espectros visíveis e invisíveis aos olhos humanos e medir com precisão a iluminância (lux), a frequência (hertz), a energia radiante (joule), a potência da energia radiativa (watt), e outras qualidades da luz.

Estas informações são recebidas na Terra, montadas e convertidas em forma de matrizes digitais com múltiplas bandas, as quais exibem como imagens coloridas no padrão RGB (red-green-blue) as frequências luminosas capturadas pelos sensores. Por meio de validação de padrões de combinações de frequências com a realidade dos ambientes correspondentes no espaço geográfico (ex: frequências XYZ equivalem ao ambiente floresta) permitem a identificação e mapeamento de vários aspectos geográficos presentes na superfície da Terra. Por exemplo, pode-se separar precisamente a floresta do deserto por meio das distintas características da luz emitidas por cada um desses ambientes. As florestas possuem muitas plantas que consomem luz para a fotossíntese (especialmente frequências do ultravioleta e infravermelho), portanto uma parte da luz emitida pelo sol não é refletida de volta para o espaço e o sensor no satélite mede esta diferença e compara com a luz solar emitida pelo deserto, que não tem muitos consumidores de luz nessas faixas, e então emite de volta muito maior quantidade de luz e em frequências diferentes do que a floresta.

A validação das faixas de frequências é feita por amostragem, por isso é muito mais precisa na área de interesse daqueles que fizeram a camada, que neste caso é a Europa - de forma que seu uso na caracterização da área nativa de Bombus terrestris foi adequado. Uma mesma faixa de frequência que corresponde a um tipo de vegetação na Europa poderá também corresponder a um tipo de vegetação no Brasil, mas não significará que sejam vegetações biologicamente similares, apenas que refletem faixas e intensidade de frequências similares.

Perante este fato, pesquisadores têm se empenhado para avaliar e revalidar a camada Globcover para diferentes regiões do planeta (ex: Fritz et al., 2011). No Brasil, Shimabukuro e colaboradores (2013) do Instituto Nacional de Pesquisas Espaciais (INPE) avaliaram a camada para o Estado de Mato Grosso e chegaram ao valor de exatidão geral de $47 \%$, ou seja, uma inexatidão geral de $53 \%$. Esse valor de precisão detectado no Brasil é bastante inferior à avaliação da precisão global feita pelos próprios autores da camada, indicando exatidão de 73\% (Defourny, et al., 2009). 
Deve-se ressaltar que embora a denominação das classes não seja tão precisa quanto desejável, o delineamento geográfico das diferentes características da cobertura do solo apresenta alta resolução espacial (300 metros) e é a camada mais recente (2009) disponível até o momento.

Pode-se reduzir o erro na classificação geral por meio da reclassificação das denominações originais para classes mais abrangentes e generalizadas, e ao mesmo tempo manter a capacidade discriminativa necessária aos objetivos do uso desta camada na análise ecogeográfica. Neste trabalho, a camada Globcover foi aplicada para identificar se a espécie possui maior afinidade com ambientes selvagens ou antropizados, e neste último caso, em relação a sua maior presença em ambientes agrícolas.

Para esta pesquisa, as classes originais que são similares quanto à tipologia (espectros similares) e geograficamente adjacentes foram unidas em novas classes individuais com denominações mais abrangentes, mas convergentes com o significado das classes originais. Este processo de reclassificação foi feito por meio da inspeção visual das classes da camada em ArcGIS (ESRI, 2010) e Google Earth (2015), e subsidiada por informações obtidas na literatura específica sobre a camada (Fritz et al., 2010, 2011; Defourny, et al., 2009; Bicheron et al., 2008). Por exemplo, plantações dependentes de chuva (Valor 14 da Tabela C3-3), plantações irrigadas ou pós-cheia (Valor 11) e os mosaicos com predominância de plantações (Valor 20) são três tipologias de cobertura de solo relacionadas às ações antrópicas de produção agrícola, portanto, foram unidas na classe Urbanização/Culturas. Outro exemplo são as classes de valores 70 e 90 (Tabela C3-3) que se referem à mesma vegetação (Floresta Aciculifoliada), pois emitem o mesmo espectro luminoso no verão. No entanto, a classe 90 possui variação anual de frequência espectral, uma vez que no inverno o espectro muda e pressupõe a queda das folhas das coníferas (caducifólia). A classe 90 também possui mais ruído geoespacial (pixelizada), sugerindo uma vegetação mais aberta, enquanto que a 70 é mais uniforme o que permite supor ser mais fechada. As classes muito distintas espectrograficamente, por exemplo, o solo exposto (Valor 200) e os corpos d'água (Valor 210), foram mantidas em classes isoladas (Tabela C3-3).

Tabela C3-3. Valores e classes originais da camada de cobertura de solo Globcover 2009 (Arino et al., 2010) e suas novas classificações.

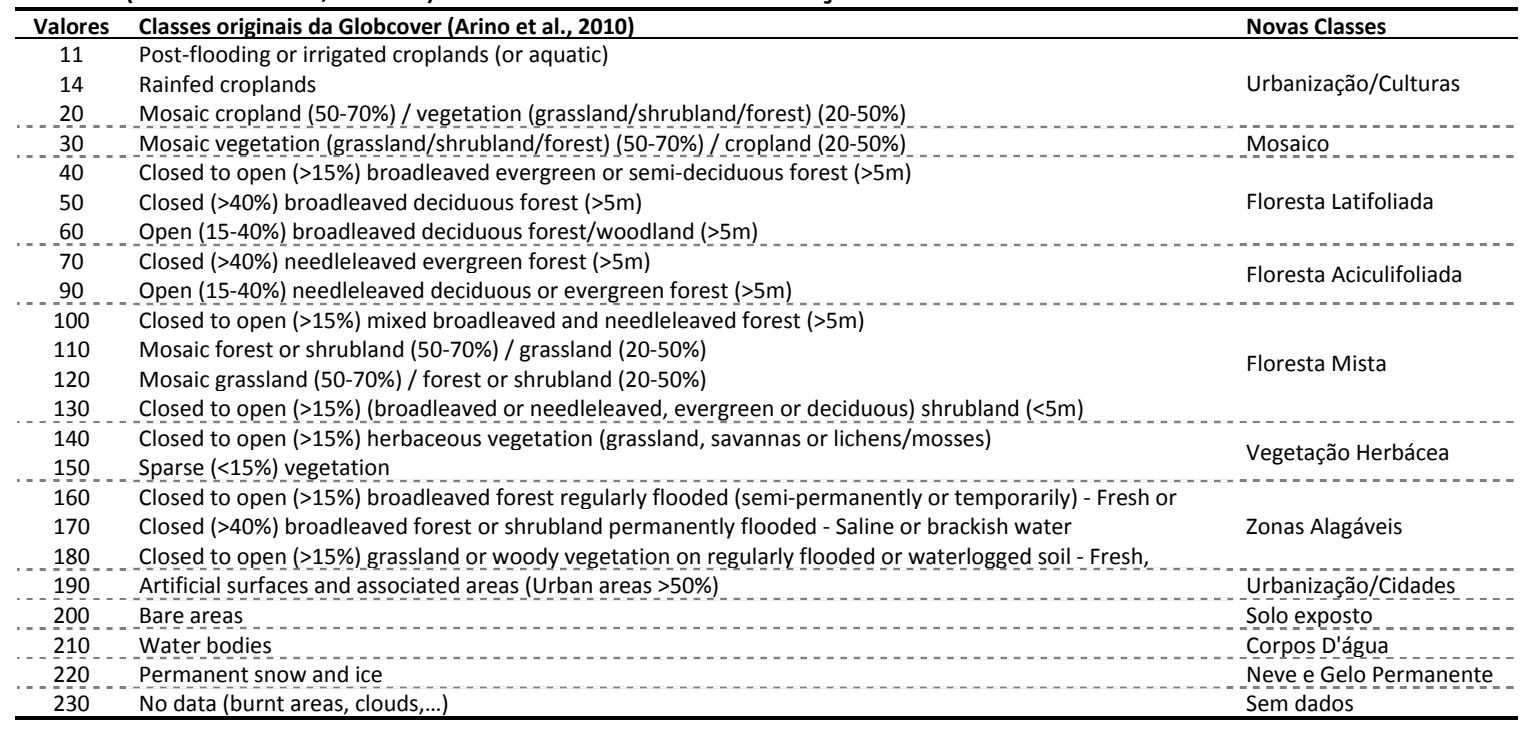


A verificação da qualidade geral da reclassificação da camada de cobertura de solo (Figura C3-15) foi feita por meio de inspeção visual das novas classes e seus respectivos significados quanto à convergência geoespacial com a realidade exibida em imagens aéreas (Google Earth), mas esta verificação foi restrita às áreas onde há registros de ocorrências nativas e invasivas de Bombus terrestris. Para tanto, foi usado um plugin para ArcGIS (ESRI, 2010), o XtoolsPro (2015), que permite a adequada exportação da camada Globcover para Google Earth (Google Inc., 2015).

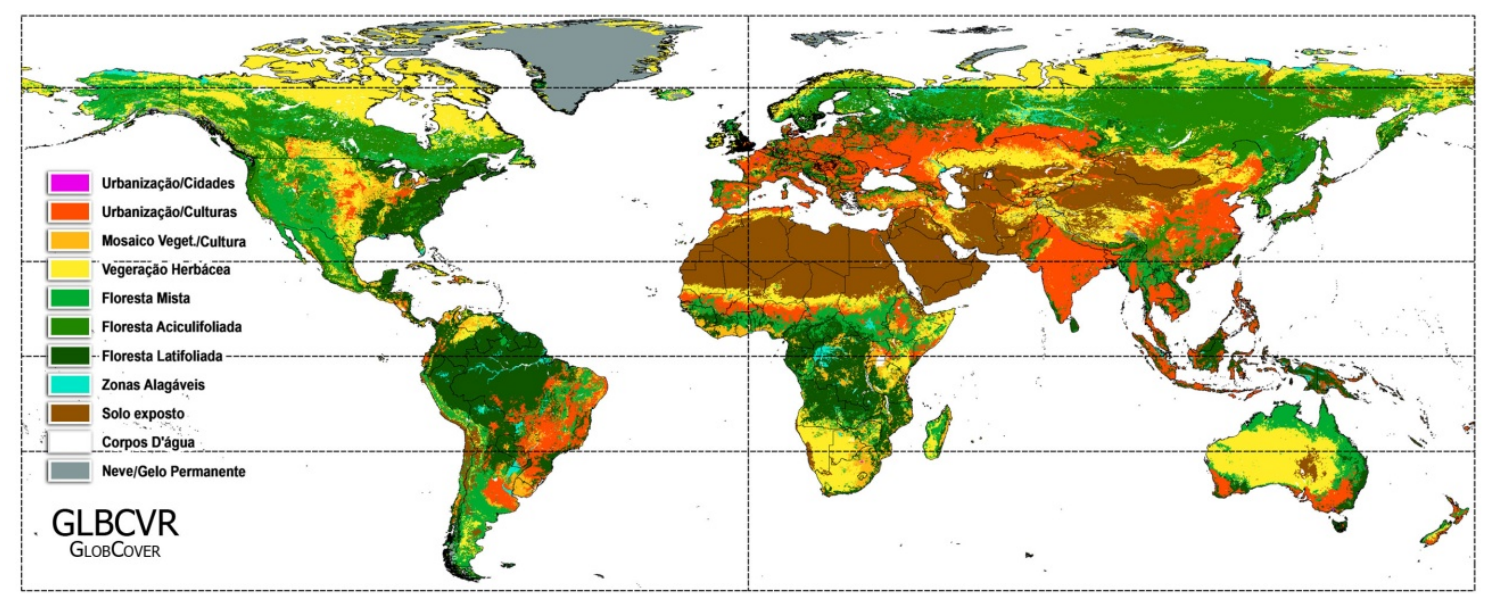

Figura C3-15. Projeção da camada de cobertura de solo Globcover reclassificada.

Pela sobreposição da Globcover com as imagens aéreas do Google Earth foi possível verificar que a denominação das novas classes é predominantemente compatível (quase totalmente na Europa) com a realidade geográfica nos locais de ocorrência da espécie. As classes que distinguem as atividades e presença humana sobre o solo (Urbanização/Cidades; Urbanização/Culturas) estavam especialmente precisas. Pode-se verificar na figura C3-16, evidenciando a zona central da ilha sul da Nova Zelândia, que a classe Urbanização/Culturas corresponde com boa precisão a coloração em tons de verde claro na imagem aérea (Google Inc., 2015) que precisamente é coberta por culturas e vilarejos. A classe Urbanização/Cidades em coloração magenta no Globcover ressalta adequadamente a cidade de Christchurch, que é o maior aglomerado de construções na região. As zonas de floresta na imagem aérea, em tonalidades de verde escuro, também foram bem delineadas pelas novas classes Floresta Mistas e Floresta Aciculifoliada (Figura C3-16). Já a classe Vegetação Herbácea não distingue corretamente algumas características geográficas, o que já não fazia antes da reclassificação. Pode-se perceber que esta classe abrange erroneamente os rios, mas acerta ao abranger topos de montanhas sem neve, pois este é o tipo de vegetação mais recorrente nestas características de relevo. 


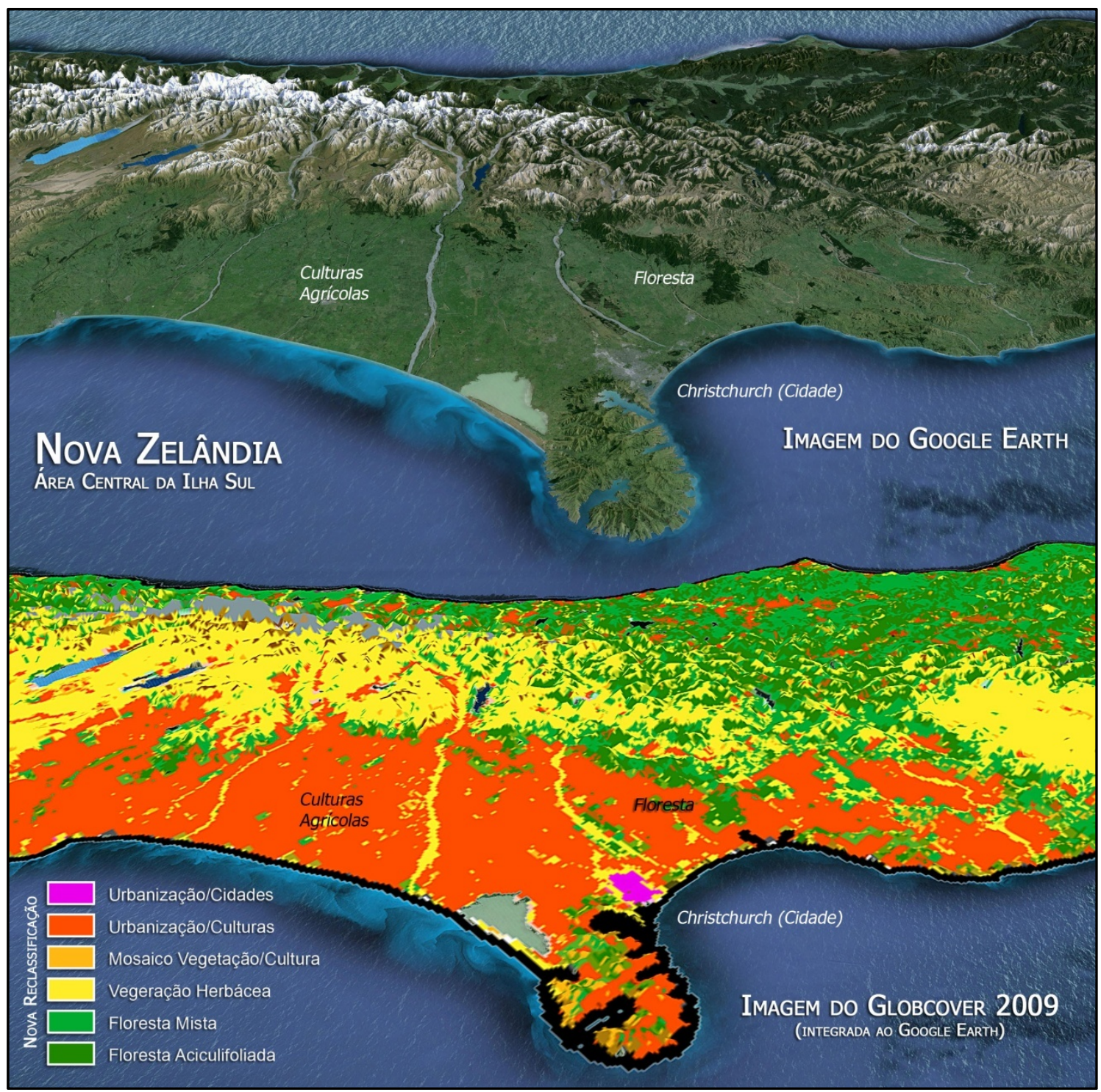

Figura C3-16. Imagem aérea (acima) e a camada Globcover (abaixo) evidenciando a mesma zona central da ilha sul da Nova Zelândia em perspectiva. Três aspectos sobre o solo estão destacados: a cidade de Christchurch, as culturas agrícolas (praticamente toda área em verde claro na imagem aérea), e fragmentos de floresta (em verde escuro na imagem aérea). Algumas classes foram omitidas na legenda por não se apresentarem na abrangência geoespacial.

\section{Camadas em projeções futuras estimadas para mudanças climáticas}

As camadas projetadas conforme estimativas de mudanças climáticas (doravante citadas como camadas futuras) são construídas por meio do acoplamento das camadas climáticas em cenário corrente (doravante citadas como camadas atuais; Hijmans et al., 2005) com modelos de mudanças climáticas estimadas para décadas vindouras, os quais são gerados por diversos institutos de pesquisa sob diversificadas premissas e métodos de cálculo.

Há mais de uma dezena de instituições de pesquisas sediadas em vários países que desenvolvem modelos de mudanças climáticas e projetam camadas futuras (ex: Hadley Centre- Inglaterra; Division of Climate System Research- Japão; Commonwealth 
Scientific and Industrial Research Organisation, CSIRO- Austrália), inclusive no Brasil (Centro de Previsão de Tempo e Estudos Climáticos, CPTEC-INPE).

As instituições desenvolvem e aplicam diferentes métodos de modelagem climática para projeções futuras, embora algumas delas, como a brasileira (CPTECINPE), usem modelos globais desenvolvidos por outras instituições (HadAM3P; IPCCTAR; em Marengo et al., 2007) para gerar modelos regionais mais refinados, como no caso da brasileira, que desenvolve modelos para a América do Sul. Mas estas instituições também diferem quanto às origens, tipos, resoluções e qualidades dos dados usados, o que se reflete também na qualidade de seus modelos.

Como estes modelos são estimativas, não há como saber neste momento qual será a melhor tendência ou representação do clima no futuro. De todo modo, existe uma vasta literatura comparando, sugerindo e descrevendo melhores aplicações para os diferentes tipos de cenários conforme as tendências de mudanças que eles estimam para o futuro (se são pessimistas, moderados ou otimistas, se preveem maior ou menor aquecimento global e emissões de gases do efeito estufa, etc.) (ex: Goodess, 2000; Parry, 2002; Murphy et al., 2004; Dessai et al., 2005; Hall, 2007; Bader, 2008; Watson, 2008; Snover et al., 2013), no entanto, apesar de existirem algumas comparações entre estimativas de modelos provenientes de diferentes instituições (ex: ), nada foi encontrado subsidiando a seleção de determinadas instituições fonte (em detrimento de outras) com base em critérios de qualidade por meio de comparações de seus produtos.

Nesta pesquisa, a instituição Goddard Institute for Space Studies (GISS-NASA, 2015) foi escolhida como fonte por apresentar o modelo mais recente (GISS-E2-R 2015) entre instituições elencadas no portal do Research Program on Climate Change, Agriculture and Food Security (CCAFS, 2015), o qual também foi desenvolvido com a mais aprimorada técnica de modelagem, o Delta Method IPCC AR5 (CMPI5, 2015; CCAFS-DM, 2015), e por apresentar publicações avaliando e justificando a qualidade preditiva do modelo (Schmidt et al., 2014; Miller et al., 2014; Stanfield et al., 2015; Nazarenko et al., 2015; e uma grande lista de publicações com usos da camada em GISS-PUBS, 2015).

A qualidade dos novos modelos (CMPI5-AR5 para cenários RCP) também é evidenciada visualmente, por meio da comparação de suas projeções em forma de mapas com relação a versão anterior, que se embasavam em linhas de referência (do inglês: storylines) sobre cenários de desenvolvimento social humano para a geração de estimativas de mudanças climáticas (Special Report on Emissions Scenarios; IPCC, 2007).

Para esta comparação visual, primeiramente é necessário isolar o modelo de projeção futura acoplada na camada ambiental. Em outras palavras, o modelo que estima a mudança do clima no futuro (seja para temperatura, precipitação ou outra variável) não inclui em si a variação dos fatores climáticos atuais, mas a diferença a partir de hoje para o futuro. Ou seja, se num ponto do planeta a temperatura média anual atual é de $20^{\circ} \mathrm{C}$ e em 2050 se tornará $22^{\circ} \mathrm{C}$, o modelo futuro (para 2015) isolado da variação do fator em questão exibirá o valor de $2^{\circ} \mathrm{C}$. Já, por exemplo, se a precipitação atual é de $100 \mathrm{~mm}$ e se tornará $80 \mathrm{~mm}$ em 2050, o modelo futuro isolado exibirá $-20 \mathrm{~mm}$. É muito simples isolar os modelos climáticos futuros acoplados as camadas futuras para verificação, basta-se subtrair a camada futura de sua variável 
equivalente em cenário atual, ou seja, para a camada Bio 1: Modelo $_{\text {Bio1 }}=$ Bio1 $_{2080}-$ Bio1 $1_{\text {atual. }}$

A figura C3-17 mostra o modelo climático global isolado para a temperatura média anual (Bio 1 em resolução de 30 segundos de arco) feito pelo Canadian Centre for Climate Modelling and Analysis (CCCMA) para 2080 em um cenário moderado (A1B) na versão de modelagem anterior a versão mais recente. É bastante fácil identificar a baixa resolução do modelo ao se identificar visualmente a matriz celular cujas células apresentam grande extensão com informações únicas. Cada dimensão celular deste modelo (células com cerca de $400 \times 400 \mathrm{~km}$ ), quando combinada com a camada atual em máxima resolução (células com cerca de $1 \times 1 \mathrm{~km}$ ) acresce ou diminui apenas único valor (futuro) em muitas células da camada atual que coincidem com sua abrangência geoespacial. Assim, se uma célula do modelo futuro previr o aumento de $1^{\circ} \mathrm{C}$ em 2080, 400 valores da variação da temperatura atual se elevarão em uma unidade $\left(1^{\circ} \mathrm{C}\right)$ na camada futura composta.

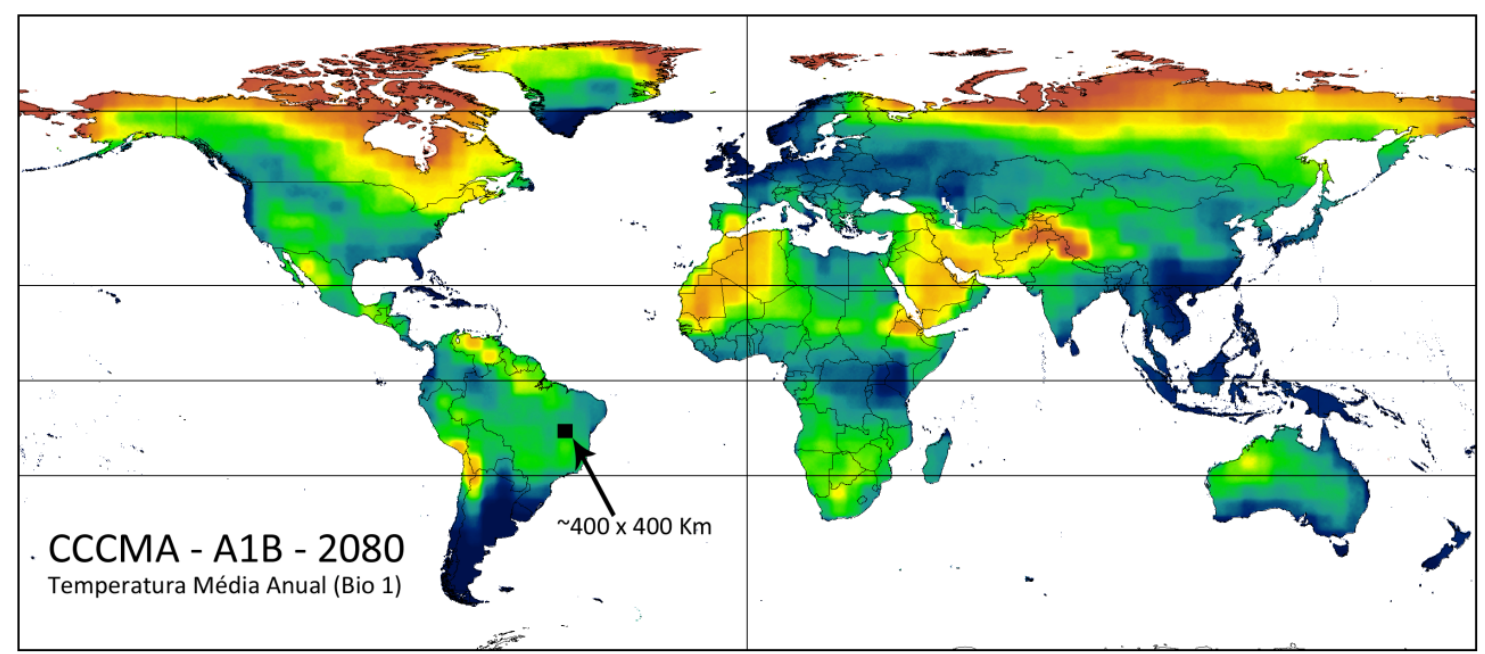

Figura C3-17. Modelo de mudança climática na temperatura média anual (Bio 1) isolado da camada atual, o qual foi gerado pelo CCCMA em cenário A1B para 2080. A única célula em preto (quadrado apontado pela seta) é uma referência de escala para a resolução global do modelo, que possuem células de aproximadamente $400 \times 400$ km quando próximas à linha do equador. Este mapa apenas ilustra a baixa resolução, portanto a escala de variação da variável foi desconsiderada.

Os modelos climáticos mais recentes, que foram disponibilizados a partir de 2015 (Figura C3-18), possuem resolução e qualidade muito superiores aos modelos de versões anteriores. Algo que foi alcançado devido aos aprimoramentos técnicos e metodológicos na modelagem, maior capacidade computacional aplicada nos cálculos e a inclusão de maior número de variáveis (Knutti e Sedláček, 2013).

Pode-se perceber claramente ao se comparar o modelo na figura C3-17 com o modelo na figura C3-18 que a versão mais recente de modelagem exibe resolução muito superior que a anterior. Na verdade, a resolução dos atuais modelos acompanha a máxima resolução das camadas climáticas em cenário atual, que é de 30 segundos de arco ( 1 x $1 \mathrm{~km}$ ), extremamente superior ao exemplo da CCCMA (Figura C3-18), que exibe uma resolução de aproximadamente 400 x $400 \mathrm{Km}$. 


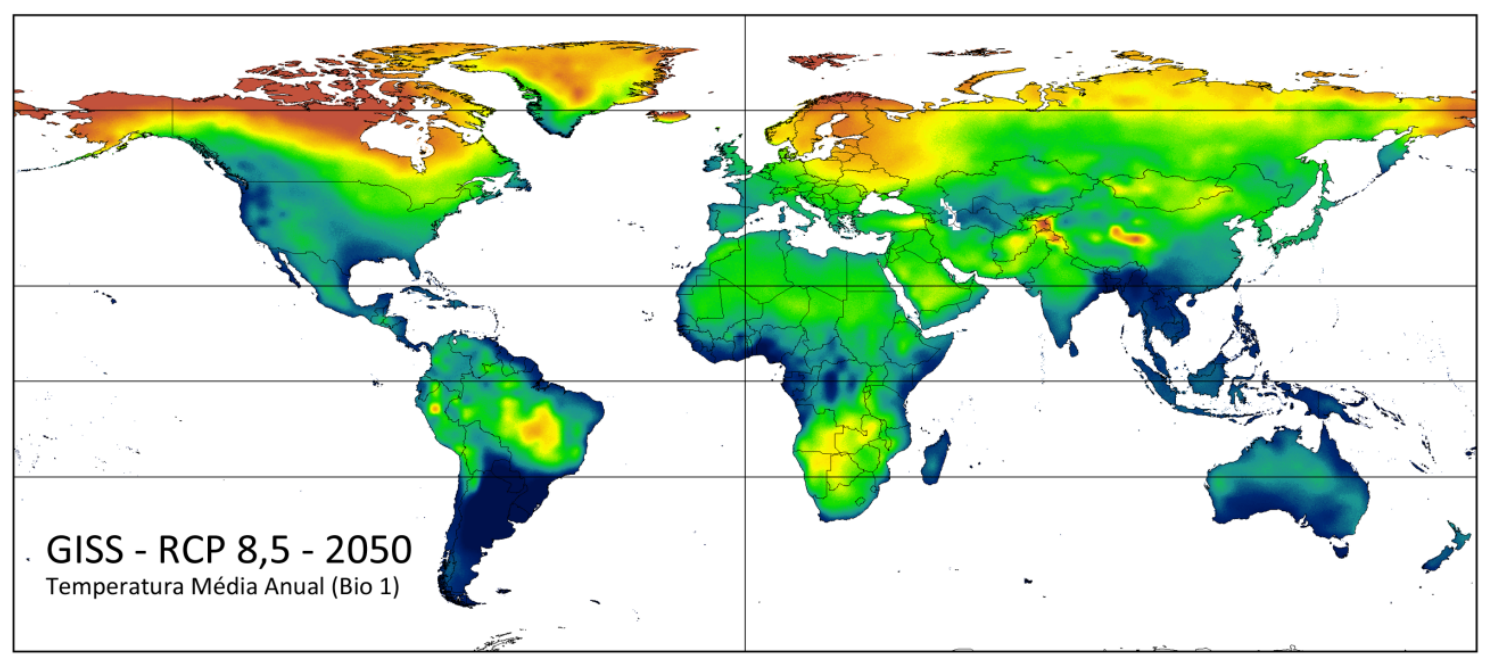

Figura C3-18. Modelo de mudança climática na temperatura média anual (Bio 1) gerado pelo GISS-NASA em cenário RCP 8,5 para 2050. A resolução deste modelo acompanha aproximadamente a mais alta resolução das camadas em cenário atual (30 segundos de arco ou, aproximadamente, células de $1 \times 1 \mathrm{Km}$ ). Este mapa apenas ilustra a alta resolução deste modelo, portanto a variação foi desconsiderada e não é correspondente em escala com a figura C3-17.

Os modelos estimados para climas futuros mais recentes utilizam como cenários de referência as denominadas Tendências Representativas de Concentrações ou, do inglês, RCPs (Representative Concentration Pathways), que foram difundidas pelo IPCC em seu último relatório de avaliação (IPCC, 2014). Estes cenários são divididos em quatro categorias: RCP 2,6; 4,5; 6,0 e; 8,5.

O cenário de RCP de valor mais baixo $(2,6)$ indica a tendência futura de baixa concentração (e não emissão) de gases de efeito estufa na atmosfera. Algo que só poderá ser alcançado se a humanidade no futuro se tornar ambientalmente amigável, possuir tecnologias de alta eficiência e que sejam acessíveis a todos. E ainda, deverá haver a predominância de biocombustíveis na matriz energética levando a uma extrema redução na queima de petróleo e carvão em relação às outras tendências/cenários (Figura C3-19).

O cenário RCP de valor mais alto $(8,5)$ sugere o extremo oposto, ou seja, um futuro potencial com elevado consumo de carvão, especialmente em termoelétricas para suprir de energia elétrica um mundo altamente populado, conflituoso, energeticamente

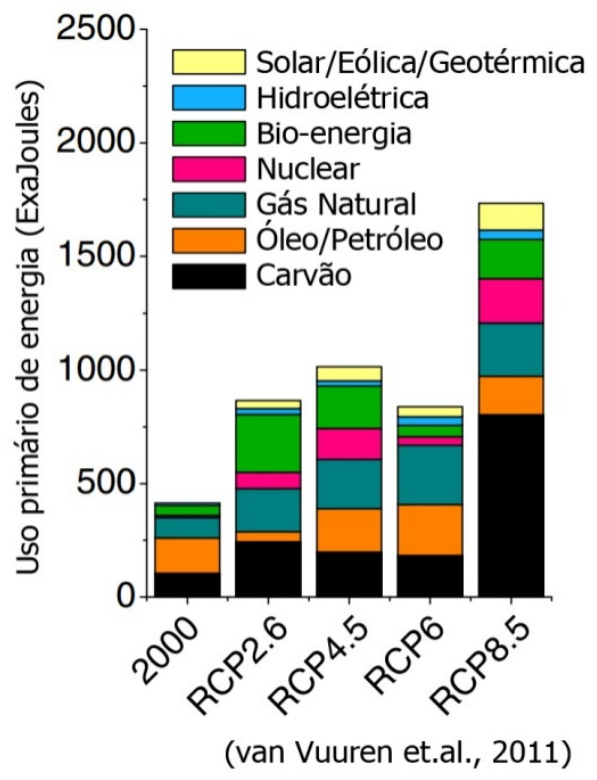

Figura C3-19. Cenários RCP (IPCC, 2014) e uso de energia. ineficiente, onde a degradação ambiental será muito intensa. Os cenários 4,5 e 6,0 predizem concentrações intermediárias, portanto estão relacionados a causas e efeitos intermediários em relação aos dois extremos $(2,6$ e 8,5). 
Por meio de uma observação superficial e cotidiana da dinâmica do desenvolvimento da sociedade humana atualmente, obtêm-se evidências de que o cenário RCP 8,5 talvez seja a tendência mais provável de representar as concentrações que serão alcançadas nas próximas décadas. Todavia, para esta pesquisa, os dois cenários intermediários foram selecionados (RCP 4,5 e 6,0), pois são as escolhas mais parcimoniosas perante as incertezas sobre o futuro social da humanidade. Também, isso se deve à ausência de sólidas sugestões sobre cenários RCP mais adequados em análises ecológicas na literatura específica; algo esperado, uma vez que estas camadas foram disponibilizadas recentemente (2015).

Escolheu-se a década de 2050 dentre a variedade de décadas disponíveis (entre 2020 a 2080) devido à maior proximidade com o presente momento em oposição, por exemplo, às de 2070 e 2080. E não se escolheu as décadas mais próximas, por exemplo, 2020 e 2030, devido à necessidade de se assegurar maior efeito discriminativo na projeção dos modelos de adequabilidade de habitat para o futuro.

Se a divergência ambiental das camadas atuais for muito pequena em relação suas respectivas projeções futuras, poderia haver baixa variabilidade entre os conjuntos de dados gerados pelo cruzamento das ocorrências com as camadas atuais e futuras, levando à baixa discriminação das influências das mudanças climáticas nos habitat adequados. Também, poderia conduzir à intensificação da colinearidade entre variáveis, o que prejudicaria os algoritmos de regressão, reduzindo o efeito discriminativo entre os diferentes cenários temporais. 


\section{Capítulo 4 - Modelo global de susceptibilidade à invasão de Bombus terrestris}

O método de modelagem e o seu resultado: o modelo global delineando as áreas susceptíveis à invasão por Bombus terrestris, são centrais a esta pesquisa, pois sobre este resultado todas as análises subsequentes decorrerão. $O$ método inclui novas abordagens e aprimoramentos para buscar resultados preditivos mais precisos em estudos com ampla dimensão geográfica e variáveis com alta resolução.

Não foi encontrado até este momento outro trabalho lidando com invasões de polinizadores de forma preditiva em escala global, por isso, este capítulo está em forma de artigo e foi submetido a uma revista de expressivo impacto científico: Plos One. 
4.1. Worldwide Alien Invasion: A methodological approach to forecast the potential spread of a highly invasive pollinator

Acosta, A. L. ${ }^{1,4}$; Giannini, T.C. ${ }^{1,3,4}$; Imperatriz-Fonseca, V.L. ${ }^{1,3.4}$; Saraiva, A.M. ${ }^{2,4}$

${ }^{1}$ Department of Ecology. Biosciences Institute, Universidade de São Paulo. Rua do Matão, travessa 14, n. 321. 05508-090. São Paulo, São Paulo, Brazil. Phone: +55 (11) 3091-7533. andreluisacosta@usp.br; giannini@usp.br; vlifonse@ib.usp.br

${ }^{2}$ Department of Computing and Digital Systems Engineering. Polytechnic School, Universidade de São Paulo. Av. Prof. Luciano Gualberto, n. 380, 05508-970. São Paulo, São Paulo, Brazil; saraiva@usp.br

${ }^{3}$ Vale Institute of Technology - Sustainable Development. Rua Boaventura da Silva, n. 955, 66055-090. Belém, Pará, Brazil.

${ }^{4}$ Research Center on Biodiversity and Computing - BioComp (http://www.biocomp.org.br/). Av. Prof. Luciano Gualberto, travessa 3, n.158, 05508-900.São Paulo Capital, São Paulo State, Brazil.

Corresponding author: andreluisacosta@usp.br 


\begin{abstract}
The ecological impacts of alien species invasion are a major threat to global biodiversity. The increasing number of invasion events by alien species and the high cost and difficulty of eradicating invasive species once established require the development of new methods and tools for predicting the most susceptible areas to invasion. Invasive pollinators pose substantial threats to biodiversity and human activity due to their close relationship with many plants (including crop species) and high potential competitiveness for resources with native pollinators. Although at an early stage of expansion, the bumblebee species Bombus terrestris is becoming a representative case of pollinator invasion at a global scale, particularly given its high velocity of invasive spread and the increasing number of reports of its impacts on native bees and crops in many countries. We present here a methodological framework of habitat suitability modeling that integrates new approaches for detecting habitats that are susceptible to Bombus terrestris invasion at a global scale. Our approach did not include reported invaded locations in the modeling procedure; instead, those locations were used exclusively to evaluate the accuracy of the models in predicting suitability over regions already invaded. Moreover, a new and more intuitive approach was developed to select the models and evaluate different algorithms based on their performance and predictive convergence. Finally, we present a comprehensive global map of susceptibility to Bombus terrestris invasion that highlights priority areas for monitoring.
\end{abstract}

Keywords: species distribution modeling, Biomod2, habitat suitability, Bombus terrestris, pollinator, biodiversity, susceptibility to invasion

\title{
Introduction
}

The ecological impacts of species invasion are a major threat to global biodiversity (CDB, 2001, 2009; Villemant et al., 2011), with widespread effects on humanity, affecting agriculture, forestry, fisheries, and human health (Williamson, 1999; Andersen et al., 2004; Mack and Smith, 2011). An alien invasive species is defined as a taxon introduced outside its native range, 
either deliberately or accidentally, presenting a high growth rate and fast range expansion, with noticeable impacts for human activities and environmental conservation (Alpert et al., 2000; Wittenberg and Cock, 2001; Kenis et al., 2008; Roques et al., 2009). Alien species are capable of naturally overcoming biogeographical barriers due to their dispersal and colonization abilities. However, species with economic value (e.g., ornamental plants) or that provide goods and services (e.g., bees) may furthermore be actively dispersed and introduced into nonnative environments by humans (Ewel et al., 1999; Levine and D'antonio, 2003; Perkins et al., 2011).

Some primary conditions are required for a terrestrial alien species to successfully invade once introduced into a nonnative habitat. First, it must overcome local environmental factors (e.g., climatic conditions, predators, diseases); second, it must acquire basic resources (e.g., food, shelter, water); and third, it must find reproductive partners (mates). If these basic requirements are met and the limiting factors are transposed, there is a high probability of the alien species becoming invasive (Moller, 1996; Perkins et al., 2011). In some cases, alien species can overcome the limiting factors but not reproduce (not acquire mates). Consequently, it will not expand its distribution in nonnative habitats, thereby becoming an exotic, but not invasive, species.

Abiotic factors are considered the initial environmental barrier that an invasive species must overcome in a nonnative environment (Pulliam, 2000; Soberón and Peterson, 2005; JiménezValverde et al., 2011), in terms of Hutchinsonian niche requirements (Hutchinson, 1957). Species cannot survive an environment where abiotic factors exceed their physiological limits (Kearney and Porter, 2009). Thus, climatic factors can be considered among the most influential types of abiotic factors that limit or, in some cases, promote the expansion process of an invasive species (Broennimann et al., 2007; Shi et al., 2010; Nenzén and Araújo, 2011).

Social insects present a high potential of invasiveness because their sociality improves their competitive and resource-finding abilities as well as enhances their ability to occupy and spread in new environments (Chapman and Bourke, 2001). Another important aspect is the ability of a single inseminated queen to establish a new colony, which can produce a large number of reproductive individuals (Moller, 1996). Thus, eventually, a single individual or colony could 
be the progenitor of an entire invasive population (Buttermore et al., 1998; Tsutsui and Case, 2001; Giraud et al, 2002).

Among social insects, invasive pollinators can pose a serious problem to biodiversity and, in some cases, to human activity due to their close relationship with many plants, particularly crop species. Moreover, they may strongly compete for resources against native species that share similar requirements (Hingston and Mcquillan, 1998; Dohzono et al., 2008; Dafni et al., 2010; Mommaerts et al., 2011).

Robust technology is urgently needed to combat the increasing number of invasion events by alien species (Levine and D'Antonio 2003), especially considering the high cost and difficulty of eradicating such species once they are established (Leung et al., 2002; Genovesi 2005). Thus, new methods and tools that can predict the areas most susceptible to invasion are needed to better understand the invasive process, to provide effective monitoring methods and to delineate possible mitigating actions (Zalba et al., 2000; Allen et al., 2006).

Species distribution modeling (SDM) has been applied to forecast the potential occupancy of a wide range of invasive species. Examples include plants (e.g., Peterson et al., 2003; Peterson and Robins, 2003; Peterson et al., 2006; Broennimann et al., 2007; Evangelista et al., 2008; Christenhusz and Toivonen, 2008; Jarnevich and Stohlgren, 2009), insects (e.g., Roura-Pascual et al., 2006; Ward, 2007; Peterson et al., 2007; De Meyer et al., 2008; Kadoya et al., 2009; Mata et al., 2010; Medley, 2010), mollusks (e.g., Loo et al., 2007) and amphibians (e.g., Ficetola et al., 2007; Giovanelli et al., 2008).

According to Lavergne et al. (2010), SDMs have been largely influenced by Hutchinson's concept of the ecological niche (Hutchinson, 1957). Currently, this type of ecological modeling is also considered able to estimate habitat suitability, as it uses reported occurrences to identify other places with similar suitable conditions (Kearney and Porter, 2009). In this work, we choose Habitat Suitability Modeling (HSM) as a standard denomination of an analytical procedure that encompasses methods and concepts described by other researchers and authors as Species Distribution Modeling (SDM) or Ecological Niche Modeling (ENM). Suitable habitat 
that occurs outside the natural range of a species can also be considered susceptible to invasion if the species is subsequently introduced there or reaches these habitats naturally.

Considering the limited knowledge of the interactions between native and invasive species during the initial stage of an invasive process, estimating habitat suitability in terms of topoclimatic similarities (climate and altitude) can be informative. The set of variables can be used to predict nonnative areas susceptible to invasion and to estimate the potential range of occupancy of an invasive distribution, even at a large spatial scale, such as worldwide (Beaumont et al., 2009; Broennimann et al., 2007; Medley, 2010; Rodderand Lotters, 2009; Urban et al., 2007).

Several HSM methodological approaches have been proposed to improve their application. For example, some studies have compared the performance of different algorithms (e.g., Elith et al., 2006) or sample sizes (e.g., Wisz et al., 2008); or examined how to fit models (e.g., AguirreGutiérrez et al., 2013); ensemble multiple projections (e.g., Araújo and New, 2007); included biotic interactions (e.g., Giannini et al., 2013); or evaluated model performance (e.g., Bahn and McGill, 2013). Additionally, some studies have used HSMs to assess information on invasive species at many spatial scales (e.g., Thuiller et al., 2005; Broennimann et al., 2007; Broennimann and Guisan, 2008; Le Maitre et al., 2008; Beaumont, 2009; Parker-Allié et al., 2009; Ballesteros-Mejia, 2011; Gallien et al., 2012). However, as far as we know, there is no methodological approach for determining areas that are susceptible to pollinator invasion on a worldwide scale.

The bumblebee Bombus terrestris (L.) (Hymenoptera: Apidae) may become one of the most representative cases of pollinator invasion at global scale, especially considering its velocity of spread (90 km per year in New Zealand; Hopkins, 1914; cited by Dafni et al., 2010) and reports of invasive expansion in new countries (Ings et al., 2006; Torreta et al., 2006).

Bombus terrestris is a eusocial bee with a relatively large and hairy body of high thermoregulatory capacity; this capacity enables individuals to maintain activity even at low temperatures $\left(<10^{\circ} \mathrm{C}\right)$ and in rain conditions (Heinrich, 1979; Kuusik et al., 2002; Winter et al., 2006; Dafni et al., 2010). The queen is capable of independently establishing a new colony, 
which can rapidly reach 500 individuals (Buttermore, 1997; Goulson et al., 2002). The wild, native distributional range of Bombus terrestris covers almost the whole of Europe, mainly the temperate and Mediterranean zones, and encompasses surrounding areas of Asia and Africa (Loken, 1973; Kruger, 1954; Winter et al., 2006; Dafni et al., 2010).

Bombus terrestris (hereafter referred to as $\mathrm{Bt}$ ) is able to perform buzz pollination (Buchmann, 1983; Westerkamp, 1991; Morandinet al., 2001a; Goulson, 2002, 2010), which improves the pollination success of plants with poricidal anthers. Bt provides this important ecosystem service to wild plants and crop species with high economic value such as tomato, pumpkin, eggplant, potato and pepper (McGregor 1976; Morandin et al., 2001a). Bt is well adapted to artificial conditions, and because of its ease of handling and breeding, colonies have been developed in captivity and commercialized for over 20 years to improve pollination in the greenhouse (Dafni, 1998; Velthuis, 2002; Winter et al., 2006; Dafni et al., 2010; Velthuis, 2002; Winter et al., 2006; Dafni et al., 2010; Velthuis and Cobb, 1991; Free, 1993; Proctor et al., 1996; Morandin et al., 2001b, 2001c; Velthuis and van Doorn, 2006).

The artificial, large-scale production of Bt nests achieved a million colonies in 2006 to supply a growing international market of crop pollination services (Velthuis and van Doorn, 2006; Winter et al., 2006). These colonies are delivered by regular mail service to many countries, including some places located outside their natural range. This international trade is reported as the main cause of Bt invasion in Chile, China, Israel, Japan, Mexico, New Zealand, South Africa, South Korea, Taiwan, and Tasmania (Ruz and Herrera, 2001; Hingston et al., 2002; Ruz, 2002; Velthuis, 2002; Goulson, 2003; Goulson and Hanley, 2004; Griffiths, 2004; Matsumura et al., 2004; Inari et al., 2005; Winter et al., 2006; Velthuis and Van Doorn, 2006; Schmid-Hempel et al., 2007; Howlett and Donovan, 2010).

Currently, the invasive distribution of Bt is increasing without direct human intervention, by means of its own dispersion capabilities. Torreta et al. (2006) reported that this species has expanded its invasive distribution from Chile (where it was first introduced in South America; Ruz and Herrera, 2001) to Argentina (Bariloche, Neuken), crossing the Andean Mountains by lowland paths that connect both countries. In most cases, this spread has occurred without prior 
assessment of the possible negative impacts on native pollinators. As a result, Bt appears to have disrupted native plant-pollinator interactions and decreased the number of some native bees (Goulson, 2003; Aizen et al., 2008; Goulson et al., 2008; Morales et al., 2013; Aizen et al., 2014). In addition, on Hokkaido Island (Japan), the population of the native bee species Bombus hypocrite sapporoensis has declined due to competition with Bt for nesting sites (Inoue et al., 2008). Reproductive fitness of Bombus hypocrite sapporoensis has also decreased in Japan due to interspecific mating with Bt (Kanbe et al., 2008; Kondo et al., 2009). In Israel, invasive Bt has also been reported as beginning its foraging activities earlier than the native bees, exhausting the nectar of various flowers and consequently reducing the number of native colonies (Dafni and Schmida 1996). Invasive Bt can increase the potential of bee and plant diseases by acting as a vector of alien microorganisms and other small organisms, transmitting them to native species (Velthuis and van Doorn, 2006; Winter et al., 2006; Goulson et al., 2008; Plischuk and Lange, 2009; Arbetman et al., 2013). Additionally, invasive pollinators (including $\mathrm{Bt}$ ) change plant-pollinator interactions in nonnative environments, impacting crops and native plants and pollinators (Ainzen et al., 2014; Morales et al., 2013).

Therefore, we consider Bt as a representative case study of an incipient worldwide alien invasion, undergoing rapid expansion in many countries outside their native range. The worldwide scale detection of areas susceptible to invasion by Bt can be used to warn of future invasions and can guide the development of precautionary measures and policies aiming to avoid or mitigate future impacts on natural environments and human activities.

To increase the accuracy of Habitat Suitability Modeling for invasive species, we present a methodological framework with new geospatial strategies to evaluate, select and ensemble models based on a multi-algorithms approach. This methodology is used to detect areas susceptible to Bombus terrestris invasion worldwide and potential areas of expansion from existing invaded areas. We also present a global map of susceptibility to $B$. terrestris invasion showing areas that should be monitored. 


\section{Materials and Methods}

\section{Environmental variables}

We obtained 20 layers of environmental topoclimatic data from Worldclim (Hijmans et al., 2005), with a spatial resolution of 5 min of arc (cell size approximately $10 \mathrm{~km}$ ) over a global range (with the exception of southern latitudes greater than $60^{\circ}$ ). These layers present data on altitude and annual trends of seasonality, temperature extremes and average precipitation over the last 50 years.

To reduce co-linearity among predictors, we performed a Pearson's pairwise correlation procedure using R v.3.0.3 (R Development Core Team, 2011) and selected those layers with Pearson's correlation coefficients less than 0.75 . When two layers were highly correlated, we chose the one least correlated, yielding a total of nine layers: Mean Temperature Diurnal Range, Maximum Temperature of the Warmest Month, Temperature Annual Range, Precipitation of the Wettest Month, Precipitation of the Driest Month, Precipitation Seasonality, Precipitation of the Warmest Quarter, Precipitation of the Coldest Quarter, and Altitude.

We did not include additional environmental variables in the modeling procedure due to the lack of available knowledge about the relationship of $\mathrm{Bt}$ with other abiotic and biotic variables in nonnative environments. Rather, because climate and altitude have several similar conditions and combinations around the globe, we considered the extrapolation of ecological considerations based solely on topoclimatic variables to be more reliable.

\section{Bombus terrestris data}

We used presence records for Bt surveyed from two main sources (for source details, see Supporting Information S1): 1) presence data extracted from published literature and 2) presence data obtained from collections and museums and compiled in internet biodiversity databases (mainly GBIF - Global Biodiversity Information Facility). For the published data, when Bt presence was georeferenced by city or other place name, the geographical coordinates were extracted using the toponyms from the Global Administrative Areas Database (GADM, 
2012). If occurrences were exhibited on a map only, we plotted the map into ArcGIS 10 (ESRI, 2010) to estimate the geographical coordinates for each point using the Georeferencing Tool.

The complete dataset was divided into two subsets based on published data (see Supporting Information S1): 1) presence within the native Bt range, referred to as Native Presence and 2) reported alien invasive presence, referred as Invasive Presence (see Supporting Information S1). Although some publications have suggested the presence of invasive $\mathrm{Bt}$ in China, Israel, Mexico, South Africa, South Korea, and Taiwan, we have found no recorded locations. Thus, we only considered as invaded those places with reports of sightings of individuals or colonies of Bt. Both subsets were plotted in ArcGIS10 (ESRI, 2010).

First, we used the sample function and visual inspections to detect unreliable or erroneous records. Any record located in a water body class (e.g., oceans, rivers, lakes) according to GlobCover 2009 land cover (cell size of approximately $0.0028^{\circ}=\sim 300 \mathrm{~m}$ )(Bontemps et al., 2009) was excluded. Furthermore, we excluded presence records from outside the range of the environmental layers selected for modeling or from countries lacking previous reports of native or invasive occurrences.

To reduce statistical overfitting due to a large number of native presence records (over 10,000 raw data records) and to avoid redundancy (Pearson et al., 2007; Parolo et al., 2008; Merckx et al., 2010), we built a fishnet composed of square cells with the same spatial extent and grid cell size of the environmental layers $(\sim 10 \mathrm{x} 10 \mathrm{~km})$. Subsequently, we joined the fishnet with the native $\mathrm{Bt}$ presence dataset in ArcGIS. To do so, we treated each respective location as a unique presence, using the centroid of fishnet cells as the geographic coordinate of species presence. This procedure transformed Bt presence into a binary variable; i.e., we attributed a value of 1 to cells with one or more geospatially coincident presence records and a value of 0 to cells without presence records. The same procedure was then conducted with invasive Bt presence records. 


\section{Pseudo-absence datasets}

All the modeling algorithms used in this work required the input of pseudo-absences when true absences were not available (Phillips et al., 2009; Mateo et al., 2010; Barbet-Massin et al., 2012, Thuiller 2010) (in the case of MAXENT, background points). Because we cannot identify the true absence data for Bt, we generated two types of pseudo-absence datasets, as follows.

The first type of pseudo-absence dataset was generated by surveying the GBIF data provider to obtain presence records of Bombus species other than Bt, inside countries with reported native $\mathrm{Bt}$ presence. This dataset is hereafter referred as BO-PA (Bombus Other than $\mathrm{Bt}$ Pseudo-Absences). Based on studies of foraging distance in Bt and the maximum distance a worker bee can travel before returning to its nest (e.g., Walther-Hellwig and Frankl, 2000; Goulsonand Stout, 2001; Wolf and Moritz, 2008), we determined that Bt workers usually forage close to their nests, generally within $1 \mathrm{~km}$ (Wolf and Moritz, 2008). However, under extreme circumstances (e.g., a scarcity of resources), a worker bee can travel greater distances; the furthest distance reported to date is $9.8 \mathrm{~km}$ (Goulson and Stout, 2001). We used the largest distance $(10 \mathrm{~km})$ as the maximum displacement distance of individual $\mathrm{Bt}$ from their nests, and we assumed that most Bt sightings could be positioned within this maximum range during the field surveys, which provided each record in our presence dataset.

Considering the previous assumption, we plotted both the BO-PA and native Bt presence datasets into ArcGIS 10 (ESRI, 2010), and using the function select by location, we detected and excluded those BO-PA records located less than $10 \mathrm{~km}$ from a $\mathrm{Bt}$ presence record. This procedure removed any pseudo-absence record (BO-PA) located within the maximum spatial range of each Bt record. The remaining BO-PA locations, i.e., field surveys reporting no Bt but reporting other Bombus spp., were considered as reliable pseudo-absence locations. As performed previously with the native and invasive dataset, we used the fishnet to remove repeated BO-PA locations per grid cell.

The second type of pseudo-absence dataset was randomly generated following two steps. First, in ArcGIS 10 (ESRI, 2010), we created a spatial buffer using the geographic locations of 
both datasets: BO-PA and the native presence dataset (not the invasive one). In addition, we considered the $10 \mathrm{~km}$ distance to define the buffer radius per record for both datasets, and the area jointly covered by all buffers was used as a restriction zone in the next step. Second, we used the function create random points of ArcGIS to generate a random pseudo-absence dataset with three spatial constraints. Random points were generated exclusively inside the extent of the climatic layers, outside the restriction zone defined in the previous step, and outside the water bodies class of land cover GlobCover 2009. Additionally, we prevented the creation of points in repeated locations per grid cell, attributing a minimum distance of $15 \mathrm{~km}$ between points. The total number of random points was calculated as follows:

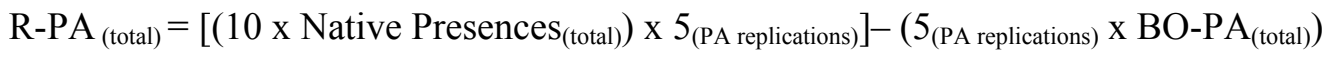

Incorporating the obtained results (see below) yields the following:

$\mathrm{R}_{-\mathrm{PA}}(\mathrm{total})=[(10 \times 4,209) \times 5]-(5 \times 3,422)=\underline{193,340}$.

The total number of Random Pseudo-Absence Points (R-PA) generated (193,340) was randomly fractionated into five subsets without replacement (38,668 per subset), such that each subset held only exclusive locations, with no duplicates. Subsequently, for each of the five random pseudo-absence subsets, we added the BO-PA records, totaling 42,090 records per subset. This yielded a total 10 times the number of native presence data points per subset (as recommended by Chefaoui and Lobo 2008).

\section{Modeling Procedure}

Bt native presence was randomly partitioned such that $75 \%$ of the data was used for training the model and the remainder (25\%) was used for mathematical evaluation using True Skill Statistic (TSS; Allouche et al., 2006). This random partitioning was repeated five times to obtain a robust estimate of the algorithms' performance (Franklin, 2009).

To generate the habitat suitability models, we used the Biomod2 package version 3.1.48 (Thuiller et al., 2009) in R (R Development Core Team, 2011) with all available algorithms in the package: Artificial Neural Networks (ANN; Ripley, 1996); Classification Tree Analysis (CTA, Breiman et al., 1984); Generalized Boosted Models (GBM; Ridgeway, 1999; Friedman, 
2001); Random Forests (RF; Breiman, 2001); Maximum Entropy (MAXENT, Phillips et al., 2006); Surface Range Envelops (SRE, Busby, 1991); Generalized Additive Models (GAM; Hastie and Tibshirani 1990); Generalized Linear Models (GLM, McCullagh and Nelder 1989); Multivariate Adaptive Regression Splines (MARS, Friedman, 1991) and Flexible Discriminant Analysis (FDA, Hastie et al., 1994).

To achieve comparability among algorithm results and considering the most frequently used parameters, we maintained the default settings in Biomod2 following the parameters recommended by Thuiller et al. (2009) and Thuiller et al. (2013). The MAXENT algorithm was used in the same way, with default settings recommended by Phillips and Dudik (2008), but with a different memory allocation size. These default parameters are described in the Supporting Information S2.

Twenty-five models were fitted per algorithm (ALGO1 to ALGO10); this was accomplished by combining five native presence partitioning (RUN1 to RUN5) and five pseudo-absence datasets (PA1 to PA5). The same pairwise combination was repeated in each round with each

algorithm [ALGO1\&RUN1\&PA1; ALGO1\&RUN1\&PA2 (..); ALGO1\&RUN2\&PA1 (...); ALGO2\&RUN1\&PA1 (...)]. We obtained 250 models, considering all possible combinations of ALGOs (10), RUNs (5) and PAs (5).

\section{Model Selection}

We developed a sequence of three evaluation criteria to select from the obtained models, as follows.

\section{Stage 1- TSS $\geq 0.8$}

First, we used a TSS evaluation index (True Skill Statistic; Alouche et al., 2006) greater than or equal to $|0.8|$. We chose TSS instead of AUC (Area Under the Curve of Receiver-Operating Characteristics) because a threshold-dependent measure was necessary to define the spatial cutting point before delineating each respective suitable (binary value=1) and unsuitable area (binary value $=0$ ) per model. AUC is a threshold-independent measure, appropriate for 
evaluating the performance of ordinal score models (such as continuous probability), but when binary models showing a clear dichotomy between suitable and unsuitable areas are needed, TSS gives better results (Allouche et al., 2006).

The TSS method is a synthetic index that considers sensitivity (ability to identify presences) and specificity (ability to identify absences) and is not sensitive to prevalence (Allouche et al., 2006). TSS values range between -1 and 1 ; positive values near one indicate high predictive accuracy. Negative values indicate poor predictions, and a zero proximity value indicates that the model performs no better than chance. In both latter cases, the models are not useful for detecting habitat suitability (Jiménez-Valverde and Lobo, 2007; Jones et al., 2010).

There are no precise threshold TSS scores defined for model evaluation; we chose a more conservative value $(\mathrm{TSS} \geq 0.8)$ than the threshold values frequently used (TSS $\geq 0.75$ ) (e.g., Domisch et al., 2013; Gallien et al., 2012; Engleret al., 2011; Mouton et al., 2010).

\section{Stage 2 - Based on invasive presence hit rate}

In the second stage, we evaluated the accuracy of each remaining model (those with TSS $\geq$ $0.8)$ to infer suitability predictions over areas other than the proximal native range of Bt. This method takes into account the rating of the geospatial coincidence of the suitable areas detected by each model (binary value 1) with the known locations of invasive $\mathrm{Bt}$ presence. In this context, the invasive dataset acts as a "validation dataset" for evaluating model accuracy by quantifying the accuracy of suitability detection of each model over the known distribution of invasive Bt.

To calculate this, we used the sensitivity component of TSS metrics. Thus, we calculated the probability of detection or hit rate (HR) according to the formula:

Invasive Hit Rate $(\mathrm{IHR})=\operatorname{Hits}_{(\text {binary one) }} /\left(\operatorname{Hits}_{(\text {binary one })}+\operatorname{Misses}_{(\text {binary zero) }}\right)$

The procedure of intersection between the Stage 1 models and the invasive presence dataset was developed in R (R Development Core Team, 2008) using the function extract of the Raster package (Hijmans and von Etten, 2012). 
We assumed that the most accurate models would be those that predicted the records of the validation dataset with higher precision, i.e., the models with higher Invasive Hit Rate (IHR) values. The minimum accuracy threshold for selecting the most precise models was defined by the overall average IHR value, meaning that each individual model that yielded an IHR value equal to or higher than the average IHR of all models was selected to proceed to Stage 3.

The procedure of intersection was replicated using the native Bt presence data, building a dataset used exclusively to compare stage performance in the final evaluation. Each value of this dataset was considered a measure of the Native Hit Rate (NHR).

\section{Stage 3- Convergence of suitability predictions}

The third stage was applied aiming to filter models with statistical biases related to underand over-fitting. A model was considered overfitted when an excessively large amount of cells with binary value $=1$ was detected in relation to all other models. This also means a large predicted area of suitable habitat based on known empirical species distributions, including some incoherent predictions, for example, suitable areas covered by arid deserts associated with tropical rainforest species.

Because of the large suitable area predicted, the chance of finding a geospatial intersection between the evaluation records (fraction of native presence records used for testing) and the validation dataset records (invasive presence records) increases, such that the binary value $=1$ can be inflated. These overfitted models yield high evaluation scores, but can have low quality.

In contrast, an underfitted model predicts small patches and/or spots of suitable habitat matching (or nearly matching) the range of presence data used to train the model. Frequently, this underfitted model predicts smaller suitable areas than most of the other models. Considering that the fraction of presence records used to evaluate the model is usually similar to the fraction of presence records used to train the model, the probability of suitable habitat predicted to match the presence evaluation records can also be increased and, in some cases, this underfitted model could yield TSS values higher than the minimum threshold. 
Thus, both undesirable statistical effects have to be considered when a massive number of presence data points and wide-extent, high-resolution environmental layers are used. The large number of pseudo-absences per dataset used here (approximately 42,000) and the extensive amount of information incorporated into each environmental layer (worldwide extent: totaling $2,287,025$ cells with information per layer) can jeopardize the specificity component of the TSS evaluation.

Another important advantage of this criterion is the detection and exclusion of divergent predictions. Metaphorically, when facing multiple points of view provided by various experts about on a subject, it is usually desirable to consider the opinion shared by the majority rather than the divergent opinion(s) provided by a minority. Therefore, only the models with considerable differences were filtered at this stage, i.e., those strongly diverging in the shape and size of suitable areas detected and differing from a large number of other models. We emphasize that the small-scale differences among models are of great importance in a multimodeling approach; these small differences increase the quality of the result and were not filtered by this procedure.

To evaluate the level of concordance among models, we calculated a similarity index using Pearson's pairwise correlation coefficients in R (Goshtasby, 2012), as highly correlated model pairs are presumably more similar in terms of habitat suitability and unsuitability prediction. For the models remaining after the previous selection stage, we estimated Pearson's correlation coefficients between model pairs. For each model, we averaged the coefficients over all paired coefficient values with the other models (except with the model itself; value $=1$ ). These averages (hereafter referred as PCCs - Pearson's correlation coefficient) were used to rank the similarity of each model in relation to the others. Thus, a model with a high average PCC is more similar in its suitability predictions with the majority of models in the set than models with lower PCCs and vice versa (the lower the PCC average, the less similar).

We predefined an ascending sequence of minimum average PCC thresholds from 0.5 to 1 in increments of 0.01 , totaling 51 PCC thresholds. We used this threshold sequence to generate sets of models with average PCC scores equal to or higher than each respective value. For each 
set generated, we projected an Ensemble Model termed the Overall Predictions Model (OPM; description provided in the next topic). Subsequently, we assessed the quality of each generated OPM to correctly predict suitability where the native (NHR) and invasive Bt presence (IHR) records were located. Moreover, we verified the ratio between the number of suitable grid cells predicted and the total number of grid cells per OPM (suitable + unsuitable cells) and termed this ratio the Suitable Cells Ratio (SCR), which was calculated as follows:

$\mathrm{SCR}=\mathrm{OPM}_{\mathrm{i} \text { (binary value } 1 \text { cells })} /\left(\mathrm{OPM}_{\mathrm{i}(\text { binary value } 1 \text { cells })}+\mathrm{OPM}_{\mathrm{i}(\text { binary value } 0 \text { cells } \mathrm{s})}\right.$

We also captured and calculated the minimum, maximum and average TSS values from the set of models that composed each OPM using the TSS values obtained from the Biomod2 output.

\section{Ensemble forecast}

Ensemble forecast models are mathematical methods that combine multiple simulations (forecasts) of a complex system into a unique and more robust result. Usually, each round of simulation (in our case, modeling runs) has different initial starting conditions and analytical logics related to, for example, input datasets, data partitioning, modeling parameters and algorithms (Araújo and New, 2007; Thuiller et al., 2009). The ensemble forecast model presents lower mean error than any individual simulation within it, thereby increasing predictive accuracy (Gallien et al., 2012; Araújo and New, 2007).

We developed our ensemble forecast model based on the committee averaging method of Biomod2, in which the probabilities of habitat suitability from different models are not averaged but are transformed into binary results (Gallien et al., 2012; Araújo and New, 2007). We used each respective model threshold that maximizes both sensitivity and specificity to define the spatial cut-off, before converting each model in binary predictions. This threshold parameter is considered to produce the most accurate results (Liu et al, 2005; Jiménez-Valverde and Lobo, 2007; Gallien et al., 2012). Another advantage of the committee averaging method is the ease of comparing outputs (binary $=1=$ presence; binary $=0=$ absence) relative to the raw algorithm 
outputs (continuous probabilities) that do not necessarily have the same meaning or same range of variation (for further details, see Araújo and New, 2007; Gallien et al., 2012).

Using binary models from each selection criterion (Stages 1, 2 and 3) and the Biomod2 output models, i.e., models without selection (hereinafter referred as Stage 0 models), we developed ensemble forecasts in two steps as follows:

Step 1) Agreement Level Ensemble Model (ALM). This model is based on the sum of binary values of each set of models, resulting in maps with geospatial classes ranging from zero (all models agree with the unsuitability of the area) to the total number of geospatial coincidences of suitable habitats detected by all models (a spatialized frequency histogram). Therefore, the class with value $=1$ indicates that only one model in the set indicated suitability in the area, the class with value $=2$ indicates that two models agreed, and so on. Note that this range is not related to probabilistic or suitability level but to the level of agreement among models in each set. We used ALMs twice. First, they were used to build the next ensemble model type. Second, they were used to build ensembles from each evaluation stage per algorithm, providing a way to compare and evaluate algorithm performance.

Step 2) Overall Prediction Ensemble Model (OPM). This model constitutes a binary map that considers every suitable habitat area predicted by the overall models of each set. Essentially, all classes exhibiting values equal to or higher than 1 in the Agreement Level Ensemble Model (previous step) were reclassified as a unique binary value $=1$. In contrast, the unsuitable areas retained the binary value $=0$. Each OPM was evaluated with respect to its predictive quality, and the selected OPMs were used to build the main ensemble model result, as described below.

\section{Evaluating and selecting ensemble forecast models}

We selected and ensemble some models to represent the global map of susceptibility to Bombus terrestris invasion. Selection was performed by visual inspection of plotted curves and analysis of changes in four evaluation indices (TSS, Invasive and Native Hit Rates, and Suitable 
Cells Ratio).We emphasized Invasive Hit Rate (IHR), which compares the obtained model to known invaded areas, a distinctive method of our work.

Among all Overall Prediction Models (OPMs) generated across the predefined Pearson's Correlation Coefficients (PCC) in Stage 3, we prioritized the selection of those positioned just before marked shifts in the evaluation indices, paying particular attention to IHR changes. When we detected a sequence of changes in the evaluation indices across the PCC range, showing a clear trend, we selected the OPM immediately preceding this sequence.

We also paid attention to the relationship between IHR and the SCR, as well as the relationship of IHR with shifts in the NHR and TSS values (minimum, mean and maximum) across the PCC range. We avoided choosing the last OPMs of the full PCC range because each of the previous OPMs in the range contains the suitable prediction of the next one, and the last OPMs tend to exhibit higher error than previous ones (as detected in the analysis). We selected the minimum possible number of OPMs, considering the highest representativeness of each selection to encompass the main changes across the PCC range.

Once the PCC thresholds were selected, the main ensemble model was produced by the sum of the respective OPMs using the raster package (Hijmans and von Etten, 2012) in the R platform (R Development Core Team, 2008). We considered the highest class value resulting from the maximum geospatial coincidence of shared suitability prediction as the "Susceptible at Maximum". To the class value $=1$ (only one OPM indicated suitability), we attributed the name "Susceptible". To the intermediate class values, we attributed denominations related to their levels of susceptibility. To the class value $=0$ (all OPMs agree with unsuitability of the area), we attributed the denomination of "Very Low Susceptibility or Insusceptible".

\section{Results}

At the end of our filtering process, the final dataset was composed of 4,209 native locations, 547 invaded locations (Figure 1) and 3,422 other Bombus spp. (i.e., Bombus spp. other than Bt) pseudo-absences (BO-PA). 


\section{Evaluation processes}

The initial set of 250 models generated by 10 algorithms (Stage 0) was reduced in Stage 1 (TSS $\geq 0.8$ ) to 195 models generated by 9 algorithms. All models from SRE were excluded, and there was a high reduction of FDA models, of which 23 were discarded (Table 1 and Figure 2). Some small losses also occurred with ANN (loss of 3 models) and MARS (loss of 4).

In Stage 2 (Invasive Hit Rate), an extreme reduction of models occurred (loss of 64 models from Stage 1) compared to the previous stage (loss of 55 from Stage 0); thus, 131 models remained from the initial number. With the exception of FDA, GAM, GLM and MARS, all algorithms lost models: ANN lost 17; CTA, 16; GBM, 4; MAXENT, 2; and RF, all 25 models.

In Stage 3 (convergence of suitability predictions), the Pearson's Correlation Coefficients (PCC) range had an upper bound of 0.79 , as no model pair yielded values higher than this. Thus, 30 Overall Predictions Models (OPMs) were selected.

Throughout the entire evaluation range, i.e., from Stage 0 to the last PCC threshold in Stage 3, the minimum TSS increased at four points (Table 1 and Figure 3). However, two increases were marked. The first occurred in Stage 1 , when models with TSS $\geq 0.8$ were excluded from the Biomod2 output models. The second occurred at the 0.62 PCC threshold (Stage 3) and was related to the marked reduction in the area of predicted suitable habitat from PCC 0.61 to 0.62 (minimum TSS from 0.800 to 0.858 ; Table 1 and Figure 3 ) and the small SCR sequential reduction in the previous PCC thresholds, beginning beyond PCC 0.59 (Figure 3).

Across the evaluation range, the maximum TSS had one marked decrease event in Stage 2 (falling from $\sim 0.931$ in Stage 1 to $\sim 0.904$ in Stage 2; Table 1) due to the exclusion of some high-scored models that correctly detected the native distribution of Bt (based on TSS values). However, the same excluded models only weakly detected suitability in locations of reported invasive Bt presence (based on Invasive Hit Rate values). For example, all $25 \mathrm{RF}$ models yielded high TSS values and passed through Stage $1(\mathrm{TSS} \geq 0.8)$ without model losses (Stage 0 minimum and maximum RF TSS values of 0.907 and 0.931 , respectively; Table 2). However, after Stage 2, no RF models remained (Table 1 and Figure 2). Subsequent to this decrease, the maximum TSS remained constant over almost the entire evaluation range until the last PCC 
threshold (Stage 3 - PCC 0.79), where a small decrease occurred. The stabilization of the maximum TSS over almost the entire PCC range is due to the permanency of a single high-TSS evaluated model since Stage 2 (MAXENT, PA 4; RUN 3, Table 2) that was only excluded from the set after PCC 0.78 .

As expected, the mean TSS was influenced by variation in its extreme values (minimum and maximum TSS) but provided an indication of the variation in TSS central tendency of models in each set across the evaluation range. The mid-range TSS variation became evident from the absent relationship between the observed interval of mean TSS variation and the changes in extreme TSS values. For example, from Stage 2 to 0.61 there were increases in the mean TSS (Table 1 and Figure 3) that were unrelated to maximum and minimum TSS variation but instead related to the exclusion of some lower-evaluated models in the TSS mid-range. This emphasizes the overall improvement in model accuracy across the evaluation range within the most central range of TSS values.

Decreases in the Native Hit Rate (NHR) were relatively minimal across the entire evaluation range (Figure 3 and Table 1), the total decrease reaching only approximately $2.5 \%$. This indicates that, from the initial number of 4,209 Bt native presence records used, 4,208 intersect suitable areas predicted by at least one model in Stage 0. From this value (Stage 0), only 104 hits were lost before the last PCC threshold (PCC 0.79, Stage 3; Table 3). Small NHR changes were observed at many points across the evaluation range (Table 1), but only four were relatively marked: one in Stage 2 and three in the final PCCs of Stage 3 (PCCs 0.77, 0.78 and 0.79) (Figure 3 and Table 1).

The Suitable Cells Ratio (SCR) exhibited the highest variability among all evaluation indices except in the range from PCC 0.62 to 0.72 , where we observed a pattern of SCR stability (Table 1). The SCR scale (Figure 3 and Table 1) does not provide a clear representation of the spatial scale contraction; for example, from Stage 1 to 2, a decrease of approximately 7.5 million $\mathrm{km}^{2}$ of suitable area was estimated (grid cell size at equator) (Table 3).

We observed positive and negative influences in the evaluation indices related to the reduction of OPMs suitable areas (SCR) across the PCC range (Stage 3) (Supporting 
Information S3). The SCR variation exhibited a strong linear relationship (Pearson's r) with IHR ( $\mathrm{r}: \sim+0.965 ; \mathrm{p}=6.9 \mathrm{E}-18)$ as well as strong, but negative, relationships with the mean TSS (r: -0.929; $\mathrm{p}=1.1 \mathrm{E}-13)$ and the minimum TSS ( $\mathrm{r}: \sim 0.884 ; \mathrm{p}=9.6 \mathrm{E}-11)$. The SCR exhibited a weak relationship with NHR (r: $\sim+0.621 ; \mathrm{p}=0.00024)$ and a non-significant relationship with maximum TSS $(\mathrm{r}: \sim+0.299 ; \mathrm{p}=0.1)$.

Invasive Hit Rate (IHR) variation and its relationships with other indices are depicted in Figure 4, where each evaluation index value was subtracted from the previous one across the evaluation range $\left(\right.$ Value $_{i+1}-$ Value $\left._{\mathrm{i}}\right)$. Some decreases in IHR occurred across the evaluation range, mainly related to SCR decreases, but three extreme decrease events were apparent at PCC $0.53,0.62$ and 0.79 . The latter PCC $(0.79)$ is preceded by a sequence of decreases starting at PCC 0.75. We detected three PCC thresholds that represent the main changes that occurred across the Stage 3 evaluation range (Figures 3 and 4; Tables 1 and 3). The first one occurred at PCC 0.53, with a pronounced decrease in IHR relative to the previous PCC threshold, indicating a reduction of 42 invasive presence values hitting suitable habitats (Table 3). Prior to this point, only 15 invasive hits were lost (Stage 0 to PCC 0.52 ). This event was also associated with a strong decrease in the Suitable Cells Ratio (SCR), an approximately $18.4 \%$ reduction in the global suitable area predicted from the previous PCC (Table 1). Based on this pronounced shift event in the evaluation indices, we chose the OPM positioned immediately preceding it to compose the final ensemble model (PCC 0.52). The second threshold occurred at PCC 0.62 (Figures 3 and 4), with an even more pronounced IHR decrease, resulting in a loss of 44 invasive hits from the previous PCC, which was also followed by a greater suitable area (SCR) reduction than the last event, approximately $22.3 \%$ from the previous PCC threshold (PCC 0.61; Table 1). Thus, we also chose the PCC 0.61 OPM to compose the final ensemble model. In the third case, we choose the PCC 0.74 OPM, which is positioned in the evaluation range just before the beginning of successive events of Invasive and Native Hit Rates (IHR and NHR) decreases, initiated at PCC 0.75 (Table 1; Figures 3 and 4). For each respective selected threshold in Stage 3 (PCC 0.52, 0.61 and 0.74), the OPMs were composed by 127 models 
generated by 8 algorithms; 113 by 6 algorithms; and 99 by 5 algorithms (Models per Algorithms in Table 1 and Figure 2).

From the ten algorithms used in the modeling procedure, only four contributed at least 20 models ( $\geq 80 \%$ of total models per algorithm) to all selected models (OPMs): GAM, GLM, MAXENT and GBM (Table 1). Considering also the algorithms that contributed more than 20 models for at least one selected OPM, we added MARS to this list, with 21 models only at PCC 0.52 (Table 1 and Figure 2). Thus, we considered these five algorithms to be more reliable for extrapolating habitat suitability predictions over more distant areas from the native distribution range of Bt, particularly the first four: GAM, GLM, MAXENT and GBM.

\section{From OPMs to Global Susceptibility Map to Bombus terrestris Invasion}

We used the three selected OPMs to ensemble our main model (D, E and F in Figure 5), which was projected as a Global Susceptibility Map to Bombus terrestris Invasion (global view in Figure 6 and framed in the spatial range of native and invasive presences in Figure 7). The Agreement Level Ensemble Models (ALMs), which were used to build the OPMs, were also projected (see the Supporting Information S4).

As each OPM contains the susceptible area predicted by the set of models of each subsequent OPM, the OPM from PCC 0.52 models predicted the largest susceptible area to $\mathrm{Bt}$ invasion on a worldwide scale (Figure $5 \mathrm{D}$ ). This covered approximately 28 million $\mathrm{km}^{2}$ (cell size estimated at the Equator; Table 3), and its susceptible area intersects 4,188 native (approximately 99.5\%) and 520 invasive presence records (approximately 95\%) of the initial total (Tables 1 and 3). However, the susceptible area identified exclusively by this OPM (class value $=1$ after the OPMs sum; green areas in Figure 6) is more spatially restricted and marginally distributed, covering approximately 9.9 million $\mathrm{km}^{2}$ and intersecting only 6 native (approximately $0.14 \%$ ) and 47 invasive presence records (approximately $8.6 \%$ ) of the initial total. We classified this area as Susceptible for the Global Susceptibility Map to Bt Invasion (Figure 6). 
The second largest susceptible area to Bt invasion was provided by the OPM PCC 0.62 (Figure $5 \mathrm{E}$ ), covering approximately 18 million $\mathrm{km}^{2}$ and intersecting 4,182 native (approximately 99.3\%) and 473 invasive presence records (approximately 86.4\%) of the initial total (Tables 1 and 3). Additionally, in this case, the exclusive susceptible area identified by this OPM plus the susceptible area from the previous one (class value $=2$; blue areas in Figure 6 ) are even more spatially restricted, covering approximately 4.4 million $\mathrm{km}^{2}$ and intersecting 4 native (approximately $0.09 \%$ ) and 47 invasive presence records (approximately $8.6 \%$ ) of the initial total. This area was classified as Highly Susceptible (Figure 6).

The susceptible area shared by all OPMs together, represented by the OPM PCC 0.74 prediction (class value $=3$ after the OPMs sum; Figure 5 F; black areas in Figure 6), covers approximately 13.9 million $\mathrm{km}^{2}$ and contains the majority of the Bt presence records. This area exclusively intersects 4,178 native (approximately 99.2\%) and 426 invasive $\mathrm{Bt}$ records (approximately 77.9\%, s 1 and 2) and was classified as Susceptible at Maximum (Figure 6).

The largest shared area among all selected OPMs, where all models agreed with no suitability and consequently no susceptibility to Bt invasion, covers approximately 168 million $\mathrm{km}^{2}$ and contains 21 native (approximately 0.5\%) and 27 invasive presence records (approximately 5\%). This area was classified as Very Low Susceptibility or Insusceptible to Bt invasion (white areas in Figure 6).

\section{Discussion}

Our methodological approach based in the three-stage selection criteria reduced the presence of statistical artifacts and incoherent predictions, retaining models with high predictive accuracy and high extrapolative capacity, i.e., the best models for delineating the global map of areas susceptible to Bt invasion. Moreover, it also showed that four algorithms (GAM, GLM, MAXENT and GBM) provided the best results, yielding models with high predictive convergence among them and high predictive and extrapolative capacity. 


\section{Overall performance of the methodological framework}

The three-stage procedure resulted in an overall improvement of TSS values, with minor decreases in the maximum and mean TSS, as well some losses in the native and invasive hit rates. However, even the lowest hit rate exhibited by the most conservative level of susceptibility can be considered a good score. In fact, the area classified as the maximum level of susceptibility contains the largest number of invasive and native $\mathrm{Bt}$ presence records. Moreover, it can be considered the most reliable representation of global susceptibility to $\mathrm{Bt}$ invasion, due to the highest prediction convergence among models and algorithms.

Stage 1 mainly excluded the models of lowest quality in terms of suitability prediction near the native Bt distribution. However, TSS did not detect models that were unable to extrapolate predictions to more distant areas nor did it detect some models with statistical artifacts and incoherent predictions (details below). Thus, Stage 2 was able to detect and filter out the models with low capacity to extrapolate suitability. However, we observed a small decrease in the Invasive Hit Rate (IHR) when compared with the previous stage, this being an undesirable but interesting result. This difference arises from the exclusion of some individual models in the Stage 2 due to their below-average IHR that nonetheless correctly predicted some specific fragments of suitable area covering invasive presence records. However, the selected models, i.e., those with scores greater than the total average IHR, were unable to predict suitability in those same specific fragments. Despite predicting some specific suitable areas that others did not, these models were correctly excluded at this stage due to their low overall capacity to extrapolate suitable areas. The main advantage of Stage 3 was the ability to detect and exclude models with highly divergent predictions when considering the majority of model predictions. These divergent predictions were mostly related to statistical artifacts and to under- and overfitting. Therefore, the progressive reduction in these undesired statistical effects was directly related to the increase in the Pearson's Correlation Coefficient (PCC) thresholds. However, a sequence of decreasing accuracy (IHR and NHR) is initiated above PCC 0.75, related to the extreme suitable area contraction (SCR). This suggests that in our case, PCC 0.74 is the last acceptable (accurate) threshold in the range. 
Overall, our framework aggregated different mathematical logics (from ten algorithms) and different input data (PAs and Bt presence partitioning) that yielded similar results. We consider the susceptibility levels of invasion obtained here to be more robust and accurate than the categorization (into classes) of continuous probabilistic approaches, even though we did not conduct a formal comparison.

\section{Algorithm performance}

The low values of TSS achieved by SRE resulted in the exclusion of all its models early in Stage 1. This was expected because SRE presents a simple logic that uses extreme values (percentiles 0.025 ) of the environmental variables captured from the area where the presence records were located, and it uses the shared intervals of all variables (between minimum and maximum limits) to delineate the suitable spatial shape (Thuiller, 2010). The large dimension of inputted data into the modeling procedure led to extremely restrictive results, predicting very small-size suitable areas (our highest underfitting) and consequently, low TSS values and the worst algorithm result.

The classification method used by FDA is influenced by the amount of input data, as very large dimensions (with high variability) may lead to reduced classification performance (Hastie et al., 1994). This likely influenced the performance of FDA, which was also poor. The suitability shape of predicted areas among FDA models was very discordant, especially at the borders, and almost the entire shared suitability area was restricted to the range covered by the inputted native Bt presence records. In general, FDA models exhibited evident underfitting compared to other models (and algorithms); nevertheless, two of its models passed Stages 1, 2 and the first PCC (0.52) of Stage 3.

In spite of the majority of MARS-generated models have reached TSS values slightly above the minimum threshold, they predicted a large and central unsuitable area covered by native Bt range. The shape of this unsuitable area, surrounded by suitable ones, diverged from almost all other models. Thus, across the PCC range, MARS dissimilarity resulted in the reduction of models at higher PCC values until total exclusion after PCC 0.61 (Stage 3). MARS and FDA 
models shared some predictive similarities, possibly related to the fact that FDA uses MARS in its regression component. However, based solely on our results, MARS alone performed better than FDA.

Some algorithms, namely, ANN, CTA and RF, were strongly affected by Stage 2, which reduced the number of generated models. These exclusions suggest that the predictive logics used by these algorithms could be considered good for detecting coherent suitable areas within or near the presence records used to train the models, based on the TSS. However, they also suggest that these algorithms are poor at extrapolating predictions over areas more distant from the training data; thus, these algorithms presented low extrapolative ability.

Almost all predictions from ANN showed clear indications of overfitting and presented many statistical artifacts. For example, ANN indicated Bt suitability in the extreme arid regions of the Sahara and the extremely humid regions of Amazonian forest. In addition, the large susceptible area predicted in eastern North America in the final ensemble model resulted from a unique ANN model that remained through Stage 3. Based in the Invasive Hit Rate (IHR), almost no ANN models were able to extrapolate suitability predictions. Moreover, ANN showed highly divergent predictions among its own models (as expected considering its logic; Thuiller, 2010) but also divergent predictions compared to the models of other algorithms. Despite these properties, 22 ANN models passed Stage 1. This finding suggests a possible inadequacy in the overall number of random generated pseudo-absences, resulting in inefficiency in the specificity component of TSS. We used a large number of pseudo-absences: for each pseudo-absence partitioning, we used ten times the number of training presences (Chefaoui and Lobo, 2008). However, TSS seems unable to detect the overfitted models generated by ANN. CTA models also exhibited divergent suitability predictions among its models but, in contrast to ANN, the predicted suitable areas were relatively small compared to all other predictions. However, some CTA models exhibited convergence with others, reaching higher PCC thresholds.

RF performance was particularly intriguing. Our results showed that despite the high TSS values obtained by RF, no model was selected past Stage 2.This result suggests some limitation 
of TSS in evaluating the extrapolative capacity of the models. While we defined a restriction zone in the range of the native Bt distribution, avoiding pseudo-absences in this area, we did not define any restriction to pseudo-absences on known invaded areas. We took this approach because we wanted the algorithms to be able to accurately detect suitability covering the invasive records without interventions in the modeling procedure relative to the invasive dataset. However, this aspect apparently reduced the efficiency of the TSS specificity component, hindering the capacity of TSS to correctly evaluate predictions in areas distant from the inputted training data. However, we emphasize that each algorithm used the same combination of five pseudo-absence datasets and five presence partitioning for testing and training; thus, there is no bias related to conditions of the input data. Overall, our results suggest that the exclusive use of TSS as a metric to evaluate the accuracy of models may be insufficient when a good suitability extrapolation is required. We demonstrated that the use of a "validation dataset" (Stage 2) can improve the evaluation procedure and validate the selection of models with high extrapolative accuracy.

The algorithms that yielded the best results were GAM, GLM, MAXENT and GBM. GAM and GLM have been described as having increased accuracy with increasing numbers of presence records used to train the model (Aguirre et al., 2013). The highest performance detected here by both algorithms was possibly related to the extremely large number of $\mathrm{Bt}$ presence records used. MAXENT and GBM also performed very well; both algorithms use more complex logics than the others, and MAXENT is known to progressively increase the mathematical complexity of the model with increasing available data (Aguirre et al., 2013; Elith et al., 2011). Moreover, the highest performance of both algorithms is reached in scale-reduced species distribution ranges and when using small training datasets (Aguirre et al., 2013). It is likely that these aspects explain why MAXENT and GBM performed slightly worse than GAM and GLM in our study. Together, these four algorithms provided the majority of models contributing to each Stage 3 model.

The high quality of the predictions of these four algorithms is apparent in the large number of models that remained after the three-stage process. Moreover, the large number of shared 
predictions among these four algorithms and the large number of shared predictions among the set of models generated by each suggest a high level of coherence and robust mathematical logics.

Despite some minimal variation between datasets (five PAs and native presence partitioning), the models yielded very similar and accurate results. This is also apparent when comparing algorithms, as each one uses particular mathematical logics to predict suitability and generate models, but they can nonetheless yield similar and accurate results. Therefore, our framework helped us to detect and filter divergent models from algorithms whose results were unreliable.

\section{Global susceptibility to Bombus terrestris invasion}

Areas susceptible to $\mathrm{Bt}$ invasion are almost entirely limited to the north and south temperate climate zones, suggesting the possible restriction of Bt invasion to tropical environments. If we consider exclusively the range of the native Bt zone, it is apparent that almost all suitable area is restricted to the Europe continent and western Russia, and the Susceptible at Maximum level covers almost exactly the entire native $\mathrm{Bt}$ distribution, emphasizing that $\mathrm{Bt}$ is predominantly a temperate species.

Large suitable areas were predicted in the easternmost region of the area of native $\mathrm{Bt}$ records used in the modeling, mainly from the northwest (Murmansk) to the southwest (Dagestan) of the Russian Federation. There was also a big suitable area covering the region of Moscow city. Nevertheless, we found no presence records there, despite the reporting of Russia as a native environment for Bt (Dafni et al., 2010).

In the southeastern region, suitable areas were predicted surrounding the continental seas of Azov, Caspian and Marmara; the Black Sea; and areas in Georgia, Azerbaijan, Syria and Lebanon. We found no reports of native Bt presence in these countries. However, these areas are close to Turkey, a country with many records and reports of native Bt presence (Özbek, 1993; Aslan, 2008; Dafni et al., 2010). 
In the southern area of native Bt records, specifically south of the Mediterranean Sea, most of the relatively small suitable areas were identified in northern Algeria, northwest Morocco and the Western Sahara, along with small areas in Tunisia, the Gaza Strip, Libya, Saudi Arabia, Jordan and Egypt. Among these countries, Morocco, Tunisia, Saudi Arabia and Jordan are reported as nonnative areas for Bt, with evidence of Bt invasion (Dafni et al., 2010). Libya and Egypt have been reported as countries without Bt (Dafni and Shmida, 1996).

Only a very low susceptibility was detected for Israel, a country that uses Bt colonies for greenhouse pollination and where Bt is reported as invasive (Dafni and Shmida, 1996; Ne'eman et al., 2000; Potts et al., 2001; Winter et al., 2006; Velthuis and van Doorn 2006; Dafni et al., 2010). Considering that the reported invasion of Bt in Israel is in the north of the country, mainly in the region of forest fires at Mt. Carmel (Ne'eman et al., 2000; Dafni et al., 2010), the resolution of variables may have been insufficient for detecting the particular topoclimatical conditions of this zone.

Reported occurrences of invasive Bt in South America were distributed in southern Chile and southwestern Argentina, but we detected large susceptible areas in eastern and southern Argentina, in central and eastern Uruguay, and in southeastern Brazil. These susceptible areas are almost entirely connected to invaded regions. Additionally, a large coastal corridor classified as Susceptible at Maximum connects the invaded regions to Uruguay and Brazil.

The first report of invasive Bt presence in Argentina (Torreta et al., 2006) suggested that this species reached the zone of San Carlos of Bariloche (Argentina), crossing the Andean Mountains via low-altitude pathways from Chile, where Bt was first introduced in South America. This scenario demonstrates the high dispersal capacity of $\mathrm{Bt}$, which increases the probability of invasive expansion over these susceptible corridors. Furthermore, it is likely that colonies (or inseminated queens) could be carried and released into these susceptible areas, accidentally or deliberately, by humans.

There is some evidence of the spontaneous spread of Bt in Uruguay after introduction (Dafni et al., 2010); however, we found no more information about sightings of Bt specimens or colonies in this country. Recently (2013), a large survey conducted during the spring and bordering the 
frontier between Brazil and Uruguay was made by the author (ALA) and collaborators, aiming to find invasive $\mathrm{Bt}$ in the wild. We found a large number of native bee species (including other Bombus spp.), but we did not find any Bt specimens. Until now, there is no strong evidence of Bt presence in either Uruguay or Brazil, but there is a strong possibility that Bt could use this susceptible pathway to reach both countries, increasing its invasive distribution from Chile and Argentina.

Bt threat was also detected by our models in the temperate zone of southwestern Oceania; notably, a large susceptible area was identified in Australia, where there is no reported invasion. Although Bt invasion was reported in the islands of Tasmania (AUS), with approximately $200 \mathrm{~km}$ of oceanic barrier separating them from Australia, and Bt invasion reported in both main islands of New Zealand, with approximately $1700 \mathrm{~km}$ of ocean between them and Australia, the global model showed a large, connected susceptible area in Australia. Assuming trade and transportation among these islands, the probability of Bt invasion into Australia could be considered high, as any inseminated queen hitchhiking via a commercial ship could start an invasion in this country.

This possibility has been a concern for some time inside academic and governmental circles (Hingston and McQuillan, 1998; NSW, 2004; McClay, 2005). This concern could be aggravated due to planned Bt importation by private agricultural sectors for greenhouse pollination (AHGA, 2005; Dafni et al., 2010) despite opposing initiatives (e.g., Winter, 2006). Regardless of whether Bt has yet to occur in Australia (we found no scientific reports of such), we strongly recommend monitoring and/or surveying in the susceptible area, particularly in the area of Susceptible at Maximum Level.

The susceptible areas detected in New Zealand and Tasmania precisely covered all reported invaded locations (Hingston and McQuillan, 1998; Hingston et al., 2002; Winter et al., 2006; Ward, 2007; Velthuis and van Doorn, 2006; Schmid-Hempel et al., 2007; Dafni et al., 2010; Howlett and Donovan, 2010). Recall that we did not include these invasive presence records in the modeling procedure; thus, in both countries, the predictions of susceptible areas can be considered very accurate. The susceptible areas in these islands cover almost all land except for the mountain ranges of highest altitude. 
In Japan, the susceptible areas coincided with Bt invasions already reported on Hokkaido Island (Kondo et al., 2009, Kadoya et al., 2009, Kadoya and Washitani 2010), mainly in the north and northeast. However, the model failed to detect the reported invasive presence on Honshu Island.

Companies that commercially produce Bt colonies for pollination in South Korea have been reported (Goulson Book 2010; Velthuis and van Doorn, 2006), and there is evidence of invasive spread (Dafni et al., 2010). However, the model detected low susceptibility to Bt invasion in this area.

A large susceptible area without reports of invasive Bt presence was detected in eastern Canada and the United States. This area has some environmental similarities with the native range of Bt, but almost all of the susceptible area detected was through a single model (from ANN); thus, we suggest that the classification for this area as suitable be considered with caution. However, we cannot disregard this prediction because other models also identified some susceptible areas in these countries.

A long strip of susceptibility in the southeast of China and a wide contour band of Susceptible at Maximum in the South Africa were detected; both countries are reported as threatened by Bt invasion (Winter et al., 2006; Dafni et al., 2010). Bt has already been introduced into South Africa, but there is no evidence of invasive spread (Dafni et al., 2010). Nevertheless, based on the model, spread is likely to occur, eventually reaching southern Namibia. Companies developing industrial pollination have been reported as commercializing Bt colonies in China (Velthuis and van Doorn 2006) and according to our models, it is likely that invasive Bt will spread through the susceptible area in the temperate zone, including Taiwan.

Many other susceptible areas were detected in countries and regions of temperate climate, but we found no information on commercial Bt colonies or sightings of Bt individuals for these areas. Examples include a narrow strip of high susceptibility in the west of the Himalaya Mountain Range covered by the Kashmir Region in India and northeastern Pakistan; a large susceptible area covering Iceland, Greenland and Svalbard (Norway); small areas in Iran and in the easternmost zone of Russia (Kamchatka Krai) and various small islands. In contrast, in tropical zones, the 
potential for Bt invasion can be considered very low. However, we cannot discard the possibility for some areas, especially if Bt colonies are introduced by humans. For example, in the highlands region of Lake Eduard (Democratic Republic of Congo), where the temperature is mild and the precipitation is high, the models detected a maximum level of susceptibility. This also applies to South American areas and the tropical highlands of the Andes.

\section{Conclusion}

The framework developed here presents new insights into multi-modeling methodological approaches of habitat suitability, mainly suggesting new criteria for model selection based on prediction convergence among models. This approach can be easily implemented in existing robust platforms of Habitat Suitability Modeling. The global map of susceptible areas can aid the design of more effective action plans for monitoring Bt invasion. It is important to consider public campaigns involving local people, which could contribute to a broader campaign for monitoring invasion over a large area. For example, Australia, Brazil and Uruguay could use the map to develop monitoring and mitigation actions that prioritize the border regions of areas already invaded. Finally, the framework proposed here can readily be adapted to other invasive species for monitoring spread. These actions could contribute to protect biodiversity and, in the case of Bombus terrestris, helping to reduce and avoid further threats to native pollinator bees, safeguarding their services.

\section{Acknowledgments}

We are grateful to Luisa Carvalheiro, Jean Paul Metzger and Jesus Aguirre-Gutierrez for their suggestions on earlier versions of this manuscript. We also thank the São Paulo State Research Foundation (FAPESP) for the scholarship of Andre L. Acosta (2011/12779-7), National Counsel of Technological and Scientific Development (CNPq) (472702/2013-0), and Research Center on Biodiversity and Computing (NAP-Biocomp, Universidade de São Paulo). 


\section{References}

Aguirre-Gutiérrez J, Carvalheiro LG, Polce C, Van Loon EE, Raes N, Reemer M, et al. Fit-forPurpose: Species Distribution Model Performance Depends on Evaluation Criteria - Dutch Hoverflies as a Case Study. PloS one. 2013; 8 (5), e63708.

AHGA - Australian Hydroponics and Greenhouse Association. Executive Summary: Proposal to import Bombus terrestris into mainland Australia for crop pollination purposes. 2005; Available from: http://www.protectedcroppingaustralia.com/documents/Final.pdf

Aizen MA, Morales CL, Vázquez DP, Garibaldi LA, Sáez A, Harder LD. When mutualism goes bad: density-dependent impacts of introduced bees on plant reproduction. New Phytologist. 2014; 204: 322-328.

Aizen MA, Morales CL, Morales JM. Invasive mutualists erode native pollination webs. PLoS biology. 2008; 6(2):e31.

Allen CR, Johnson AR, Parris L. A framework for spatial risk assessments: potential impacts of nonindigenous invasive species on native species. Ecology and Society. 2006; 11, Article 39.

Allouche O, Tsoar A, Kadmon R. Assessing the accuracy of species distribution models: prevalence, kappa and the true skill statistic (TSS). Journal of Applied Ecology. 2006; 43(6), $1223-1232$.

Alpert P, Bone E, Holzapfel C. Invasiveness, invasibility and the role of environmental stress in the spread of nonnative plants. Perspectives in Plant Ecology. 2000; 3:52-66.

Andersen MC, Adams H, Hope B, Powell M. Risk assessment for invasive species. Risk Analysis. 2004; 24, 787-793.

Araújo MB, New M. Ensemble forecasting of species distributions. Trends in Ecology \& Evolution. 2007; 22(1), 42-7.

Arbetman MP, Meeus I, Morales CL, Aizen MA, Smagghe G. Alien parasite hitchhikes to Patagonia on invasive bumblebee. Biological Invasions. 2013; 15: 489-494.

Aslan, MM. Seasonal activity of Bombus terrestris in east Mediterranean region, Turkey. J Environ Biol. 2008; 29(2):151-4.

Bahn V, McGill BJ. Testing the predictive performance of distribution models. Oikos. 2013; 122(3), 321-331.

Ballesteros-Mejia L, Kitching IJ, Beck J. Projecting the potential invasion of the Pink Spotted Hawkmoth (Agrius cingulata) across Africa. International Journal of Pest Management. 2011; 57, 153-159.

Barbet-Massin M, Jiguet F, Albert CH, Thuiller W. Selecting pseudo-absences for species distribution models: how, where and how many? Methods in Ecology and Evolution. 2012; 3: 327-338.

Beaumont LJ, Gallagher RV, Thuiller W, Downey PO, Leishman MR, Hughes L. Different climatic envelopes among invasive populations may lead to underestimations of current and future biological invasions. Diversity and Distributions. 2009; 15, 409-420.

Bontemps S, Defourny P, Bogaert EV, Arino O, Kalogirou V, Perez JR. GlobCover: Product description and validation report UCLouvain and ESA GlobCover project. 2009. Available from: http://due.esrin.esa.int/globcover

Breiman L. Random Forests. Machine Learning. 2001; 45: 5-32. DOI:10.1023/a:1010933404324.

Breiman L, Friedman JH, Olshen RA, Stone CJ. Classification and regression trees. New York: Chapman and Hall; 1984.

Broennimann O, Guisan A. Predicting current and future biological invasions: both native and invaded ranges matter. Biology Letters. 2008; 4, 585-589.

Broennimann O, Treier UA, Müller-Schärer H, Thuiller W, Peterson AT, Guisan A. Evidence of climatic niche shift during biological invasion. Ecology Letters. 2007; 10(8), 701-9.

Buchmann SL. Buzz Pollination in Angiosperms. In: Jones CE, Little RJ (Eds). Handbook of Experimental Pollination Biology. New York: Van Nostrand Reinhold Company Inc; 1983. p274. 
Busby JR. BIOCLIM - A bioclimate analysis and prediction system. In: Margule, CR, Austin MP (Eds). Nature Conservation: Cost Effective Biological Surveys and Data Analysis. Canberra, Australia: CSIRO; 1991. pp 64-68.

Buttermore, RE. Observations of successful Bombus terrestris (L) (Hymenoptera: Apidae) colonies in southern Tasmania. Australian Journal of Entomology. 1997;36:251-254.

Buttermore RE, Pomeroy N, Hobson W, Semmens T, Hart R. Assessment of the genetic base of Tasmanian bumble bees (Bombus terrestris) for development as pollination agents. Journal of Apicultural Research. 1998;37: 23-25.

CDB - Convention on Biological Diversity, INVASIVE ALIEN SPECIES: a threat to biodiversity. 2009. Available from: http://www.cbd.int/doc/bioday/2009/idb-2009-bookleten.pdf

CDB - Secretariat of the Convention on Biological Diversity Assessment and Management of Alien Species that Threaten Ecosystems, Habitats and Species. Montreal: CBD Technical Series N1; 2001. Available from: http://www.cbd.int/doc/publications/cbd-ts-01.pdf

Chapman RE, Bourke AFG. The influence of sociality on the conservation biology of social insects. Ecology Letters. 2001; 4: 650-662.

Chefaoui RM, Lobo JM. Assessing the effects of pseudo-absences on predictive distribution model performance. Ecological Modelling. 2008; V210, 4: 478-486.

Christenhusz MJM, Toivonen TK. Giants invading the tropics: the oriental vessel fern, Angiopteris evecta (Marattiaceae). Biological Invasions. 2008; 10: 1215-1228.

Dafni A. The threat of Bombus terrestris spread. Bee World. 1998; 79: 113-114.

Dafni A, Kevan P, Gross CL, Goka K. Bombus terrestris, pollinator, invasive and pest: An assessment of problems associated with its widespread introductions for commercial purposes. Applied Entomology and Zoology. 2010; 45(1), 101-113.

Dafni A, Shmida A. The possible Ecological Implications of the Invasion of Bombus terrestris (L) (Apidae) at Mt Carmel, Israel. In: Matheson A, Buchmann SL, O'toole C, Westrich P, Williams IH (Eds). London: The Conservation of Bees. Academic Press. 1996.

De-Meyer M, Robertson MP, Peterson AT, Mansell MW. Ecological niches and potential geographical distributions of Mediterranean fruit fly (Ceratitis capitata) and Natal fruit fly (Ceratitis rosa). Journal of Biogeography. 2008; 35: 270-281.

Dohzono I, Kunitake YK, Yokoyama J, Goka AK. Alien bumble bee affects native plant reproduction through interactions with native bumble bees. Ecology. 2008; 89(11):30823092.

Domisch S, Kuemmerlen M, Jähnig SC, Haase P. Choice of study area and predictors affect habitat suitability projections, but not the performance of species distribution models of stream biota. Ecological Modelling. 2013; V.257: 1-10.

Elith J, Graham CH, Anderson RP, Dudik M, Ferrier S, Guisan A, Hijmans RJ, et al. Novel methods improve prediction of species' distributions from occurrence data. Ecography. 2006; 29:129-151.

Elith J, Phillips SJ, Hastie T, Dudík M, Chee YE, Yates, CJ. A statistical explanation of MaxEnt for ecologists. Diversity and Distributions, 2011; 17: 43-57.

ESRI - ArcGIS Desktop 10. Environmental Systems Research Institute. Redlands, CA. 2010; R10.

Evangelista PH, Kumar S, Stohlgren TJ, Jarnevich CS, Crall AW, Norman JB, et al. Modelling invasion for a habitat generalist and a specialist plant species. Diversity and Distributions. 2008; 14(5): 808-817.

Ewel JJ, O'Dowd DJ, Bergelson J, Daehler CC, D'Antonio CM, Gomez LD, et al. Deliberate introductions of species: Research needs - Benefits can be reaped, but risks are high. BioScience. 1999; 49:619-630.

Ficetola GF, Thuiller W, Miaud C. Prediction and validation of the potential global distribution of a problematic alien invasive species - the American bullfrog. Diversity and Distributions. 2007; 13(4): 476-485.

Franklin J. Mapping species distributions - spatial inference and prediction. Cambridge: Cambridge University Press. 2009.

Free, JB. Insect Pollination of Crops London: Academic Press Limited. 1993. 
Friedman J. Multivariate adaptive regression splines. Ann Stat. 1991; 19: 1-141.

Friedman BJH. Reitz Lecture 29. 2011; p1189-1232. DOI: 10.1214/aos/1013203451.

GADM. Global Administrative Areas of Year 2012. 2012; v.20. Available from: http://www.gadm.org

Gallien L, Douzet R, Pratte S, Zimmermann NE, Thuiller W. Invasive species distribution models - how violating the equilibrium assumption can create new insights. Global Ecology and Biogeography. 2012; 21(11):1126-1136.

Genovesi P. Eradications of invasive alien species in Europe: a review. Biological Invasions. 2005; 7, 127-133.

Giannini TC, Chapman DS, Saraiva AM, Alves dos Santos I, Biesmeijer JC. Improving species distribution models using biotic interactions: a case study of parasites, pollinators and plants. Ecography. 2013; 36:520: 649-656.

Giovanelli JGR, Haddad CFB, Alexandrino J. Predicting the potential distribution of the alien invasive American bullfrog (Lithobates catesbeianus) in Brazil. Biological Invasions. 2008; 10: 585-590.

Giraud T, Pedersen JS, Keller L. Evolution of supercolonies: the Argentine ants of southern Europe. Proceedings of the National Academy of Sciences. 2002; 99:6075-6079.

Goulson D. Effects of introduced bees on native ecosystems. Annual Review of Ecology Evolution and Systematics. 2003; 34: 1-26.

Goulson D. Bumblebees: Behaviour and Ecology. v2, Ed: Oxford, Oxford University Press. 2010.

Goulson D, Hanley ME. Distribution and Forage Use of Exotic Bumblebees in South Island, New Zealand. New Zealand Journal of Ecology. 2004; 28(2): 225-232.

Goulson D, Hughes WOH, Derwent LC, Stout JC. Colony Growth of the Bumblebee, Bombus terrestris, in Improved and Conventional Agricultural and Suburban Habitats. Oecologia. 2002; 130(2): 267-273.

Goulson D, Lye GC, Darvill B. Decline and Conservation of Bumble Bees. Annual Review of Entomology. 2008; 53: 191-208.

Griffiths D. A critical study on the introduction onto mainland Australia of the bumblebee Bombus terrestris for the commercial pollination of protected tomato and other crops. Practical Hydroponics and Greenhouses. 2004; 77, 42-59.

Hastie T, Tibshirani R, Buja A. Flexible Discriminant Analysis by Optimal Scoring. JASA. 1994; p1255-1270.

Hastie TJ, Tibshirani RJ. Generalized Additive Models. Chapman \& Hall: CRC Monographs on Statistics \& Applied Probability. 1990.

Heinrich B. Bumblebee Economics. Cambridge: Harvard University Press. 1979.

Hijmans RJ, Cameron SE, Parra JL, Jones PG, Jarvis A. Very high resolution interpolated climate surfaces for global land areas International. Journal of Climatology 2005; 25(15):1965-1978.

Hijmans RJ, van Etten J. Raster: Geographic analysis and modeling with raster data R package. 2012; v20-12. Available from: http://CRANR-projectorg/package=raster

Hingston AB, Marsden-Smedley J, Driscoll DA, Corbett S, Fenton J, Anderson R, Plowman C, Mowling F, Jenkin M, Matsui K, et al. Extent of invasion of Tasmanian native vegetation by the exotic bumblebee Bombus terrestris (Apoidea : Apidae). Austral Ecology. 2002; 27: 162172.

Hingston AB, McQuillan PB. Does the recently introduced bumblebee Bombus terrestris (Apidae) threaten Australian ecosystems? Australian Journal of Ecology. 1998; 23: 39-549.

Hopkins I. History of the bumble bee in New Zealand: its introduction and results. New Zealand Department of Agriculture, Industries and Commerce. 1914; 46: 1-29.

Howlett B, Donovan B. A Review of New Zealand's Deliberately Introduced Bee Fauna: Current Status and Potential Impacts. New Zealand Entomologist. 2010; 33(1): 92-101.

Hutchinson, GE. Concluding remarks Cold Spring Harbor Symposia on Quantitative Biology. 1957; 22: 415-427. 
Inari N, Nagamitsu T, Kenta T, Goka K, Hiura T. Spatial and temporal pattern of introduced Bombus terrestris abundance in Hokkaido, Japan, and its potential impact on native bumblebees. Population Ecology. 2005; 47(1): 77-82.

Inoue MN, Yokoyama J, Washitani I. Displacement of Japanese Native Bumblebees by the Recently Introduced Bombus terrestris (L) (Hymenoptera : Apidae). Journal of Insect Conservation. 2008; 12(2): 135-146.

Janzen DH. Why mountain passes are higher in the tropics. The American Naturalist. 1967; 101, N919: 233-249.

Jarnevich CS, Stohlgren TJ. Temporal management of invasive species management of invasive weeds. (Ed: Inderjit RL), Dordrecht:Springer. 2009; p103-122.

Jiménez-Valverde A, Lobo JM. Threshold criteria for conversion of probability of species presence to either-or presence-absence. Acta Oecologica. 2007; 31(3): 361-369.

Jiménez-Valverde A, Peterson AT, Soberón J, Overton JM, Aragón P, Lobo JM. Use of niche models in invasive species risk assessments. Biological Invasions. 2011; 13(12): 2785-2797.

Jones CC, Acker SA, Halpern CB. Combining local- and large-scale models to predict the distributions of invasive plant species. Ecological Applications: Ecological Society of America. 2010; 20(2): 311-26.

Kadoya T, Ishii HS, Kikuchi R, Suda S, Washitani I. Using monitoring data gathered by volunteers to predict the potential distribution of the invasive alien bumblebee Bombus terrestris. Biological Conservation. 2009; 142: 1011-1017.

Kadoya T, Washitani I. Predicting the rate of range expansion of an invasive alien bumblebee (Bombus terrestris) using a stochastic spatio-temporal model. Biological Conservation. 2010; 143(5): 1228-1235.

Kanbe Y, Okada I, Yoneda M, Goka K, Tsuchida K. Interspecific mating of the introduced bumblebee Bombus terrestris and the native japanese bumblebee Bombus hypocrita sapporoensis results in inviable hybrids. Naturwissenschaften. 2008; 95(10):1003-1008.

Kearney M, Porter WP. Mechanistic niche modelling: combining physiological and spatial data to predict species' ranges. Ecology Letters. 2009; 12: 334-350.

Kenis M, Auger-Rozenberg MA, Timms L, Péré C, Cock JW, Settele J, Lopez-Vaamonde C. Ecological effects of invasive alien insects. Biological Invasions. 2008; 11: 21-45.

Kondo N, Yamanaka D, Kanbe Y, Kunitake Y, Yoneda M, Tsuchida K, Goka K. Reproductive disturbance of japanese bumblebees by the introduced european bumblebee Bombus terrestris. Naturwissenschaften. 2009; 96(4): 467-475.

Kozak KH, Wiens JJ. Climatic zonation drives latitudinal variation in speciation mechanisms. Proceedings Biological Sciences:The Royal Society. 2007; 274(1628):2995-3003.

Kruger E. Phaenoanalytische Studien an einigen Arten der Untergattung Terrestribombus O. Vogt (Hymenoptera, Bombidae). II. Teil. Tijdschrift voor Entomologie. 1954; 97: 263-298.

Kuusik A, Martin AJ, Mand M, Hiiesaar K, Metspalu L, Tartes U. Interrelations of gas exchange cycles, body movements and heartbeats in the foragers of bumblebee Bombus terrestris (Hymenoptera : Apidae) at low temperatures European. Journal of Entomology. 2002; 99(2): 209-214.

Lavergne S, Mouquet N, Thuiller W, Ronce O. Biodiversity and Climate Change: Integrating Evolutionary and Ecological Responses of Species and Communities. Annual Review of Ecology, Evolution, and Systematics. 2010; 41(1):321-350.

Le Maitre DC, Thuiller W, Schonegevel L. Developing an approach to defining the potential distributions of invasive plant species: a case study of Hakea species in South Africa. Global Ecology and Biogeography. 2008; 17:569-584.

Leung B, Lodge DM, Finnoff D, Shogren JF, Lewis MA, Lamberti G. An ounce of prevention or a pound of cure: bioeconomic risk analysis of invasive species. Proceedings of the Royal Society of London. 2002; B269: 2407-2413.

Levine JM, D'Antonio CM. Forecasting biological invasions with increasing international trade. Conservation Biology. 2003; 17:322-326.

Liu CR, Berry PM, Dawson TP, Pearson RG. Selecting thresholds of occurrence in the prediction of species distributions. Ecography. 2005; 28: 385-393. 
Loken A. Studies on Scandinavian bumblebees (Hymenoptera, Apidae). Norsk Entomol Tidsskr. 1973; 20: 1-219.

Loo SE, MacNally R, Lake PS. Forecasting New Zealand mud snail invasion range: Model comparisons using native and invaded ranges. Ecol Applic. 2007; 17:181-189.

Mack RN, Smith MC. Invasive plants as catalysts for the spread of human parasites. NeoBiota. 2011; 9: 13-29.

Mata RA, Tidon R, Côrtes LG, De Marco P, Diniz-Filho JAF. Invasive and flexible: niche shift in the drosophilid Zaprionus indianus (Insecta, Diptera). Biological Invasions. 2010; 12(5): 1231-1241.

Mateo RG, Croat TB, Felicísimo ÁM, Muñoz J. Profile or group discriminative techniques? Generating reliable species distribution models using pseudo-absences and target-group absences from natural history collections. Divers Distrib. 2010; 16: 84-94.

Matsumura C, Yokoyama J, Washitani I. Invasion status and potential ecological impacts of an invasive alien bumblebee, Bombus terrestris L (Hymenoptera: Apidae) naturalized in Southern Hokkaido, Japan. Global Environmental Research. 2004; 8(1): 51-66.

McClay A. Climex: Models to Predict the Potential Naturalized Range of the European Bumblebee Bombus terrestris (L) in Mainland Australia. Report. IN: AHGA - Australian Hydroponics and Greenhouse Association. Proposal to Import Bombus terrestris into Mainland Australia for Crop Pollination Purposes. 2005.

McCullagh P, Nelder JA. Generalized Linear Models (2ed). Chapman \& Hall/CRC Monographs on Statistics \& Applied Probability. 1989.

McGregor SE. Insect pollination of cultivated crop plants United States Department of Agriculture, Washington, DC. 1976. Available from: http://www.ars.usda.gov/SP2UserFiles/Place/20220500/OnlinePollinationHandbook.pdf

Mclain DH. Drawing contours from arbitrary data points. The Computer Journal. 1974; 17: 318324.

Medley KA. Niche shifts during the global invasion of the Asian tiger mosquito, Aedes albopictus Skuse (Culicidae), revealed by reciprocal distribution models. Global Ecology and Biogeography. 2010; 19(1): 122-133.

Merckx B, Steyaert M, Vanreusel A, Vincx M, Vanaverbeke J. Null models reveal preferential sampling, spatial autocorrelation and overfitting in habitat suitability modelling. Ecological Modelling; 2011;222(3),p588-597.

Moller H. Lessons for invasion theory from social insects. Biol Conserv. 1996; 78: 125-142.

Mommaerts V, Put K, Smagghe G. Bombus terrestris as pollinator-and-vector to suppress Botrytis cinerea in greenhouse strawberry. Pest Management Science. 2011; p1069-1075.

Morales CL, Arbetman MP, Cameron SA, Aizen MA. Rapid ecological replacement of a native bumble bee by invasive species. Frontiers in Ecology and the Environment. 2013; 11: 529534.

Morandin LA, Laverty TM, Kevan PG, Effect of bumble bee (Hymenoptera : Apidae) pollination intensity on the quality of greenhouse tomatoes. J Econ Entomol. 2001a; 94: 172179.

Morandin LA, Laverty TM, Kevan PG. Bumble bee (Hymenoptera: Apidae) Activity and Pollination Levels in Commercial Tomato Greenhouses. Journal of Economic Entomology. 2001c; 94(2): 462-467.

Morandin LA, Laverty TM, Kevan PG, Khosla S, Shipp L. Bumble Bee (Hymenoptera: Apidae) Activity and Loss in Commercial Tomato Greenhouses. Canadian Entomologist. 2001b; 133(6): 883-893.

Mouton AM, De Baets B, Goethals PLM. Ecological relevance of performance criteria for species distribution models. Ecological Modelling. 2010; 221 (16): 1995-2002.

Ne'eman G, Dafni A, Potts SG. The effect of fire on flower visitation and fruit set in four corespecies in east Mediterranean scrubland. Plant Ecol. 2000; 146: 97-104.

Nenzén HK, Araújo MB. Choice of threshold alters projections of species range shifts under climate change. Ecological Modelling. 2011; 222(18): 3346-3354.

NSW - New South Wales Government, Australia Introduction of the large earth bumblebee, Bombus terrestris - key threatening process listing. NSW Scientific Committee. 2004; 
Available

from:

http://www.environment.nsw.gov.au/determinations/BombusTerrestrisKtpDeclaration.htm

Özbek H. Decline in Bombus terrestris (L) populations in Turkey. Melissa. 1993; 6:7-8.

Parker-Allié F, Musil CF, Thuiller W. Effects of climate warming on the distributions of invasive European annual grasses: a Southern African perspective. Climatic Change. 2009; 94: 87-103.

Parolo G, Rossi G, Ferrarini A. Toward improved species niche modelling: Arnica montana in the Alps as a case study. Journal of Applied Ecology. 2008; 45(5): 1410-1418.

Pearson RG, Raxworthy CJ, Nakamura M, Peterson AT. Predicting species distributions from small numbers of occurrence records: a test case using cryptic geckos in Madagascar. J Biogeogr. 2007; 34: 102-117.

Perings C, Williamson M, Dalmozzone S. The economics of biological invasions. Edward Elgar, Cheltenham: United Kingdom. 2000; p183-207.

Perkins LB, Leger EA, Nowak RS. Invasion triangle: an organizational framework for species invasion. Ecology and Evolution. 2011; 1(4): 610-25.

Peterson AT, Papes M, Kluza DA. Predicting the potential invasive distributions of four alien plant species in North America. Weed Science. 2003; 51: 863-868.

Peterson AT, Papes M, Reynolds MG, Perry ND, Hanson B, Regnery RL, et al. Native-range ecology and invasive potential of Cricetomys in North America. Journal of Mammalogy. 2006; 87: 427-432.

Peterson AT, Robins CR. Using ecological niche modeling to predict Barred Owl invasions with implications for Spotted Owl conservation. Conservation Biology. 2003; 17: 1161-1165.

Peterson AT, Soberon J, Pearson RG, Anderson RP, Martinez-Meyer E, Nakamura M, Araújo, MB. Ecological Niches and Geographic Distributions. New Jersey: Princeton University Press. 2011.

Peterson AT, Williams R, Chen G. Modeled global invasive potential of Asian gypsy moths, Lymantria dispar. Entomol Exp Appl. 2007; 125: 39-44.

Phillips S, Anderson R, Schapire R. Maximum Entropy Modeling of Species Geographic Distributions. Ecological Modelling. 2006; 190(3-4): 231-259.

Phillips SJ, Anderson RP, Schapire RE. Maximum entropy modeling of species geographic distributions. Ecological Modelling. 2006; 190: 231-259.

Phillips SJ, Dudík M. Modeling of species distributions with Maxent: new extensions and a comprehensive evaluation. Ecography. 2008; 31(2): 161-175.

Phillips SJ, Dudík M, Elith J, Graham CH, Lehmann A, Leathwick J, Ferrier S. Sample selection bias and presence-only distribution models: implications for background and pseudo-absence data. Ecological Applications. 2009; 19: 181-197.

Plischuk S, Lange C. Invasive Bombus terrestris (Hymenoptera: Apidae) Parasitized by a Flagellate (Euglenozoa: Kinetoplastea) and a Neogregarine (Apicomplexa: Neogregarinorida). Journal of Invertebrate Pathology. 2009; 102(3): 263-265.

Potts SG, Dafni A, Ne'eman G. Pollination of a core flowering shrub species in Mediterranean phrygana: variation in pollinator diversity, abundance and effectiveness in response to fire. Oikos. 2001; 92: 71-80.

Proctor M, Yeo P, Lack A. The Natural History of Pollination. Oregon, Timber Press. 1996.

Pulliam HR. On the relationship between niche and distribution. Ecol Lett. 2000; 3:349-361.

R Development Core Team. R: A Language and Environment for Statistical Computing. R Foundation for Statistical Computing. Vienna: Austria. 2011. Available from: http://www.rproject.org.

Ridgeway G. 2 Boosting for classification. Bernoulli. 1999; 172-181.

Ripley BD. Pattern recognition and neural networks. Cambridge, UK:Cambridge University Press. 1996.

Rodder D, Lotters S. Niche shift versus niche conservatism? Climatic characteristics of the native and invasive ranges of the Mediterranean house gecko (Hemidactylus turcicus). Glob Ecol Biogeogr. 2009; 18: 674-87.

Rodder D, Schmidtlein S, Veith M, Lötters S. Alien invasive slider turtle in unpredicted habitat: a matter of niche shift or of predictors studied? PloS One. 2009; 4(11). 
Roques A, Rabitsch W, Rasplus J-Y. Alien terrestrial invertebrates of Europe In: Nentwig WHP, Pysek P, Vila ME (Eds). Handbook of Alien Species in Europe. Springer-Verlag, Berlin. 2009.

Roura-Pascual N, Suarez AV, McNyset K, Gomez C, Pons P, Touyama Y, et al. Niche differentiation and fine-scale projections for Argentine ants based on remotely sensed data. Ecol Applic. 2006; 16: 1832-1841.

Ruz L. Bee Pollinators Introduced to Chile: a Review In: Kevan PG, Imperatriz- Fonseca VL (Eds). Pollinating Bees - the Conservation Link between Agriculture and Nature. Brasília, Ministry of Environment. 2002; p155-167.

Ruz L, Herrera R. Preliminary Observations on Foraging Activities of Bombus dahlbomii and Bombus terrestris (Hym: Apidae) on Native and Nonnative Vegetation in Chile. Acta Horticulturae. 2001; 561: 165-169.

Schmid-Hempel P, Schmid-Hempel R, Brunner PC, Seeman OD, Allen GR. Invasion success of the Bumblebee, Bombus terrestris, despite a drastic genetic bottleneck. Heredity. 2007; 99: 414-422.

Shi J, Luo Y-Q, Zhou F, He P. The relationship between invasive alien species and main climatic zones. Biodiversity and Conservation. 2010; 19(9): 2485-2500.

Soberón J, Peterson AT. Interpretation of models of fundamental ecological niches and species distributional areas. Biodiversity Informatics. 2005; 2: 1-10.

Thuiller W, Georges D, Engler R. Ensemble platform for species distribution modeling Package "biomod2". 2013. Available from: http://cran.rproject.org/web/packages/biomod2/biomod2.pdf

Thuiller W, Lafourcade B, Engler R, Araújo MB. BIOMOD - A platform for ensemble forecasting of species distributions. Ecography. 2009; 32: 369-373.

Thuiller W, Richardson DM, Pyšek P, Midgley GF, Hughes GO, Rouget M. Niche-based modelling as a tool for predicting the risk of alien plant invasions at a global scale. Global Change Biology. 2005; 11: 2234-2250.

Torretta JP, Medan D, Arahamovich AH. First Record of the Invasive Bumblebee Bombus terrestris (L) (Hymenoptera, Apidae) in Argentina. Transactions of the American Entomological Society. 2006; 132(3-4): 285-289.

Tsutsui ND, Case TJ. Population genetics and colony structure of the Argentine ant (Linepithema humile) in its native and introduced ranges. Evolution. 2001; 55: 976-985.

Urban MC, Phillips BL, Skelly DK, Shine R. The cane toad's (Chaunus [Bufo] marinus) increasing ability to invade Australia is revealed by a dynamically updated range model. Proc R Soc Lond. 2007; 274: 1413-19.

Václavík T, Meentemeyer R. Invasive Species Distribution Modeling (iSDM): Are absence data and dispersal constraints needed to predict actual distributions? Ecological Modelling. 2009; 220(23): 3248-3258.

Velthuis HHW. The historical background of the domestication of the bumble-bee, Bombus terrestris, and its introduction in agriculture IN: Kevan, P, Imperatriz-Fonseca, VL (eds) Pollinating Bees: the conservation link between agriculture and nature Ministry of Environment, Brazil. 2002; p177-184.

Velthuis HHW, Cobb L. Pollination of Primula in a greenhouse using Bumblebees. Acta Horticulturae. 1991; 288: 199-203.

Velthuis HHW, Van Doorn A. A century of advances in Bumblebee domestication and the economic and environmental aspects of its commercialization for pollination. Apidologie. 2006; 37(4): 421-451.

Villemant C, Barbet-Massin M, Perrard A, Muller F, Gargominy O, Jiguet F, et al. Predicting the invasion risk by the alien bee-hawking Yellow-legged hornet Vespa velutina nigrithorax across Europe and other continents with niche models. Biological Conservation. 2011; 144(9): 2142.

Ward DF. Modelling the potential geographic distribution of invasive ant species in New Zealan. Biol Inv. 2007; 9: 723-735.

Westerkamp C. Honeybees are poor pollinators - Why? Plant Systematics and Evolution. 1991; 177(1): 71-75. 
Williamson M. Invasions. Ecography. 1999; 22:5-12.

Winter K, Adams L, Thorp R, Inouye D, Day L, Ascher J. Importation of nonnative Bumble Bees into North America: potential consequences of using Bombus terrestris and other nonnative Bumble Bees for greenhouse crop pollination in Canada, Mexico, and the United States. White Paper of the North American Pollinator Protection Campaign (NAPPC). 2006; p1-31.

Available

from: http://www.pollinator.org/Resources/BEEIMPORTATION_AUG2006.pdf

Wisz MS, Hijmans RJ, Li J, Peterson AT, Graham CH, Guisan A. Effects of sample size on the performance of species distribution models. Divers Distrib. 2008; 14: 763-773.

Wittenberg R, Cock MJW. Invasive Alien Species: A Toolkit of Best Prevention and Management Practices. CABI Publishing, Wallingford, Oxon, UK. 2001.

Zalba SM, Sonaglioni MI, Compagnoni CA, Belenguer CJ. Using a habitat model to assess the risk of invasion by an exotic plant. Biological Conservation. 2000; 93,p203-208.

\section{Tables and Figures}

\begin{tabular}{|c|c|c|c|c|c|c|c|c|c|c|c|c|c|c|c|c|c|}
\hline \multirow{2}{*}{\multicolumn{2}{|c|}{ 岂 }} & \multicolumn{10}{|c|}{ Models per Algorithms } & \multicolumn{6}{|c|}{ Evaluation Indices } \\
\hline & & $\begin{array}{l}\text { Total of } \\
\text { Models }\end{array}$ & ANN & CTA & FDA & GAM & GBM & GLM & MARS & MAXENT & RF SRE & IHR & NHR & SCR & $\begin{array}{c}\text { TSS } \\
\text { (Minimum) }\end{array}$ & $\begin{array}{c}\text { TSS } \\
\text { (Mean) }\end{array}$ & $\begin{array}{c}\text { TSS } \\
\text { (Maximum) }\end{array}$ \\
\hline \multirow{33}{*}{ 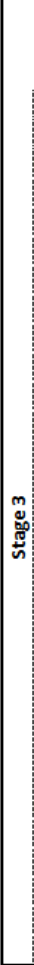 } & Stage 0 & 250 & 25 & 25 & 25 & 25 & 25 & 25 & 25 & 25 & 2525 & 0.97806 & 0.99976 & 0.25882 & 0.69000 & 0.84934 & 0.93100 \\
\hline & Stage 1 & 195 & 22 & 25 & 2 & 25 & 25 & 25 & 21 & 25 & 25 & 0.97075 & 0.99976 & 0.22311 & 0.80000 & 0.87634 & 0.93100 \\
\hline & Stage 2 & 131 & 5 & 9 & 2 & 25 & 21 & 25 & 21 & 23 & & 0.96709 & 0.99525 & 0.18470 & 0.80000 & 0.86873 & 0.90400 \\
\hline & $\mathrm{PCC} 0.50$ & 129 & 3 & 9 & 2 & 25 & 21 & 25 & 21 & 23 & & 0.96161 & 0.99525 & 0.15155 & 0.80000 & 0.86960 & 0.90400 \\
\hline & PCC 0.51 & 129 & 3 & 9 & 2 & 25 & 21 & 25 & 21 & 23 & & 0.96161 & 0.99525 & 0.15155 & 0.80000 & 0.86960 & 0.90400 \\
\hline & PCC 0.52 & 127 & 1 & 9 & 2 & 25 & 21 & 25 & 21 & 23 & & 0.95064 & 0.99501 & 0.14354 & 0.80000 & 0.86998 & 0.90400 \\
\hline & PCC 0.53 & 126 & & 9 & 2 & 25 & 21 & 25 & 21 & 23 & & 0.87386 & 0.99454 & 0.11711 & 0.80000 & 0.87033 & 0.90400 \\
\hline & PCC 0.54 & 125 & & 9 & 2 & 25 & 21 & 25 & 20 & 23 & & 0.86837 & 0.99430 & 0.11037 & 0.80000 & 0.87088 & 0.90400 \\
\hline & PCC 0.55 & 125 & & 9 & 2 & 25 & 21 & 25 & 20 & 23 & & 0.86837 & 0.99430 & 0.11037 & 0.80000 & 0.87088 & 0.90400 \\
\hline & PCC 0.56 & 124 & & 9 & 1 & 25 & 21 & 25 & 20 & 23 & & 0.86837 & 0.99430 & 0.11033 & 0.80000 & 0.87142 & 0.90400 \\
\hline & $\mathrm{PCC} 0.57$ & 124 & & 9 & 1 & 25 & 21 & 25 & 20 & 23 & & 0.86837 & 0.99430 & 0.11033 & 0.80000 & 0.87142 & 0.90400 \\
\hline & PCC 0.58 & 123 & & 9 & & 25 & 21 & 25 & 20 & 23 & & 0.86654 & 0.99359 & 0.09981 & 0.80000 & 0.87196 & 0.90400 \\
\hline & PCC 0.59 & 123 & & 9 & & 25 & 21 & 25 & 20 & 23 & & 0.86654 & 0.99359 & 0.09981 & 0.80000 & 0.87196 & 0.90400 \\
\hline & PCC 0.60 & 117 & & 9 & & 25 & 21 & 25 & 14 & 23 & & 0.86654 & 0.99359 & 0.09809 & 0.80000 & 0.87509 & 0.90400 \\
\hline & PCC 0.61 & 113 & & 9 & & 25 & 21 & 25 & 10 & 23 & & 0.86472 & 0.99359 & 0.09324 & 0.80000 & 0.87741 & 0.90400 \\
\hline & PCC 0.62 & 103 & & 9 & & 25 & 21 & 25 & & 23 & & 0.78428 & 0.99287 & 0.07241 & 0.85800 & 0.88379 & 0.90400 \\
\hline & PCC 0.63 & 103 & & 9 & & 25 & 21 & 25 & & 23 & & 0.78428 & 0.99287 & 0.07241 & 0.85800 & 0.88379 & 0.90400 \\
\hline & PCC 0.64 & 103 & & 9 & & 25 & 21 & 25 & & 23 & & 0.78428 & 0.99287 & 0.07241 & 0.85800 & 0.88379 & 0.90400 \\
\hline & PCC 0.65 & 103 & & 9 & & 25 & 21 & 25 & & 23 & & 0.78428 & 0.99287 & 0.07241 & 0.85800 & 0.88379 & 0.90400 \\
\hline & PCC 0.66 & 103 & & 9 & & 25 & 21 & 25 & & 23 & & 0.78428 & 0.99287 & 0.07241 & 0.85800 & 0.88379 & 0.90400 \\
\hline & $\mathrm{PCC} 0.67$ & 103 & & 9 & & 25 & 21 & 25 & & 23 & & 0.78428 & 0.99287 & 0.07241 & 0.85800 & 0.88379 & 0.90400 \\
\hline & PCC 0.68 & 103 & & 9 & & 25 & 21 & 25 & & 23 & & 0.78428 & 0.99287 & 0.07241 & 0.85800 & 0.88379 & 0.90400 \\
\hline & PCC 0.69 & 103 & & 9 & & 25 & 21 & 25 & & 23 & & 0.78428 & 0.99287 & 0.07241 & 0.85800 & 0.88379 & 0.90400 \\
\hline & PCC 0.70 & 102 & & 8 & & 25 & 21 & 25 & & 23 & & 0.78428 & 0.99287 & 0.07241 & 0.85800 & 0.88368 & 0.90400 \\
\hline & PCC 0.71 & 102 & & 8 & & 25 & 21 & 25 & & 23 & & 0.78428 & 0.99287 & 0.07241 & 0.85800 & 0.88368 & 0.90400 \\
\hline & PCC 0.72 & 100 & & 6 & & 25 & 21 & 25 & & 23 & & 0.78062 & 0.99287 & 0.07230 & 0.85800 & 0.88341 & 0.90400 \\
\hline & $\mathrm{PCC} 0.73$ & 99 & & 6 & & 25 & 21 & 24 & & 23 & & 0.77879 & 0.99263 & 0.07093 & 0.85800 & 0.88348 & 0.90400 \\
\hline & PCC 0.74 & 99 & & 6 & & 25 & 21 & 24 & & 23 & & 0.77879 & 0.99263 & 0.07093 & 0.85800 & 0.88348 & 0.90400 \\
\hline & PCC 0.75 & 91 & & 5 & & 25 & 21 & 17 & & 23 & & 0.77148 & 0.99216 & 0.06819 & 0.85800 & 0.88456 & 0.90400 \\
\hline & PCC 0.76 & 76 & & 3 & & 24 & 20 & 6 & & 23 & & 0.75868 & 0.99168 & 0.06545 & 0.85800 & 0.88614 & 0.90400 \\
\hline & PCC 0.77 & 48 & & 1 & & 8 & 17 & & & 22 & & 0.73492 & 0.98788 & 0.05476 & 0.87300 & 0.88665 & 0.90400 \\
\hline & PCC 0.78 & 28 & & & & & 9 & & & 19 & & 0.71846 & 0.98147 & 0.04721 & 0.87300 & 0.88639 & 0.90400 \\
\hline & PCC 0.79 & 7 & & & & & & & & 7 & & 0.61792 & 0.97505 & 0.04195 & 0.87800 & 0.88671 & 0.89600 \\
\hline
\end{tabular}

Table 1. Stages (y-axis) and the respective numbers of models per algorithm, as well the respective changes in the evaluation indices. 
Models TSS values from Biomod output - Stage 0 (Number in Red: TSS $\Rightarrow>0.8$ )
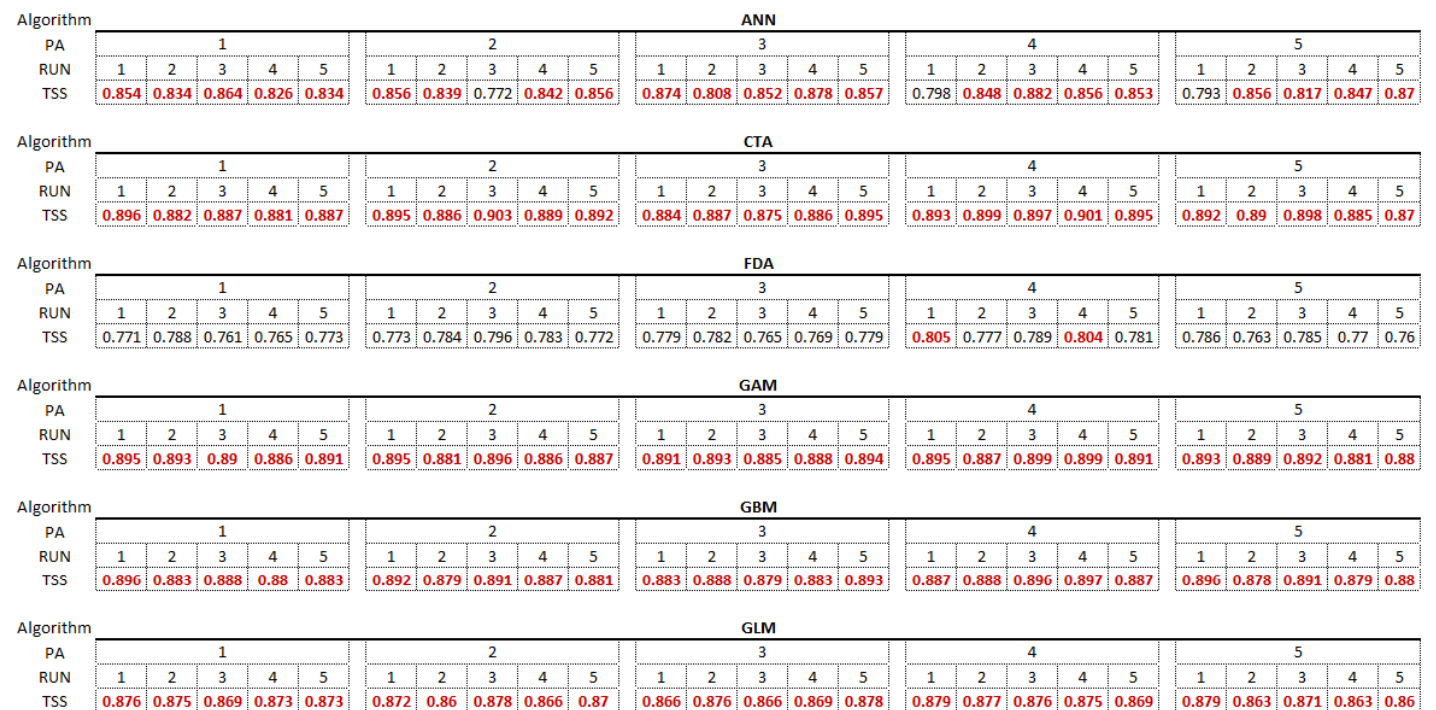

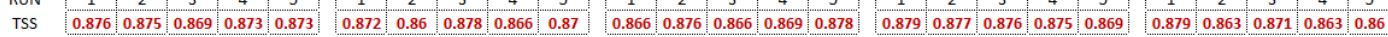
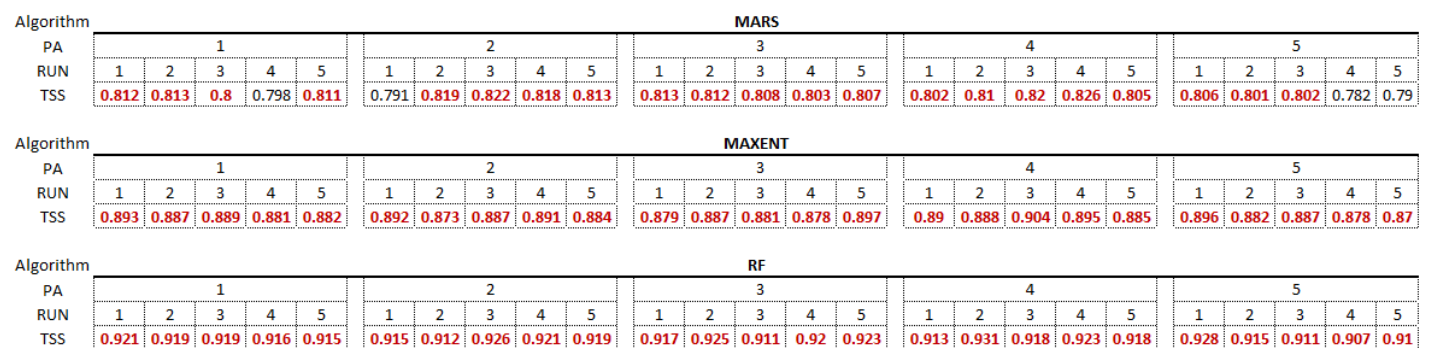

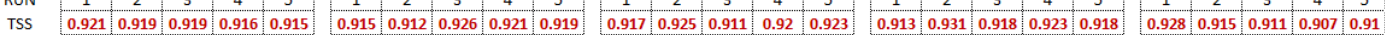

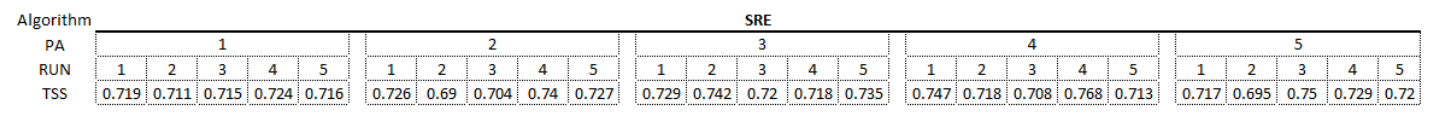

Table 2. Biomod2 evaluation output: model TSS values per algorithm $(250$ models $=5$ pseudoabsences dataset $\mathrm{x} 5$ training and test partitioning of the native presence records $\mathrm{x} 10$ different algorithms). 


\begin{tabular}{|c|c|c|c|c|c|c|}
\hline & \multirow{2}{*}{$\begin{array}{l}\text { 苞 } \\
\text { 芯 }\end{array}$} & \multicolumn{2}{|c|}{$\begin{array}{c}\text { Presences Intersecting Suitable } \\
\text { Area Predicted }{ }^{*}(\text { Binary }=1)\end{array}$} & \multicolumn{3}{|c|}{$\begin{array}{c}\text { Suitable Habitat Area } \\
\text { (Binary }=1 \text { Grid Cells) }\end{array}$} \\
\hline & & $\begin{array}{l}\text { N Invasive Hits } \\
(\mathrm{Ni}=547)\end{array}$ & $\begin{array}{l}\text { N Native Hits } \\
(\mathrm{Ni}=4209)\end{array}$ & $\begin{array}{c}\text { N Bin }=1 \\
\text { (Ntotal=2287025) }\end{array}$ & $\begin{array}{l}\text { Suitable Area } \\
\qquad\left(\mathrm{Km}^{2 * *}\right)\end{array}$ & $\begin{array}{l}\text { Suitable Area } \\
\text { Shift }\left(\mathrm{Km}^{2 * *}\right)\end{array}$ \\
\hline \multirow{33}{*}{$\begin{array}{l}m \\
\stackrel{0}{ } \\
\ddot{0} \\
\ddot{n}\end{array}$} & Stage 0 & 535 & 4208 & 591939 & 50921922.03 & - \\
\hline & Stage 1 & 531 & 4208 & 510260 & 43895435.06 & -7026486.97 \\
\hline & Stage 2 & 529 & 4189 & 422418 & 36338772.17 & -7556662.89 \\
\hline & PCC 0.50 & 526 & 4189 & 346591 & 29815707.16 & -6523065.01 \\
\hline & PCC 0.51 & 526 & 4189 & 346591 & 29815707.16 & 0 \\
\hline & PCC 0.52 & 520 & 4188 & 328270 & 28239631.69 & -1576075.46 \\
\hline & PCC 0.53 & 478 & 4186 & 267835 & 23040673.09 & -5198958.61 \\
\hline & PCC 0.54 & 475 & 4185 & 252430 & 21715448.35 & -1325224.74 \\
\hline & $\mathrm{PCC} 0.55$ & 475 & 4185 & 252430 & 21715448.35 & 0 \\
\hline & PCC 0.56 & 475 & 4185 & 252337 & 21707447.96 & -8000.38 \\
\hline & PCC 0.57 & 475 & 4185 & 252337 & 21707447.96 & 0 \\
\hline & $\mathrm{PCC} 0.58$ & 474 & 4182 & 228272 & 19637241.31 & -2070206.65 \\
\hline & PCC 0.59 & 474 & 4182 & 228272 & 19637241.31 & 0 \\
\hline & PCC 0.60 & 474 & 4182 & 224332 & 19298300.35 & -338940.96 \\
\hline & PCC 0.61 & 473 & 4182 & 213236 & 18343760.03 & -954540.33 \\
\hline & PCC 0.62 & 429 & 4179 & 165602 & 14246015.44 & -4097744.59 \\
\hline & PCC 0.63 & 429 & 4179 & 165602 & 14246015.44 & 0 \\
\hline & PCC 0.64 & 429 & 4179 & 165602 & 14246015.44 & 0 \\
\hline & PCC 0.65 & 429 & 4179 & 165602 & 14246015.44 & 0 \\
\hline & PCC 0.66 & 429 & 4179 & 165602 & 14246015.44 & 0 \\
\hline & PCC 0.67 & 429 & 4179 & 165602 & 14246015.44 & 0 \\
\hline & $\mathrm{PCC} 0.68$ & 429 & 4179 & 165602 & 14246015.44 & 0 \\
\hline & PCC 0.69 & 429 & 4179 & 165602 & 14246015.44 & 0 \\
\hline & $\mathrm{PCC} 0.70$ & 429 & 4179 & 165602 & 14246015.44 & 0 \\
\hline & PCC 0.71 & 429 & 4179 & 165602 & 14246015.44 & 0 \\
\hline & $\mathrm{PCC} 0.72$ & 427 & 4179 & 165345 & 14223906.85 & -22108.59 \\
\hline & $\mathrm{PCC} 0.73$ & 426 & 4178 & 162228 & 13955764.98 & -268141.87 \\
\hline & PCC 0.74 & 426 & 4178 & 162228 & 13955764.98 & 0 \\
\hline & PCC 0.75 & 422 & 4176 & 155960 & 13416556.37 & -539208.61 \\
\hline & PCC 0.76 & 415 & 4174 & 149685 & 12876745.58 & -539810.79 \\
\hline & PCC 0.77 & 402 & 4158 & 125230 & 10772988.93 & -2103756.64 \\
\hline & PCC 0.78 & 393 & 4131 & 107970 & 9288186.66 & -1484802.28 \\
\hline & PCC 0.79 & 338 & 4104 & 95945 & 8253728.52 & -1034458.13 \\
\hline
\end{tabular}

* Presence records intersecting suitable areas predicted by at least one model in the set of models from each stage. ** Area estimated using the fixed value of 1 degree at equator $=111.319 \mathrm{Km}$, thus: cellsize $(\mathrm{X}, \mathrm{Y})=5$ arcminutes or 0.083333333 degrees $\times 111.319 \mathrm{Km}=9.275 \mathrm{Km}$ : Area of each cell $=9.275 \times 9.275=\sim 86 \mathrm{Km}^{2}$.

Table 3. Stages (y-axis) and the number of invasive and native presence records hitting suitable areas per each respective Stage OPM generated, as well as the raw number of suitable cells per model, the total suitable area $(\mathrm{km} 2)$ and the difference in suitable area predicted from the current model minus the previous one (delta values). 


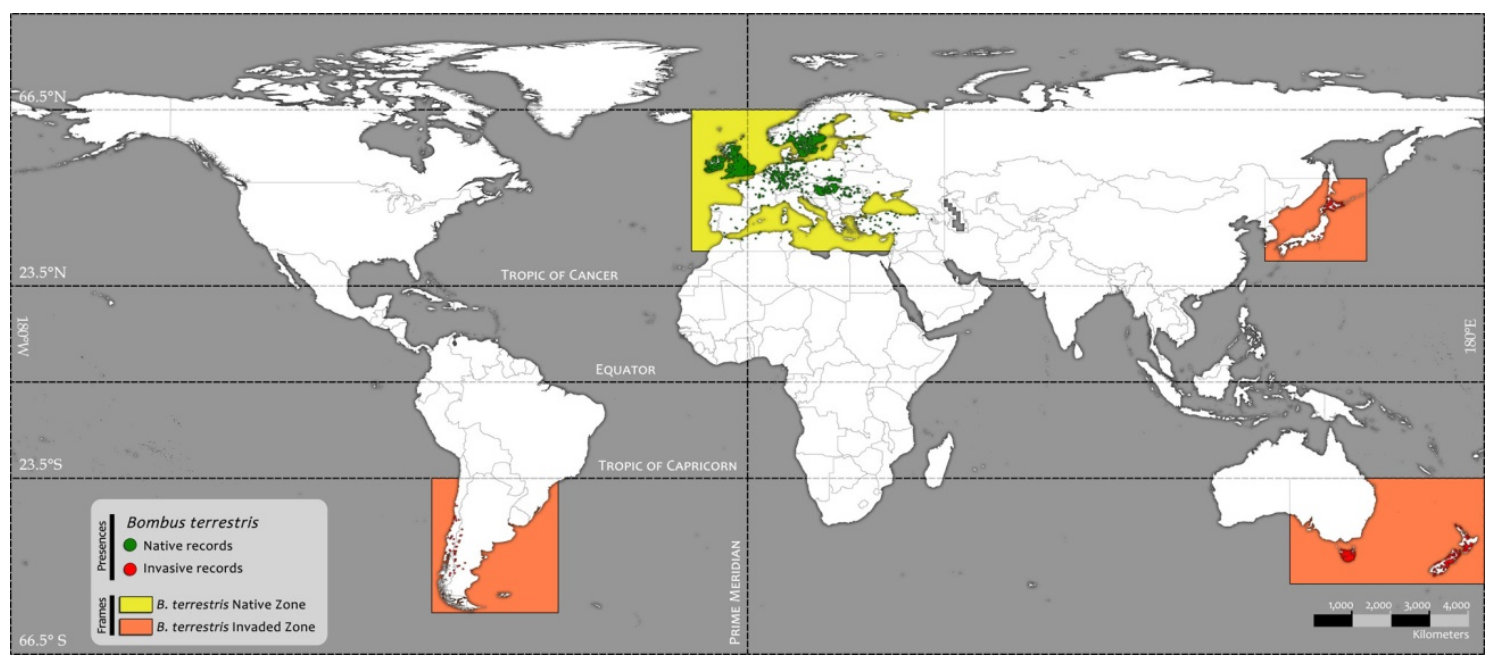

Figure 1. Native and invasive presence records of Bombus terrestris at a global scale.

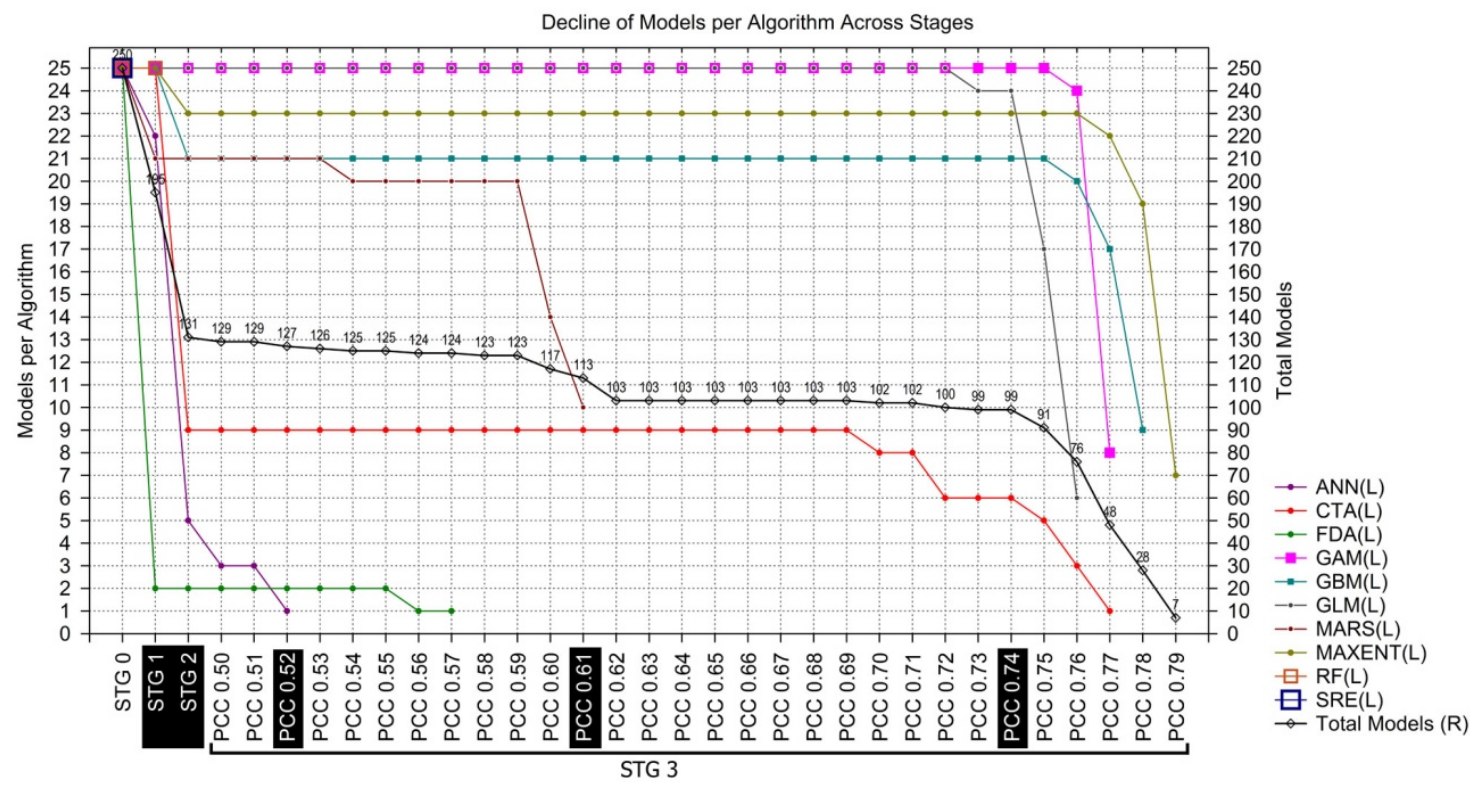

Figure 2. Progressive decrease of models per algorithm across stages (and across PCCs in Stage3). Stage 0: the total number of models per algorithm from the Biomod2 output before selection. Stage 1: Models that yielded TSS $\geq 0.8$. Stage 2 : Models that yielded an Invasive Hit Rate $($ IHR) $\geq$ the total IHR average. Stage 3: Models that yielded a total average paired Pearson's correlation coefficient (average of paired PCC values between itself and all others) above each predefined threshold. 


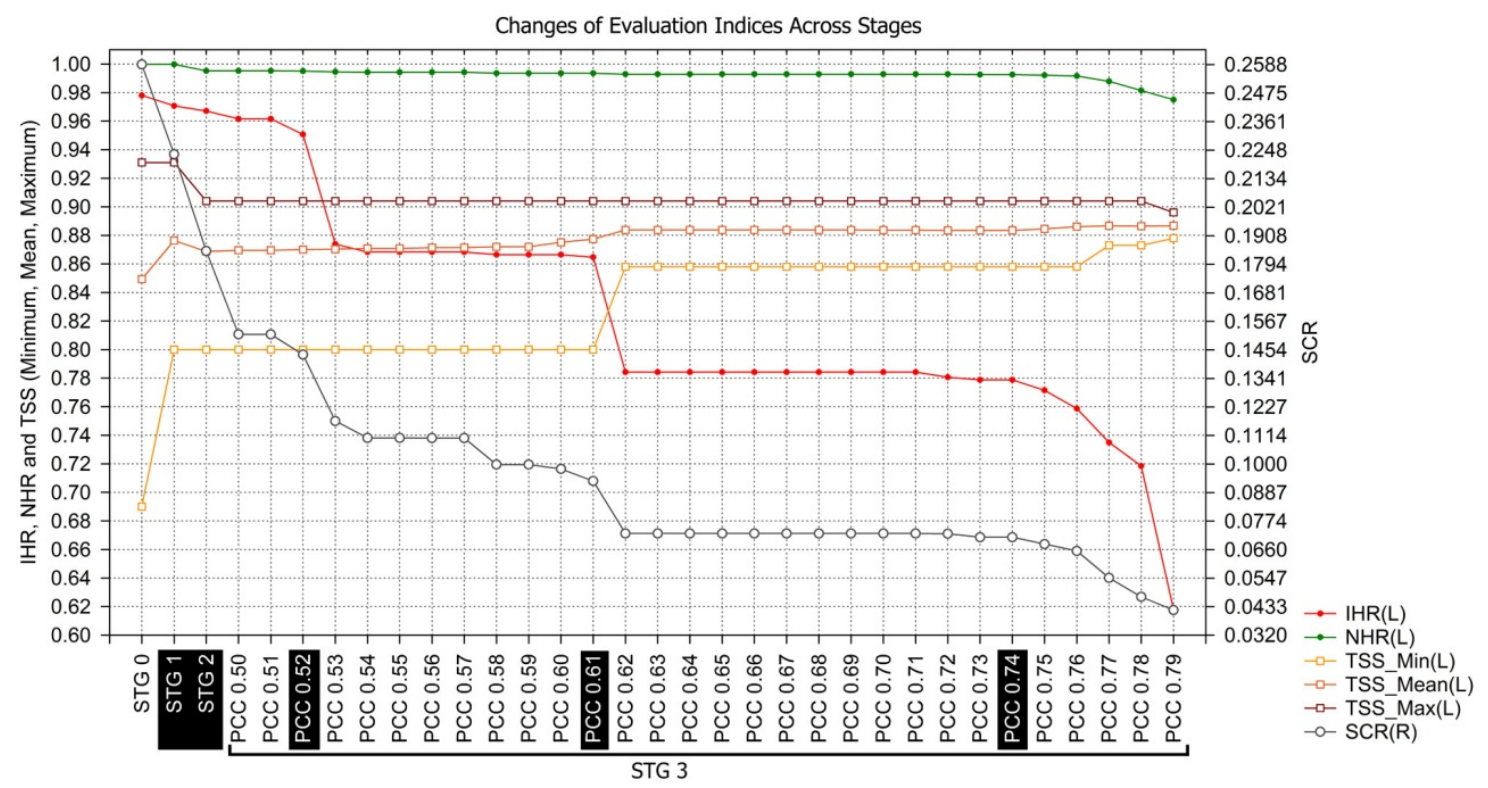

Figure 3. Shifts in the evaluation indices per model (IHR; NHR; SCR; minimum, mean and maximum TSS) across stages. Each evaluation index was recalculated at each step, but the TSS (minimum, maximum, mean) values were obtained at each step from the evaluation results of the Biomod2 output.

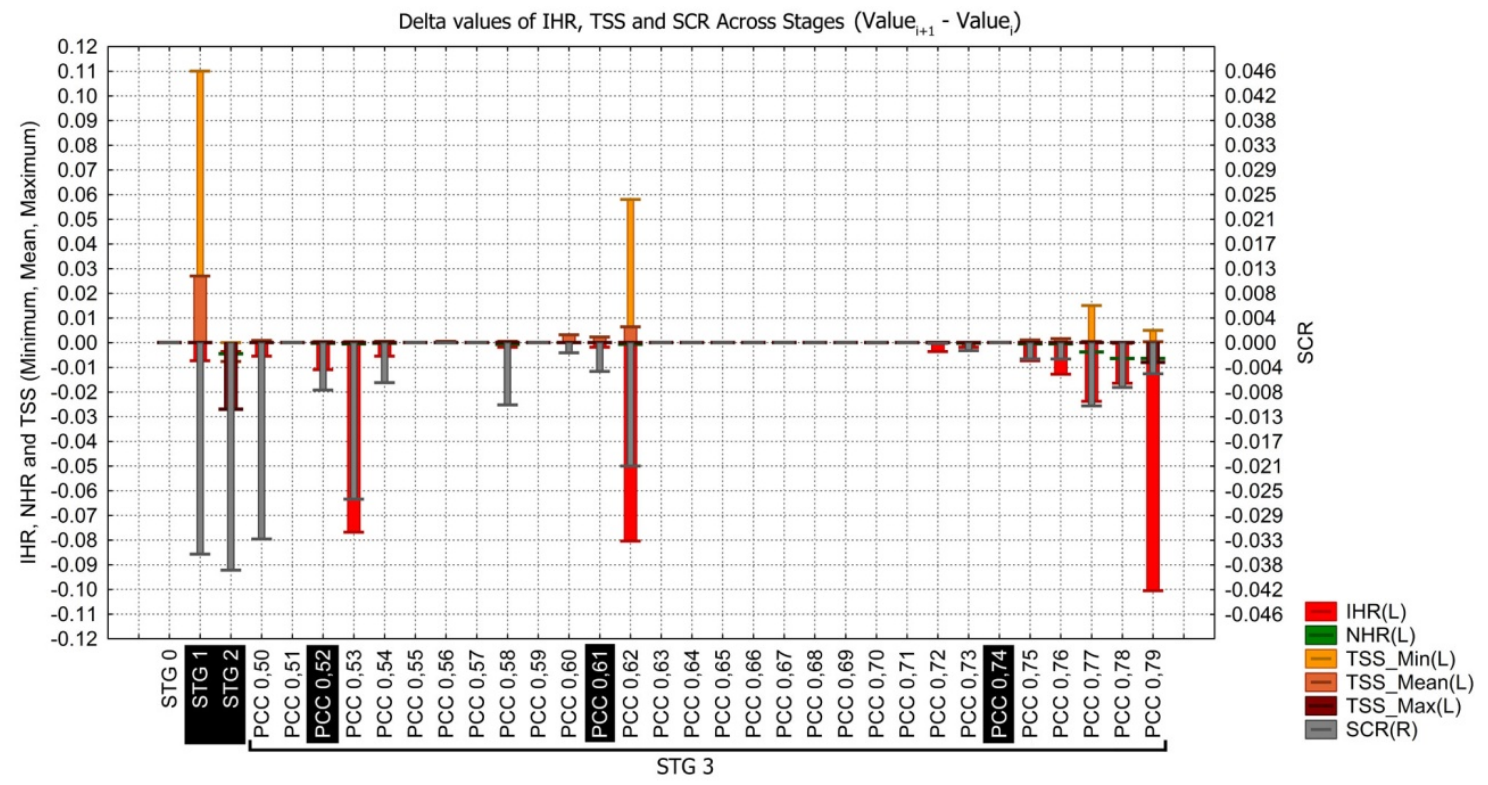

Figure 4. Difference between the current value minus the preceding one (delta value) of each evaluation index across stages. This plot facilitated the identification of three marked changes across the PCC range (PCC: $0.53,0.62,0.79)$ and the sequence of changes from PCC 0.75 to 0.79 used to select the OPMs (PCC: $0.52 ; 0.61 ; 0.74$ ) that built the final ensemble model. 

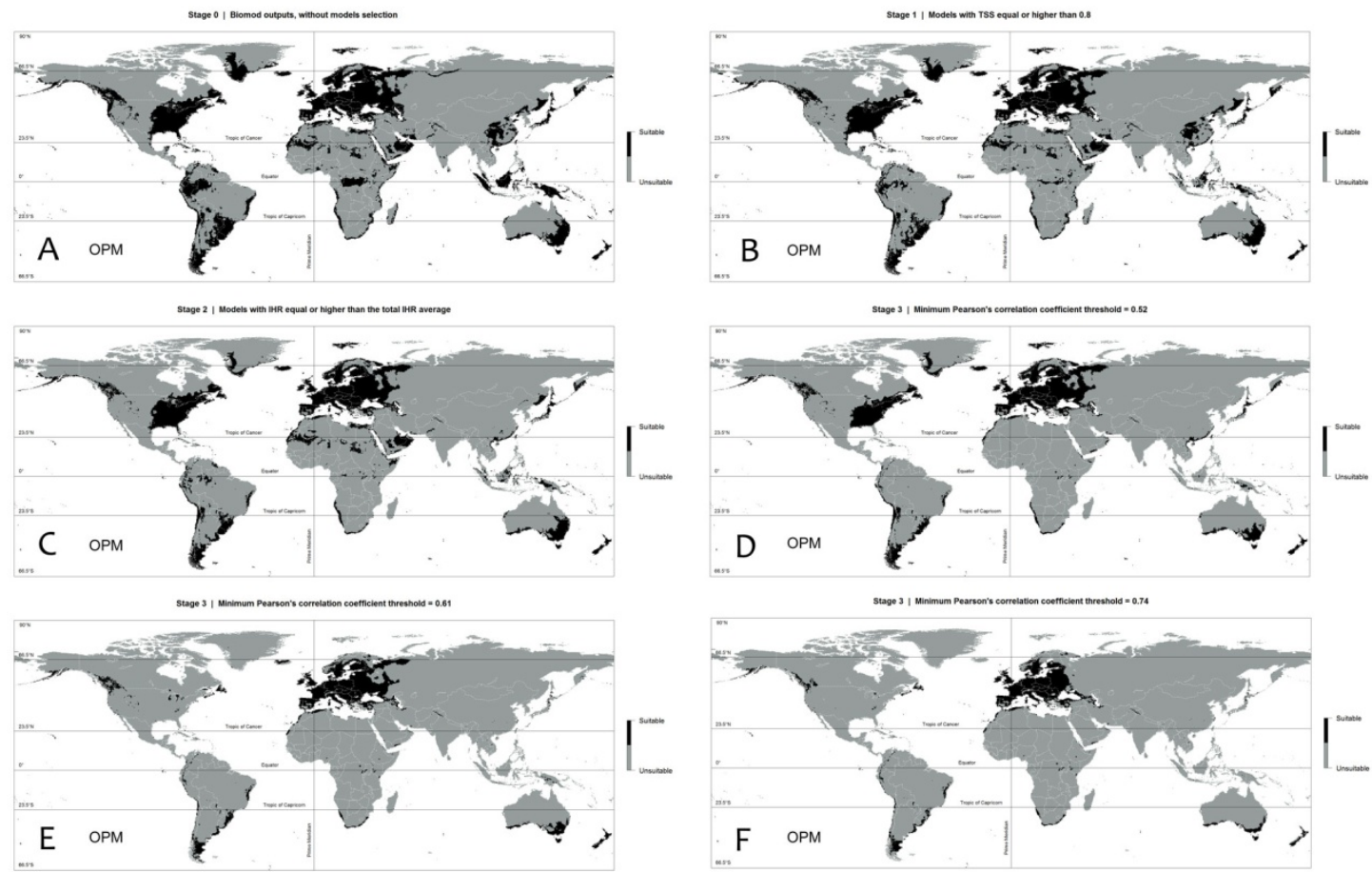

Figure 5. Overall Prediction Ensemble Models (OPMs) of Stages 0, 1, 2, and Stage 3 PCCs $0.52,0.61$, and 0.74 . The OPM considers all suitability predictions of every model from each selected set per Stage.

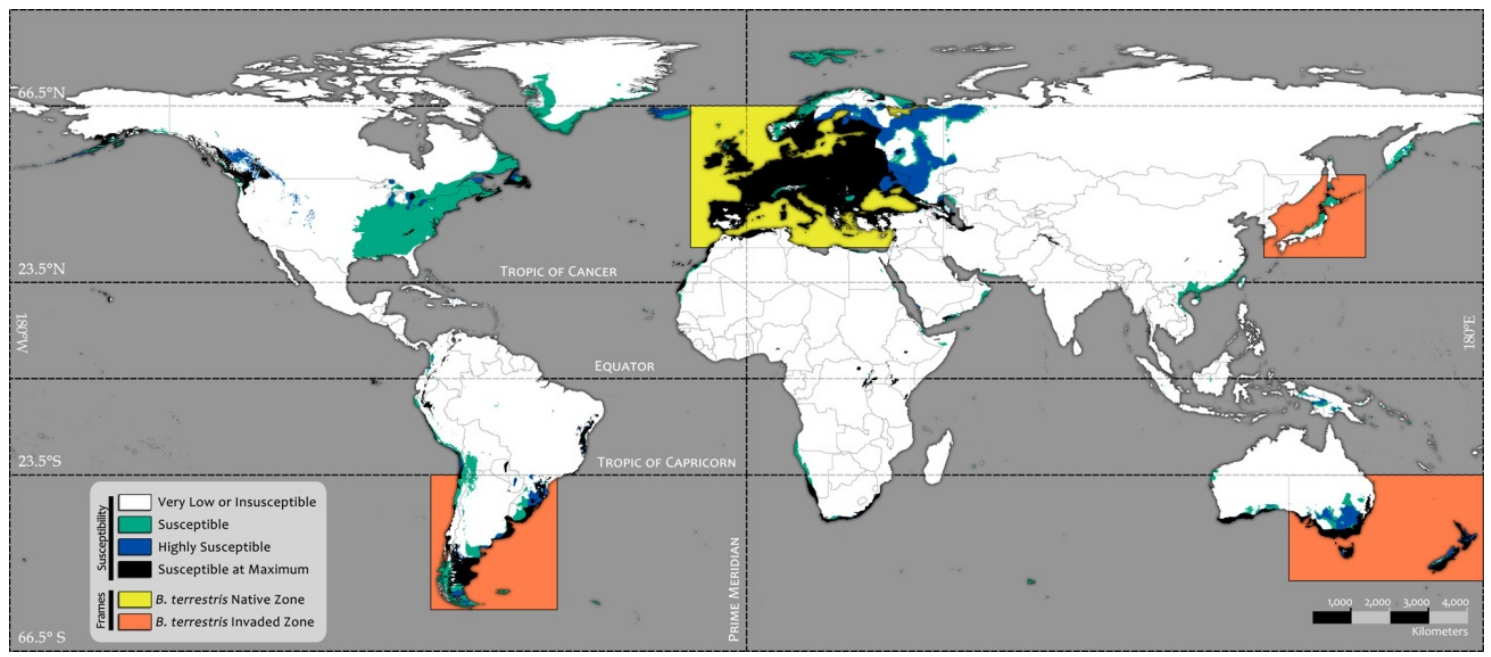

Figure 6. Global Susceptibility Map to Bombus terrestris Invasion. 

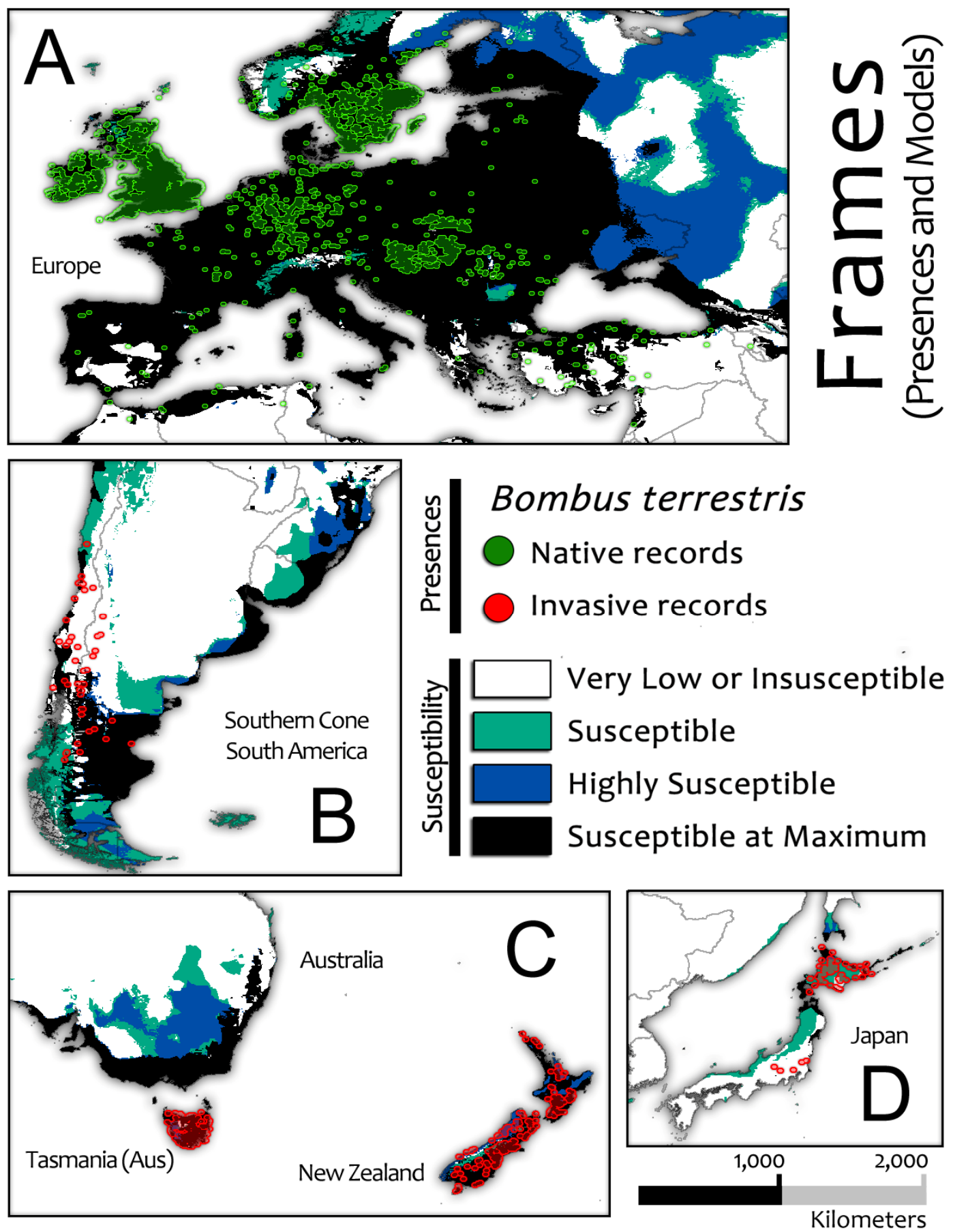

Figure 7. Frames extracted from the Global Susceptibility Map to Bombus terrestris Invasion with both invasive and native presence records plotted. 


\section{Supporting Information}

S1. Data providers and bibliographical surveyed for Bombus terrestris native and invasive occurrences

S1.1 - Internet biodiversity data providers used for presences data survey and the amount of records after filtering by type of distribution (native or invasive; between brackets):

\begin{tabular}{l}
\hline GBIF - Global Biodiversity Information Facility (native: 8,614; invasive: 28). \\
http://www.gbif.org/ \\
\hline DL - Discover Life (native: 1,225; invasive: 19). http://www.discoverlife.org/ \\
NBN - National Biodiversity Network (native: 946). http://www.nbn.org.uk/ \\
SeiyouStatus - See reference below: Seiyou Status, 2013 (invasive: 67). \\
http://www.seiyoubusters.com/seiyou/en/ \\
Extracted from bibliography - See references in S1.2 ( native: 467; invasive: 503).
\end{tabular}

S1.2 - Bibliographical References from which native and invasive occurrences data of Bombus terrestris were extracted.

S1.2.1- References used for occurrences data extraction that were also cited on text:

Hopkins, 1914; Buttermore, 1997; Buttermore et al., 1998; Hingston and McQuillan, 1998 ;

Ruz, 2002; Velthuis, 2002; Goulson and Hanley, 2004; Matsumura et al., 2004; AHGA, 2005;

Inari et al., 2005; Torretta et al., 2006; Velthuis and van Doorn, 2006; Winter et al., 2006; Inoue

et al., 2007; Schmid-Hempel et al., 2007; Ward, 2007; Inoue et al., 2008; Kanbe et al., 2008;

Kadoya et al., 2009; Kondo et al., 2009; Dafni et al., 2010; Howlett and Donovan, 2010;

Kadoya and Washitani, 2010; Hingston et al., 2012.

S1.2.2-References exclusively used for occurrences data extraction:

Ban CM. Apoid hymenopterans (Megachilidae, Anthophoridae, Apidae) from Fagaras mountains area (Romania). Brvkenthal Acta Mvsei. 2006; I3: 107-112. (ISSN: 1842-2691). Available from: http://www.brukenthalmuseum.ro/pdf/BAM/BAM\%20I\%203.pdf

Ban-calefariu C, Sárospataki M. Contributions to the knowledge of Bombus and Psithyrus Genera (Apoidea: Apidae) in Romania. Travaux de Museum National d Historie Naturelle: Grigore Antipa. 2007; p239-258.

Beekman M, van Stratum P. Does the diapause experience of bumblebee queens Bombus terrestris affect colony characteristics? Ecol Entomol. 2000; 25:1-6. 
Bloch G, Borst DW, Huang ZY, Robinson GE, Cnaani J, Hefetz A. Juvenile hormone titers, juvenile hormone biosynthesis, ovarian development and social environment in Bombus terrestris. J Ins Physiol. 2000; 46: 47-57.

Bosch M, Simon J, Rovira AM, Molero J, Blanche C. Pollination ecology of the pre-Pyrenean endemic Petrocoptis montsicciana (Cariophyllaceae): effects of population size. Biol J Linn Soc. 2002; 76:79-90.

Bourke AFG, Ratnieks FLW. Kin-selected conflict in the bumble-bee Bombus terrestris (Hymenoptera : Apidae) Proc R Soc Lond B. 2001; 268: 347-355.

Buide ML. Pollination ecology of Silene acutifolia (Caryophyllaceae): Floral traits variation and pollinator attraction. Ann Bot. 2006; 97: 289-297.

Calzoni GL, Speranza A. Insect controlled pollination in Japanese plum (Prunus salicina Lindl). Sci Hort. 1998; 72: 227-237.

Coppée A, Terzo M, Valterova I, Rasmont P. Intraspecific variation of the cephalic labial gland secretions in Bombus terrestris (L) (Hymenoptera: Apidae). Chemistry \& Biodiversity. 2008; 5(12): 2654-61.

Damerdji A, Djedid A. Contribuition à l'étude bioécologique de la faune du genêt (Calycotome spinosa L(Link)) dans la region de Tlemcen (Algérie). Mésogée. 2005; 61: 51-59.

Durieux PE. Rapport de recherche Etude des choix floraux des bourdons (Hymenoptera, Apidae) de la commune d'Eyne (France, Pyrénées-Orientales ), Université de Mons-Hainaut Service de Zoologie. 2000. Available from: http://zoologie.umh.ac.be/hymenoptera/biblio/Durieux_1999_Choix_floraux_Bourdons_Eyne TFE.pdf

Duvoisin N, Baer B, Schmid-Hempel P. Sperm transfer and male competition in a bumblebee. Anim Behav. 1999; 58: 743-749.

Frehn E, Schwammberger KH. Social parasitism of Psithyrus vestalis in free-foraging colonies of Bombus terrestris (Hymenoptera : Apidae). Entomol Gen. 2001; 25: 103-105.

Gadoum S, Iserbyt S, Michez D, Terzo M, Rasmont P. Les Abeilles sauvages du Parc naturel régional du Vexin français. Courrier Scientifique du Parc Naturel Régional du Vexin Français. 2005; $1: 28-33$.

Genissel A, Aupinel P, Bressac C, Tasei JN, Chevrier C. Influence of pollen origin on performance of Bombus terrestris micro-colonies. Entomol Exp Appl. 2002; 104: 329-336.

Gosselin M, Iserbyt S, Rasmont P. Faunistique des bourdons (Hymenoptera: Apoidea ) de la vallée de Nohèdes (France, Pyrénées-Orientales ) et des zones limitrophes. Notes fauniques de Gembloux. 2007; 60 (1), 13-23.

Guitian J, Guitian P, Medrano M, Sanchez JM. Variation in floral morphology and individual fecundity in Erythronium dens-canis (Liliaceae). Ecography. 1999; 22: 708-714.

Hartfelder K, Cnaani J, Hefetz A. Caste-specific differences in ecdysteroid titers in early larval stages of the bumblebee Bombus terrestris. J Ins Physiol. 2000; 46: 1433-1439.

Herrera CM. Componentes del flujo génico en Lavandula latifolia medicus: polinización de dispersión de semillas. Anal J Bot Madrid. 1987; 44: 49-61.

Herrera CM, Cerda X, Garcia MB, Guitian J, Medrano M, Rey PJ, Sanchez-Lafuente AM. Floral integration, phenotipic covariance structure and pollination variation in bumblebeepollinated Helleborus foetidus. J Evol Biol. 2002; 15: 108-121.

Hirsch M, Pfaff S, Wolters V. The influence of matrix type on flower visitors of Centaurea jacea L. Agric Ecosyst Environ. 2003; 98: 331-337.

Ings TC, Ings NL, Chittka L, Rasmont P. A failed invasion? Commercially introduced pollinators in Southern France. Apidologie. 2009; 41(1): 1-13.

Ings TC, Ward NL, Chittka L. Can commercially imported bumble bees out-compete their native conspecifics? Journal of Applied Ecology. 2006; 43(5): 940-948.

Ings TC, Schikora J, Chittka L. Bumblebees, humble pollination or assiduous invaders? A population comparison of the foranging performance of Bombus terrestris. Oecologia. 2005; 144(3): 508-516.

Inoue MN, Yokoyama J. Competition for flower resources and nest sites between Bombus terrestris (L) and Japanese native bumblebees. Applied Entomology and Zoology. 2010; 45(1), 29-35. 
Iserbyt S. La faune des bourdons (Hymenoptera?: Apidae) du Parc National des Pyrénées occidentales et des zones adjacentes. Ann Soc Entomol Fr. 2009; 45(2), 217-244.

Jablonski B. Agronomic and beekeeping value of short-tube populations of red clover (Trifolium pratense L). J Api Res. 2001; 45: 37-50.

Keasar T. The spatial distribution of non rewarding artificial flowers affects pollinator attraction. Anim Behav. 2000; 60: 639-646.

Keasar T, Motro U, Shur Y, Shmida A. Overnight memory retention of foraging skills by bumblebees is imperfect. Anim Behav. 1996; 52: 95-104.

Kreyer D, Oed A, Walther-Hellwig K, Frankl R. Are forests potential landscape barriers for foraging bumblebees? Landscape scale experiments with Bombus terrestris and Bombus pascuorum (Hymenoptera, Apidae). Biol Conserv. 2004; 116: 111-118.

Lopez-Vaamonde C, Koning JW, Jordan WC, Bourke AFG. No evidence that reproductive bumblebee workers reduce the production of new queens. Anim Behav. 2003; 66: 577-584.

Lopez-Vaamonde C, Koning JW, Jordan WC, Bourke AFG. A test of information use by reproductive bumblebee workers. Anim Behav. 2004;68:811-818.

Mahe G. Memo Pour L'atlas Des Bourdons Armoricains. 2012;1-11. Available from: http://www.atlashymenoptera.net/biblio/Memo2012_Atlas_Bombus_Armor.pdf.

Monsevièius V. Comparison of three methods of sampling wild bees (Hymenoptera, Apoidea) in Ėepkeliai Nature Reserve (South Lithuania). Ekologija. 2004; 4:32-39.

Mtcsez D. Eco-éthologie des visiteurs de Lythrum salicaria L (Lythraceae) en Belgique. 2008; $10,37-55$.

Nagamitsu T, Yamagishi H, Kenta T, Inari N, Kato E. Competitive effects of the exotic Bombus terrestris on native bumble bees revealed by a field removal experiment. Population Ecology. 2009; 52(1), 123-136.

Olesen JM, Valido A. Floral morphology and pollen flow in the heterostylous species Pulmonaria obscura Dumort (Boraginaceaea). N Phytol. 1979; 82:757-767.

Oustrauskas H, Monsevièius V. Wild bees (Apoideat, Hymenoptera) caught with Green funnel traps in Lithuania. Acta Zool Lituan. 2002;12:191-196.

Pawlikowski T, Hirsch J. Bees (Hymenoptera: Apoidea) as indicators of xerisation processes in the lower Vistula Valley. Acta Zool Crac. 2002;45:321-333.

Petanidou T, Ellis WN. Pollinating fauna of a phyganic ecosystem: composition and diversity. Biodiversity Letters. 1993; 1:9-22.

Rasmont P. Bombus terrestris (L) (Hymenoptera, Apidae) dans les massif des Maures (France, Var), une generation d'Hiver? Bull Annal Soc R Belge d'Entomol. 1984; 120:359-363.

Rasmont P, Adamski A. Le bourdons de la Corse (Hymenoptera, Apoidea, Bombinae). Note Faun Gembloux. 1995; 31:3-87.

Rasmont P, Durieux E-A, Iserbijt S, Baracetti M. Why are there so many bumblebees species in Eyne (France, Pyrénée-Orientales, Cerdagne) IN: Sommeijer MJ, de Ruijter A (ed). Insect pollination in greenhouses: proceedings of the specialists' meeting held in Soesterberg, The Netherlands, Utrecht, Universiteit Utrecht, 2000. p220.

Rasmont P, Regali A, Ings T C, Lognay G, Baudart E, Marlier M, Delcarte E, et al. Analysis of pollen and nectar of Arbutus unedo as a food source for Bombus terrestris (Hymenoptera: Apidae). Journal of Economic Entomology. 2005;98(3), 656-63.

Sarospataki M, Novak J, Molnar V. Distribution and relative abundance of bumble bee species (Bombus and Psithyrus) in Hungary. J, Api Res. 2003; 47:73-78.

Seiyou Status - Current status of invasive alien bumblebee Bombus terrestris by participatory monitoring in Hokkaido, Japan. 2013. Acessed: 2013-01-15. Available from: http://www.seiyoubusters.com/seiyou/en/ 


\section{S2. Biomod2 Algorithms Parameters}

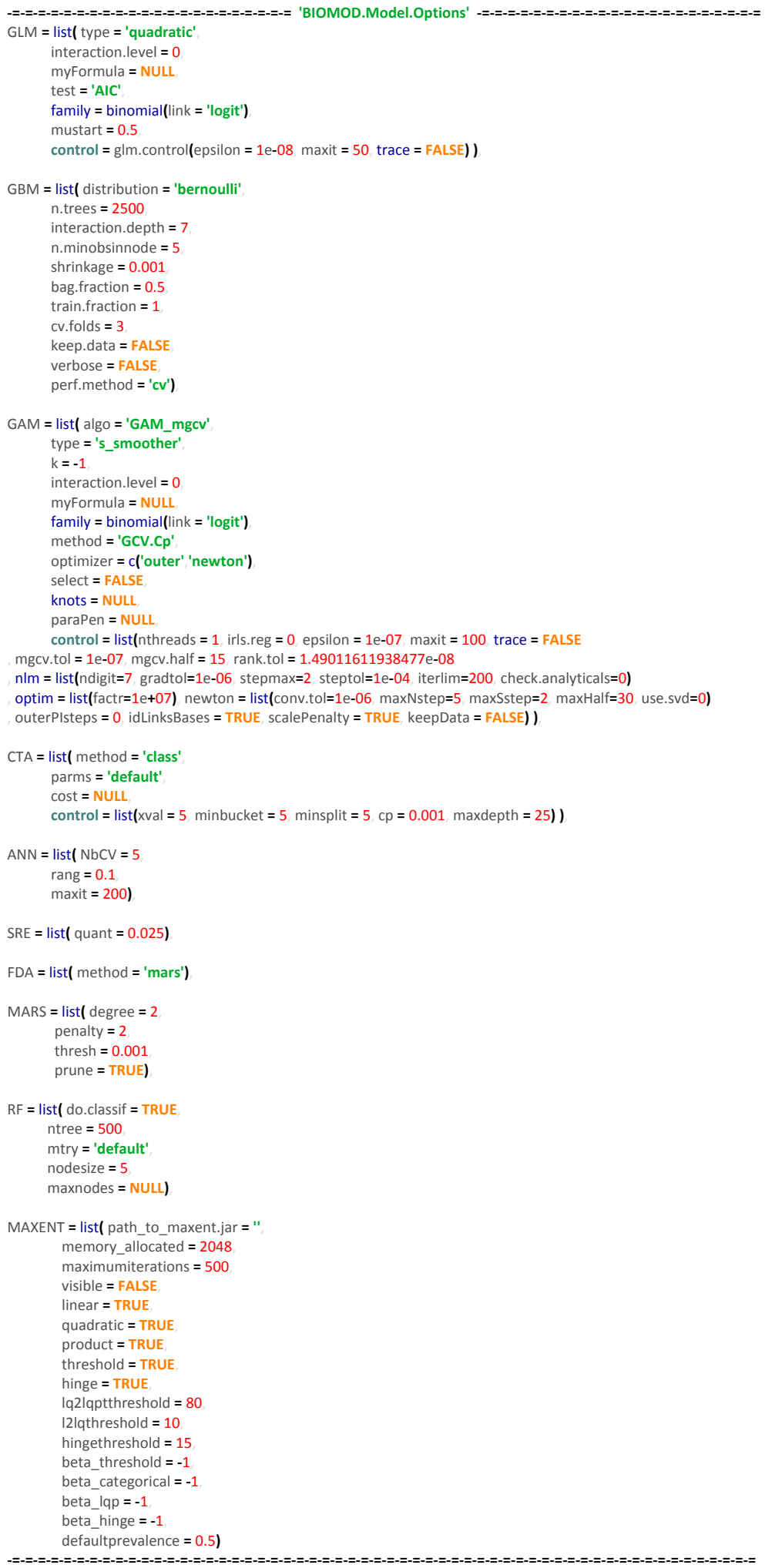


S3. Pearson correlation between paired evaluation indices

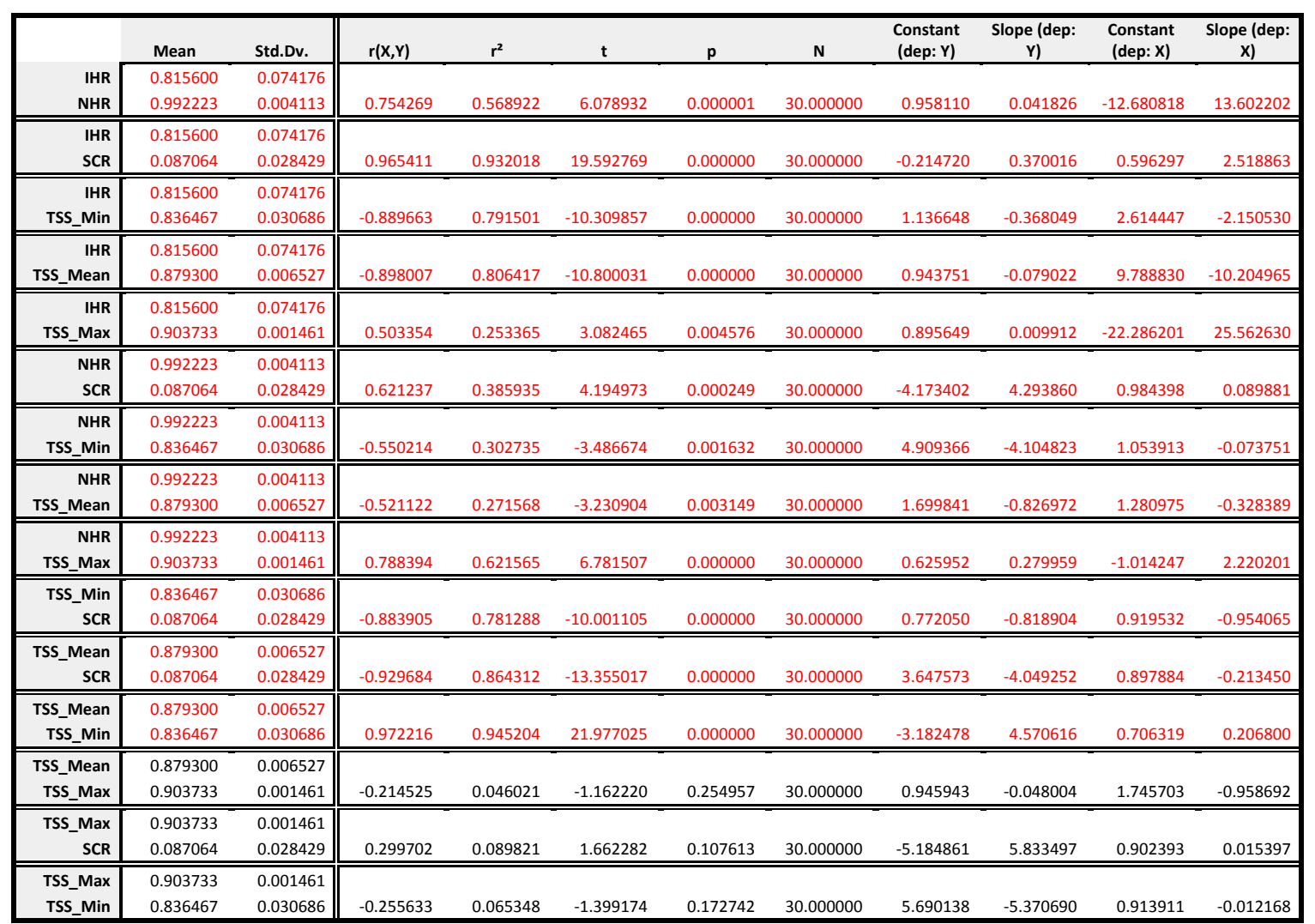

S4. Agreement Level Models
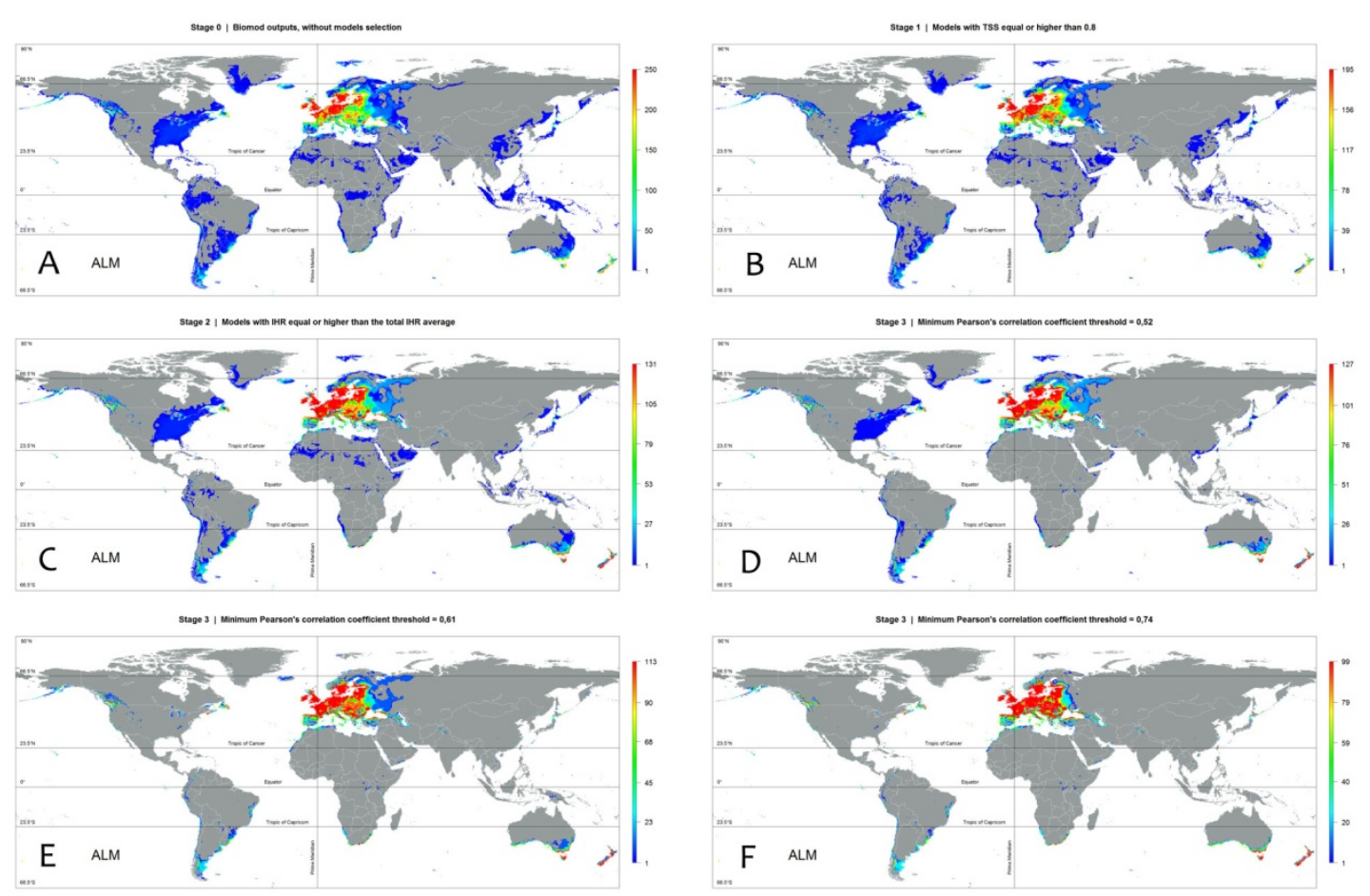


\subsection{Projeção do modelo de susceptibilidade para cenários climáticos futuros}

O modelo global das áreas susceptíveis à invasão de Bombus terrestris apresentado no item 4.1 deste capítulo foi gerado com o uso de variáveis climáticas que compreendem médias do período entre 1950 a 2000 (Worldclim; Hijmans et al., 2005). Considerando-se que já se passaram 15 anos (2015) desde o limite desse período, e que há uma rápida mudança do clima em curso, os resultados do modelo em cenário climático atual estão se tornando menos precisos ao longo do tempo. Além disso, a expansão invasiva de Bombus terrestris pela América do Sul poderá levar algum tempo para alcançar o Brasil a partir da Argentina e do Chile, de forma que os caminhos ambientalmente favoráveis para o deslocamento da espécie invasora poderão sofrer impactos e variações decorrentes das mudanças climáticas. Estes aspectos evidenciam a necessidade de se projetar os resultados do modelo atual para um período mais adiante no tempo, objetivando identificar as mudanças geoespaciais das classes de susceptibilidade do modelo levando em conta cenários estimados de mudança climática e, assim, ampliar a validade temporal das predições do modelo.

Os resultados desta análise também são importantes no desenvolvimento metodológico do Capítulo 5, pois permitiram verificar as mudanças da suscetibilidade nos caminhos potenciais de expansão invasiva de Bombus terrestris no sul na América do Sul, os quais poderão ser usados pela espécie para alcançar e se expandir sobre o Brasil.

Este item (4.2) é complementar ao item anterior (4.1) e abordou exclusivamente o processo de projeção do modelo global de susceptibilidade à invasão de Bombus terrestris gerado para a condição climática recente, para dois cenários futuros de mudança climática estimados para a década de 2050: o RCP 4,5 e o RCP 6,0 (detalhes sobre seleção destes cenários estão no Capítulo 3).

Da mesma forma como foi feito no Capítulo 3, os resultados não foram desvinculados da descrição do processo metodológico, almejando tornar mais fluido o acompanhamento dos passos em seu progresso sequencial.

Como a projeção para cenários futuros utilizará os mesmos dados e parâmetros predefinidos no processo de modelagem para o cenário atual, não se repetiu sua descrição aqui, a qual pode ser consultada no item anterior (4.1). Nesta parte se deu unicamente o prosseguimento, após a modelagem, da projeção do modelo em cenários futuros e a apresentação dos seus resultados com enfoque exclusivo nas seguintes abrangências geoespaciais de especial interesse para a pesquisa:

1) áreas focais, contendo os registros conhecidos de presença invasora da espécie delineadas pelos quadros: SA (cone sul da América do Sul); JP (Japão e arredores); e NZT (sudeste da Austrália e Nova Zelândia);

2) dimensões político-administrativas de países com registros de invasão abrangidos pelo quadro SA: o Chile e a Argentina; pelo quadro JP: o Japão; e pelo quadro NZT: Nova Zelândia e Tasmânia;

3) áreas parciais das dimensões político-administrativas de países sem relatos de invasão que estão sob risco devido às suas proximidades com locais com registros de invasão: a Austrália, o Brasil e o Uruguai. 
O pacote BIOMOD2, por meio da função BIOMOD_Projection, projeta os modelos desenvolvidos para novas dimensões espaciais (outras extensões, áreas e resoluções) e diferentes escalas temporais (variáveis estimadas para passado ou futuro) em relação à temporalidade das variáveis ambientais inicialmente usadas (Manual do Biomod2; Thuiller, 2015).

Para a projeção - que neste caso foi feita para cenários futuros com variáveis ambientais de mesma resolução e extensão que as usadas no cenário atual - o BIOMOD2 montou o conjunto de variáveis de projeção (doravante citada como camadas futuras) selecionando do conjunto total de variáveis futuras apenas aquelas cujos nomes (de arquivo) coincidiam com os nomes das variáveis em cenário atual que foram inicialmente usadas na modelagem (citadas como camadas atuais), buscando manter a coerência de significado ambiental entre pares de variáveis temporalmente distintas (Bio 2 atual | Bio 2 futura; Bio 15 atual | Bio 15 futura; ...). Desta maneira, as variáveis utilizadas para as projeções nos dois cenários futuros (RCP: 4,5 e 6,0) foram as mesmas (de mesmo nome) que apresentaram menor correlação por meio do coeficiente de Pearson para o desenvolvimento do modelo atual (detalhes sobre a seleção no item 4.1 deste capítulo), as quais foram: Alt, Bio 2, Bio 5, Bio 7, Bio 13, Bio 14, Bio 15, Bio 18, Bio 19 (Tabela C3-2). Ressalta-se que a camada Alt (altitude) não varia significativamente na dimensão temporal abrangida entre o cenário "atual" e "futuro" - apenas cinquenta anos, que é um tempo ínfimo em termos geológicos portanto esta camada é mantida na projeção para cenários futuros.

Os modelos não são integralmente recalculados na projeção, como ocorreu no procedimento de modelagem em cenário atual; de fato, os modelos matemáticos obtidos são projetados para o novo conjunto de valores futuros das mesmas variáveis utilizadas para a modelagem feita para valores atuais. No entanto, este processo requer que o BIOMOD2 volte a reacessar cada algoritmo previamente utilizado, pois as projeções seguirão as lógicas particulares de cada um deles para reestimar a mudança.

Não foram reprojetados para o futuro todos os 250 modelos gerados em cenário atual, mas apenas os 127 de mais alta qualidade preditiva que compõe os três níveis de susceptibilidade. Vale lembrar que no item 4.1 a identificação dos modelos atuais mais precisos em termos preditivos decorreu por meio de um procedimento em três estágios com diferentes critérios de seleção em cada um. Do total de modelos gerados inicialmente (250) apenas 127 modelos alcançaram o primeiro nível do último estágio de avaliação (Estágio 3, primeiro nível $P C C=0,52$ ). Neste conjunto estão todos os modelos necessários para a composição dos 3 níveis de susceptibilidade no modelo final [( $P C C=0,52: 127$ modelos $) \supset$ ( $P C C=0,61: 113$ modelos $) \supset$ ( $P C C=0,74: 99$ modelos)].

As projeções futuras não precisam ser reavaliadas em termos de qualidade preditiva por meio de métricas de avaliação como o TSS (Alouche, 2006), afinal estas são reprojeções de modelos previamente avaliados e selecionados pelas suas altas qualidades preditivas; as variações ambientais dos habitat adequados à espécie que foram robustamente detectadas para a composição do modelo atual se manterão na projeção futura, apenas suas expressões geoespaciais serão redefinidas.

A figura C4.2-1 exibe o fluxo dos passos metodológicos, os quais também estão detalhadamente descritos a seguir. Ressalta-se que, para fins práticos, não se repetiu a descrição dos passos de reprojeção, afinal eles foram feitos duas vezes, pois são dois 
cenários climáticos futuros (RCP: 4,5 e 6,0), mas os passos metodológicos seguidos para a projeção de cada cenário são exatamente os mesmos com a exceção da mudança do conjunto de camadas futuras.

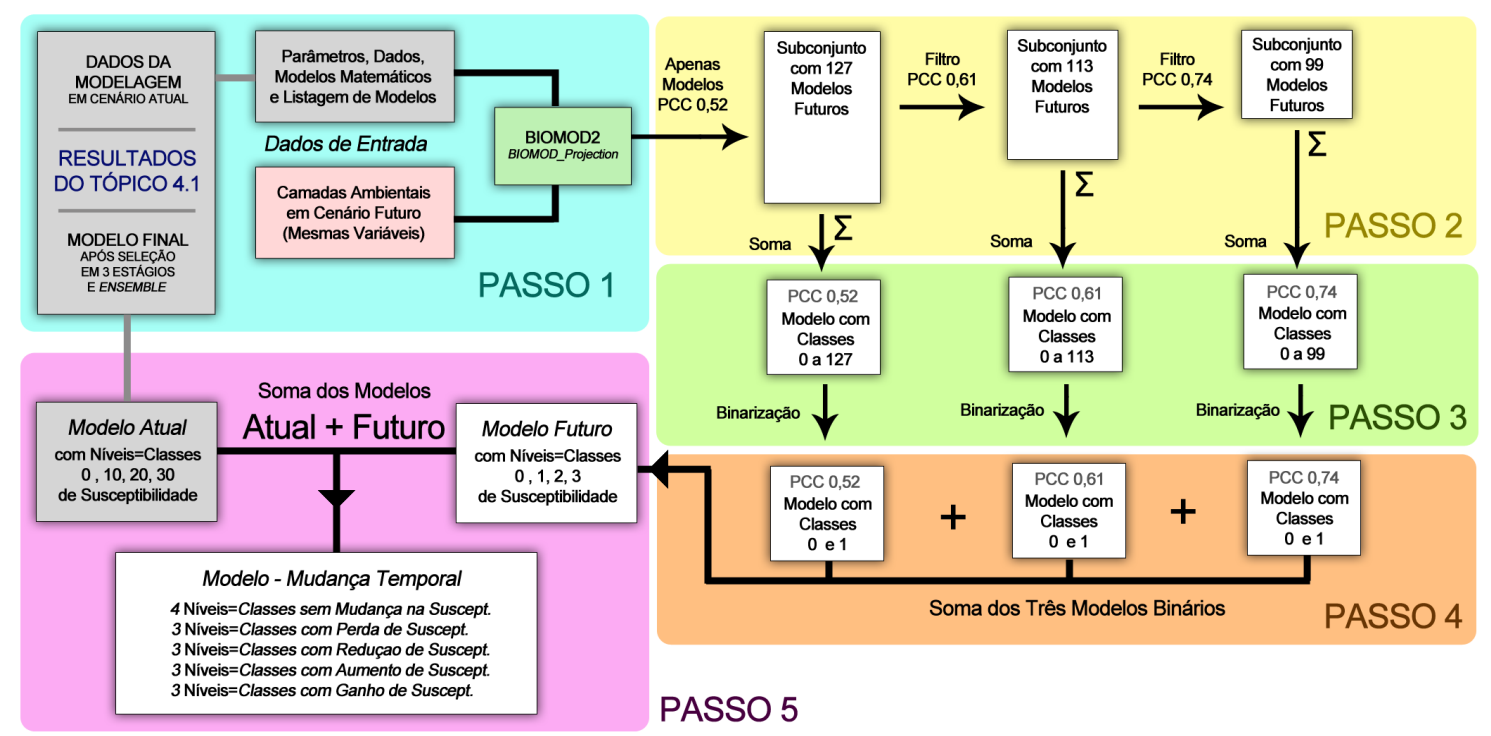

Figura C4.2-1. Fluxograma dos passos da projeção para cenário climáticos futuros. Como são dois conjuntos de camadas futuras (RCP 4,5 e 6,0), toda a sequência foi repetida duas vezes apenas mudando-se o conjunto de camadas futuras (Passo 1, quadro em magenta).

Passo 1) O conjunto de nove camadas ambientais em cenário futuro, os modelos matemáticos resultantes da modelagem em cenário atual e a listagem dos nomes dos 127 modelos a serem projetados foram incluídos na função de projeção do BIOMOD2 (BIOMOD_Projection). A função foi executada, e os modelos matemáticos foram projetados sobre as camadas em cenário futuro gerando 127 arquivos do tipo raster, os quais exibem valores binários de predição (habitat adequado|susceptível $=1$ e inadequado (insusceptível $=0$ ).

Passo 2) As 127 projeções foram agrupadas em três subconjuntos com reposição, respectivamente aos três limiares mínimos de coeficientes de Pearson (PCC; verificar o item 4.1 para detalhes). Cada conjunto, separadamente, teve os seus modelos geoespacialmente somados, gerando três modelos individuais cujas classes de valores variam de zero (áreas insusceptíveis) ao máximo de sobreposição de áreas susceptíveis em cada conjunto (de 0 a 127 no PCC 0,52; de 0 a 113 no PCC 0,61 e; de 0 a 99 no PCC 0,74). Ressaltando-se novamente que o conjunto de modelos do PCC menor $(0,52)$ contém os modelos do PCC subsequente $(0,61)$ e ambos os conjuntos contém os modelos do último PCC $(0,74)$, portanto, $\Sigma(P C C 0,74) \subseteq \Sigma(P C C 0,61) \subseteq \Sigma(P C C$ $0,52)$.

Passo 3) Cada um dos três modelos, que neste passo exibem um escala de valores contínua após a soma, foi convertido em valores binários por meio da função reclassify em ArcGIS (ESRI, 2010) usando-se a seguinte lógica de reclassificação: as células com valores iguais ou maiores a "um" recebem um único valor $=1$, e o "zero" mantém seu valor original $=0$.

Passo 4) Os três modelos binários foram então somados (PCC 0,52 + PCC 0,61 + PCC 0,74). Gerou-se um único modelo apresentando 4 classes de valores $(0,1,2,3)$ - 
de forma idêntica ao modelo de susceptibilidade em cenário atual desenvolvido no item 4.1. As áreas abrangidas pela classe de valor $=0$ indicam as áreas insusceptíveis à invasão; a classes de valores 1, 2 e 3, indicam os níveis crescentes de susceptibilidade (convergência preditiva; abordado no item 4.1). Os dois resultados deste passo foram exportados em forma de mapas para verificação visual (Figura C4.2-2, B e C).

Passo 5) Para identificar os tipos e níveis de mudanças entre o modelo atual e o modelo futuro, as classes do modelo atual (gerado no item 4.1; ver Figura C4.2-2 A) foram multiplicadas por 10 [(classes $0,1,2,3) * 10=($ classes $0,10,20,30)$ ] e, subsequentemente, este modelo foi geoespacialmente somado ao modelo futuro (classes $0,1,2,3$ ), gerando um modelo composto com 16 de classes de valores, como consequência das máximas combinações possíveis das 4 classes do modelo atual com as 4 classes do futuro $(4 \times 4=16)$, conforme exibido na coluna Classes de Identificação na Tabela C4.2-1.

\begin{tabular}{|c|c|c|c|c|c|c|}
\hline \multicolumn{3}{|c|}{ Classes de Identificação } & \multirow{2}{*}{$\begin{array}{l}\text { Desrição das classes de identificação } \\
\text { (do cenário atual para o futuro) }\end{array}$} & \multirow{2}{*}{$\begin{array}{l}\text { Mudança } \\
\text { (Delta) }\end{array}$} & \multicolumn{2}{|c|}{ Classes de Qualificação (susceptibilidade crescente) } \\
\hline Atual & Futuro & Combinação & & & Nivel de Mudança & Tipo de Mudança \\
\hline 0 & 0 & 0 & continuará insusceptível & 0 & 0 & \multirow{4}{*}{$\begin{array}{l}\text { Não muda } \\
\text { (mantém os níveis atuais) }\end{array}$} \\
\hline 10 & 1 & 11 & continuará susceptível & 0 & 1 & \\
\hline 20 & 2 & 22 & continuará alta suceptibilidade & 0 & 2 & \\
\hline 30 & 3 & 33 & continuará máxima susceptibilidade & 0 & 3 & \\
\hline 30 & 0 & 30 & de máxima susceptibilidade se tornará insusceptivel & -3 & 4 & \multirow{3}{*}{$\begin{array}{c}\text { Perda } \\
\text { (torna-se insusceptível) }\end{array}$} \\
\hline 20 & 0 & 20 & de alta suceptibilidade se tornará insusceptível & -2 & 5 & \\
\hline 10 & 0 & 10 & de susceptivel se tornará insusceptível & -1 & 6 & \\
\hline 30 & 1 & 31 & de máxima susceptibilidade se tornará susceptível & -2 & 7 & \multirow{3}{*}{$\uparrow \stackrel{\text { Redução }}{\uparrow \text { (torna-se menos susceptível) }}$} \\
\hline 20 & 1 & 21 & de alta suceptibilidade se tornará susceptível & -1 & 8 & \\
\hline 30 & 2 & 32 & de máxima susceptib. se tornará alta suceptibilidade & -1 & 9 & \\
\hline 10 & 2 & 12 & de susceptível se tornará alta suceptibilidade & 1 & 10 & \multirow{3}{*}{$\downarrow$ Aumento } \\
\hline 20 & 3 & 23 & de alta suceptib. se tornará máxima susceptibilidade & 1 & 11 & \\
\hline 10 & 3 & 13 & de susceptível se tornará máxima susceptibilidade & 2 & 12 & \\
\hline 0 & 1 & 1 & de insusceptível se tornará susceptível & 1 & 13 & \multirow{3}{*}{$\downarrow \quad \begin{array}{c}\text { Ganho } \\
\text { (torna-se susceptível) }\end{array}$} \\
\hline 0 & 2 & 2 & de insusceptível se tornará alta suceptibilidade & 2 & 14 & \\
\hline 0 & 3 & 3 & de insusceptivel se tornará máxima susceptibilidade & 3 & 15 & \\
\hline
\end{tabular}

Tabela C4.2-1. Classes de identificação dos níveis de susceptibilidade dos modelos, combinação das classes do modelo atual e futuro e descrições de seus significados, e aspectos quantitativos e qualitativos dos níveis de mudança da susceptibilidade do cenário atual para o futuro.

Interpretação e análise das mudanças na susceptibilidade no futuro

Os dois modelos projetados para o futuro no Passo 4 foram exportados na forma de mapas (Figura C4.2-2, B e C) e apresentam as classes de susceptibilidade no mesmo formato apresentado pelo modelo atual (item 4.1), permitindo a verificação da distribuição global dos três níveis de susceptibilidade. Para auxiliar a comparação visual entre cenários, o modelo atual (já apresentado no item 4.1) também foi incluído na Figura C4.2-2 (A).

Como é possível perceber por meio de comparação visual entre o modelo atual (Figura C4.2-2 A) e as respectivas projeções futuras (Figura C4.2-2 B e C), não é simples identificar as mudanças dos níveis de susceptibilidade da projeção atual para as futuras e ainda menos entre as projeções futuras, devido a grande escala geográfica abrangida pelo mapa. Por outro lado, a discriminação das mudanças geoespaciais dos níveis de susceptibilidade são melhor explicitadas nos mapas gerados pelas combinações feitas no Passo 5, e por isso estes dois resultados (Figura C4.2-3 A e B) são os principais deste item e que serão usados em várias análises nos capítulos subsequentes. 

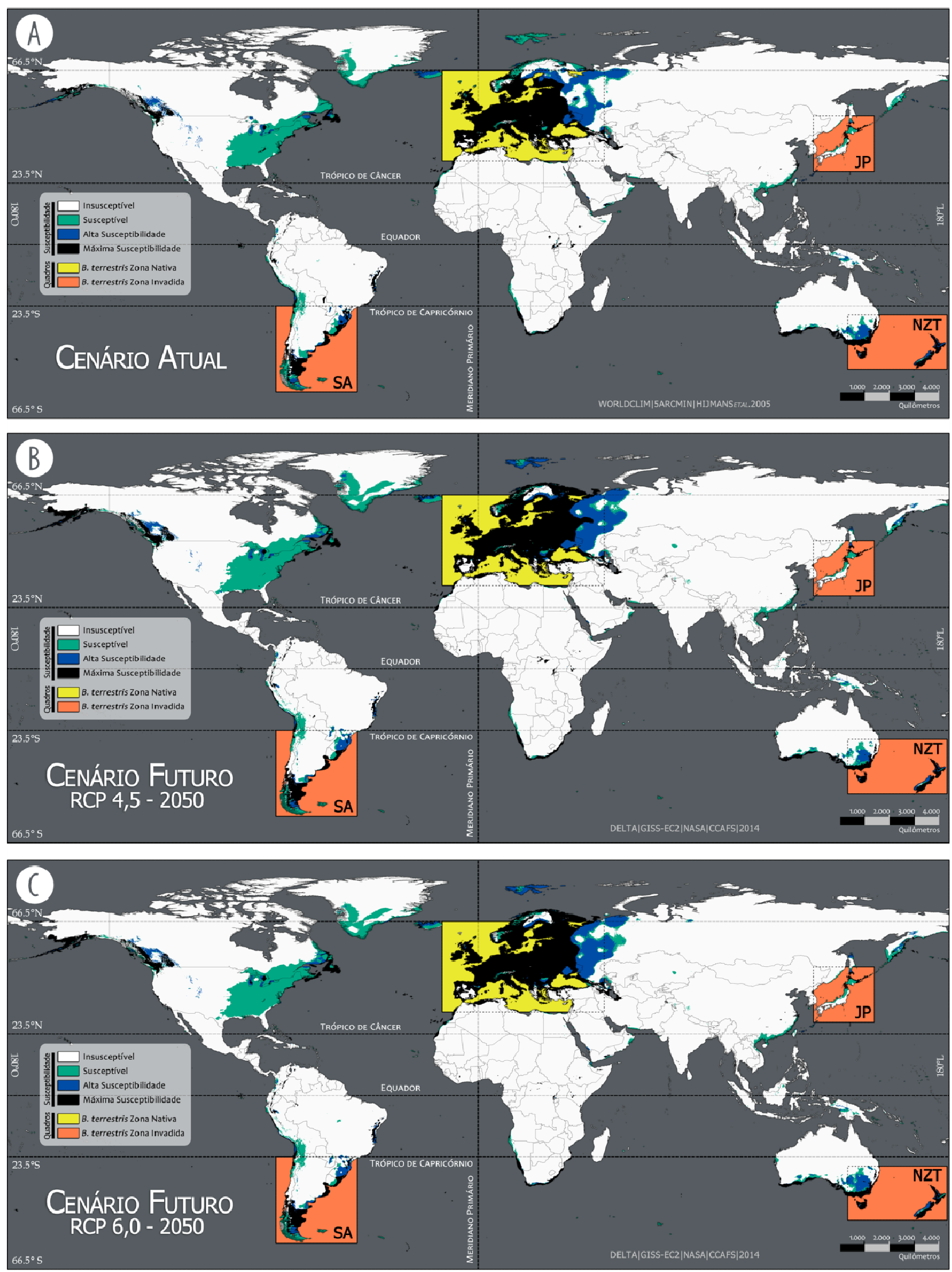

Figura C4.2-2. Mapas dos níveis de susceptibilidade de invasão de Bombus terrestris em escala global: em " $A$ " o mapa exibe o modelo de susceptibilidade em cenário climático atual; em "B" na projeção em cenário climático futuro RCP 4,5 para 2050; em "C" na projeção em cenário climático futuro RCP 6,0 para 2050. 

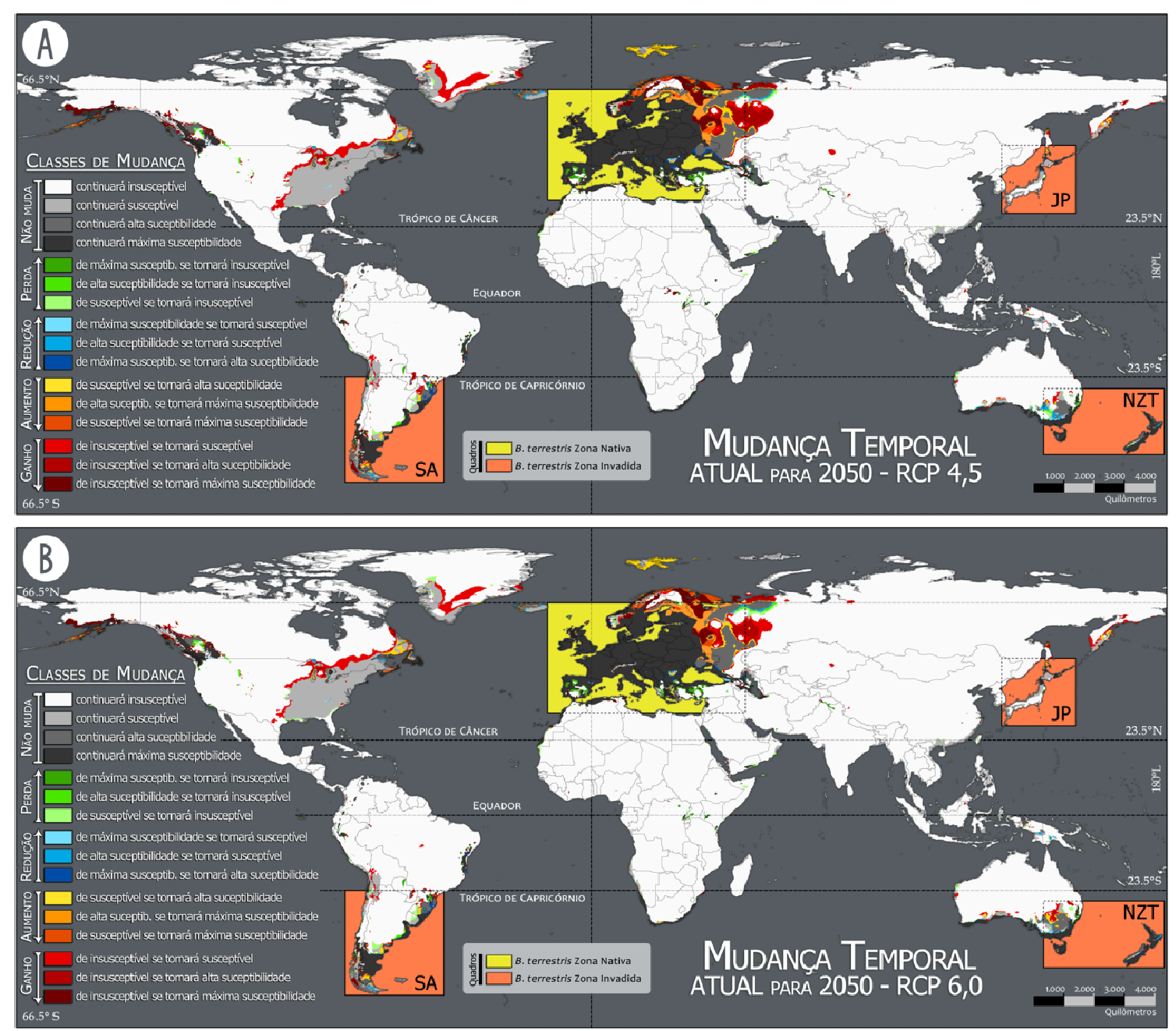

Figura C4.2-3. Mapas dos modelos de mudança temporal dos níveis e tipos de susceptibilidade: em " $A$ " exibe as mudanças da susceptibilidade do cenário atual para o futuro RCP 4,5 (2050); em " $B$ " exibe as mudanças da susceptibilidade do cenário atual para o futuro RCP 6,0 (2050). Verificar Tabela C4.2-1 para maiores detalhes sobe as legendas.

Os Modelos de Mudança Temporal (Figura C4.2-3) exibem as diferenças de suscetibilidade do cenário atual para cada cenário futuro de forma relativa, permitindo qualificar as variações temporais da susceptibilidade e agrupá-las em tipos similares (Tipos de Mudança na Tabela C4.2-1), assim como atribuir níveis de intensidade nas mudanças da suscetibilidade (Nível de Mudança na Tabela C4.2-1).

Com base na combinação das classes de identificação numéricas (16 combinações) que indicam o tipo de susceptibilidade atual e futura, foi possível associar seus significados (de atual para futuro) e descrever cada particular mudança (Descrição das Classes de Identificação na Tabela C4.2-1). Isso se deu pela combinação dos significados textuais das classes de identificação atual e futura; por exemplo: Classe atual 10 (equivale a susceptível) + Classe futura 3 (equivale a máxima susceptibilidade) resulta na classe combinada 13 ("de" susceptível "se tornará" máxima susceptibilidade).

A variação delta $\left(\right.$ Valor $_{i}-$ Valor $_{i-1}$ ) do nível de mudança da susceptibilidade entre cenários foi calculada (Mudança Delta na Tabela C4.2-1), de forma que se uma 
área que era insusceptível no cenário atual (valor=0) e se tornar susceptível no futuro (valor=1), terá ocorrido o salto de 1 nível na susceptibilidade da área (de 0 a $1=+1$ ); já e se ela se tornar máxima susceptibilidade (valor=3), o salto terá sido de 3 níveis (de 0 a $3=+3$ ). Mas também poderá ocorrer o inverso, de forma que se uma área com máxima susceptibilidade (valor=3) se tornar insusceptível (valor=0), o salto terá sido de 3 níveis, mas neste caso indicará valor negativo (de 3 a $0=-3$ ).

Com base nos valores delta e nas descrições das mudanças foram identificados cinco grupos, cada qual abrangendo tipos similares de mudanças na susceptibilidade, que foram denominados Tipo de Mudança (Tabela C4.2-1) e agrupam as seguintes características discriminativas: as áreas cujos níveis de susceptibilidade atual não mudarão no futuro; as áreas que no futuro perderão totalmente a susceptibilidade apresentada atualmente; as áreas que terão redução da suscetibilidade atual para níveis mais baixos no futuro; as áreas que terão aumento de susceptibilidade atual para níveis mais elevados no futuro; áreas que são insuscetíveis atualmente e ganharão algum nível de susceptibilidade no futuro.

Por meio da interpretação conjunta de todos estes aspectos qualitativos e quantitativos, foram atribuídos níveis numéricos ordenados conforme a intensidade da mudança sugerida pelos seus significados (Nível de Mudança na Tabela C4.2-1). Por exemplo, o nível 11 (Nível de Mudança na Tabela C4.2-1) possui uma unidade a mais do que o nível 10, pois no futuro a classe 10 será alta susceptibilidade e a 11 será máxima susceptibilidade, ou seja, o salto de um nível de 10 para 11. Já as classes mais altas indicam as mudanças mais drásticas. Por exemplo, a classe 13 indica o acréscimo de apenas um nível de susceptibilidade no futuro, mas neste caso a área parte da inaptidão atual para a espécie (insusceptível) para a aptidão (susceptível), que é uma mudança que foi considerada mais intensa do que a apresentada pelo exemplo anterior (de 10 para 11), em que há apenas o aumento de suscetibilidade em uma área já susceptível. Os quatro primeiros níveis da escala $(0,1,2,3)$ são classes que não mudam no futuro, de forma que seus níveis de susceptibilidade sem mantém como no cenário atual. $\mathrm{O}$ nível 4 pode ser visto como a melhor perspectiva na ótica contrária à invasão, pois indica a perda total de susceptibilidade de uma área no futuro a partir da máxima susceptibilidade atual. No outro extremo da escala, o valor 15 , está a pior perspectiva, ou seja, uma área atualmente insusceptível que se tornará máxima susceptibilidade no futuro.

Em cada tipo de mudança (Ganho, Aumento, Redução, Perda) o nível da mudança foi ordenado conforme o significado de suas designações (Nível de Mudança na Tabela C4.2-1). Desta maneira, as setas em cada agrupamento (exceto "Não muda") indicam o sentido do aumento da intensidade da mudança em cada compartimento quanto ao seu tipo. Por exemplo, no grupo denominado "Perda", a seta aponta do nível 6 para nível 4, indicando o sentido de aumento da perda crescente de susceptibilidade. No caso do grupo "Ganho" a seta aponta o sentido oposto, do nível 13 para o nível 15, indicando o sentido do ganho crescente de susceptibilidade.

Para facilitar a comparação entre cenários (RCP 4,5 e RCP 6,0) e entre áreas focais (quadros e países) quanto aos níveis e os tipos de mudança, o percentil de cobertura espacial de cada nível (de 0 a 15) e cada tipo (5 tipos) foram calculados por meio de histogramas de frequência. Os quadros na Figura C4.2-3 foram extraídos dos mapas e incluídos ao longo do texto para facilitar a visualização das mudanças e a comparações entre cenários. 
Mudanças nos níveis e tipos de susceptibilidade entre cenários temporais

\section{Quadro JP e país Japão}

A extensão abrangida pelo quadro JP (Figura C4.2-4) compreende o Japão e áreas de países próximos separados pelo Mar do Leste. O Japão possui registros de invasão de Bombus terrestris e poderá prover indivíduos para outros países adjacentes ampliando a área de invasão, no entanto, neste caso será necessária a intervenção humana (deliberada ou indeliberadamente), pois a abelha não é capaz de cruzar a extensão marinha que separa o Japão de outros países.

Pode-se observar que acima da ilha norte do Japão (Hokkaido) há uma pequena ilha russa (Sakhalin) separada em cerca de $50 \mathrm{~km}$ de faixa de mar, esta distância é uma barreira para o deslocamento da espécie, e esta faixa de oceano é a menor distância do Japão para outros países. Coincidentemente, estas áreas próximas apresentam máxima susceptibilidade, permitindo sugerir que a zona do extremo leste da Federação Russa poderá ter áreas invadidas pela espécie no futuro, caso uma rainha fecundada seja transportada para lá de forma não intencional por um barco, por exemplo.
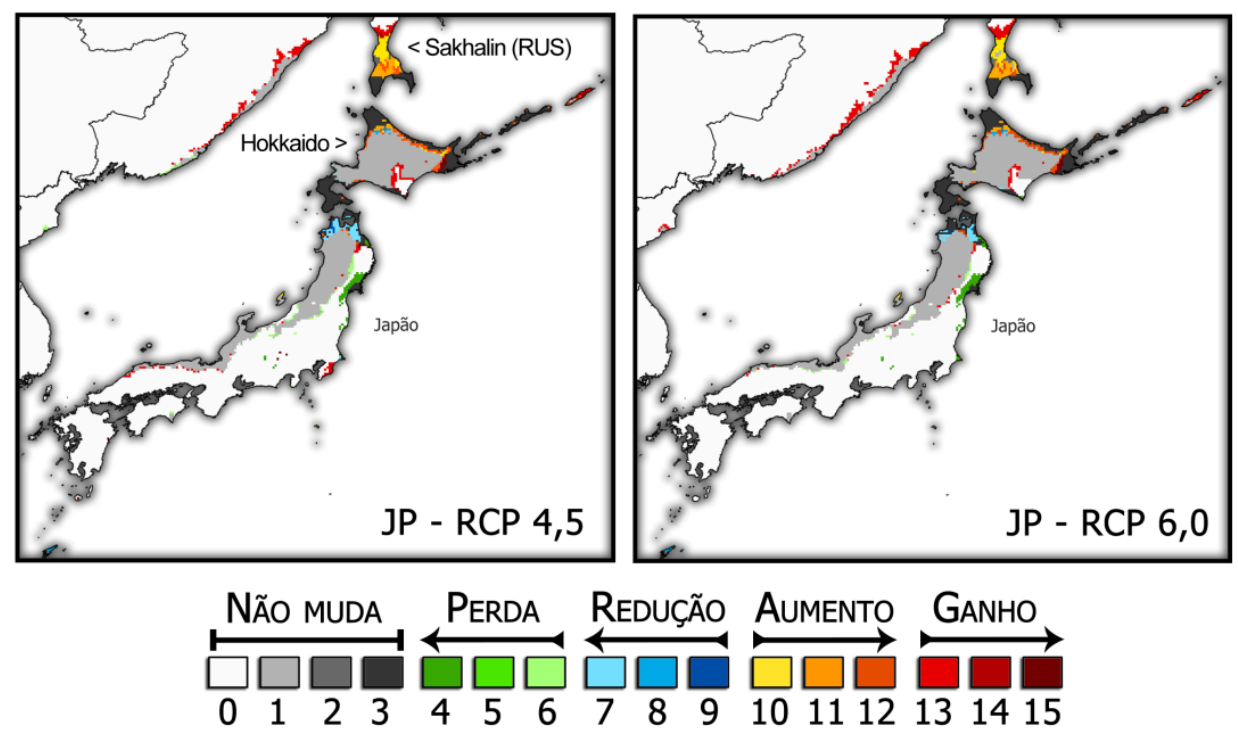

Figura C4.2-4. Área focal JP e o Japão, país com registros de invasão. Consultar a Tabela C4.2-1 para verificar as qualificações e quantificações associadas à sequência numérica de 0 a 15.

No quadro JP (Figura C4.2-4) pode-se perceber visualmente que as mudanças entre o cenário atual e os futuros serão pequenas (níveis de 4 a 15). E quantitativamente (Figura C4.2-5), apenas cerca de 5\% das áreas no JP terão mudanças $^{12}$ de suscetibilidade no futuro em ambos cenários. 0 tipo de mudança que indica ganho de susceptibilidade é o maior dentre as mudanças de susceptibilidade

\footnotetext{
${ }^{12}$ O valor total da mudança não é exibido no gráfico (Figura C4.2-5) e consiste da soma dos percentuais de todos os tipos de mudanças exceto o tipo "Não Muda". Este valor indica o percentual total de área de terra seca que terá algum tipo de mudança no nível de susceptibilidade do cenário atual para o futuro.
} 
que ocorrerão, em torno de 1,8\% e $1.9 \%$ nos cenários RCP 4,5 e 6,0, respectivamente. Dentre as mudanças de susceptibilidade, ressalta-se a conversão de $2 \%$ daquelas áreas atualmente insusceptíveis para susceptíveis (nível 13; Figura C4.2-6) e 1\% das áreas atualmente susceptíveis que se tornarão máxima susceptibilidade (nível 12; Figura C4.2-6).

$\mathrm{Na}$ abrangência da área que não terá mudanças no futuro, permanecerá predominando a insusceptibilidade, com 78\% (nível 0; Figura C4.2-6). Portanto, 22\% do JP permanecerá com algum nível de susceptibilidade no futuro, neste percentual o nível susceptível (nível 1) permanecerá cobrindo em torno de 12\%, e em seguida a máxima susceptibilidade, que permanecerá cobrindo 5\% (nível 3).

Percentil dos tipos de mudanças por cenário futuro - JP

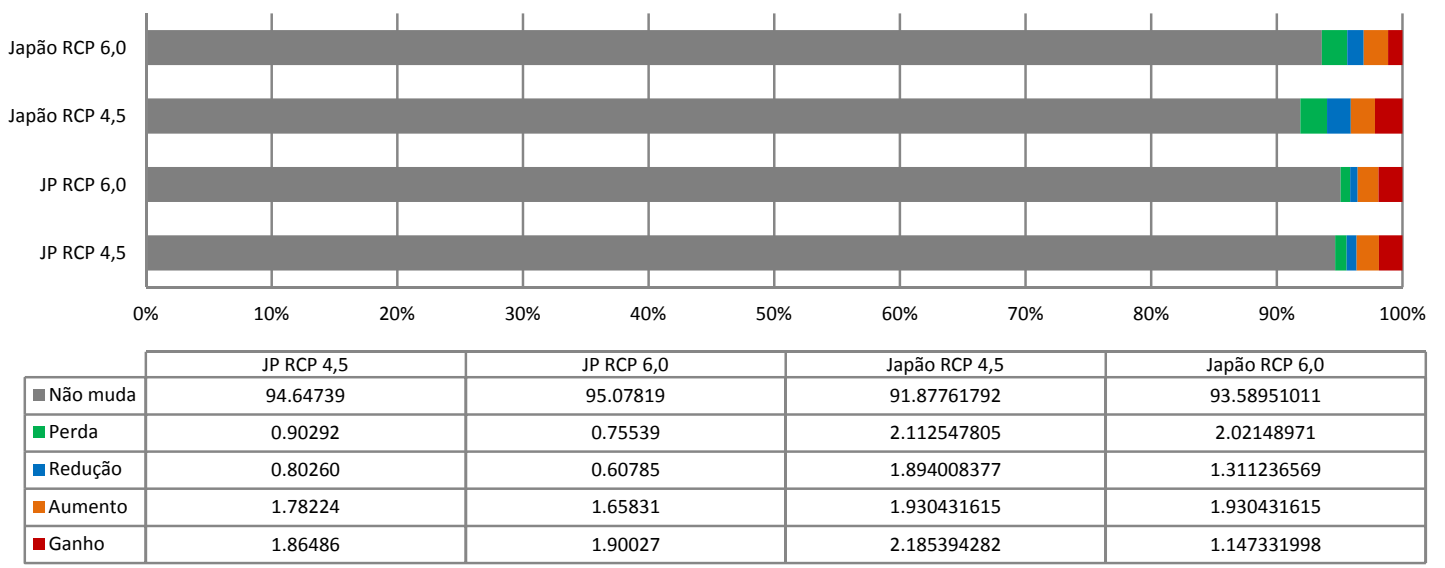

Figura C4.2-5. Percentil de cobertura dos cinco tipos de mudança da susceptibilidade na área focal JP. Consultar a Tabela C4.2-1 para verificar as qualificações e quantificações associadas à aos cinco tipos de mudanças.

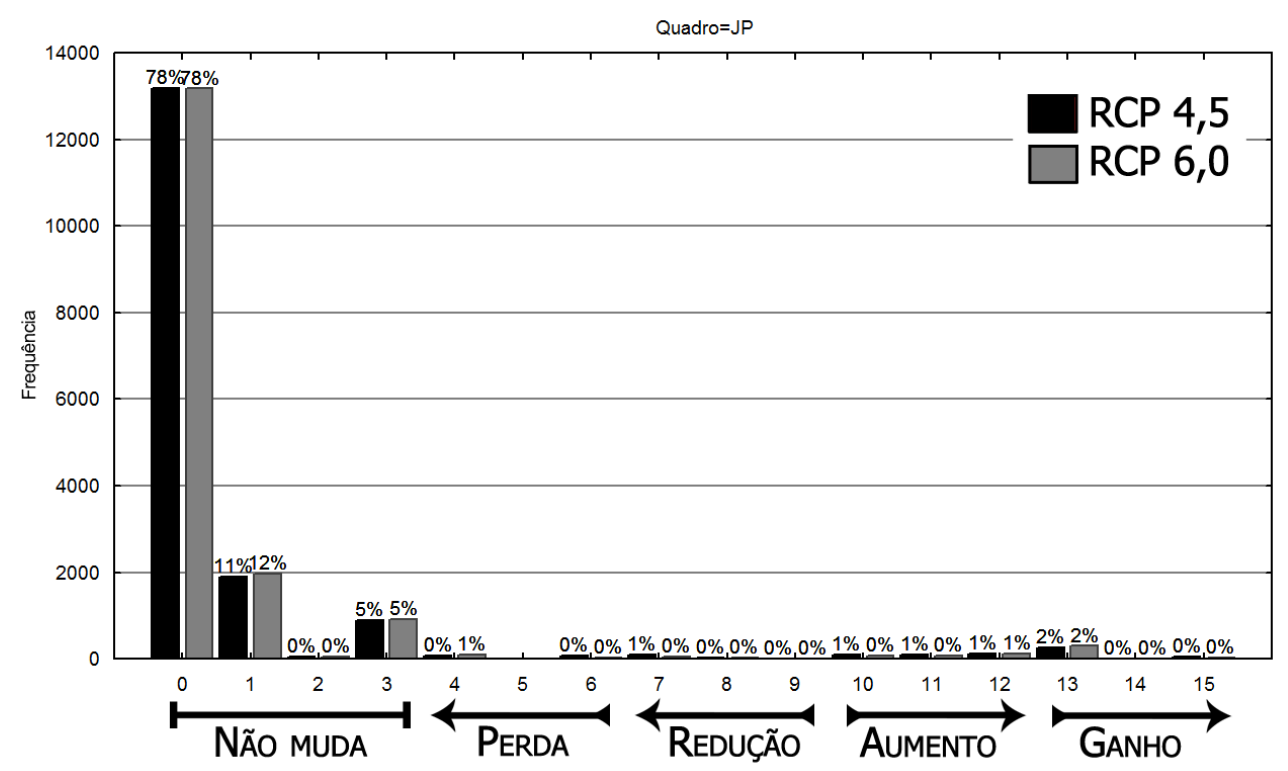

Figura C4.2-6. Percentil de cobertura de cada nível de mudança da susceptibilidade na área focal JP. Consulte a Tabela C4.2-1 para verificar as qualificações e quantificações associadas à sequência numérica do eixo $X$. 
$\mathrm{Na}$ área compreendida pelo país Japão (Figura C4.2-4) haverá uma mudança relativamente maior do que a mudança em toda a área abrangida pelo quadro JP, onde cerca de $8 \%$ de sua cobertura sofrerá mudanças de suscetibilidade no cenário RCP 4,5 e 6,4\% no cenário RCP 6,0 (Figura C4.2-5). O tipo de mudança mais elevada no cenário RCP 4,5 será o ganho de susceptibilidade, com 2,2\%, seguido pela perda de susceptibilidade, com $2,1 \%{ }^{13}$ (Figura C4.2-5). Já no cenário RCP 6,0, o tipo de mudança mais elevada é a perda de susceptibilidade, com $2 \%$, e em seguida o aumento de susceptibilidade, com 1,9\% (Figura C4.2-5).

No Japão a área abrangida pelo nível insusceptível permanecerá cobrindo um pouco mais da metade deste país no futuro (nível 0; Figura C4.2-7), o que é especialmente evidente no sudeste da ilha sul (cor branca, Figura C4.2-4). Também, as áreas que apresentam o nível susceptível (nível 1; Figura C4.2-7) permanecerão cobrindo cerca de $30 \%$, e a máxima susceptibilidade (nível 3) permanecerá cobrindo cerca de $8 \%$ do país em ambos os cenários.

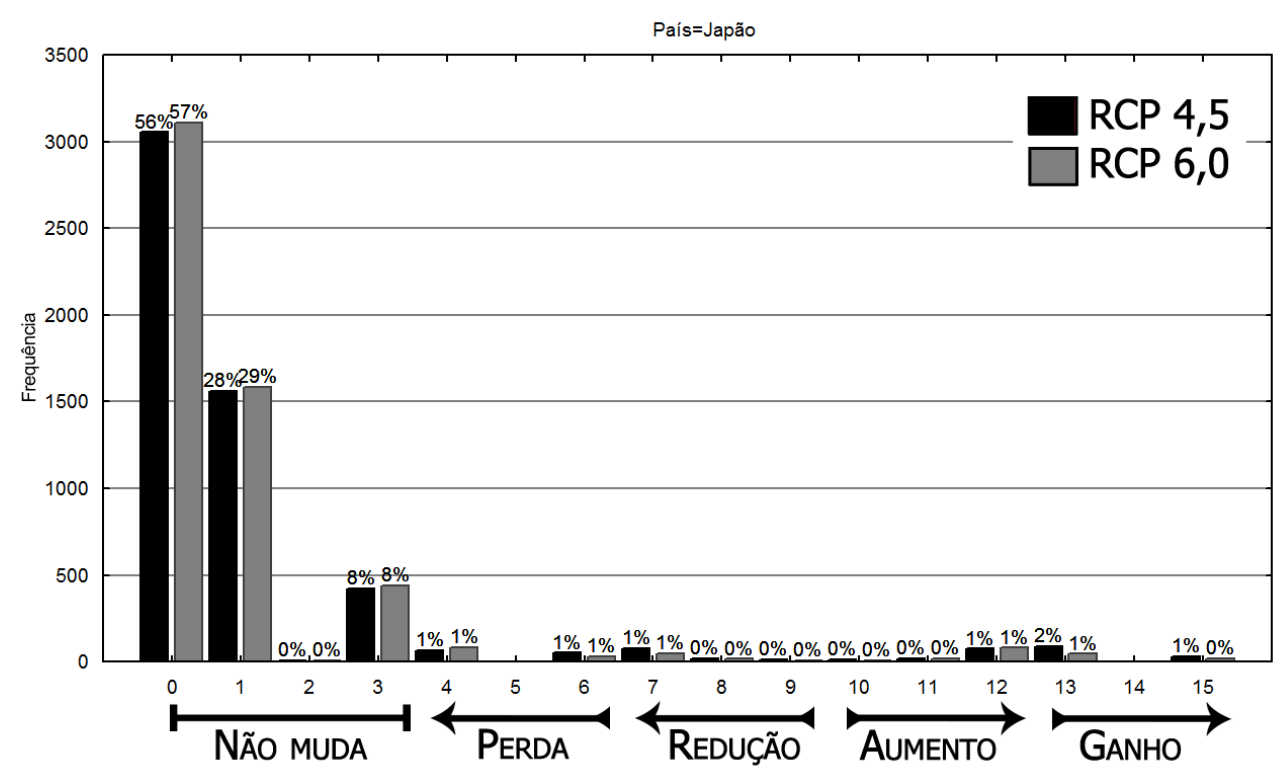

Figura C4.2-7. Percentil de cobertura de cada nível de mudança da susceptibilidade no país Japão. Consulte a Tabela C4.2-1 para verificar as qualificações e quantificações associadas à sequência numérica do eixo $X$.

\section{Quadro SA e seus países: Argentina, Chile, Uruguai e Brasil}

A extensão abrangida pelo quadro SA (Figura C4.2-8) compreende áreas do Chile e da Argentina, países que possuem registros de invasão de Bombus terrestris, mas também abrange outros países sul-americanos de notável importância para esta pesquisa: o Brasil e o Uruguai, os quais possuem áreas susceptíveis conectadas com locais já invadidos no Chile e na Argentina. Parte do Paraguai também é abrangida pela SA, mas este país não foi considerado devido ao isolamento de suas áreas susceptíveis.

Pela observação dos quadros (Figura C4.2-8) é possível identificar a extensa faixa litorânea com vários níveis de suscetibilidade ligando estes quatro países, bem como a grande área susceptível no extremo sul do continente. Haverá, em ambos

\footnotetext{
${ }^{13}$ O ganho de susceptibilidade não compensa a perda de susceptibilidade e vice-versa, pois não ocorrem no mesmo espaço.
} 
cenários futuros, alguma perda de susceptibilidade em faixas adjacentes ao longo de sua extensão (tons verdes). Na faixa mais estreita de susceptibilidade no litoral da Argentina (Bahía Blanca) permanecerá uma disjunção de cerca de $100 \mathrm{~km}$ de comprimento (verificado em Google Earth; Google Inc., 2015) na faixa de suscetibilidade desde o cenário atual até o cenário RCP 4,5 (evidenciado na Figura C4.2-8 SA-RCP 4,5), mas no cenário RCP 6,0 haverá aumento e ganho de suscetibilidade, levando ao aumentando da conectividade.

No Brasil (Figura C4.2-8), em ambos cenários, haverá redução da susceptibilidade em áreas (tons azuis) cuja zona central passa pelo litoral e as extremidades adentram no interior do país. Também haverá a perda de susceptibilidade (tons verdes) em zonas mais ocidentais da faixa de susceptibilidade, todavia, também haverá aumentos (faixa amarela) e ganhos (área vermelha) de susceptibilidade em áreas próximas das faixas de perda, que no geral ampliam a cobertura da área susceptível à invasão.
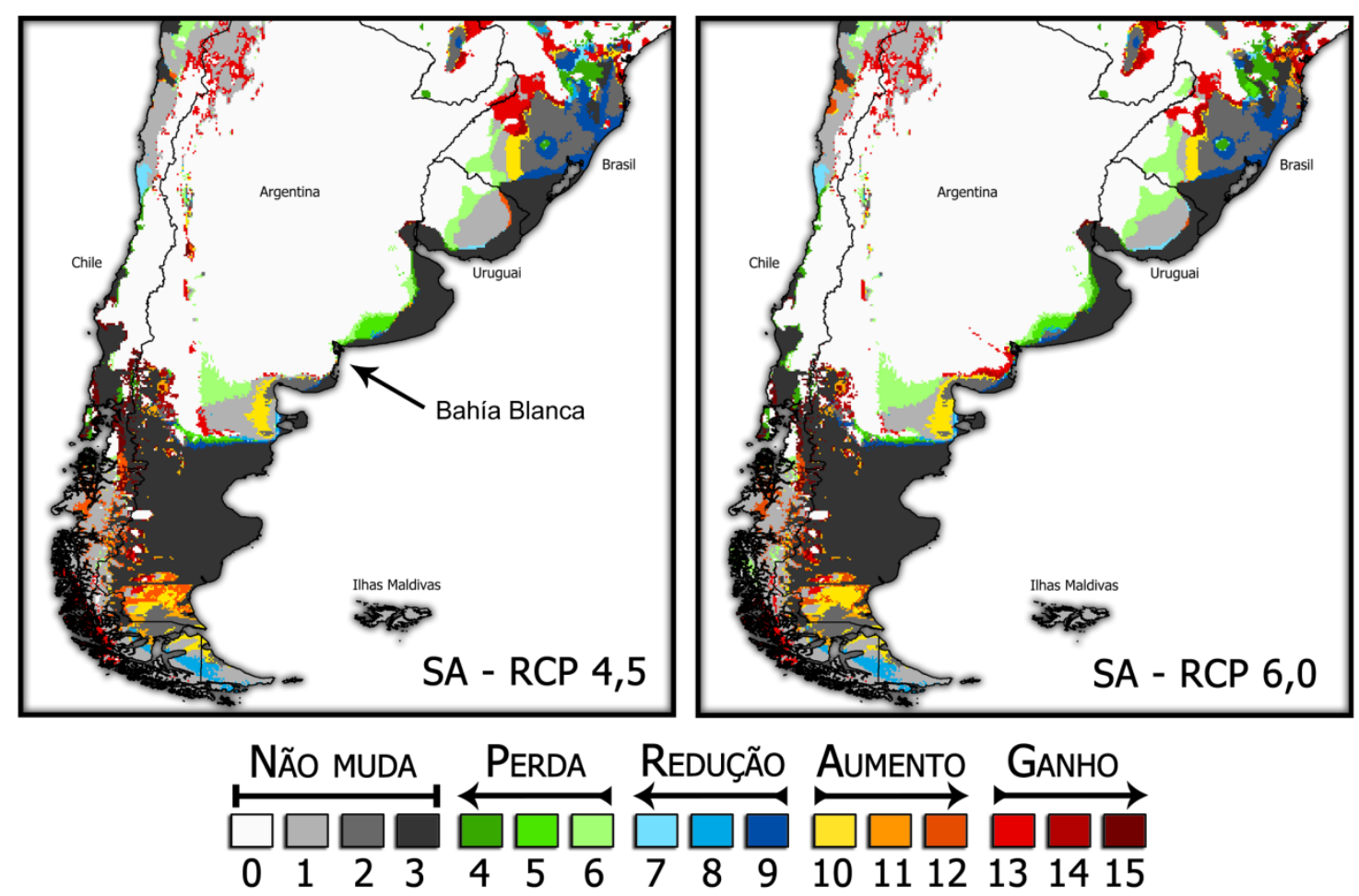

Figura C4.2-8. Área focal SA abrangendo parte dos países com registros de invasão: Chile e Argentina; e parte dos países sob risco de invasão devido à proximidade: Brasil e Uruguai. Consulte a Tabela C4.2-1 para verificar as qualificações e quantificações associadas à sequência numérica de 0 a 15.

As mudanças de susceptibilidade na SA serão relativamente pequenas, mas maiores do que no JP; já em termos absolutos, a mudança na SA é extremamente maior que no JP. Em torno de $84 \%$ da cobertura da SA permanecerá com os mesmos níveis atualmente apresentados (tipo "Não Muda" na Figura C4.2-9). Nesta abrangência espacial, cerca de metade da área (54\%) permanecerá insusceptível (nível 0, Figura C4.2-10) e aproximadamente um terço ( 31\%) permanecerá com algum nível de susceptibilidade (níveis 1+2+3; Figura C4.2-10). Nesta área susceptível, em torno de $10 \%$ permanecerá coberta pelo nível susceptível (nível 1) e $16 \%$ coberta pela a máxima 
susceptibilidade (nível 3, Figura C4.2-10). Notavelmente (Figura C4.2-8), ambos níveis juntos (1 e 3) predominam sobre a longa faixa litorânea susceptível no sudeste Argentino e na ampla área susceptível do extremo sul da América do Sul, evidenciando a importancia desta faixa para este estudo, que potencialmente será um condutor de invasão de Bombus terrestris do sul para sentido norte, permitindo a invasão alcançar o Brasil.

Percentil dos tipos de mudanças por cenário futuro - SA

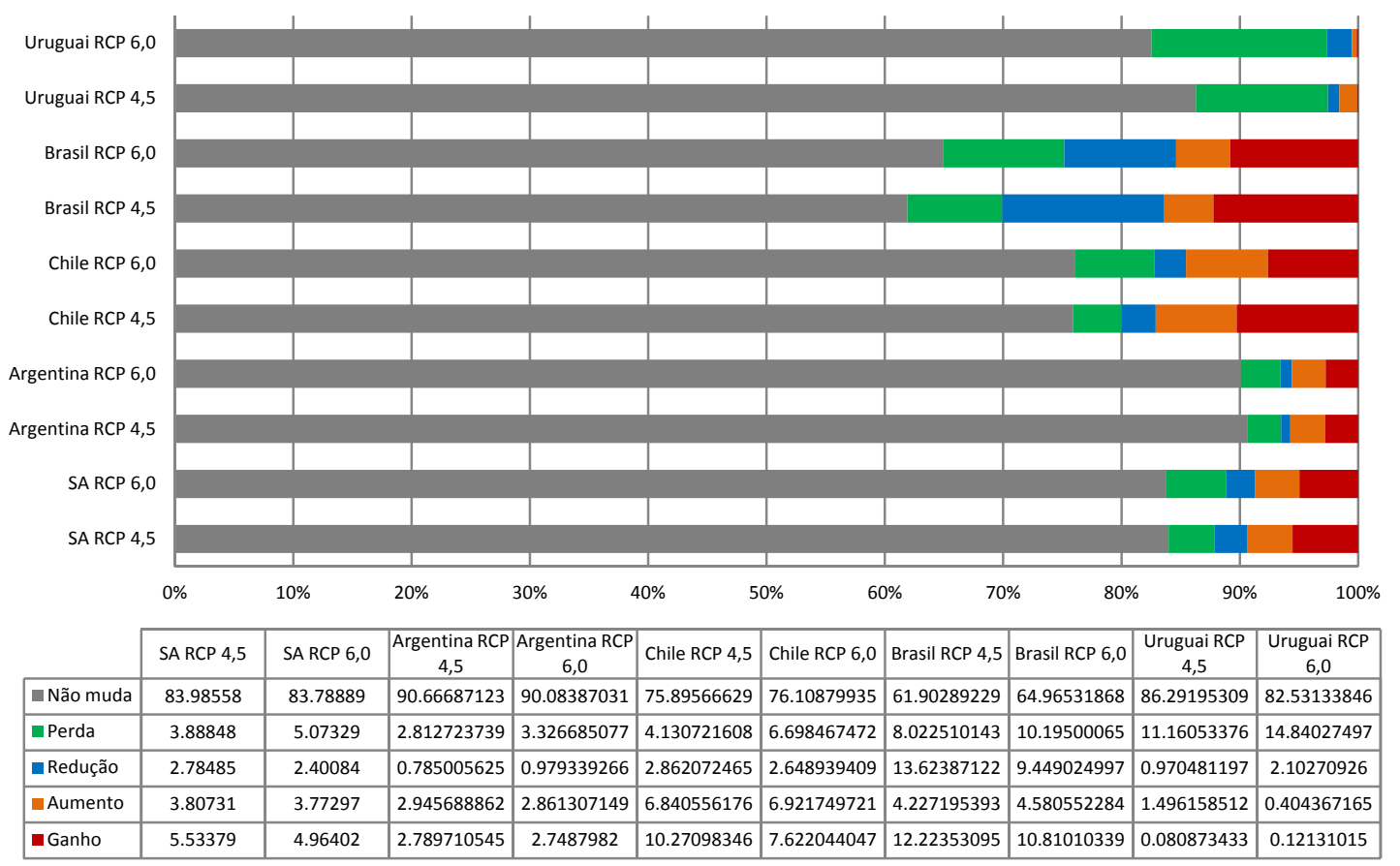

Figura C4.2-9. Percentil de cobertura dos cinco tipos de mudança da susceptibilidade na área focal SA. Consulte a Tabela C4.2-1 para verificar as qualificações e quantificações associadas à aos cinco tipos de mudanças.

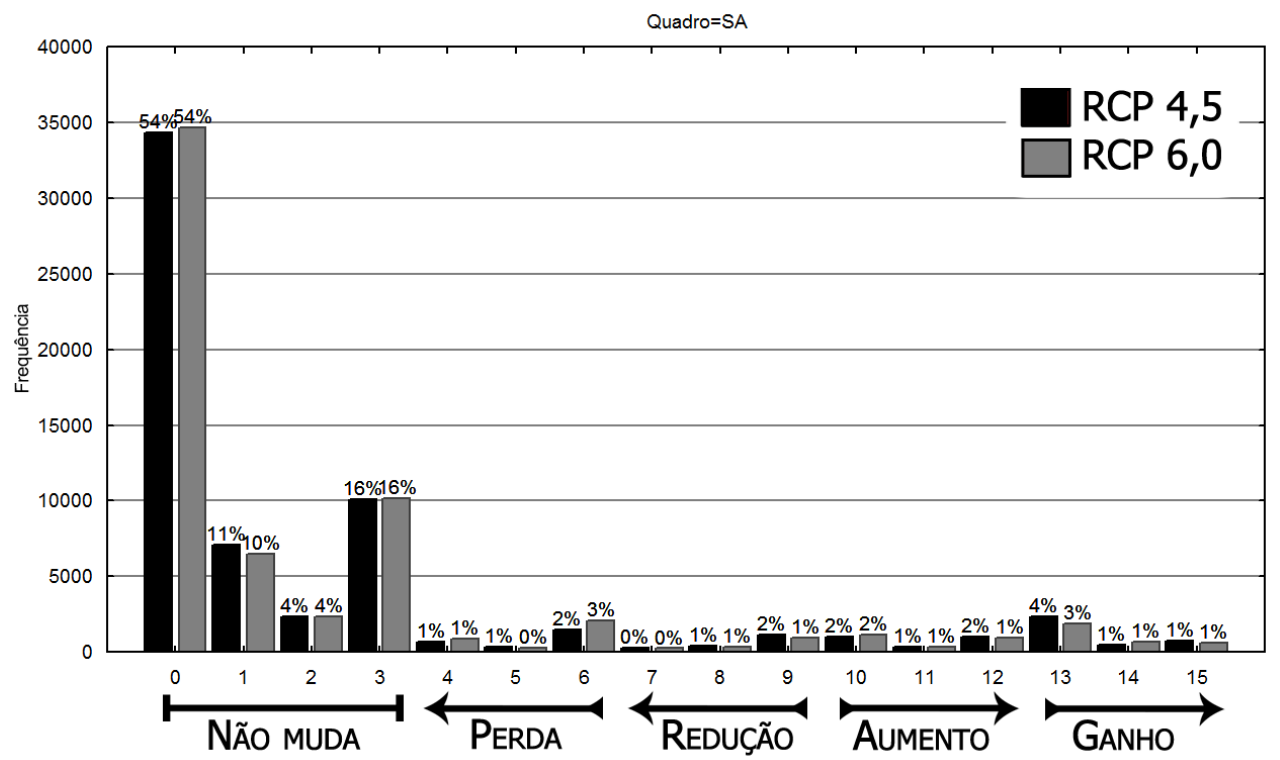

Figura C4.2-10. Percentil de cobertura de cada nível de mudança da susceptibilidade na área focal SA. Consulte a Tabela C4.2-1 para verificar as qualificações e quantificações associadas à sequência numérica do eixo $X$. 
$\mathrm{Na}$ Argentina as mudanças na susceptibilidade serão as mais baixas relativamente às outras áreas sul-americanas, com apenas 9,3\% no RCP 4,5 e 9,9\% no RCP 6,0 (Figura C4.2-9). Dentre as mudanças que ocorrerão, as mais altas compreendem cerca de $2 \%$ das áreas susceptíveis que se tornarão insusceptíveis (nível 6 na Figura (4.2-11) e também 2\% delas se tornarão susceptíveis a partir de área insusceptíveis em ambos os cenários (nível 13 na Figura C4.2-11). Nas áreas que permanecerão com os mesmos níveis no futuro há o predomínio de cobertura da insusceptibilidade, com $68 \%$ (nível 0 na Figura C4.2-11), em seguida, pela máxima susceptibilidade com $17 \%$ (nível 3) em ambos os cenários futuros.

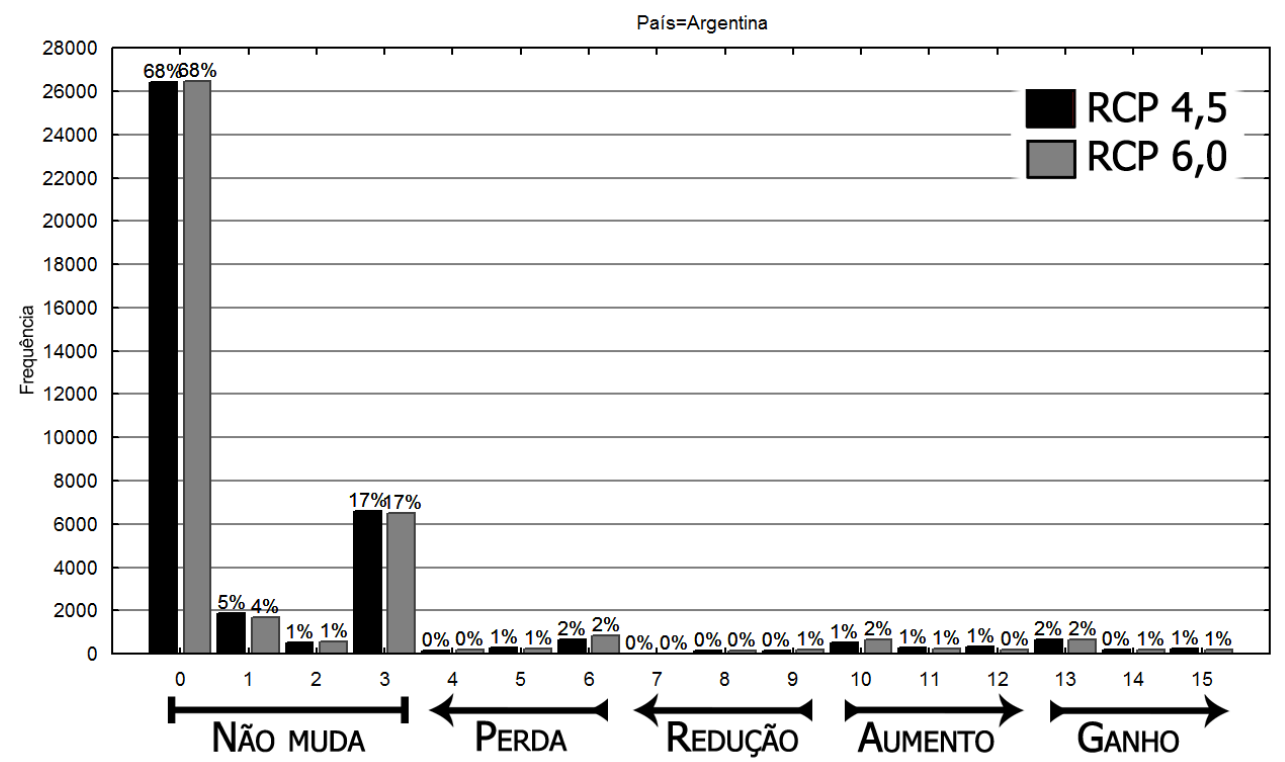

Figura C4.2-11. Percentil de cobertura de cada nível de mudança da susceptibilidade no país Argentina. Consulte a Tabela C4.2-1 para verificar as qualificações e quantificações associadas à sequência numérica do eixo $X$.

No Uruguai há razoável diferença entre os dois cenários quanto às mudanças dos níveis de susceptibilidade. As mudanças ocorrerão em $12,7 \%$ da área do país no cenário RCP 4,5 e 17,4\% no RCP 6,0 (Figura C4.2-9). No entanto, em ambos os cenários as mudanças serão predominantemente de perda de susceptibilidade (tons verdes; Figura C4.2-9 e (4.2-8), representando o encolhimento de $11 \%$ e $14 \%$ da área susceptível (nível 6 na Figura C4.2-12) neste país em cada cenário, respectivamente (RCP 4,5 e 6,0). Na maior parte da área do Uruguai, em torno de $85 \%$ em ambos cenários (Figura C4.2-9), não haverá mudanças nos níveis de susceptibilidade no futuro, o que significa que o país permanecerá com cerca da metade de toda a sua extensão territorial susceptível à invasão (nível $1+3$ na Figura C4.2-12), e um pouco mais de um terço do país (36\%) permanecerá insusceptível (nível 0 na Figura C4.2-12).

O sul do Brasil, na abrangência da área focal (Figura C4.2-8), apresentará as maiores mudanças dos níveis de susceptibilidade no futuro dentre todas as áreas sulamericanas. A susceptibilidade mudará em $38 \%$ da extensão do país no cenário RCP 4,5 e $35 \%$ no RCP 6,0 (Figura C4.2-9). Em torno de 12\% (RCP 4,5) e 10\% (RCP 6,0) da abrangência territorial brasileira atualmente insusceptível se tornará susceptível (Figura C4.2-9) e cerca de $4 \%$ das áreas atualmente susceptíveis terão aumento do nível de susceptibilidade no futuro. No entanto, também haverá a perda de 8,0 e 10,2 
$\%$ (RCP 4,5 e 6,0) da susceptibilidade e a redução de seus níveis em 13,6 e 9,4\% (RCP $4,5$ e 6,0$)$. No restante da área do país, em torno de $62 \%$ no RCP 4,5 e $65 \%$ no RCP 6,0 os níveis atuais de susceptibilidade permanecerão no futuro ("Não Muda" na Figura C4.2-9). Nesta abrangência, em torno de 30\% permanecerá coberto por áreas insusceptíveis (nível 0 na Figura C4.2-13), cerca de $18 \%$ por áreas com alta susceptibilidade (nível 2) e 10\% (RCP 4,5) e 13\% (RCP 6,0) permanecerá com máxima susceptibilidade (nível 3 na Figura C4.2-13).

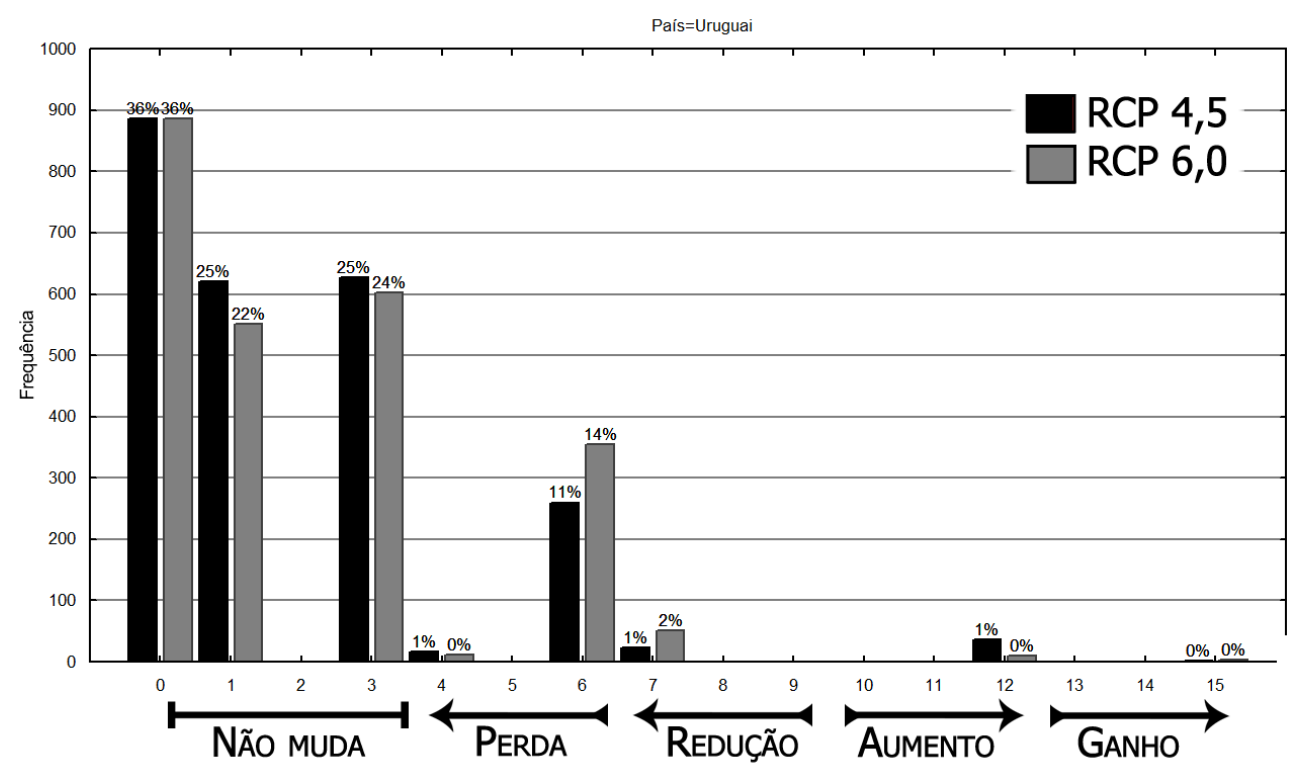

Figura C4.2-12. Percentil de cobertura de cada nível de mudança da susceptibilidade no país Uruguai. Consulte a Tabela C4.2-1 para verificar as qualificações e quantificações associadas à sequência numérica do eixo $X$.

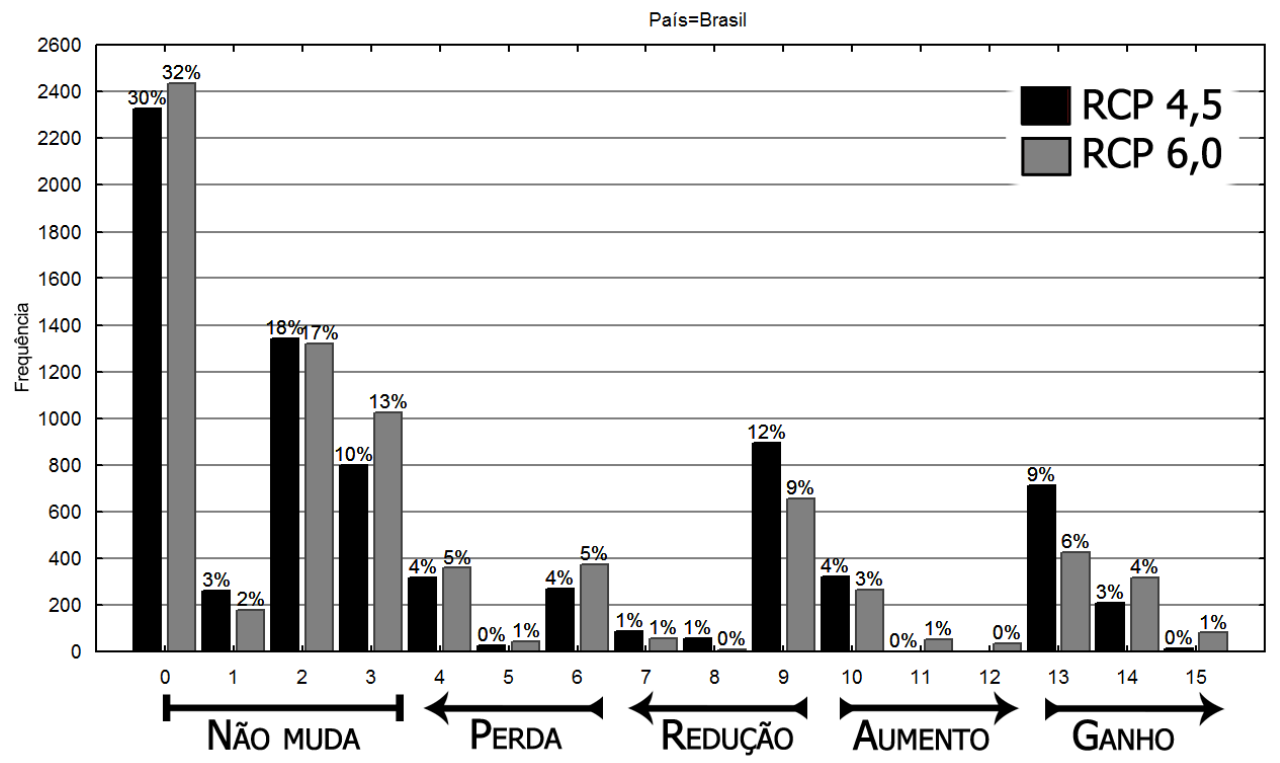

Figura C4.2-13. Percentil de cobertura de cada nível de mudança da susceptibilidade no país Brasil. Consulte a Tabela C4.2-1 para verificar as qualificações e quantificações associadas à sequência numérica do eixo $X$. 
O Chile é o segundo país com os maiores percentuais de mudanças nos níveis de susceptibilidade dentre as áreas da SA (Figura C4.2-9), em torno de $24 \%$ em ambos cenários futuros. Dentre as mudanças mais marcadas, está a conversão de $6 \%$ e $5 \%$ (RCP 4,5 e 6,0) para áreas susceptíveis partir de áreas atualmente insusceptíveis (nível 13 na Figura (4.2-14) e o aumento do nível de susceptibilidade para a máxima susceptibilidade em torno de 5\% em ambos os cenários (nível 12 na Figura C4.2-14).

Nas áreas que permanecerão com os mesmos níveis de susceptibilidade no futuro (níveis 0 a 3 na Figura C4.2-14), o cenário RCP 4,5 indica que a maior cobertura permanecerá como áreas susceptíveis (nível 1), com 31\%, depois como áreas insusceptíveis (nível 0), com $28 \%$, e em terceiro lugar com áreas cobertas por máxima susceptibilidade (nível 3), com 15\%. No cenário RCP 6,0 as áreas insusceptíveis serão um pouco maiores que o cenário anterior, cobrindo $30 \%$ do país (nível 0 na Figura C4.2-14), as áreas susceptíveis (nível 1) permanecerão cobrindo 29\%, e em terceiro lugar a máxima susceptibilidade (nível 3), com 14\%.

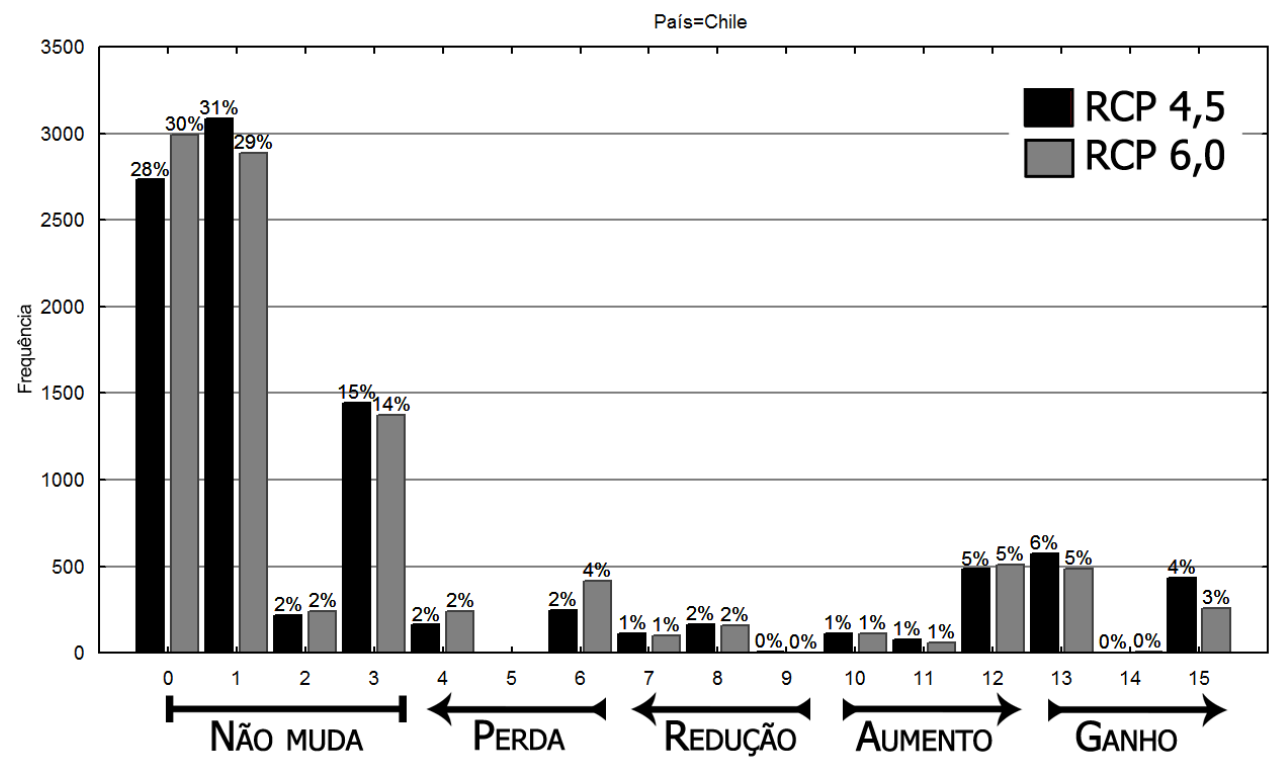

Figura C4.2-14. Percentil de cobertura de cada nível de mudança da susceptibilidade no país Chile. Consulte a Tabela C4.2-1 para verificar as qualificações e quantificações associadas à sequência numérica do eixo $X$.

\section{Quadro NZT e países Austrália (incluindo Tasmânia) e Nova Zelândia}

A extensão abrangida pelo NZT (Figura C4.2-8) compreende o sudeste da Austrália continental, a Tasmânia (administrada pela Austrália como um estado) e a Nova Zelândia. A Tasmânia e a Nova Zelândia possuem registros de invasão de Bombus terrestris, mas na Austrália continental (citada doravante apenas como Austrália) ainda não há registros de sua presença.

Pela observação dos quadros (Figura C4.2-15) é possível perceber as grandes extensões de áreas susceptíveis em todas estas ilhas: onde altos níveis de susceptibilidade predominam em praticamente toda a Tasmânia e Nova Zelândia, e uma grande faixa de máxima susceptibilidade pode ser verificada no sudeste da Austrália, área próxima à Tasmânia, que é uma ilha extensivamente invadida. 
As mudanças mais intensas e com maiores dimensões nos níveis de suscetibilidade no futuro ocorrerão na Austrália. Pode-se ver, especialmente no cenário RCP 6,0, uma grande área onde haverá ganho de susceptibilidade (níveis 13 a 15 na Figura C4.2-15) margeada por uma borda de aumento de susceptibilidade (níveis 10 a 12) adjacentes a uma área de alta susceptibilidade (nível 2). Mas também há zonas que terão a redução de susceptibilidade, especialmente no cenário RCP 4,5. Na Nova Zelândia há uma estreita faixa central ao longo do comprimento das ilhas indicando grande variedade de mudanças. Esta faixa cobre quase que precisamente as áreas mais montanhosas e com alta altitude destas duas ilhas. Na Tasmânia, as poucas mudanças também estão relacionadas às zonas montanhosas a oeste desta ilha.

Embora ainda não haja relatos de invasão na Austrália, a existência de tráfego de pessoas e produtos entre a Tasmânia e o continente australiano poderá desencadear a invasão em um futuro próximo. Tendo em vista a grande dimensão de áreas susceptíveis na Austrália, pode-se sugerir que e espécie encontraria condições ambientais muito similares àquelas que Ihe permitiu ocupar praticamente toda a Tasmânia.
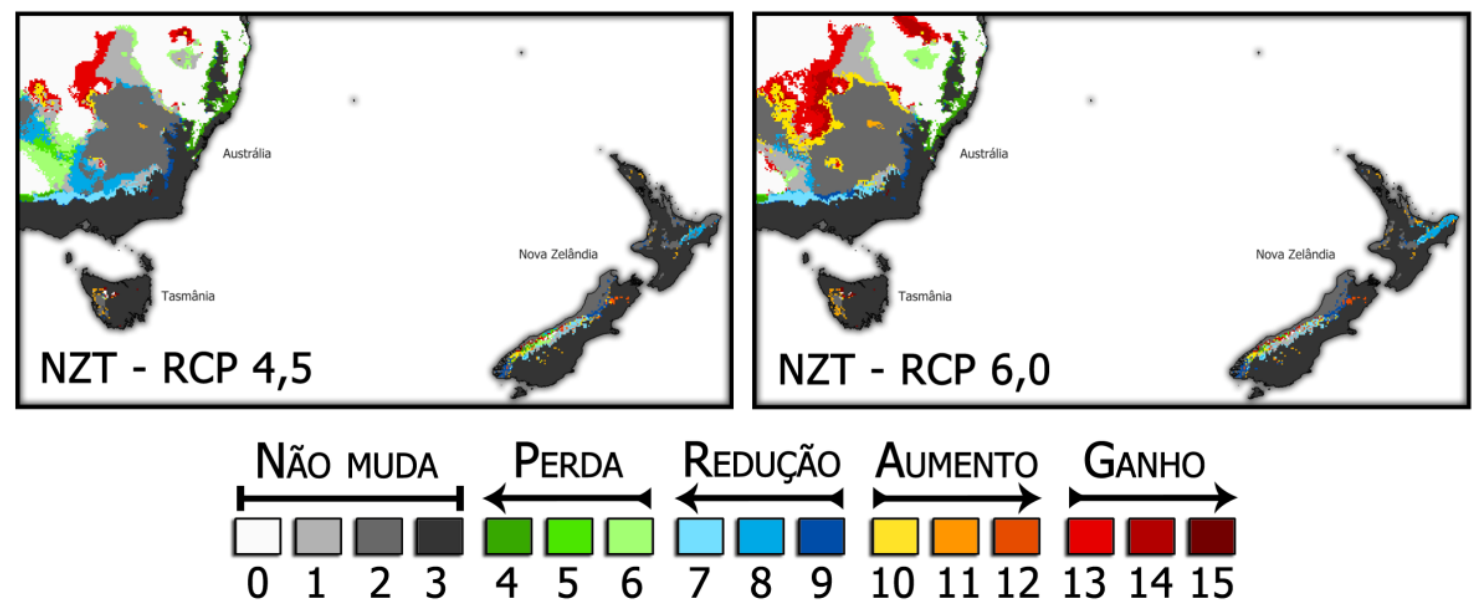

Figura C4.2-15. Área focal NZT abrangendo as áreas com registros de invasão: Tasmânia e Nova Zelândia; e parte sudeste da Austrália continental que está sob risco de invasão devido à proximidade com estes locais invadidos. Consulte a Tabela C4.2-1 para verificar as qualificações e quantificações associadas à sequência numérica de 0 a 15.

As mudanças de susceptibilidade na NZT variam bastante entre cenários RCP. No cenário RCP 4,5, a perda, com 7\%, e a redução de susceptibilidade, com 6,5\%, serão mais intensas do que o ganho, com $3,6 \%$, e o aumento de susceptibilidade, com apenas 1.3\%, (Figura C4.2-16). No entanto, no cenário RCP 6,0 haverá a inversão destes níveis de mudança, sendo o ganho, com 8,1\% e o aumento de susceptibilidade, com $4.51 \%$, serão mais intensos do que a perda, com 4,5\%, e a redução de susceptibilidade, com 3.6 \%. Mas a dimensão total da área coberta por mudanças de susceptibilidade são similares entre cenários, em ambos com cerca de $20 \%$.

A área que não terá mudanças de susceptibilidade no futuro (níveis de 0 a 3 na Figura C4.2-17) permanecerá coberta em 33\% por máxima susceptibilidade (nível 3) em ambos cenários, em segundo lugar por áreas insusceptíveis (nível 0), com $27 \%$ e $23 \%$ (RCP 4,5 e 6,0), e a terceira maior dimensão permanecerá com áreas de alta susceptibilidade (nível 2), com 15\% e 18\% (RCP 4,5 e 6,0). 
Percentil dos grupos de mudanças por cenário futuro - NZT

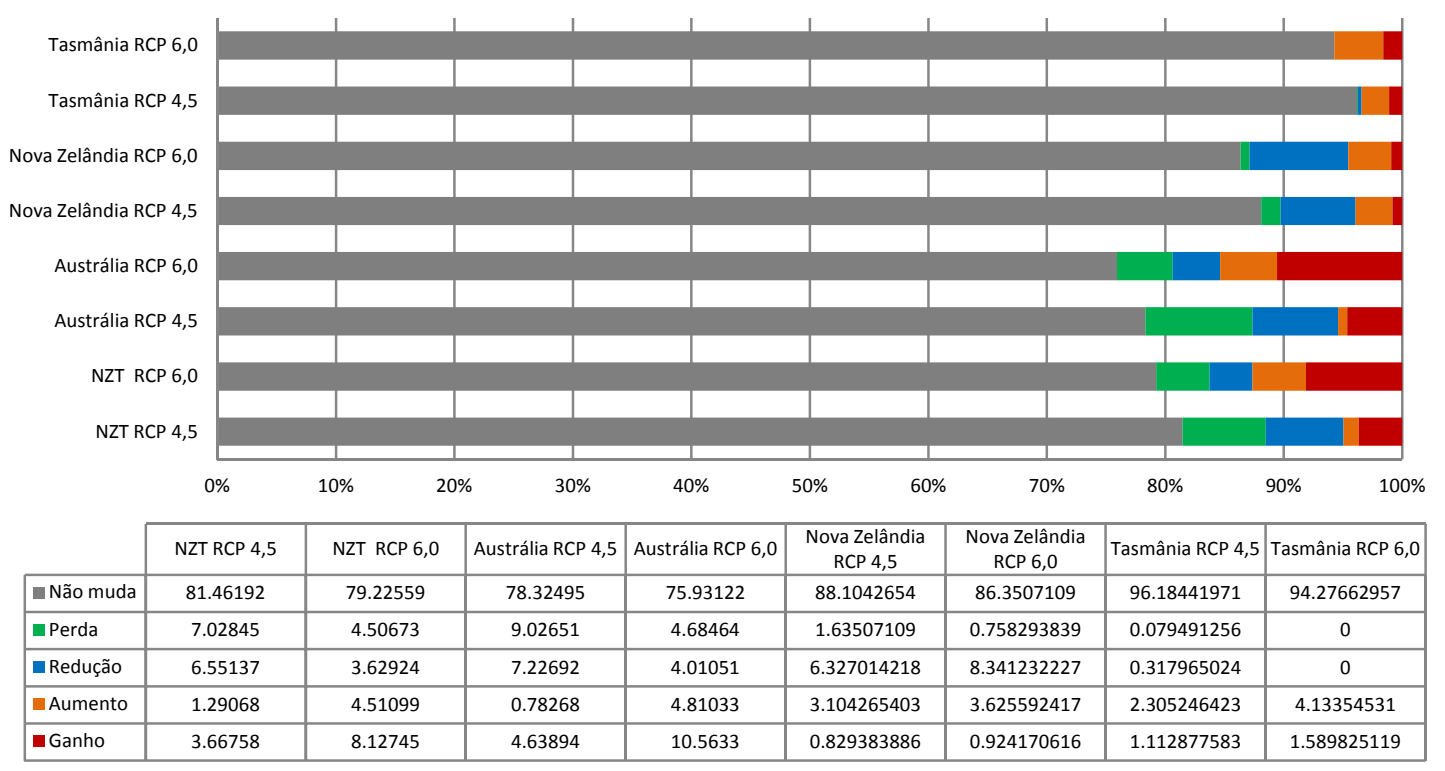

Figura C4.2-16 - Percentil de cobertura dos cinco tipos de mudança da susceptibilidade na área focal NZT. Consulte a Tabela C4.2-1 para verificar as qualificações e quantificações associadas à aos cinco tipos de mudanças.

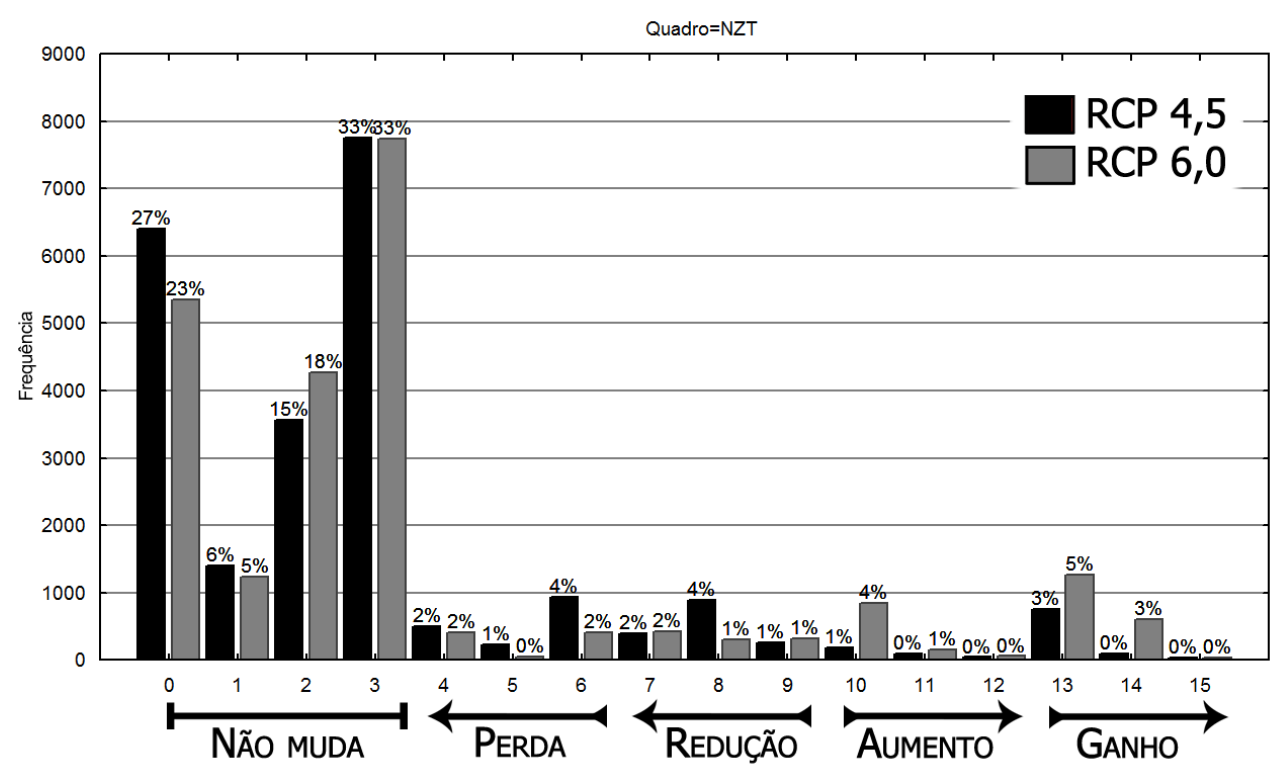

Figura C4.2-17. Percentil de cobertura de cada nível de mudança da susceptibilidade na área focal NZT. Consulte a Tabela C4.2-1 para verificar as qualificações e quantificações associadas à sequência numérica do eixo $X$.

Na Austrália as mudanças de susceptibilidade serão as mais altas dentre todas as áreas no NZT, as quais também variam bastante entre cenários. No cenário RCP 4,5, haverá mudanças em cerca de $21 \%$ da área do país (Figura C4.2-16), sendo que a perda de susceptibilidade, em $9 \%$, será a maior dentre as mudanças, e é seguida pela redução de susceptibilidade, com 7,2\%. No RCP 6,0 haverá mudanças de susceptibilidade em $24,1 \%$ da área do país, sendo que a maior mudança será o ganho 
de susceptibilidade (Figura C4.2-16), com o acréscimo de 10,5\% de cobertura a partir de áreas atualmente insusceptíveis, mas também haverá o aumento da susceptibilidade em $4,8 \%$ no futuro.

Nas áreas em que não haverá mudanças de susceptibilidade no futuro, 36\% (RCP 4,5) e 31\% (RCP 6,0) permanecerão cobertas por insusceptibilidade (nível 0 na Figura C4.2-18), em seguida por $15 \%$ (RCP 4,5) e 20\% (RCP 6,0) com alta susceptibilidade (nível 2) e, em terceiro, 19\% da área permanecerá com máxima susceptibilidade em ambos os cenários (nível 3).

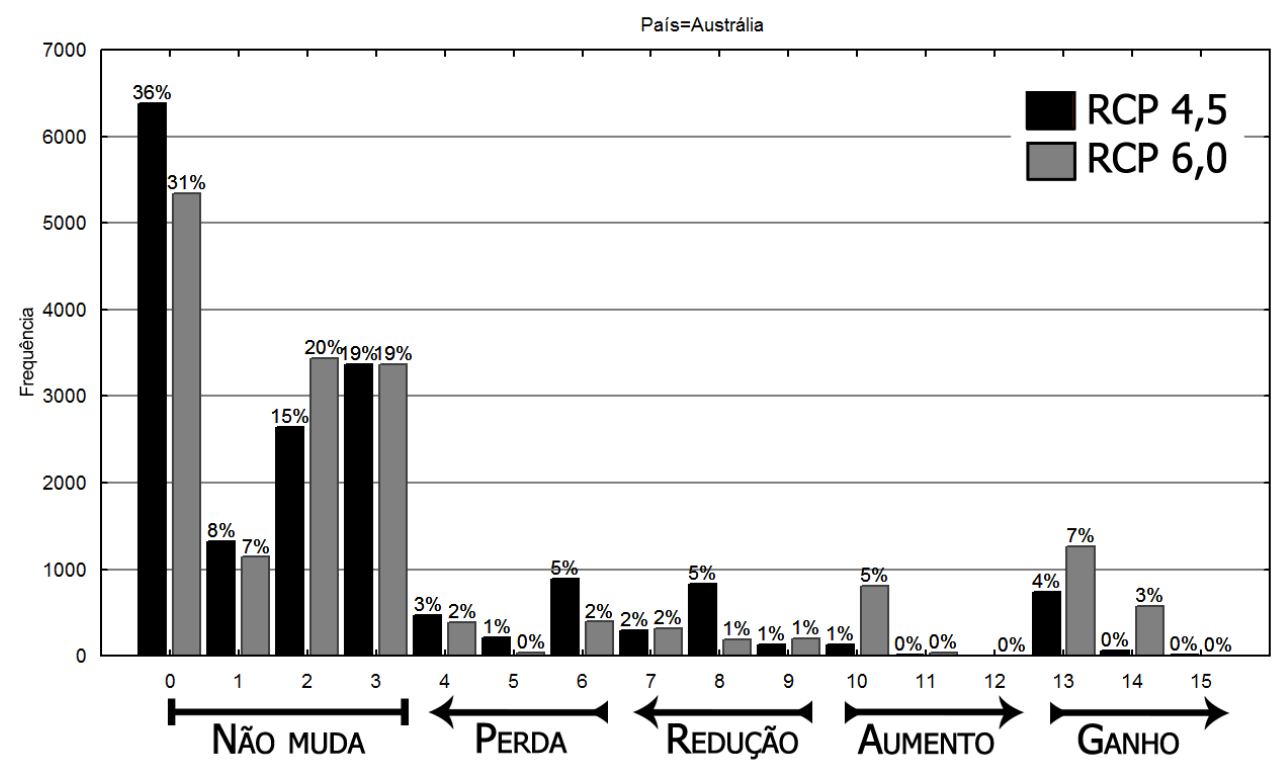

Figura C4.2-18. Percentil de cobertura de cada nível de mudança da susceptibilidade no país Austrália. Consulte a Tabela C4.2-1 para verificar as qualificações e quantificações associadas à sequência numérica do eixo $\mathrm{X}$.

$\mathrm{Na}$ pequena ilha da Tasmânia as mudanças de susceptibilidade serão as menores dentre todas as áreas de todos os quadros (Figura C4.2-16). O cenário RCP 4,5 indica que haverá mudanças em apenas cerca de $4 \%$ da área desta ilha e o RCP 6,0 em apenas cerca de $6 \%$ (Figura C4.2-16). Nestas áreas em que a susceptibilidade mudará, a maior representação é a do aumento em $2,3 \%$ e $4,1 \%$ (RCP 4,5 e 6,0) e ganho de susceptibilidade em 1,1\% e 1,5\% (RCP 4,5 e 6,0; Figura C4.2-16). Sendo que nas áreas que terão aumento de susceptibilidade haverá, principalmente, a conversão da alta para máxima susceptibilidade no RCP 4,5 em 2\% da área, e no RCP 6,0 em 4\% (nível 11 na Figura C4.2-19). A perda e a redução da susceptibilidade serão ínfimas em ambos cenários, sendo que no RCP 4,5 ocorrerá em menos de $1 \%$ da área e no RCP 6,0 serão inexistentes (Figura C4.2-16). Dentre as áreas sem mudanças (níveis 0 a 3 na Figura C4.2-19), cerca de $90 \%$ da ilha permanecerá coberta por máxima susceptibilidade e apenas $5 \%$ e $3 \%$ (RCP 4,5 e 6,0) com alta susceptibilidade. 


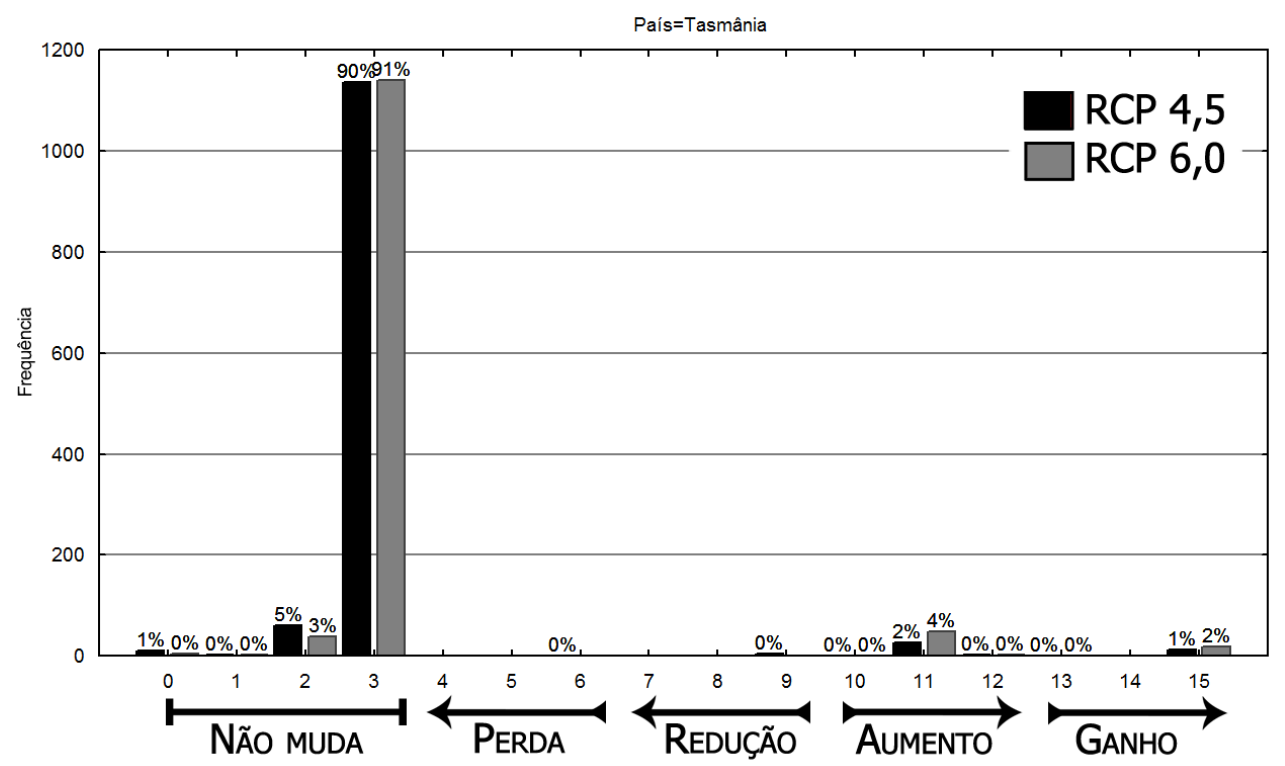

Figura C4.2-19. Percentil de cobertura de cada nível de mudança da susceptibilidade na ilha australiana da Tasmânia. Consulte a Tabela C4.2-1 para verificar as qualificações e quantificações associadas à sequência numérica do eixo $X$.

Na Nova Zelândia haverá mudanças de susceptibilidade em torno de $12 \%$ e $14 \%$ (RCP 4,5 e 6,0) de sua área total, considerando as duas ilhas juntas (Figura C4.216). Dentre estas mudanças, há o predomínio da redução da susceptibilidade (RCP 4,5: 6,3\%; RCP 6,0: 8,3\%), especialmente em as áreas cuja máxima susceptibilidade se tornará alta susceptibilidade, em 3\% da área do país em ambos os cenários (nível 9 na Figura (4.2-20), mas também alta susceptibilidade que se tornará susceptível, em $1 \%$ (RCP 4,5) e 3\% (RCP 6,0). Na dimensão das áreas que não terão mudança de susceptibilidade, $68 \%$ permanecerão com máxima susceptibilidade e em torno de $17 \%$ em ambos cenários (nível 2) permanecerá com alta susceptibilidade.

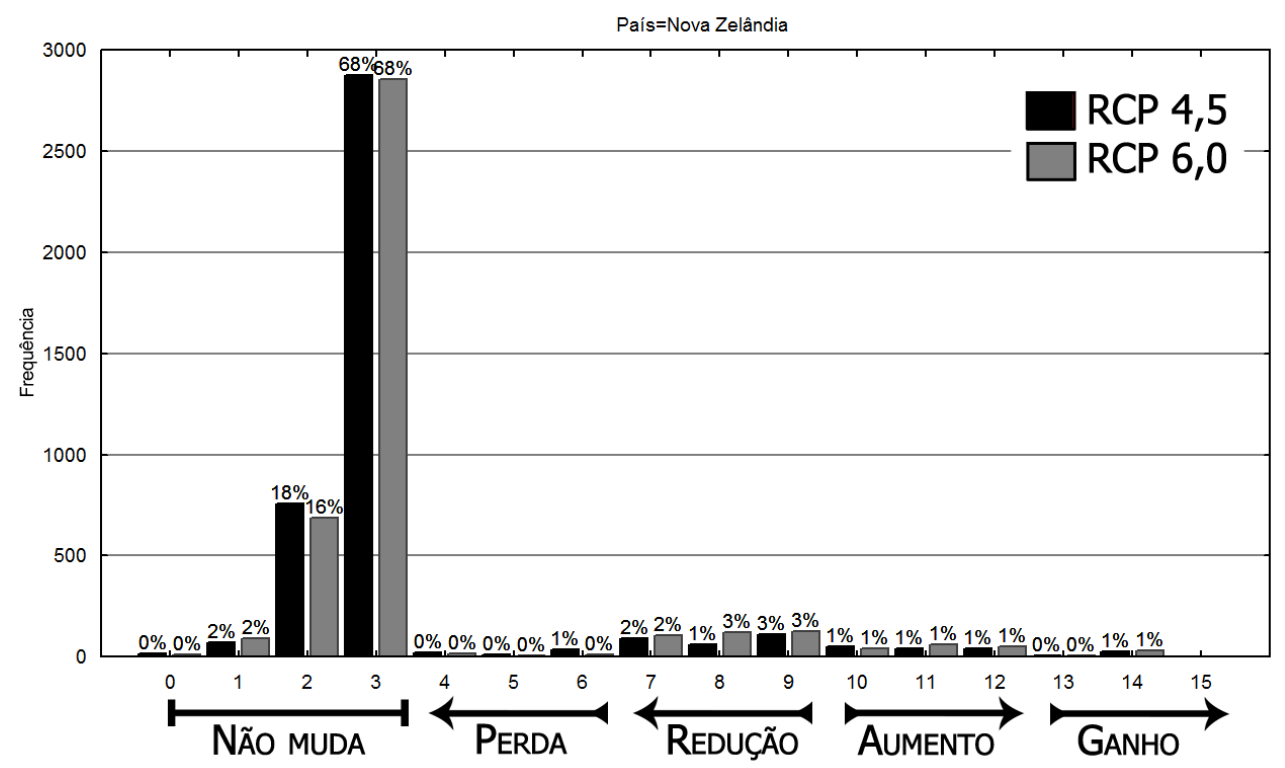

Figura C4.2-20. Percentil de cobertura de cada nível de mudança da susceptibilidade no país Nova Zelândia. Consulte a Tabela C4.2-1 para verificar as qualificações e quantificações associadas à sequência numérica do eixo $\mathrm{X}$. 


\section{Avaliação e considerações gerais}

Para quantificar em termos gerais, por área, as tendências de acréscimo e decréscimo da suscetibilidade perante cada cenário isoladamente, os percentuais do aumento (níveis 10, 11 e 12) e ganho (níveis 13, 14 e 15) por área foram somados um ao outro ( $\Sigma$ dos níveis 10 a 15 ), bem como o mesmo procedimento foi feito para os percentuais de redução (níveis 7, 8 e 9) e de perda (níveis 4, 5 e 6 ) ( $\Sigma$ dos níveis 4 a 9).

Subsequentemente, o valor da soma indicando decréscimo ( $\sum$ dos níveis 4 a 9 ) foi subtraído do valor da soma indicando acréscimo ( $\Sigma$ dos níveis 10 a 15 ), exibindo o balanço líquido entre acréscimo e decréscimo por área e por cenário, e este valores foram exibidos em barras na Figura C4.2-21. Dever-se ter cautela na interpretação destes valores, pois, embora o valor do ganho (e aumento) de susceptibilidade possa ser usado para contrapor o valor da perda (e redução) numa mesma escala numérica (\%) na comparação entre áreas delimitadas com ampla abrangência espacial, deve-se ter clareza que esta ponderação não atua no espaço de ocupação da espécie, e não existirá o empilhamento de valores contrários de mudança em uma mesma unidade geoespacial (ex: ganho e perda numa mesma célula) de forma que se possa anular um efeito aditivo (ex: ganho) com uma penalização opostamente equivalente (ex: perda).

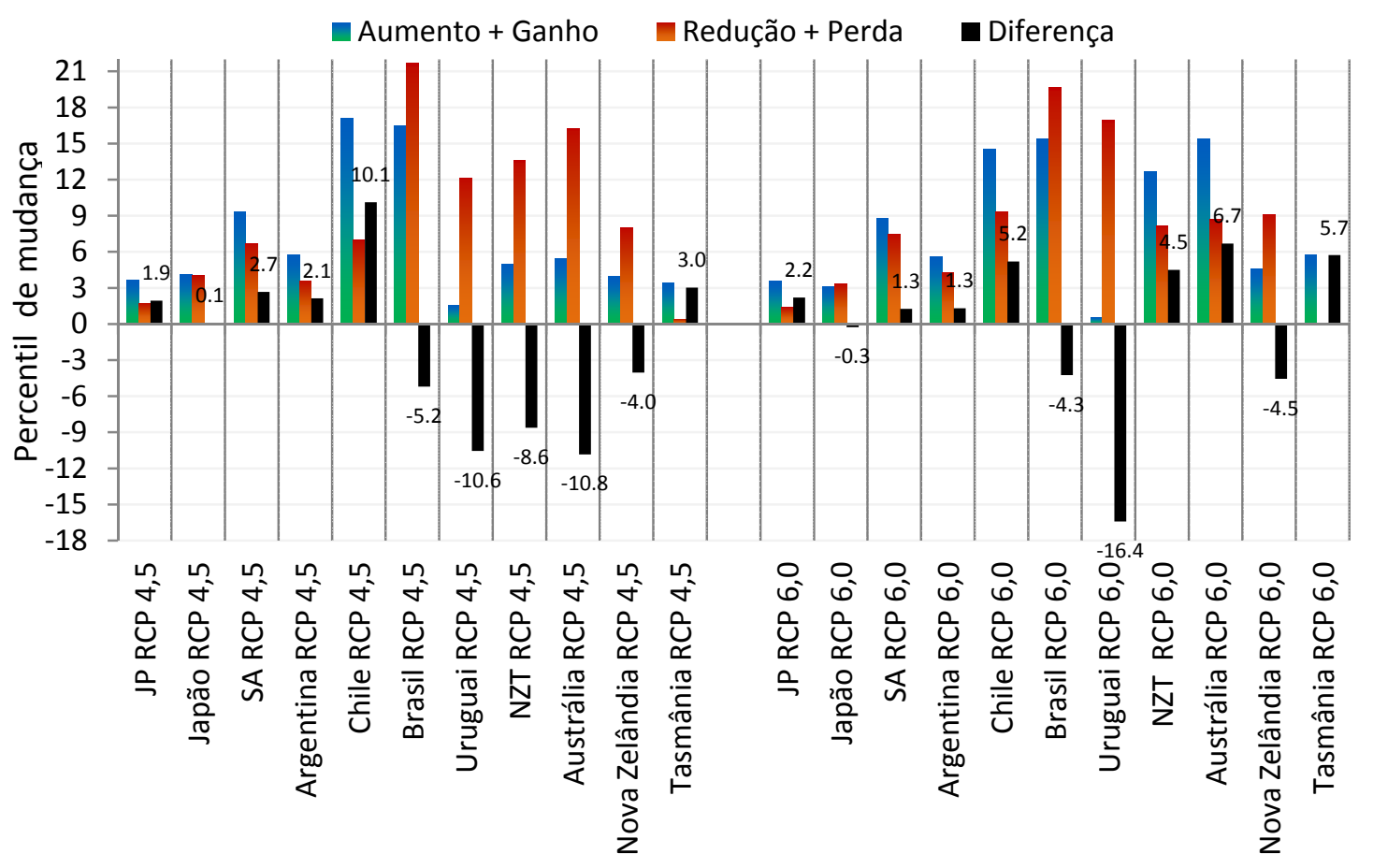

Figura C4.2-21. Balanço geral entre acréscimo (ganho + aumento) e decréscimo (perda + redução) de susceptibilidade entre áreas.

O decréscimo da suscetibilidade no cenário RCP 4,5 ocorrerá em cinco áreas, sendo que a Austrália, o Uruguai, e a NZT serão as áreas mais afetadas. No cenário RCP 6,0, o Uruguai sofrerá o maior decréscimo dentre todas as áreas, mas mesmo assim o país continuará com cerca de metade do seu território com alta ou máxima susceptibilidade (Figura C4.2-12), o decréscimo ocorrerá predominantemente em uma faixa central deste país (Figura C4.2-3). 
O Chile terá grande acréscimo de susceptibilidade em ambos cenários, mas será mais intenso no cenário RCP 4,5, onde este acréscimo decorrerá em sua maior parte na forma de aglomerados de fragmentos nos extremos sul e norte do país (considerando que a fração mais extrema do norte do Chile, onde se localiza a parte mais árida do deserto do Atacama, não está compreendido pela SA; Figura C4.2-3).

A Austrália e a NZT exibem peculiares distinções entre cenários quanto à mudança da susceptibilidade, com decréscimo no RCP 4,5 enquanto no RCP 6,0 haverá o oposto, acréscimo de susceptibilidade. Estes aspectos são também evidentes no mapa que compreende parte da Austrália continental (Figura C4.2-3); abstraindo-se os tons cinzentos (níveis 1 a 3), pode-se observar que a abrangência das tonalidades de cores quentes no RCP 6,0 supera as outras cores, já no RCP 4,5 os tons da cor verde e azul predominam sobre as outras cores.

No Japão em ambos cenários haverá mudanças mínimas, e na Tasmânia praticamente só haverá acréscimo de fragmentos de suscetibilidade a oeste da ilha. $A$ Argentina, a SA e o JP terão apenas poucos acréscimos de susceptibilidade em ambos cenários. Na Argentina, a maior zona com acréscimo está no extremo sul do país, a qual compensa (relativamente) o decréscimo verificado a leste do país (em verde), margeando a faixa de máxima suscetibilidade.

No Brasil, em ambos cenários haverá decréscimo da suscetibilidade, mas no mapa (Figura C4.2-8) observa-se a grande variedade de mudanças dos níveis de susceptibilidade, a maior entre as áreas, e uma grande área que permanecerá susceptível no futuro em ambos cenários.

A SA exibe um adelgaçamento da longa faixa susceptível litorânea em sua margem oeste em ambos os cenários, mas que potencialmente não levará a total perda de conectividade entre as áreas invadidas no Chile e Argentina com os países Uruguai e Brasil. Deve-se ressaltar que na SA a espécie será favorecida em sua expansão invasiva no cenário RCP 6,0, devido à ampliação da conectividade entre áreas susceptíveis, na faixa litorânea da Argentina em uma pequena disjunção apresentada em cenário atual.

Para particularizar as mudanças por cada tipo de abrangência espacial, permitindo comparar as áreas invadidas com as áreas não invadidas e todas as áreas juntas, foi feito o cálculo das médias das diferenças nas mudanças da susceptibilidade conforme os seguintes agrupamentos: 1) todos os países com registros de invasão (Argentina, Chile, Japão, Nova Zelândia e Tasmânia); 2) todos os países ainda não invadidos (Brasil, Uruguai e Austrália continental) e; 3 ) todos os quadros juntos (SA, NZT, JP).

Por meio da comparação entre os três agrupamentos (Figura C4.2-22) pode-se verificar que a mudança climática, considerando-se a média de todos os quadros, irá favorecer a expansão invasiva da espécie no cenário RCP 6,0, enquanto irá desfavorecê-la no RCP 4,5. Os países já invadidos terão acréscimo de suscetibilidade em ambos cenários climáticos futuros, já os países ainda não invadidos terão uma expressiva redução de susceptibilidade, especialmente no cenário RCP 4,5.

De uma forma geral, em uma perspectiva contrária a invasão de Bombus terrestris, espera-se que o cenário RCP 4,5 venha a se tornar a realidade climática de 2050 (nos termos da análise), reduzindo o potencial invasivo da espécie na América do Sul. Todavia, com base nos dados obtidos neste capítulo, seja qual for o cenário climático futuro, a espécie continuará francamente a se expandir a partir de áreas 
invadidas na América do Sul. Pelo menos em termos de mudanças climáticas nas áreas susceptíveis, não se poderá sugerir que a espécie encontrará alguma barreira efetiva que a limitará em alcançar o Brasil.

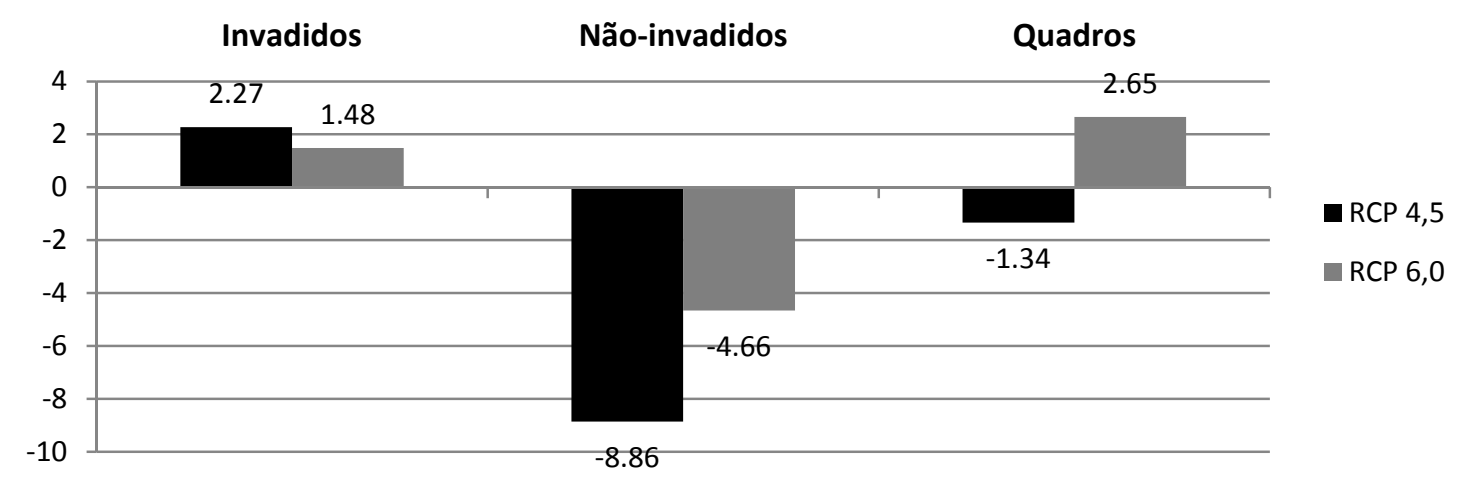

Figura C4.2-22. Médias das diferenças de mudanças de susceptibilidade entre países invadidos, países não invadidos, mas susceptíveis, e todas as áreas focais juntas (quadros SA, NZT, JP). 


\section{Capítulo 5. Bombus terrestris chegará ao Brasil?}

Para responder à questão central desta pesquisa foi necessário o desenvolvimento de uma sequência de métodos analíticos encadeados, de forma que análises prévias provêm dados para o desenvolvimento das análises subsequentes. Buscou-se fundamentar plenamente todas as análises por meio de subsídios teóricos e referências de aplicações anteriores, e quando foi necessário, premissas foram explicitamente assumidas de forma justificada.

As análises abrangidas por este capítulo podem ser integralmente contextualizadas por um termo específico que se refere a um novo campo de pesquisa: a Ecogeografia. Mas a definição deste termo como área de pesquisa científica deve ser abordada conceitualmente, logo no início deste capítulo, devido à sua recente reinterpretação e conforme as suas novas aplicações no âmbito científico.

Para propósitos de melhor organização textual, os métodos foram descritos sequencialmente, conforme o melhor encadeamento dos processos, mas os seus desenvolvimentos, de fato, seguiram ordens variadas. Para aprimorar a fluidez na descrição da metodologia, em alguns momentos houve a necessidade de se incluir premissas imprescindíveis e alguns resultados parciais, sem os quais haveria prejuízo ao leitor no acompanhamento do desenvolvimento da lógica analítica. Os resultados principais e as discussões, compreendendo as questões fundamentais do capítulo, estão abordados logo após a metodologia; e para se evitar repetições desnecessárias, as conclusões deste capítulo estão integradas às conclusões gerais de toda a pesquisa no capítulo seguinte (Capítulo 6).

Detalhes matemáticos dos processos analíticos foram deliberadamente omitidos no texto, mas poderão ser verificados de forma completa nos scripts escritos em linguagem $\mathrm{R}$, contidos em anexos que serão apontados ao longo do texto.

Ao longo do processo metodológico, a escala geográfica foi reduzida da dimensão global, a qual foi utilizada até o momento, para a área de abrangência focal de maior interesse, a região sul da América do Sul (quadro SA), não mais se tratando das outras áreas invadidas (quadros JP e NZT) e, subsequentemente, foi novamente reduzida para o sul do Brasil e parte do Estado de São Paulo abaixo do Trópico de Capricórnio, e nesta dimensão permanecerá até a conclusão desta pesquisa.

\subsection{A ciência por detrás da Ecogeografia}

A fragmentação da Ciência em distintas disciplinas é um reflexo do modelo de pensamento reducionista proposto por René Descartes (sec. XVII) em seu trabalho Discurso do Método, no qual advogou que se pode alcançar a compreensão do todo por meio do entendimento de suas partes. Este modelo consolidou-se no âmbito científico pela contribuição de outros racionalistas modernos (ex: Baruch Spinoza, Gottfried W. Leibniz, Immanuel Kant) e se difundiu globalmente como padrão do método científico durante a revolução industrial (Clarke, 1982; Henry, 2002; Hyland, 2004). Neste período havia maior interesse social em competências técnicas e em habilidades específicas, que contribuíssem com as necessidades de mão de obra altamente especializada, e menor demanda de pensadores e cientistas com perspectivas abrangentes (Deane, 1979; Jessop, 1994; Rand e Schwartz, 1999; Crouzet, 2006). 
Hoje, devido ao maior nível de esclarecimento da humanidade sobre si mesma e sobre a natureza, percebe-se que há a necessidade de conciliar as disciplinas existentes para viabilizar maior abrangência e aprofundamento científico no entendimento das sociedades e dos fenômenos naturais, os quais se manifestam e são influenciados por múltiplos fatores, de forma transversal, compreendendo todos os campos práticos e teóricos do conhecimento.

Esta demanda por interdisciplinaridade intensificou a tendência de casamentos entre disciplinas gerando-se áreas de pesquisa compostas, por exemplo, a Antropologia Ecológica, a Bioinformática, a Geoengenharia e mais recentemente, a Ecogeografia. Estas combinações ampliam o alcance da pesquisa científica ao expandir as fronteiras conceituais dos campos de pesquisa devido à sobreposição de disciplinas, bem como viabilizam o desenvolvimento de novas ferramentas e métodos inovadores de pesquisa.

A recente revitalização do termo Ecogeografia - agora como campo de estudo (referências adiante) - decorre da necessidade de se caracterizar uma nova forma de se estudar a Natureza, com a acoplagem de ferramentas e métodos analíticos que outrora não estavam desenvolvidos ou disponíveis aos pesquisadores.

Para justificar seu uso no contexto analítico deste trabalho será necessário argumentar brevemente sobre definições e conceitos de algumas disciplinas, para então posicionar a Ecogeografia em sua abrangência e aplicação.

Em termos hierárquicos na Ciência cartesiana, a Biologia é um compartimento das Ciências Naturais que agrega em seus domínios o estudo da vida. Na Biologia encontram-se outras fragmentações, algumas mais restritivas como a Microbiologia, que estuda os organismos microscópicos e suas relações com o ambiente vivo e não vivo. Mas também há fragmentos mais abrangentes, os quais podem estudar desde os microrganismos, as interações entre espécies, até as mudanças climáticas, assim como os seres humanos em meio às repercussões de tudo isso, como é o caso da Ecologia.

O alcance da Ecologia na abrangência da ciência é imenso, dificultando a caracterização de suas limitações teóricas e práticas dentro da própria disciplina que a restringe, a Biologia. Certamente, um biólogo, e mesmo um ecólogo, irá pensar bastante para responder uma simples pergunta: O que é a Ecologia dentro da Biologia?

Em termos conceituais gerais a Biologia é o estudo de todas as formas de vida, todos os seus ambientes e aglomerações, bem como tudo que emerge no (e do) contexto interativo de todas estas coisas (primeiramente definida por Jean-Baptiste Lamarck em 1805; Magner, 2002). A Ecologia, por sua vez, é o estudo das interações entre as formas de vida e delas com seu ambiente (primeiramente definida por Ernst Haeckel em 1869; Rana, 2013). Assim, sob uma perspectiva ampla, busca-se delimitar a Ecologia ao estudo das interações intra e interespecíficas, portanto, não há fronteiras consistentes para a Ecologia dentro da Biologia em termos de abrangência (visão) ou mesmo de objeto de estudo, tendo em vista a potencial inexistência de organismos não interativos nos sistemas naturais, mas, de certa forma, direciona-se o contexto e tipo de sua resposta.

Esse enfoque conceitual é fundamentalmente expresso no significado da palavra Eco-logia, que vem do grego, "casa" + "estudo" que é, essencialmente, o estudo da casa; tal como Eco-nomia, a organização da casa. A casa em ambos os contextos - ecologia e economia - pode ser interpretada como um compartimento, afinal nossa casa é um compartimento onde guardamos nossas coisas e nos abrigamos. Mas, especificamente no contexto da Ecologia, o compartimento pode ser atribuído a um determinável e 
mensurável conjunto de interações fortemente interligadas entre si; o que converge com a definição da menor unidade funcional ecológica, que pode ser determinada por um ecossistema (sistema da casa), que é um conjunto de organismos e elementos não vivos que interagem entre si funcionalmente e estruturadamente.

Considerando estes aspectos, podemos então caracterizar a Ecologia como o estudo voltado à identificação, entendimento e descrição de lógicas e padrões de estruturação e funcionalidade em conjuntos de interações relativamente delimitáveis pela força de suas conexões, e que ocorrem em determinadas dimensões espaciais e temporais.

As interações, suas forças de ligações e dimensões, conforme se apresentam no presente, decorrem de diversos processos e eventos pregressos que repercutiram na história natural dos organismos atuais e em seus ambientes, incluindo-se, por exemplo, especiação, dispersão, isolamento geográfico, deriva continental, glaciações, e até meteoros. E talvez a temporalidade da causalidade dos eventos naturais possa sustentar a discriminação da Ecologia dentre alguns compartimentos da Biologia.

A Ecologia, de uma forma geral, tem tratado primariamente (não, exclusivamente) dos efeitos recentes decorrentes de processos e eventos pregressos, e secundariamente das suas causas, que começaram ou aconteceram no passado, as quais são aspectos que têm sido abrangidos primariamente por outras ramificações da Biologia, por exemplo, a Biologia Evolutiva, a Sistemática e a Paleontologia.

Agora, a Ecogeografia pode ser contextualizada com base no significado do casamento dos termos Ecologia e Geografia; assim, uma combinação de elementos destas duas disciplinas.

Sendo a Geo-grafia (descrição da Terra) o estudo dos fenômenos que ocorrem na superfície terrestre e suas influências nos seus habitantes com especial enfoque na espacialidade (geográfica) destes fenômenos (Fisher, 1998; Holt-Jensen, 2009). A Ecogeografia pode ser caracterizada como o estudo que busca identificar, entender e descrever padrões geoespaciais existentes nos padrões de organização e funcionalidade de conjuntos de interações entre os seres vivos e deles com os elementos não-vivos.

Esta definição de Ecogeografia, sob alguns aspectos, é convergente com aqueles da Biogeografia e da Macroecologia: a Biogeografia é conceituada como uma ciência que busca documentar e compreender os padrões espaciais da biodiversidade tanto no passado como no presente (Brown e Lomolino, 2006). Já a Macroecologia é uma forma de estudar (sic) o relacionamento entre organismos e seu ambiente, envolvendo explicações estatísticas e caracterizações dos padrões de abundância, distribuição e diversidade, explorando os domínios onde a ecologia, biogeografia, paleontologia (passado) e macroevolução (passado) se encontram (Brown, 1995).

As definições de macroecologia e biogeografia - igualmente - ressaltam a necessidade da consideração das causas pregressas, e esta consideração pode ser a principal diferença entre estas duas áreas para a da Ecogeografia, que trata, em sua abrangência, primariamente dos efeitos recentes decorrentes dos processos e eventos pregressos. A Ecogeografia também pode obter subsídios do passado para explicar fenômenos correntes, embora seu foco primário seja responder questões contemporâneas e estimar, para o futuro, potenciais consequências. Assim, a dimensão temporal na Ecogeografia direciona-se, fundamentalmente, do presente para o futuro, permitindo dizer que em algumas pesquisas ecogeográficas as causas podem ser atuais e os efeitos, futuros. 
O uso do termo ecogeografia e suas derivações (ex: barreiras ecogeográficas) não é recente na Biologia. Tem sido usada, por exemplo, na Zoologia para classificar padrões morfológicos e fisiológicos manifestados em organismos no presente que potencialmente são decorrentes de processos evolutivo-adaptativos em resposta aos fatores ambientais em longo prazo. Muitas destas observações ecogeográficas foram feitas há várias décadas, mas a maioria de seus autores nunca usou o termo ecogeografia em seus trabalhos; de fato, suas ideias foram posteriormente enquadradas como regras ou normas ecogeográficas por outros autores, mais recentes (Quadro 1).

Hoje o termo Ecogeografia, revitalizado como designação de campo de estudo, é muito mais abrangente do que apenas um termo usado na Zoologia para descrever um aspecto biogeográfico. A pesquisa em Ecogeografia tornou-se referência para estudos que envolvem a combinação de pesadas análises geoestatísticas, por meio de Sistemas de Informações Geográficas, e ecológicas, por meio da Modelagem Ecológica Computacional, para explicar fenômenos biológicos diretamente relacionados ao espaço geográfico ocupado por espécies em resposta à conjuntura de características ecológicas e ambientais existentes nestes espaços.

As definições de Ecogeografia, caracterizando-a como campo de pesquisa, começaram a ser publicadas a partir de 1980, e algumas delas - pois ainda são poucas estão relatadas a seguir.

Uma das primeiras recomendações de uso do termo Ecogeografia para aplicações mais abrangentes foram feitas por Peeters e Williams em 1984, eles citam que: “A combinação de dados climáticos, ecológicos e geográficos (ou 'ecogeográfico' [sic]) oferece benefícios potenciais em disciplinas como a biologia da conservação e a agricultura. Por exemplo, princípios ecogeográficos poderiam ser usados para ajudar a selecionar amostras úteis a partir de bancos de genes, onde a diversidade armazenada muitas vezes não é avaliada e/ou é descrita exclusivamente por sua origem." (Peeters e Williams 1984; Peters et al., 1990)

Anos depois, a Ecogeografia foi definida por Maxted et al. (1995) como: "um processo de coleta e síntese de informações ecológicas, geográficas e taxonômicas sobre um táxon em particular. Os resultados [dos estudos ecogeográficos] são preditivos e podem ser usados como auxílio na formulação de prioridades de conservação."

Recentemente e ressaltando diferenças entre Biogeografia e Ecogeografia, Allen (2014) descreveu o seguinte: "[...] Este é o reino da Ecogeografia - o casamento entre geografia e ecologia. Este é o estudo das relações entre as plantas e os animais e seu ambiente - a influência do clima, processos geomorfológicos, solos e especialmente as pessoas. Em certo sentido, é semelhante ao significado da biogeografia para o geógrafo o estudo da biosfera e dos efeitos humanos sobre as plantas e animais. É, no entanto, diferente da compreensão de biogeografia para um biólogo - estudo das distribuições atuais e passadas de plantas e animais em várias escalas e como essas distribuições aconteceram".

A Ecogeografia, como campo de estudo, enquadra adequadamente o escopo analítico proposto nesta pesquisa, o que não ocorreria se o termo de referência fosse Biogeografia ou Macroecologia, afinal, e entre outros aspectos, não se tratou aqui de causas pregressas, mas de efeitos no presente (invasão global) que poderão ser as causas de efeitos futuros (invasão e repercussões no Brasil). 


\section{Quadro C5-1. Regras ou normas ecogeográficas}

Regra ecogeográfica de Gloger: Constantin Wilhelm Lambert Gloger (1883) publicou um trabalho sugerindo que os padrões de coloração nos organismos endotérmicos variam conforme as características físicas do ambiente; animais em ambientes mais úmidos e quentes (próximos ao Equador) possuem pigmentação mais intensa e com coloração escura; já em locais mais secos, o amarelo e o vermelho são predominantes; em áreas frias, a pigmentação é menor.

Regra ecogeográfica de Bergman: Carl Bergman (1847) sugeriu que as populações e as espécies de animais (especialmente endotérmicos) com maior porte físico tendem a ocorrer mais frequentemente em ambientes frios (latitudes superiores); já as de menor porte em ambientes quentes (latitudes próximas ao equador).

Regra ecogeográfica de Allen: Joel Asaph Allen (1878) identificou que em ambientes mais quentes os animais endotérmicos possuem apêndices (ex: pernas, braços, orelhas, focinhos) mais compridos do que aqueles animais em ambientes mais frios; minimizando a perda de temperatura interna quando em ambiente frio e aumentando a perda de calor quando em ambiente quente (Allen, 1878; Lincoln et al., 1982).

Regra ecogeográfica de Foster: J. Bristol Foster (1964) detectou que dependendo da disponibilidade de recursos no ambiente e da pressão de predação, as espécies podem se tornar com o tempo maior ou menor em tamanho corporal do que seu ancestral, e que no caso de ilhas os animais tendem a ser menores que suas variedades no continente (Foster, 1964; Adler e Levins, 1994; Wu et al., 2006). As observações de Foster foram posteriormente (1967) ampliadas matematizadas por Edward O. Wilson e Robert MacArthur com a publicação de: A Teoria da Biogeografia de Ilhas; ambos os autores são considerados os pais da disciplina Biogeografia. 


\subsection{Justificativa e objetivos da análise ecogeográfica}

Deve-se reavivar que a suscetibilidade à invasão é uma interpretação da adequabilidade do habitat em locais distantes da ocorrência nativa da espécie, e que os três níveis detectados pelo modelo de susceptibilidade exibem o grau de convergência preditiva das rodadas de modelagem, que foram identificados por meio de índices de correlação de Pearson. Portanto, este níveis não se referem diretamente às escalas de variação dos fatores ambientais mais adequados à espécie invasora, mas a uma gradação de acerto ou robustez de predição.

Linhas teóricas da ecologia de populações (teoria do nicho, dinâmica de populações clássica e de metapopulações) concordam que para uma espécie, apesar do envolvimento de outros fatores intrínsecos e extrínsecos a ela (ex: imigração, predadores, doenças), quanto maior for a qualidade de um habitat em termos de recursos essenciais (ex: alimento, abrigo) e condições ambientais (ex: clima) melhor será o desempenho e a manutenção de suas populações (taxa de crescimento positiva, maior número de populações, menor taxa de extinções locais) (Hutchinson, 1978; Van Horne, 1983; Knutson et al., 2006; Leibold, 2009; Vögeli et al, 2010).

$\mathrm{Na}$ dimensão espacial detectada como susceptível - portanto adequada à espécie em habitat não nativo - existem diferentes níveis de qualidade ambiental. A variação da qualidade parte do nível máximo, onde ocorre o ótimo ambiental para a espécie (ou próximo disso) e decresce em direção aos limiares mais extremos de tolerância, onde ainda há qualidade, mas em menor nível; e a qualidade deixa de existir quando a conjuntura de fatores ambientais é limitante à ocorrência da espécie, que são as áreas de habitat inadequado - portanto, em locais não nativos, são áreas insusceptíveis à invasão.

A gradação da qualidade ambiental permite também sugerir uma variação de susceptibilidade à invasão, e refinar as categorias detectadas pelos modelos fracionando-as em maior quantidade de níveis de suscetibilidade diretamente relacionados, neste caso, à qualidade ambiental dos habitat não nativos para a espécie. A identificação do gradiente de qualidade ambiental em áreas susceptíveis à invasão, conforme foi feita nesta pesquisa, permitiu detectar as faixas geográficas que poderão ser mais rapidamente acessadas e as zonas preferencialmente ocupadas pela espécie, bem como permitiu detectar potenciais corredores de invasão que conectam as áreas de alta qualidade ambiental para a espécie com locais já invadidos por ela, e destes, aqueles que se conectam com o Brasil.

A análise ecogeográfica realizada neste estudo compreendeu quatro objetivos específicos em três diferentes escalas espaciais que foram sucessivamente reduzidas ao longo da análise, conforme segue:

1) Caracterizar ecogeograficamente Bombus terrestris em escala global e identificar as diferenças e similaridades ecogeográficas em áreas focais de ocorrência nativa e invasiva.

2) Mapear as rotas e zonas potenciais de expansão e ocupação invasiva da espécie na América do Sul a partir de locais já invadidos.

3) Mapear as cidades brasileiras que potencialmente serão as primeiras a serem invadidas pela espécie, e aquelas que estão na potencial rota de progressão da invasão no Brasil. 
4) Mapear o potencial de sobreposição ecogeográfica de Bombus terrestris no Brasil com habitat adequados para as abelhas nativas do gênero Bombus e culturas agrícolas com as quais a espécie é conhecida por interagir.

\subsection{Metodologia}

A metodologia é composta por uma série de etapas consecutivas, cuja sequência processual está ilustrada no diagrama da figura 5-1.

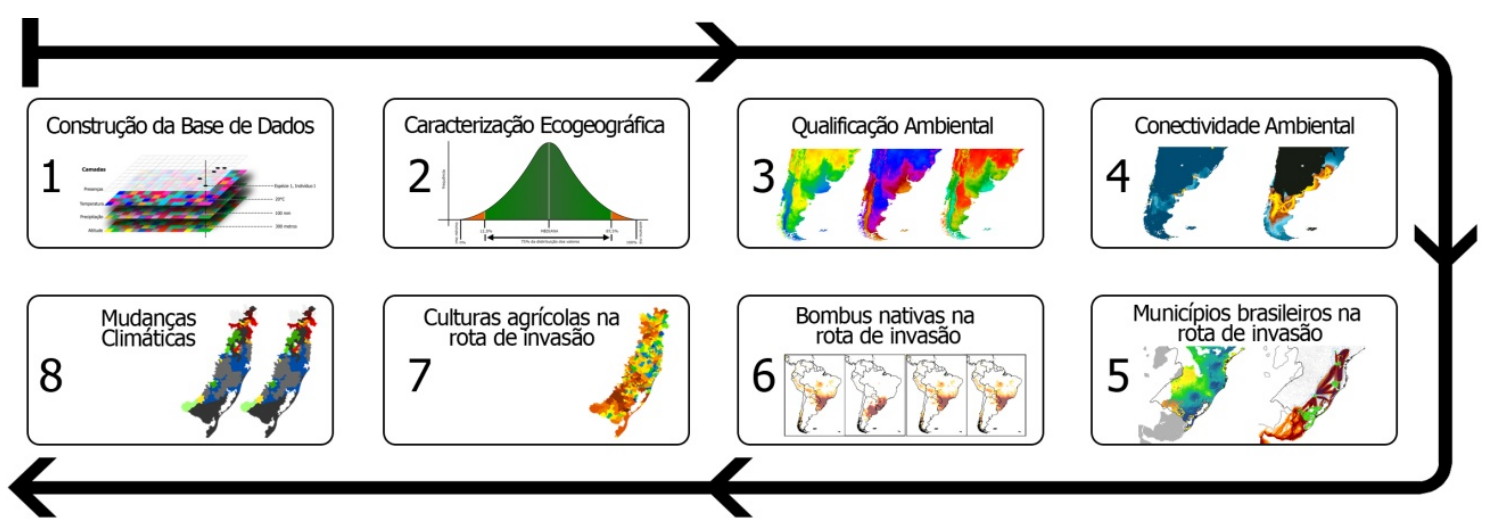

Figura C5-1. Diagrama da sequência de processos metodológicos. A numeração interna na figura combina com o último número na numeração dos itens a seguir.

\subsubsection{Construção da base de dados}

A análise ecogeográfica, conforme foi desenvolvida para esta pesquisa, requer a entrada de dois tipos de dados: 1 ) variáveis ambientais abióticas e bióticas - sendo que o conjunto de camadas topoclimáticas representam as características abióticas e a camada de cobertura de solo representa as características bióticas ${ }^{14}$; 2 ) registros de ocorrências nativas e invasivas de Bombus terrestris. (A seleção de variáveis ambientais e a obtenção e filtragem das ocorrências foram abordadas no capítulo 3)

O procedimento de construção da base de dados para o desenvolvimento da análise ecogeográfica consiste na extração de valores ambientais por meio da interceptação das intersecções entre as localidades de ocorrência de cada indivíduo da espécie e as células de cada camada ambiental.

$O$ procedimento de extração foi feito por meio de script escrito em linguagem $R$ especificamente para isso - o qual está detalhado no Anexo C5-1A - e gerou um banco de dados com 4756 linhas representando as posições geográficas nativas e invasivas dos indivíduos da espécie e 71 colunas representando as variáveis ambientais. No total, portanto, a base de dados gerada contém 337.676 informações ambientais

\footnotetext{
${ }^{14}$ A camada de cobertura de solo não permite a identificação efetiva das espécies abrangidas espacialmente por suas classes individuais, e se estas espécies, de fato, interagem com Bombus terrestris, mas permite identificar a tipologia de cobertura (especialmente vegetacional) cuja espéciealvo é mais frequente em seus ambientes de ocorrência, as quais incluem per se elementos bióticos particulares, especialmente provedores de recursos à espécie, que permitem a maior frequência da ocorrência da espécie. Assim, se a espécie ocorre frequentemente em uma determinada classe de cobertura de solo pode-se presumir que os componentes bióticos que a compõem são mais favoráveis à espécie do que outras classes de ocorrência infrequente, menos frequentes ou nas que a espécie não ocorre.
} 
referentes a todas as localidades de ocorrência de Bombus terrestris em escala global. No entanto, na base de dados também há colunas acessórias, com nome da espécie, o número de identificação do indivíduo na coleção, suas coordenadas geográficas, se são registros nativos ou invasivos e os quadros em que cada ocorrência coincidiu. Os quadros permanecem os mesmos conforme foram definidos no Capítulo 3 (Item 3.3) e também serão úteis neste capítulo para evidenciar as áreas focais onde há registros de ocorrências nativas (EU) e invasivas (SA, JP, NZT) de Bombus terrestris no planeta.

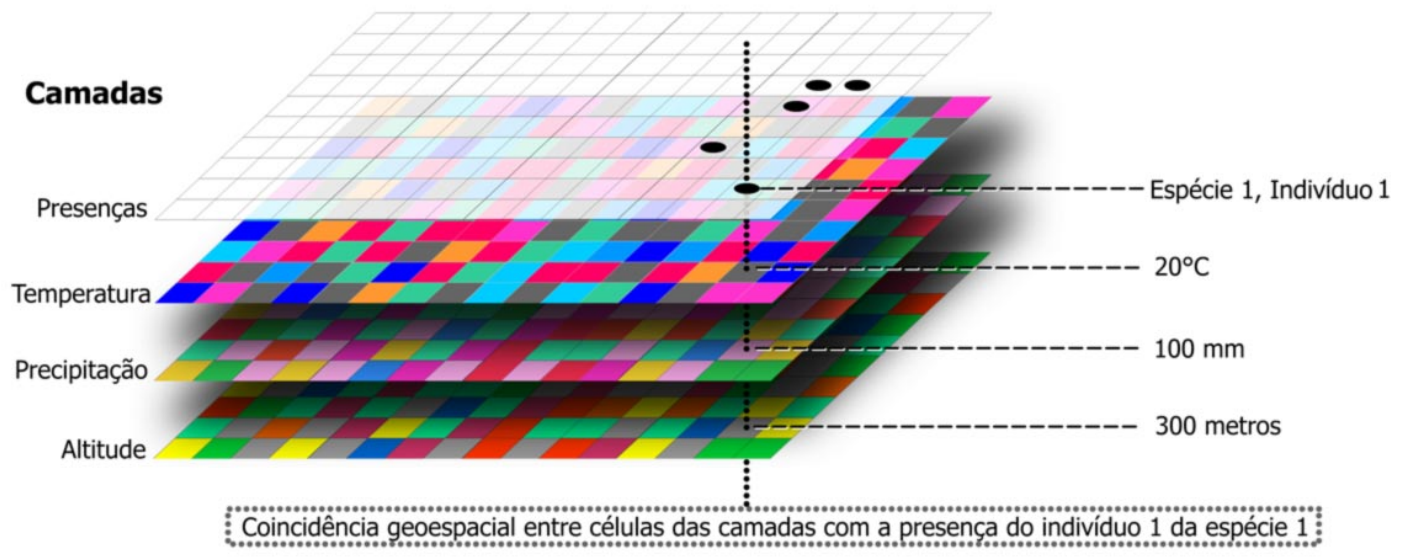

Figura C5-2. Representação teórica do procedimento de extração de informações de cada célula coincidente com ocorrências nas camadas ambientais.

\subsubsection{Caracterização ecogeográfica de Bombus terrestris}

Premissas e subsídios para a definição dos limiares ecogeográficos

Para o desenvolvimento da análise ecogeográfica é necessário assumir inicialmente que em uma área de habitat adequado a maioria (definido numericamente adiante) dos indivíduos de Bombus terrestris será encontrada na extensão geográfica onde a conjuntura de fatores ambientais é altamente adequada à espécie, pois neste espaço ambiental os indivíduos encontram integralmente tudo o que necessitam para sobreviverem e se reproduzirem (recursos, condições, interações, parceiros). O intervalo da variação de cada fator ambiental onde a maioria dos indivíduos da espécie ocorre foi denominado de faixa de afinidade.

A premissa anterior leva a se assumir que a conjuntura de faixas ambientais onde a minoria dos indivíduos da espécie ocorre dentro da área de habitat adequado não apresenta o mesmo nível de qualidade ambiental que a zona supracitada. Os indivíduos da espécie são capazes de tolerar este ambiente, forragear pela área e até mesmo ocupá-la, mas não encontrarão a mesma quantidade, qualidade e/ou diversidade de requisitos necessários às suas populações. O intervalo compreendido entre os máximos e mínimos de cada fator ambiental no qual pelo menos um indivíduo da espécie ocupa foi denominado de faixa de tolerância.

Para cada fator ambiental, a faixa de afinidade está contida na faixa de tolerância, assim, por exemplo, se a maioria dos indivíduos de uma espécie ocorre na faixa de afinidade de altitude entre 100 e 500 metros, a faixa de tolerância será sempre mais larga, por exemplo, entre 50 e 800 metros. 
Conforme verificado na literatura específica, a atribuição estatística de limiares que definem os intervalos das faixas de afinidade e de tolerância é bastante diversificada entre autores e tipos de aplicação, e não foram encontrados critérios matemáticos e/ou biológicos que subsidiassem a definição destes limiares para espécies invasoras.

Nix (1986) sugeriu o intervalo entre $2,5 \%$ e $97,5 \%$ da distribuição total dos valores como abrangência da faixa de afinidade em um estudo sobre cobras australianas. Busby (1991) definiu o intervalo entre 5\% e $95 \%$ da distribuição dos valores como limiares extremos da faixa de afinidade como um parâmetro do pacote de envelopes climáticos BIOCLIM. Lindenmayer et al. (1991) definiu os limiares 0-100\% como sendo o alcance máximo da espécie (faixa de tolerância) e 10-90\% como representando a distribuição nuclear (faixa de afinidade) de uma espécie de possum ${ }^{15}$ sob ameaça. Jackson e Claridge (1999) consideraram apenas os limiares 0-100\% para ultrapassar problemas ${ }^{16}$ relativos à definição da zona climática/habitat "nuclear" e "marginal" em um estudo sobre marsupiais planadores.

Nesta pesquisa, a definição dos limiares das faixas de afinidade e tolerância levou em consideração três aspectos biológicos de Bombus terrestris, os quais seguem:

1) O potencial de dispersão de Bombus terrestris - é plausível considerar que quanto maior for a capacidade de dispersão de uma espécie mais alta será a capacidade dos seus indivíduos em tolerar maior variabilidade e diversidade de circunstâncias ambientais, relativamente a uma outra espécie com menor capacidade de dispersão. Pode-se dizer que, de uma forma geral entre os polinizadores, Bombus terrestris está dentre as espécies com alta capacidade de dispersão, tendo em vista a extensa dimensão de seu habitat natural e a alta velocidade de sua expansão em locais invadidos, entre 15 e $90 \mathrm{~km}$ por ano. Estes aspectos sugerem que tanto a faixa de tolerância como de afinidade da espécie são bastante amplas e cobrem grande variedade de características ambientais.

2) Mobilidade do indivíduo - operárias de Bombus terrestris podem voar mais de $10 \mathrm{~km}$ a partir de sua colônia para buscar recursos e podem alcançar velocidades de voo superiores a $15 \mathrm{Km} / \mathrm{h}$, a rainha inseminada poderá voar de forma similar para encontrar um local adequado para construir sua colônia. Neste trajeto, uma abelha poderá cruzar ambientes bastante diversificados, inclusive voar sobre ambientes inadequados. Estes aspectos sugerem que a faixa de tolerância de Bombus terrestris poderá ser consideravelmente ${ }^{17}$ mais larga do que a faixa de afinidade.

3) Capacidade de tolerância fisiológica dos indivíduos que se reflete na ocupação nativa e na capacidade de invasão da espécie - Bombus terrestris é conhecida por tolerar circunstâncias ambientais usualmente adversas para outras abelhas, permitindo-lhe explorar e ocupar (assim como invadir) ambientes notavelmente diferentes uns dos outros. Este aspecto sugere que a largura das faixas de afinidade e tolerância para a espécie é bastante variável entre áreas invadidas e delas para a área nativa.

\footnotetext{
${ }^{15}$ Possum ou Phalangeriformes, são organismos marsupiais arborícolas comuns na Austrália.

${ }^{16}$ Trecho extraído de Jackson e Claridge, 1999: "The 0-100\% envelopes were used for the predicted range to overcome problems concerning definitions of core (optimal climate) and marginal climate (minimum and maximum values) and habitat and climate."

${ }^{17}$ Se a considerarmos, relativamente, com organismos sésseis (ex: plantas terrestres) e organismos com baixa mobilidade (ex: moluscos terrestres), pois nestes dois casos a faixa de tolerância será muito próxima ou quase equivalente ao intervalo da faixa de afinidade.
} 
Levando em consideração estes aspectos biológicos da espécie e perante os objetivos da análise ecogeográfica, pode-se sugerir que a mais ajustada atribuição da faixa de afinidade para Bombus terrestris será feita pela definição de um intervalo mais restrito do que aqueles que foram encontrados na literatura para outras espécies. Já a faixa de tolerância deverá compreender a escala total de variação de cada fator ambiental. Uma atribuição mais restritiva da faixa de afinidade é favorável para reduzir a interferência da variabilidade entre as diferentes zonas ambientais de ocorrência da espécie, aumentando a convergência das faixas de afinidade entre as áreas focais, auxiliando na identificação das preferências ambientais da espécie como um todo, em escala global. A variabilidade permanecerá representada nos valores mais extremos na faixa de tolerância. Uma atribuição mais restritiva também favorecerá a detecção das faixas ambientais mais próximas do ótimo ambiental potencial para a espécie que, se assumirá aqui, compreende uma faixa mais estreita cujo centro tende ou coincide com a mediana da distribuição dos dados. Todavia, se a atribuição da faixa de afinidade for extremamente restritiva, potenciais áreas e corredores com menor adequabilidade, mas que também podem ser usadas pela espécie, poderão não ser detectados na análise.

Por meio da consideração conjunta dos aspectos supracitados, foi feita a atribuição dos limiares da faixa de afinidade como sendo os valores contidos entre $12,5 \%$ e $87,5 \%$ da distribuição total dos dados. Assim, a faixa de afinidade compreende $75 \%$ do intervalo ambiental total para cada variável contínua (Figura C5-3). Os limiares 0 e $100 \%$ foram atribuídos para a faixa de tolerância, para evidenciar a largura total da variação ambiental nas diferentes áreas de ocorrência da espécie. A faixa de tolerância não proverá dados para a qualificação ambiental das áreas susceptíveis, tendo em vista que se almeja encontrar as faixas ambientais mais favoráveis e não aquelas que se aproximam de valores limitantes, afinal, as áreas insusceptíveis já foram delineadas pelos modelos (Capítulo 4). Mas, os extremos de tolerância também são informações úteis para a caracterização ecogeográfica da espécie, portanto, foram abordados no tópico específico.

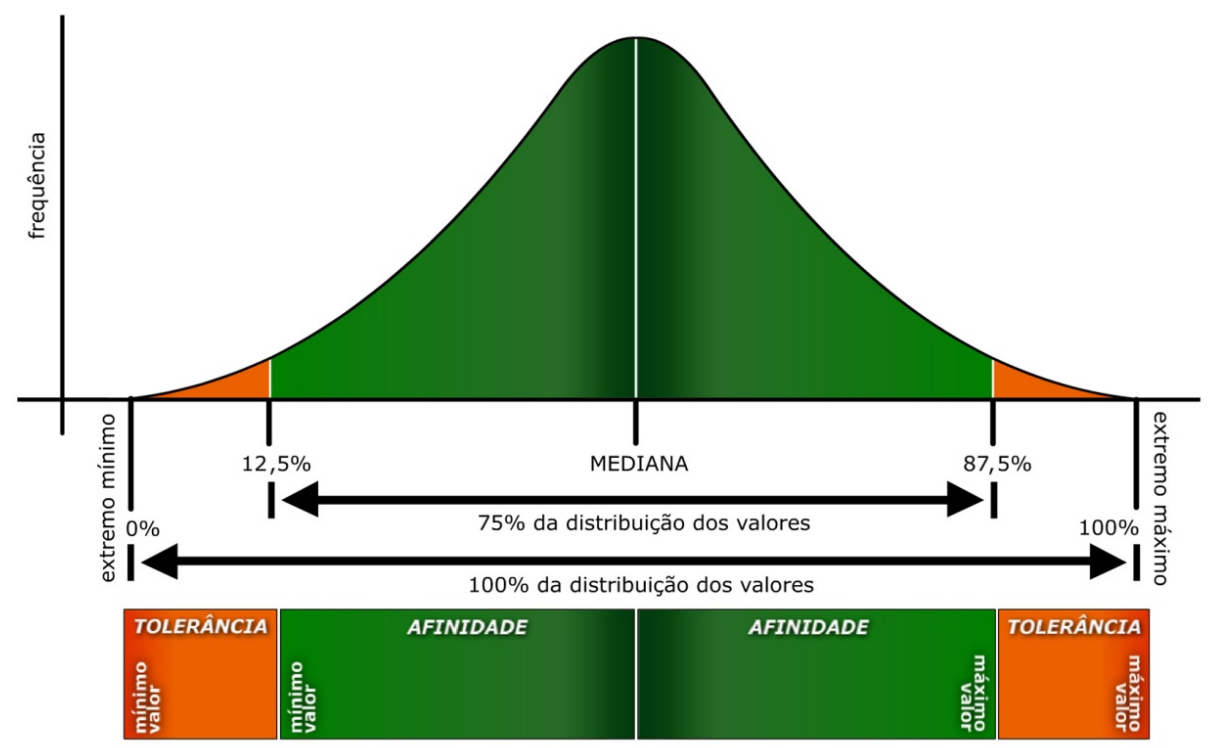

Figura C5-3. Representação teórica da curva da distribuição dos valores de cada variável ambiental e as atribuições dos limiares máximos e mínimos de afinidade e tolerância. 
A definição de limiares de afinidade e tolerância não se aplicará à variável discreta, nomeadamente, a camada de cobertura do solo Globcover (Arino et al., 2010), pois neste trabalho todas suas categorias foram verificadas e comparadas entre áreas focais na caracterização ecogeográfica de Bombus terrestris, embora se tenha ressaltado apenas aquelas mais frequentes. Para a qualificação ambiental das áreas susceptíveis no sul da América do Sul (Quadro SA), apenas as classes mais frequentes na $\mathrm{SA}$, que juntas abrangem $85 \%$ das ocorrências, foram consideradas, pois são estas que melhor representam os fatores bióticos a que a espécie estará efetivamente sujeita durante seu deslocamento do Chile e Argentina até o Brasil.

\section{Apresentação e análise dos dados na caracterização ecogeográfica}

Após a atribuição dos limiares das faixas de afinidade e tolerância, os seus valores foram identificados para cada variável contínua e para cada área focal separadamente (EU, SA, JP, NZT) (detalhes sobre o cálculo matemático poderão ser verificados no Anexo $(5-1 B)$. Suas variações foram exibidas por meio de gráficos do tipo boxplot.

A análise dos limiares foi feita visualmente, de forma comparativa e interpretativa, buscando-se subsídios na literatura para averiguar a coerência e convergência das faixas detectadas com o que já se conhece sobre a espécie.

Alguns efeitos matemáticos indesejáveis foram previstos e considerados na interpretação dos dados a fim de evitar erros de interpretação. Dentre eles, ressalta-se que a faixa de tolerância é altamente influenciada por dados excepcionais ou excêntricos presentes nas ocorrências e/ou nas camadas ambientais, os quais podem não ter sido detectados por meio da filtragem e avaliação de qualidade. Por exemplo, a ocorrência de apenas um único registro de Bombus terrestris em ambientes excepcionalmente diferentes da maioria dos indivíduos poderá influenciar os valores extremos da faixa de tolerância para uma ou várias variáveis ambientais.

Este tipo de efeito indesejável poderá ocorrer, por exemplo, se indivíduos de Bombus terrestris forem capturados por pesquisadores (e as suas coordenadas registradas) em locais ambientalmente inadequados ou atípicos, devido a excepcionais circunstâncias que obrigaram os indivíduos da espécie a cruzar estes ambientes na busca por parceiros sexuais ou recursos alimentares distantes de sua colônia. Também, por exemplo, se uma ou mais células nas variáveis ambientais exibirem um valor extremamente diferente das células adjacentes por conta de artefatos da interpolação; se estas células eventualmente coincidirem geoespacialmente com um ou mais ocorrências da espécie, os dados ambientais poderão expressar-se em extremos irreais de variações.

Os algoritmos de modelagem lidam com estes potenciais outliers por meio de atribuições de intervalos de confiança e outros critérios matemáticos, mas a análise ecogeográfica seria prejudicada por filtragens matemáticas automatizadas, pois juntamente com potenciais erros se poderiam excluir valores reais que indicam limiares mais extremos de tolerância da espécie e que são informações importantes na caracterização ecogeográfica. Ao invés de critérios matemáticos, os dados brutos também foram exibidos nos gráficos de avaliação, permitindo-se detectar visualmente 
se um determinado valor extremo ocorria por conta de apenas um ou poucos registros, o que poderia indicar potenciais exceções.

Similaridades e diferenças ambientais de Bombus terrestris entre áreas invadidas e delas com a área nativa, sugerem o nível de convergência ecogeográfica (intervalos similares entre áreas focais por fator ambiental) e o nível de plasticidade ecogeográfica (intervalos diferentes entre áreas focais por fator ambiental). Estes aspectos ecogeográficos são fundamentais para se entender a capacidade invasiva da espécie, pois quanto mais ecogeograficamente "plástica" for Bombus terrestris, maior será a variedade de ambientes que ela poderá explorar e, eventualmente, invadir.

\subsubsection{Qualificação ambiental da área susceptível}

Para a qualificação ambiental, o maior valor entre os máximos e o menor valor entre os mínimos detectados nas faixas de afinidade de todas as áreas focais para cada variável ambiental (Tabela C3-2) foram identificados e utilizados como limiares de afinidade global para a espécie. Ou seja, para cada variável ambiental, o maior e o menor valor da faixa de afinidade, independentemente da área em que foi detectado, foram usados como extremos representativos da faixa de afinidade da espécie em sua ampla distribuição global (nativa e invasiva).

Por meio de um script específico em linguagem $R$ (Anexo C5-1C), cada camada ambiental contínua (70 camadas; exceto a Globcover), uma de cada vez, foi importada para o $\mathrm{R}$ e sua escala ambiental foi reclassificada por meio de três segmentações da largura total de sua variação da seguinte forma: o segmento superior varia do máximo valor da camada ambiental até o máximo da afinidade global da espécie; o segmento intermediário varia do máximo da afinidade global até o mínimo da afinidade global; o segmento inferior varia do mínimo da afinidade global da espécie até o mínimo da camada ambiental. Os valores das escalas abrangidas pelos segmentos superior e inferior foram anulados (=NA), de forma que as áreas que exibiam geograficamente estas escalas de variação em cada variável foram excluídas. A escala do segmento intermediário foi, de forma contínua e a partir de sua mediana, normalizada de 1 a 0 . Assim, o valor "um" inicia-se na mediana da faixa de afinidade global e "irradia" decrescendo para os extremos da afinidade global, cujos dois valores mais extremos (o máximo e o mínimo) receberam valor "zero".

Este procedimento foi feito, sequencialmente, para todas as 70 camadas contínuas com base nos valores da faixa de afinidade global de cada variável. Cada resultado exibe a variação, a partir da mediana - que se considerou o valor mais central da faixa do ótimo ambiental - a redução progressiva da qualidade ambiental até tornar-se nula quando alcança o início das escalas superior e inferior da faixa de tolerância. Deve-se ressaltar que o valor de qualidade zero não significa na análise a ausência de qualidade, apenas menor qualidade relativa; este aspecto será evidente mais adiante ao longo da metodologia.

Após a reclassificação, todas as camadas ambientais foram somadas umas às outras e o resultado da soma foi normalizado inversamente e variando de 1 a 1001 (mil classes sem o zero). Portanto, o mínimo valor (um) exibe geograficamente as áreas onde o máximo dos "ótimos ambientais para a espécie" de todas ou a maioria das variáveis se sobrepõe no espaço geográfico, ou seja, é a conjuntura de maior qualidade ambiental para a espécie. A partir do valor 1 até o valor 1001, há o progressivo 
decréscimo de qualidade ambiental, cujo máximo valor (1001) exibe geograficamente as áreas com mais baixa qualidade ambiental relativa, mas ainda adequada à espécie. Esta escala foi truncada para agrupar e anular frações (ex: os valores 500,23455 e 500,73423 tornaram-se um único valor $=500$ ), de forma que a escala contínua exibe exclusivamente 1001 valores absolutos (sem o valor zero na escala). Este resultado foi denominado de Camada de Qualidade Abiótica Contínua (CQAC).

As classes da camada de cobertura de solo (Globcover) cujas ocorrências invasivas de Bombus terrestris na América do Sul (SA) coincidem com maior frequência e que juntas somaram mais de $85 \%$ das ocorrências, foram consideradas os tipos de cobertura de solo preferenciais da espécie. Portanto, os tipos de vegetação que oferecem maior abundância e/ou qualidade de recursos necessários à espécie nas áreas invadidas sul-americanas.

A camada de cobertura de solo, agora em resolução original ${ }^{18}$ (células com aproximadamente $300 \times 300$ metros), foi importada em ambiente $\mathrm{R}$ e as classes mais frequentes na SA foram reclassificadas para o mesmo valor $=1$. Já, as classes em que a espécie estava presente em pelo menos uma área focal (SA, JP, NZT, EU), mas em baixa frequência na $S A$, receberam o mesmo valor $=2$. As classes sobre as quais a espécie não se distribuiu em nenhuma das áreas focais foram reclassificas com o mesmo valor = 3. Esta camada com três classes (valores 1, 2 e 3) foi denominada de Camada de Qualidade Biótica Categórica (CQBC).

Além disso, a classe da cobertura de solo (Globcover=210) referente às águas oceânicas, marítimas e continentais (ex: rios, lagos, mares interiores) foi extraída e exportada isoladamente por meio de ArcGIS (ESRI, 2010). A camada resultante em formato de mapa de bits (raster) foi então convertida para o formato poligonal vetorial (shapefile) com suavização das bordas (polígono de limite mínimo). Um buffer em sentido inverso foi criado nesta camada, ou seja, gerando uma faixa de contorno para dentro dos corpos d'água de $10 \mathrm{~km}$ de espessura, considerando-se para isso a máxima distância de voo da espécie (tratado no capítulo 4). O resultado do buffer foi exportado como uma camada denominada de Faixas de Água (FA), e será utilizada como uma zona de atribuição de máxima resistência e delimitação de habitat/não habitat; que será tratada novamente mais adiante.

Todas as camadas resultantes (CQAC, CQBC e FA) foram recortadas na dimensão da área focal SA, e as análises a partir deste ponto tratarão apenas desta abrangência espacial até a próxima redução de dimensão, que será explicitada no momento específico. Ressalta-se que a geração das camadas (CQAC, CQBC) foi feita globalmente, pois requerem informações das ocorrências nativas e invasivas em todas as localidades (SA, JP, NZT, EU), mas a análise dos seus resultados foi limitada à abrangência da $S A$, pois esta é a área de fundamental interesse desta pesquisa.

Após a redução da dimensão espacial, a CQAC foi geoespacialmente multiplicada pela CQBC para se gerar uma camada de resistência ${ }^{19}$ ambiental, que

\footnotetext{
${ }^{18}$ A camada de cobertura de solo (Globcover) foi usada em resolução reduzida (5 minutos de arco) apenas na interceptação dos dados, mas na composição da camada de resistência foi utilizada em resolução original.

${ }^{19}$ Os termos resistência (e seu oposto: a condutância) são termos da Física, sobre eletricidade, que neste caso foram utilizados analogamente à dificuldade e à facilidade de indivíduos de uma espécie ao transitar através de diferentes tipos de paisagem ou por uma gradiente de diferentes condições ambientais. Estes termos têm sido utilizados em ferramentas de conectividade ambiental utilizadas
} 
expressa a escala inversa da qualidade ambiental. Através da multiplicação, a dimensão espacial da classe biótica na qual a espécie ocorre com maior frequência ( $\mathrm{CQBC}$; classe $=1$ ) não alterou os valores da variação contínua abiótica geoespacialmente coincidente (CQAC; mantendo-se variando entre 1 e 1001). Já no caso da classe biótica em que a espécie ocorre com menor frequência (CQBC; classe = 2) a multiplicação duplica o valor da variação contínua abiótica nos locais em que ambas coincidem geoespacialmente (CQAC; variando de 2 a 2002). E a classe biótica em que a espécie não ocorreu (CQBC; classe $=3$ ) triplica o valor da variação contínua abiótica em áreas em que se coincidem geoespacialmente (CQAC; variando de 3 a 3003). Este cálculo estabelece uma ponderação sobre os valores da resistência dos componentes biótico e abiótico na SA, sendo que a CQBC poderá ter um efeito neutro (x1) ou penalizador (acresce resistência) em dois níveis de intensidade (x2 e x3) sobre a variação contínua da resistência da CQAC. Desta forma, a variação contínua da "resistência abiótica" (CQAC) é progressivamente intensificada em ambientes bioticamente menos adequados à espécie (CQBC). Com isso, se assume que, em ambientes bioticamente adequados para a espécie (por exemplo, na floresta temperada), as condições abióticas variam neste compartimento (biótico) em um gradiente de resistência mais "suave" para a espécie do que aquela variação abiótica encontrada em ambientes bioticamente inadequados (por exemplo, na floresta tropical). Mas deve-se ressaltar que nesta camada de resistência combinada (biótico $\mathrm{x}$ abiótico) a escala de variação não é limitante à espécie, pois trata da qualidade ambiental e não de limiares de tolerância da espécie. Portanto, mesmo na faixa de maior resistência, a espécie poderá transitar sobre elas e, eventualmente, ocupá-las.

Para se atribuir geoespacialmente a faixa de resistência infinita, ou seja, os habitat inadequados à espécie, o modelo de susceptibilidade foi utilizado, pois exerce esta função com grande robustez e ainda exibe suas mudanças da inadequabilidade dos habitat para o futuro perante estimativas de mudanças climáticas.

Os modelos de mudança temporal da susceptibilidade (RCP 4,5 e 6,0) que foram projetados considerando-se dois cenários futuros (Capítulo 4 - Item 4.2) contêm integrados aos seus valores a informação do modelo de susceptibilidade em cenário atual (Capítulo 4 - Item 4.1), assim, bastará utilizar apenas estas duas projeções futuras para acoplar as informações de suscetibilidade/insusceptibilidade à camada de resistência ambiental.

Como foram utilizados dois diferentes cenários futuros, agora há a necessidade de juntá-los de forma a combinar as previsões de ambos cenários e definir a zona de exclusão (resistência infinita) mais ajustada aos propósitos da pesquisa. Assim, foi definido que as áreas que são insusceptíveis atualmente e que permanecerão nesta condição em ambos cenários futuros, considerando-os simultaneamente, receberam a resistência infinita. Portanto, nas areas onde houver discordância entre projeções quanto à insusceptibilidade futura, a projeção que indicar susceptibilidade futura na área imperará sobre aquela que indicar insusceptibilidade. Os diferentes tipos de mudança da susceptibilidade no futuro - perda, ganho, aumento e redução - foram posteriormente sobrepostos e avaliados de forma interpretativa conjuntamente com os resultados finais.

principalmente na área de Ecologia de Paisagens, que também foram usadas aqui e estão abordadas mais adiante. 
Tal como foi feito para a camada das faixas d'água (FA), fez-se um buffer inverso de $10 \mathrm{~km}$, reduzindo marginalmente a área de restrição na abrangência decorrente da combinação dos modelos de susceptibilidade em cenários futuros. As áreas da SA externas ao delineamento do buffer foram geoespacialmente anuladas pela atribuição de valor nulo (=NA). Assim, seja sobre água ou sobre zonas de habitat inadequado, considera-se que a abelha poderá voar linearmente $10 \mathrm{~km}$ sobre eles e regressar linearmente $10 \mathrm{~km}$ para o ponto de origem, ou cruzar linearmente uma faixa de $20 \mathrm{~km}$ de habitat inadequado ou água para alcançar um habitat adequado adiante. No entanto, na faixa marginal de $10 \mathrm{~km}$ do buffer da FA, por atribuição, foi definido o mais alto valor de resistência (= 3003), mas isto não foi feito para o buffer das projeções futuras combinadas, mantendo os valores de resistência detectados originalmente, antes da restrição geoespacial. Esta diferenciação decorre de que no caso dos modelos futuros, que são preditivos, há menor nível de garantia em termos de limitações nesta estreita faixa marginal de $10 \mathrm{~km}$ (buffer); já todo elemento geoespacial abrangido pela FA é um fato geográfico - corpos d'água - cujo nível de garantia de resistência para à espécie é elevado. Para fins práticos e de melhor desempenho computacional, a escala de variação da camada (com escala de 1 a 3003) foi novamente normalizada de 1 a 1001 e seus valores foram transformados para números inteiros (agora, arredondados para cima). Este resultado foi denominado Camada de Resistência Ambiental à Expansão Invasiva (CRAEI).

\subsubsection{Conectividade ambiental na área susceptível à invasão na América do Sul}

Para a quantificação e mapeamento da conectividade entre localidades invadidas no Chile e na Argentina, e destas localidades até as áreas susceptíveis no sul do Brasil, foram utilizadas ferramentas de modelagem usualmente aplicadas em estudos de Ecologia de Populações e Paisagens, as quais permitem identificar os caminhos mais "vantajosos" para o deslocamento de indivíduos entre áreas com algum nível de isolamento ou ambientalmente heterogêneas, cujas áreas que as conectam possuem diferentes graus de qualidade ambiental, refletindo-se em maior ou menor permeabilidade para os indivíduos ao longo do trajeto entre áreas.

A conectividade funcional, no contexto do habitat, é definida como o grau (métrico de força ou resistência) exercido por uma paisagem ao facilitar ou dificultar o movimento de uma espécie (de fato, seus indivíduos) entre fragmentos de recursos (Taylor et al., 1993). O gradiente de conectividade em uma paisagem, ou entre paisagens, influencia a dinâmica das populações de uma espécie; por exemplo (extraídos de Zeigler et al., 2011), permitirá ou dificultará na busca por recursos (Dunning et al., 1992, Kozakiewicz, 1995), na recolonização de fragmentos impactados (Henderson et al., 1985), na recuperação de populações em declínio por meio de imigração (Brown e Kodric-Brown, 1977), no aprimoramento da diversidade intraespecífica por meio de fluxo gênico entre populações (Richards 2000) e na manutenção das populações em prazo mais longo (Anzures-Dadda e Manson, 2007; Fagan et al., 2002).

Nesta pesquisa, as métricas de conectividade foram aplicadas para detectar potenciais corredores de invasão, pelos quais a espécie poderá se deslocar com maior facilidade através das áreas susceptíveis, e como ferramenta auxiliar na detecção de zonas de constrição espacial para a expansão invasiva, que são áreas onde a espécie 
encontrará estreita faixa adequada entre amplas áreas inadequadas, sugerindo locais prioritários para o monitoramento do progresso da invasão e, porventura, locais onde ações de controle poderão ser feitas para impedir a progressão da espécie. Também, as métricas de conectividade foram usadas para a detecção de áreas de alta qualidade para a espécie em grandes dimensões espaciais, sugerindo locais com elevado potencial para o estabelecimento de maior número de populações proximamente conectadas entre si, as quais poderão atuar como congregações permanentes de populações-fonte, difundindo indivíduos invasores em longo prazo, consolidando e ampliando o processo invasivo de Bombus terrestris na América do Sul.

Existem vários métodos de análises de conectividade no contexto dos estudos de populações e paisagens, e de forma similar com o que acontece com a modelagem de adequabilidade de habitat, existem diversificadas teorias e princípios que fundamentam análises diversificadas em busca do mesmo tipo de resultado.

A métrica de conectividade mais comumente encontrada em pesquisas de ecologia de paisagens e frequentemente utilizada na identificação de corredores ecológicos para a vida selvagem e como auxiliar na definição de ações de restauração da conectividade entre fragmentos de habitat isolados, são as medidas de distância ponderada pelo custo (cost-weighted distance) (ex: Hoctor et al., 2000; Carroll e Miquelle, 2006). Diferente da distância Euclidiana, em que o menor caminho entre dois pontos é uma reta invulnerável aos elementos do trajeto - analogamente ao trajeto de um avião entre duas cidades, desconsiderando-se os eventos atmosféricos a distância ponderada pelo custo calcula o menor caminho entre dois pontos equilibradamente com o menor custo no deslocamento (para o objeto que se desloca) frente aos elementos existentes ao longo do trajeto, os quais podem ser neutros, adversos ou favoráveis ao deslocamento - analogamente a um carro fazendo o mesmo trajeto que o avião, mas encontrando buracos na estrada, subidas, descidas, congestionamento, etc.

No contexto biológico, a lógica de cálculo da distância ponderada pelo custo considera dois elementos principais: 1) a distância Euclidiana entre os pontos de origem e destino, que é referência de direção e distância do trajeto ideal e; 2) a variedade de características ambientais entre os pontos, que exercem diferentes influências no deslocamento do organismo, e normalmente é representada por uma variável de resistência ao deslocamento. Esta métrica no contexto de um estudo biológico não considera a "entrada de energia externa" (Resistência < 0), que poderia favorecer o movimento para além da permissividade da inexistência de resistência, ou seja, apenas há a neutralidade ambiental ao movimento (Resistência $=0$ ) e a dificuldade crescente ao movimento (Resistência $>0$ ). Embora se possa utilizar uma variável de condutância (ou permeabilidade) ao invés de resistência, esta não implica na entrada de energia externa no movimento $(R<0)$ e será convertida para resistência durante o cálculo (1/condutância = resistência). Este cálculo também assume, a priori, que os indivíduos possuem conhecimento de todos os caminhos potenciais na área onde estão, conhecem o seu destino final de deslocamento e optarão pelo melhor caminho dentre as opções disponíveis, que é o de menor custo.

Recentemente, foi proposta uma métrica complementar na avaliação da conectividade que é baseada na teoria dos circuitos (McRae, 2006; McRae et al., 2008). Essencialmente, a métrica faz uma analogia entre o movimento de indivíduos de uma espécie através da paisagem ao movimento de carga através de circuitos elétricos. A 
lógica do cálculo é inspirada na lei de Ohm (em homenagem a Georg Simon Ohm, 1787-1854), que postula que a diferença do potencial elétrico (ou tensão em unidade Volt - V) existente entre dois pontos conectados por um condutor mantido à temperatura constante é resultado da intensidade da corrente elétrica ( 1 em unidade Ampere) multiplicada pela resistência elétrica do material condutor ( $R$ em unidade Ohm) e é equacionada assim: $\mathbf{V}=\mathbf{R}^{*}$ I. Desta forma, a alta resistência elétrica (R) equivale à menor qualidade ambiental para a espécie no trajeto entre dois pontos; a alta diferença de potencial elétrico (V) equivale à maior força dedicada ao movimento para os organismos superarem as "adversidades" da resistência entre a origem e o destino; e a alta intensidade de corrente (I) equivale a maior magnitude do fluxo de organismos cruzando o ambiente.

O cálculo da resistência é feito celularmente, a partir de um pixel focal inicial e seguindo pelos pixels vizinhos adjacentes com menor resistência e, sequencialmente, pixel a pixel, até o pixel focal de destino; os trajetos são feitos de forma pareada, ponto a ponto de cada vez até o total de pareamentos formados pela máxima combinação entre pares de pontos; o caminho tem como referência de direção ideal uma reta de distância Euclidiana entre pares de pontos; o sentido entre pares de pontos poderá ser uni ou bidirecional, atribuído conforme a necessidade da pesquisa.

Estas duas métricas foram aplicadas nesta pesquisa para avaliar a conectividade, mas não se utilizou áreas ou faixas curto-circuito (teoria dos circuitos) ou de custo zero (distância ponderada pelo custo), que são zonas ambientais onde a resistência ao deslocamento não existe, por dois motivos: primeiramente, por se acreditar que em ambientes terrestres e em circunstâncias naturais não exista fluxo de organismos que não sofra algum nível de resistência; e depois, por se considerar que a espécie, que é invasora, terá sempre que superar obstáculos ambientais durante sua ocupação em áreas previamente inexploradas - portanto não há valor=0 (zero) na camada de resistência.

A ferramenta usada foi um pacote integrativo que inclui estas duas métricas, simplificando a análise de conectividade para a área susceptível à invasão. Os resultados alcançados em outras pesquisas que a aplicaram estes métodos são extremamente convergentes com as necessidades desta pesquisa (ex: Schwartz et al., 2009; Koen et al., 2010; Zeigler et al., 2011). O pacote é denominado Linkage Mapper (McRae e Kavanagh, 2011), o qual é executado em ambiente ArcGIS (ESRI, 2010) e acessa interativamente o software externo Circuitscape 4.0 (McRae, 2006; McRae et al., 2008) para calcular a conectividade sob a teoria de circuitos.

Os dados utilizados na análise de conectividade foram:

1) a Camada de Resistência Ambiental à Expansão Invasiva (CRAEI);

2) vinte e três registros de ocorrências invasivas de Bombus terrestris na América do Sul (SA) que permaneceram após a seguinte sequência de exclusões: 10 registros coincidentes com habitat inadequado foram excluídos; 7 registros que se localizavam em zonas de habitat adequado mas que não proveriam resultados contributivos à análise por estarem em locais relativamente isolados (com evidente alto custo); dois registros excluídos pois distavam apenas cerca de $10 \mathrm{~km}$ de outros registros, neste caso a escolha dos pontos excluídos considerou a manutenção do registro mais distante dos demais (Figura $\mathrm{C} 5-4$ );

3) e sete pontos para referência de trajeto, que foram atribuídos em áreas susceptíveis dentro da zona administrativa do Brasil, sendo um ponto para cada 
município brasileiro fronteiriço com o Uruguai no estado do Rio Grande do Sul: Aceguá; Bagé; Chuí; Dom Pedrito; Herval; Jaguarão; Pedras Altas. Estes pontos foram posicionados em aproximadamente $30 \mathrm{~km}$ de distância da fronteira com o Uruguai, relativamente equidistantes entre si e centralizados tanto quanto possível nas dimensões municipais. Apenas um destes sete pontos não seguiu os padrões gerais de atribuição, pois a característica geográfico-administrativa da cidade de Chuí-RS não permitia (Figura C5-4).

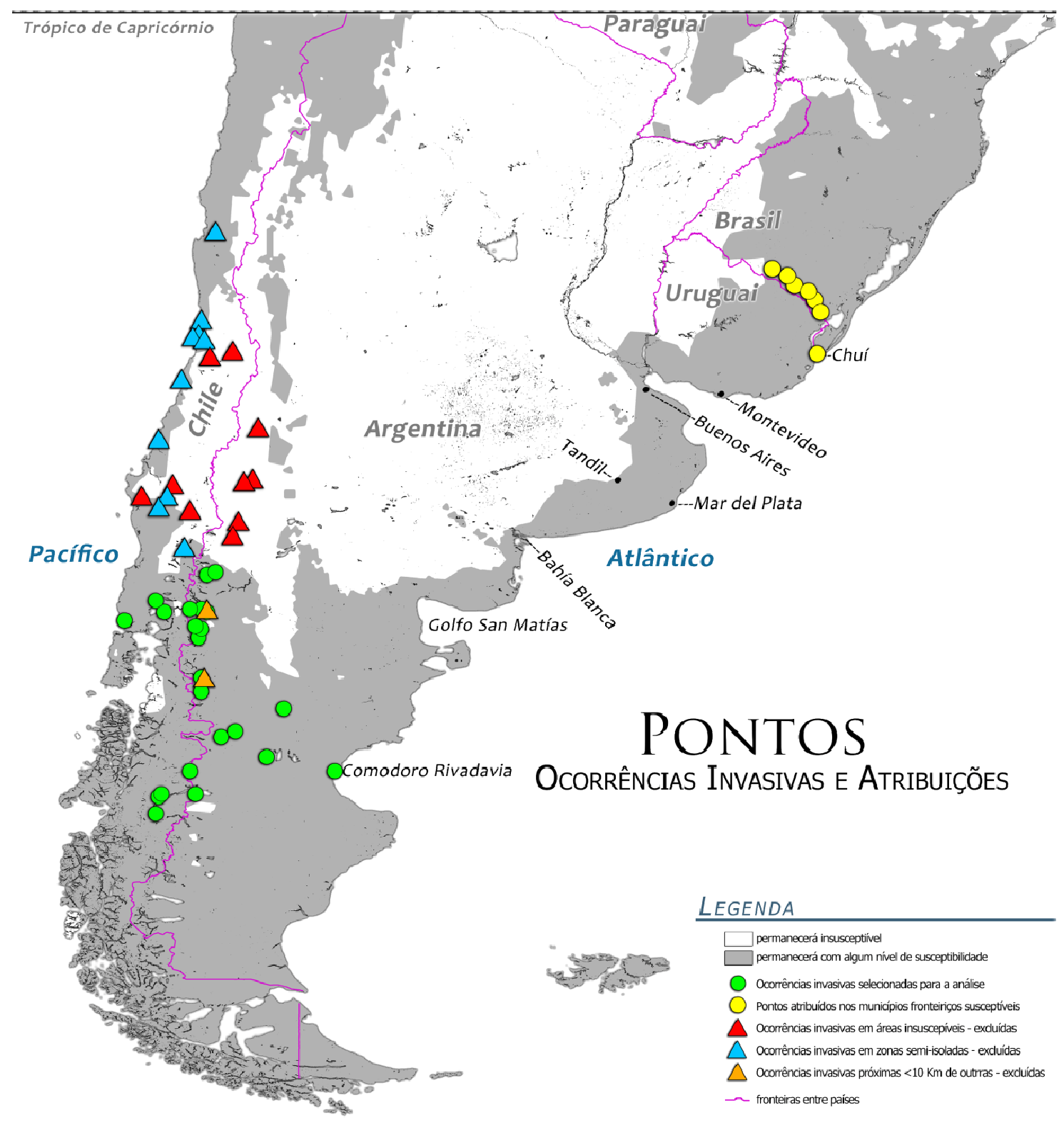

Figura C5-4. Ocorrências invasivas e atribuições no Brasil usadas na análise de conectividade. Os pontos em verde representam as 23 ocorrências invasivas selecionadas para a análise e os pontos em amarelo representam as atribuições de referência no Brasil para identificação de corredores potenciais, sendo que cada um foi atribuído dentro de um município brasileiro fronteiriço com o Uruguai. Os triângulos representam pontos excluídos da análise. 
Os parâmetros da modelagem da conectividade seguiram os padrões originais da análise por omissão, recomendada pelos autores para a maioria das aplicações (McRae 2006; McRae et al., 2008; McRae e Kavanagh, 2011), e a conectividade foi avaliada por meio de iteração pareada pela máxima combinação possível entre os pontos presentes no conjunto total.

A escala métrica utilizada na análise para a comparação dos trajetos lineares de menor custo foi a razão entre a distância ponderada pelo custo e a distância Euclidiana (Cost-weighted Distance to Euclidean Distance Ratio); como estes valores resultantes da análise são relativos, fez-se a normalização da escala de 0 a 1000, sendo que zero é custo mínimo (por distância) e mil é o custo máximo (por distância). Para fins práticos, atribuiu-se à escala normalizada resultante (0 a 1000) uma sigla e uma unidade de referência intuitiva: a CPD (Custo Pela Distância), tornando a apresentação dos resultados e a discussão mais fluida ao evitar a repetitiva citação da frase "normalização da razão entre a distância ponderada pelo custo e a distância Euclidiana" sempre que foi necessário referir-se à métrica; desta forma, usou-se apenas a palavra "custo", "custo pela distância" ou quando referir-se ao valor numérico normalizado, usou-se simplesmente a sigla CPD após o número.

Nos resultados da análise com base na teoria dos circuitos, as zonas originalmente denominadas de pinch points foram traduzidas do inglês para pontos de constrição, que são as zonas de alta concentração de corrente (alta probabilidade de fluxo) por unidade métrica de espaço.

Para a análise dos dados, foram projetados seis mapas com os dados resultantes para a SA exibindo: 1) todos os trajetos lineares de menor custo identificados e seus valores CPD; 2) apenas os trajetos lineares que conectam áreas invadidas com o Brasil sobre a CRAEI; 3) os corredores de invasão; 4) a corrente e os pontos de constrição; 5) os trajetos lineares sobre o modelo de mudança temporal no cenário RCP 4,5 e; 6) os trajetos lineares sobre o cenário RCP 6,0.

\subsubsection{Municípios brasileiros na rota de invasão de Bombus terrestris}

Para a estimativa da potencial progressão invasiva de Bombus terrestris no território brasileiro, fez-se o seguinte procedimento em cinco passos principais:

1) A camada de resistência (CRAEI) foi recortada na dimensão dos estados do sul do Brasil (PR, SC, RS) e parte do Estado de São Paulo (SP) abaixo do Trópico de Capricórnio. Uma cópia desta camada com escala de resistência original foi reservada para a análise de conectividade no passo 4 , e uma outra cópia teve sua escala reclassificada em percentis para reduzir a variabilidade dos valores de resistência mantendo a proporção da escala (de 1 a 1001 para 1 a 100). Esta reclassificação foi feita para aprimorar a amostragem pela maioria dos valores que foi desenvolvida no próximo passo (Figura C5-5 - Quadro 1).

2) Foi criada uma grade de células hexagonais (Jenness, 2012) com dimensão celular de aproximadamente $100 \mathrm{Km}^{2}$, com a extensão máxima necessária para cobrir precisamente a camada de resistência. Esta grade foi utilizada para amostrar a camada de resistência reclassificada por percentis e 
identificar os valores mais frequentes $\left(\right.$ majority $\left.^{20}\right)$ na dimensão de cada unidade celular da grade (Figura C5-5 - Quadro 2). O procedimento de amostragem foi feito em ArcGIS (ESRI, 2010) por meio da função Zonal Statistics.

3) As células desta grade de amostragem cujos valores compreendem o primeiro decil da variação total amostrada foram selecionadas e isoladas em uma nova camada - ou seja, as células com os menores valores de resistência, portanto, com os maiores valores de qualidade ambiental foram selecionadas e separadas das outras. Nesta nova camada, as células selecionadas que eram adjacentes a outras células selecionadas, pois compartilham vértices, foram agrupadas como áreas únicas. Estes agrupamentos e as células selecionadas que permaneceram isoladas (pois não compartilhavam vértices com outras) receberem números exclusivos de identificação, que no total individualizaram 20 diferentes áreas (Figura C5-5 - Quadro 3).

4) Estas 20 áreas e a camada de resistência com escala inicial (reservada no Passo 1) foram utilizadas na análise de conectividade, seguindo-se as mesmas ferramentas e parâmetros do item 5.3.4. Os corredores de menor custo resultantes da análise de conectividade foram geoespacialmente cruzados com a malha de fronteiras administrativas municipais do IBGE (2010) para identificar no Brasil as áreas municipais que cobrem integralmente ou parcialmente estes corredores potenciais de deslocamento invasivo de Bombus terrestris. Os municípios identificados foram isolados e exportados para uma camada externa (municípios em azul na Figura C5-5 - Quadro 4). Também, foram identificados os municípios que intersectam os trajetos lineares de menor custo e os municípios que abrangem total ou parcialmente as 20 áreas de maior qualidade ambiental para Bombus terrestris identificados no passo 3 (em verde na Figura C5-5 Quadro 4).

5) Com o uso da camada reclassificada por percentis (Passo1), calculou-se o valor de resistência mais frequente (majority) nas abrangências dos polígonos referentes a cada município; para isso, foi usada a função Zonal Statistics em ArcGIS (ESRI, 2010). A escala dos valores de amostragem de resistência por município foi então normalizada e invertida pela fórmula:

QUAL_NORM $(\mathrm{i})=\left(\mathrm{MAX}_{\text {res }}-\mathrm{RES}_{(\mathrm{i})}\right) /\left(\mathrm{MAX}_{\text {res }}-\mathrm{MIN}_{\text {res }}\right) \quad|F 1|$

Em que, QUAL_NORM(i) é a qualidade (o inverso da resistência) normalizada por município (i), $\mathrm{RES}_{(\mathrm{i})}$ é o valor (majority) de resistência por município (i), $\mathrm{MAX}_{\text {res }}$ é o máximo e $\mathrm{MIN}_{\text {res }}$ é o mínimo valor de resistência entre todos os municípios.

\footnotetext{
${ }^{20} \mathrm{O}$ cálculo pela maioria dos valores na abrangência celular para a amostragem da resistência é estatisticamente mais favorável neste caso do que o cálculo de tendências centrais como a média ou mediana, pois a dimensão celular de amostragem abrange uma variedade de valores de resistência, cuja maioria destes valores gerará maior influência no trajeto da espécie cruzando esta dimensão, do que um único valor "comprimido" pela média, ou um único valor que se encontra na centralidade da distribuição dos valores de resistência (mediana).
} 
Este procedimento gerou uma camada de polígonos (shapefile) identificando os municípios que estão nos corredores de invasão de Bombus terrestris no Brasil. Estes polígonos exibem as dimensões espaciais destes municípios e, associados a cada um deles, os valores de qualidade ambiental para a espécie. Esta camada será utilizada em todos os procedimentos subsequentes, e novas colunas serão acrescidas à tabela de atribuições desta camada a cada resultado. A partir deste item a escala geográfica foi reduzida para a dimensão destes municípios selecionados e seus arredores.
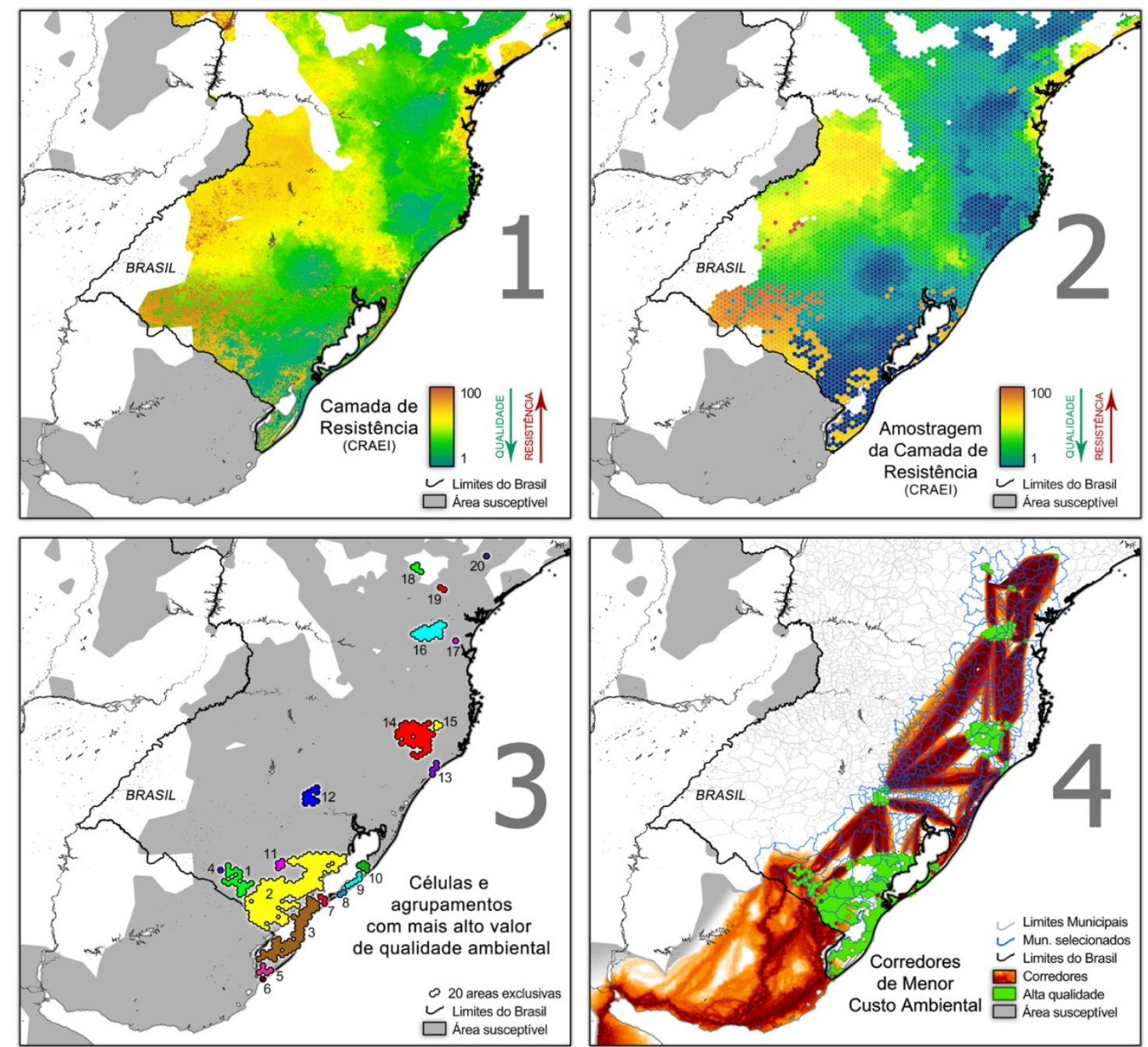

Figura C5-5. Sequência de passos para a identificação dos municípios brasileiros na potencial rota de expansão invasiva de Bombus terrestris pela América do Sul. Quadro 1) Passo 1: Ajuste das dimensões e escala da camada de resistência ambiental (CRAEI). Quadro 2) Passo 2: Amostragem celular ( $100 \mathrm{Km} 2$ de área) dos valores de resistência. Quadro 3) Passo 3: Identificação de 20 áreas com maior qualidade ambiental para a espécie no Brasil. Quadro 4) Passo 4: Municípios brasileiros (em azul) que abrangem corredores de menor custo que conectam áreas de alta qualidade ambiental para a espécie invasora, evidenciando também os corredores identificados na América do Sul a partir de locais invadidos. 


\subsubsection{Abelhas Bombus nativas na rota de invasão de Bombus terrestris no Brasil}

Para se estimar o potencial de interação entre Bombus terrestris e as abelhas nativas do gênero Bombus que ocorrem nos municípios do Brasil, foram feitos modelos de adequabilidade de habitat para as quatro espécies de Bombus que se distribuem na região: Bombus atratus; Bombus brasiliensis; Bombus bellicosus; Bombus morio.

O método de modelagem que foi utilizado para as espécies nativas seguiu praticamente o mesmo método utilizado para Bombus terrestris (consultar Capítulo 4 para mais detalhes) com a diferença apenas na geração dos conjuntos de pseudoausências. Assim, os modelos foram executados com as mesmas nove variáveis independentes menos correlacionadas (Bios 2, 5, 7, 13, 14, 15, 18, 19 e Altitude), na mesma extensão (global) e resolução ( 5 minutos de arco), com os mesmos parâmetros e algoritmos (10 ao todo), também com 5 rodadas por espécie com particionamento aleatório do conjunto de ocorrências, sendo $25 \%$ para teste e $75 \%$ para treino. Entretanto, para as espécies nativas, os 5 conjuntos das pseudo-ausências (PA1 a PA5) foram exclusivamente gerados aleatoriamente de forma automatizada pelo Biomod2, e cada conjunto PA conteve 10 vezes o número total de registros por espécie sem reposição entre conjuntos, e foi atribuído na função integrada do Biomod2 (strategy) o impedimento da geração automática de pseudo-ausências em áreas circundantes as presenças com raio de aproximadamente $20 \mathrm{~km}$.

Já o método de seleção dos modelos mais precisos entre os 250 gerados para cada espécie nativa de Bombus (resultantes da combinação de 10 algoritmos x 5 particionamento das presenças $x 5$ conjuntos de pseudo-ausências) foi diferente daquele feito para Bombus terrestris. Primeiramente, deve ser relembrado que no processo de seleção de modelos para Bombus terrestris no cenário atual (Capítulo 4, Item 4.1) os registros de ocorrência invasiva foram usados no estágio 2 para qualificar as rodadas de modelagem em termos de capacidade de extrapolação da previsão de adequabilidade para locais distantes da ocorrência nativa da espécie (ou susceptibilidade, naquele caso). No estágio 3, os registros de ocorrência invasivas também foram utilizados para a seleção dos conjuntos de modelos formados em cada limiar PCC (Pearson's Correlation Coefficient), em que três agrupamentos de modelos foram selecionados por abarcarem conjuntamente as mais marcadas mudanças nos índices de avaliação, em especial, o IHR (Invasive Hit Rate; taxa de acerto nas ocorrências invasivas).

No caso das espécies de Bombus nativas, notoriamente, não há registros de invasão, pois não são consideradas espécies invasoras, de forma que as métricas de avaliação dos estágios 2 e 3 desenvolvidas para Bombus terrestris não são aplicáveis. Assim, para a seleção do conjunto de modelos mais precisos dentre os 250 gerados por espécie nativa utilizou-se as seguintes métricas de seleção de modelos e método de geração de modelos compostos por espécie:

1) Avaliação da qualidade preditiva por TSS (True Skill Statistics; Allouche et al., 2006). A mesma métrica estatística utilizada no estágio 1 do capítulo 4 para Bombus terrestris também foi utilizada para as espécie nativas, assim: dentre os 250 modelos gerados por espécie, apenas aqueles que alcançaram valores de TSS superiores ou igual a 0,8 foram mantidos no conjunto para a próxima etapa de avaliação, os outros modelos foram excluídos. 
2) Com base na lógica aplicada para Bombus terrestris no estágio 3 do capítulo 4, uma métrica similar foi aplicada para selecionar os modelos preditivamente mais convergentes no contexto geral do conjunto de modelos remanescentes após a seleção por TSS. Conforme já abordado no Capítulo 4, quanto maior for a correlação geoespacial média (coeficiente de correlação de Pearson - PCC) por modelo, maior será a convergência preditiva deste no contexto geral das predições no conjunto de modelos, assim: por cada espécie, foram selecionados exclusivamente aqueles modelos cuja média dos índices de correlação pareados com todos os outros modelos (exceto com ele mesmo; que é $=1$ ) superava a média geral deste mesmo índice entre todos os modelos. Detalhes sobre a lógica poderão ser consultados no Capítulo 4 e sobre o método matemático de cálculo e seleção modelos para as espécies nativas no Anexo C5-1D.

3) Após as duas etapas de seleção, a composição dos modelos remanescentes por espécie seguiu o método aplicado para Bombus terrestris para se gerar o Agreement Level Ensemble Model (ALM; Capítulo 4); que é soma geoespacial dos modelos mais precisos e preditivamente mais convergentes. Mas para as espécies nativas não se gerou o Overall Prediction Ensemble Model (OPM), pois apenas o ALM permite identificar por espécie o gradiente de convergência preditiva entre modelos. Este gradiente, de fato, não trata especificamente da probabilidade de ocorrência de uma espécie no espaço geográfico, devido não ser um indicativo direto da variação da menor para a maior qualidade na conjuntura dos fatores ambientais para a espécie, mas é um indicativo da "probabilidade" de acerto na predição da adequabilidade do habitat, pois exibe o nível de concordância entre modelos de alta precisão (após filtragem) gerados por múltiplas rodadas, cujos resultados foram alcançados por meio de diferentes lógicas de cálculo (diferentes algoritmos) e uma parcial variação nos dados de entrada (diferentes partições das presenças em teste e treino e diferentes conjuntos de pseudo-ausência). Assim, mesmo indiretamente, as áreas com maior convergência preditiva também poderão ser consideradas mais robustas na indicação da potencial presença da espécie, pois consolida as diferentes evidências (variáveis dependentes) e modos de análise (algoritmos) numa resposta compartilhada entre rodadas em diferentes níveis. Esta grandeza escalar foi utilizada na classificação do potencial de interação entre Bombus nativas e a espécie invasora nos municípios no trajeto da invasão. 0 processo metodológico para as espécies nativas é secundário à pesquisa, apenas seus resultados finais são prioritários, assim, a verificação da robustez do gradiente de convergência preditiva, os ALM por espécie, as avaliações em termos de TSS, PCC, e o desempenho dos algoritmos foram incluídos no Anexo C5-2.

Convém relembrar que os valores das classes dos ALM variam de zero, indicando as áreas em que todos os modelos convergiram na predição da inadequabilidade, até o número total de modelos selecionados, indicando as áreas em que todos os modelos convergiram na predição da adequabilidade (ex: 22 para Bombus bellicosus e 34 para Bombus morio; Anexo (5-2). Para se estabelecer a equivalência de escalas dos ALM 
entre espécies, aprimorando a comparabilidade da convergência preditiva entre elas, os ALM foram normalizados de 0 a 1 seguindo a lógica na fórmula:

$\mathrm{ALM}_{\mathbf{N}} \mathrm{NORM}_{(\mathrm{i})}=\mathrm{ALM}_{(\mathrm{i})} / \mathrm{MAX}_{\mathrm{alm}(\mathrm{i})} \quad|F 2|$

Em que, ALM_NORM(i) é o resultado da convergência preditiva normalizada para a espécie (i), $A_{L M}(i)$ é o modelo de convergência preditiva da espécie (i) em escala original e $\mathrm{MAX}_{\mathrm{alm}(\mathrm{i})}$ é o máximo valor de convergência no ALM da espécie (i). Considerando que o mínimo valor de convergência preditiva sempre é zero (o habitat inadequado), bastará dividir o modelo pelo máximo valor de convergência para normalizá-lo.

A camada com os polígonos dos municípios na rota de invasão de Bombus terrestris no Brasil, gerada no item anterior, foi aqui utilizada para se calcular a média dos valores das células de cada ALM normalizado (por espécie) por área municipal; cálculo que foi feito em ArcGIS (ESRI, 2010) pela função Zonal Statistics.

\subsubsection{Potenciais interações com as culturas agrícolas no Brasil}

Foram identificadas vinte culturas agrícolas com as quais Bombus terrestris estabelece interações, pois as polinizam, e que são desenvolvidas nos municípios brasileiros na rota de invasão (Tabela C-5.1). Dentre estas culturas, foram encontrados dados de produção no período de 2006 a 2013 (este último, é o ano mais recente disponível) para oito culturas, e para o ano de 2006 foram doze. A identificação das culturas agrícolas com que a espécie invasora interage foi feita com base em informações da literatura e de empresas que comercializam colônias para polinização agrícola (ex: Velthuis e Van Doorn, 2004, 2006; Biobest, 2015). Os dados de produção agrícola municipal foram obtidos do portal de internet que acessa o banco de dados agregados do Instituto Brasileiro de Geografia e Estatística (SIDRA, 2014; Sistema IBGE de Recuperação Automática).

Tabela C5-1. Plantas agrícolas com que Bombus terrestris interage e cujas produções são monitoradas pelo IBGE. Entre parênteses estão exibidos o período ou o ano em que os valores de produção estão disponibilizados pelo IBGE.

\begin{tabular}{ll}
\hline Abacate (2006 a 2013) & Melancia (2006 a 2013) \\
Abóbora (2006) & Melão (2006 a 2013) \\
Abobrinha (2006) & Morango (2006) \\
Alho-poró (2006) & Pepino (2006) \\
Batata (2006 a 2013) & Pera (2006 a 2013) \\
Berinjela (2006) & Pimenta (2006) \\
Cebola (2006 a 2013) & Pimentão (2006) \\
Cenoura (2006) & Repolho (2006) \\
Kiwi (2006) & Tomate estaqueado - mesa (2006 a 2013) \\
Maçã (2006 a 2013) & Tomate rasteiro - indústria (2006) \\
\hline
\end{tabular}

Tendo em vista que algumas culturas são permanentes e outras temporárias, atribuiu-se por cultura agrícola o valor binário 1 para os municípios produtores no período de 2006 a 2013 ou produtores apenas ano de 2006 (Tabela C-5.1), indiferentemente se a produção ocorreu em um ou em todos os anos, bem como indiferentemente quanto à quantidade plantada, colhida, ou valor de produção; o 
valor binário 0 foi atribuído para os municípios que não produziram as determinadas culturas em quaisquer anos no período de 2006 a 2013.

Subsequentemente, os valores binários referentes à presença (ou a ausência) de culturas por município foram somados, obtendo-se a estimativa da diversidade de culturas, dentre o total de 20 , que cada município produziu no período. Para os propósitos da análise deve se assumir que estes municípios possuem estas culturas em desenvolvimento ou que possuem o potencial de voltar ou continuar a produzi-las no futuro. Após a soma, a variação da quantidade de culturas por município foi normalizada de 0 a 1, pela fórmula:

CULT_NORM $(\mathrm{i})=\left(\mathrm{CULT}_{(\mathrm{i})}-\mathrm{MIN}_{\text {muni }}\right) /\left(\mathrm{MAX}_{\text {muni }}-\mathrm{MIN}_{\text {muni }}\right) \quad$ /F3/

Em que CULT_NORM(i) é o resultado normalizado da diversidade de culturas no município (i), CULT (i) é o valor da soma (binária) da quantidade de culturas produzidas no município (i) , MIN muni é o mínimo de culturas produzidas por um município dentre todos os municípios considerados (ou igualmente mínima em mais de um município) e $\mathrm{MAX}_{\text {muni }}$ é o máximo de culturas produzidas por um município dentre todos os municípios considerados (ou igualmente máxima em mais de um município). Portanto, a camada de municípios agora também agrega uma grandeza escalar relativa da diversidade de culturas agrícolas na rota potencial de invasão de Bombus terrestris no Brasil com as quais a espécie é conhecida por interagir.

\subsubsection{Repercussões das mudanças climáticas na rota de invasão no Brasil}

As potenciais repercussões das mudanças climáticas na rota de invasão de Bombus terrestris no Brasil foram verificadas por meio da amostragem por área municipal das estimativas feitas pelos modelos em dois cenários futuros (RCP 4,5 e 6,0 ). Considerando-se que as mudanças são representadas por categorias, o tipo de mudança predominante (majority) na abrangência municipal foi considerado o mais significativo para apontar as mudanças futuras da susceptibilidade por município, assim, estes valores foram calculados em ArcGIS (ESRI, 2010) pela função Zonal Statistics. Portanto, estes valores categóricos também se tornaram acrescidos à camada de municípios em seu formato numérico original, mas que posteriormente foram associados às descrições textuais dos significados de suas categorias (função join); e mapas foram gerados para cada cenário.

\subsubsection{Integração dos dados para a avaliação da progressão invasiva de Bombus terrestris no Brasil}

É plausível sugerir que Bombus terrestris poderá interagir com as espécies de Bombus nativas quando (e se) invadir Brasil, bastando-se para isso considerar os relatos de interações entre a espécie invasora com outras espécies nativas do gênero Bombus em vários locais do mundo (Dafni e Shmida, 1996; Kearns et al., 1998; Ruz, 2002; Inoue et al., 2008; Kanbe et al., 2008; Kondo et al., 2009; Arbetman et al., 2013; Morales et al., 2013). As características compartilhadas entre as espécies do gênero Bombus, especialmente no que concerne à socialidade e ao uso de recursos, poderão resultar em interações desarmônicas para uma parte ou para ambos interagentes, especialmente na decorrência de competição por recursos, que poderá levar a reduções populacionais ou mesmo exclusões locais para as espécies nativas e à 
redução do progresso ou mesmo o impedimento da expansão invasiva de Bombus terrestris em determinadas áreas no Brasil. Deve-se considerar ainda que Bombus terrestris poderá contrair e/ou disseminar doenças ao longo de sua expansão invasiva na decorrência de interações com plantas e abelhas nativas.

Nos municípios brasileiros onde há alta qualidade ambiental para a espécie invasora e, simultaneamente, também há alta convergência preditiva para uma determinada Bombus nativa, pode-se sugerir que o potencial de interação entre Bombus terrestris com esta determinada espécie será elevado. É razoável supor que quanto mais Bombus nativas estiverem potencialmente presentes neste município invadido, indicado indiretamente pelas convergências preditivas de cada espécie nativa, o potencial de interação entre a invasora e as nativas será ainda maior.

É possível que haja diferenças nas interações entre cada particular espécie nativa com a invasora, dependendo dos diferentes tipos de recursos disponíveis e dos peculiares requerimentos de cada espécie. No entanto, nada foi encontrado na literatura que permitisse sugerir preditivamente diferentes tipos ou níveis de interações potenciais entre as espécies (nativas <-> invasora). Por conta disso, não foram incluídos pesos diferenciais entre as espécies nativas nos valores de convergência preditiva normalizados por município (resultado do item 5.3.6), que foram então somados e divididos por quatro, obtendo-se a combinação das convergências preditivas das espécies nativas com base na média municipal.

A diversidade de culturas agrícolas nos municípios brasileiros susceptíveis na rota de invasão indicará, indiretamente, o nível de disponibilidade de recursos alimentares para a espécie invasora, mas também o nível de potenciais repercussões a estas culturas, que podem ser tanto negativas (ex: doenças exóticas) quanto positivas (ex: serviços de polinização). Não é possível estimar robustamente a riqueza de plantas selvagens nativas nos Pampas, as quais a espécie invasora poderá efetivamente explorar quando invadir, mas é possível sustentar com alguma segurança que as culturas desenvolvidas nestes municípios lhe proverão recursos, e quanto maior for a diversidade de culturas, potencialmente maior será a variedade e a disponibilidade destes recursos. Além disso, como se poderá ler no próximo capítulo, após a verificação em campo constatou-se que devido à intensidade da degradação dos ambientes naturais no sul do país, a sobrevivência das abelhas que eventualmente dependem exclusivamente de recursos selvagens estará comprometida; por outro lado, aquelas que usufruem de culturas agrícolas para sua sobrevivência poderão ter recursos disponíveis, pelo menos aqueles providos por culturas não afetadas por agroquímicos.

Em projeções cartográficas, as representações das distribuições de grande quantidade de dados numéricos por meio de um gradiente contínuo de cores são especialmente úteis para comparações visuais entre regiões geográficas sem detalhamento dos valores numéricos intermediários, apenas expondo os valores extremos da escala. Já quando se deseja delinear geoespacialmente determinadas áreas, a fim de priorizá-las ou discriminá-las geoespacialmente de forma mais precisa, o fracionamento da variação contínua em um menor número de classes será necessário, pois permitirá representar em mapa áreas com cores visualmente distinguíveis e representativas de intervalos numéricos bem definidos.

Três mapas foram projetados em escala contínua para a variação municipal normalizada da (A) qualidade ambiental para Bombus terrestris (resultado do item 
5.3.5), (B) convergência preditiva média das espécies de Bombus nativas (resultado do item 5.3.6) e (C) diversidade de culturas agrícolas (resultado do item 5.3.7). Mas também dois mapas foram projetados em escala categórica, combinando as variáveis " $A$ " com " $B$ " e " $A$ " com " $C$ ". Para tanto, as variações das escalas contínuas ( $A, B$ e C) foram fracionadas em 3 intervalos iguais, ou seja, cada intervalo abrange um terço da variação total, e estes intervalos tiveram seus valores reclassificados para três níveis em ordem crescente (1, 2 e 3$)$.

Para a combinação das variáveis, os dados categorizados de uma variável (ex: qualidade ambiental) foram concatenados (e não calculados) de forma pareada por município com os dados categorizados da outra variável (ex: diversidade de culturas), gerando-se uma nova variável combinada com nove classes categóricas $(11,12,13,21$, $22,23,31,32,33)$, a qual foi usada na geração de dois mapas coropléticos bivariados. A representação visual da covariação de pares de variáveis no espaço geográfico por meio de uma escala matricial com nove classes é bastante intuitiva, e sua lógica de construção e interpretação em mapa esta ilustrada pela Figura C5-6.
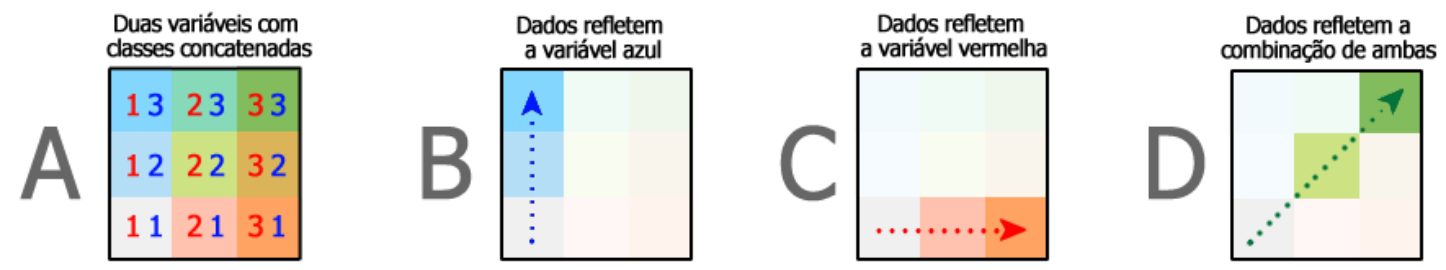

Figura C5-6. Diagrama de construção e interpretação da escala matricial bivariada. A concatenação de duas variáveis com três categorias cada gera uma matriz de nove classes (A). O eixo $Y(B)$, de baixo para cima, exibe a variação crescente da primeira variável (neste exemplo em azul), que ocorre igualmente em todas as colunas subsequentes. $O$ eixo $X(C)$, da esquerda para direita, exibe a variação crescente da segunda variável (em vermelho), que ocorre igualmente em todas as linhas subsequentes. A covariação de ambas é exibida pelo eixo diagonal (em verde) a partir da célula inferior-esquerda para a célula superior-direita (D).

\subsection{Resultados e Discussões}

Para referenciar as diferentes zonas de ocorrência de Bombus terrestris na apresentação dos resultados e nas discussões integradas ao longo do texto, as siglas atribuídas às áreas focais em escala global foram preferencialmente utilizadas. Portanto, "EU" foi usada para referenciar a abrangência nativa da espécie, que ocorre predominantemente na Europa, mas inclui países adjacentes (Capítulo 1 para detalhes); para referenciar as abrangências das ocorrências invasivas: na América do Sul usou-se SA, no Japão usou-se JP e na Nova Zelândia e Tasmânia (Austrália) usou-se NZT.

Os valores numéricos das faixas de afinidade e tolerância por cada variável e área poderão ser integralmente consultados no Anexo C5-3, pois, ao longo do texto foram citados apenas valores de variáveis quando foram considerados importantes para fundamentar ou contextualizar a argumentação, nem todos os valores foram incluídos no texto.

Para caracterizar ecogeograficamente Bombus terrestris assumiu-se, na interpretação das variações ambientais nas localidades de ocorrência da espécie em todo o planeta, uma perspectiva ampla e geral que foi, sempre que havia dados 
disponíveis ou que foram encontrados, subsidiada e comparada por conhecimentos previamente publicados sobre a espécie e as áreas por outros autores.

Não se seguiu uma ordem numérica específica ao se abordar as variáveis ambientais, elas foram cruzadas conforme a conveniência argumentativa, mas seguiuse uma ordem lógica entre grupos de variáveis afins, sendo que primeiro foi abordada a altitude, depois as variáveis relacionadas a temperatura, em seguida as relacionadas a precipitação e, finalmente, a cobertura de solo.

\subsubsection{Caracterização Ecogeográfica de Bombus terrestris}

A análise ecogeográfica demonstrou que Bombus terrestris em seu ambiente nativo (EU) tem afinidade com as baixas altitudes, entre 21 a 278 metros (Alt; Figura C5-7). Apenas um registro isolado ocorreu no valor extremo superior máximo da faixa de tolerância, 2167 metros, e menos que 1\% (41 registros) ocorreu em altitudes superiores a 1000 metros. Pode-se observar também que a maioria das ocorrências invasivas (75\%) no JP também ocorre em baixas altitudes, cuja faixa de afinidade varia entre 22.8 e 238.3 metros, que são valores muito similares àqueles detectados para EU nesta mesma faixa. Já na SA e na NZT a maioria das ocorrências da espécie ocorre em altitudes um pouco mais elevadas, mas ainda baixas, respectivamente, entre $136 \mathrm{e}$ 1204.5 metros e entre 60.8 e 720.5 metros.

Rasmont e Flagothier (1996) relataram que Bombus terrestris na Turquia evita as altas altitudes e é a espécie de mamangava predominante nas zonas de planícies e no alto de colinas baixas, entre as altitudes de 1 e 500 metros. Apesar de que $75 \%$ dos indivíduos que estes pesquisadores observaram na Turquia ocorriam abaixo dos 500 metros, também encontraram indivíduos em altitudes de 2200 metros. Iserbyt et al. (2008) encontraram, nos Pirineus Orientais da França, 98 indivíduos de Bombus terrestris vivendo em altitudes entre 1480 e 2685 metros. Estes relatos sugerem que o valor máximo de altitude detectado na faixa de tolerância da EU (2167 m) é plausível para a espécie e não uma exceção, bem como indica a alta tolerância da espécie às elevadas altitudes em determinadas regiões do planeta. Outros dois aspectos também estão relacionados com a presença da espécie em baixas altitudes: 1) Torreta et al. (2006) relatam que Bombus terrestris na América do Sul possivelmente cruzou os Andes, do Chile para a Argentina, transitando por corredores de baixas altitudes; 2) 0 modelo de susceptibilidade atual e os dois projetados em cenários futuros (Capítulo 4), com raras exceções, mostrou que a conjuntura de fatores ambientais em zonas de elevadas altitudes (acima de 3000 metros), se mostra inadequada à espécie; por exemplo, a insusceptibilidade detectada em montanhas dos Alpes, dos Pirineus, dos montes Escandinavos e nas zonas montanhosas da NZT.

A caracterização ecogeográfica permitiu verificar que a faixa de tolerância de Bombus terrestris às temperaturas máximas no mês mais quente do ano (Bio 5; Figura $\mathrm{C} 5-7)$ em sua área nativa (EU; 14 a $35,7^{\circ} \mathrm{C}$ ) é consideravelmente mais larga do que nas áreas invadidas (JP, SA, NZT). Algo que também foi verificado na temperatura média na estação (trimestre) mais quente do ano (EU; Bio 10; entre 8 e 27, $8^{\circ} \mathrm{C}$; Figura $\mathrm{C} 5-8$ ). Deve-se considerar que a maior amplitude de tolerância térmica detectada na área nativa em relação às áreas invadidas é também um reflexo da dimensão espacial da abrangência dos registros na EU, que é muito superior às outras áreas focais, compreendendo um grande gradiente de variações ambientais. 
Velthuis e van Doorn (2006) relatam que a Bombus terrestris cessa a atividade de forrageio quando em ambientes com temperaturas superiores a $32^{\circ} \mathrm{C}$, mas permanece hábil para voar mesmo quando a temperatura do ar supera os $35^{\circ} \mathrm{C}$. Bombus terrestris possui a capacidade de ventilar as colônias para mantê-las internamente abaixo do limiar de $30^{\circ} \mathrm{C}$. Mas os ambientes que apresentam estas temperaturas altas geram riscos às colônias, pois se as colônias forem elevadas a temperaturas superiores a $30^{\circ} \mathrm{C}$, a prole poderá ser prejudicada (Vogt, 1986; Weidenmuller, 2004; Gurel e Gosterit, 2008).

Não se pode identificar nos dados climáticos o período de permanência dos máximos térmicos na área nativa; se estes valores são eventuais (um dia, ou poucos dias) ou são frequentes ao longo do mês ou da estação mais quente do ano na área onde os indivíduos estão expostos a estes valores extremos. O valor máximo exibido no mês mais quente na EU $\left|35,7^{\circ} \mathrm{C}\right|$ (Bio 5; Figura C5-7) possivelmente é eventual, haja vista que o máximo durante a estação mais quente do ano (3 meses) nesta mesma área (EU) é bastante menor $\left|27,8^{\circ} \mathrm{C}\right|$ (Bio 10; Figura $\mathrm{C} 5-8$ ), assim como também a máxima da temperatura média anual na EU que é de apenas $19^{\circ} \mathrm{C}$ (Bio 1; Figura $\mathrm{C5}-7$ ). Além disso, os valores na faixa dos $35^{\circ} \mathrm{C}$ na variação anual das temperaturas máximas (Figura C5-12) na área nativa (EU) ocorrem em apenas julho e agosto, e pelos dados brutos (traços pretos) a quantidade de localidades na EU que alcançam estes altos valores é muito pequena. É possível que a espécie (de fato, suas colônias) apenas tolere valores ambientais superiores a $35^{\circ} \mathrm{C}$ quando estes ocorrerem por curtos períodos, de forma que sua habilidade de ventilar a colônia seja capaz de manter a temperatura interna em níveis seguros, e que a espécie não poderá sobreviver em ambientes onde valores iguais ou superiores a $35^{\circ} \mathrm{C}$ poderão ocorrer com frequência ou por longos períodos no mês ou na estação mais quente do ano.

A faixa de afinidade de Bombus terrestris às temperaturas máximas no mês mais quente (Bio 5; Figura C5-7) na área nativa (EU), que varia entre 18.6 e $23^{\circ} \mathrm{C}$, é muito mais restrita do que a faixa de tolerância nesta mesma área, e também é muito similar à faixa de afinidade na NZT $\left(18,1\right.$ e $\left.22,6^{\circ} \mathrm{C}\right)$. Já as faixas de afinidade na SA $(18,7$ e $\left.27,8^{\circ} \mathrm{C}\right)$ e no JP $\left(21,7\right.$ e $\left.25,8^{\circ} \mathrm{C}\right)$ são um pouco mais altas (Bio 5; Figura C5-7). Já as afinidades nas médias da estação mais quente (Bio 10; Figura C5-8) são, para todas as áreas, um pouco mais baixas (EU: 14,0 a $17,0^{\circ} \mathrm{C}$; SA: 12,0 a $18,6^{\circ} \mathrm{C}$; JP: 16,7 a $19,8^{\circ} \mathrm{C}$; NZT: 12,2 e $\left.16,6^{\circ} \mathrm{C}\right)$.

Os máximos das faixas de afinidade em todas as áreas para as temperaturas máximas no mês mais quente do ano (Bio 5; Figura C5-7) e para as médias na estação mais quente do ano (Bio 10; Figura C5-8) estão sempre abaixo do limiar máximo de temperatura que as colônias podem alcançar internamente antes de ocorrem riscos à prole $\left|30^{\circ} \mathrm{C}\right|$ (Vogt, 1986; Weidenmuller, 2004, Gurel e Gosterit, 2008). Todavia, Gurel e Gosterit (2008) detectaram experimentalmente que a faixa ótima de temperatura interna para o desenvolvimento das colônias de Bombus terrestris varia entre 24 e $30^{\circ} \mathrm{C}$. Considerando-se estes aspectos, pode-se sugerir que, em termos relativos globais, Bombus terrestris tem maior afinidade ecogeográfica com locais cujos verões são mais amenos, e que a espécie "prefere" aquecer a temperatura interna da colônia, em circunstâncias de temperaturas externas mais baixas, do que resfriá-la, em circunstâncias de temperaturas externas mais altas.

As Bombus são hábeis em resfriar o interior das colônias por meio da ventilação gerada pelo bater de asas, mas são também hábeis para aquecer o interior da colônia 
por meio de vibração muscular. Pode-se sugerir que a eficiência de aquecimento é superior à eficiência de resfriamento em certos casos, pois o resfriamento dependerá diretamente da temperatura externa, afinal o ar que circula (que vem de fora da colônia) para ventilar o interior da colônia não poderá estar muito aquecido pelo sol, o que comprometeria a eficiência do resfriamento. Já o aquecimento dependerá menos da temperatura externa e mais do poder do isolamento térmico da colônia e da capacidade (e da quantidade) dos indivíduos em aquecê-la. Assim, as faixas de afinidade detectadas em todas as áreas, que exibem valores mais baixos que o ótimo térmico para o desenvolvimento das colônias, sugerem que a espécie poderá ter alguma limitação às temperaturas muito elevadas no verão, como aquelas que ocorrem em faixas tropicais do planeta. De fato, em termos geográficos globais, as faixas térmicas de afinidade detectadas para a espécie compreendem as áreas mais ao norte da zona temperada do hemisfério norte, e mais ao sul da zona temperada do hemisfério sul.

Foi identificado que Bombus terrestris encontra no JP os ambientes mais frios dentre todas as áreas focais de ocorrência. Pode-se observar que as faixas de afinidade e tolerância da espécie no JP para as temperaturas mínimas no mês mais frio do ano (Bio 6; Figura C5-7) são bastante baixas; e o mesmo também pode ser observado na temperatura média na estação mais fria do ano (Bio 11; Figura C5-8). Novamente, para ambas variáveis (Bio 6 e 11), a imensa dimensão da ocorrência nativa da espécie na EU captura uma vasta variedade de condições ambientais, cuja faixa de tolerância quase abrange toda a variabilidade das temperaturas mínimas das áreas invadidas, mas com exceção dos mínimos em ambas variáveis no JP, que são ainda mais baixos.

Existe uma complexidade na avaliação das temperaturas mínimas no mês e na estação mais fria do ano (Bio 6 e 11) que decorre de uma característica biológica da espécie. Em muitas das localidades de ocorrência de Bombus terrestris o período em que a área atinge as temperaturas mais baixas do ano os indivíduos estarão em diapausa. Mesmo diante de circunstâncias de temperaturas extremamente baixas (ex: mínimo de tolerância na EU para a Bio $6=-17,4^{\circ} \mathrm{C}$; Figura $\mathrm{C} 5-7$ ) a rainha poderá sobreviver se estiver em diapausa, pois estará protegida do frio enterrada no solo (abaixo de camadas de folhas, musgos, terra e outros estratos que podem atuar como isolantes térmicos) e com a taxa metabólica muito reduzida, permitindo-a se conservar por muitos meses sem se alimentar e com mínima demanda respiratória. Desta forma, não se pode ter alguma segurança ao se sugerir que os valores mínimos de temperatura nas áreas de ocorrência da espécie serão efetivamente limitantes para sua ocorrência, mesmo que estes caracterizem seus habitat.

Não há uma definição precisa dos gatilhos que induzem o início e o fim da diapausa em mamangavas, pois, provavelmente, estes são multifatoriais e variam entre populações em distintas localidades. Tauber et al. (1986) e Danks (1987) citados por Beekman (1999) relatam que o início da diapausa nos insetos não é uma resposta direta às condições desfavoráveis que imediatamente se apresentam no ambiente em que vivem, mas uma série de "dicas" ambientais que a espécie interpreta como evidências de que uma estação desfavorável se aproxima. Estas dicas estão relacionadas, por exemplo, à variação do fotoperíodo, à temperatura, à umidade e à redução de recursos bióticos usados na alimentação, como a senescência e redução do número de flores lhes proveem alimentos. 
Bombus terrestris possui diferentes respostas em diferentes populações, tal como uma alta flexibilidade em termos de gatilho para início e fim da diapausa, a qual também é facultativa (Estoup et al., 1996; Dafni, 1998; Beekman et al., 1999).

Os gatilhos de emergência da diapausa para Bombus terrestris estão relacionados aos fatores ambientais que podem ser percebidos pela rainha em seu abrigo invernal, pois de lá não poderá verificar, por exemplo, a luminosidade e a disponibilidade de recursos alimentares (flores abertas), pois está enterrada. Alford (1969) relata que o fim da diapausa em Bombus terrestris é governada pela temperatura, já Gurel et al., (2008) encontrou que em duas distintas populações de Bombus terrestris, uma emergiu da diapausa induzida pela precipitação possivelmente pela percepção do aumento da umidade no solo - e a outra pelo aumento temperatura - possivelmente percebida pela rainha pela variação da temperatura do solo.

Já o início da diapausa em Bombus terrestris obedece a uma sincronização estabelecida nas populações ao longo das gerações, em resposta aos múltiplos fatores ambientais que evidenciam a chegada de uma estação desfavorável. Em alguns locais, em resposta a esta sincronização, jovens rainhas tão logo encontram parceiros sexuais e são inseminadas já tendem a buscar um abrigo para diapausa, mesmo que ainda seja verão (Alford, 1975). Contudo, esta sincronização do ciclo de vida univoltino é específica ao local de ocorrência da população e quando a diapausa é mandatória, mas poderá ser modificada em locais cujas condições ambientais permaneçam favoráveis à espécie ao longo do ano. Tanto é que algumas populações nativas próximas ao mar Mediterrâneo e outras invasivas na Nova Zelândia e na Tasmânia apresentam ciclos bivoltinos (dois ciclos de vida anual), pois as circunstâncias ambientais nestas regiões são amenas e plantas forrageiras permanecem disponíveis ao longo do ano (De Jonghe, 1986; Estoup et al., 1996; Buttermore, 1997; Rasmont et al., 2005).

Alguns trabalhos ressaltam a elevada tolerância de Bombus terrestris ao frio em relação às outras abelhas devido à alta capacidade de termorregulação que possui. Seus indivíduos foram avistados em atividade mesmo sob temperaturas inferiores a $10^{\circ} \mathrm{C}$, algo raro entre as abelhas (Heinrich, 1979; Kuusik et al., 2002; Winter et al., 2006, Coppée, 2010; Dafni et al., 2010). Corbet et al., (1993) relatam que em temperaturas abaixo de $6^{\circ} \mathrm{C}$ a Bombus terrestris cessa a atividade de forrageamento e, possivelmente, este valor deve estar muito próximo do limiar térmico mínimo de tolerância da espécie quando vivendo em colônias.

Com base nos valores mínimos dos limiares detectados pela análise ecogeográfica (Bio 6 e 11 ; Figura C5-7 e C5-8) e o relato de Corbet et al., (1993), sugere-se que no mês e na estação mais fria do ano existem localidades de ocorrência na EU, na SA e na NZT em que Bombus terrestris poderá não entrar em diapausa (> $6^{\circ} \mathrm{C}$ ), permanecendo em atividade o ano todo. Já no JP, possivelmente, todos os indivíduos de Bombus terrestris entram em diapausa, pois até o máximo valor da faixa de tolerância (Bio 6 no JP; Máximo $=-1,6^{\circ} \mathrm{C}$; Figura $\mathrm{C} 5$-7) é bastante baixo para que os indivíduos sejam capazes de se manter em atividade ou permanecerem em colônias expostas a estas condições, mesmo que por curtos períodos.

A inversão das estações do ano entre hemisférios possivelmente faz com que Bombus terrestris entre em diapausa na EU e no JP em períodos similares do ano (quando for obrigatória), mas que serão distintos dos períodos de diapausa na SA e na NZT. Eventualmente, considerando-se exclusivamente a variação anual da 
temperatura (Figuras C5-10; C5-11 e C5-12), os ciclos de vida entre hemisférios podem ser invertidos. Todavia, quando também se considera a dinâmica da precipitação (Figura C5-13) a possibilidade da existência de ciclos inversamente sincrônicos entre hemisférios torna-se pouco provável, pois o padrão geral da precipitação é muito irregular entre áreas, e como se acredita, os gatilhos relacionados à diapausa são multifatoriais. Nada foi encontrado na literatura tratando de aspectos fenológicos relacionados a esta inversão temporal nos ciclos de variação térmica anual entre populações de Bombus em distintos hemisférios.

Em termos térmicos, as estações do ano são extremamente aparentes na EU e no JP, algo que na SA e na NZT também é observável, porém menos marcadamente (Figuras C5-10; C5-11 e C5-12). Estas diferenças cíclicas da temperatura entre áreas também estão evidenciadas na sazonalidade da temperatura (Bio 4; Figura C5-7) e na variação anual da temperatura (Bio 7; Figura C5-7). Estas duas últimas variáveis exibem padrões gerais muito similares, embora com escalas bastante diferentes, demonstrando que entre as áreas focais, o JP exibe a mais alta amplitude de variação da temperatura ao longo do ano, e a NZT, a mais baixa. Também exibe que a EU apresenta a maior variedade de ciclos de oscilação térmica anuais dentre todas as áreas, e a SA exibe a segunda maior variedade.

Considerando-se conjuntamente as máximas (Bio 5; Figura C5-7), as médias (Bio 1, 10 e 11; Figura C5-7 e C5-8) e as mínimas (Bio 6; Figura C5-7) de temperatura e suas variações ao longo do ano (Bio 7; Figura C5-7), Bombus terrestris em sua área nativa (EU) apresenta tolerância a uma grande variedade de condições térmicas cujas amplitudes cobrem a maioria das faixas de tolerância identificadas em áreas invadidas, com apenas algumas exceções para o JP, cujas tolerâncias em dois casos alcançam valores sutilmente mais baixos (Bio 6 e 11; Figura C5-7 e C5-8) e um caso que o JP alcança valores um pouco mais altos (Bio 7; Figura C5-7). Estes aspectos caracterizam que em termos térmicos gerais, a espécie invade locais não muito diferentes daqueles que ocupa nativamente.

Mesmo assim, de uma forma geral e relativa, Bombus terrestris no hemisfério sul, SA e NZT, ocorre em ambientes mais amenos nos períodos mais frios do ano e mais frescos nos períodos mais quentes do ano; estas duas áreas (SA e NZT) também apresentam maior uniformidade térmica anual do que as outras (Bio 4 e 7; Figura C57). Na SA, a espécie encontra a maior variação diária média da temperatura (Bio 2; Figura (5-7), que pode estar diretamente relacionada com a baixa presença de água atmosférica indicada pela menor precipitação nesta área (Bio 12, 13 e 14; Figura C5-8), pois é bem conhecido que a maior concentração de água na atmosfera atua como um amenizador da variação térmica diária e até mesmo anual (ex: Trenberth, 2010). Do mesmo modo, o índice de aridez global também reforça que a SA apresenta as localidades com maior aridez entre todas as áreas focais (Arid; Figura C5-9).

Hingston et al.(2002; referenciando Dafni e Shmida 1996; Estoup et al., 1996; Goodwin e Steiner, 1997) advogaram que o melhor indicador de limites de tolerância climática de Bombus terrestris é o fato de sua distribuição nativa ser restrita às regiões não áridas; mas também citaram que, entretanto, o limite mais ao sul da distribuição nativa da espécie é marcada por uma zona climática quente e árida, ao invés de quente e úmida, o que tornaria impraticável predições seguras sobre limites latitudinais da espécie em regiões não áridas. 
A análise ecogeográfica demonstrou que Bombus terrestris se distribui predominantemente (75\%) sobre zonas do planeta que variam de média a baixa precipitação. A faixa de afinidade para a precipitação anual acumulada em sua ocorrência nativa (Bio 12; EU; Figura C5-8) varia entre 570 a 1042 mm, que compreende as cotas das zonas climáticas semiáridas e subúmidas do planeta.

Bombus terrestris na EU pode ser observada em localidades em que na estação mais seca há total ausência de chuva (Bio 17; Figura C5-9), e na SA é impressionante verificar que a espécie ocorre em zonas tão áridas que a precipitação anual acumulada varia apenas entre 18 e 33 mm (Bio 12; Figura C5-8). Cinco ocorrências na SA foram identificadas nesta faixa de extrema aridez, e após verificação em mapa pode-se constatar que se localizam sobre áreas desérticas de uma zona marginal do sul do Atacama (Chile).

No entanto, a faixa de afinidade da espécie na EU para o índice de aridez global (Arid; Figura C5-9) compreende a categoria das áreas úmidas, mas o mínimo valor e uma parte da variação mais baixa da faixa de tolerância se inserem na zona climática do semiárido (Zomer et al., 2007, 2008). Seja no mês (Bio 13; Figura C5-8) ou na estação (Bio 16; Figura C5-9) mais úmida do ano, a faixa de afinidade da espécie na EU compreende cotas similares às encontradas no semiárido brasileiro, nas zonas de Sahel africano (transição entre Savana e Sahara), uma grande parte central da Sibéria e do nordeste dos Estados Unidos (verificado em ArcGIS; ESRI, 2010).

No mês mais seco do ano (Bio 14; Figura C5-8) as cotas de precipitação abrangidas pelas faixas de tolerância na EU, no JP e na SA são bastante baixas, enquanto na NZT há uma elevada amplitude de cotas de precipitação - algo notável, tendo em vista a reduzida dimensão espacial das ilhas na NZT em relação à área continental da EU. Após inspeção visual das variáveis Bio 13 e 14 (Figura C5-8) projetadas em mapa, pôde-se identificar que as zonas mais ocidentais da NZT, especialmente da ilha da Tasmânia, são extremamente mais chuvosas do que as zonas orientais, tanto no mês mais seco (Bio 14) quanto no mês mais úmido (Bio 13).

A sazonalidade da precipitação na NZT (Bio 15; Figura C5-8), de uma forma geral (considerando-se a mediana e a amplitude da faixa de tolerância), é a mais baixa entre as áreas focais. Já a faixa de afinidade na NZT para variação anual da precipitação supera as faixas de afinidade da espécie no JP e na EU (Bio 20; Figura C5-9). Estas diferenças indicam que, em termos relativos, a precipitação (Bio 15) varia pouco entre estações chuvosas e secas na NZT, mas, em termos absolutos, a cota que reduz da estação chuvosa para a seca é bastante elevada relativamente às outras áreas.

A NZT é uma área-chave para se confirmar que a espécie também é capaz de ocupar zonas onde há alta frequência de chuvas ao longo do ano todo, cujas cotas de precipitação são bastante elevadas (Prec; Figura C5-13), haja vista que a análise indicou que na NZT a espécie se distribui em áreas que alcançam cotas de precipitação encontradas em florestas tropicais, entre 2500 e 5103 mm (Bio 12; Figura C5-8).

Stout e Goulson (2000) argumentaram que Bombus terrestris na Tasmânia poderia não ser capaz de ocupar algumas zonas desta ilha devido à alta altitude e a precipitação. Quanto à altitude, a análise ecogeográfica converge na sugestão de que as localidades superiores a $\mathbf{3 0 0 0}$ metros podem ser limitantes à espécie em algumas regiões do planeta, mas, quanto à precipitação, a análise ecogeográfica não sustenta este argumento. 
Além do verificado analiticamente nesta pesquisa, outros pesquisadores observaram empiricamente a alta tolerância da espécie à elevada precipitação: Hingston et al. (2002), relataram que fizeram observações de operárias, rainhas e machos ocorrendo em cotas que alcançavam $3200 \mathrm{~mm}$ anuais na Tasmânia. Goulson e Hanley (2004) observaram indivíduos na Nova Zelândia em cotas ainda superiores do que a análise ecogeográfica indicou, em locais em que a precipitação alcança $7000 \mathrm{~mm}$ anuais.

Também foi identificado que, de uma forma geral (medianas, faixas de afinidade e tolerância), a ocorrência da espécie na SA e na NZT se dá em locais onde as altas cotas de precipitação no ano acontecem em épocas mais frias, relativamente a EU e ao JP (Bio 8 e 19; Figura C5-8 e C5-9). Convergentemente, na estação mais seca do ano (Bio 9; Figura C5-8), a SA e a NZT apresentam temperaturas mais altas do que na EU (faixas de afinidade e medianas) e no JP. No entanto, na estação mais seca do ano (Bio 17; Figura C5-9), as cotas de precipitação na NZT são muito superiores àquelas identificadas na SA e também nas outras áreas (EU e JP). No hemisfério sul (SA e NZT) a ocorrência invasiva está sujeita a um menor impacto da variação térmica ao longo do ano, e por conta disso, a espécie poderá permanecer em atividade o ano todo em várias localidades nestas áreas, o que na perspectiva do invasor pode ser favorável ao seu desempenho populacional e à sua expansão invasiva.

Esta imensa diversidade de características de precipitação a qual a espécie está sujeita reforça a sugestão de que ela não é diretamente limitada pela precipitação. Peat et al., (2005) sugerem que existe uma forte influência da alta precipitação na maior disponibilidade de néctar nas flores, o que também poderia estar relacionado à maior presença de abelhas grandes em locais chuvosos, pois estas requerem mais energia que abelhas menores. Por outro lado, não se explica (e nada foi encontrado na literatura para sustentar) como a espécie pode ser hábil em ocupar ambientes tão áridos como o sul do Atacama. Porventura, o poliletismo e alta capacidade de aprendizado da espécie na exploração de novos recursos florais (inclusive roubar néctar por meio de furos na corola) possam ser argumentos plausíveis para subsidiar que mesmo nestes ambientes muito áridos Bombus terrestris é hábil para obter recursos adequados e suficientes para sua sobrevivência; possivelmente explorando flores em herbáceas, gramíneas e arbustos, que são os tipos vegetacionais mais frequentes nesta região.

Bombus terrestris, além de ser uma espécie polilética, é uma das mais oportunistas dentre as espécies de mamangavas (Olesen, 1985; Dafni e Shmida, 1996; Hingston e McQuillan, 1998). Hingston et al. (2002) ressaltam que devido a habilidade da espécie em explorar uma vasta variedade de tipos florais, poderá ser capaz de se adaptar a forragear com eficiência em qualquer lugar onde houver disponibilidade suficiente de recursos florais. A espécie em ambientes invadidos é hábil em explorar recursos alimentares de plantas europeias introduzidas em bosques artificiais e parques urbanos, plantas nativas nos habitat não nativos e ainda uma vasta variedade de plantas agrícolas (Hingston e McQuillan, 1998; Hingston et al., 2002).

A análise ecogeográfica também capturou a alta plasticidade da espécie em termos de preferências a determinados agrupamentos de fatores bióticos que cobrem o solo por onde se distribui. Não obstante, algumas peculiaridades compartilhadas entre diferentes áreas focais também puderam ser identificadas (Figura C5-14). 
Em sua área de ocorrência nativa, Bombus terrestris ocorre principalmente em zonas onde há presença de culturas agrícolas (32\%), vegetação herbácea (21\%) e floresta mista (20\%), e nesta última, a composição vegetacional é principalmente de arbustivas e herbáceas (Figura C5-14). No JP a espécie ocorre majoritariamente (somase $75 \%$ ) em áreas onde há atividade humana: nas culturas agrícolas (61\%) e nos mosaicos de culturas agrícolas e vegetação (14\%). Na NZT, a espécie é mais frequente em ambientes florestais cujas árvores são do tipo latifoliada (45\%), mas também há uma grande parcela que ocorre em culturas agrícolas (34\%). Na SA, a maioria dos registros (soma-se 75\%) ocorre em ambientes florestais dos tipos misto (53\%) e latifoliado (22\%), mas também há uma quantidade razoável de ocorrências em ambientes cobertos por culturas agrícolas (13.3\%). A espécie apenas não se distribuiu sobre zonas alagáveis, solo exposto e zonas com neve e gelo permanente. É razoável considerar que para uma espécie que requer (ou preferencialmente utiliza) solo para construir ninhos e, em alguns locais do planeta, requer solo para a diapausa, estes tipos de cobertura de solo podem ser inadequados.

Pode-se observar a clara convergência entre as áreas focais quanto à alta frequência de ocorrência da espécie em zonas cobertas ou integradas com culturas agrícolas, mas duas marcadas diferenças: uma na SA, devido à elevada quantidade de ocorrências em florestas mistas, e a outra na NZT, devido à elevada quantidade de ocorrência em florestas latifoliadas. Por meio de inspeção visual das áreas em Google Earth (Google Inc., 2015) também foi possível averiguar que os registros na SA e na NZT são mais recorrentes em zonas selvagens ou transicionais entre fragmentos nativos e culturas agrícolas, enquanto na EU e no JP - que são locais mais degradados pelas atividades humanas - a maioria das ocorrências estão sobre zonas com alguma interferência antrópica e próximas das cidades.

A maior frequência da presença de Bombus terrestris em zonas próximas ou sobre as áreas com atividades humanas, como as culturas agrícolas, também poderá ser um reflexo da inventariação. É de amplo conhecimento que as coletas de organismos ocorrem com maior frequência em locais de fácil acesso e próximos de ambientes urbanizados, podendo gerar vieses de amostragem que se refletem nas análises. Mas este potencial viés de amostragem em nada prejudica o fato de que Bombus terrestris é altamente hábil em ocupar ambientes antropizados, indicando que a espécie se beneficiará de áreas com culturas agrícolas, com as quais conhecidamente ela interage, e que lhe proveem recursos alimentares.

Em suma, Bombus terrestris é uma espécie com alta plasticidade ecogeográfica, e suas limitações ambientais possivelmente decorrem de uma conjuntura de múltiplos fatores adversos e não por apenas um ou poucos fatores limitantes específicos. Foi detectado que a espécie ocorre mais frequentemente em baixas altitudes e que as áreas acima de 3000 metros poderão exibir conjunturas ambientais inadequadas à espécie em algumas localidades do planeta. Porventura, a escassez de recursos e as baixas temperaturas relacionadas às altas altitudes podem ser os aspectos limitadores efetivos para a ocorrência da espécie dependendo da área em questão, afinal, nem todas as altas altitudes apresentam as mesmas características ambientais.

Também foi possível identificar que os locais que apresentam temperaturas próximas ou superiores a $35^{\circ} \mathrm{C}$ por períodos longos ou com maior frequência poderão ser limitantes à ocorrência da espécie; o que também converge com a aparente 
limitação da espécie em se distribuir por ambientes tropicais. Estes aspectos sugerem a limitação de sua ocorrência invasiva para as faixas temperadas do planeta.

A precipitação, aparentemente, não exerce influência decisiva em sua ocupação, pois a espécie ocorre desde os ambientes semiáridos até os úmidos.

Apesar de que algumas preferências tenham sido identificadas, a espécie é capaz de habitar todos os tipos de vegetação com exceção daqueles que apresentam solos inviáveis a ela (solo exposto, alagável e permanentemente congelado). A espécie poderá usufruir de recursos alimentares disponíveis em plantas agrícolas e selvagens, embora, de uma forma geral, parece preferir explorar ambientes com maior presença de culturas agrícolas. 

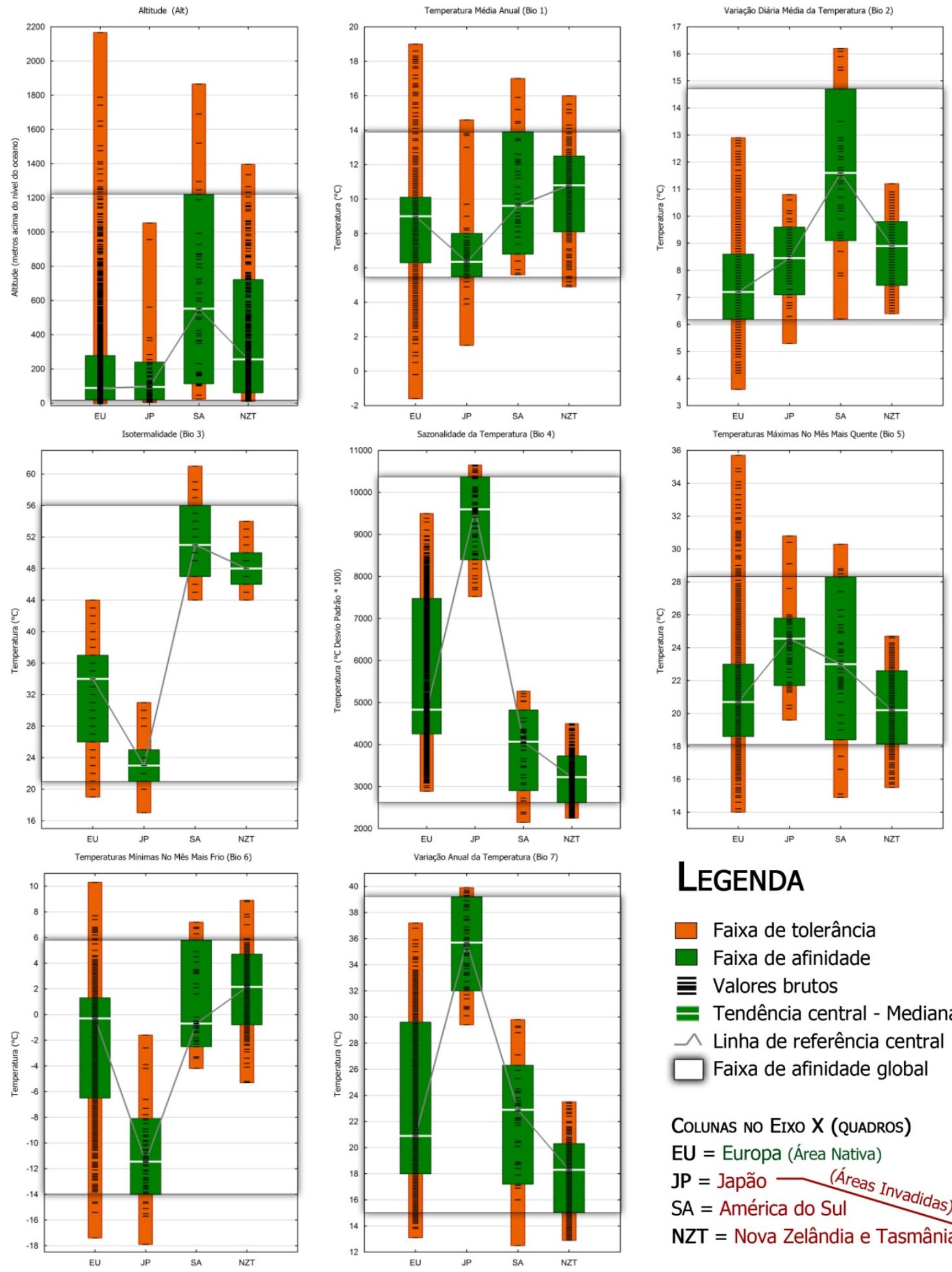

\section{LEGENDA}

$\square$ Faixa de tolerância

$\square$ Faixa de afinidade

三 Valores brutos

E Tendência central - Mediana

$\wedge$ Linha de referência central

$\square$ Faixa de afinidade global

\section{Colunas no Eixo X (QuAdRos)}

$\mathrm{EU}=$ Europa (Área Nativa)

JP $=$ Japão
SA $=$ América do Sul Invadidas) NZT = Nova Zelândia e Tasmânia

Figura C5-7. Faixas de afinidade e de tolerância de Bombus terrestris nas áreas focais de em toda sua ocorrência conhecida em escala global para as seguintes variáveis ambientais: Alt-Altitude; BIO1-Temperatura Média Anual; BIO2-Variação Diária Média da Temperatura; BIO3-Isotermalidade; BIO4-Sazonalidade da Temperatura (Desvio Padrão * 100); BIO5-Temperaturas Máximas No Mês Mais Quente; BIO6-Temperaturas Mínimas No Mês Mais Frio; BIO7-Variação Anual da Temperatura. 

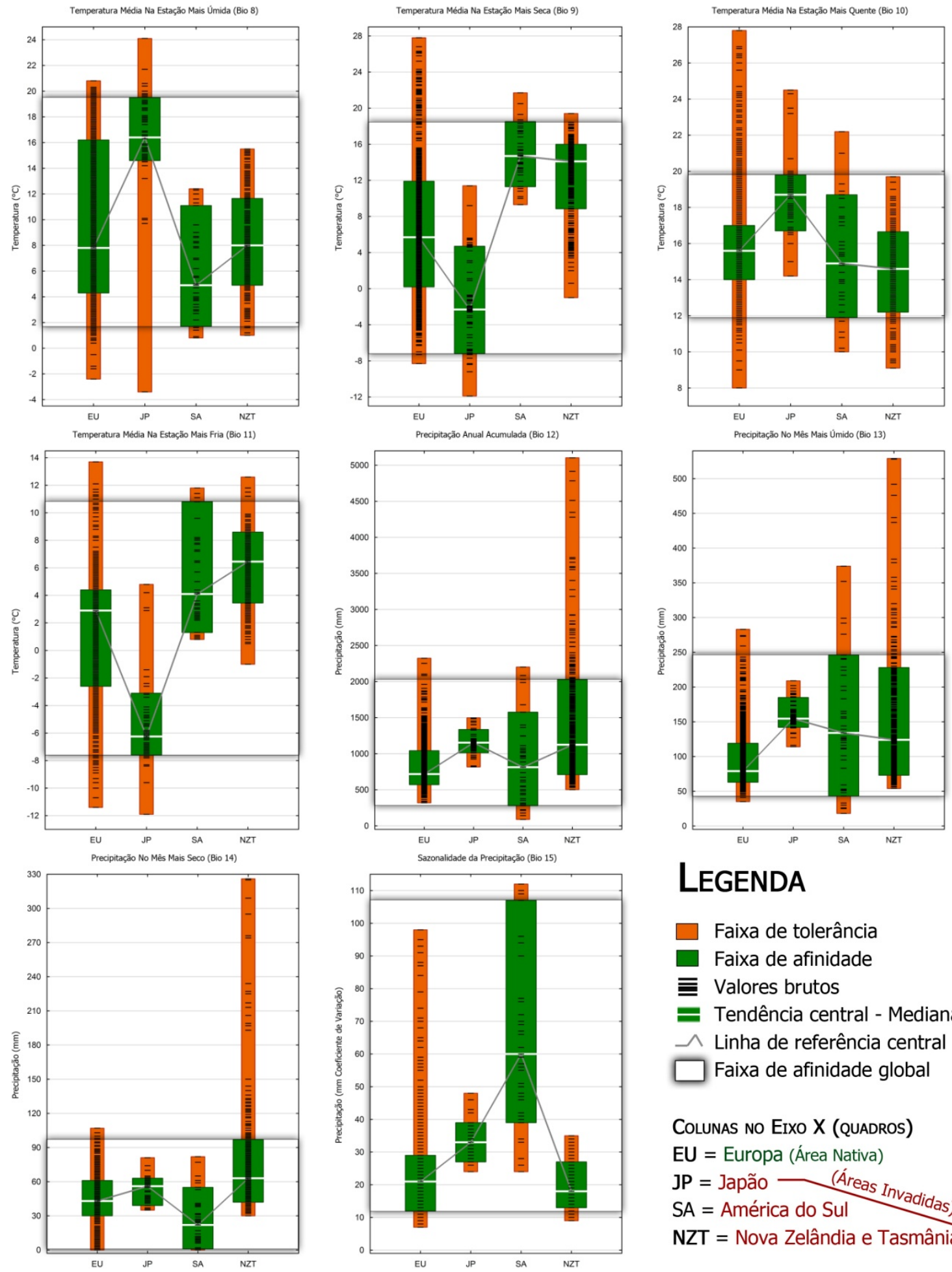

\section{LEGENDA}

$\square$ Faixa de tolerância

$\square$ Faixa de afinidade

三 Valores brutos

E Tendência central - Mediana

$\wedge$ Linha de referência central

$\square$ Faixa de afinidade global

\section{Colunas no Eixo X (quadros)}

$\mathrm{EU}=$ Europa (Área Nativa)

$\mathrm{JP}=$ Japão
$\mathrm{SA}=$ América do Sul NZT = Nova Zelândia e Tasmânia

Figura C5-8. Faixas de afinidade e de tolerância de Bombus terrestris nas áreas focais de em toda sua ocorrência conhecida em escala global para as seguintes variáveis ambientais: BIO8-Temperatura Média Na Estação Mais Úmida; BIO9-Temperatura Média Na Estação Mais Seca; BIO10-Temperatura Média Na Estação Mais Quente; BIO11-Temperatura Média Na Estação Mais Fria; BIO12-Precipitação Anual (Acumulada no Ano); BIO13-Precipitação No Mês Mais Úmido; BIO14-Precipitação No Mês Mais Seco; BIO15-Sazonalidade da Precipitação (Coeficiente de Variação). 

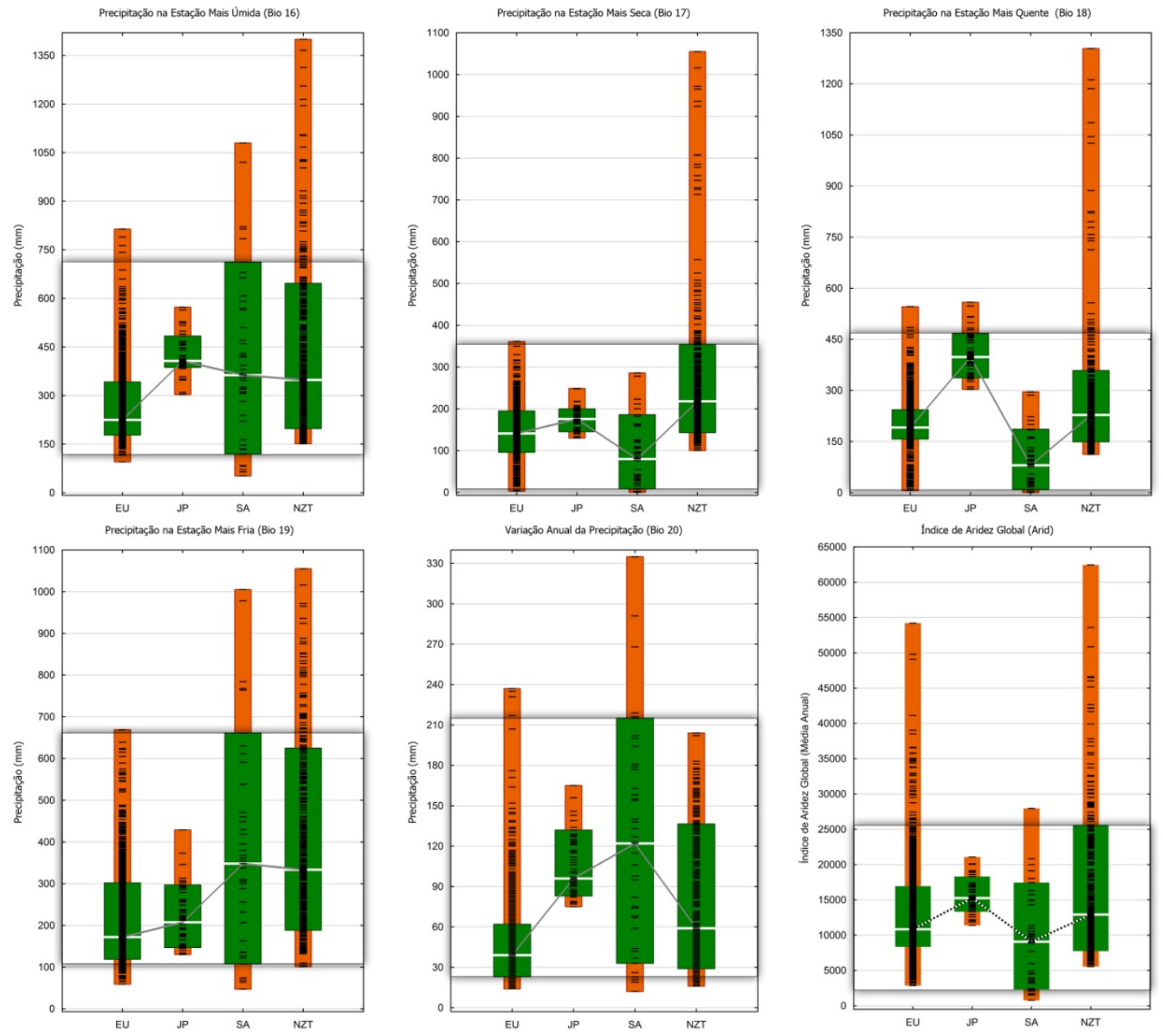

\section{LEGENDA}

Faixa de tolerância

$\square$ Faixa de afinidade

三 Valores brutos

E Tendência central - Mediana

$\wedge$ Linha de referência central

$\square$ Faixa de afinidade global

Colunas no Eixo X (quadros)

$\mathrm{EU}=$ Europa (Área Nativa)

$\mathrm{JP}=$ Japão (Áreas Invadidas)
$\mathrm{SA}=$ América do Sul NZT = Nova Zelândia e Tasmânia

Figura C5-9. Faixas de afinidade e de tolerância de Bombus terrestris nas áreas focais de em toda sua ocorrência conhecida em escala global para as seguintes variáveis ambientais: BIO16-Precipitação na Estação Mais Úmida; BIO17-Precipitação na Estação Mais Seca; BIO18-Precipitação na Estação Mais Quente; BIO19-Precipitação na Estação Mais Fria; Bio20-Variação Anual da Precipitação; Arid-Índice de Aridez Global. 

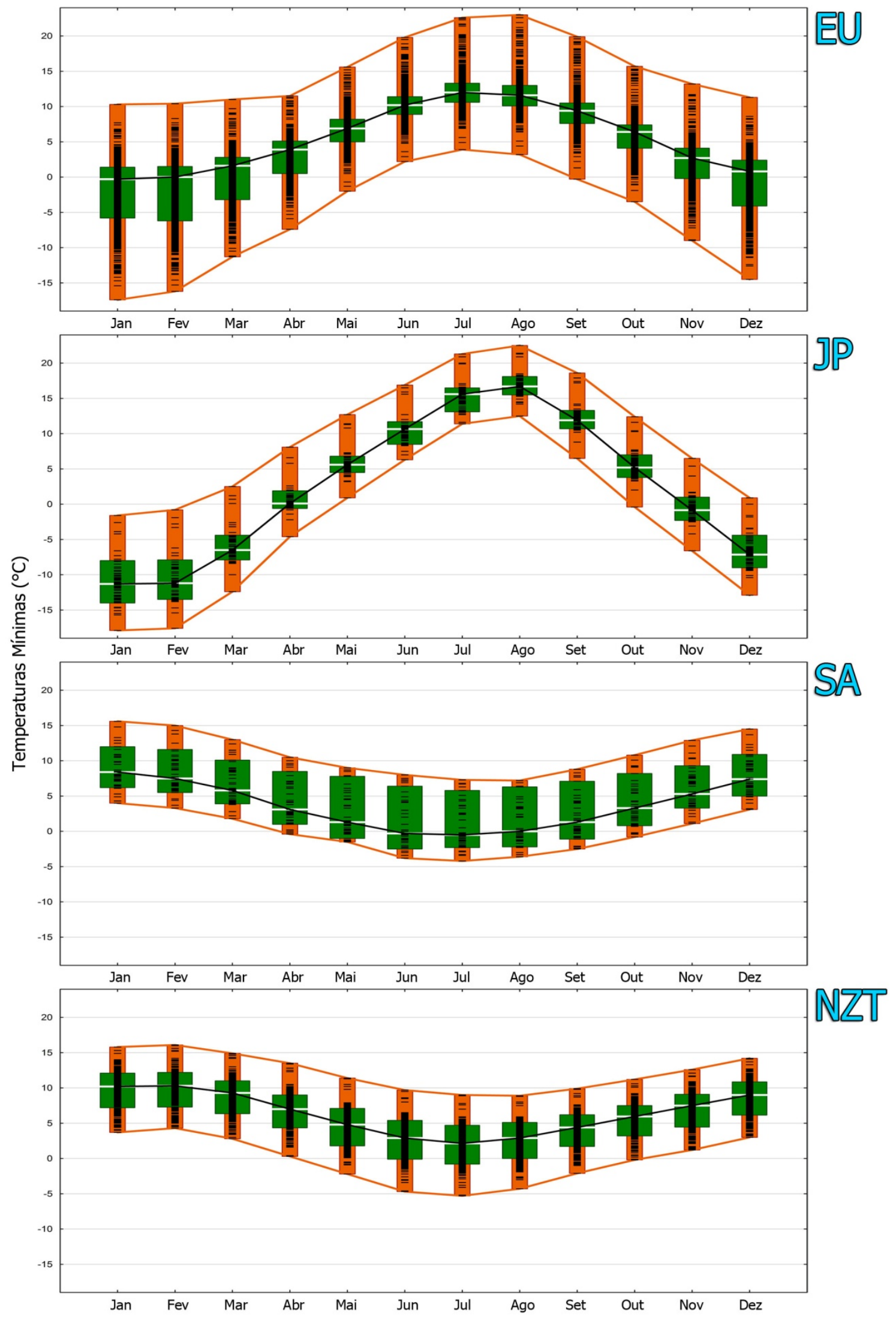

Figura C5-10. Faixas de afinidade e de tolerância de Bombus terrestris nas áreas focais de em toda sua ocorrência conhecida em escala global para as médias mensais das temperaturas mínimas. 


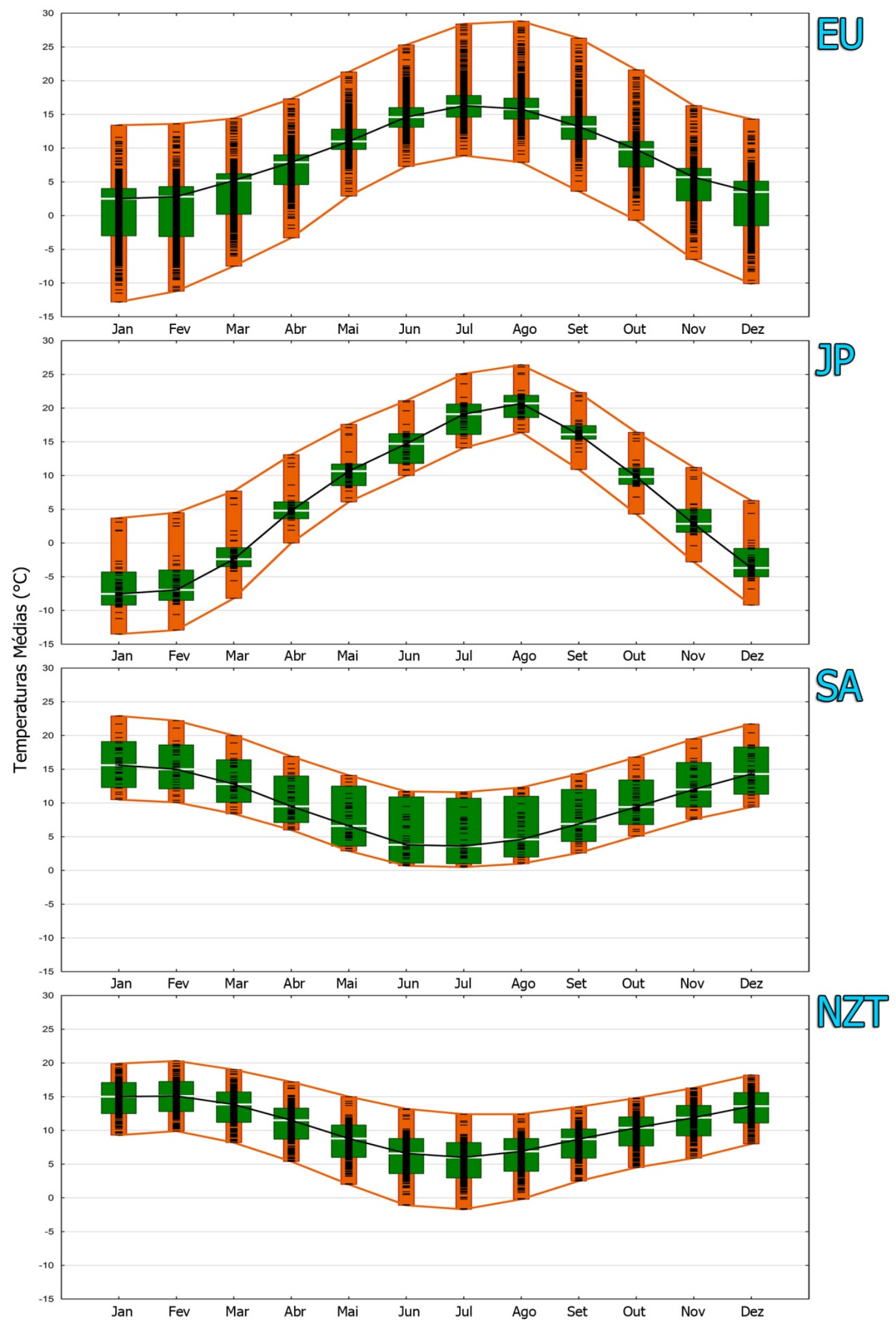

Figura C5-11. Faixas de afinidade e de tolerância de Bombus terrestris nas áreas focais de em toda sua ocorrência conhecida em escala global para as médias mensais das temperaturas médias. 


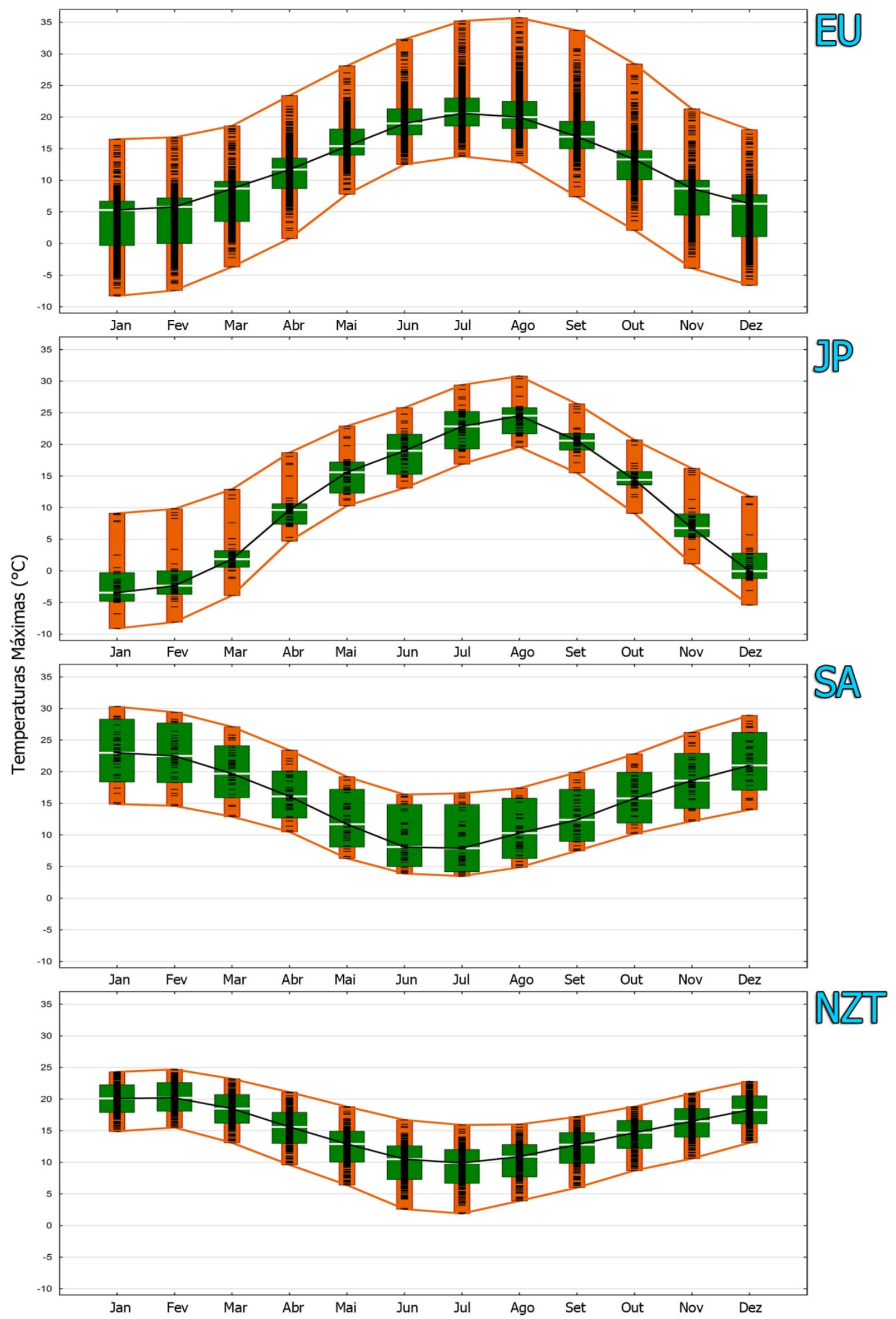

Figura C5-12. Faixas de afinidade e de tolerância de Bombus terrestris nas áreas focais de em toda sua ocorrência conhecida em escala global para as médias mensais das temperaturas máximas. 

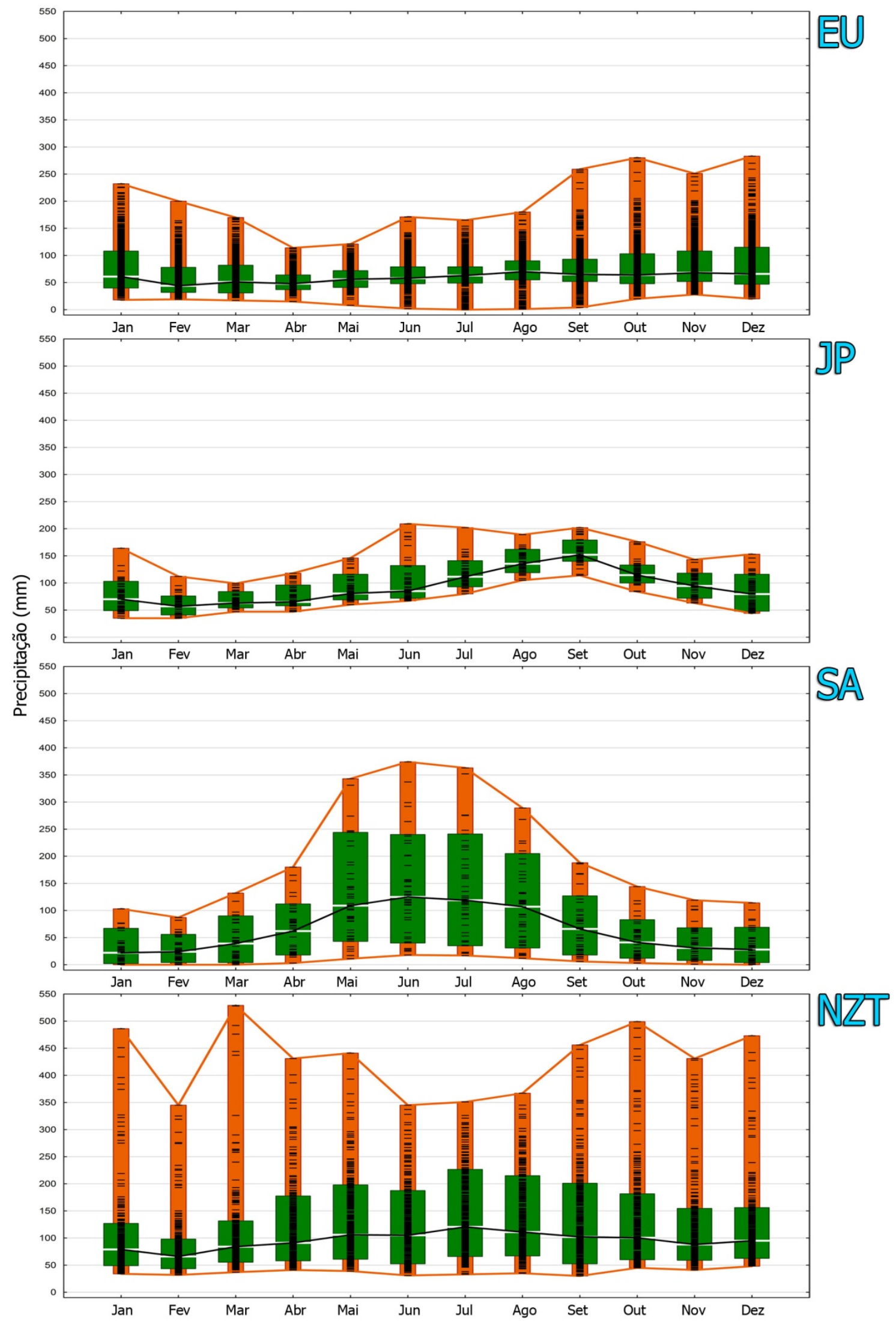

Figura C5-13. Faixas de afinidade e de tolerância de Bombus terrestris nas áreas focais de em toda sua ocorrência conhecida em escala global para as médias mensais da precipitação. 


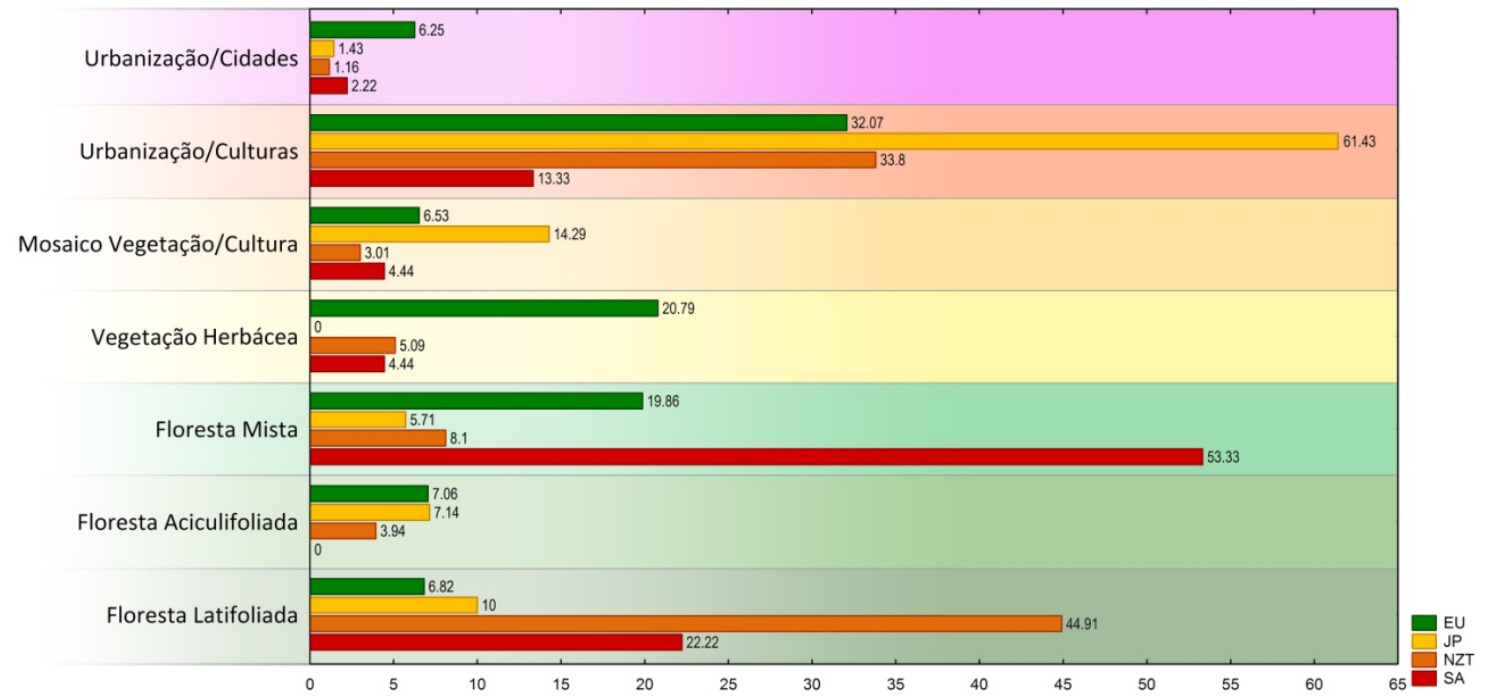

Figura C5-14. Frequências dos registros de Bombus terrestris nas áreas focais de toda sua ocorrência conhecida em escala global para sete classes de cobertura de solo sobre as quais a espécie se distribui (cujos valores originais da Globcover [2009] foram agrupados e reclassificados; e o processo poderá ser consultado no Capítulo 3). 


\subsubsection{Corredores de invasão para Bombus terrestris na América do Sul}

A análise de conectividade delineou 81 trajetos lineares de menor custo para Bombus terrestris na América do Sul (Figura C5-15), dentre os quais, quatro potenciais trajetos para a espécie alcançar o Brasil por meio da longa faixa de susceptibilidade no litoral da Argentina (Figura C5-16). Apesar de que a menor distância entre um registro de invasão na Argentina e uma atribuição no Brasil supera os dois mil quilômetros, o seu custo (CPD) é menor do que alguns trajetos mais curtos que conectam localidades invadidas vizinhas. Por exemplo, entre os pontos 17 e 3 (Figura C5-15) o trajeto tem cerca de $2500 \mathrm{~km}$ e um custo de 508 CPD, já o trajeto entre os pontos 16 e 17 há uma distância de apenas cerca de 150 km, mas que apresenta o custo de 1000 CPD.

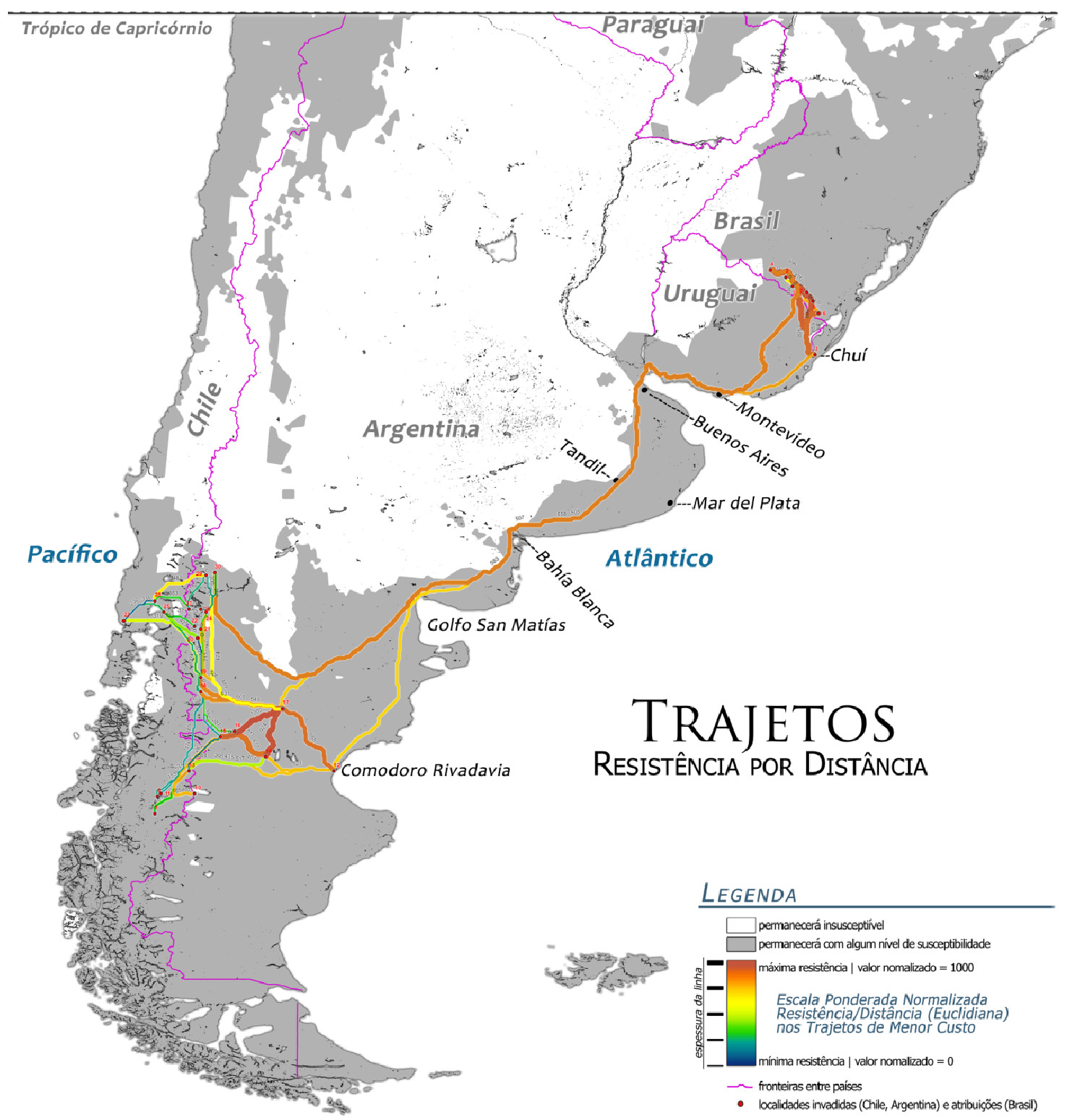

Figura C5-15. Trajetos lineares de menor custo entre localidades invadidas e localidades atribuídas no Brasil e seus valores. 
Pode-se observar (Figura C5-17) a alta conectividade entre as ocorrências invasivas adjacentes ao longo da fronteira do Chile com a Argentina, bem como estas também se conectam intimamente com as ocorrências no oeste do Chile, através dos Andes, aspectos diretamente relacionados com a alta qualidade ambiental identificada nesta zona para a espécie (em tons azuis na Figura C5-16). Com base nestas observações, pode-se sugerir que nesta faixa extremamente conectada há grande fluxo migratório de indivíduos entre populações favorecendo ao pleno estabelecimento da invasora na região. Ademais, potencialmente, esta zona é o primeiro núcleo de irradiação da expansão invasiva na América do Sul, afinal, além da alta qualidade ambiental e alta conectividade, também é a zona indicada nos primeiros relatos de observação desta espécie neste continente (Torreta et al., 2006; Plischuk e Lange, 2009).

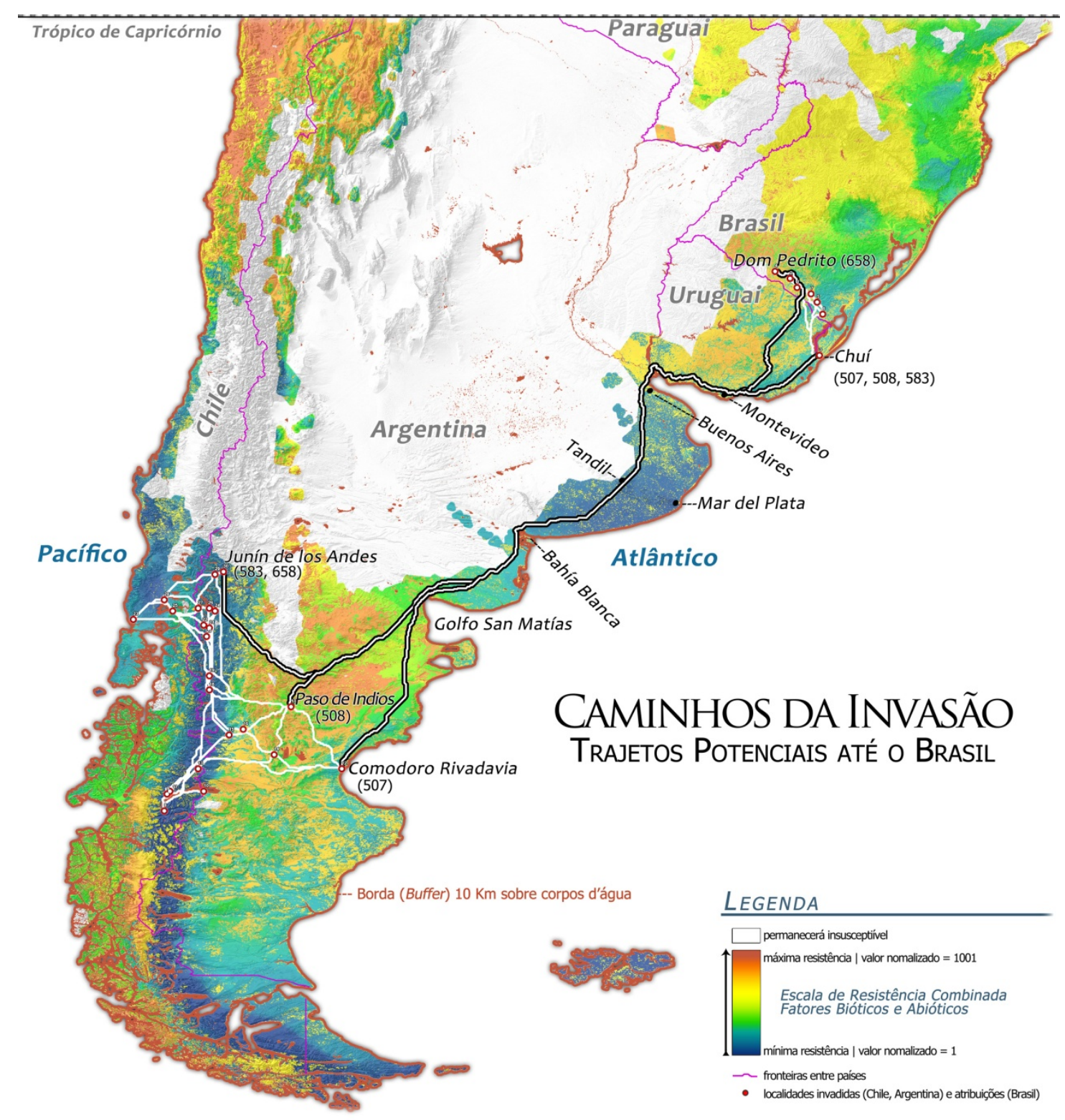

Figura C5-16. Os quatro trajetos lineares de menor custo que alcançam o Brasil a partir de localidades invadidas na Argentina (linhas destacadas em preto) sobre a camada de resistência ambiental utilizada na análise de conectividade e sobre relevo (SRTM). 
Também foi possível averiguar que os Andes nesta zona do extremo sul da América do Sul, que apresenta altitudes relativamente mais baixas que nas zonas centrais e mais ao norte da cordilheira, não atua como uma barreira intransponível para a espécie, sustentando a sugestão de Torreta et al. (2006) de que a espécie cruzou do Chile para a Argentina por meio de corredores de baixa altitude. De fato, foram verificados corredores com altitudes relativamente baixas e com alta qualidade ambiental à espécie conectando o Chile com a Argentina através dos Andes.

Dentre os quatro trajetos que conectam localidades invadidas com o Brasil, o de menor custo apresenta o valor de 507 CPD, e liga a cidade argentina de Comodoro Rivadavia (ponto 12), onde há ocorrência invasiva confirmada (Schmid-Hempel et al., 2014), com a cidade brasileira de Chuí (ponto 3) (Figura C5-15). Apesar de que o custo deste trajeto seja o menor dentre os quatro, o registro de invasão no litoral argentino (Comodoro Rivadavia; ponto 12) está relativamente isolado dos outros registros na Argentina, estabelecendo apenas três outras conexões, sendo que duas possuem valores de CPD mais altos que o do trajeto até o Brasil (521 e 688 CPD; e a com menor: 407 CPD).

O segundo trajeto possui valor de custo quase idêntico ao primeiro, 508 CPD, e liga a região próxima à localidade argentina de Paso de Indios (ponto 17; Figura C5-15), também com a cidade de Chuí-RS (ponto 3). Este trajeto difere fundamentalmente do primeiro por iniciar-se no interior da Argentina, cruzando uma zona mais árida que o primeiro, mas este registro de origem estabelece nove conexões com outros registros invasivos, sendo que três possuem valores de custo similares aos trajetos até o Brasil (605, 631, 549 CPD), três possuem valores de custo menores $(506,474,489$ CPD) e três possuem valores mais altos $(688,924,1000 \mathrm{CPD})$.

$\mathrm{O}$ terceiro e quarto trajetos (583 e 658) são mais custosos. Ambos começam na cidade de Junín de Los Andes (ponto 30; Figura C5-15), mas um deles (583) termina na cidade litorânea de Chuí-RS (ponto 3) e o outro (658) termina no interior, na cidade de Dom Pedrito-RS (ponto 4). Apesar do maior custo em relação aos dois primeiros, o registro de origem compartilhado por ambos os trajetos (ponto 30) está localizado em uma zona com alta qualidade ambiental para a espécie, a qual é bastante superior às dos outros registros de origem de trajetos. 0 ponto 30 estabelece três conexões com outros registros invasivos, e todos com valores de custo menores que os trajetos até o Brasil (474, 263 e 0 CPD).

Embora sejam identificados quatro trajetos, eles compartilham mesmos segmentos em várias partes de suas extensões. De fato, efetivamente se têm três origens e dois destinos, e cerca de $60 \%$ de todo o comprimento é comum entre trajetos. Esta longa extensão compartilhada, de cerca de $1400 \mathrm{Km}$, inicia-se pela fusão dos trajetos em uma zona entre o Golfo de San Matías e Bahía Blanca (Argentina) que volta a ramificar-se a partir da cidade de Montevidéu (Uruguai). Com base nos trajetos identificados, se pode sugerir que o litorâneo (507) apresenta as melhores condições de deslocamento para a espécie sobre a área, mas os trajetos 508 e 583 apresentam na origem o maior potencial de prover indivíduos para a expansão invasiva, pois são mais conectados com populações em ambientes altamente adequados à espécie, indicando maior abundância potencial de indivíduos exploradores do que no $507 \mathrm{em}$ seu ponto de origem (12). Nos destinos potenciais, com base nos trajetos lineares, a cidade de Chuí poderá ser a primeira cidade brasileira a receber indivíduos invasores 
de Bombus terrestris, pois se conecta com três trajetos de menores custos, enquanto o único trajeto que se direciona a Dom Pedrito possui o mais alto custo.

Os trajetos proveem referências lineares (angulares) de caminhos potenciais e quantificam o custo entre origens e destinos, que são informações importantes especialmente na obtenção de valores comparáveis. Mas para o caso da progressão invasiva de Bombus terrestris, que ocorre por meio de sucessivas colonizações de novas áreas, e considerando-se a grande distância da Argentina até o Brasil, os corredores ambientais poderão sugerir de forma mais realista o potencial espalhamento da espécie invasora sobre a SA, pois a expressão geoespacial de suas informações se expande a partir da linha de menor custo para áreas mais extensas, onde a qualidade ambiental também é favorável à espécie e, por conseguinte, também poderá ocupá-las.

Conforme a análise indicou, o corredor de invasão mais largo a partir das ocorrências invasivas inicia-se na cidade de Comodoro Rivadávia (Figura C5-17) e segue marginalmente à faixa litorânea da Argentina, e quando alcança o Golfo de San Matías encontra uma zona de estreitamento da faixa de susceptibilidade que resulta em alta concentração de corrente em uma pequena área, principalmente numa delgada faixa adjacente ao litoral com cerca de $10 \mathrm{~km}$ de largura (faixa amarela no Circulo $1 \mathrm{da}$ Figura C5-18). Este ponto é estratégico para o monitoramento da expansão invasiva em direção norte na SA e poderá ser uma referência para estudos e ações de controle do progresso invasivo.

A partir deste ponto, ambos os corredores (juntamente com o que parte de Paso de Indios) unificam-se e seguem pelo mesmo trajeto sobre uma ampla área com alta qualidade ambiental. Esta ampla área de alta conectividade e qualidade ambiental entre o Golfo de San Matías e Baía Blanca poderá, potencialmente, permitir um núcleo de expansão regional da invasão, onde a espécie poderá se espalhar sobre a área por meio da fundação de um grande número de populações (aglomerados de colônias) intimamente interconectadas por curtos trajetos de mínimo custo. Populações maiores e em maior número incrementarão a aptidão reprodutiva e a competição intraespecífica por recursos, podendo intensificar a necessidade de se buscar novas áreas para explorar recursos, aumentando potencialmente o número de indivíduos desbravadores e, como consequência, poderá se intensificar o processo de expansão invasiva.

Após esta ampla área, um novo estreitamento da área susceptível ocorre um pouco antes da Bahía Blanca (Círculo 2 na Figura 4). Neste ponto há uma grande concentração de corrente em uma pequena faixa com largura de cerca de $30 \mathrm{~km}$. Esta faixa com baixa resistência ambiental ocorre entre as cidades de Villalonga e Pedro Luro (Argentina). Esta região é densamente coberta por culturas agrícolas e possui raríssimos e diminutos fragmentos de vegetação natural (verificado por meio de Google Earth; Google Inc., 2015), os corpos d'água que cruzam a área são estreitos e não se configuram como potenciais barreiras à espécie (Figura C5-16). O corredor continua estreito por cerca de $90 \mathrm{~km}$ em direção norte e novamente sofre uma constrição (Círculo 3 na Figura 4), que neste caso é extrema, sobrando apenas uma faixa de terra com apenas $12 \mathrm{Km}$ de espessura na cidade de Bahía Blanca. No entanto, como se pode conferir na camada de resistência (Figura C5-16), as entradas do oceano no continente nesta localidade não são barreiras instransponíveis para a espécie, 
apenas faixas de alta resistência; ao se considerá-las potenciais ao deslocamento, este estreitamento extremo diminui para cerca de $50 \mathrm{~km}$ de largura.

As cidades presentes nesta estreita faixa de alta corrente, Bahía Blanca (365 mil hab.; Wikipédia, 2015) e Ingeniero White (10 mil hab., Wikipédia, 2015), são regionalmente importantes por constituírem um complexo portuário de grãos. Portanto, esta é uma zona bastante urbanizada e com grande atividade humana. Ambas as cidades cobrem toda área de habitat adequado nesta constrição, mas, conforme relatado na revisão sobre a espécie e verificado na caracterização ecogeográfica, as cidades não são barreiras ambientais para Bombus terrestris, que continuará seu trajeto em sentido norte.

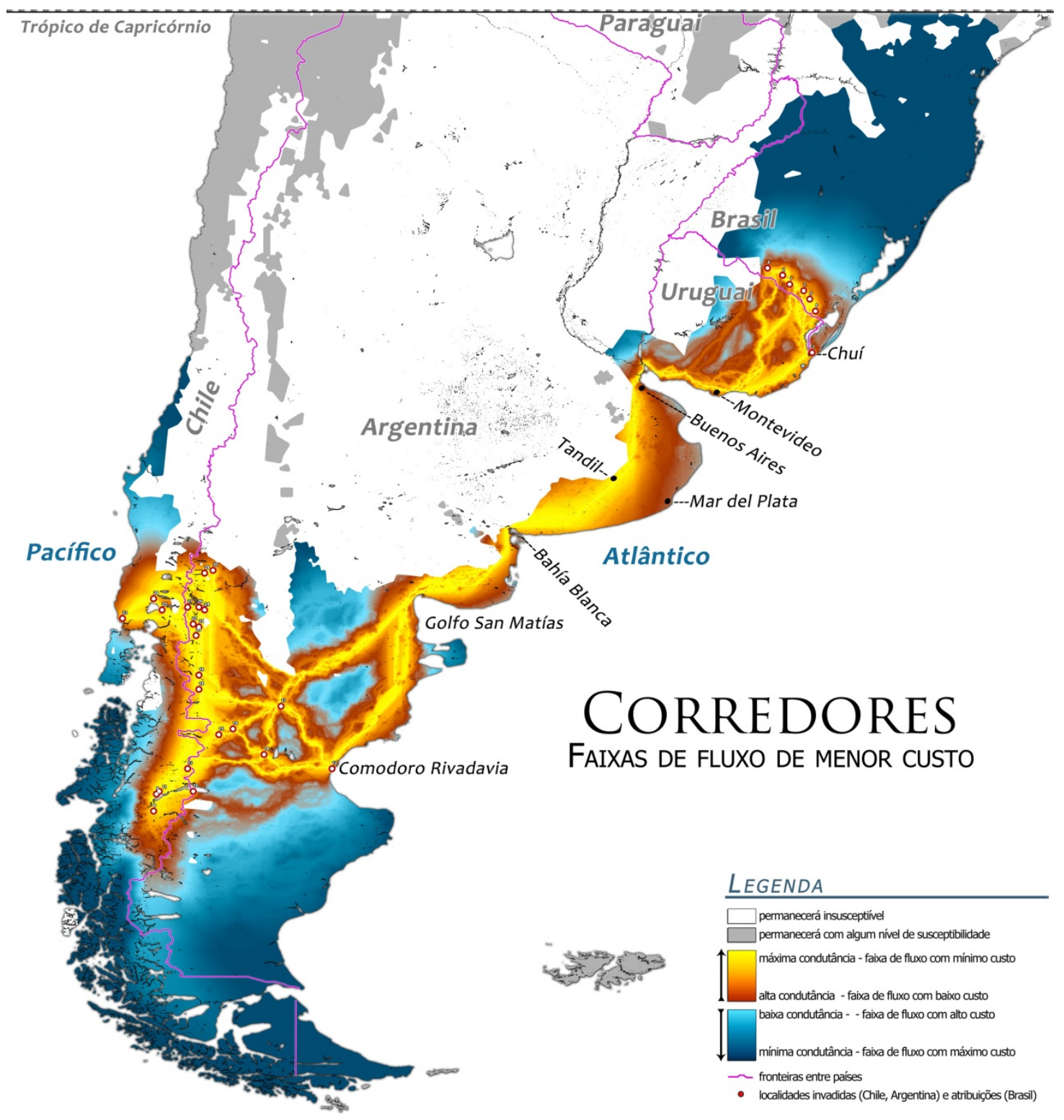

Figura C5-17. Corredores de invasão identificados por análises de conectividade que associam métricas de trajetos de menor custo com a teoria de circuitos, evidenciando a expansão e o espalhamento da espécie pelas áreas de maior qualidade ambiental (menor resistência ao fluxo) entre as localidades invadidas na América do Sul, e delas até as atribuições feitas nos municípios brasileiros susceptíveis que estão adjacentes à fronteira com o Uruguai. 
Estes dois pontos de constrições sequenciais formam a segunda região estratégica para monitoramento, estudos e eventuais ações de controle, que é ainda mais favorável que a primeira por ser mais restrita que as áreas adiante, com grande estreitamento na cidade de Bahía Blanca e com alta concentração de carga em ambos os pontos de constrição, sugerindo que a espécie deverá concentrar muito sua expansão nestas pequenas faixas de terra para prosseguir invadindo as regiões mais para norte. Além disso, é uma zona urbanizada, que poderá favorecer campanhas de monitoramento da chegada da invasora ao envolver a população nesta atividade por meio de projetos de ciência cidadã, por exemplo.

Após a cidade de Bahía Blanca, Bombus terrestris encontrará o ambiente de melhor qualidade ao longo de todo seu trajeto até o Brasil. Esta área de habitat de alta qualidade para a espécie tem cerca de $550 \mathrm{~km}$ de comprimento, entre Bahía Blanca e Buenos Aires, e tem a largura de aproximadamente $150 \mathrm{~km}$, entre Tandil e Mar Del Plata (Figura (5-16). Potencialmente, esta área permitirá à espécie estabelecer o segundo núcleo de expansão regional da invasão, mas neste caso a qualidade ambiental e a dimensão da área são ainda maiores que no primeiro. Se Bombus terrestris ocupar esta zona, ou quando isto ocorrer, as chances da espécie alcançar o Brasil poderão ser consideradas ainda maiores.

O corredor de invasão de Bombus terrestris circunda a zona oeste da capital argentina, Buenos Aires, e segue sentido norte (Figura C5-17), neste trecho há uma intensa concentração de corrente devido a uma constrição da área susceptível (Círculo 4, Figura C5-18), cuja largura mais estreita tem cerca $25 \mathrm{~km}$. Este ponto de constrição é o último no trajeto até o Brasil, e será a última chance para o desenvolvimento de monitoramento e planos de ação. A região de Buenos Aires possui instituições de pesquisa, universidades públicas e privadas (ex: Universidade de Buenos Aires, Pontifícia Universidade Católica da Argentina) e, inclusive, ações governamentais para monitoramento de polinizadores no âmbito da produção agrícola (MAA, 2015). Estes aspectos que poderão favorecer a rápida deteç̧ão da presença da espécie quando alcançar esta região, bem como para o desenvolvimento estudos e ações de controle do processo invasivo. No entanto, tão logo relatos forem publicados sobre a presença de Bombus terrestris nas proximidades de Buenos Aires, ações deveriam começar a ser planejadas também no Brasil, para intensificar o monitoramento de suas fronteiras e planejar ações de prevenção, avaliação e mitigação de potenciais impactos ambientais e às culturas agrícolas.

Logo após Buenos Aires, a faixa susceptível torna-se mais ampla (cerca de 120 $\mathrm{km}$ de largura) é recortada pelos rios Paraná e Uruguai, que desembocam no rio Prata. Com exceção do largo estuário do rio Prata (de 50 a $80 \mathrm{~km}$ ), os outros dois rios não impedem o trânsito da espécie, contudo o fluxo torna-se mais concentrado (Figura C518). A mais alta corrente foi detectada em uma pequena área onde as margens do rio Uruguai são mais próximas, entre as cidades de Nueva Palmira e Colonia Esterella, já no Uruguai. Entre Buenos Aires (Argentina) e Montevidéu (Uruguai) a espécie encontra um trajeto com maior resistência (Figura C5-18) e o corredor torna-se bastante estreito (Figura C5-17), o qual prossegue adjacente ao litoral.

Após Montevidéu, o corredor se expande e se ramifica em dois fluxos principais (Figura C5-17), um mais largo seguindo por via litorânea até o Chuí (Brasil) e outro adentra pelo interior do Uruguai, mas um pouco mais adiante, volta a se dividir em dois estreitos corredores, sendo que um ramo segue em direção as cidades de Bagé de 
Dom Pedrito e outro em direção às cidades de Pedras Altas e Herval. Entretanto, os trajetos de menor custo (Figura C5-16) não evidenciam uma ramificação do corredor que se dirige mais a oeste, para Dom Pedrito (Figura C5-17), apenas o corredor mais central que adentra ao Brasil entre as cidade de Aceguá-RS e Pedras Altas-RS e então, já em território brasileiro, se redireciona a oeste passando pelo norte de Aceguá-RS e Bagé-RS até alcançar Dom Pedrito (Figura C5-16).

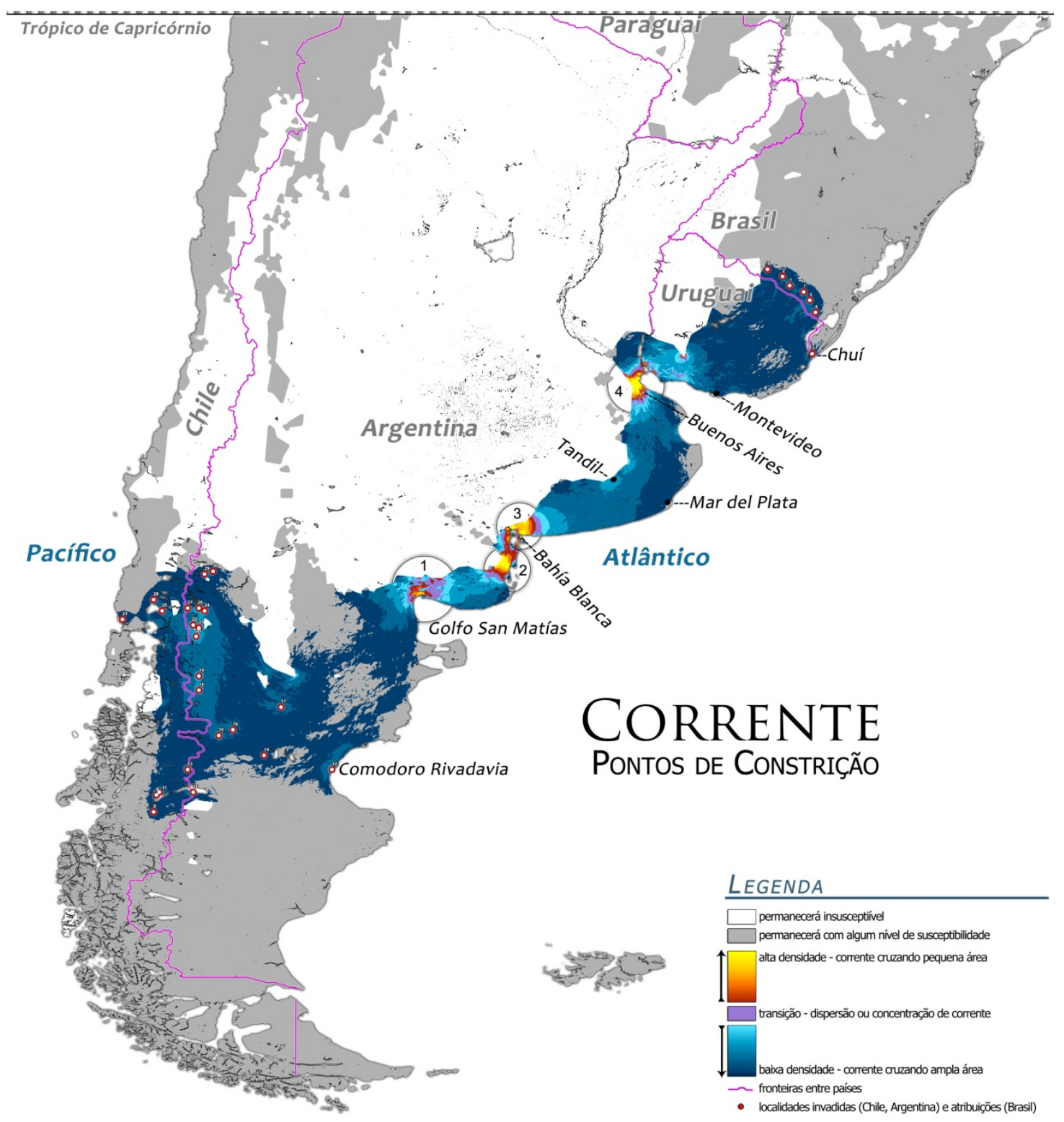

Figura C5-18. Mapa da "corrente elétrica", gerado pela métrica de conectividade com base na teoria de circuitos. Exibe os pontos de constrição (probabilidade de fluxo) no deslocamento da espécie através da área susceptível à invasão. Os círculos evidenciam as zonas prioritárias para monitoramento, estudos e ações de controle do processo invasivo, pois indicam as faixas mais estreitas de terra que possuem qualidade ambiental para a espécie ao longo de todo o trajeto.

Os efeitos das mudanças climáticas estimadas na SA, considerando-se ambos cenários futuros (RCP 4,5 e 6,0), não se apresentarão como grandes prejuízos à conectividade ambiental para Bombus terrestris no seu deslocamento invasivo, pois 
não foram detectadas extensas disjunções ou significativas fragmentações no amplo corredor litorâneo de susceptibilidade que liga as localidades invadidas com o Brasil (Figuras C5-19 e C5-20). No entanto, algumas potenciais influências na expansão da espécie foram detectadas.

Nas proximidades das ocorrências invasivas há uma miríade de pequenas áreas com diversificados tipos de mudanças, porém há entre elas o predomínio do aumento e ganho de susceptibilidade, denotando que esta área que atualmente apresenta alta qualidade para a espécie poderá torna-se ainda melhor no futuro.

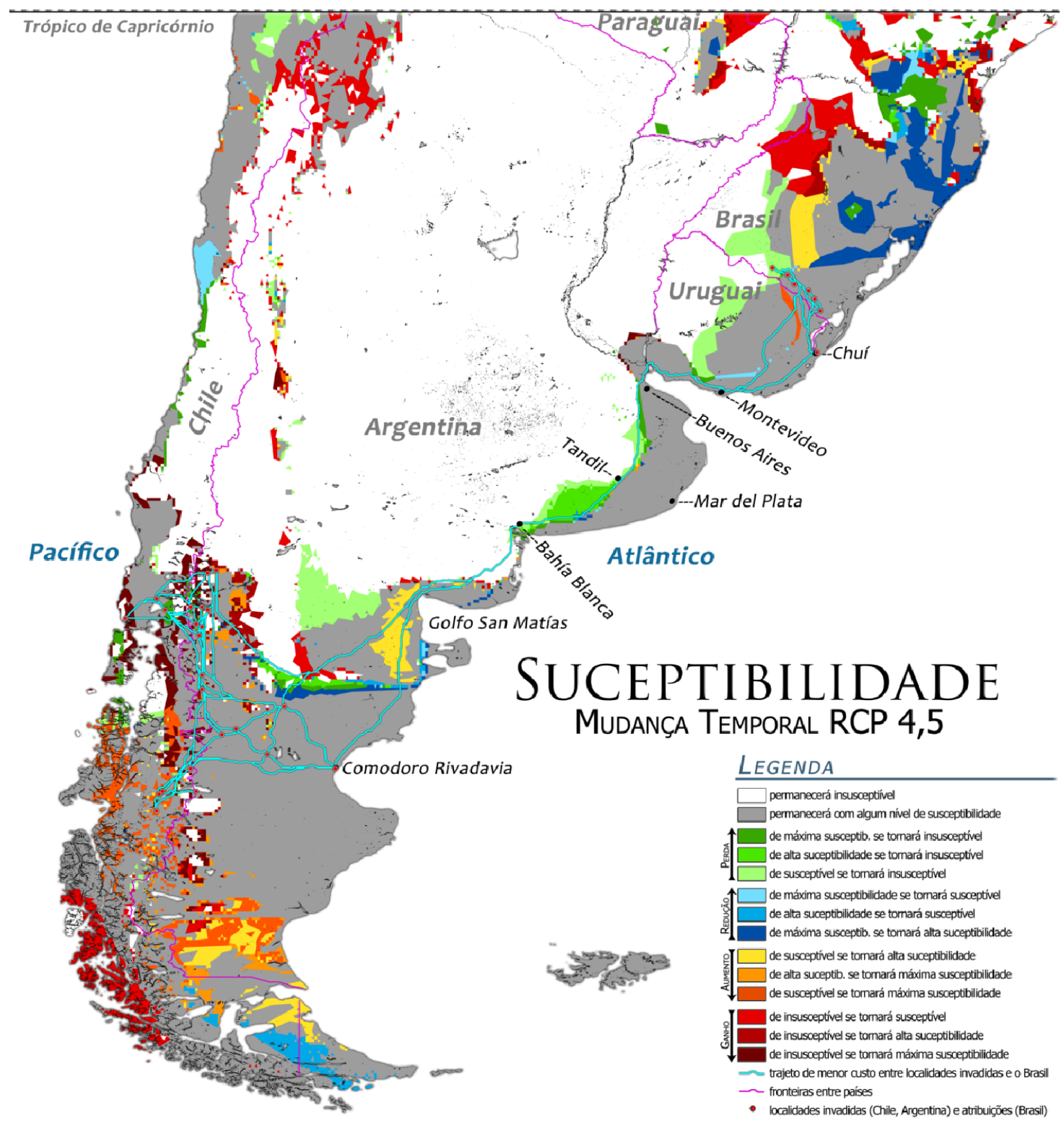

Figura C5-19. Trajetos de menor custo sobre o modelo de mudança temporal na susceptibilidade à invasão para o ano de 2050 no cenário RCP 4,5.

Em uma faixa horizontal que parte do litoral e adentra ao interior precisamente entre Comodoro Rivadávia e Golfo San Matías apresenta uma grande diversidade de mudanças (faixas horizontais com tons azuis e verdes e partes em vermelho), mas há o predomínio de perda e redução da susceptibilidade em ambos cenários, o que poderá prejudicar o deslocamento da espécie por meio dos corredores que partem do ponto 
17 e 30 e se dirigem ao Brasil. Esta evidência permite sugerir que o corredor que parte de Comodoro Rivadávia, que já apresenta o menor custo (507 CPD), tenderá, ao longo do tempo, ser a principal origem potencial dos indivíduos invasores que alcançarão o Brasil.

Em ambos cenários a região à esquerda do Golfo San Matías terá aumento de suscetibilidade, o que poderá favorecer a espécie em sua expansão ao longo deste percurso (área em amarelo; Figuras C5-19 e C5-20).

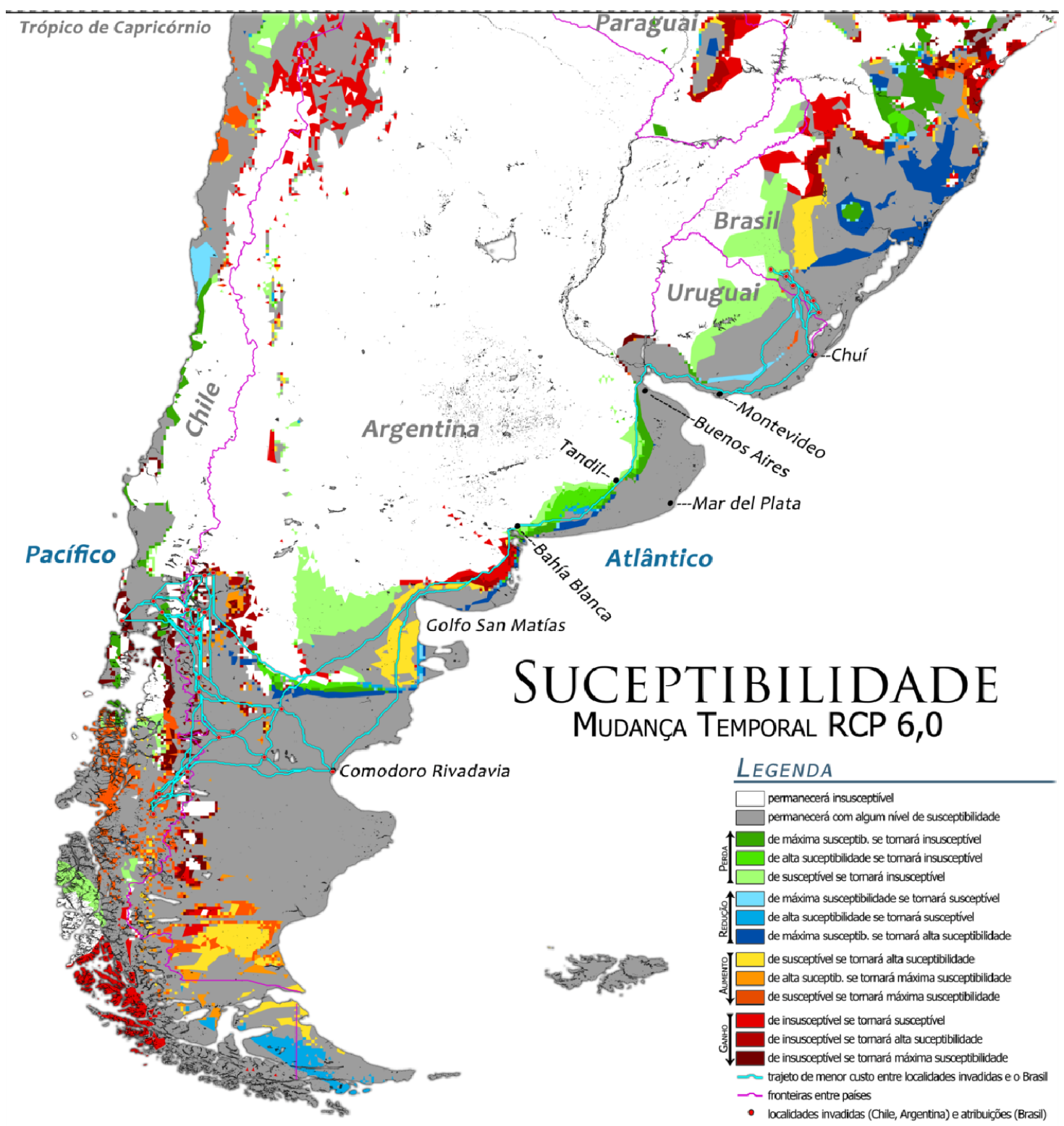

Figura C5-20. Trajetos de menor custo sobre o modelo de mudança temporal na susceptibilidade à invasão para o ano de 2050 no cenário RCP 6,0.

Adiante ao Golfo de San Matías e antes de Bahía Blanca, a expansão invasiva de Bombus terrestris será altamente favorecida se o cenário $\operatorname{RCP} 6,0$ for a tendência climática futura (Figura C5-20), pois haverá a ampliação da conectividade nesta região, provendo à espécie um significativo alargamento da faixa de susceptibilidade. Pode-se verificar que no cenário RCP 6,0 o trajeto de menor custo cruza pela área identificada como atualmente insusceptível que se tornará susceptível (em vermelho na Figura C5- 
20), esta faixa atualmente insusceptível foi incluída na análise de conectividade devido à divergência entre ambos os cenários, e imperou aquele que sugeriu susceptibilidade no futuro (o RCP 6,0). Se o cenário RCP 4,5 for a tendência climática futura, o trajeto linear detectado torna-se pouco provável e a espécie potencialmente apenas poderá alcançar a cidade de Bahía Blanca por uma estreita faixa susceptível litorânea (Figura C5-19). Pode-se considerar que esta faixa de susceptibilidade é a mais sensível à progressão da invasão de Bombus terrestris ao longo de todo o percurso, afinal, além de ser bastante estreita poderá sofrer alta influência das mudanças climáticas.

A região de Tandil terá perda de grandes áreas susceptíveis em uma faixa ocidental que coincide com o trajeto linear (área em verde; Figuras 5.4.2-5 e 6), mas a área com alta qualidade ambiental permanecerá bastante extensa, de forma que estas perdas previstas potencialmente não comprometem o fluxo da espécie sobre a área.

No corredor a partir Buenos Aires haverá um estreitamento justamente antes de Montevidéu em ambos cenários (RCP 4,5 e 6,0), mas o trajeto linear de menor custo se dá por uma delgada faixa próxima ao litoral que permanecerá susceptível no futuro, evidenciando que o fluxo não será impedido. Embora haja uma grande redução no oeste da área susceptível no Uruguai, esta não afetará o deslocamento da espécie, que se dará pelo leste do país.

\subsubsection{Por onde Bombus terrestris entrará no Brasil}

Foram identificados oito municípios brasileiros abrangidos pela faixa susceptível à invasão de Bombus terrestris e que fazem fronteira com o Uruguai. Potencialmente, será através deles que a espécie adentrará o Brasil deslocando-se naturalmente por meio de sucessivas colonizações a partir de locais já invadidos na América do Sul. Estes municípios apresentam diferentes níveis de qualidade ambiental conforme os requisitos da espécie invasora, bem como diferentes níveis de conectividade ambiental com os locais já invadidos na SA. Os municípios identificados foram: Aceguá; Bagé; Chuí; Dom Pedrito; Herval; Jaguarão; Pedras Altas e; Santa Vitória do Palmar (Figura C5-21).

O Uruguai, a partir de Montevidéu, é atravessado por dois principais trajetos lineares de menor custo ao deslocamento para a espécie invasora, sendo que um dos trajetos, o litorâneo, alcança a cidade de Chuí-RS e contém três diferentes origens (pontos 12, 17 e 30; Figura C5-16), também é relativamente mais curto e possui menores custos (507, 508, $583 \mathrm{CPD}$ ) do que o outro trajeto, o mais interiorano (658 CPD).

Os corredores de invasão também indicam que a espécie será favorecida se sua dispersão invasiva acompanhar o litoral uruguaio, pois encontrará áreas mais amplas com maior qualidade ambiental. Estas evidências reforçam a sugestão de que a espécie invasora adentrará o Brasil primeiramente por Chuí-RS e seu município adjacente, Santa Vitória do Palmar (Figura C5-21), onde os indivíduos encontrarão em território brasileiro amplas áreas de habitat adequado, abundantes recursos alimentares de origem agrícola e menor potencial de competir com espécies nativas do gênero Bombus, potencialmente permitindo-lhe ocupar eficientemente toda esta região (estas últimas inferências serão fundamentadas pelo item seguinte).

Foi possível verificar que municípios rio-grandenses de Jaguarão, Herval e parte dos municípios de Pedras Altas e Aceguá também estão vulneráveis aos primeiros 
eventos de invasão no país, pois além de estarem diretamente conectados com localidades invadidas através de trajetos de menor custo e corredores, também apresentam amplas áreas com alta qualidade ambiental que estão estreitamente conectadas entre si e, inclusive, com o município de Chuí (Figura C5-21).

A região sul da Lagoa Mirim, compartilhada com o Uruguai, possivelmente não será uma barreira intransponível para a espécie, pois a maior largura entre margens possui cerca de $20 \mathrm{~km}$, mas na maior parte desta extensão as margens opostas estão em distâncias ainda menores, permitindo a sugestão de que se primeira invasão vier a ocorrer no Chuí, não demorará muito até que a espécie alcance as outras cidades mais a norte, especialmente, Jaguarão e Herval.

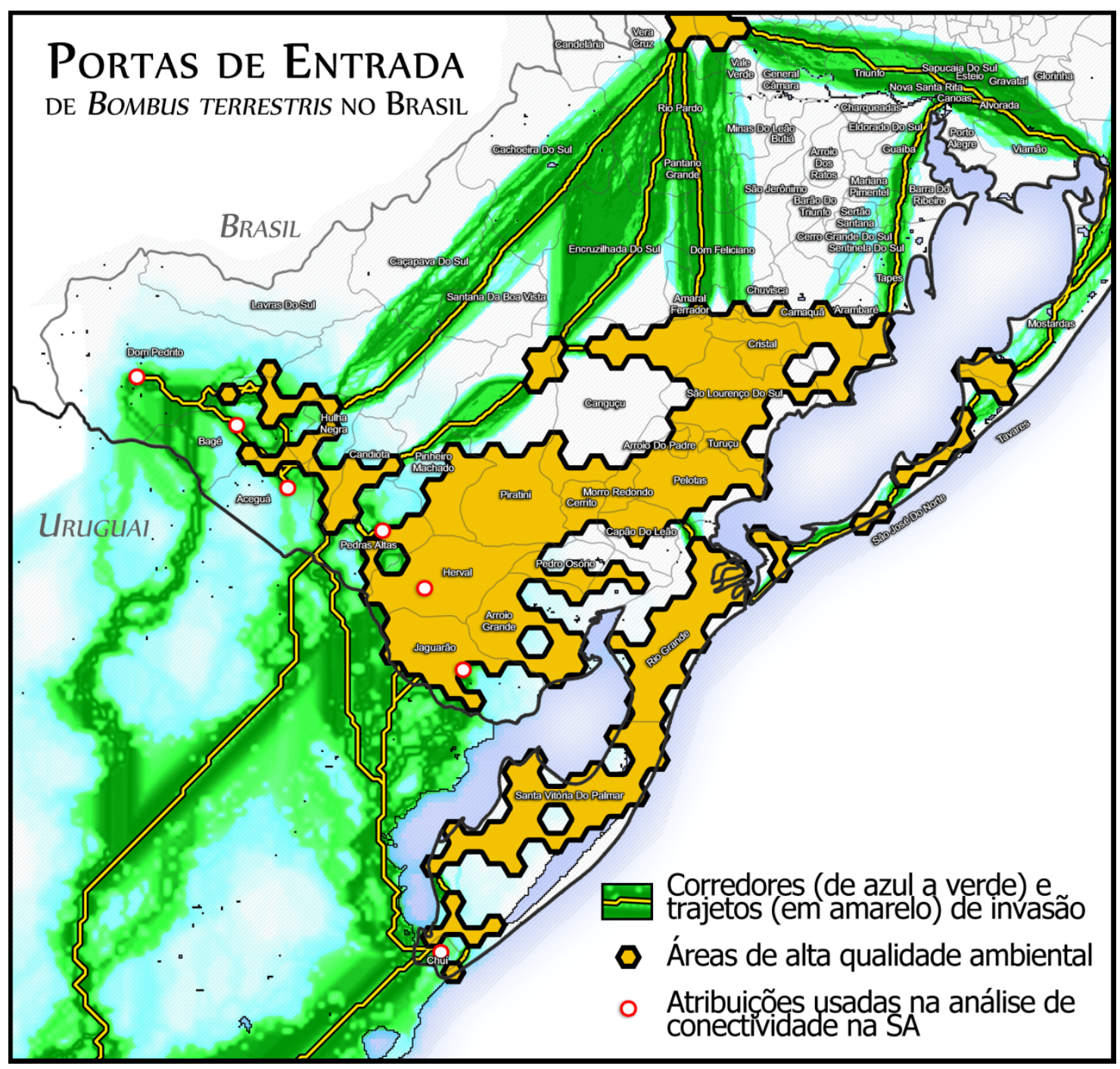

Figura C5-21. Corredores e trajetos de menor custo que partem de locais invadidos na América do Sul e alcançam cidades brasileiras próximas à fronteira com o Uruguai, bem como áreas de alta qualidade ambiental para a espécie invasora que poderão prover ambientes adequados ao seu estabelecimento no Brasil.

Os outros municípios fronteiriços, Dom Pedrito, Bagé e parte de Aceguá, também apresentam características ambientais favoráveis à invasão, ocupação e estabelecimento de Bombus terrestris nos termos ambientais avaliados, todavia, relativamente aos outros, estes não possuem a mesma alta qualidade (Figura C5-16). 
No caso de Dom Pedrito, estima-se que se tornará ambientalmente inadequado à espécie no futuro (Figura C5-19 e C5-20). A menor qualidade ambiental relativa na zona fronteiriça destes municípios também é revelada pelo não delineamento de trajetos de menor custo diretamente alinhados aos pontos atribuídos em seus interiores; o trajeto que os conectam partem de uma ramificação que cruza as divisas de Aceguá com Pedras Altas, fazendo praticamente uma curva à esquerda já dentro do Brasil, desviando-se de uma zona com maior resistência relativa (tons amareladoalaranjados na Figura C5-16). Com base nestes aspectos, é possível reforçar que Dom Pedrito é o limite mais ocidental das "portas de invasão" de Bombus terrestris no Brasil, e que os municípios fronteiriços com o Uruguai adiante a Dom Pedrito, em direção ao interior, então pouco vulneráveis à invasão.

\subsubsection{A potencial progressão da invasão no Brasil}

Para melhor apresentar os resultados da análise sobre a progressão de Bombus terrestris em território brasileiro após invasão, foi adotada, em alguns momentos, a perspectiva de que a espécie já adentrou ao país e está expandindo sobre os 418 municípios que foram identificados por cobrirem integralmente ou parcialmente corredores potenciais à invasão.

O gradiente de cores da Figura C5-22 exibe, de forma relativa, a variação da qualidade ambiental entre municípios na rota de invasão de Bombus terrestris no Brasil. Mas todos os municípios presentes no mapa estão sujeitos à invasão, pois apresentam a conjuntura de fatores ambientais adequados à espécie. Portanto, os municípios com a menor qualidade ambiental (tons de azul) também são vulneráveis, mas aqueles com maior qualidade poderão ser primeiramente ocupados ao longo da progressão invasiva da espécie no Brasil, que se iniciará pelo sul e seguirá em direção norte/nordeste.

A região "A" da Figura C5-22 (hachurados em preto) abrange sete dos oito municípios pelos quais Bombus terrestris potencialmente adentrará ao Brasil, ressaltando-se os municípios no extremo sul, Chuí (código 108 no mapa) e Santa Vitória do Palmar (código 332), que poderão ser os primeiros invadidos. Esta região contém a mais ampla dimensão de alta qualidade ambiental e maior conectividade com as ocorrências invasivas, portanto, corresponde potencialmente a área que será primeiramente ocupada por Bombus terrestris na decorrência do evento de invasão no Brasil.

Pode-se observar que além da grande quantidade de municípios com alta qualidade na região " $A$ " (Figura C5-22) também, de uma forma geral, há menor potencial relativo de competição por recursos com as espécies de Bombus nativas (Figura C5-23) e alta disponibilidade de recursos alimentares providos pelas culturas agrícolas desenvolvidas na região (Figura C5-24). Ademais, a máxima susceptibilidade atualmente exibida nesta região continuará existindo no futuro (Figuras C5-25 e C5-26; RCP 4,5 e 6,0; 2050).

A área "A" possui cerca de 4,5 milhões de hectares $\left(45,541 \mathrm{Km}^{2}\right)$ e a "porta da invasão" para o Brasil tem a largura de cerca de $380 \mathrm{~km}$ (medida acompanhando a linha de fronteira). Estes aspectos evidenciam que se a espécie alcançar o Brasil, esta região será extremamente favorável ao rápido espalhamento e estabelecimento da invasão adentro ao território brasileiro, o que poderá também se refletir em alta 
dificuldade de controle da invasão e menor capacidade de se mitigar potenciais impactos aos sistemas naturais e agrícolas.

Após a colonização desta ampla região " $A$ " se pode indicar que o progresso da expansão se direcionará primeiramente para a área " $B$ ", pois é a menor distância euclidiana para outra região com alta qualidade ambiental e o trajeto também apresenta baixa resistência, refletindo-se no menor custo de deslocamento. No entanto, a área " $B$ " tenderá a se tornar ambientalmente inadequada à espécie em 2050, e no futuro os seus municípios adjacentes perderão um pouco da qualidade ambiental atualmente apresentada, conforme estimado em ambos cenários futuros (Figuras C5-25 e C5-26). Neste trajeto de " $A$ " para "B" a espécie invasora cruzará através de grande diversidade de culturas agrícolas, que potencialmente lhe proverá abundantes recursos alimentares, mas também por uma faixa com elevado potencial de competir por recursos com espécies Bombus nativas (Figura C5-23)

Se a espécie seguir de " $A$ " para " $C$ ", poderá fazer dois trajetos potenciais: $(\alpha)$ um trajeto circundando a Lagoa dos Patos pela esquerda, por onde encontrará ampla área ambientalmente favorável, uma faixa adjacente à lagoa com baixo potencial de competir com as Bombus nativas e razoável diversidade de culturas agrícolas que the proverá recursos, ou então $(\beta)$ poderá alcançar a região " $C$ " expandindo sua distribuição pela relativamente estreita faixa de terra entre barreiras de água (Oceano Atlântico e Lagoa dos Patos), que apresenta menor qualidade ambiental em dois municípios ao longo do trajeto (Tavares-RS [376] e Mostardas-RS [241]), todavia, encontrará maior diversidade de recursos alimentares e menor potencial de competir com Bombus nativas que o trajeto $\alpha$. Os modelos de mudança temporal em ambos cenários indicam que os dois trajetos potenciais permanecerão no futuro com máxima ou alta susceptibilidade, com insignificantes diferenças entre eles. Os trajetos $\alpha$ e $\beta$ de " $A$ " para " $C$ " aparentam ser similarmente potenciais e, eventualmente, a espécie utilize-os simultaneamente para expandir sua invasão.

A região " $C$ " é a segunda mais ampla área com alta qualidade ambiental na dimensão total dos municípios mapeados (Figura C5-22), mas apresenta menor diversidade relativa de culturas (Figura C5-24) e um potencial geral mediano de competição por recursos com as Bombus nativas (Figura C5-23), mas este potencial é bastante elevado nos municípios marginais a noroeste. De uma forma geral, haverá uma pequena redução de suscetibilidade no futuro, de máxima para alta, na maioria dos municípios abrangidos, mas manterá algumas áreas municipais com máxima suscetibilidade em ambos cenários; a região " $C$ "no cenário RCP 4,5 ganhará de novas áreas susceptíveis próximas ao litoral (Figura C5-25 e C5-26).

A partir da região " $C$ " os trajetos de Bombus terrestris seguem orientados a norte, distanciando-se um pouco do litoral. As áreas com alta qualidade ambiental neste caminho são menores e mais fragmentadas; todas estas três áreas mais a norte estão abrangidas pela denominada região " $D$ ". A maior delas está mais ao sul desta região, e apresenta alta diversidade de culturas agrícolas (Figura C5-24), mas também alto potencial de Bombus terrestris competir por recursos com as Bombus nativas (Figura C5-23). Em termos de diversidade de culturas agrícolas, de fato, todas as áreas abrangidas pela região " $D$ " são favoráveis à espécie invasora, e os dois fragmentos mais a norte são favoráveis também por apresentarem menor potencial relativo de competição com as Bombus nativas (Figura C5-23). 
O potencial de expansão invasiva da espécie no norte da região " $D$ " sofrerá grande influência por decorrência das mudanças climáticas estimadas para 2050. No RCP 6,0 a região ganhará susceptibilidade, que poderá permitir que a espécie alcance áreas mais para o norte. Já no RCP 4,5 a espécie terá a redução de seu alcance nesta mesma direção, mas ganhará maior largura na região " $D$ ". O extremo norte da região " $D$ " já exibia no modelo de susceptibilidade global (Capítulo 4.1) a deterioração da qualidade ambiental para Bombus terrestris, o que se reflete na grande variabilidade de susceptibilidade detectada pelos modelos de mudança temporal em ambos cenários (Capítulo 4.2). Esta região já está muito próxima ao limiar latitudinal de alcance máximo da espécie dentro da faixa temperada. Conforme foi ressaltado na caracterização ecogeográfica (5.4.1), a espécie potencialmente é impedida de adentrar aos trópicos. Estes municípios próximos ao Trópico de Capricórnio poderão ser os últimos a serem alcançados ou nunca serem alcançados pela espécie. 


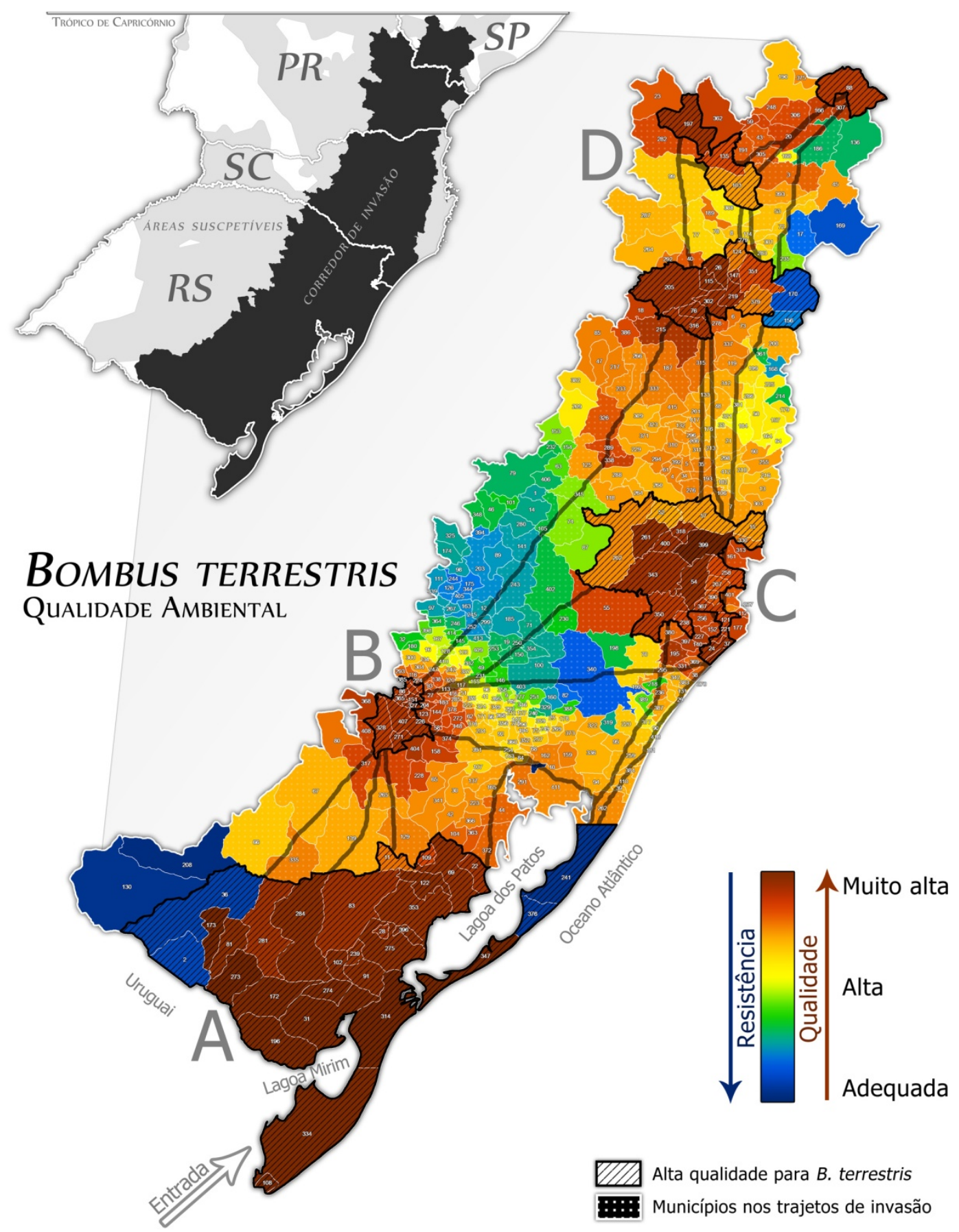

Figura C5-22. Mapa dos municípios na rota de invasão de Bombus terrestris no Brasil destacando quatro regiões com a mais alta qualidade ambiental para a espécie invasora (hachurados) e os trajetos de menor custo que as conectam (linhas pretas). A escala em cores exibe a variação da qualidade ambiental normalizada amostrada por município (e seu inverso equivalente, a resistência). A numeração sobre os municípios são referências em ordem alfabética que apontam os nomes de cada um deles, a unidade federal e os valores numéricos de cada análise, os quais poderão ser consultados no Anexo C5-4. 


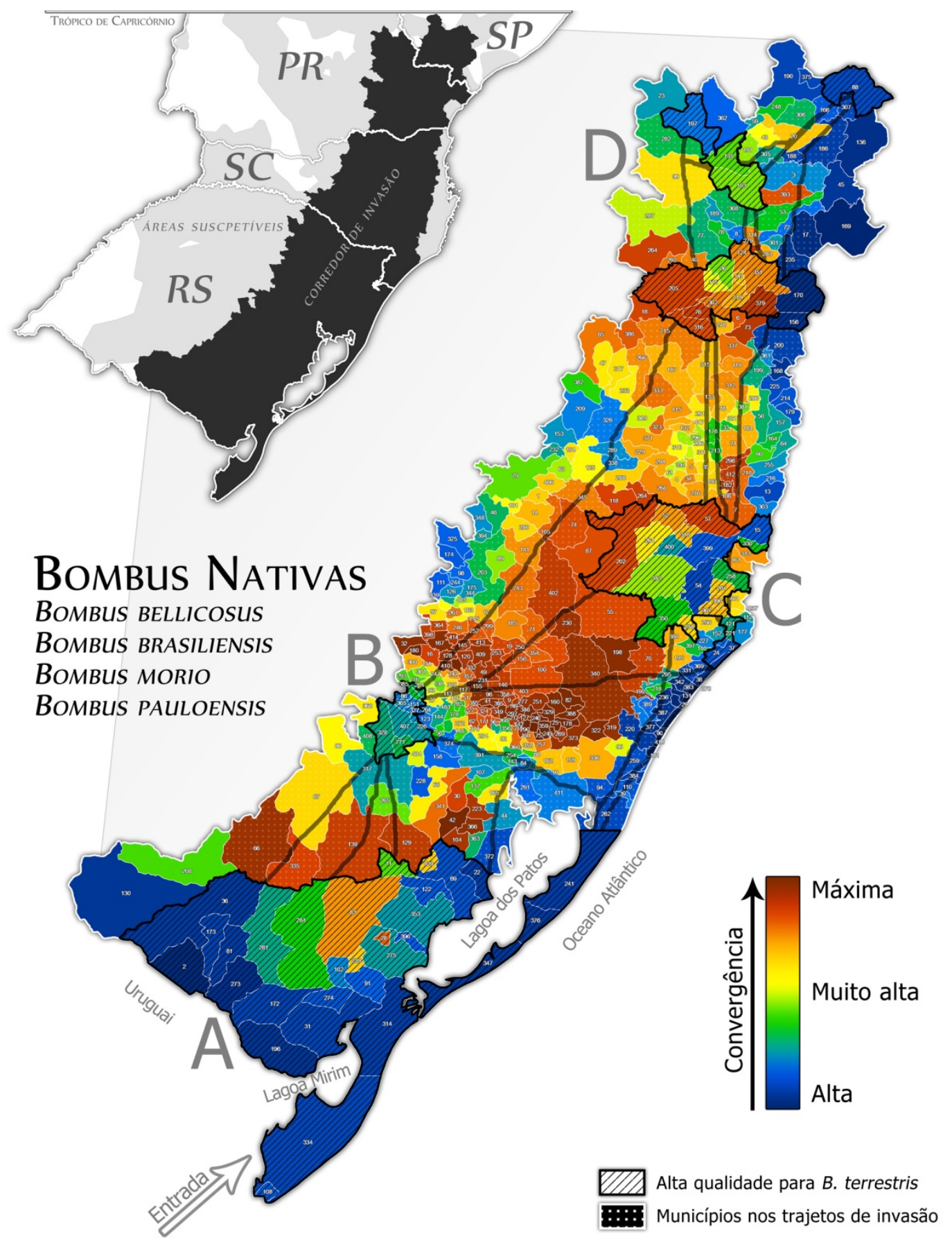

Figura C5-23. Mapa dos municípios na rota de invasão de Bombus terrestris no Brasil destacando quatro regiões com a mais alta qualidade ambiental para a espécie invasora (hachurados) e os trajetos de menor custo que as conectam (linhas pretas). A escala em cores exibe a variação da convergência preditiva normalizada média dos modelos de adequabilidade de habitat das quatro espécies de Bombus nativas no sul do Brasil, amostrada por município. A numeração sobre os municípios são referências em ordem alfabética que apontam os nomes de cada um deles, a unidade federal e os valores numéricos de cada análise, os quais poderão ser consultados no Anexo C5-4. 


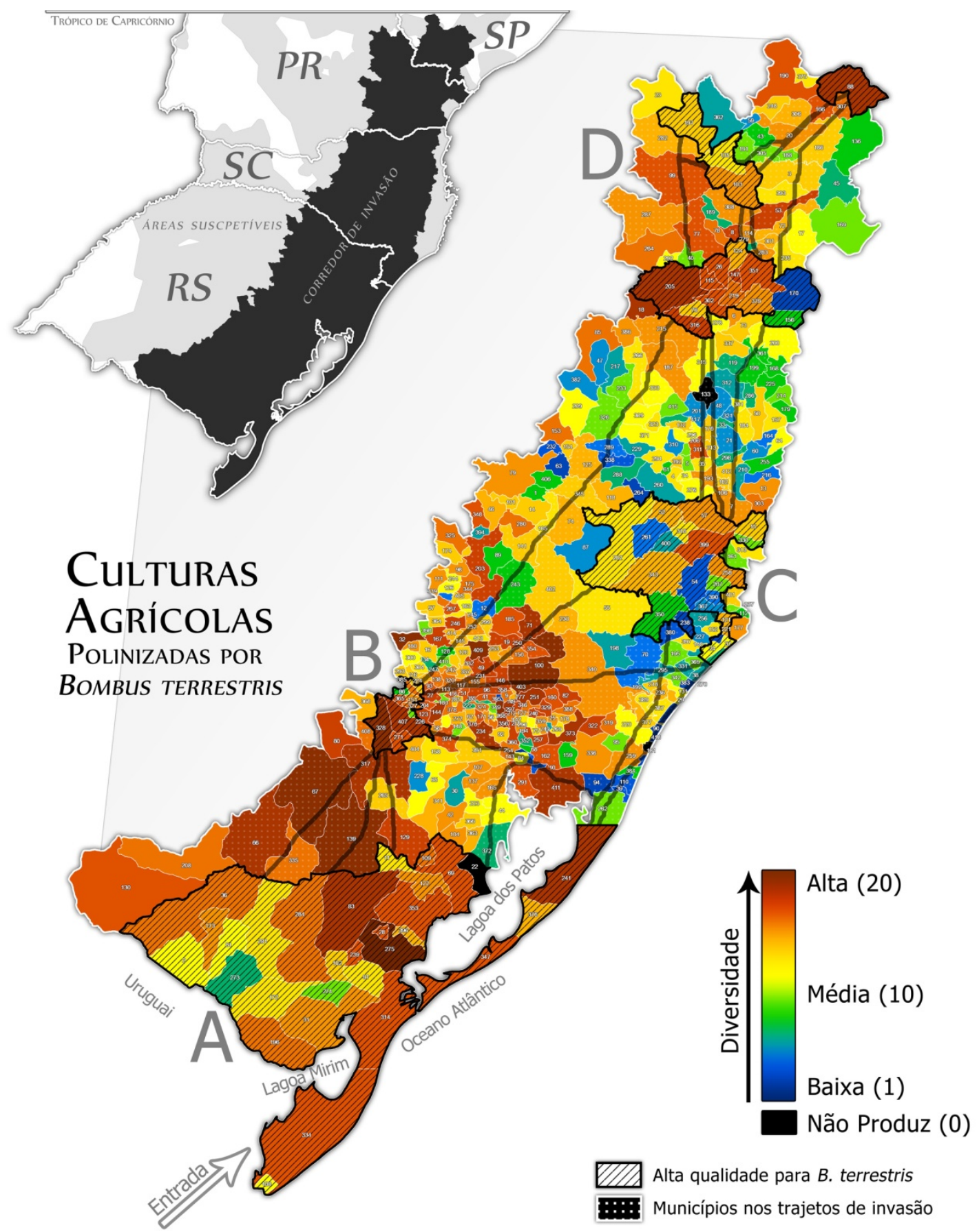

Figura C5-24. Mapa dos municípios na rota de invasão de Bombus terrestris no Brasil destacando quatro regiões com a mais alta qualidade ambiental para a espécie invasora (hachurados) e os trajetos de menor custo que as conectam (linhas pretas). A escala em cores exibe a variação em escala normalizada da diversidade de culturas agrícolas municipais que são polinizadas por Bombus terrestris. A numeração sobre os municípios são referências em ordem alfabética que apontam os nomes de cada um deles, a unidade federal e os valores numéricos de cada análise, os quais poderão ser consultados no Anexo C5-4. 


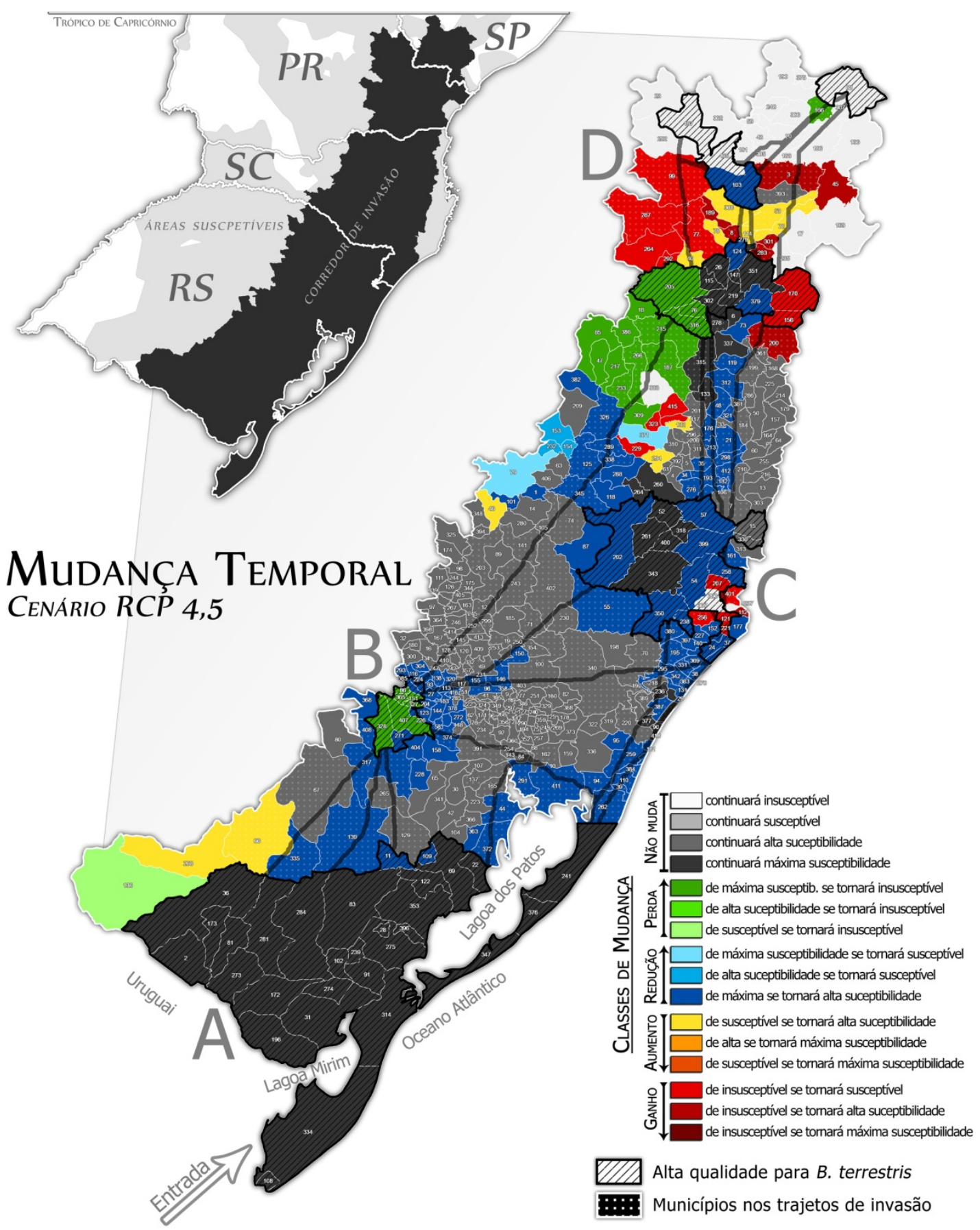

Figura C5-25. Mapa dos municípios na rota de invasão de Bombus terrestris no Brasil destacando quatro regiões com a mais alta qualidade ambiental para a espécie invasora (hachurados) e os trajetos de menor custo que as conectam (linhas pretas). A escala categórica em cores indica o tipo de mudança na susceptibilidade à invasão amostrada por municípios para 2050 no cenário RCP 4,5 (detalhes no Capítulo 4.2). A numeração sobre os municípios são referências em ordem alfabética que apontam os nomes de cada um deles, a unidade federal e os valores numéricos de cada análise, os quais poderão ser consultados no Anexo C5-4. 


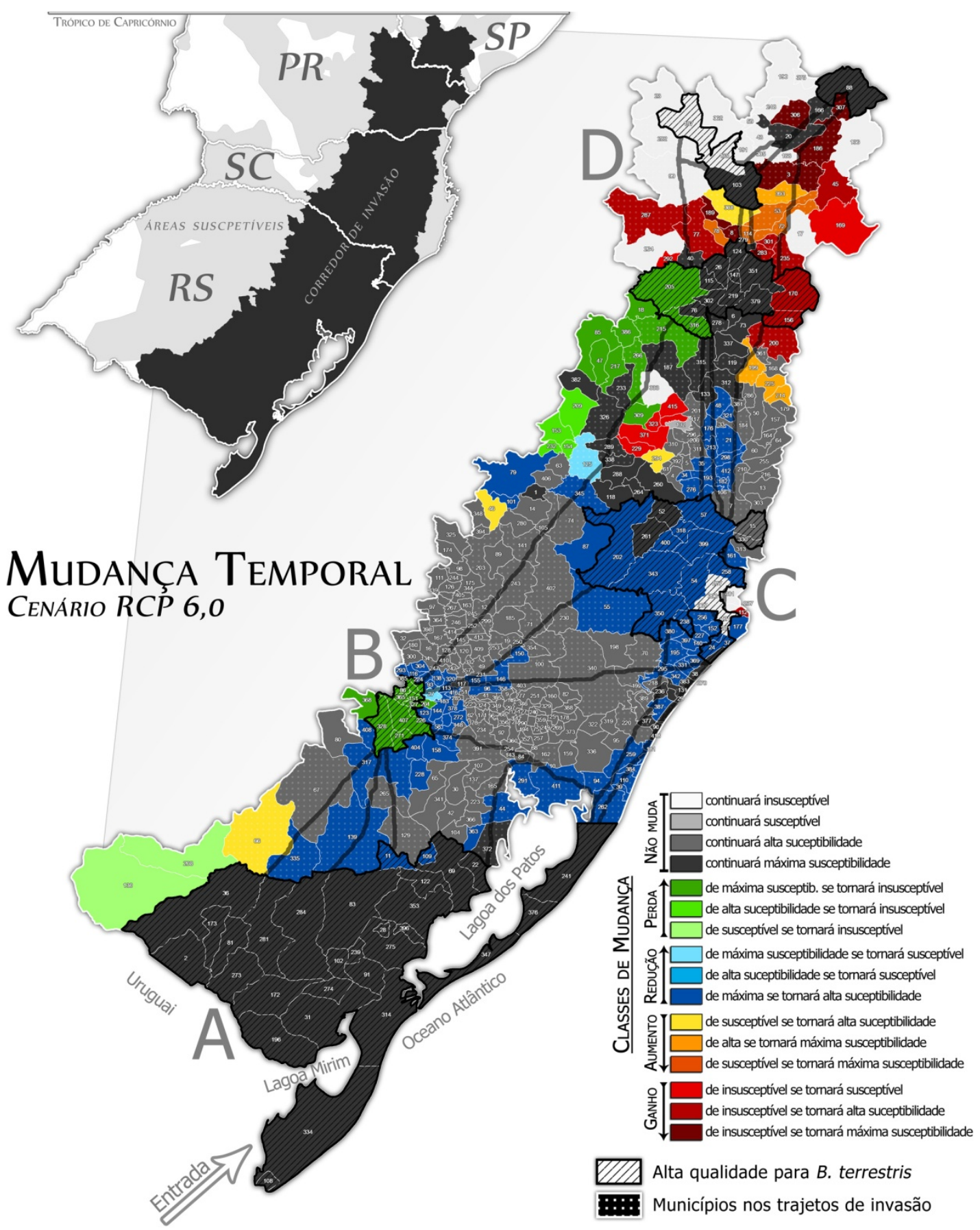

Figura C5-26. Mapa dos municípios na rota de invasão de Bombus terrestris no Brasil destacando quatro regiões com a mais alta qualidade ambiental para a espécie invasora (hachurados) e os trajetos de menor custo que as conectam (linhas pretas). A escala categórica em cores indica o tipo de mudança na susceptibilidade à invasão amostrada por municípios para 2050 no cenário RCP 6,0 (detalhes no Capítulo 4.2). A numeração sobre os municípios são referências em ordem alfabética que apontam os nomes de cada um deles, a unidade federal e os valores numéricos de cada análise, os quais poderão ser consultados no Anexo C5-4. 


\subsection{5. Áreas prioritárias para o monitoramento e ações após invasão no Brasil}

Se, ou quando, Bombus terrestris alcançar o Brasil, será recomendável o acompanhamento da progressão invasiva por meio de monitoramento sistemático periódico. Devido à estreita relação entre os polinizadores e as plantas selvagens e agrícolas, que por sua vez são exploradas direta e indiretamente por muitas outras espécies na cadeia trófica (inclusive pelos humanos), a presença de um polinizador invasor como a Bombus terrestris irá seguramente afetar vários níveis e em diferentes intensidades as redes de interações ecológicas onde estiver presente. $O$ delineamento e seleção de áreas prioritárias poderá ser referência para subsidiar planejamentos de estudos observacionais e experimentais para avaliar potenciais impactos da presença desta espécie nos sistemas naturais e agrícolas em áreas invadidas.

A rota de invasão no Brasil, que é abrangida por 418 municípios em 4 estados, compreende aproximadamente 23,3 milhões de hectares $\left(\sim 233135 \mathrm{Km}^{2}\right.$ ), e para que seja exequível uma amostragem científica em termos de viabilidade logística e econômica, se deverá priorizar áreas nesta ampla dimensão.

As cidades na rota de invasão foram classificadas em três níveis em ordem decrescente de prioridade (numericamente de 1 a 3, sendo que 1 é a máxima prioridade) e nove subníveis (em cores) que caracterizam tipos/intensidades variáveis de interações entre pares potencialmente interagentes, os quais são: Bombus terrestris e Bombus Nativas (Figura C5-27) e Bombus terrestris e Culturas Agrícolas (Figura C5-28).

Deve-se ressaltar que embora estejam atribuídos níveis de prioridade, todos os municípios exibidos estão susceptíveis a interações que poderão repercutir de formas diversificadas às espécies nativas de Bombus e às culturas agrícolas desenvolvidas na região, que em muitos casos poderão resultar em severos impactos ambientais. Considerando que a expansão invasiva se dará do sul para norte, os municípios mais ao sul são prioritários no início do processo de invasão, e a dimensão geográfica da área priorizada deverá ser progressivamente ampliada a partir do sul para o norte conforme se observar o espalhamento da espécie pelo Brasil.

Ações de mitigação de impactos que envolvem o controle populacional da espécie com base nas áreas prioritárias apontadas podem ser recomendáveis em casos específicos, especialmente em focos isolados, e com extrema cautela em todos os casos. Quando as ações de controle forem consideradas aplicáveis, após avaliação prévia, deverão ser planejadas e executadas exclusivamente por especialistas neste tipo de atividade e assessorados por especialistas na espécie e nos grupos taxonômicos que podem ser direta ou indiretamente afetados pela ação. Neste contexto, deve-se alertar que não foram encontrados casos na literatura científica relatando sucessos na erradicação de polinizadores invasores.

Ações almejando o impedimento da progressão invasiva de Bombus terrestris na América do Sul terão maior potencial de sucesso e melhor viabilidade logística, técnica e econômica se forem desenvolvidas nos pontos de constrição identificados no item 5.4.2 e que estão apontados na figura C5-18. No Brasil, devido à grande dimensão da área susceptível, o potencial de sucesso no controle ou na erradicação poderá ser baixo; obviamente, este potencial também dependerá da magnitude do esforço dedicado. Mas estudos ecológico-econômicos nestas áreas serão sempre recomendáveis após e a invasão e durante a progressão. 
Duas grandes regiões prioritárias foram identificadas por apresentarem simultaneamente a mais alta convergência entre as predições de adequabilidade de habitat para as Bombus nativas e a mais alta qualidade ambiental para Bombus terrestris (Prioridade 1; Figura C5-27; Anexo C5-4).

Estas regiões juntas abrangem 268 municípios ( $64 \%$ do total de municípios no mapa) e apontam as zonas onde potencialmente ocorrerão os maiores e/ou os mais frequentes impactos às espécies nativas do gênero Bombus, e podem servir como referência para estudos e ações de conservação das espécies nativas após a invasão.

Há uma grande quantidade de relatos de impactos às abelhas nativas em outros países por decorrência direta e indireta da presença invasiva de Bombus terrestris. Por exemplo, no Japão, a invasora tem sido responsabilizada por reduzir a aptidão reprodutiva de Bombus nativas ao cruzar com seus indivíduos e gerar proles não viáveis; também é apontada como responsável pelo declínio do número de colônias de Bombus hypocrita sapporoensis, devido à competição por recursos e à agressão direta ao matar rainhas para usurpar de suas colônias (Kearns et al., 1998, Inoue et al., 2008; Kanbe et al., 2008; Kondo et al., 2009). Em Israel, além de a espécie esgotar os recursos florais compartilhados com outras abelhas, pois inicia seu forrageio mais cedo e captura maior quantidade de recursos, os indivíduos da invasora são capazes de expulsar outras abelhas das flores, prejudicando as espécies nativas (Dafni e Shmida, 1996; Ruz, 2002).

Vários fragmentos foram identificados com alta prioridade (Prioridade 1; Figura C5-28; Anexo C5-4) para o monitoramento de potenciais interações da espécie invasora com as culturas agrícolas desenvolvidas nos 110 municípios abrangidos ( $26 \%$ dos municípios). Estas áreas prioritárias indicam alta variedade de culturas sujeitas às ações de um maior número potencial de populações invasoras de Bombus terrestris (consequentemente, maior número de indivíduos), ainda mais pela própria alta diversidade e, possivelmente, alta disponibilidade de recursos alimentares providos por estas culturas para a espécie invasora, além da alta qualidade ambiental conjunta. Bombus terrestris é conhecida por polinizar estas culturas em vários locais do mundo, além do mais, suas colônias são comercializadas por empresas para isso. Estas culturas são exóticas e introduzidas no país, portanto não fazem parte dos sistemas naturais brasileiros e, possivelmente, algumas destas culturas são decorrentes de variedades biológicas idênticas, ou de mesma origem, ou muito similares àquelas que Bombus terrestris habitualmente explora em outros locais do planeta. Ademais, as matrizes genéticas de Bombus terrestris que se espalham pela América do Sul, que potencialmente alcançarão o Brasil, são de origem industrial, destas empresas que produzem colônias e as venderam para o Chile, para polinização de tomate em estufa.

Seria uma trivial e evidente negligência científica omitir que algumas destas culturas seriam beneficiadas pela a presença invasiva de Bombus terrestris nestes municípios. Mas, em contrapartida à polinização, tem sido demonstrado que a espécie traz uma série de prejuízos a algumas destas mesmas culturas, bem como para outras culturas que ocorrem nestas mesmas áreas. Já na América do Sul, Aizen et al.(2014) reportaram que a produção de framboesas na Patagônia tem sido prejudicada por conta de danos causados pela invasora às estruturas reprodutivas da flor durante sua atividade de forrageio, prejudicando a fertilização, consequentemente, reduzindo produtividade destas culturas agrícolas. Há outros tantos relatos indicando que a espécie é um vetor de doenças e parasitas, tanto para outras abelhas como para as 
plantas agrícolas e selvagens, podendo repercutir negativamente na produção agrícola quando contaminada (Velthuis e van Doorn, 2006; Winter et al., 2006; Kenta et al., 2007; Goulson et al., 2008; Plischuk e Lange, 2009).

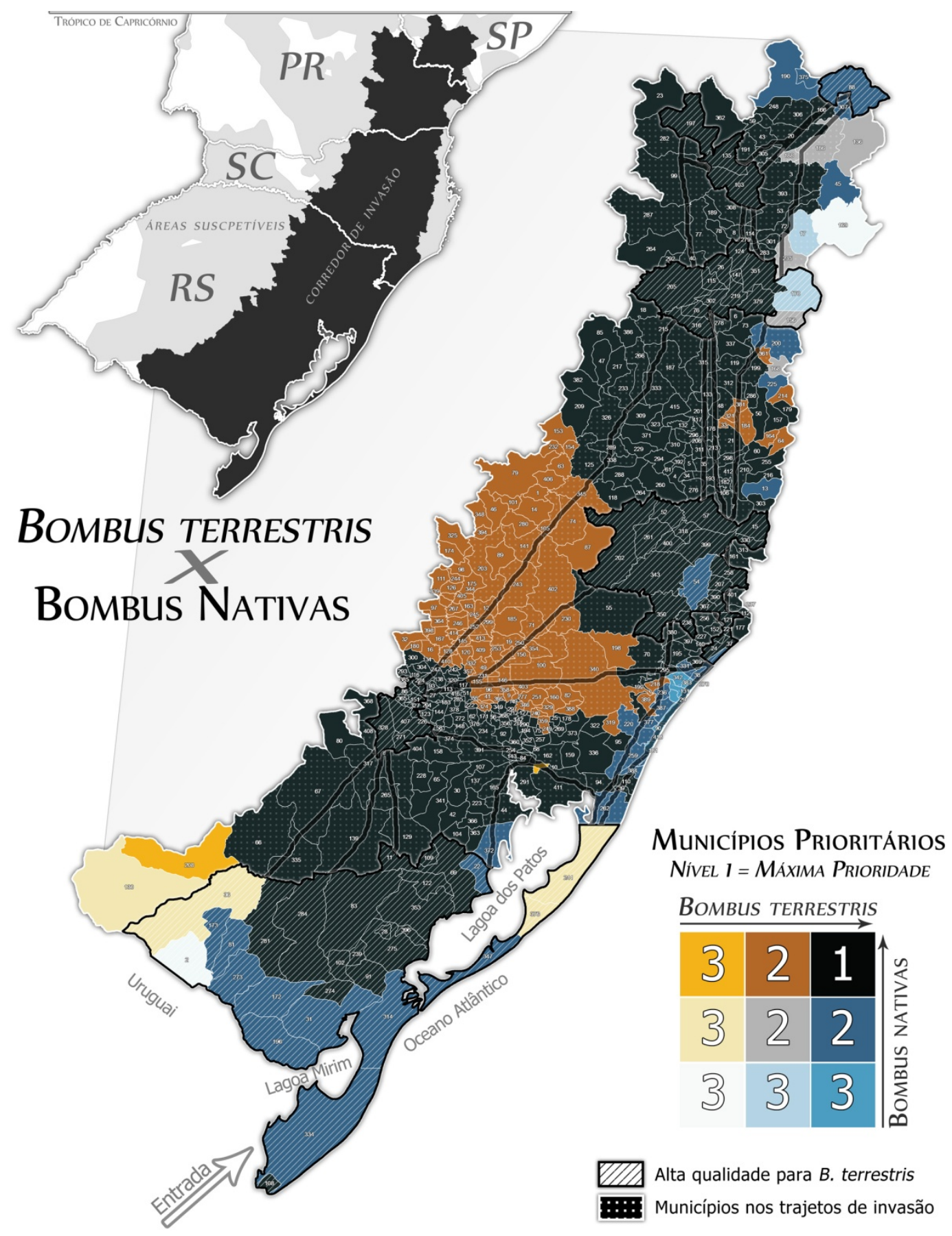

Figura C5-27. Mapa dos municípios na rota de invasão de Bombus terrestris no Brasil destacando quatro regiões com a mais alta qualidade ambiental para a espécie invasora (hachurados) e os trajetos de menor custo que as conectam (linhas pretas). A legenda bivariada em cores indica a combinação das escalas categorizadas municipais da variação da qualidade ambiental para Bombus terrestris (Fig. C5-22) e variação da convergência preditiva para as Bombus nativas (Fig. C5-23). A numeração sobre os municípios são referências em ordem alfabética que apontam os nomes de cada um deles, a unidade federal e os valores numéricos de cada análise, os quais poderão ser consultados no Anexo C5-4. 


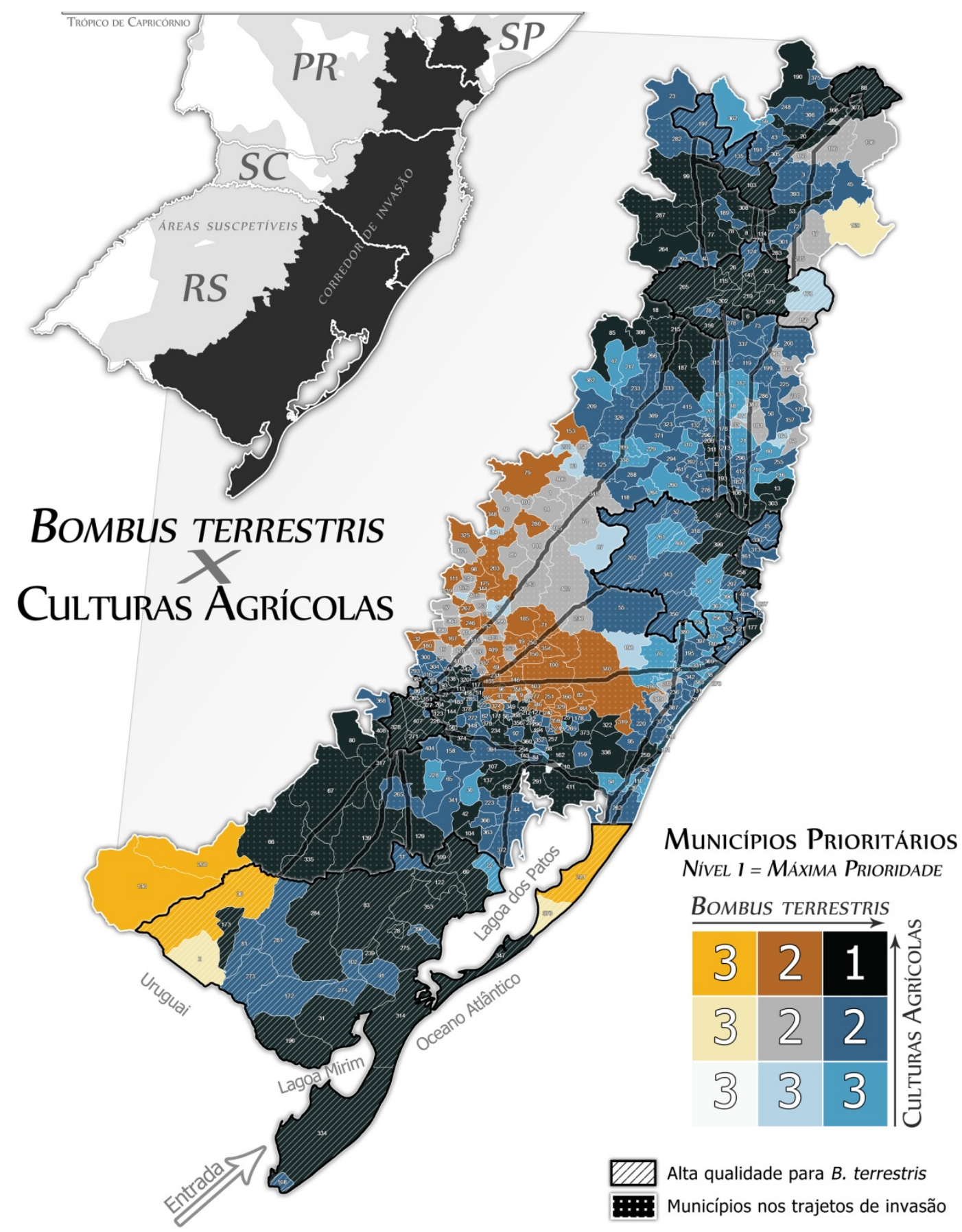

Figura C5-28 - Mapa dos municípios na rota de invasão de Bombus terrestris no Brasil destacando quatro regiões com a mais alta qualidade ambiental para a espécie invasora (hachurados) e os trajetos de menor custo que as conectam (linhas pretas). A legenda bivariada em cores indica a combinação das escalas categorizadas municipais da variação da qualidade ambiental para Bombus terrestris (Fig. C5-22) e variação da diversidade de culturas agrícolas municipais (Fig. C5-24). A numeração sobre os municípios são referências em ordem alfabética que apontam os nomes de cada um deles, a unidade federal e os valores numéricos de cada análise, os quais poderão ser consultados no Anexo C5-4. 


\section{Capítulo 6. Observações da paisagem rio-grandense e ações práticas}

Logo no início desta pesquisa, após o desenvolvimento do modelo preliminar de suscetibilidade de invasão de Bombus terrestris em escala global, constatou-se a vulnerabilidade do Brasil ao se detectar uma grande faixa susceptível que partia do sul da América do Sul e adentrava por quatro estados brasileiros. Esta faixa coincidia com vários registros empíricos de colônias e indivíduos da espécie invasora que já estavam estabelecidas neste continente. Acresce ainda, que vários relatos foram encontrados na literatura sobre a rápida expansão da espécie na Argentina a partir de locais já invadidos no Chile, onde fora primeiramente introduzida.

Mas, além disso, o mais preocupante foram os relatos que indicavam que o Uruguai poderia já ter sido invadido pela espécie, não por meio de progressão natural da invasão, mas por introdução direta de colônias naquele país por agricultores, para polinização de culturas agrícolas. No entanto, nada foi encontrado que confirmasse a presença da espécie no Uruguai; mas a suspeita não poderia ser totalmente eliminada, pois também nada foi encontrado que confirmasse a ausência. Considerando-se tudo isso, não seria prudente o desenvolvimento de uma série de aprofundadas análises averiguando o potencial de o Brasil ser invadido sem antes averiguar se a espécie já estaria, ou não, por aqui. Afinal, se a espécie já tivesse invadido o Brasil, o enfoque da pesquisa deveria ser outro.

Assim, foi feito um levantamento em campo sobre a área susceptível mais próxima à fronteira com o Uruguai, para verificar a presença ou ausência de Bombus terrestris no Brasil, cuja presença não foi confirmada (Capítulo 3), todavia, o nível de segurança para se certificar sua ausência é ainda muito baixo. O levantamento também proveu coleta de indivíduos de Bombus nativas (Capítulo 3) e, sobretudo, uma perspectiva empírica da paisagem rio-grandense pela qual a invasora poderá acessar o país no futuro. Estas observações in loco, nas potenciais "portas de entrada" de Bombus terrestris no Brasil, contribuíram com informações complementares que auxiliaram na conclusão desta pesquisa. Estas informações estão abordadas logo a seguir, no item 6.1.

Pela leitura dos capítulos anteriores pôde-se perceber que esta pesquisa foi, até este momento, fundamentalmente metodológica e analítica - utilizando-se de uma variedade de lógicas matemáticas, lidando com conceitos biológicos, definindo premissas imprescindíveis e subsidiando resultados com base em conhecimentos publicados - para prover uma grande quantidade de informações sobre a ecogeografia de Bombus terrestris e seu potencial de invasão em escala global, objetivando responder por onde potencialmente decorrerá a progressão invasiva pela América do Sul até chegar ao Brasil, e dentro de nosso país. Todavia, desejou-se ir um pouco além de um estudo preditivo sobre uma invasão potencial ao incluir também uma aplicação prática por meio do estabelecimento de colaborações com setores da sociedade e pesquisadores. Assim, foi desenvolvida uma campanha de monitoramento participativo, convidando a sociedade brasileira para participar da "caçada" à Bombus terrestris no Brasil aos moldes da modalidade de extensão científica denominada ciência cidadã (Citizen Science); o que está abordado no item 6.2. 


\subsection{Observações in loco nas "portas de entrada" de Bombus terrestris no Brasil.}

Em praticamente todo o trajeto percorrido na faixa susceptível no extremo sul do Estado do Rio Grande do Sul (em vermelho na Figura C6-1) tinha-se a percepção de que não havia um metro de terra que não havia sido modificado pelas atividades humanas. O solo estava coberto por "oceanos" de monoculturas (Figura C6-2: A, B, C, E) e pastagens (Figura C6-2: D, G). As zonas alagadas observadas, quase sempre estavam modificadas e degradadas (Figura C6-2: D). Frequentemente, o que se observava de vegetação nativa eram pequenos fragmentos isolados em meio a monoculturas (Figura C6-2: B). Apenas em duas regiões ao longo de todo trajeto foram observadas com grande quantidade de fragmentos de vegetação, sendo que em apenas uma destas regiões se observou faixas contínuas, porém relativamente estreitas.

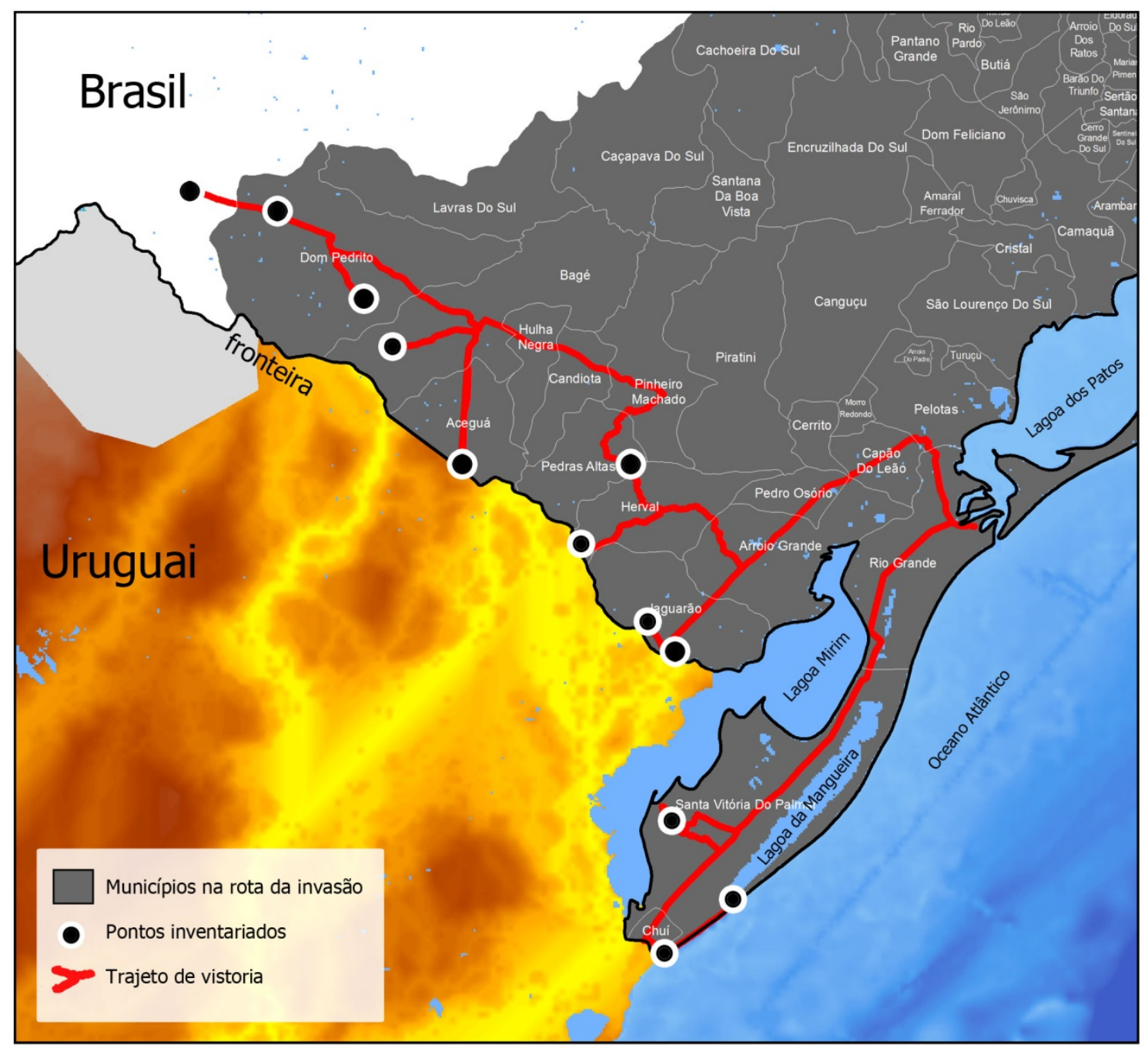

Figura C6-1. Trajeto percorrido sobre a área susceptível à invasão por Bombus terrestris no extremo sul do Brasil. A figura evidencia a abrangência dos municípios identificados na rota de invasão, os pontos inventariados e os corredores de invasão que alcançam o Brasil a partir de localidades invadidas na Argentina. 
Na região que é abrangida pelo município de Herval foi observada grande quantidade de fragmentos de vegetação nativa com diversas plantas floridas no caminho para o ponto de coleta que distava apenas alguns metros do Uruguai (Figura 6-1). Nesta região, em termos relativos ao que se observou no trajeto, havia considerável abundância de abelhas nativas, especialmente Xylocopa, que aparentemente eram os principais visitantes de uma espécie de maracujazeiro selvagem recorrente em toda a região (Figura 6-3: A e B).
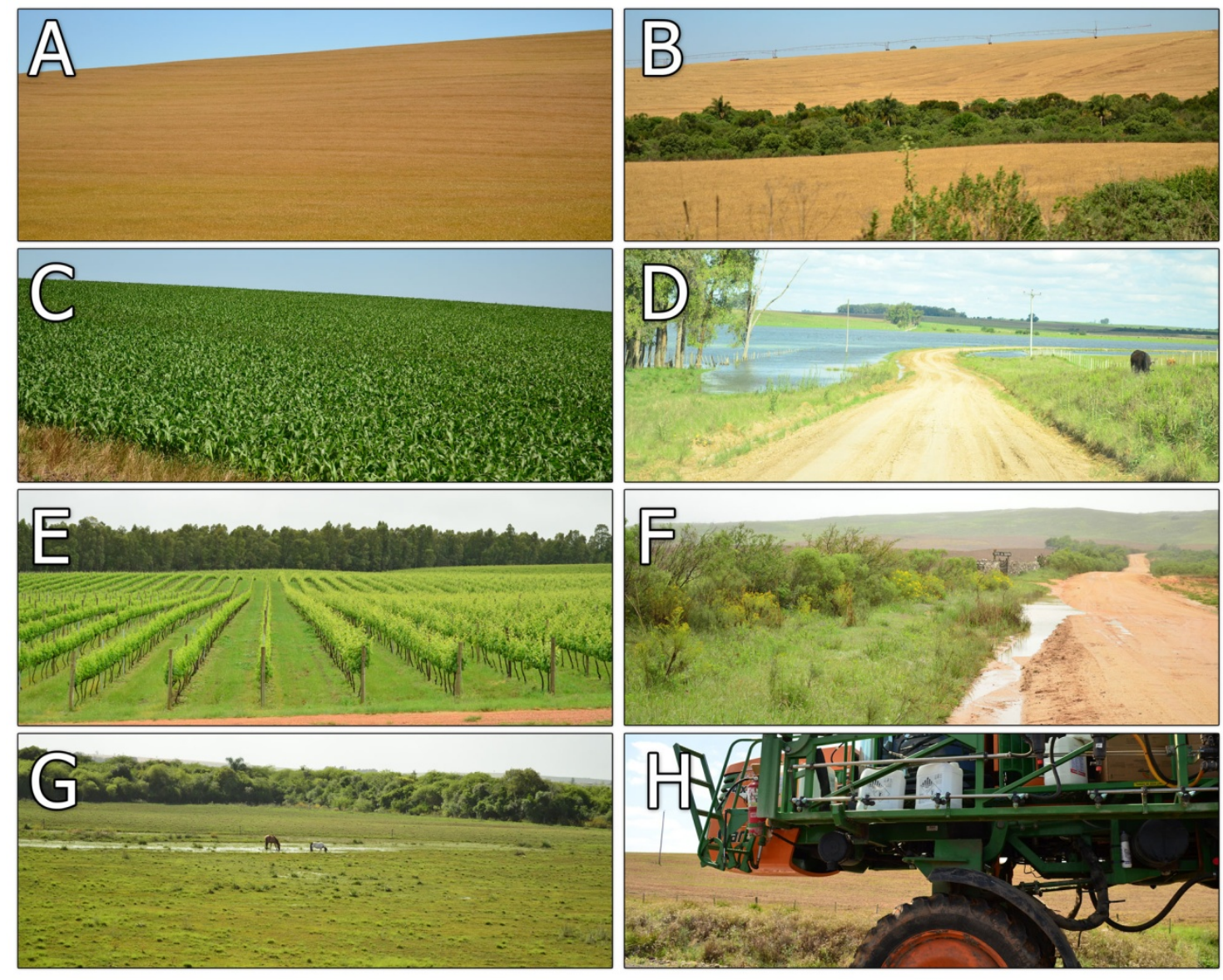

Figura C6-2. A, B, C e E: Monoculturas. B: Foco de vegetação nativa "ilhado" por monocultura. D e G: Zonas alagáveis modificadas em pastagem. F: Finas faixas de recursos alimentares e nidificação nas margens das estradas. H: Uma dentre as várias máquinas aplicadoras de agrotóxicos observadas no trajeto.

$\mathrm{Na}$ área compreendida pela faixa de terra isolada por água em ambos os lados, coberta pelas cidades de Chuí, Santa Vitória do Palmar e Rio Grande, notavelmente entre o Atlântico e a Lagoa da Mangueira (Figura C6-1), observou-se uma faixa contínua de um particular tipo vegetacional de restinga com grande quantidade e variedade de herbáceas floridas, mas também alguns arbustos floridos, que estavam sendo visitadas por grande diversidade de abelhas, inclusive abelhas grandes dos gêneros Xylocopa e Bombus. Nesta região litorânea foi observada (não quantificada) uma maior abundância e riqueza de abelhas no período e, aparentemente, este é um ambiente bastante favorável para as abelhas nativas, pois havia grande quantidade e diversidade de recursos florais de plantas nativas. Devido à maior presença de solo ainda não modificado pelas atividades humanas, observou-se grande disponibilidade 
de recursos para nidificação que estavam sendo utilizados pelas abelhas, como troncos em decomposição, arbustos secos, cupinzeiros abandonados, entre outros. Mas mesmo nesta faixa litorânea mais preservada se podia ver à distância a área na outra margem da Lagoa da Mangueira, em direção ao interior, em que o solo já estava totalmente dominado por culturas agrícolas.
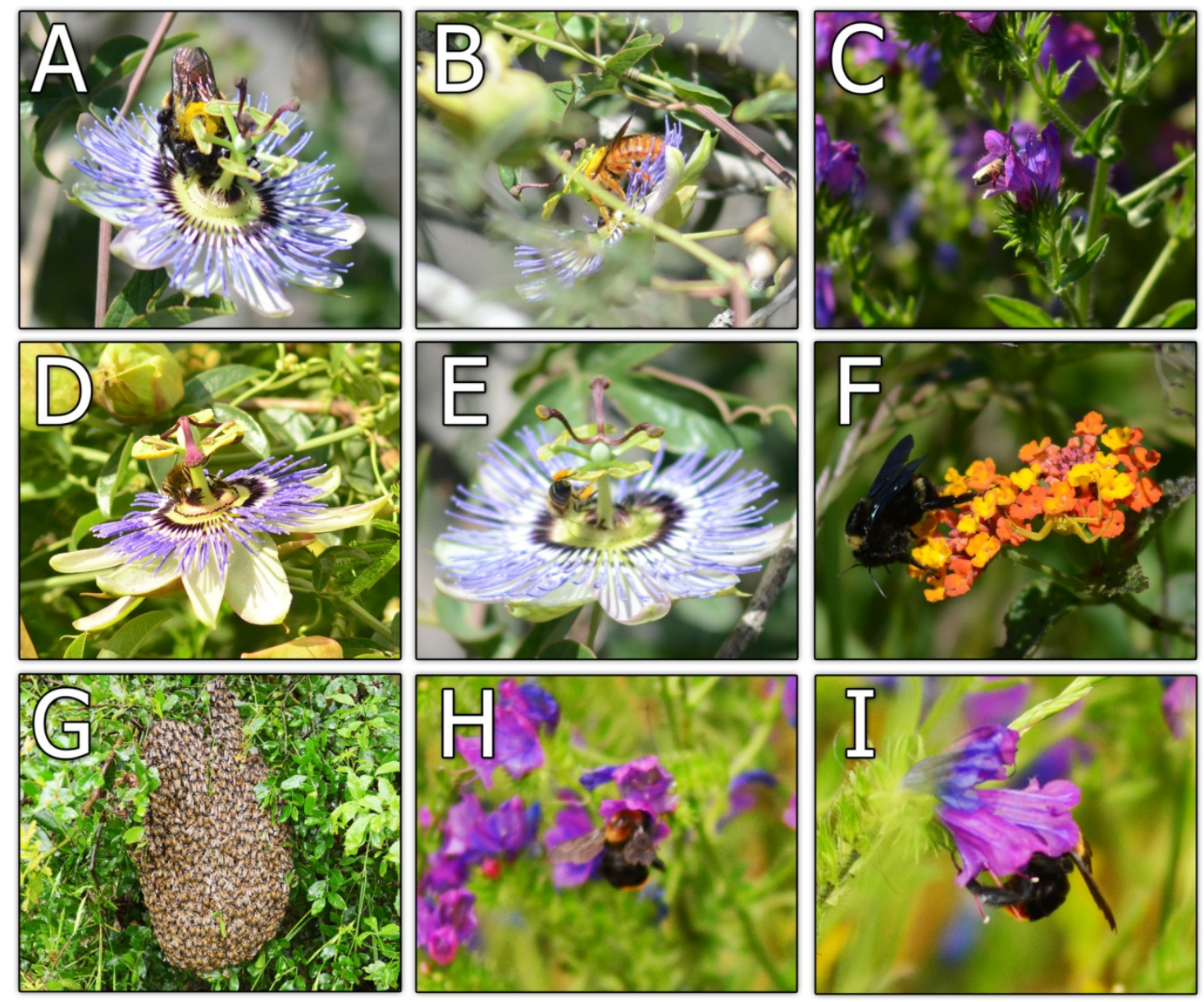

Figura C6-3. A e B: Polinização efetiva por Xylocopa sp. (fêmea e macho); C: Apis mellifera explorando recursos em flores tubulares; D: Possível pilhagem de recurso floral por Apis mellifera; E: Apis mellifera tocando as anteras do maracujá; F: Sob ameaça por uma aranha a espreita; G: Enxameamento de Apis mellifera; $\mathrm{H}$ e I: Bombus bellicosus visitando flores roxas tubulares longas.

Nitidamente, por meio de uma observação geral, maior riqueza e abundância de abelhas nativas foram verificadas nas zonas com maior riqueza e abundância de plantas nativas. Por outro lado, Apis mellifera fora observada em todos os lugares, de forma bastante generalizada; além de quase sempre se observar indivíduos explorando plantas floridas (Figura C6-3: C, D, E), pôde-se observar colônias em mourões de cercados e muros de pedra, mas também grandes exameamentos pendurados em arbustos (Figura C6-3: G).

Pouco se pode afirmar com segurança sobre como será o desempenho populacional de Bombus terrestris quando invadir o Brasil, pois não se sabe precisamente as barreiras bióticas que a espécie deverá transpor para se estabelecer nesta região, como as doenças e os predadores que encontrará. Mas com base nos 
conhecimentos publicados, nos resultados da análise indicando sua alta frequência em zonas agrícolas, e ainda considerando a presença generalizada de Apis mellifera, que é outra invasora europeia que praticamente coocorre com Bombus terrestris na Europa, pode-se reforçar que a espécie de Bombus invasora encontrará um ambiente biótico e abiótico (conforme detectado) bastante favorável para sua plena ocupação e expansão em território brasileiro.

No advento do sucesso da invasão, a espécie invasora potencialmente irá competir com maior frequência e intensidade com as Bombus nativas nas zonas com maior quantidade de fragmentos naturais de vegetação. Por outro lado, nas zonas predominadas por culturas, Bombus terrestris e Apis mellifera poderão ser as espécies de polinizadores dominantes no futuro, talvez até de abelhas; evidentemente, a ser futuramente verificado por análises e levantamentos sistemáticos.

As observações sobre a atividade de forrageio, requerimentos ambientais e comportamento das abelhas nativas de grande porte do gênero Bombus e Xylocopa podem prover indícios sobre os tipos de recursos nativos que Bombus terrestris poderá usufruir quando invadir o Brasil, tendo em vista algumas similaridades comportamentais entre as espécies do gênero Bombus e a relativa proximidade em tamanho físico com as abelhas do gênero Xylocopa e Bombus nativas do Brasil.

Pôde-se perceber a distinta preferência das abelhas nativas grandes por flores roxas, avermelhadas ou rosadas (Figura $\mathrm{C6} 6-3$ : $\mathrm{H} \mathrm{e} \mathrm{I}$ ), em detrimento de algumas flores brancas e esverdeadas que também estavam disponíveis, mas que eram usadas apenas por Apis mellifera e alguns outros artrópodes. Diversas pesquisas tratam destas preferências florais relacionadas à coloração para Bombus terrestris e algumas suportam que suas preferências por determinadas cores são similares ao que foi observado nas Bombus nativas (ex: Gumbert, 2000; Dyer e Chittka, 2004; Dyer et al., 2008, Forrest e Thomson, 2009; Foster et al., 2014).

Peculiarmente, se observou tentativas fracassadas de abelhas grandes em explorar recursos alimentares em algumas plantas herbáceas de caule fino com flores não tubulares cuja de abertura na corola ${ }^{21}$ variava entre 10 e $15 \mathrm{~mm}$, pois quando pousavam sobre elas o pedúnculo floral envergava porque não era capaz de sustentar seu peso, e a abelha era obrigada a se direcionar para outras plantas. Por outro lado, plantas herbáceas de caule fino com flores tubulares com aberturas de corola deste mesmo diâmetro permitiam às abelhas grandes acessarem os recursos, pois elas podiam se agarrar ao tubo floral e mesmo com o envergamento do pedúnculo não inviabilizava a obtenção dos recursos. Esta interessante característica poderá ser considerada em avaliações de disponibilidade (ou restrições) de recursos alimentares à espécie invasora quando (e se) invadir o Brasil.

Foram poucas as observações de plantas com flores que apresentavam aberturas de corola de diâmetro superior que $20 \mathrm{~mm}$ naquele período em todo o trajeto. A grande maioria das plantas floridas era de baixo porte, havendo a predominância de flores roxas e amarelas. O maracujá silvestre foi uma das raras plantas floridas que apresentava flores com aberturas de corola maiores (Figura C6-3:

21 O diâmetro da abertura da corola foi obtido com a flor em seu estado natural, com uso de fita métrica, sem a coleta e achatamento da flor. As landmarks de referência foram os dois pontos visualmente mais distantes na base das pétalas (aproximadamente o disco floral). Esta medida não possui propósitos analíticos, serviu apenas como referência de tamanho da abertura de acesso para a abelha, tomada com base em Savriama et al., 2012 (landmarks 13 a 29) e Gómes et al. (2008). 
A, B, D e E). Por ser uma liana, cujas flores obtêm suporte de caules rígidos de outras plantas arbustivas e arbóreas, a flor do maracujá recebia abelhas grandes com facilidade, e como é amplamente conhecido, as abelhas grandes são seus polinizadores efetivos. A Figura C6-3 exibe em " $A$ " e " $B$ " a potencialmente bem sucedida transferência de pólen decorrente do contato do dorso das abelhas grandes com as anteras do maracujá silvestre, já em " $\mathrm{D}$ " pode-se ver um indivíduo de Apis mellifera usufruindo do recurso floral do néctar sem que seu dorso seja capaz de tocar as anteras devido o seu menor tamanho, mas em " $\mathrm{E}$ " observa-se que Apis mellifera também explora a antera do maracujá.

Embora houvesse várias abelhas grandes visitando o maracujá (Figura C6-3: A, B), nenhuma Bombus foi avistada visitando esta planta. As Bombus coletadas e observadas estavam sempre em plantas com flores roxas e corolas tubulares, na maioria dos casos eram flores longas que estavam pendentes ou no sentido horizontal (Figura C6-3: $\mathrm{H}$ e I), a abelha Apis mellifera também foi observada explorando este tipo de flor (Figura C6-3, C).

Durante as observações nenhuma abelha grande foi predada, no entanto diversos potenciais predadores foram vistos, especialmente répteis e aves, entretanto alguns potenciais perigos às abelhas grandes foram acompanhados, mas não se efetivaram em predação (Figura C6-3, F). Algumas aranhas, tal como a Thomisidae na fotografia (Figura C6-3, F), são capazes de predar abelhas grandes, inclusive Bombus terrestris (imagem no Anexo C6-1).

Culturas agrícolas também podem prover recursos alimentares às abelhas nativas, mas estas também necessitam de ambientes adequados para nidificação, que estão adequadamente disponíveis em áreas naturais, no entanto, mesmo em meio às culturas agrícolas poderão existir alguns recursos alternativos disponíveis.

No caso das abelhas carpinteiras (Xylocopa sp.), pôde-se verificar dois tipos de recursos de nidificação utilizados nestas áreas tomadas por monoculturas, que eram os mourões de cercas (duas observações) e alguns poucos e antigos postes de eletricidade de madeira abandonados (uma observação), pois a maioria deles já era de concreto. Raramente se observou árvores (vivas ou mortas) nas beiras das estradas entre monoculturas e, aparentemente, os suportes de madeira de placas de trânsito não são utilizados, pois se averiguou com frequência a presença de ninhos neles, mas eles não foram encontrados; talvez tratamentos químicos ou a tinta os tornem inadequados. Também foi observado que uma Bombus fez um ninho em um barranco na beira de estrada, e que outra abelha do tipo sem ferrão utilizava para nidificar uma pequena cavidade em uma curva de nível já solidificada pelas intempéries.

Apesar de terem sido poucas as observações de recursos de nidificação utilizados e disponíveis, o fato de haver abelhas nativas nidificando em meio às monocultas indica que Bombus terrestris poderá não ter dificuldades para nidificar no sul do Brasil, haja vista que seu ninho é preferencialmente fundado no solo utilizandose cavidades preexistentes, abandonadas por aves, répteis e roedores, que foi um recurso observado com frequência em ambientes naturais e nas estradas.

Foi possível verificar que a disponibilidade de recursos alimentares nestas regiões tomadas por culturas agrícolas é, em termos relativos, maior e mais frequente na beira das estradas que em qualquer outro lugar. As flores de plantas herbáceas e arbustivas existentes nas estreitas faixas de terra nas bordas das estradas funcionam como potenciais corredores de recursos (Figura C6-2: F), que podem também gerar 
algo similar a estreitos corredores ecológicos ou de maior conectividade, por onde poderão transcorrer fluxos populacionais (e genéticos). De todo modo, não se sabe se a diversidade, a quantidade e a qualidade destes recursos em beiras de estradas são adequadas, pois foram observadas abelhas forrageando apenas pólen e néctar nestas flores, mas não foi percebida a disponibilidade e coleta de seiva e óleo floral.

Possivelmente a quantidade de recursos nestas áreas é baixo relativamente às cotas que estas abelhas encontrariam em meio a fragmentos naturais e em ambientes preservados, algo que poderá estar influenciando nos tamanhos das colônias e na quantidade de populações das espécies de Bombus nativas, por isso, talvez, a maior abundância e diversidade observada em zonas com maior quantidade de fragmentos naturais.

Além destas dificuldades que as espécies nativas devem superar para persistirem no sul do Brasil, outra potencialmente ainda maior foi observada, e que poderá afetar também a Bombus terrestris. Uma grande quantidade de pulverizadores de agroquímicos circulando por estas regiões de monoculturas (Figura C6.2: H) e certamente algumas destas substâncias que são pulverizadas por meio deles são destinadas ao controle de pragas pertencentes aos grupos dos artrópodes, ou seja, podem matar abelhas. A dispersão destes inseticidas deve aniquilar as abelhas nas áreas de monoculturas e próximas a elas, e poderão gerar barreiras para as espécies nativas e para a invasora por determinado tempo, durante a vigência do efeito do químico. Este aspecto talvez torne as beiras de estradas um dos poucos ambientes em que as abelhas encontram refúgio nestas zonas de agricultura intensiva, e também poderá condicionar a dispersão invasiva de Bombus terrestris, que poderá ocorrer principalmente por meio das estradas durante o processo de invasão no extremo sul do Brasil.

\subsection{Campanha de monitoramento}

O insucesso em se encontrar a abelha invasora no sul do Rio Grande do Sul é algo evidentemente positivo, mas o curto tempo de vistoria, a pequena amostragem e as condições meteorológicas desfavoráveis inviabilizam a afirmação de que a espécie, de fato, não está presente. A suspeita de que a espécie poderia já estar no Uruguai (vide Capítulo 1) acresce ainda mais preocupação de que a invasão é iminente ou, pior, já pode ter acontecido, mas ainda não foi detectada.

Considerando-se o nível de isolamento daquela região, com pouca concentração de habitantes por unidade de área e imensas propriedades privadas (rurais) que dificultam o acesso a muitas localidades, a hipótese de um pesquisador eventualmente encontrá-la e identificá-la é bastante baixa. Desenvolver uma campanha de levantamento em longo prazo sobre aquela extensa área para averiguar a presença desta espécie invasora sem qualquer segurança de que ela já está lá, seria um projeto com custo considerável. Tendo isso em consideração, surgiram questões sobre como seria possível descobrir o momento da entrada da invasora no Brasil ou se ela já está aqui; quais meios poderiam ser utilizados para monitorar esta imensa área com mínimo custo e por um maior período. A resposta foi torná-la conhecida dentre as pessoas que vivem lá, pois elas poderiam denunciar a presença da invasora.

Evidentemente, não se espera que a espécie seja realmente identificada pelas pessoas, afinal identificar uma espécie é uma tarefa bastante complexa mesmo para 
especialistas com uso de equipamentos laboratoriais. Mas as pessoas poderiam ser instruídas para diferenciar as abelhas grandes de outros insetos, como os besouros, e fotografá-las com seus telefones móveis e então reportar o avistamento enviando a foto e a localização via internet, mas sem compromisso de acertar a abelha.

Bombus terrestris possui uma coloração bastante peculiar e que difere consideravelmente das outras quatro espécies de Bombus nativas, especialmente a sua cauda branca e o padrão das listras amarelas e pretas. Estes caracteres são bastante discriminativos, e dependendo da qualidade e do posicionamento da fotografia é possível descartar relatos incosistentes, mantendo-se apenas aqueles suspeitos. Conforme estes relatos suspeitos se repetirem em uma determinada zona, se poderá ir à região para confirmar em campo a presença da espécie e, eventualmente, o coletor poderá ser acompanhado pelos observadores que reportaram para auxiliar na localização dos avistamentos.

Mas seria necessária extrema cautela na abordagem da elaboração do material de divulgação, tanto para evitar atribuir extremo peso negativo à espécie invasora, que poderia conduzir a generalizações perigosas para as espécies de abelhas nativas de grande porte, como para evitar que a pessoas tentassem capturá-la, o que poderia resultar em ferroadas e perigosas reações alérgicas.

\section{Estratégia de difusão da campanha}

A primeira estratégia desenvolvida e aplicada para se difundir informações sobre a invasão, a espécie e a campanha de monitoramento foi a distribuição de panfletos informativos, conclamando a população do Rio Grande do Sul para a participação em uma pesquisa científica. A população foi convidada para ajudar a encontrar e reportar a presença de uma Abelha Invasora prestes a entrar ou que já pode ter entrado no Brasil. Para tanto criou-se um ícone da Bombus terrestris associando-a a imagem do "bandido" estereotipado ao estilo "Procurado Vivo ou Morto".

A ideia de "bandido" transmitida pela roupalistrada de prisioneiro (combinando com as listras da própria abelha), pela postura das mãos indicando ideias más intencionadas, pela máscara nos olhos e um sorriso malicioso, não gera real conotação negativa e há fraca associação com o crime de fato, devido à banalização desta representação visual pelos veículos de mídia e entretenimento, que há tempos vem associando esta imagem com elementos cômicos e fantasiosos. O conceito visual do layout do impresso também acompanha esta contextualização visual, esperando-se que o impresso, como um todo, gere maior interesse das pessoas em obter a informação transmitida textualmente, favorecendo também a fixação da mensagem por mais tempo em suas memórias.

Após a definição da estratégia visual, foi

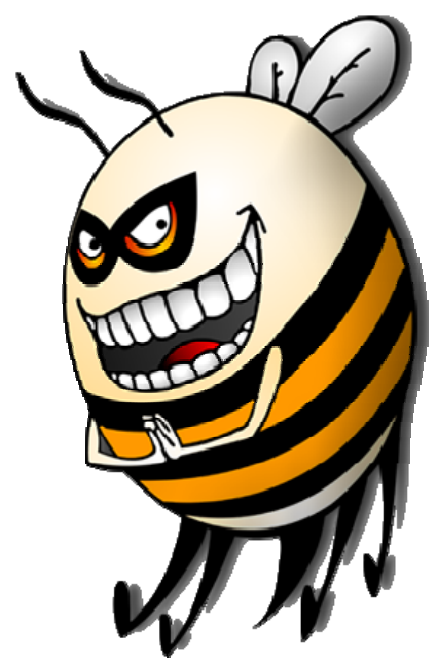

Figura C6-4. A "bandida" Bombus terrestris. necessário desenvolver a informação que associada à imagem, que deveria ser clara, concisa e transmitir os principais elementos da pesquisa, mas também atrair as 
pessoas para reportar avistamentos desta abelha sem induzir à captura e/ou a morte da abelha invasora ou, equivocadamente, de alguma abelha nativa.

Durante este processo de definição da abordagem textual, duas imprescindíveis colaborações foram estabelecidas com a Pontifícia Universidade Católica (PUC-RS), por meio da Dr. Betina Blochtein, e com a Empresa de Assistência Técnica e Extensão Rural do Rio Grande do Sul (EMATER-RS), por meio dos Srs. Paulo Francisco Conrad e Dulphe Pinheiro Machado Neto. Ambas as instituições, por meio de seus representantes, contribuíram com a distribuição do informativo impresso e a difusão de informações sobre a busca pela abelha em meio à população do Rio Grande do Sul. Os aspectos da colaboração na difusão serão novamente abordados mais adiante, pois, além disso, os colaboradores contribuíram com a adequação da informação textual do impresso, ajustando os modelos previamente escritos para uma versão com linguajar, conteúdo e abordagem mais correta para efetiva transmissão da informação nuclear ao seu público alvo, composto em grande parte por fazendeiros.

O impresso pode ser verificado no Anexo C6-2; foram feitas e distribuídas 5 mil cópias.

Estratégia de coleta de observações por meio virtual

A estratégia textual do impresso, além de prover o básico de informações sobre a campanha, consistiu em levar o leitor a acessar o website planejado e desenvolvido para cativar o potencial observador a reportar um avistamento, mas também para melhor informá-lo sobre a espécie e a invasão. Ao acessá-lo, informações mais detalhadas e grande quantidade de imagens da abelha estão disponíveis, assim como as instruções e meios virtuais simplificados para enviar as fotografias e a localização dos avistamentos.

Tanto no website como no informativo impresso foi incisiva e repetidamente destacada a solicitação para não capturar e não matar a abelha, apenas reportar o avistamento. Isso se dá para evitar a morte equivocada de abelhas e que as pessoas sejam ferroadas, mas, principalmente, devido ao desejo científico de se observar e estudar a espécie invasora viva, forrageando, interagindo com outras abelhas e, eventualmente, encontrar colônias para averiguar o seu desenvolvimento em ambiente invadido no Brasil.

$\mathrm{O}$ website www.abelhaprocurada.com.br (Figura C6-5) foi desenvolvido e linguagem PHP sobre uma plataforma de gerenciamento de conteúdo, que permite seu acesso via qualquer tipo de dispositivo que possua acesso à internet.

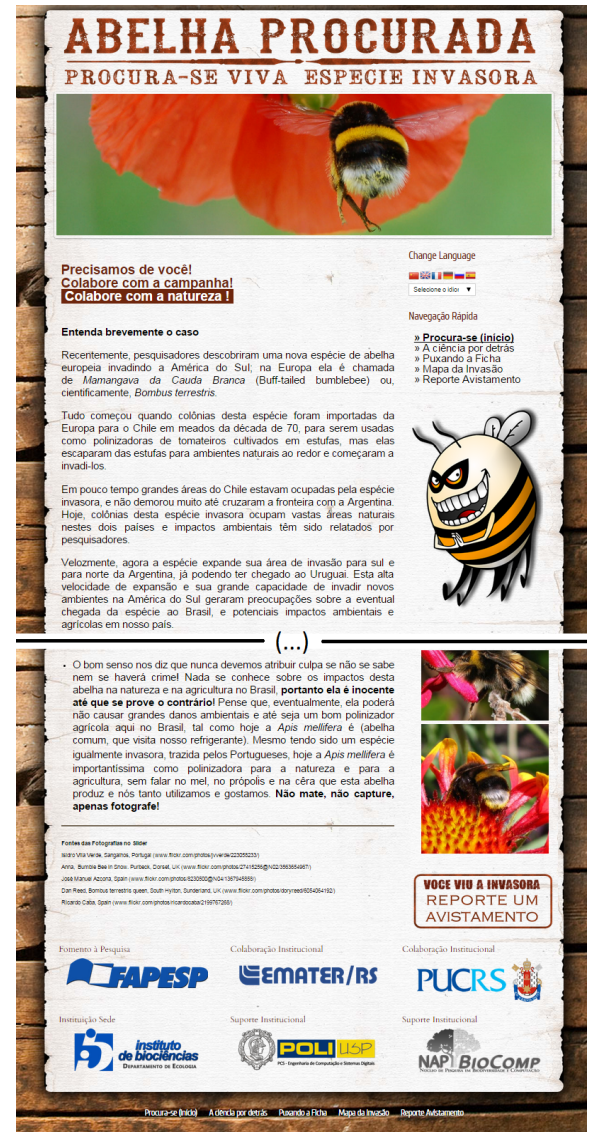

Figura C6-5. Topo e base da primeira página do website www.abelhaprocurada.com.br. 
Neste ambiente o observador é informado que poderá relatar o avistamento por meio do e-mail destinado a isso (abelhaprocurada@gmail.com) ou por meio de formulário especificamente desenvolvido, o qual permite o envio da fotografia e com campos compreendendo meios de contato com o observador e a descrição da observação, incluindo sua localização.

Além do website, outros meios digitais de divulgação também foram trabalhados e permanecem sendo usados para difusão, tal como as listas de e-mail em comunidades relacionadas aos apicultores, meliponicultores e outros grupos ligados à temática das abelhas e agricultura. Redes sociais também foram usadas para a divulgação e contato, como o Facebook e Twitter.

Início e desenvolvimento da campanha até o momento

A campanha, desde a proposta até sua realização foi apoiada por diversos pesquisadores e instituições, nomeadamente: A Fundação de Amparo à Pesquisa do Estado de São Paulo, FAPESP (financiadora); Empresa de Assistência Técnica e Extensão Rural do Rio Grande do Sul, EMATER-RS (colaboração); Pontifícia Universidade Católica do Rio Grande do Sul, PUC-RS (colaboração); Instituto de Biociências da Universidade de São Paulo IB-USP (instituição sede); Escola Politécnica da Universidade de São Paulo POLI-USP (suporte infraestrutural e institucional); Núcleo de pesquisa em Biodiversidade e Computação, NAP-BIOCOMP (suporte infraestrutural e institucional).

A campanha foi iniciada em Janeiro de 2015 por meios virtuais (internet) e permanecerá ativa até pelo menos Janeiro de 2016. Podendo ser renovada indefinidamente enquanto houver interesse mútuo de seus participantes e colaboradores, e recursos para sua manutenção.

A distribuição dos impressos iniciou-se em fevereiro de 2015 pelos colaboradores em seus âmbitos de difusão, sendo que a PUC focou-se na distribuição e difusão de informações para o público do ambiente acadêmico e de pesquisa, e a EMATER para o público rural (RS), especialmente na fronteira do Brasil com o Uruguai.

A colaboração da EMATER é fundamental para a campanha, pois possui mais de uma dezena de escritórios e mais de 2 mil empregados cobrindo praticamente toda a zona rural do Rio Grande do Sul. Para prover a dimensão do alcance da instituição no estado, foi incluída abaixo a descrição encontrada na apresentação da empresa em seu site oficial (www.emater.tche.br).

"A Instituição atende às demandas diárias de seu público, formado por agricultores familiares, quilombolas, pescadores artesanais, indígenas, assentados, um contingente superior a 250 mil familias de assistidos com áreas em mais de 480 municípios [do total de 497]. É no coração de 9.550 comunidades rurais dessas localidades que pulsa a atuação transversal do Serviço de Extensão Rural, revigorada pelo convênio com as Prefeituras, fertilizando o desenvolvimento socioeconômico e cultural do Rio Grande do Sul."

Além da ampla distribuição de material impresso e a difusão verbal feita entre os produtores rurais pelos técnicos da EMATER, também se difundiu regionalmente a campanha de monitoramento por meio de rádio e TV (colaborativamente associados com a EMATER). 
Desde o início da campanha foram recebidos mais de 300 e-mails, entretanto, apenas cerca de $7 \%$ deles continham informações estreitamente relacionadas à campanha, e ainda nenhuma observação apresentou potencial para averiguação em campo.

O monitoramento de acessos do website da campanha (Figura C6-6) indica que no mês de fevereiro de 2015 houve um aumento nos acessos em relação a janeiro, potencialmente relacionado ao início da distribuição dos impressos, esta cota permaneceu em março, mas em abril houve uma intensa queda, sugerindo que talvez um novo lote de impressos seja necessário. De toda forma, as estatísticas de acesso ao website sugerem uma pequena resposta à campanha perante as expectativas geradas pela ampla difusão.

Entretanto, alguns efeitos de difícil avaliação podem estar relacionados a esta resposta: a expectativa sobrevalorizada, a efetividade do impresso, da difusão dos impressos e/ou da difusão feita pelos outros meios. Mas, por outro lado, considerando que mais de 100 diferentes pessoas acessaram o website em cada um dos primeiros meses da campanha (indicado pela soma de visitantes únicos ${ }^{22}$ na Figura C6-6) não se poderá considerar que a atratividade e a difusão da campanha para seu público alvo foram totalmente ineficazes. Afinal, não se poderia esperar um massivo e generalizado interesse pela temática, que é essencialmente bastante específica, porventura atraindo maior atenção de determinados grupos dentro do público alvo, por exemplo, aqueles que se interessam pela natureza, pelas abelhas ou temem alguma repercussão à sua produção agrícola ou à sua criação de abelhas. Ainda, não se poderia pressupor uma grande aderência do público a uma proposta que busca participação incondicional, sem qualquer bônus. Mas este subgrupo que acessou o website poderá, em algum momento, reportar o avistamento.

Além do mais, o objetivo desta primeira campanha vai além da efetivação do monitoramento e da difusão da questão, é também um experimento que indica os caminhos mais adequados para o aprimoramento de um plano de monitoramento participativo com a população em ampla escala geográfica, e já exibe evidências de que o uso do recurso Ciência Cidadã poderá ser promissor para este feito.

Evidentemente, será necessário maior investimento, força de trabalho e número de parcerias para tornar altamente eficiente um projeto que almeja um monitoramento deste porte, o que esta humilde pesquisa jamais poderia alcançar.

\footnotetext{
${ }^{22}$ Visitantes únicos são contabilizados por IP combinados de provedores e indivíduos, excluindo-se o tráfego chamado de "não visto" que é gerado por robots, worms ou respostas a códigos de status HTTP especiais; indicando com boa robustez a quantidade de indivíduos exclusivos que acessaram o website, mesmo que eles o acessem várias vezes, só contabilizará uma única vez. Para mais informações acesse www.awstats.org, que é o serviço utilizado para analisar o tráfego do website abelhaprocurada.com.br.
} 


\section{Capítulo 7. Conclusões gerais da pesquisa}

A espécie de abelha europeia Bombus terrestris foi recentemente introduzida na América do Sul. Primeiramente, invadiu o Chile, na década de 1970, por decorrência de importações de colônias para polinização de culturas agrícolas em estufas. Em 2006, foi relatado que a área de invasão da espécie já havia alcançado a Argentina, pela constatação de colônias estabelecidas em ambientes naturais no oeste deste país. Tendo em vista a inexistência de registros de importação de colônias de Bombus terrestris pela Argentina, sugere-se que a espécie tenha expandido naturalmente sua invasão a partir do Chile. A invasão na Argentina está em franca expansão, inclusive em direção ao Uruguai. Segundo relatos publicados, este último país já pode ter importado colônias da espécie para polinização agrícola, bem como pode já ter colônias em ambientes naturais, no entanto a invasão no Uruguai não foi confirmada até o momento por meio de avistamento e coleta de indivíduos. Estes aspectos levantaram a questão sobre a possibilidade de Bombus terrestris alcançar o Brasil, e a avaliação deste potencial foi o principal objetivo desta pesquisa.

O estudo iniciou-se por meio de análises em uma ampla escala espacial; identificando globalmente as áreas susceptíveis à invasão com base nas características topoclimáticas mais adequadas à espécie. Áreas vulneráveis foram mapeadas em vários locais do planeta, dentre as quais muitas poderão sofrer eventos de invasão se a espécie for levada até elas, como no sul do continente Africano e no sul da Austrália continental. Também foram identificadas áreas e corredores susceptíveis que se conectam com locais já invadidos, pelos quais a espécie poderá expandir sua invasão conforme sua própria capacidade de dispersão. Notavelmente, foi identificada uma larga faixa susceptível no cone sul da América do Sul, interligando locais invadidos na Argentina com áreas susceptíveis à invasão no Brasil.

Além da dimensão espacial, este estudo considerou a dimensão temporal; identificando para a década de 2050 as mudanças geoespaciais das áreas susceptíveis e dos seus níveis de susceptibilidade perante dois potenciais cenários climáticos futuros estimados para mudança climática global. Estas projeções permitiram identificar que, caso o cenário climático RCP 6,0 venha a representar a tendência climática futura, a espécie poderá ser favorecida em sua expansão invasiva através do continente sulamericano até o Brasil, pois haverá a redução do estreitamento da faixa susceptível na região de Bahía Blanca (Argentina), o que poderá facilitar seu deslocamento ao ampliar a conectividade neste ponto, enquanto que no cenário climático RCP 4,5, poderá ocorrer 0 contrário, embora também não irá impedir a expansão da espécie.

Por meio da caracterização ecogeográfica, os limiares de afinidade e tolerância da espécie em áreas invadidas e nativa foram quantificados e qualificados, evidenciando a alta capacidade da espécie em ocupar uma grande diversidade de ambientes. A espécie apresentou alta tolerância a uma grande variedade de condições térmicas e pluviométricas, mas foi possível identificar as potenciais limitações da espécie em ocupar ambientes tropicais e as áreas com altitudes superiores a três mil metros. Também foi possível identificar a alta afinidade da espécie às baixas altitudes (até 500 metros) e a maior preferência por temperaturas amenas, que se apresentam no norte da faixa temperada do hemisfério norte e no sul da faixa temperada do hemisfério sul.

Para a América do Sul, que é a área de principal interesse desta pesquisa, foram mapeados os corredores ambientalmente mais favoráveis à espécie e os trajetos de 
menor custo para a sua expansão, os quais indicam potenciais rotas que poderão ser usadas pela espécie para espalhar sua invasão pelo continente através de sucessivas colonizações, o que poderá culminar na chegada da espécie ao Brasil.

Ao longo destas rotas foram apontadas áreas de constrição, onde a espécie encontrará uma estreita faixa de habitat adequado restringida por áreas ambientalmente inadequadas; estas zonas pontuais são estratégicas para o desenvolvimento de estudos e monitoramento, mas, especialmente, para ações de controle do processo invasivo, que se desenvolvidos nestes pontos poderão ser mais eficazes e menos custosos. Este aspecto evidencia que para se evitar a chegada da espécie ao Brasil, acordos políticos e científicos binacionais podem ser necessários, pois as ações deverão ser feitas ainda na Argentina, para o benefício de ambos os países.

A "porta de entrada" da espécie no Brasil foi mapeada; foram identificados oito municípios altamente vulneráveis, mas, dentre eles, os municípios de Chuí-RS e Santa Vitória do Palmar apresentam, conjuntamente, a maior conectividade com localidades invadidas na Argentina e, por conta disso, poderão ser os primeiros a serem invadidos em eventual decorrência da expansão invasiva natural da espécie.

Também foram identificados os municípios brasileiros cujas áreas cobrem rotas potenciais de invasão país adentro, e para estes municípios averiguou-se o potencial de interação da espécie invasora com a diversidade culturas agrícolas que são produzidas em suas abrangências, as quais beneficiam a espécie por proveem recursos, e podem favorecer sua expansão invasiva no Brasil. Mas estas culturas também podem estar vulneráveis a doenças e a outros impactos da presença da espécie invasora, assim como as espécies de abelhas nativas que usufruem destes recursos ou habitam a região.

Ainda neste aspecto, e para estes municípios, também se averiguou o potencial de sobreposição de habitat adequado para a espécie invasora e para as abelhas nativas do gênero Bombus, indicando-se as áreas com maior potencial de interações interespecíficas, onde poderá ocorrer com mais frequência e/ou mais intensidade relações ecológicas de competição por recursos alimentares e nidificação, consequentemente, prejudicando as espécies nativas. Mas este gradiente de potencial de interação também exibe níveis de resistência à progressão invasiva sobre ambientes com maior diversidade de espécies nativas, pois o encontro da invasora com espécies competidoras poderá também dificultar a sua expansão em ambientes não nativos.

A combinação dos resultados das análises gerou dois mapas delineando áreas prioritárias, as quais, após a eventual ocorrência do evento de invasão no Brasil, podem subsidiar planejamentos de estudos ecológicos almejando, entre outros aspectos, avaliar as interações entre a espécie invasora e as plantas agrícolas e nativas, bem como as interações com as espécies de abelhas nativas, que poderão resultar em mudanças nas redes de interações ecológicas e repercutir em impactos ambientais.

Estas áreas delineadas, que foram quantificadas em termos de prioridade, poderão auxiliar na decisão de investimentos e na concentração de esforços em ações de controle da invasão e para mitigação de impactos ambientais e econômicos, tendo em vista a necessidade de se priorizar áreas perante a vasta dimensão susceptível à invasão que foi identificada. As áreas municipais com maior potencial de interação entre Bombus terrestris e as Bombus nativas podem ser referências auxiliares na definição de áreas prioritárias para a conservação das espécies de Bombus nativas e seus habitat que ocorrem no sul do Brasil. 
Além dos resultados decorrentes das análises, que se direcionam à problemática desta invasão e à Bombus terrestris, esta pesquisa desenvolveu um encadeamento de métodos e processos analíticos, com uma variedade de lógicas que sequencialmente se alimentam de dados, e resultam em uma grande quantidade de caracterizações ecológicas com respostas úteis para estudos de invasões em larga escala espacial e com uso de grande quantidade e variedade de dados. A metodologia que foi desenvolvida considerando-a integralmente como um framework - foi uma das primeiras que combinou um robusto método de modelagem de adequabilidade de habitat com métricas de conectividade da paisagem (trajetos de menor custo e teoria dos circuitos), a qual poderá ser facilmente aplicada para outras problemáticas e espécies, e todo o detalhamento necessário foi provido para que se possa replicar a metodologia, bem como modificá-la, ajustá-la e aprimorá-la conforme a necessidade.

No entanto, mesmo após a série de análises feitas e os seus resultados interpretados subsidiadamente pela literatura científica, esta pesquisa ainda não poderia afirmar peremptoriamente que a Bombus terrestris irá invadir o Brasil em breve, nem no futuro. Mas foram identificadas e analisadas diversas evidências sustentando a existência de uma alta possibilidade desta invasão alcançar o Brasil, dentre elas se destacam as seguintes: 1) existem fontes de indivíduos invasores relativamente próximos; 2) existe habitat adequado e conectividade ambiental desde localidades invadidas até o Brasil, e há uma grande faixa de habitat adequado cruzando quatro estados brasileiros; 3) nenhuma barreira foi identificada que impediria a progressão invasiva, nem mesmo relacionadas às mudanças climáticas; 4) a espécie é altamente tolerante a uma grande variedade de condições ambientais e; 5) os resultados das análises convergem com conhecimentos publicados sobre Bombus terrestris e seu processo invasivo ao redor do mundo, reforçando a precisão das análises.

Deve-se salientar que a condição de Bombus terrestris como espécie invasora não decorre de um evento natural em que seus indivíduos se dispersaram a partir de seu habitat original até o Japão, Nova Zelândia, Tasmânia e Chile. Elas chegaram nestes ambientes por intervenção direta de humanos, que são os responsáveis pelos eventos de invasão que se espalham atualmente pelo planeta. Além disso, as empresas que comercializam colônias para áreas nas quais a espécie não ocorre naturalmente deveriam ser responsabilizadas pelos custos ambientais e econômicos em casos de invasões que comprovadamente decorreram de seus produtos, algo que poderá ser provado por meio de marcadores genéticos, por exemplo. Medidas restritivas deveriam ser implementadas por diversos países, de forma politicamente conjunta, para evitar as invasões que decorrem das atividades humanas. Acresce-se ainda que nada foi encontrado na literatura tratando de métodos efetivos de controle ou impedimento da progressão invasiva de polinizadores em ambientes alóctones. Neste contexto, vale citar o caso de invasão global por Apis mellifera como um exemplo de que uma vez que a invasão se estabelece em uma ampla escala geográfica, pouco ou nada se pode fazer para controlar sua progressão, e esta invasão possivelmente permanecerá para sempre.

Por fim, apoderando-se do dito popular: é mais inteligente, mais econômico e mais ecológico prever eventos de invasões e tentar se prevenir do que, depois, como única alternativa restante, mitigar os seus impactos. 


\section{Referências Bibliográficas}

Aarssen, L.W. 1984. On the distinction between niche and competitive ability: implications for coexistence theory. Acta Biotheor. 33: 67-83.

Adler, G.H.; Levins, R. 1994. The island syndrome in rodent populations. Quarterly Review of Biology, 69, 473-490.

Adobe, 2005. Adobe Creative Suite 6 Master Collection (Release 2005). Adobe Systems Software Ireland Ltd.

Aguirre-Gutierrez J.; Carvalheiro, L.G.; Polce, C.; Loon, E.E.; Raes, N.; Reemer, M.; Biesmeijer, J.C. 2013. Fit-for-purpose: Species distribution model performance depends on evaluation criteria. Dutch hoverflies as a case study. PlosOne; 8: e63708.

AHGA, 2008. Executive Summary Proposal to Import Bombus terrestris into mainland Australia for crop pollination purposes proponents. Australian Hydroponic \& Greenhouse Association, PO BOX 538, Narrabeen NSW. Disponível em: http://www.ahga.org.au; Acessado em 2012.

Aizen, M.A.; Morales, C.L.; Vázquez, D.P.; Garibaldi, L.A.; Sáez, A.; Harder, L.D. 2014. When mutualism goes bad: density-dependent impacts of introduced bees on plant reproduction. New Phytologist 204: 322-328.

Akçakaya, H.R. 2000. Viability analyses with habitat-based metapopulation models. Population Ecology, 42(1), 45-53.

Alaux, C.; Jaisson, P.; Hefetz, A. 2004. Queen influence on worker reproduction in bumblebees (Bombus terrestris) colonies. Insect Soc 51:287-293

Alaux, C.; Jaisson, P.; Hefetz, A. 2005. Reproductive decision-making in semelparous colonies of the bumblebee Bombus terrestris, Behav. Ecol. Sociobiol. 59, 270-277.

Alford, D. V. 1975. Bumblebees. Davis-Poynter Ltd; London, UK. 352 pp.

Allen, H.D. 2014. Mediterranean Ecogeography, Ecogeography Series. Routledge, 288p.

Allen, J.A. 1878. The influence of physical conditions in the genesis of species. Radical Review, 1, 108140.

Allouche, O.; Tsoar, A.; Kadmon, R. 2006. Assessing the accuracy of species distribution models: prevalence, kappa and the true skill statistic (TSS). Journal of Applied Ecology, 43: 1223-1232.

Anagnostopoulos, I.T. 2005. The bumblebee fauna of Greece an annotated species list including new records for Greece Hymenoptera Apidae, Bombini. Linzer Biologische Beitraege 16; 37(2): 10131026

Anderson, B.; Terblanche, J.S.; Ellis, A.G. 2010. Predictable patterns of trait mismatches between interacting plants and insects. BMC Evolutionary Biology., 10:204.

Anzures-Dadda, A.; Manson, R.H. 2007. Patch-and landscape-scale effects on howler monkey distribution and abundance in rainforest fragments. Anim. Conserv. 10:69-76.

Araújo, M.B.; Nogues-Bravo, D.; Reginster, I.; Rounsevell, M.; Whittaker, R.J. 2008. Exposure of European biodiversity to changes in human-induced pressures. Environmental Science \& Policy 11: 38-45.

Araújo, M.B.; Rahbek, C. 2006. How Does Climate Change Affect Biodiversity? Science, 313, p1396.

Araújo, M.B.; Williams, P. 2000. Selecting areas for species persistence using occurrence data. Biological Conservation 96: 331-345

Arbetman, M.P.; Meeus, I.; Morales, C.L.; Aizen, M.A.; Smagghe, G. 2013. Alien parasite hitchhikes to Patagonia on invasive bumblebee. Biological Invasions 15: 489-494.

Arceo-Gomez, G.; Martinez, M.L.; Parra-Tabla, V.; Garca-Franco, J.G. 2011. Anther and stigma morphology in mirror-image flowers of Chamaecrista chamaecristoides (Fabaceae): implications for buzz pollination. Plant Biol, 13(Suppl 1):19-24.

Arino, O.; Perez, R.; Julio, J.; Vasileios, K.; Defourny, P. 2009. GLOBCOVER 2009. ESA Living Planet Symposium 2010, 28th June - 2nd July, Bergen, Norway, SP-686, poster, hdl:10013/epic.39894.d001 
Austin, M.P.; Cunningham, R.B.; Fleming, P.M. 1984. New approaches to direct gradient analysis using environmental scalars and statistical curve-fitting procedures. Vegetatio 55,Il-27.

Azure. 2012. Biobest: Agricultural Firm Uses Cloud Service to Distribute Sales Data, Improve Insight. Disponível em: <http://www.microsoft.com/sv-se/kundreferenser/Microsoft-Azure/Biobest/AgriculturalFirm-Uses-Cloud-Service-to-Distribute-Sales-Data-Improve-Insight/225000000081> Acessado em Jan/2015.

Bader, D.C. et al. 2008. Climate models: an assessment of strengths and limitations. A Report by the U.S. Climate Change Science Program and the Subcommittee on Global Change Research. Department of Energy, Office of Biological and Environmental Research, Washington, D.C., USA. 124 pp.

Barry, R.G.; Chorley, R.J. 1987. Atmosphere, Weather and Climate, 5 ed., Methuen, New York, 460 p., ill., 4 app. ISBN 0-416-97142-2

BDP, 2013. BioFresh Data Portal, Freshwater Information Platform. Disponível em: <http://data.freshwaterbiodiversity.eu/> , Acessado em Jan/2015.

Beekman, M.; van Stratum, P. 2000. Does the diapause experience of bumblebee queens Bombus terrestris affect colony characteristics? Ecol Entomol 25:1-6.

Beekman, M.; van Stratum, P.; Lingeman, R. 1998. Diapause survival and post-diapause performance in bumblebee queens (Bombus terrestris). Entomologia Experimentalis et Applicata 89, 207-214.

Beekman, M.; van Stratum, P.; Veerman, A. 1999. Selection for non-diapause in the bumblebee Bombus terrestris, with notes on the effect of inbreeding. Entomologia Experimentalis et Applicata 93, 6975.

Begon, M.; Townsend, C.R.; Harper, J.L. 2006. Ecology: From Individuals to Ecosystems. Blackwell Publishing, Oxford.

Bergmann, C. (1847) Uber die Verhaltnisse der Warmeokonomie der Thiere zu ihrer Grosse. Gottinger Studien, 3, 595-708.

Beshers, S. N.; Fewell, J. H. 2001. Models of division of labor in social insects. Annu. Rev. Entomol. 46, 413-440 (2001).

Bicheron, P.; Defourny, P.; Brockmann, C.; Schouten, L.; Vancutsem, C.; Huc, M.; Bontemps, S.; Leroy, M.; Achard, F.; Herold, M.; Ranera, F.; Arino, O. 2008. GlobCover 2005 - Products description and validation report, Version 2.1, 2008. Disponível em <http://ionia1.esrin.esa.int/>, Acessado Jan/2008.

Biobest, 2015. Biological control \& bumblebee pollination: Pollination Section - High quality bumblebee hives for successful pollination. Disponível em: <http://www.biobestgroup.com/>. Acessado em Jan/2015.

Bloch, G.; Hefetz, A. 1999. Regulation of reproduction by dominant workers in bumblebee (Bombus terrestris) queenright colonies. Behavioral Ecology and Sociobiology, 45, 125-135.

Bontemps, S., Defourny, P., Bogaert, E.V., Arino, O., Kalogirou, V., Perez, J.R., 2009. GlobCover: Product description and validation report. UCLouvain and ESA GlobCover project. Disponível em: <http://due.esrin.esa.int/globcover/> Acessado em Jan/2013.

Boyce, M.S.; McDonald, L.L. 1999. Relating populations to habitats using resource selection functions. Trends in Ecology and Evolution, 14, 268-272

Brito, J.C.; Acosta, A.L.; Álvares, F.; Cuzin, F. 2009. Biogeography and conservation of taxa from remote regions: An application of ecological-niche based models and GIS to North-African Canids. Biological Conservation 142, 3020-3029

Brown, J. H. 1995. Macroecology. University of Chicago Press, Chicago.

Brown, J.; Kodric-Brown, A. 1977. Turnover rates in insular biogeography: effect of immigration on extinction. Ecology 58:445-449

Brown, J.H.; Lomolino, M.V. 2006. Biogeografia. 2nd ed. Funpec, Ribeirão Preto. 692p.

Buchmann, S.L., 1983. Buzz Pollination in Angiosperms. In: Jones, C.E., Little, R.J., (Eds.). Handbook of Experimental Pollination Biology. New York, Van Nostrand Reinhold Company Inc., pp. 1-274.

Bumblebee.org, 2015. Recognising common British bumblebees. Disponível em: <http://www.bumblebee.org>, Acessado em Jan/2015. 
Busby, J.R., 1991. BIOCLIM - a bioclimate analysis and prediction system. In: Margules, C.R., Austin, M.P.,(Eds.). Nature Conservation: Cost Effective Biological Surveys and Data Analysis. Canberra, Australia: CSIRO. pp. 64-68.

Buttermore, R.E., 1997. Observations of successful Bombus terrestris (L.) (Hymenoptera: Apidae) colonies in southern Tasmania. Australian Journal of Entomology, 36:251-254.

Carroll, C.; Miquelle, D.G. 2006. Spatial viability analysis of Amur tiger Panthera tigris altaica in the Russian Far East: the role of protected areas and landscape matrix in population persistence. Journal of Applied Ecology 43: 1056-1068

CCAFS, 2015. Abbreviations Used For Bioclimatic Variables. Disponível em <http://www.ccafsclimate.org/downloads/docs/bioclimatic-variables.pdf>. Acessado em Jan/2015.

CCAFS-DM, 2015. Statistical Downscaling (Delta Method) CMIP5 Data. Disponível em: <http://ccafsclimate.org/statistical_downscaling_delta_cmip5/>, Acessado em Jan/2015.

CGIAR-CCAFS, 2015, CGIAR Data Portal from Research Program on Climate Change, Agriculture and Food Security (CCAFS); Disponível em: <http://ccafs-climate.org/data/>, Acessado em Jan/2015.

CGIAR-CSI, 2015. Global Potential Evapo-Transpiration and Global Aridity Index Database, Consortium for Spatial Information. Disponível em <http://www.cgiar-csi.org/data/global-aridity-and-petdatabase>, Acessado em Jan/2014.

Chapman, R.E., Bourke, A.F.G., 2001. The influence of sociality on the conservation biology of social insects. Ecology Letters 4:650-662.

Chase, J. M.; Myers, J. A. 2011. Disentangling the importance of ecological niches from stochastic processes across scales. Philosophical Transactions of the Royal Society B: Biological Sciences 366:2351 -2363.

Chen, Y.H. 2009. Conservation biogeography of the snake family Colubridae of China. North-Western Journal of Zoology 5: 251-262.

Chittka, L.; Ings, T.C.; Raine, N.E. 2004. Chance and adaptation in the evolution of island bumblebee behaviour. Popul Ecol 46:243- 251.

Clarke, D.M. 1982. Descartes' Philosophy of Science. Manchester University Press, 249pp

CMPI5, 2015. Coupled Model Intercomparison Project - World Climate Research Programme. Disponível em: <http://cmip-pcmdi.Ilnl.gov/cmip5/availability.html>, Acessado em Jan/2010

Cnaani, J.; Borst, D.W.; Huang. Z.Y.; Robinson, G.E.; Hefetz, A. 1997. Caste determination in Bombus terrestris: differences in development and rates of $\mathrm{JH}$ biosynthesis between queen and worker larvae. J Insect Physiol 43:373-381

Cnaani, J.; Robinson, G.E.; Hefetz, A. 2000. The critical period for caste determination in Bombus terrestris and its juvenile hormone correlates. J. Comp. Physiol. 186: 1089-1094.

COF, 2013. Catalogue of Life. Disponível em:<http://www.catalogueoflife.org/>

Colwell, R. K.; Rangel, T. F. 2009. Hutchinson's duality: The once and future niche. Proceedings of the National Academy of Sciences of the United States of America PNAS November 17, 2009 vol. 106 suppl. 2 19651-19658

Coppée, A. 2010. Bombus terrestris ( L . 1758 ) : A complex species or a species complex ? Impacts on the speciation. PhD-Thesis. Universite de Mons.

Coppée, A.; Terzo, M.; Valterova, I.; Rasmont, P. 2008. Intraspecific variation of the cephalic labial gland secretions in Bombus terrestris (L.) (Hymenoptera: Apidae). Chemistry \& biodiversity, 5(12), 265461.

Corbet, S. A.; Fussell, M.; Ake, R.; Fraser, A.; Gunson, C.; Savage, A.; Smith, K. 1993. Temperature and pollinating activity of social bees. Ecological Entomology 18, 17-30.

Costa, J.; Peterson, A.T.; Beard, C.B. 2002. Ecologic niche modeling and differentiation of populations of Triatoma brasiliensis neiva, 1911, the most important Chagas' disease vector in northeastern Brazil (Hemiptera, Reduviidae, Triatominae). American Journal of Tropical Medicine and Hygiene 67: 516-520.

Crouzet, F. 2006. Labour and Industrial Relations: The Victorian Economy (Economic History), Routledge (Reprint ed.), 448pp 
Cumber, R.A. 1949. The biology of humble-bees, with special reference to the production of the worker caste. Trans. R. Ent. Soc. London 100: 1-45.

Dafni, A. 1998. The threat of Bombus terrestris spread. Bee World 79:113-114.

Dafni, A.; Kevan, P.; Gross, C. L.; Goka, K. 2010. Bombus terrestris, pollinator, invasive and pest: An assessment of problems associated with its widespread introductions for commercial purposes. Applied Entomology and Zoology, 45(1), 101-113. doi:10.1303/aez.2010.101

Dafni, A.; Shmida, A., 1996. The possible Ecological Implications of the Invasion of Bombus terrestris (L) (Apidae) at Mt Carmel, Israel. In: Matheson, A., Buchmann, S. L., O'toole, C., Westrich, P., Williams, I. H., (Eds.). The Conservation of Bees. London, Academic Press.

Dalla Torre, K.W. von. 1882. Bericht des Naturwissenschaftlich-medizinischen Vereins in Innsbruck, 12, 14-31.

Danks, H. V. 1987. Insect Dormancy: an Ecological Perspective. Biological survey of Canada, Ottawa, 439 $\mathrm{pp}$.

Darvill, B.; Knight, M.E.; Goulson, D. 2004. Use of genetic markers to quantify bumblebee foraging range and nest density. Oikos 107

Darwin, C.R. 1859. The origin of species by means of natural selection, or the preservation of favoured races in the struggle for life. London: John Murray, Albemarle Street.

De Jonghe, R. 1986. Crossing experiments with Bombus terrestris terrestris (Linnaeus, 1758) and Bombus terrestris xanthopus Kriechbaumer, 1870) and some notes on diapause and nosemose (Hymenoptera: Apidae). Phegea, 14:19-23.

De Luca, P.A.; Bussiere, L.F.; Souto-Vilaros, D.; Goulson, D.; et al. 2013. Variability in bumblebee pollination buzzes affects the quantity of pollen released from flowers. Oecologia. Jul;172(3):80516.

De Luca, P.A.; Vallejo-Marin, M. 2013. What's the 'buzz' about? The ecology and evolutionary significance of buzz-pollination. Current Opinion in Plant Biology, Vol16, 14, 429-435p.

Deane, P. M. 1979. The First Industrial Revolution. Cambridge University Press, London 318pp.

Defourny, P.; Schouten, L.; Bartalev, S.; Bontemps, S.; et al. 2009. Accuracy Assessment of a $300 \mathrm{~m}$ Global Land Cover Map: The GlobCover Experience 33rd International Symposium on Remote Sensing of Environment, Sustaining the Millennium Development Goals - ISBN 978-0-932913-13-5

Des Newman, 2013. OziExplorer GPS Mapping Software. v.3.95.4, D\&L Software Pty Ltd. Brisbane, Autralia. Disponível em <http://www.oziexplorer.com/>, Acessado em Jan/2014.

Dessai, S.; Lu, X.; Risbey, J.S. 2005. On the role of climate scenarios for adaptation planning. Global Environmental Change 15: 87-97.

Dice L. R. 1952. Natural communities. Univ. Michigan, Ann Arbor. 547 pp.

DL, 2013. Discover Life: Information about taxonomy, natural history, distribution, abundance, and ecology of many species worldwide. Disponível em: <http://www.discoverlife.org/>.

Duchateau, M.J.; Velthuis, H.H.W. 1988. Development and reproductive strategies in Bombus terrestris colonies. Behaviour, 107: 186-207.

Dunning, J.B.; Danielson, B.J.; Pulliam, H.R. 1992. Ecological processes that affect populations in complex landscapes. Oikos 65:169-175

Dyer, A.G.; Chittka, L. 2004. Biological significance of discriminating between similar colours in spectrally variable illumination: bumblebees as a study case. J Comp Physiol A 190:105-114

Dyer, A.G.; Spaethe, J.; Prack, S. 2008. Comparative psychophysics of bumblebee and honeybee colour discrimination and object detection. J Comp Physiol A 194:617-627.

Elton, C. 1927. Animal ecology. Sidgwick and Jackson, London. 209 pp.

Elton, C. 1950. The ecology of animals. 3rd ed. Methuen, London.97 pp.

Engler, R.; Guisan, A.; Rechsteiner, L. 2004. An improved approach for predicting the distribution of rare and endangered species from occurrence and pseudo-absence data. Journal of Applied Ecology 41:263-274.

ESA, 2015 ENVISAT: Environmental Satellite. European Space Agency. Disponivel em: <http://www.esa.int/Our_Activities/Observing_the_Earth/Envisat>, Acessado em Jan/2015 
ESRI, 2010. ArcGIS Desktop: Release 10. Redlands, CA: Environmental Systems Research Institute.

Estoup, A.; Solignac, M.; Cornuet, J.M.; Goudet, J.; Scholl, A. 1996. Genetic differentiation of continental and island populations of Bombus terrestris (Hymenoptera: Apidae) in Europe, Mol. Ecol. 5, 1931.

Fagan, W.; Unmack, P.; Burgess, C.; et al. 2002. Rarity, fragmentation, and extinction risk in desert fishes. Ecology, 83:3250-3256.

Fawcett, T. 2006. An introduction to ROC analysis. Pattern Recognition Letters 27, 861-874.

Fisher, T. 1998. Developing as a Teacher of Geography. Network Continuum Education, 96pp, ISBN-10: 1899857176

Forrest, J.; Thomson, J.D. 2009. Background complexity affects colour preference in bumblebees. Naturwissenschaften, 96, 921e925.

Foster, J.B. 1964. The evolution of mammals on islands. Nature, 202, 234-235.

Free, J.B. 1955. The behaviour of egg-laying workers of bumble-bee colonies. Br J Anim Behav 3:147 153

Free, J.B., 1993. Insect Pollination of Crops. London: Academic Press Limited.

Fritz, S.; et al. 2010. Comparison of global and regional land cover maps with statistical information for the agricultural domain in Africa Int. J. Remote Sensing 25 1527-32.

Fritz, S.; See, L.; McCallum, I.; Schill, C.; Obersteiner, M.; van der Velde, M.; Boettcher, H.; Havlik, P.; Achard, F. 2011. Highlighting continued uncertainty in global land cover maps to the user community. Environmental Research Letters, (6) 044005.

Fussell, M.; Corbet, S.A. 1992. Flower usage by bumblebees: A basis for forage plant management, J. Appl. Ecol. 29, 451-465.

Fye, R.E.; Medler, J.T. 1954. Field domiciles for bumblebees. J. Econ. Entomol. 47, 672-676.

GADM, 2012. Global Administrative Areas of Year 2012. GADM database of Global Administrative Areas, version 2.0. Available at: www.gadm.org.

GAGPET, 2012. Global Geospatial Potential EvapoTranspiration \& Aridity Index - Methodology and Dataset Description.Disponível em: <http://www.cgiar-csi.org/wpcontent/uploads/2012/11/Global-Aridity-and-Global-PET-Methodology.pdf>, Acessado em Jan/2015.

Garmin, 2013. GPS Garmin Montana 650. Disponível em:<http://sites.garmin.com/en-US/montana/>

Gaston, K. 2003. The Structure and Dynamics of Geographic Ranges. Oxford University Press, Oxford.

Gause, G. F. 1934. The struggle for existence. Hafner Pub. Co., N. Y.

GBIF, 2013. Global Biodiversity Information Facility: Data Portal. Disponível em: <http://www.gbif.org>

Geo Studio, 2013. TrackMaker - GPS Software and Automatic Vehicle Location. Geo Studio Tecnologia Ltda. Disponível em:<http://www.trackmaker.com/>.

Giannini, T.C. ; Pinto, C.E. ; Acosta, A.L. ; Taniguchi, M. ; Saraiva, A.M. ; Alves dos Santos I. 2013. Interactions at large spatial scale: The case of Centris bees and floral oil producing plants in South America. Ecological Modelling, v. 258, p. 74-81.

Giannini, T.C.; Siqueira, M.F.; Acosta, A.L. et al. 2012. Desafios atuais da modelagem preditiva de distribuição de espécies. Rodriguésia 63(3): 733-749

GISS-NASA, 2015. ModelE CMIP5 Climate Simulations: Configurations for CMIP5 Simulations, Updates, and Issues, NASA. Disponível em <http://data.giss.nasa.gov/modelE/ar5//>, Acessado em Jan/2015.

GISS-PUBS, 2015. Annual Publication Indices: NASA,National Aeronautics and Space Administration. Goddard Institute for Space Studies. Disponível em: <ttp://pubs.giss.nasa.gov/year/2015.html>.

Gloger, C.L. 1883. Das Abandern der Vogel durch Einfluss des Klimas. A. Schulz, Breslau.

Goka, K. 2006. The European bumblebee Bombus terrestris and Invasive Alien Species Act. The Nat and Insects 41(13):22-26

Gomez, J.M.; Bosch, J.; Perfectti, F; Fernandez, J.D.; Abdelaziz. M.; Camacho, J.P.M. 2008. Spatial variation in selection on corolla shape in a generalist plant is promoted by the preference patterns of its local pollinators. Proc R Soc Lond B Biol Sci 275:2241-2249 
Goodchild, M.F. 1997. What is Geographic Information Science?, NCGIA Core Curriculum in GIScience, Disponível em: <http://www.ncgia.ucsb.edu/giscc/units/u002/u002.html.> Acessado em Jun/2012.

Goodess, C. 2000. Climate change scenarios. No. 9, Climatic Research Unit, University of East Anglia.

Goodwin, S.; Steiner, M. 1997. Introduction of Bombus terrestris for pollination of horticultural crops in Australia. A submission to AQIS and Environment Australia. Disponível em: http://www.tmag.tas.gov.au/workshop/append2.html.

Google Inc., 2015. Google Incorporation. 1600 Amphitheatre Parkway, Mountain View CA 94043

Goulson, D., 2003. Effects of introduced bees on native ecosystems. Annual Review of Ecology Evolution and Systematics 34: 1-26.

Goulson, D., 2010. Bumblebees: Behaviour and Ecology. 2. ed. Oxford, Oxford University Press.

Goulson, D., Lye, G.C., Darvill, B., 2008. Decline and Conservation of Bumble Bees. Annual Review of Entomology, 53: 191-208.

Goulson, D.; Hanley, M.E. 2004. Distribution and Forage Use of Exotic Bumblebees in South Island, New Zealand. New Zealand Journal of Ecology 28(2): 225-232.

Goulson, D.; Stout J.C. 2001. Homing ability of the bumblebee Bombus terrestris (Hymenoptera: Apidae), Apidologie 32, 105-111.

Grinnell, J. 1917. The niche-relationship of the California thrasher. Auk 34: 427-433.

Grinnell, J. 1928. Presence and absence of animals. Univ. Calif. Chron.30:429-40.

Guisan, A.; Zimmermann, N.E. 2000. Predictive habitat distribution models in ecology. Ecological Modelling, 135, 147-186.

Gumbert, A. 2000. Color choices by bumble bees (Bombus terrestris): innate preferences and generalization after learning. Behav Ecol Sociobiol 48:36-43

Guo, Q.; Liu, Y. 2010. ModEco: an integrated software package for ecological niche modeling. 390 Ecography 33: 637-642.

Gurel, F.; Gosterit, A. 2008. Effects of temperature treatments on the bumblebee (Bombus terrestris L.) colony development. Akdeniz Universitesi Ziraat Fakultesi Dergisi 21, 75-78.

Gurel, F.; Gosterit, A.; Eren, Ö. 2008. Life-cycle and foraging patterns of native Bombus terrestris (L.) (Hymenoptera, Apidae) in the Mediterranean region. Insect. Soc. 55: 123-128.

Hall, J. 2007. Probabilistic climate scenarios may misrepresent uncertainty and lead to bad adaptation decisions. Hydrological Processes 21: 1127-1129.

Hanley, M.E.; Goulson, D. 2003. Introduced weeds pollinated by introduced bees: cause or effect? Weed Biology and Management, 3, 204-212.

Hanna, S.R.; Briggs, G.A.; Hosker, R.P. 1982. Handbook on atmospheric diffusion, US Dept. of Energy DOE/TIC -22800, NTIS, Springfield, VA., $102 \quad$ p. Disponível em:<http://www.wmo.int/pages/prog/www/DPFSERA/documents/workbook.pdf>.

Harris, M. 1780. An exposition of English insects. White \& Robson, London, VIII+166,4pp.50pls.

Hasselrot T.B. (1952) A new method for starting bumblebee colonies, Agron. J. 44, 218-219.

Hasselrot T.B. (1960) Studies on Swedish bumblebees (genus Bombus Latr.): their domestication and biology, Opusc. Entomol. Suppl. 17, 1-192.

Hastie, T.J.; Tibshirani, R. 1990. Generalized additive models. Londres: Chapman and Hall.

Heinrich, B., 1979. Bumblebee Economics. Cambridge, Harvard University Press.

Heinrich, B., 2004. Bumblebee Economics. Cambridge, MA: Harvard University Press.

Henderson, M; Merriam, G; Wegner, J. 1985. Patchy environments and species survival: chipmunks in an agricultural mosaic. Biol Conserv 31:95-105

Henry, J. 2002. The Scientific Revolution and the Origins of Modern Science. Studies in European History, 2ed, New York: Palgrave. 160 pp.

Heuschen, B; Gumbert, A; Lunau, K. 2005. A generalised mimicry system involving angiosperm Xower colour, pollen and bumblebees innate colour preferences. Plant Syst Evol 252:121-137. 
Hijmans, R.; Phillips, S.; Leathwick, J.; Elith J. 2010. Dismo: species distribution modeling. R package version 0.5-4. Disponível em: $<$ http//CRAN. R-project. org/package= dismo $>$.

Hijmans, R.J.; Cameron, S.E.; Parra, J.L.; Jones, P.G.; Jarvis, A. 2005. Very high resolution interpolated climate surfaces for global land areas. International Journal of Climatology 25(15): 1965-1978.

Hijmans, R.J.; van Etten, J. 2011. raster: Geographic analysis and modeling with raster data. R package version 2.0-12. Available at: http://CRAN.R-project.org/package=raster

Hingston, A.B.; McQuillan, P.B. 1998. Does the recently introduced bumblebee Bombus terrestris (Apidae) threaten Australian ecosystems? Australian Journal of Ecology 23, 39-549.

Hingston, A.B.; Marsden-Smedley, J.; Driscoll, D.A.; Corbett, S.; Fenton, J.; Anderson R. et al. 2002. Extent of invasion of Tasmanian native vegetation by the exotic bumblebee Bombus terrestris (Apoidea : Apidae). Austral Ecology 27:162-172.

Hirzel, A.H.; Hausser, J.; Perrin, N. 2004. Biomapper 3.1. Lab. of Conservation Biology, Department of Ecology and Evolution, University of Lausanne. Disponível em: <http://www.unil.ch/biomapper>, Acessado em Jan/2015.

Hirzel, A.H.; Lay, L. G. 2008. Habitat suitability modelling and niche theory. J. Appl. Ecol. 45: 13721381.

Hoctor, T.S.; Carr, M.H.; Zwick, P.D. 2000. Identifying a linked reserve system using a regional landscape approach: the Florida ecological network. Conservation Biology 14:984-1000.

Holm S. N. 1960. Experiments on the domestication of bumble-bees (Bombus Latr.) in particular B. lapidarius L. and B. terrestris L. Royal Vet. and Agric. Coll., Copenhagen; Yearbook : 1-19.

Holm, S.N. 1966. The utilization and management of bumble bees for red clover and alfalfa seed production. Ann. Rev. Entomol., 11:155-182.

Holt-Jensen, A. 2009. Geography: History and Concepts. SAGE Publications Ltd, 4ed, 280pp ISBN-10: 1412946506

Howlett, B.; Donovan, B. 2010. A Review of New Zealand's Deliberately Introduced Bee Fauna: Current Status and Potential Impacts. New Zealand Entomologist, 33(1): 92-101.

Hutchinson, G.E. 1944. Limnological studies in Connecticut. Part 7. A critical examination of the supposed relationship between phytoplankton periodicity and chemical changes in lake waters. Ecology 35: 3-26.

Hutchinson, G.E. 1957. Concluding remarks. Cold Spring Harbour Symposium on Quantitative Biology 22: 415-427.

Hutchinson, G.E., 1978. An Introduction to Population Ecology. Yale University Press, New Haven.

HWSD, 2009. Harmonized World Soil Database (version 1.1). Nachtergaele et al., (Coord.), FAO/IIASA/ISRIC/ISS-CAS/JRC, Rome, Italy and IIASA, Laxenburg, Austria.

Hyland, K. 2004. Disciplinary Discourses: Social Interactions in Academic Writing. University of Michigan Press, 211pp.

IBGE, 2010. Instituto Brasileiro de Geografia e Estatística. Malhas municipais digitais (Ano 2010). Disponivel em:<http://mapas.ibge.gov.br/pt/bases-e-referenciais/bases-cartograficas/malhasdigitais>.

Imperatriz-Fonseca, V.L.; Dias, B.F.S. 2004. Brazilian Pollinator Initiative. In: Solitary bees and their role in pollination. In: Freitas \& Pereira (ed.), Solitary bees: conservation, rearing and management for pollination. Fortaleza, CE, p. 27-34.

Imperatriz-Fonseca, V.L.; Saraiva, A.M.; De Jong D. 2006. Bees as Pollinators in Brazil: assessing the status and suggesting the best practices, Holos Ed., Ribeirão Preto.

Ings, T.C.; Ward, N.L.; Chittka, L. 2006. Can commercially imported bumble bees out-compete their native conspecifics? J. Appl. Ecol. 43:940-948

Inoue, M.; Yokoyama, J.; Washitani, I. 2008. Displacement of Japanese native bumblebees by the recently introduced Bombus terrestris (L.) (Hymenoptera: Apidae), J. Insect. Conserv. 12, 135146.

Inouye, D.W., 1980. The effects of proboscis and corolla tube length on patterns and rates of flower visitation by bumblebees. Oecologia 45, 197-201. 
IPCC, 2007. Climate Change 2007: The Physical Science Basis. Contribution of Working Group I to the Fourth Assessment Report of the Intergovernmental Panel on Climate Change [Solomon, S., D. Qin, M. Manning, Z. Chen, M. Marquis, K.B. Averyt, M.Tignor and H.L. Miller (eds.)]. Cambridge University Press, Cambridge, United Kingdom and New York, NY, USA.

IPCC, 2014. Climate Change 2014: Synthesis Report. Contribution of Working Groups I, II and III to the Fifth Assessment Report of the Intergovernmental Panel on Climate Change [Core Writing Team, R.K. Pachauri and L.A. Meyer (eds.)]. IPCC, Geneva, Switzerland, 151 pp

Iserbyt, S., E.A. Durieux \& P. Rasmont, 2008. The remarkable diversity of bumblebees (Hymenoptera: Apoidea: Bombus) in the Eyne Valley (France, Pyrénées-Orientales). Annales de la Société Entomologique de France, 44(2) : 211-241.

ISI Web of Knowledge, 2013. Thomson Reuters Web of Science. Disponível em: <portal.isiknowledge.com>.

ISO, 2004. Portable Network Graphic - PNG format. http://www.iso.org/iso/home/store/catalogue_tc/catalogue_detail.htm?csnumber=29581

ISO, 2008. Portable Document File - PDF format ISO 32000-1:2008. Disponível em:<http://www.iso.org/iso/iso_catalogue/catalogue_tc/catalogue_detail.htm?csnumber=5150 2>, Acessado em Jan/2015.

Jackson, S.M.; Claridge, A. 1999. Climatic modelling of the distribution of the mahogany glider (Petaurus gracilis), and the squirrel glider (P. norfolcensis), Australian Journal of Zoology, vol. 47, pp. 47-57.

JCR, 2013. Journal Citation Report, Thomson Reuters. Released Year 2014.

Jenness, J. 2012. Repeating shapes for ArcGIS. Jenness Enterprises. Disponível em <http://www.jennessent.com/arcgis/repeat_shapes.htm>

Jessop, B. 1994. Post-Fordism and the State, in Post-Fordism: A Reader (ed A. Amin), Blackwell Publishers Ltd, Oxford, UK. doi: 10.1002/9780470712726.ch8

Jordan R. 1936. Ein Weg zur zwangsläufigen Nestgründung überwinterter Bombus weibchen an einem bestimmten Platze, Arch. Bienenkd. 17, 39-44.

JPL-NASA, 2015. Instrument: Shuttle Radar Topography Mission. Jet Propulsion Laboratory, California Institute of Technology. Disponível em <http://www2.jpl.nasa.gov/srtm/instr.htm>, Acessado em Jan/2015.

Kanbe, Y.; Okada, I.; Yoneda, M.; Goka K.; Tsuchida, K. 2008. Interspecific mating of the introduced bumblebee Bombus terrestris and the native Japanese bumblebee Bombus hypocrita sapporoensis results in inviable hybrids. Naturwissenschaften 95: 1003-1008.

Kearns, C.A.; Inouye, D.W.; Waser, N.M. 1998. Endangered mutualisms: the conservation of plantpollinator interactions. Annu. Rev. Ecol. Syst. 29, 83-112.

Kells, A.R.; Goulson, D. 2003. Preferred nesting sites of bumblebee queens (Hymenoptera: Apidae) in agroecosystems in the UK. Biological Conservation 109, 165-174.

Kenta, T.; Inari, N.; Nagamitsu, T.; Goka, K.; Hiura, T. 2007. Commercialized European bumblebee can cause pollination disturbance: an experiment on seven native plant species in Japan. Biological Conservation, 134, 298-309.

King, M.J.; Buchmann, S.L. 1995. Bumble bee-initiated vibration release mechanism of Rhododendron pollen. Am J Bot 82:1407-1411

Knight M.E.; Martin A.P.; Bishop S.; et al. 2005. An interspecific comparison of foraging range and nest density of four bumblebee (Bombus) species, Mol. Ecol. 14, 1811-1820.

Knutson, M.G.; Powell, L.A.; Hines, R.K.; Friberg, M.A.; Niemi, G.J. 2006, An assessment of bird habitat quality using population growth rates: Condor, v. 108, no. 2, p. 301-314.

Knutti, R.; Sedlácek, J. 2013. Robustness and uncertainties in the new CMIP5 climate model projections. Nature Clim. Change (4), NPG, Vol.3, 369-373pp

Koen, E.L.; Garroway, C.J.; Wilson, P.J.; Bowman, J. 2010. The Effect of Map Boundary on Estimates of Landscape Resistance to Animal Movement. PLOS ONE 5: e11785.

Kondo, N.I.; Yamanaka, D.; Kanbe, Y.; Kunitake, Y.K.; Yoneda, M.; Tsuchida, K.; Goka, K. 2009. Reproductive disturbance of Japanese bumblebees by the introduced European bumblebee Bombus terrestris. Naturwissenschaften 96:467-475 
Kozakiewicz, M. 1995. Resource tracking in space and time. In: Hanson, L.; Fahrig, L.; Merriam, G. (eds) Mosaic landscapes and ecological processes. Chapman and Hall, London, pp 136-148

Krüger, E. 1954. Phaenoanalytische Studien an einigen Arten der Untergattung TerrestriBombus O. Vogt (Hymenoptera, Bombidae). II. Teil. Tijdschrift voor Entomologie 97, 263-298.

Krüger, E. 1956. Phaenoanalytische Studien an einigen Arten der Untergattung TerrestriBombus O. Vogt (Hymenoptera, Bombidae). II. Teil. Tijdschrift voor Entomologie 99, 75-105.

Krüger, E. 1958. Phaenoanalytische Studien an einigen Arten der Untergattung TerrestriBombus O. Vogt (Hymenoptera, Bombidae). II. Teil. Tijdschrift voor Entomologie 101, 283-344.

Kuusik, A.; Martin, A. J.; Mand, M.; Hiiesaar, K.; Metspalu, L.; Tartes, U. “Interrelations of Gas Exchange Cycles, Body Movements and Heartbeats in the Foragers of Bumblebee Bombus terrestris (Hymenoptera : Apidae) at Low Temperatures". European Journal of Entomology, 99(2): 209-214, 2002.

Leadbeater, E.; Chittka, L. 2007. The dynamics of social learning in an insect model, the bumblebee (Bombus terrestris) Behav Ecol Sociobiol. DOI 10.1007/s00265-007-0412-4.

Leibold. M.A. 2009. Spatial and Metacommunity Dynamics in Biodiversity. In: The Princenton Guide to Ecology. Cap.III 8. Princeton University Press, New Jersey.

Levine, R.S.; Peterson, A.T.; Yorita, K.L.; Carroll, D.; Damon, I.K. \& Reynolds, M.G. 2007. Ecological niche and geographic distribution of human monkeypox in Africa. Plos One 2: e176

Lincoln, R.J.; Boxshall, G.A.; Clark, P.F. 1982. A dictionary of ecology, evolution and systematics. Cambridge University Press, Cambridge.

Lindenmayer, D.; Nix, H.; McMahon, J. P.; Hutchinson, G. E.; Tanton, M. T. 1991. The conservation of Leadbeater's possum, Gymnobelideus leadbeateri (McCoy): a case study of the use of bioclimatic modeling. Journal of Biogeography 18:371-383.

Löken, A., 1973. Studies on Scandinavian Bumble Bees (Hymenoptera, Apidae). Norsk entomologisk Tidsskrift, 20(1): 1-218.

Longley, P.A.; Goodchild, M.F.; Maguire, J.D.; Rhind, D.W. 2015. Geographic Information Systems Science, 4th Edition, Wiley. 496 p. ISBN : 978-1-118-67695-0

Lotka, A.J. 1910. Contribution to the Theory of Periodic Reaction., J. Phys. Chem., 14 (3), pp 271-274

Lye, G.C.; Kaden, J.C.; Park, K.J.; Goulson, D. 2010. Forage use and niche partitioning by non-native bumblebees in New Zealand: implications for the conservation of their populations of origin. Journal of Insect Conservation, V14, I-6, pp 607-615.

MAA. 2015. Ministerio de Asuntos Agrarios: La Provincia de Buenos Aires creó el primer registro de polinizadores. 06/02/2015. Disponível em: < http://www.maa.gba.gov.ar/2010/prensa/noticia.php?idnoticia=1071>

MacArthur, R.H.; Wilson, E.O. 1967. The theory of island biogeography. Princeton, NJ, USA, Princeton University Press.

Macfarlane, R.P.; Gurr L. 1995. Distribution of bumblebees in New Zealand. NZ Entomol. 18, 29-36.

Magner, L.N. 2002. A History of the Life Sciences, Revised and Expanded. CRC Press. 3ed. 520pp. ISBN10: 0824708245

Maloof, J.E.; Inouye, D.W. 2000. Are nectar robbers cheaters or mutualists? Ecology, 81:2651-2661.

Manly, B. F. J.; McDonald, L. L.; Thomas, D. L. 2002. Resource selection by animals - statistical design and analysis for field studies. Springer, New York.

Marengo, J.A. et al. 2007. Mudanças Climáticas Globais e seus Efeitos sobre a Biodiversidade: Caracterizacao do Clima Atual e Defnicao das Alteracoes Climáticas para o Território Brasileiro ao longo do Século XXI. Brasília: Ministério do Meio Ambiente. Série Biodiversidade, v.26.

Maxted N, M.W; van Slagaren, J.R. Rihan. 1995. Ecogeographic surveys. IN: L. Guarino, V. Ramanatha Rao and R. Reid R. (eds.) Collecting Plant Genetic Diversity: Technical Guideline. CAB International, IPGRI and FAO.Pp. 255-287

McClay, A. 2005. Climex ${ }^{\circledR}$ Models to Predict the Potential Naturalized Range of the European Bumblebee Bombus terrestris (L.) in Mainland Australia. Report prepared for the Australian Hydroponic and Greenhouse Assoc, 2005. 
McRae, B.H. 2006. Isolation by resistance. Evolution 60:1551-1561

McRae, B.H.; D.M. Kavanagh. 2011. Linkage Mapper Connectivity Analysis Software. The Nature Conservancy, Seattle WA. Disponível em: <http://www.circuitscape.org/linkagemapper>.

McRae, B.H.; Dickson, B.G.; Keitt, T.H.; Shah, V.B. 2008. Using circuit theory to model connectivity in ecology, evolution, and conservation. Ecology 89:2712-2724

Mehdiabadi, N.J.; et al. 2003 Queen versus workers: sex ratio conflictin eusocial Hymenoptera. Trends Ecol. Evol. 18, 88-93

Michener, C.D. 1974. The social behavior of bees: a comparative study. Cambridge: The Blacknap Press.

Michener, C.D. 2007. The bees of the Word. 2nd ed. Baltimore: The Johns Hopkins University Press. 953 p.

Microsoft Inc., 2015. Microsoft Office Enterprise 2015.

Miller, R.L.; Schmidt, G.A.; Nazarenko, L.S; Tausnev, N.; Bauer, S.E.; Del Genio, A.D.; et al. 2014 CMIP5 historical simulations (1850-2012) with GISS ModelE2. J. Adv. Model. Earth Syst., 6, no. 2, 441477, doi:10.1002/2013MS000266.

Molet, M.; Chittka, L.; Raine N.E. 2009. How floral odours are learned inside the bumblebee (Bombus terrestris) nest. Naturwissenschaften 96:213-219

Morales, C.L. 2007. Introducción de abejorros (Bombus) no nativos: causas, consecuencias ecológicas y perspectivas. Ecología Austral 17:51-65.

Morales, C.L.; Arbetman, M.P.; Cameron, S.A.; Aizen, M.A. 2013. Rapid ecological replacement of a native bumble bee by invasive species. Frontiers in Ecology and the Environment 11: 529-534.

Morandin, L. A.; Laverty, T. M.; Kevan, P. G.; Khosla, S.; Shipp, L. 2001a. Bumblebee (Hymenoptera: Apidae) activity and loss in commercial tomato greenhouses. Can.Entomol. 133: 883-893.

Morandin, L. A.; Laverty, T.M.; Kevan, P. G. 2001b. Bumble bee (Hymenoptera: Apidae) activity and pollination levels in commercial tomato greenhouses. J. Econ. Entomol. 94: 462-467.

Murphy, J.M. et al. 2004. Quantification of modelling uncertainties in a large ensemble of climate change simulations. Nature 430: 768-772.

Nazarenko, L.; Schmidt, G.A.; Miller, R.L.; Tausnev, N.; Kelley, M. et al., 2015: Future climate change under RCP emission scenarios with GISS ModelE2. J. Adv. Model. Earth Syst., 7, no. 1, 244-267, doi:10.1002/2014MS000403.

NBN, 2013. National Biodiversity Network Gateway (UK). disponível em: <https://data.nbn.org.uk/>, Acessado em: Jan/2013.

ND, 2013. NaturData - Biodiversity Portal or Portugal. Disponível em: <http://naturdata.com/>.

Ne'eman, G.; Dafni, A. 1999. Fire, bees and seed production in Mediterranean key species Salvia fruticosa Miller (Lamiaceae). Isr. J. Plant Sci. 47: 157-163.

Newman, H. W. 1851. Habitus of the Bombinatrices. Proc. Entomol. Soc. Lond. 1:86- 92.

NIES, 2012. National Institute for Environmental Studies, Japan. Disponível em: $<$ https://www.nies.go.jp>.

NII, 2012. National Institute of Informatics, Japan. Disponível em: <http://www.nii.ac.jp/en/>.

Nix, H.A. 1986. A biogeographic analysis of Australian elapid snakes. In: Atlas of Elapid Snakes of Australia. (Ed.) R. Longmore, pp. 4-15. Australian Flora and Fauna Series Number 7. Australian Government Publishing Service: Canberra.

NS, 2013. NatureServe. A Network Connecting Science with Conservation.Disponível em: $<$ http://www.natureserve.org/>, Acessado em Jan/2015.

Oberhauser, K.; Peterson, A.T. 2003. Modeling current and future potential wintering distributions of eastern North American monarch butterflies. PNAS 100, 14063-14068.

OBIS, 2013. Ocean Biogeographic Information System. Intergovernmental Oceanographic Commission (IOC) of UNESCO - International Oceanographic Data and Information Exchange (IODE) programme. Disponível em: <http://www.iobis.org/>, Acessado em Jan/2015.

Olesen J. M. 1985. The Macaronesian bird-flower element and its relation to bird and bee opportunists. Bot. J. Linn. Soc. 91, 395-414. 
Olesen, J. M.; Forfang, A. S.; Báez, M. 1998. Stress-induced male sterility and mixed mating in the island plant Cedronella canariensis (Lamiaceae). Plant Syst. Evol. 212: 159-176.

OpenModeller, 2012. OpenModeller Framework: Muñoz, M.E.S., Giovanni, R., Siqueira, M.F., Sutton, T., Brewer, P., Pereira, R.S., Canhos, D.A.L. \& Canhos, V.P. (2009) "openModeller: a generic approach to species' potential distribution modelling". Geolnformatica. Disponível em:<http://openmodeller.sourceforge.net/>, Acessado em Jul/2012.

Ortega-Huerta, M.A.; Peterson, A.T. 2004. Modelling spatial patterns of biodiversity for conservation prioritization in North-eastern Mexico. Diversity and Distribution, 10, 39-54.

Parry, M.L. 2002. Scenarios for climate impact and adaptation assessment. Global Environmental Change 12: 149-153.

Patten, B. C.; Auble, G.T. 1981. System Theory of the Ecological Niche. The American Naturalist, Vol. 117, No. 6 (Jun., 1981), pp. 893-922

Pearson, R.G.; Dawson, T.E. 2003. Predicting the impacts of climate change on the distribution of species: are bioclimate envelope models useful? Glob. Ecol. Biogeogr., 12, 361-372.

Pearson, R.G.; et al. 2006. Model-based uncertainty in species range prediction. Journal of Biogeography, 33: 1704-1711.

Peat, J.; Darvill, B.; Ellis, J.; Goulson, D. 2005. Effects of climate on intra- and interspecific size variation in bumble-bees. p. 145-151, 2005. Functional Ecology, 19 , 145-151.

Peeters, J.P.; Williams, J.T. 1984. Towards better use of genebanks with special reference to information. Plant Genetic Resources Newsletter 60: 22-31.

Pekkarinen, A.; Teräs, I.; Viramo, J.; Paatela, J. 1981. Distribution of bumblebees (Hymenoptera, Apidae: Bombus and Psithyrus) in eastern Fennoscandia. Notulae Entomologicae 61: 71-89.

Pelosi, P.; Zhou, J.J.; Ban, L.P.; Calvello, M. 2006. Soluble proteins in insect chemical communication.Cellular and Molecular Life Sciences.V.63, I.14, pp1658-1676.

Pereboom, J. J. M.; Velthuis, H. H.W.; Duchateau, M. J. 2003. The organisation of larval feeding in bumblebees (Hymenoptera, Apidae) and its significance to caste differentiation. Insectes Soc. 50 (2003) 127-133.

Pérez, J. 1895. Excursion Entomologique dans la province d’Oran (Algérie) (suite) Description des Hyménoptères nouveaux. Revue scientifique du Bourbonnais et du Centre de la France 8: 173180.

Peterson, A.T. 2006. Uses and requirements of ecological niche models and related distributional models. Biodiversity Informatics, 3:59-72.

Peterson, A.T.; Soberón, J. 2012. Species distribution modeling and ecological niche modeling: getting the concepts right. Natureza \& Conservação 10(2):102-107.

Peterson, A.T.; Lash, R.R.; Carroll, D.S. \& Johnson, K.M. 2006b. Geographic potential for outbreaks of Marburg hemorrhagic fever. American Journal of Tropical Medicine and Hygiene 75: 9-15.

Peterson, A.T.; Ortega-Huerta, M.A.; Bartley, J.; Sánchez-Cordero, V.; Soberón, J.; Buddemeier, R.H. \& Stockwell, D.R.B. 2002. Future projections for Mexican faunas under global climate change scenarios. Nature 416: 626-629.

Peterson, A.T.; Papes, M.; Kluza, D.A. 2003. Predicting the potential invasive distributions of four alien plant species in North America. Weed Science 51: 863-868.

Peterson, A.T.; Papes, M.; Reynolds, M.G.; Perry, N.D.; Hanson, B.; Regnery, R.L.; Hutson, C.L.; Muizniek, B.; Damon, I.K. \& Carroll, D.S. 2006a. Native-range ecology and invasive potential of Cricetomys in North America. Journal of Mammalogy 87: 427-432

Peterson, A.T.; Papes, M. \& Eaton, M. 2007. Transferability and model evaluation in ecological niche modeling: a comparison of GARP and Maxent. Ecography 30: 550-560.

Peterson, A.T.; Robins, C.R. 2003. Using ecological-niche modeling to predict Barred Owl invasions with implications for Spotted Owl conservation. Conservation Biology 17: 1161-1165.

Phillips, S.J.; Anderson, R.P.; Schapire, R.E. 2006. Maximum entropy modeling of species geographic distributions. Ecological Modelling 190, 231-259. 
Plischuk, S.; Lange, C.E. 2009. Invasive Bombus terrestris (Hymenoptera: Apidae) parasitized by a flagellate (Euglenozoa: Kinetoplastea) and a neogregarine (Apicomplexa: Neogregarinorida). Journal of Invertebrate Pathology 102, 263-265.

Proctor, M.; Yeo, P.; Lack, A. 1996. The Natural History of Pollination. Harper Collins, London. 479 pp.

Pulliam, H. R. and N. Waser. 2009. Ecological invariance and the search for generality in ecology. In: M. Price and I Billick, (Editors), The Idiosyncrasy of Place, U. Chicago Press

Pulliam, H.R. (2000). On the relationship between niche and distribution. Ecol. Lett., 3, 349-361.

R Development Core Team. 2011 R: A language and environment for statistical computing.

Rana, S.V.S. 2013. Essentials of Ecology and Environmental Science. PHI Learning Pvt Ltd. 5ed, 608pp

Rand, A., Schwartz, P. 1999. The Return of the Primitive: The Anti-Industrial Revolution. Penguin Putnam Inc, United States, 304pp

Ranta, E.; Lundberg, H. 1980. Resource partitioning in bumblebees: the significance of differences in proboscis length. Oikos 35:298-302. doi:10.2307/3544643

Rasmont, P.; Flagothier, D. 1996. Biogéographie et choix floraux des bourdons de la Turquie - Rapport préliminaire 1995-1996, N.A.T.O.,TU-Pollination Project.

Rasmont, P.; Pauly, A.; Terzo, M.; Patiny, S.; Michez, D.; Iserbyt, S.; Barbier, Y.; Haubruge, E. 2005. The Survey of Wild Bees (Hymenoptera, Apoidea) in Belgium and France. Food and Agriculture Organisation, Rome. 18pp.

Rasmont. P.; Coppee, A.; Michez, D.; De Meulemeester, T. 2008. An overview of the Bombus terrestris (L. 1758) subspecies (Hymenoptera: Apidae). Ann Soc Entomol Fr (ns) 44:243-250

Ravestijn, W.; Nederpel, L. 1988. Trostrillers in België aan de kant: hommels doen het werk, Groenten en Fruit 6 (12 februari), 38-41.

Richards, C. 2000. Inbreeding depression and genetic rescue in a plant metapopulation. Am. Nat. 155:383-394

Roig-Alsina, A.; Aizen, M.A. 1996. Bombus ruderatus Fabricius, un nuevo Bombus para la Argentina (Hymenoptera: Apidea). Physis, 5: 49-50.

Root, R. B. 1967. The niche exploitation pattern of the blue-gray gnatcatcher. Ecol. Monogr. 37:317-350.

Ruz L, Herrera R (2001) Preliminary observations on foraging activities if Bombus dahlbomii and Bombus terrestris (Hym: Apidae) on native and non-native vegetation in Chile. Acta Hort 561:165-169

Ruz, L. 2002. Bee pollinators introduced to Chile: A review. Pp. 155-167 in: Kevan, P.G.; ImperatrizFonseca V.L. Pollinating Bees. The Conservation Link between Agriculture and Nature. Proceedings of the workshop on the Conservation and Sustainable Use of Pollinators in Agriculture, with emphasis on Bees. Brasília.

Savriama, Y.; Gómez, J. M.; Perfectti, F.; Klingenberg, C. P. 2012, Geometric morphometrics of corolla shape: dissecting components of symmetric and asymmetric variation in Erysimum mediohispanicum (Brassicaceae). New Phytologist, 196: 945-954.

Schmidt, G.A.; Kelley, M.; Nazarenko, L.; Ruedy, R.; Russell, G.L.; Aleinov, I.; et al., 2014. Configuration and assessment of the GISS ModelE2 contributions to the CMIP5 archive. J. Adv. Model. Earth Syst., 6, no. 1, 141-184, doi:10.1002/2013MS000265

Schwartz, M.K.; Copeland, J.P.; Anderson, N.J.; Squires, J.R.; Inman, R.M.; McKelvey, K.S.; Pilgrim, K.L.; Waits, L.P.; Cushman, S.A. 2009. Wolverine gene flow across a narrow climatic niche. Ecology 90 : 3222-3232.

Scielo, 2013. SciELO - Scientific Electronic Library Online. Disponível em: <http://www.scielo.org/>.

Sciencedirect, 2013. ScienceDirect: a leading full-text scientific database offering journal articles and book chapters. Elsevier B.V. Dispinível em: <http://www.sciencedirect.com/>

Scopus, 2013. Elsevier's Scopus - The largest up-to-date collection of global, unbiased and expertly sourced research. Acessado via: <www.scopus.com>

Semmens, T.D.; Turner, E.; Buttermore, R. 1993. Bombus terrestris (L.) (Hymenoptera: Paidae) now established in Tasmania. Journal of the Australian Entomological Society, 32: 346.

Shimabukuro, Y.E.; Verona, J.D.; Bernardes, T.; Pereira, G. 2013. Avaliação da qualidade do produto Globcover para o Estado do Mato Grosso, Brasil, por meio de imagens do Google Earth e séries 
temporais de índices de vegetação derivados de imagens MODIS. INPE, São José dos Campos SP, Brasil. Anais XVI Simpósio Brasileiro de Sensoriamento Remoto - SBSR, Foz do Iguaçu, PR, Brasil, 13 a 18 de abril de, INPE

Shpigler, H .; Tamarkin , M.; Gruber, Y. 2013. Social influences on body size and developmental time in the bumblebee Bombus terrestris. Behavioral Ecology and Sociobiology, Vol 67, Issue 10, pp 1601-1612 p.

SIDRA, 2014. Sistema IBGE de Recuperação Automática. Disponível em: <http://www.sidra.ibge.gov.br/>

Siqueira, M.F.; Peterson, A.T. 2003. Consequences of global climate change for geographic distributions of cerrado tree species. Biota Neotropica 3: 1-14.

Sladen, 1912. The humble-bee; its life history and how to domesticate it. Macmillan \& Co., London, UK. $283 \mathrm{pp}$.

Snover, A.K.; Mantua, N.J.; Littell, J.S. 2013. Choosing and Using Climate-Change Scenarios for EcologicalImpact Assessments and Conservation Decisions. Conservation Biology, Volume 27, No. 6, 11471157. DOI: $10.1111 /$ cobi.12163.

Soberon, J. 2007. Grinnellian and Eltonian niches and geographic distributions of species. Ecology Letters, 10, 1115-1123.

Soberón, J. 2010. Niche and area of distribution modeling: a population ecology perspective. Ecography 33: 159-167.

Soberón, J.; Nakamura, M. 2009. Niches and distributional areas: concepts, methods, and assumptions. PNAS 106: 19644-19650.

Soberón, J.; Peterson, A.T. 2005. Interpretation of models of fundamental ecological niches and species distributional areas. Biodiversity Informatics 2: 1-10.

Spaethe, J.; Weidenmüller, A. 2002. Size variation and foraging rate in bumblebees (Bombus terrestris). Insectes Sociaux, 49, 142e146.

SPL, 2013. SpeciesLink: sistema distribuído de Informação que integra em tempo real, dados primários de coleções científicas. Disponível em: <http://splink.cria.org.br/>

SpringerLink, 2013.Providing researchers with access to millions of scientific documents. Springer International Publishing AG. Disponivel em: $<$ http://link.springer.com/>

Stanfield, R.E.; Dong, X.; Xi, B.; Del Genio, A.D.; Minnis, P.; Doelling, D.; Loeb, N. 2015. Assessment of NASA GISS CMIP5 and Post-CMIP5 simulated clouds and TOA radiation budgets using satellite observations. Part II: TOA radiation budget and CREs. J. Climate, 28, no. 5, 1842-1864, doi:10.1175/JCLI-D-14-00249.1.

Statcom, 2015. Interacting $\mathrm{R}$ with Spreadsheets. Disponível em:<http://www.burnsstat.com/spreadsheet-r-vector/>

Statsoft Inc., 2015. STATISTICA, the most comprehensive suite of data mining and statistical analysis software. StatSoft Inc., a DELL corp. Disponível em:<http://www.statsoft.com/>

Stelzer, R.J.; Chittka, L.; Carlton, M.; Ings, T.C. 2010. Winter Active Bumblebees (Bombus terrestris) Achieve High Foraging Rates in Urban Britain. Plos One 5.

Stockwell, D. \& Peters, D. 1999. The GARP modeling system: problems and solutions to automated spatial prediction. International Journal of Geographical Information Science 13: 143-158.

Stockwell, D.; Peters, D. 1999. The GARP modelling system: problems and solutions to automated spatial prediction. International Journal of Geographical Information Systems,13, 143-158.

Stockwell, D.R.B.; Peterson, A.T. 2002. Effects of sample size on accuracy of species distribution models. Ecological Modelling 148: 1-13.

Stout, J. C.; Allen, J. A.; Goulson, D. 1998. The influence of relative plant density and floral morphological complexity on the behaviour of bumblebees. Oecologia, 112: 543-550.

Stout, J. C.; Goulson, D. 2000. Bumblebees in Tasmania: Their distribution and potential impact on Australian flora and fauna. Bee World 81, 80-6.

Stout, J.C.; D. Goulson. 2000. Bumble bees in Tasmania: their distribution and potential impact on Australian flora and fauna. Bee World 81: 80-86. 
Stout, J.C.; Kells, A.R.; Goulson, D. 2002. Pollination of the invasive exotic shrub Lupinus arboreus (Fabaceae) by introduced bees in Tasmania. Biol Conserv 106:425-434

Tauber, M.J.; Tauber, C.A.; Masaki, S. 1986. Seasonal Adaptations of Insects. Oxford University Press, Oxford, UK.

Taylor, P.; Fahrig, L.; Henein, K. et al. 1993. Connectivity is a vital element of landscape structure. Oikos 68:571-573

Thomas, C.D.; Cameron, A.; Green, R.E.; Bakkenes, M.; et al. 2004. Extinction risk from climate change. Nature 427: 145-148

Thuiller, W. 2003. BIOMOD - optimizing predictions of species distributions and projecting potential future shifts under global change. Global Change Biology 9: 1353-1362

Thuiller, W.; Georges, D.; Engler, R. 2015. Ensemble platform for species distribution modeling - Package 'biomod2'. (Versão disponibilizada em Jan/2015)

Torreta, J.P.; Medan, D.; Abrahamovich, A.H. 2006. First record of the invasive bumblebee Bombus terrestris (L.) (Hymenoptera, Apidae) in Argentina. Transactions of the American Entomological Society, 132: 285-289.

Trenberth, K.E. 2010. The Role of the Oceans in Climate. NOAA. National Center for Atmospheric Research , Boulder, CO. Disponível em:<http://www.oco.noaa.gov/roleofOcean.html>

Trivers, R.L., and Hare, H. (1976). Haplodiploidy and the evolution of the social insects. Science 191, 249263.

UNEP, 1997. World atlas of desertification, United Nations Environment Programme. 2ED. UNEP, London.

Van Horne, B. 1983. Density as a misleading indicator of habitat quality. The Journal of Wildlife Management, Vol. 47, No. 4. (Oct., 1983), pp. 893-901.

Van Valen, L. 1960. Further competitive exclusion. Science 132:1674-1675.

Van Valen, L. 1971. Adaptive zones and the orders of mammals. Evolution 25:420-428.

Velthuis, H.H.W.; Cobb, L. 1991. Pollination of Primula in a greenhouse using bumblebees. Acta Hortic. 288: 199-203.

Velthuis, H.H.W.; van Doorn, A. 2004. The breeding, commercialization and economic value of bumblebees. In: Freitas \& Pereira ed., Solitary bees: conservation, rearing and management for pollination. Fortaleza, 135-149.

Velthuis, H.H.W.; van Doorn, A. 2006. A century of advances in bumblebee domestication and the economic and environmental aspect of its commercialization for pollination. Apidologie 37: 421451.

Vögeli, M.; Serrano, D.; Pacios, F.; Tella, J.L. 2010. The relative importance of patch habitat quality and landscape attributes in a declining steppe-bird metapopulation. Biol Conserv 143: pp. 1057-1067

Vogt F.D. 1986. Thermoregulation in bumblebee colonies. I. Thermoregulatory versus brood maintenance behaviors during acute changes in ambient temperature, Physiol. Zool. 59, 55-59.

Walther-Hellwig K.; Frankl R. 2000. Foraging habitats and foraging distances of bumblebees, Bombus spp. (Hym., Apidae), in agricultural landscape, J. Appl. Entomol. 124, 299-306.

Watson, A.J. 2008 Certainty and uncertainty in climate change predictions: what use are limate models? Environmental Resource Economy, 39: 37-44.

Weidenmuller, A. 2004. The control of nest climate in bumblebee (Bombus terrestris) colonies: interindividual variability and self reinforcement in fanning response. Behavioral Ecology, 15, 120-128.

Westerkamp C. 1991. Honeybees are poor pollinators - why? Plant Syst. Evol. 177, 71-75.

Wiens, J.A.; Stralberg, D.; Jongsomjit, D.; Howell, C.A.; Snyder, M.A. 2009. Niches, models, and climate change: assessing the assumptions and uncertainties. Proceedings of the National Academy of Sciences of the United States of America 106: 19729-19736.

Wikipédia, 2015. Wikipedia: The free encyclopedia. FL: Wikimedia Foundation, Inc. Disponível em:<http://www.wikipedia.org> 
Williams, P. H. 1986. Environmental change and the distributions of British bumble bees (Bombus Latr.). Bee World 67, 50-61.

Williams, P.H., 1998. An annotated checklist of bumble bees with an analysis of patterns of description (Hymenoptera: Apidae, Bombini). Bulletin of The Natural History Museum (Entomology) 67, 79152.

Winter, K.; Adams, L.; Thorp, R.; Inouye, D.; Day, L.; Ascher, J. 2006. Importation of nonnative bumble bees into North America: Potential consequences of using Bombus terrestris and other nonnative bumble bees for greenhouse crop pollination in Canada, Mexico, and the United States. White Paper of the North American Pollinator Protection Campaign (NAPPC), San Francisco, CA. v.1, s/n, p.1-31.

WMO, 2013. World Meteorological Organization: Conversion of Snowfall Depths to Water Equivalents in the Swiss Alps, Zürcher Geographische Schriften, ETH Zürich, No. 23, 13-23. Disponível em <https://www.wmo.int/pages/prog/www/IMOP/meetings/SI/IOC-SPICE-4/INF-4_Sevruk.pdf>.

Wolf, S.; Moritz. R.F.A. 2008. Foraging distance in Bombus terrestris L. (Hymenoptera: Apidae). Apidologie 39: 419-427.

Wu, Z.J., Li, Y.M. \& Murray, B.R. (2006) Insular shifts in body size of rice frogs in the Zhoushan Archipelago, China. Journal of Animal Ecology, 75, 1071-1080.

XtoolsPro, 2015. XTools Pro is a comprehensive set of useful vector spatial analysis, shape conversion, and table management tools for ArcGIS.Data East, LLC, Novosibirsk, Russia. Disponível em: <http://www.xtoolspro.com/>.

Zeigler, S.L.; Neel, M.C.; Oliviera, L.; Raboy, B.E.; Fagan, W.F. 2011. Conspecific and heterospecific attraction in assessments of functional connectivity. Biodivers Conserv, 20:2779-2796.

Zomer, R.J.; Bossio, D.A.; Trabucco, A.; Yuanjie, L.; Gupta, D.C. Singh, V.P. 2007. Trees and Water: Smallholder Agroforestry on Irrigated Lands in Northern India. Colombo, Sri Lanka: International Water Management Institute. pp 45. (IWMI Research Report 122).

Zomer, R.J.; Trabucco, A.; Bossio, D.A.; van Straaten, O; Verchot, L.V. 2008. Climate Change Mitigation: A Spatial Analysis of Global Land Suitability for Clean Development Mechanism Afforestation and Reforestation. Agric. Ecosystems and Envir. 126: 67-80. 


\section{Anexo C5-1}

C5-1A - Script em linguagem R para extração dos valores ambientais por registro \#Pacote necessário library("raster")

\#Empilhando as variáveis ambientais camadas<-stack(list.files("E:/ pasta_variaveis/", pattern="alt $\mid$ bio $\mid$ prec $\mid$ tmin $\mid$ tmean $\mid$ tmax $\mid$ arid $\mid$ glob", full.names = T))

\#Lendo os registros (estrutura colunas: ID, Nome_espécie, Longitude, Latitude) registros<-read.table("E:/registros.csv", header=T, sep=",") \#Procedimento de extração (cruzamento registros $x$ camadas) extracao<-cbind(registros, extract(camadas, SpatialPoints(registros[,c("Longitude", "Latitude")]), df=T)) \#Salvando os dados em tabela externa write.csv(extracao, "E:/tabela_extracao.csv")

C5-1B - Cálculo dos limiares de afinidade, tolerância, mediana e outros valores úteis \#Recarregando tabela com dados ambientais extraídos por ocorrência a partir do arquivo de salvamento extracao<-read.csv("E:/tabela_extracao.csv", header=T) \#Inserindo os valores dos limiares atribuídos (mínimo, 12,5\%, mediana, 87,5\%, máximo) limiares<-c(0, 0.125, 0.5, 0.875, 1)

\#Gerando a função de cálculo dos limiares e dos outros valores auxiliares

func_limiares<- function(x)\{

\#Parte da função que calculará os limiares

c(quantile $(x$, probs $=$ limiares, na.rm= $\mathrm{T}$, names $=\mathrm{T}$, type $=7$ ),

\#Parte da função que calculará a média, a soma, o desvio padrão e contará os registros calculados mean $=$ mean $(x$, na.rm $=T)$,

$\operatorname{sum}=\operatorname{sum}(x$, na.rm $=T)$,

$\operatorname{std}=s d(x$, na.rm $=T)$,

count $=\operatorname{sum}(\operatorname{complete} . \operatorname{cases}(\mathrm{x})))\}$

\#Executando a função em lote, para calcular todas variáveis de uma vez limiares_valores<-data.frame(round(sapply)

\#Selecionando as colunas de interesse (variáveis ambientais)

extracao[,grep("alt|bio|prec|tmin|tmean|tmax|arid ", colnames(extracao), value=T)], func_limiares),

\#Atribuindo a quantidade de dígitos das frações $(0,00 . .$.

digits $=2)$ )

\#Salvando os dados em tabela externa

write.csv(limiares_valores, "E:/tabela_limiares.csv")

\section{C5-1C - Geração da Camada de Qualidade Ambiental Abiótica - CQAA}

\# Empilhando as variáveis ambientais abióticas

camadas<-stack(list.files("E:/pasta_variaveis /", pattern="alt|bio|prec|tmin|tmean|tmax|arid", full. names $\mathbf{=}$ T))

\#Recarregando tabela com valores dos limiares a partir do arquivo de salvamento limiares_valores<-read.csv("E:/ tabela_limiares.csv", header=T, row.names=1)

\# Sequência de cálculos por camada ambiental (Loop)

for(nome in names(camadas))\{

cat(nome, "\n\n")

\#Gera a tabela de reclassificação da camada ambiental

mat_recla<-matrix(rbind/

\# Concatena o valor mínimo da camada com o limiar mínimo de afinidade (minVar, 12,5\%)

c(as.numeric(minValue(camadas[[nome]])), as.numeric(limiares_valores[c("12.5\%"), nome]), NA),

\# Concatena o limiar máximo de afinidade e com o valor máximo da camada (87.5\%, maxVar)

c(as.numeric(limiares_valores[c("87.5\%"), nome]), as.numeric(maxValue(camadas[[nome]])), NA)),

nrow $=2$, ncol=3, byrow $=$ F) 
\#Anula os valores das faixas de reclassificação atribuídas, mantendo apenas a faixa de afinidade modelo_eco<-reclassify(camadas[[nome]], mat_recla, include.lowest=FALSE, right=NA)

\#Subtrai a mediana da faixa de afinidade da variação (para a normalização a partir da mediana) modelo_eco<-abs(modelo_eco-limiares_valores[c("50\%"),nome])

\#Faz a normalização inversa

modelo_eco<-(1-(modelo_eco/maxValue(modelo_eco)))

\#Atribui zero para as células com Nas, e salva o raster por camada ambiental e fecha a sequência modelo_eco[is.na(modelo_eco)]<-0

writeRaster((modelo_eco*1000), paste("E:/TESTES/", nome, sep=""), overwrite=TRUE, format="HFA")\}

\#Após todas camadas ambientais normalizadas (passo acima), este passo empilha-as

todos_ecomods<-sum(stack(list.files("E:/TESTES/", pattern="\l.img\$", full.names = T)))

\#As camadas empilhadas são somadas e o resultado é normalizado de 1 a 1001

soma_norm<-1+((1-(((todos_ecomods)-minValue(todos_ecomods))/(maxValue(todos_ecomods)-

minValue(todos_ecomods)) ))*1000)

\# A camada CQAA está pronta e será salvada

writeRaster(soma_norm, "E:/TESTES/CQAA", overwrite=TRUE, format="HFA")

\section{C5-1D - Composição de modelos para Bombus nativas (convergência preditiva)}

library("raster") \#Pacote necessário

setwd("E:/ENSENBLE/") \#Definindo diretório de trabalho

path_mod<-"E:/BIOMO2/"\#Apontando o caminho da pasta de saída da modelagem BIOMOD2

\#Listando o nome dos modelos/espécies desenvolvidos pelo BIOMOD2

list_models<-c("brasiliensis", "bellicosus", "morio", "pauloensis")

\# Apontando a métrica de avaliação a ser usada/ aquela que foi usada no BIOMOD2

evaluation_metric<-"TSS" \#ex: TSS, ROC, KAPPA

limiarEVA<-as.numeric(0.8) \#Limiar mínimo (=>) para a métrica de avaliação

\#Inicio da sequência, quando para múltiplas espécies (neste caso Bombus no sul do Brasil)

for(i in list_models)\{

nome<-as.character(i)\#Captura o nome do modelo/espécie a cada ciclo

cat("-=-=-= Processo iniciado para a espécie:", nome, "\n\n") \# mensagem no terminal

\#Lendo avaliações feitas pelo BIOMO2

load(paste(path_mod, nome, "/.BIOMOD_DATA/", nome, "/models.evaluation", sep="'))

\#Empilhando modelos BIOMO2 (.gri)

Models<-stack(paste(path_mod, nome, "/proj_current/proj_current_", nome, sep="'))

\#Selecionando, dentre as métricas de avaliação, aquela escolhida, e montado a tabela EVAL_VAL

EVAL_VAL<-t(data.frame(models.evaluation)[which(rownames(data.frame(models.evaluation)) \%in\% evaluation_metric),grep("Testing.data", colnames(data.frame(models.evaluation)))])

EVAL_VAL<-cbind(names(Models), t(data.frame(strsplit(rownames(EVAL_VAL), ".", fixed=T))),

EVAL_VAL[,evaluation_metric])

rownames(EVAL_VAL)<-NULL

colnames(EVAL_VAL)<-c("MODEL", "DROP", "DROP", "ALGO", "RUN", "PA", "EVAL")

EVAL_VAL<-(EVAL_VAL[,!(colnames(EVAL_VAL) == "DROP")])

\#Filtragem de valores na tabela que sejam $>=$ ao limiar mínimo de avaliação

EVAL_ABOVE<-data.frame(subset(EVAL_VAL, as.numeric(paste(EVAL_VAL[,"EVAL"])) >=

as.numeric(limiarEVA)))

cat(">>", nrow(EVAL_ABOVE), "modelos selecionados com", evaluation_metric, "=>", limiarEVA,

"<<\n") \# mensagem no terminal

\#Extraindo valores de correlação pareada para os modelos (processo demorado)

cat(">> correlacão iniciada em", date(), "<<\n") \# mensagem no terminal

CORREL<-data.frame(layerStats(stack(Models[[as.character(EVAL_ABOVE[,"MODEL"])]]), 'pearson', na.rm=TRUE))

cat(">> correlacão terminada em", date(), "<<|n") \# mensagem no terminal

\#Calculando média da correlação pareada por modelo: Sabendo que a tabela de correlação é estruturada como dois triângulos retângulos (idênticos) verticalmente opostos; os valores em cada coluna (ou linha) são duplicados, com exceção do valor 1 (variável correlacionada com ela mesma); 
Portanto, para a obtenção da média, basta-se somar os valores da coluna (ou linha) de cada variável e subtrair 1; Depois dividir o total resultante pela quantidade de valores somados menos 1 gen_mean<-data.frame(apply(CORREL[,1:nrow(CORREL)], 2, function(x) \{((sum(x)1)/as.numeric((nrow(CORREL))-1))\})) row.names(gen_mean)<-gsub("pearson.correlation.coefficient.", "'", as.character(rownames(gen_mean))) colnames(gen_mean)<-"CORREL"

Merged_Table<-merge(EVAL_ABOVE, gen_mean, by.x="MODEL", by.y="row.names", all=TRUE) uq $<-$ mean(Merged_Table\$CORREL)

\#Selecionando os modelos que apresentam valores iguais ou superiores a média geral Sel_mods<-data.frame(subset(Merged_Table, Merged_Table[["CORREL"]]>=uq)) \#Somando modelos selecionados cat(">> Somando", nrow(Sel_mods), "modelos selecionados com PCC =>", uq, "<<>n") SELECTED_MODELS<-sum(Models[[as.character(Sel_mods\$MODEL)]], na.rm = TRUE) cat(">> Salvando dados finais e modelos <<\n") \# mensagem no terminal \#Salvando tudo dir.create(nome) write.table(EVAL_VAL, paste(nome, "/", nome, "_P1_EVALs.csv", sep=""), sep=",", row.names=F) write.table(Merged_Table, paste(nome, "/", nome, "_P2_EVALs.csv", sep=""), sep=",", row.names=F) write.table(Sel_mods, paste(nome, "/", nome, "_P3_EVALs.csv", sep=""), sep=",", row.names=F) writeRaster(SELECTED_MODELS, filename = paste(nome, "/", nome, "_EV", sep="'), format="HFA", overwrite=TRUE)

cat("-=-=-= Processo concluído para a espécie:", nome, "\n\n\n") \# mensagem final no terminal \} 
Anexo C5-2. Avaliação geral dos modelos para as Bombus nativas

Os modelos selecionados para as espécies nativas alcançaram elevados valores de qualidade conforme os índices de avaliação matemáticos indicam $(T S S>=0,8)$ e apresentaram alta convergência preditiva entre eles, de um modo geral. Apenas Bombus brasiliensis apresentou valores mais baixos, indicando que entre os modelos restantes após a seleção ainda havia alta variabilidade entre as predições de adequabilidade de habitat, que se refletiu em relativamente baixos valores pareados de coeficientes de correlação de Pearson (Figura C5-2.1).

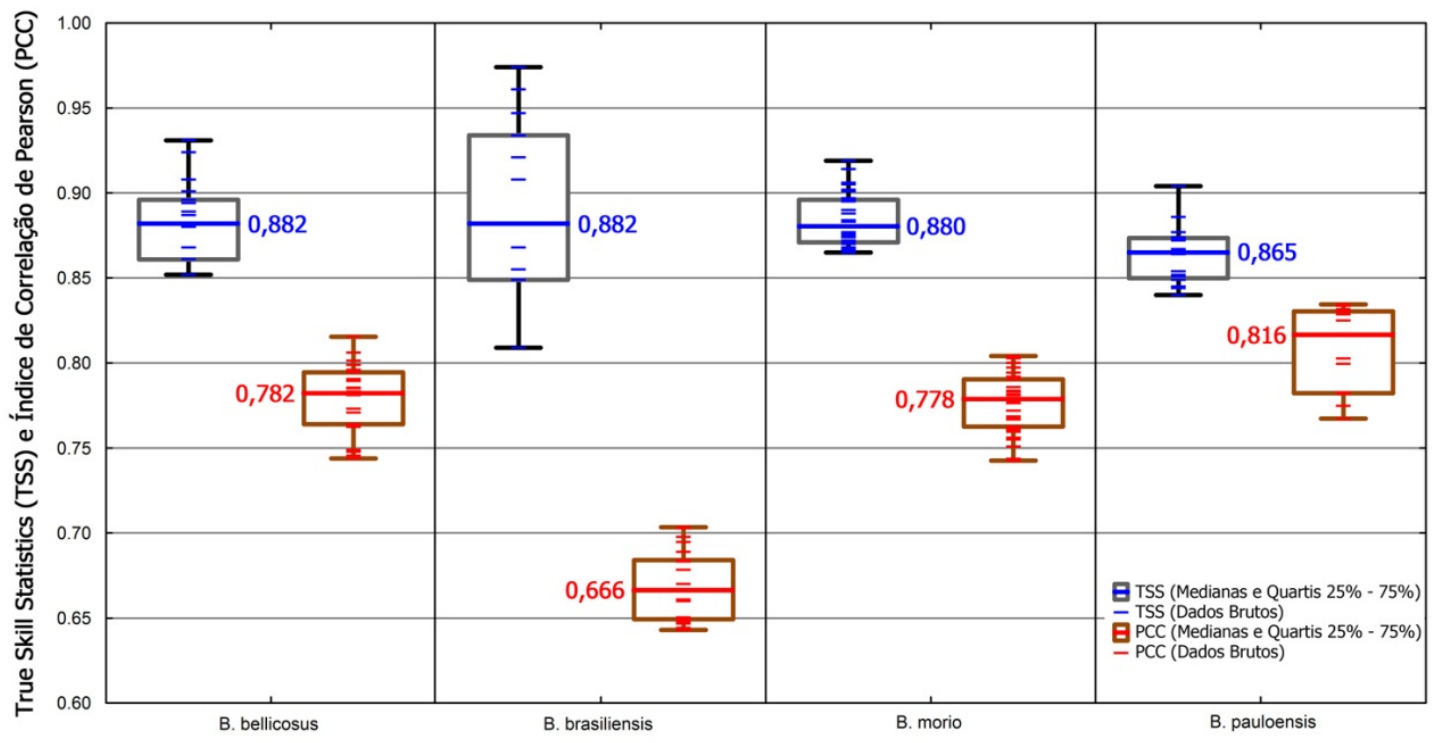

Figura C5-2.1. Valores de TSS e PCC dos modelos remanescentes após todo o procedimento de seleção, para as espécies de Bombus nativas do Brasil.

De uma forma geral, os modelos compostos (ALM) foram robustos e apresentaram altos valores de convergência preditiva coincidentes com a maioria das ocorrências das espécies (Figura C5-2.2). Apenas as espécies Bombus pauloensis e Bombus morio tiveram ocorrências que coincidiram com áreas de habitat inadequado (valor $=0$ ) e também com áreas com baixos valores de convergência, indicando que uma minoria de suas ocorrências foi abrangida por apenas poucos dos modelos selecionados, mesmo assim há um bom nível de convergência geral.

A representação geográfica da adequabilidade de habitat para Bombus bellicosus pode ser considerada a mais robusta entre as espécies, pois além de altos valores de avaliação (Figura C5-2.1) suas ocorrências empíricas foram predominantemente abrangidas pela faixa de mais alta convergência preditiva (Figura C5-2.2), indicando que entre os modelos que compõem seu ALM - apesar das diferentes lógicas preditivas (algoritmos), das variações no particionamento do dados de ocorrência e na aleatoriedade na geração de pseudo-ausências - a grande maioria concordou na indicação geoespacial da adequabilidade de seu habitat. Percebe-se também a consistência da predição para esta espécie pela visualização de seu ALM em mapa (Figura C5-2.4), que demarca quase uniformemente uma área, com margens bem delimitadas e poucas fragmentações na área de adequabilidade.

Os algoritmos mais robustos foram o GBM, o FDA e o GLM, com exceção destes e do MARS, do MAXENT e do RF, os modelos gerados pelos outros quatro algoritmos não foram selecionados, pois não alcançaram valores mínimos no processo de seleção. 


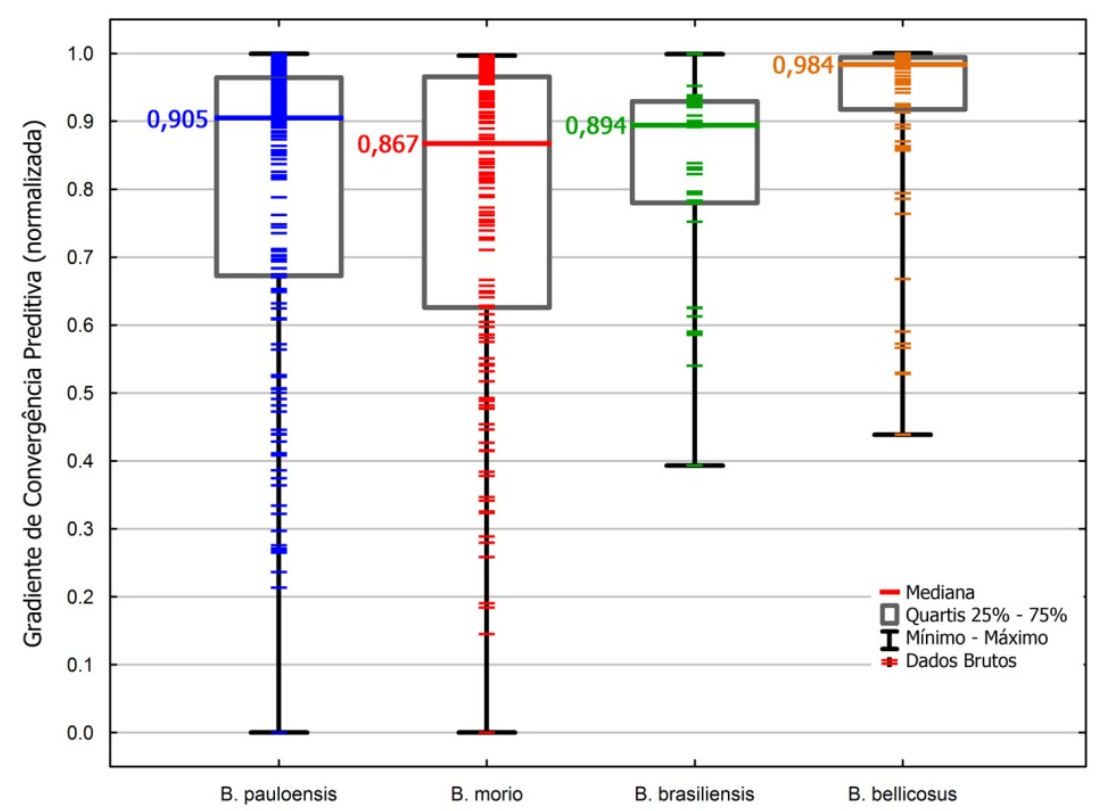

Figura C5-2.2. Esta figura exibe a distribuição das ocorrências de cada espécie sobre a variação da convergência preditiva de cada respectivo modelo composto (ALM).

\section{Desempenho dos algoritmos na modelagem de adequabilidade de habitat para} as aspécies de Bombus nativas após seleção

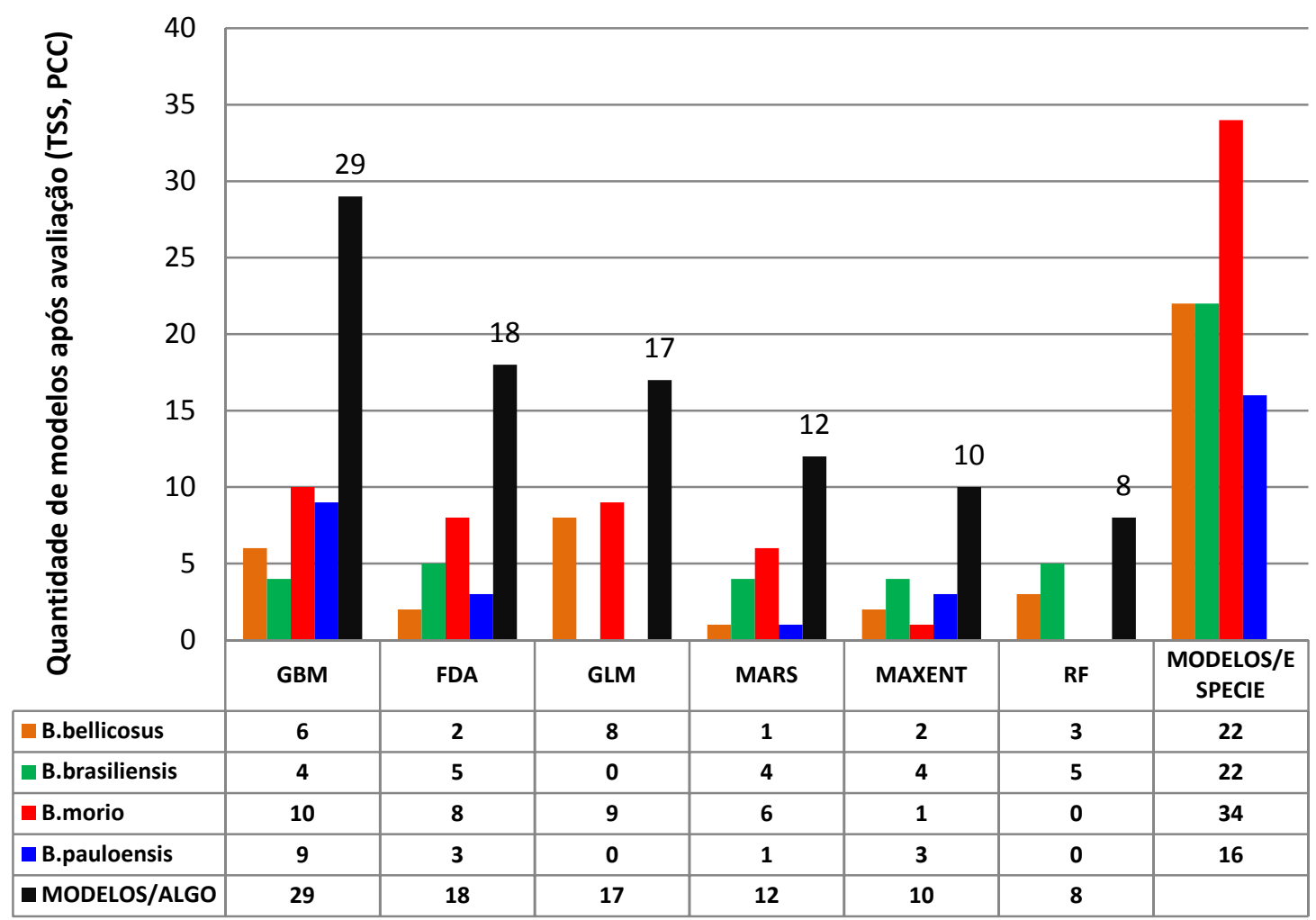

Figura C5-2.3. Desempenho dos algoritmos após o procedimento de seleção (TSS e PCC). 


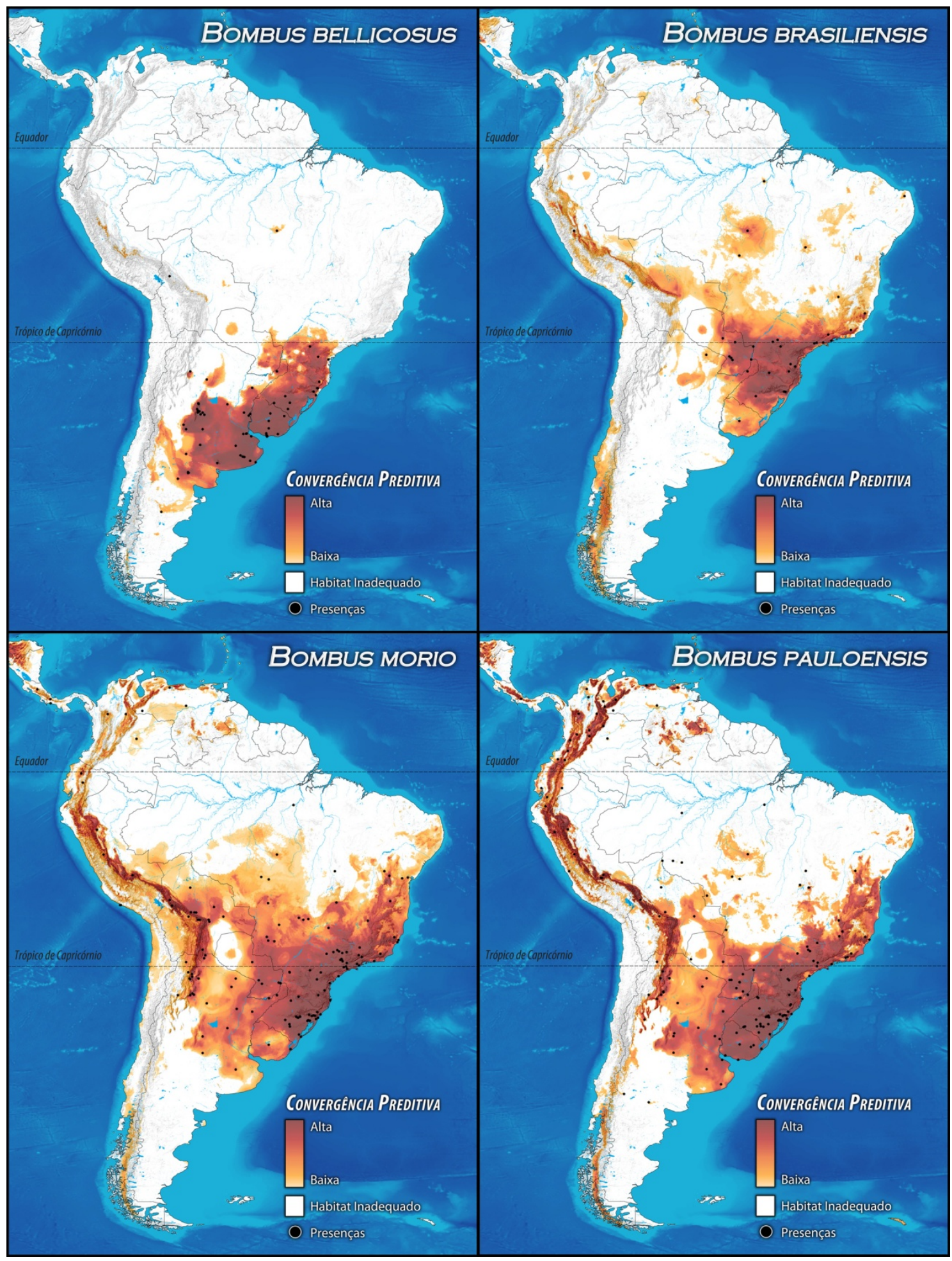

Figura C5-2.4. Modelos compostos por espécie nativa de Bombus. 
Anexo C5-3. Limiares ecogeográficos, médias e desvios por cada quadro (EU, SA, JP, NZT)

\begin{tabular}{|c|c|c|c|c|c|c|c|c|c|c|c|c|}
\hline Faixa & Bio 1 & Bio 2 & Bio 3 & Bio 4 & Bio 5 & Bio 6 & Bio 7 & Bio 8 & Bio 9 & Bio 10 & Bio 11 & \\
\hline Min_Tolerância & -1.60 & 3.60 & 19.00 & 2887.00 & 14.00 & -17.40 & 13.10 & -2.40 & -8.30 & 8.00 & -11.40 & \\
\hline Min_Afinidade & 6.30 & 6.20 & 26.00 & 4254.00 & 18.60 & -6.50 & 18.00 & 4.30 & 0.20 & 14.00 & -2.60 & \\
\hline Mediana & 9.00 & 7.20 & 34.00 & 4830.00 & 20.70 & -0.30 & 20.90 & 7.80 & 5.70 & 15.60 & 2.90 & \\
\hline Max_Afinidade & 10.10 & 8.60 & 37.00 & 7475.00 & 23.00 & 1.30 & 29.60 & 16.20 & 11.90 & 17.00 & 4.40 & \\
\hline Max_Tolerância & 19.00 & 12.90 & 44.00 & 9497.00 & 35.70 & 10.30 & 37.20 & 20.80 & 27.80 & 27.80 & 13.70 & \\
\hline Média & 8.57 & 7.35 & 32.56 & 5503.93 & 20.93 & -1.78 & 22.70 & 9.84 & 5.88 & 15.70 & 1.66 & U \\
\hline Desvio_Padrão & 1.80 & 1.13 & 4.70 & 1365.56 & 2.44 & 3.45 & 4.72 & 5.12 & 5.17 & 1.79 & 3.08 & 0 \\
\hline & Bio 12 & Bio 13 & Bio 14 & Bio 15 & Bio 16 & Bio 17 & Bio 18 & Bio 19 & Bio 20 & Altitude & Aridez & \\
\hline Min_Tolerância & 319.00 & 35.00 & 0.00 & 7.00 & 95.00 & 3.00 & 6.00 & 59.00 & 14.00 & -4.00 & 2870.00 & \\
\hline Min_Afinidade & 570.00 & 63.00 & 30.00 & 12.00 & 178.00 & 96.00 & 157.00 & 119.00 & 23.00 & 21.00 & 8347.75 & \\
\hline Mediana & 717.00 & 79.00 & 43.00 & 21.00 & 225.00 & 141.00 & 191.00 & 172.00 & 39.00 & 88.00 & 10849.00 & \\
\hline Max_Afinidade & 1042.00 & 119.00 & 61.00 & 29.00 & 342.00 & 195.00 & 243.00 & 302.00 & 62.00 & 278.00 & 16941.00 & \\
\hline Max_Tolerância & 2324.00 & 283.00 & 107.00 & 98.00 & 814.00 & 361.00 & 546.00 & 669.00 & 237.00 & 2167.00 & 54206.00 & \\
\hline Média & 772.09 & 87.04 & 44.66 & 21.47 & 247.04 & 144.22 & 198.17 & 195.24 & 42.38 & 142.60 & 12010.98 & \\
\hline Desvio_Padrão & 214.33 & 26.86 & 13.90 & 8.54 & 76.93 & 42.36 & 47.01 & 81.23 & 19.67 & 184.58 & 4415.96 & \\
\hline & $\operatorname{Tmin} \mathrm{M} 1$ & $\operatorname{Tmin} \mathrm{M} 2$ & Tmin M3 & Tmin M4 & Tmin M5 & Tmin M6 & Tmin M7 & Tmin M8 & Tmin M9 & Tmin M10 & Tmin M11 & Tmin M12 \\
\hline Min_Tolerância & -17.40 & -16.20 & -11.30 & -7.40 & -2.00 & 2.20 & 3.90 & 3.20 & -0.30 & -3.50 & -9.00 & -14.50 \\
\hline Min_Afinidade & -5.80 & -6.20 & -3.20 & 0.50 & 5.00 & 8.90 & 10.60 & 10.10 & 7.60 & 4.10 & -0.20 & -4.10 \\
\hline Mediana & -0.30 & 0.00 & 1.60 & 3.90 & 6.90 & 10.20 & 12.00 & 11.60 & 9.40 & 6.40 & 2.70 & 0.80 \\
\hline Max_Afinidade & 1.40 & 1.50 & 2.80 & 5.10 & 8.20 & 11.40 & 13.30 & 13.00 & 10.50 & 7.40 & 4.10 & 2.40 \\
\hline Max_Tolerância & 10.30 & 10.40 & 11.00 & 11.50 & 15.60 & 19.80 & 22.60 & 23.00 & 19.90 & 15.70 & 13.20 & 11.30 \\
\hline Média & -1.60 & -1.40 & 0.64 & 3.33 & 6.81 & 10.26 & 12.03 & 11.63 & 9.20 & 6.02 & 2.29 & -0.19 \\
\hline Desvio_Padrão & 3.31 & 3.35 & 2.61 & 2.00 & 1.58 & 1.42 & 1.45 & 1.50 & 1.53 & 1.69 & 2.04 & 2.88 \\
\hline & Tmed M1 & Tmed M2 & Tmed M3 & Tmed M4 & Tmed M5 & Tmed M6 & Tmed M7 & Tmed M8 & Tmed M9 & Tmed M10 & Tmed M11 & Tmed M12 \\
\hline Min_Tolerância & -12.80 & -11.20 & -7.50 & -3.30 & 2.90 & 7.30 & 8.90 & 7.90 & 3.60 & -0.70 & -6.50 & -10.10 \\
\hline Min_Afinidade & -3.00 & -3.10 & 0.20 & 4.60 & 9.80 & 13.10 & 14.60 & 14.30 & 11.30 & 7.20 & 2.20 & -1.50 \\
\hline Mediana & 2.50 & 2.80 & 5.20 & 7.90 & 11.00 & 14.60 & 16.30 & 15.80 & 13.20 & 9.80 & 5.70 & 3.50 \\
\hline Max_Afinidade & 4.00 & 4.30 & 6.20 & 9.00 & 12.80 & 16.00 & 17.80 & 17.40 & 14.70 & 11.00 & 7.00 & 5.10 \\
\hline Max_Tolerância & 13.40 & 13.60 & 14.40 & 17.30 & 21.30 & 25.30 & 28.40 & 28.80 & 26.30 & 21.60 & 16.30 & 14.30 \\
\hline Média & 1.10 & 1.55 & 4.14 & 7.36 & 11.28 & 14.75 & 16.45 & 15.98 & 13.20 & 9.47 & 5.10 & 2.42 \\
\hline Desvio_Padrão & 3.23 & 3.19 & 2.59 & 2.06 & 1.74 & 1.71 & 1.84 & 1.84 & 1.82 & 1.81 & 2.20 & 2.89 \\
\hline & Tmax M1 & Tmax M2 & Tmax M3 & Tmax M4 & Tmax M5 & Tmax M6 & Tmax M7 & Tmax M8 & Tmax M9 & Tmax M10 & Tmax M11 & Tmax M12 \\
\hline Min_Tolerância & -8.30 & -7.40 & -3.70 & 0.80 & 7.80 & 12.50 & 13.80 & 12.80 & 7.40 & 2.10 & -3.90 & -6.60 \\
\hline Min_Afinidade & -0.30 & 0.00 & 3.50 & 8.70 & 14.00 & 17.20 & 18.60 & 18.20 & 15.00 & 10.10 & 4.50 & 1.10 \\
\hline Mediana & 5.30 & 5.80 & 8.70 & 11.70 & 15.40 & 19.00 & 20.60 & 20.00 & 16.90 & 13.30 & 8.70 & 6.30 \\
\hline Max_Afinidade & 6.70 & 7.20 & 9.80 & 13.50 & 18.10 & 21.30 & 23.00 & 22.50 & 19.30 & 14.70 & 10.00 & 7.70 \\
\hline Max_Tolerância & 16.50 & 16.80 & 18.60 & 23.40 & 28.10 & 32.30 & 35.20 & 35.70 & 33.70 & 28.40 & 21.30 & 18.00 \\
\hline Média & 3.86 & 4.54 & 7.70 & 11.44 & 15.79 & 19.29 & 20.92 & 20.39 & 17.26 & 12.98 & 7.96 & 5.08 \\
\hline Desvio_Padrão & 3.19 & 3.09 & 2.69 & 2.32 & 2.16 & 2.21 & 2.44 & 2.41 & 2.38 & 2.22 & 2.44 & 2.94 \\
\hline & Prec M1 & Prec M2 & Prec M3 & Prec M4 & Prec M5 & Prec M6 & Prec M7 & Prec M8 & Prec M9 & Prec M10 & Prec M11 & Prec M12 \\
\hline Min_Tolerância & 18.00 & 19.00 & 17.00 & 15.00 & 8.00 & 2.00 & 0.00 & 1.00 & 4.00 & 20.00 & 28.00 & 20.00 \\
\hline Min_Afinidade & 40.00 & 32.00 & 31.00 & 37.00 & 41.00 & 48.00 & 49.00 & 55.00 & 52.00 & 48.00 & 52.00 & 47.00 \\
\hline Mediana & 61.00 & 44.00 & 51.00 & 48.00 & 56.00 & 58.00 & 63.00 & 70.00 & 65.00 & 64.00 & 68.00 & 66.00 \\
\hline Max_Afinidade & 108.00 & 78.00 & 82.00 & 64.00 & 72.00 & 79.00 & 79.00 & 90.00 & 93.00 & 103.00 & 108.00 & 115.00 \\
\hline Max_Tolerância & 232.00 & 200.00 & 170.00 & 114.00 & 121.00 & 171.00 & 165.00 & 180.00 & 259.00 & 280.00 & 251.00 & 283.00 \\
\hline Média & 69.27 & 50.88 & 55.24 & 49.98 & 56.89 & 61.80 & 64.15 & 71.54 & 70.00 & 71.23 & 75.63 & 75.46 \\
\hline Desvio_Padrão & 30.21 & 20.90 & 21.78 & 12.29 & 14.13 & 16.78 & 16.44 & 17.28 & 21.30 & 26.68 & 26.08 & 31.08 \\
\hline
\end{tabular}




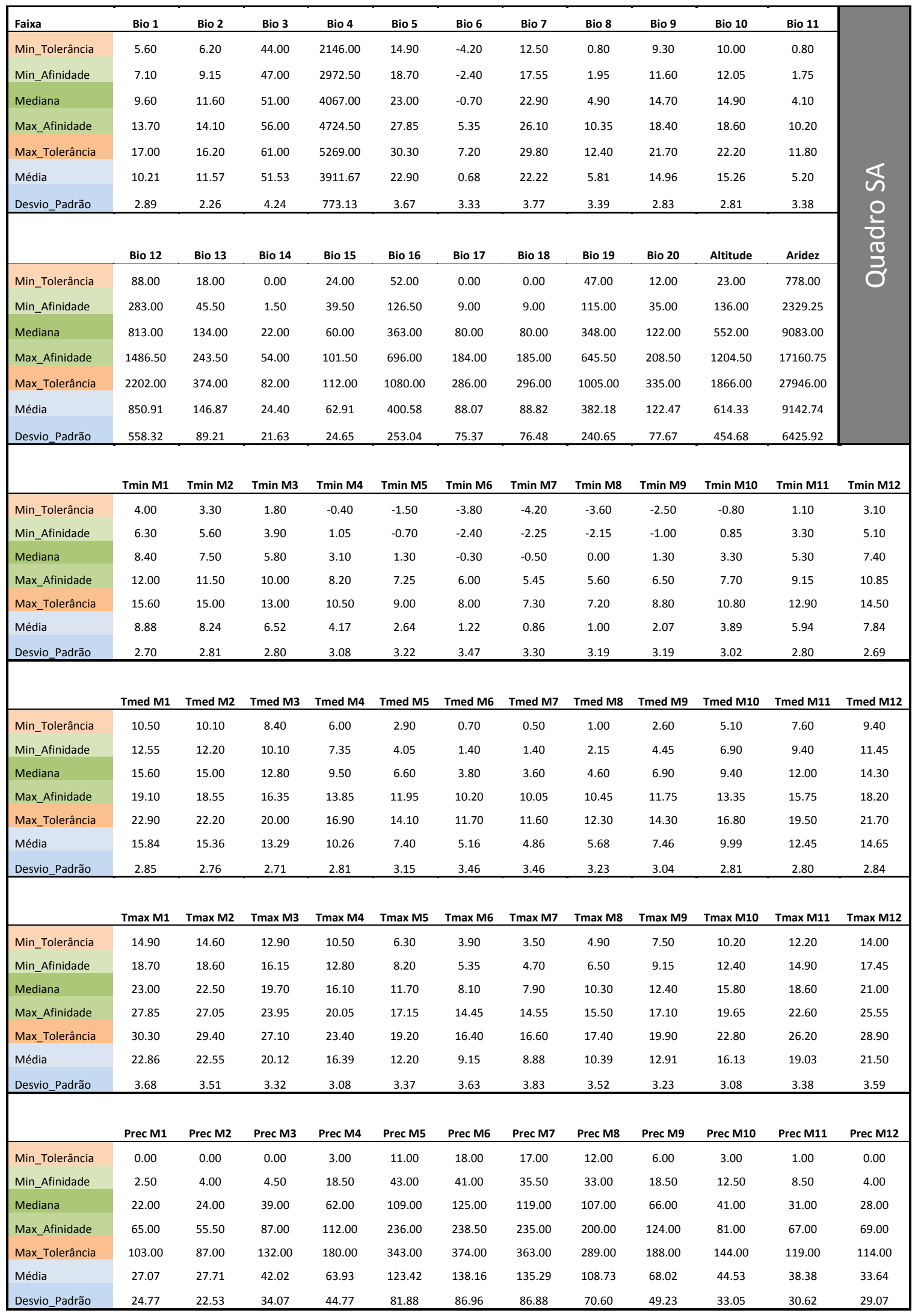




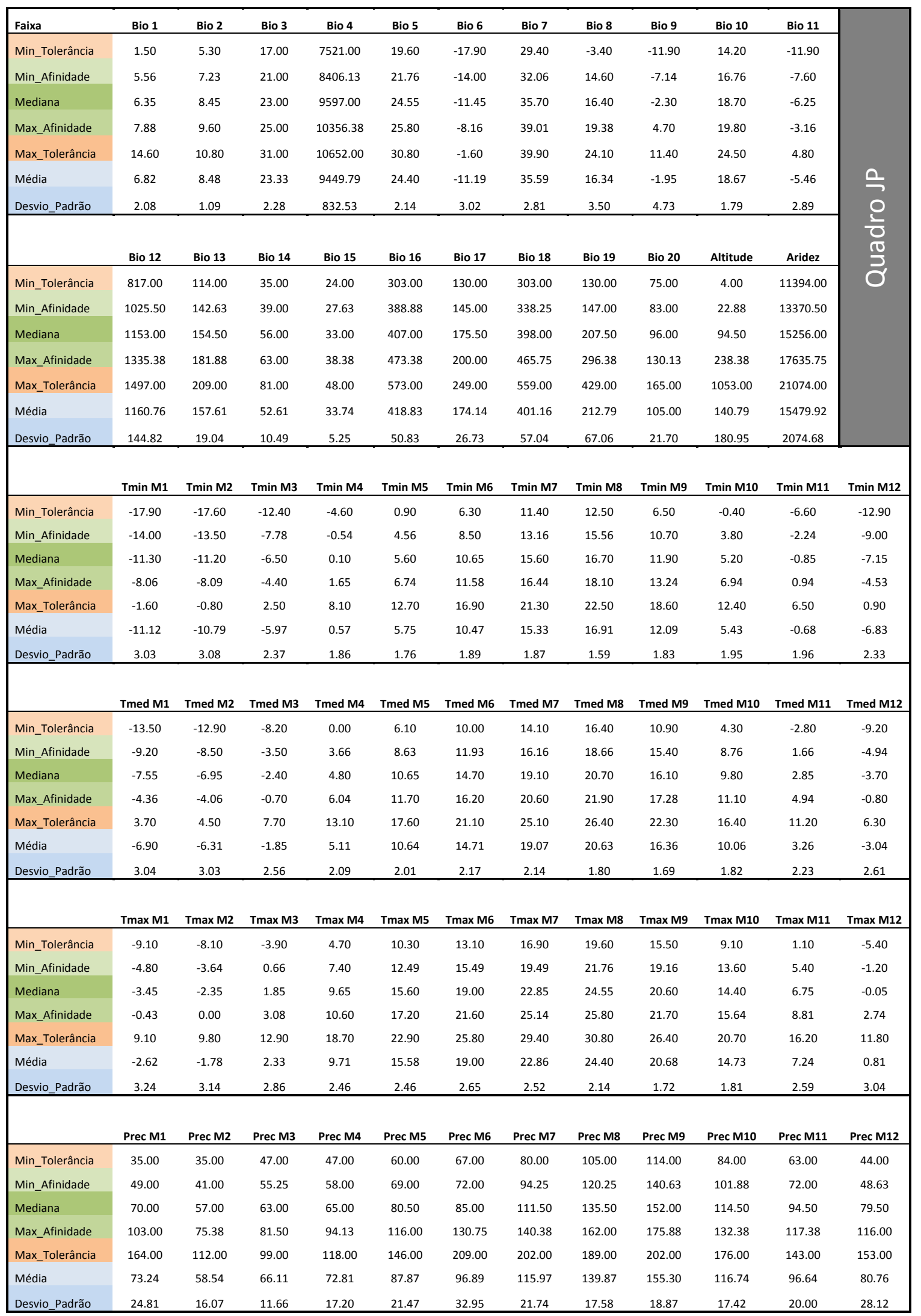




\begin{tabular}{|c|c|c|c|c|c|c|c|c|c|c|c|c|}
\hline Faixa & Bio 1 & Bio 2 & Bio 3 & Bio 4 & Bio 5 & Bio 6 & Bio 7 & Bio 8 & Bio 9 & Bio 10 & Bio 11 & \\
\hline Min_Afinidade & 8.10 & 7.49 & 46.00 & 2629.75 & 18.19 & -0.80 & 15.09 & 4.90 & 8.89 & 12.20 & 3.49 & \\
\hline Max_Afinidade & 12.50 & 9.80 & 50.00 & 3727.88 & 22.60 & 4.70 & 20.30 & 11.61 & 16.00 & 16.61 & 8.60 & \\
\hline Max_Tolerância & 16.00 & 11.20 & 54.00 & 4498.00 & 24.70 & 8.90 & 23.50 & 15.50 & 19.40 & 19.70 & 12.60 & \\
\hline \multirow[t]{2}{*}{ Desvio_Padrão } & 1.98 & 0.96 & 2.04 & 474.60 & 1.86 & 2.29 & 2.22 & 2.91 & 3.49 & 1.95 & 2.22 & \\
\hline & Bio 12 & Bio 13 & Bio 14 & Bio 15 & Bio 16 & Bio 17 & Bio 18 & Bio 19 & Bio 20 & Altitude & Aridez & $\sqrt{0}$ \\
\hline Min_Tolerância & 502.00 & 54.00 & 30.00 & 9.00 & 151.00 & 100.00 & 112.00 & 101.00 & 16.00 & 10.00 & 5552.00 & \\
\hline Max_Tolerância & 5103.00 & 529.00 & 326.00 & 35.00 & 1400.00 & 1055.00 & 1304.00 & 1055.00 & 204.00 & 1396.00 & 62461.00 & \\
\hline Média & 1349.98 & 146.39 & 72.13 & 19.03 & 412.17 & 252.93 & 262.40 & 387.13 & 74.26 & 347.06 & 16065.42 & \\
\hline \multirow[t]{2}{*}{ Desvio_Padrão } & 729.94 & 77.97 & 41.26 & 6.26 & 220.87 & 143.26 & 156.22 & 193.07 & 44.77 & 293.23 & 9089.23 & \\
\hline & Tmin M1 & $\mathrm{Tmin} \mathbf{M} 2$ & $\operatorname{Tmin} \mathrm{M3}$ & Tmin M4 & Tmin M5 & Tmin M6 & Tmin M7 & Tmin M8 & Tmin M9 & Tmin M10 & Tmin M11 & Tmin M12 \\
\hline Min_Tolerância & 3.70 & 4.30 & 2.80 & 0.30 & -2.20 & -4.70 & -5.30 & -4.30 & -2.10 & -0.20 & 1.20 & 3.00 \\
\hline Min_Afinidade & 7.28 & 7.30 & 6.39 & 4.39 & 1.80 & -0.10 & -0.80 & 0.00 & 1.70 & 3.20 & 4.49 & 6.19 \\
\hline Mediana & 10.20 & 10.30 & 9.30 & 7.00 & 4.80 & 2.90 & 2.15 & 2.90 & 4.40 & 5.95 & 7.50 & 9.00 \\
\hline Max_Afinidade & 12.10 & 12.20 & 11.00 & 9.00 & 7.10 & 5.40 & 4.70 & 5.10 & 6.20 & 7.50 & 9.10 & 10.81 \\
\hline Min_Afinidade & 12.50 & 12.80 & 11.20 & 8.70 & 6.00 & 3.60 & 2.99 & 3.99 & 5.90 & 7.70 & 9.20 & 11.10 \\
\hline Mediana & 15.00 & 15.10 & 13.85 & 11.50 & 8.80 & 6.60 & 6.00 & 6.90 & 8.70 & 10.40 & 11.90 & 13.60 \\
\hline Max_Afinidade & 17.10 & 17.21 & 15.70 & 13.30 & 10.80 & 8.80 & 8.20 & 8.80 & 10.20 & 12.00 & 13.70 & 15.60 \\
\hline Max_Tolerância & 19.90 & 20.30 & 19.00 & 17.20 & 15.00 & 13.20 & 12.40 & 12.40 & 13.50 & 14.80 & 16.30 & 18.20 \\
\hline Média & 14.92 & 15.06 & 13.61 & 11.15 & 8.57 & 6.42 & 5.79 & 6.57 & 8.27 & 10.05 & 11.67 & 13.47 \\
\hline \multirow[t]{2}{*}{ Desvio_Padrão } & 1.98 & 1.91 & 1.98 & 2.08 & 2.13 & 2.27 & 2.27 & 2.14 & 2.01 & 1.90 & 1.98 & 1.94 \\
\hline & Tmax M1 & Tmax M2 & Tmax M3 & Tmax M4 & Tmax M5 & Tmax M6 & Tmax M7 & Tmax M8 & Tmax M9 & Tmax M10 & Tmax M11 & Tmax M12 \\
\hline Min_Tolerância & 14.90 & 15.50 & 13.10 & 9.60 & 6.40 & 2.60 & 1.90 & 3.90 & 6.00 & 8.70 & 10.60 & 13.10 \\
\hline Min_Afinidade & 17.90 & 18.10 & 16.20 & 13.00 & 10.09 & 7.30 & 6.70 & 7.70 & 9.89 & 12.20 & 14.00 & 16.10 \\
\hline Mediana & 20.10 & 20.20 & 18.50 & 15.60 & 12.90 & 10.50 & 9.90 & 10.90 & 12.80 & 14.70 & 16.50 & 18.30 \\
\hline Max_Afinidade & 22.21 & 22.60 & 20.70 & 17.90 & 14.90 & 12.60 & 12.00 & 12.80 & 14.70 & 16.60 & 18.50 & 20.50 \\
\hline Max_Tolerância & 24.30 & 24.70 & 23.20 & 21.10 & 18.80 & 16.70 & 15.90 & 16.00 & 17.20 & 18.80 & 20.90 & 22.80 \\
\hline Média & 20.04 & 20.21 & 18.41 & 15.53 & 12.55 & 10.15 & 9.54 & 10.50 & 12.49 & 14.56 & 16.35 & 18.27 \\
\hline Desvio_Padrão & 1.90 & 1.85 & 1.93 & 2.14 & 2.22 & 2.35 & 2.40 & 2.27 & 2.09 & 1.91 & 1.97 & 1.92 \\
\hline & Prec M1 & Prec M2 & Prec M3 & Prec M4 & Prec M5 & Prec M6 & Prec M7 & Prec M8 & Prec M9 & Prec M10 & Prec M11 & Prec M12 \\
\hline Min_Tolerância & 34.00 & 32.00 & 37.00 & 41.00 & 39.00 & 31.00 & 33.00 & 35.00 & 30.00 & 45.00 & 41.00 & 48.00 \\
\hline Min_Afinidade & 49.00 & 43.88 & 55.88 & 58.00 & 61.00 & 52.88 & 66.00 & 67.00 & 52.88 & 60.00 & 59.00 & 62.88 \\
\hline
\end{tabular}


Anexo C5-4 - Tabela com valores municipais para: (1) Qualidade ambiental normalizada para Bombus terrestris; (2) Convergência preditiva normalizada para as Bombus nativas; (3) Diversidade de culturas agrícolas normalizada e a (4) quantidade de culturas produzidas; Níveis de prioridade considerando (5) potencial de interação entre a invasora e as Bombus nativas e (6) entre a invasora e as culturas agrícolas; (7 e 8) Tipo de mudança no nível da adequabilidade considerando-se os dois cenários climáticos futuros (RCP) e a variação delta, do cenário climático atual para 2050.

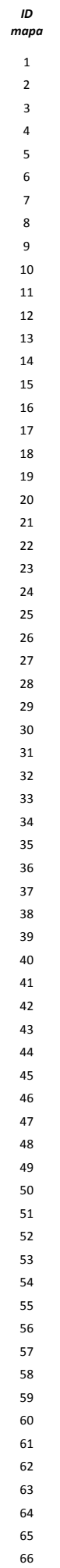

\begin{tabular}{|c|c|c|c|}
\hline Cidade e Estado & $\begin{array}{l}\text { Bombus } \\
\text { terrestris } \\
\text { (Qual. Amb.) }\end{array}$ & $\begin{array}{l}\text { Bombus } \\
\text { nativas (BR) } \\
\text { (Conv.Pred) }\end{array}$ & $\begin{array}{l}\text { Diversidade } \\
\text { de Culturas } \\
\text { (Norm.). }\end{array}$ \\
\hline Abdon Batista - SC & 0.51 & 0.86 & 0.40 \\
\hline Aceguá - RS & 0.24 & 0.08 & 0.50 \\
\hline Adrianópolis - PR & 0.84 & 0.75 & 0.60 \\
\hline Agrolândia - SC & 0.81 & 0.86 & 0.55 \\
\hline Agronômica - SC & 0.81 & 0.87 & 0.45 \\
\hline Agudos do Sul - PR & 0.82 & 0.91 & 0.70 \\
\hline Alfredo Wagner-SC & 0.78 & 0.90 & 0.70 \\
\hline Almirante Tamandaré - $P R$ & 0.74 & 0.73 & 0.85 \\
\hline Alto Feliz - RS & 0.62 & 0.94 & 0.75 \\
\hline Alvorada-RS & 0.00 & 0.77 & 0.15 \\
\hline Amaral Ferrador-RS & 0.82 & 0.83 & 0.55 \\
\hline André da Rocha - RS & 0.50 & 0.87 & 0.20 \\
\hline Angelina -SC & 0.76 & 0.65 & 0.70 \\
\hline Anita Garibaldi - SC & 0.53 & 0.87 & 0.60 \\
\hline Anitápolis - SC & 0.78 & 0.68 & 0.60 \\
\hline Anta Gorda - RS & 0.65 & 0.92 & 0.60 \\
\hline Antonina - $P R$ & 0.43 & 0.15 & 0.50 \\
\hline Antônio Olinto - PR & 0.90 & 0.92 & 0.90 \\
\hline Antônio Prado - RS & 0.54 & 0.92 & 0.85 \\
\hline Apiai $-S P$ & 0.88 & 0.86 & 0.70 \\
\hline Apiúna - SC & 0.75 & 0.87 & 0.25 \\
\hline Arambaré-RS & 0.94 & 0.57 & 0.00 \\
\hline Arapoti - $P R$ & 0.85 & 0.77 & 0.55 \\
\hline Araranguá - SC & 0.94 & 0.68 & 0.50 \\
\hline Araricá-RS & 0.71 & 1.00 & 0.30 \\
\hline Araucária - $P R$ & 0.96 & 0.83 & 0.80 \\
\hline Arroio do Meio - RS & 0.90 & 0.84 & 0.85 \\
\hline Arroio do Padre - RS & 0.94 & 0.90 & 0.80 \\
\hline Arroio do Sal - RS & 0.69 & 0.12 & 0.05 \\
\hline Arroio dos Ratos - RS & 0.78 & 0.92 & 0.30 \\
\hline Arroio Grande - RS & 0.99 & 0.62 & 0.70 \\
\hline Arvorezinha - RS & 0.57 & 0.96 & 0.95 \\
\hline Ascurra - SC & 0.66 & 0.81 & 0.35 \\
\hline Atalanta - SC & 0.79 & 0.89 & 0.50 \\
\hline Aurora - SC & 0.81 & 0.85 & 0.55 \\
\hline Bagé-RS & 0.22 & 0.54 & 0.75 \\
\hline alneário Arroio do Silva - SC & 0.94 & 0.63 & 0.35 \\
\hline Balneário Gaivota - SC & 0.84 & 0.34 & 0.30 \\
\hline Balneário Pinhal - RS & 0.76 & 0.73 & 0.15 \\
\hline Balsa Nova - PR & 0.85 & 0.89 & 0.45 \\
\hline Barão - RS & 0.65 & 0.96 & 0.80 \\
\hline Barão do Triunfo - RS & 0.79 & 1.00 & 0.70 \\
\hline Barra do Chapéu - SP & 0.85 & 0.84 & 0.40 \\
\hline Barra do Ribeiro - RS & 0.84 & 0.76 & 0.50 \\
\hline Barra do Turvo - SP & 0.78 & 0.52 & 0.35 \\
\hline Barracão - RS & 0.56 & 0.80 & 0.65 \\
\hline Bela Vista do Toldo - SC & 0.81 & 0.85 & 0.25 \\
\hline Benedito Novo - SC & 0.76 & 0.86 & 0.25 \\
\hline Bento Gonçalves - RS & 0.59 & 0.95 & 0.85 \\
\hline Blumenau-SC & 0.68 & 0.80 & 0.60 \\
\hline Boa Vista do Sul - RS & 0.74 & 0.89 & 0.80 \\
\hline Bocaina do Sul - SC & 0.76 & 0.87 & 0.65 \\
\hline Bocaiúva do Sul - PR & 0.74 & 0.81 & 0.85 \\
\hline Bom Jardim da Serra - SC & 0.96 & 0.65 & 0.15 \\
\hline Bom Jesus - RS & 0.88 & 0.91 & 0.55 \\
\hline Bom Principio - RS & 0.69 & 0.97 & 0.95 \\
\hline Bom Retiro - sC & 0.78 & 0.91 & 0.70 \\
\hline Bom Retiro do Sul - RS & 0.91 & 0.82 & 0.70 \\
\hline Som Sucesso de Itararé - SP & 0.90 & 0.78 & 0.25 \\
\hline Botuverá - SC & 0.78 & 0.82 & 0.25 \\
\hline Braço do Trombudo - SC & 0.81 & 0.83 & 0.40 \\
\hline Brochier-RS & 0.84 & 0.93 & 0.65 \\
\hline Brunópolis - SC & 0.60 & 0.83 & 0.10 \\
\hline Brusque - SC & 0.65 & 0.78 & 0.50 \\
\hline Butiá - RS & 0.79 & 0.85 & 0.50 \\
\hline Caçapava do Sul - RS & 0.72 & 0.95 & 0.90 \\
\hline
\end{tabular}
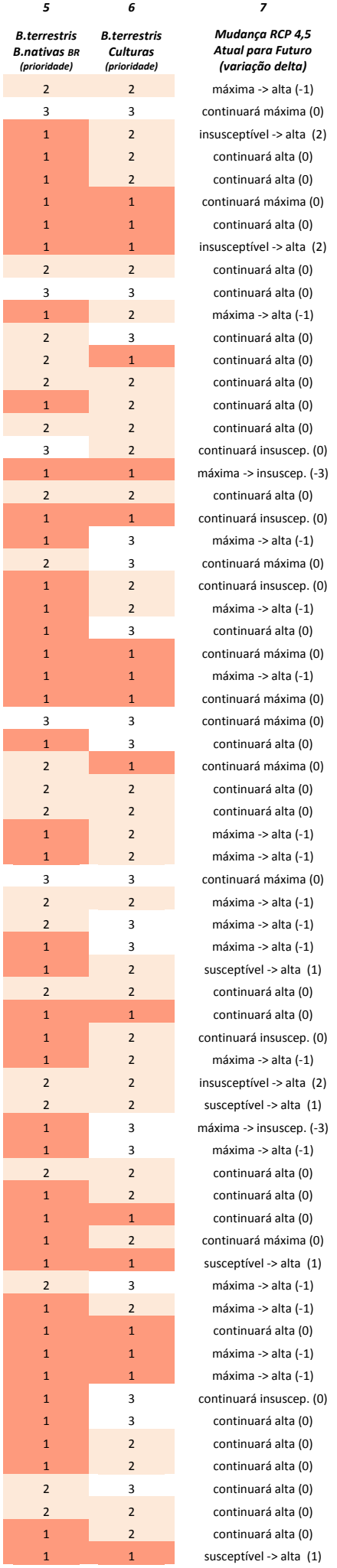

Mudanca $R C P 6,0$ (variação delta)
(vâa continuará máxima (0) continuará máxima (0) insuscep. .> máxima (3) continuará alta (0) continuará alta (0)

continuará máxima (0) continuará alta (0) insuscep. -> máxima (3) continuará alta $(0)$ continuará alta (0) máxima -> alta $(-1)$ continuará alta $(0)$ continuará alta (0) continuará alta $(0)$ continuará alta (0) continuará alta (0) continuará insuscep. (0) máxima -> insuscep. (-3) continuará alta $(0)$ continuará máxima (0) máxima -> alta (-1) continuará máxima (0) continuará insuscep. (0) máxima -> alta (-1) continuará alta (0) continuará máxima (0) máxima -> susceptivel (-2) continuará máxima (0) continuará máxima (0) continuará alta (0) continuará máxima (0) continuará alta (0) continuará alta (0) máxima -> alta $(-1)$ máxima -> alta $(-1)$ continuará máxima (0) continuará máxima (0) continuará máxima (0) máxima -> alta $(-1)$ continuará máxima (0) continuará alta (0) continuará alta (0) continuará insuscep. (0) máxima -> alta (-1) insusceptível -> alta (2) susceptivel -> alta (1) máxima -> insuscep. (-3) máxima -> alta $(-1)$ continuará alta (0) continuará alta $(0)$ continuará alta (0) continuará máxima (0) suscep. -> máxima (2) máxima -> alta (-1) máxima -> alta $(-1)$ continuará alta (0) máxima -> alta (-1) máxima -> alta $(-1)$ continuará insuscep. (0) continuará alta (0) continuará alta $(0)$ continuará alta (0) continuará alta (0) continuará alta $(0)$ continuará alta (0) susceptivel -> alta (1) 


\begin{tabular}{|c|c|c|c|c|}
\hline 67 & Cachoeira do Sul - RS & 0.75 & 0.85 & 0.95 \\
\hline 68 & Cachoeirinha - RS & 0.79 & 0.78 & 0.15 \\
\hline 69 & Camaquã - RS & 0.96 & 0.67 & 0.80 \\
\hline 70 & Cambará do Sul - RS & 0.71 & 0.93 & 0.20 \\
\hline 71 & Campestre da Serra - RS & 0.53 & 0.90 & 0.90 \\
\hline 72 & Campina Grande do Sul - PR & 0.72 & 0.72 & 0.65 \\
\hline 73 & Campo Alegre - SC & 0.79 & 0.94 & 0.60 \\
\hline 74 & Campo Belo do Sul - SC & 0.62 & 0.91 & 0.65 \\
\hline 75 & Campo Bom - RS & 0.72 & 1.00 & 0.55 \\
\hline 76 & Campo do Tenente - PR & 0.94 & 0.93 & 0.60 \\
\hline 77 & Campo Largo - PR & 0.71 & 0.80 & 0.80 \\
\hline 78 & Campo Magro - PR & 0.71 & 0.81 & 0.75 \\
\hline 79 & Campos Novos - SC & 0.54 & 0.83 & 0.70 \\
\hline 80 & Candelária - RS & 0.82 & 0.84 & 0.85 \\
\hline 81 & Candiota - RS & 0.97 & 0.57 & 0.50 \\
\hline 82 & Canela - RS & 0.43 & 0.99 & 0.85 \\
\hline 83 & Canguçu-RS & 0.94 & 0.88 & 0.90 \\
\hline 84 & Canoas - $R S$ & 0.74 & 0.74 & 0.50 \\
\hline 85 & Canoinhas - SC & 0.81 & 0.90 & 0.75 \\
\hline 86 & Canudos do Vale - RS & 0.91 & 0.73 & 0.40 \\
\hline 87 & Capão Alto - SC & 0.62 & 0.91 & 0.25 \\
\hline 88 & Capão Bonito - SP & 0.91 & 0.65 & 0.90 \\
\hline 89 & Capão Bonito do Sul - RS & 0.49 & 0.83 & 0.40 \\
\hline 90 & Capão da Canoa - RS & 0.68 & 0.19 & 0.10 \\
\hline 91 & Capão do Leão - RS & 0.97 & 0.71 & 0.55 \\
\hline 92 & Capela de Santana - RS & 0.72 & 0.84 & 0.60 \\
\hline 93 & Capitão - RS & 0.85 & 0.84 & 0.80 \\
\hline 94 & Capivari do Sul-RS & 0.76 & 0.67 & 0.10 \\
\hline 95 & Caraá -RS & 0.75 & 0.84 & 0.45 \\
\hline 96 & Carlos Barbosa - RS & 0.65 & 0.96 & 0.85 \\
\hline 97 & Casca - RS & 0.50 & 0.85 & 0.60 \\
\hline 98 & Caseiros - RS & 0.50 & 0.72 & 0.70 \\
\hline 99 & Castro - $P R$ & 0.72 & 0.85 & 0.80 \\
\hline 100 & Caxias do Sul - RS & 0.51 & 0.91 & 0.95 \\
\hline 101 & Celso Ramos - SC & 0.57 & 0.84 & 0.60 \\
\hline 102 & Cerrito - RS & 0.97 & 0.75 & 0.60 \\
\hline 103 & Cerro Azul - PR & 0.78 & 0.83 & 0.70 \\
\hline 104 & Cerro Grande do Sul - RS & 0.84 & 0.95 & 0.70 \\
\hline 105 & Cerro Negro - SC & 0.56 & 0.90 & 0.55 \\
\hline 106 & Chapadão do Lageado - SC & 0.79 & 0.87 & 0.50 \\
\hline 107 & Charqueadas - RS & 0.71 & 0.76 & 0.70 \\
\hline 108 & Chui-RS & 1.00 & 0.68 & 0.50 \\
\hline 109 & Chuvisca - RS & 0.88 & 0.86 & 0.75 \\
\hline 110 & Cidreira - RS & 0.76 & 0.68 & 0.15 \\
\hline 111 & Ciríaco-RS & 0.49 & 0.71 & 0.70 \\
\hline 112 & Cocal do Sul - SC & 0.81 & 0.85 & 0.45 \\
\hline 113 & Colinas - $R S$ & 0.85 & 0.80 & 0.45 \\
\hline 114 & Colombo - PR & 0.71 & 0.88 & 0.70 \\
\hline 115 & Contenda - $P R$ & 0.96 & 0.84 & 0.80 \\
\hline 116 & Coqueiro Baixo - RS & 0.84 & 0.83 & 0.60 \\
\hline 117 & Coronel Pilar - RS & 0.75 & 0.87 & 0.75 \\
\hline 118 & Correia Pinto - sC & 0.78 & 0.92 & 0.65 \\
\hline 119 & Corupá - SC & 0.79 & 0.88 & 0.35 \\
\hline 120 & Cotiporã -RS & 0.65 & 0.94 & 0.60 \\
\hline 121 & Criciúma -SC & 0.88 & 0.80 & 0.65 \\
\hline 122 & Cristal - RS & 0.97 & 0.69 & 0.70 \\
\hline 123 & Cruzeiro do Sul - RS & 0.93 & 0.73 & 0.85 \\
\hline 124 & Curitiba - $P R$ & 0.81 & 0.89 & 0.65 \\
\hline 125 & Curitibanos - SC & 0.78 & 0.84 & 0.65 \\
\hline 126 & David Canabarro - RS & 0.46 & 0.76 & 0.50 \\
\hline 127 & Dois Irmãos - RS & 0.68 & 1.00 & 0.50 \\
\hline 128 & Dois Lajeados - RS & 0.63 & 0.95 & 0.40 \\
\hline 129 & Dom Feliciano - RS & 0.81 & 0.94 & 0.85 \\
\hline 130 & Dom Pedrito - RS & 0.15 & 0.49 & 0.80 \\
\hline 131 & Dom Pedro de Alcâtara - RS & 0.74 & 0.08 & 0.65 \\
\hline 132 & Dona Emma - SC & 0.78 & 0.87 & 0.60 \\
\hline 133 & Doutor Pedrinho-SC & 0.76 & 0.87 & 0.00 \\
\hline 134 & Doutor Ricardo - RS & 0.76 & 0.86 & 0.35 \\
\hline 135 & Doutor Ulysses - PR & 0.87 & 0.83 & 0.55 \\
\hline 136 & Eldorado-SP & 0.54 & 0.35 & 0.40 \\
\hline 137 & Eldorado do Sul-RS & 0.78 & 0.83 & 0.70 \\
\hline 138 & Encantado-RS & 0.87 & 0.83 & 0.75 \\
\hline 139 & Encruzilhada do Sul - RS & 0.76 & 0.93 & 0.95 \\
\hline 140 & Ermo-sC & 0.88 & 0.72 & 0.30 \\
\hline 141 & Esmeralda-RS & 0.50 & 0.88 & 0.60 \\
\hline 142 & Estância Velha - RS & 0.74 & 0.95 & 0.70 \\
\hline 143 & Esteio - RS & 0.72 & 0.74 & 0.05 \\
\hline 144 & Estrela - RS & 0.90 & 0.78 & 0.90 \\
\hline 145 & Fagundes Varela - RS & 0.57 & 0.95 & 0.65 \\
\hline 146 & Farroupilha - RS & 0.59 & 0.93 & 0.85 \\
\hline 147 & Fazenda Rio Grande - PR & 0.94 & 0.86 & 0.85 \\
\hline 148 & Fazenda Vilanova - $R S$ & 0.88 & 0.81 & 0.50 \\
\hline
\end{tabular}

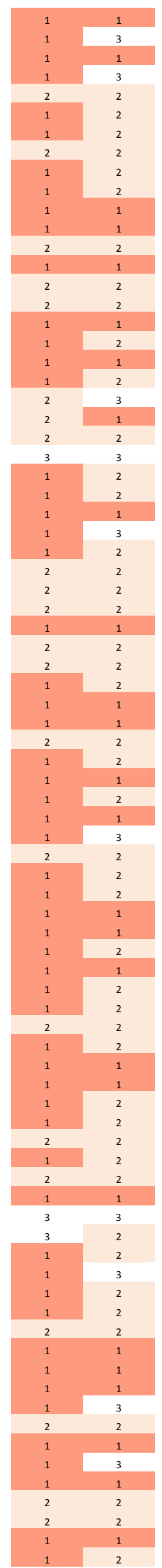
continuará máxima (0) continuará alta (0) continuará alta (0) susceptível -> alta (1) máxima -> alta $(-1)$

continuará alta (0) continuará alta (0) máxima -> insuscep. (-3) insuscep. $\rightarrow>$ suscep.(1) susceptível -> alta (1) máxima -> susceptível (-2) continuará alta (0)

continuará máxima (0) continuará alta (0) continuará máxima (0)

continuará alta (0)

máxima -> insuscep. (-3) máxima -> insuscep. (-3)

náxima -> alta $(-1)$

continuará insuscep. (0) continuará alta (0) continuará máxima (0) continuará máxima (0) continuará alta (0) máxima -> alta (-1) máxima -> alta (-1) máxima -> alta (-1) máxima -> alta $(-1)$ continuará alta (0) continuará alta (0)

insuscep. -> suscep.(1) continuará alta $(0)$

máxima -> alta (-1) continuará máxima (0) máxima -> alta $(-1)$ continuará alta (0) continuará alta (0) máxima -> alta $(-1)$ continuará alta (0) continuará máxima (0) máxima -> alta $(-1)$ máxima -> alta $(-1)$ continuará alta $(0)$ continuará insuscep. (0) máxima -> alta $(-1)$ susceptível -> alta (1) continuará máxima (0) máxima -> alta (-1) continuará alta $(0)$

máxima -> alta (-1) máxima -> alta (-1) continuará alta (0) insuscep. -> suscep.(1) continuará máxima (0) máxima -> alta $(-1)$ máxima -> alta $(-1)$

máxima -> alta (-1) continuará alta (0) continuará alta (0) continuará alta (0) continuará alta (0) suscep. - > insuscep. (-1) continuará máxima (0)

susceptível -> alta (1) continuará máxima (0) continuará alta (0) continuará insuscep. (0) continuará insuscep. (0) continuará alta (0) máxima -> alta (-1)

máxima $\rightarrow$ alta $(-1)$ máxima -> alta $(-1)$ continuará alta $(0)$ continuará alta (0) continuará alta $(0)$ máxima -> alta $(-1)$ continuará alta (0) máxima -> alta (-1) continuará máxima (0) máxima -> alta (-1) continuará alta (0) continuará alta $(0)$ continuará máxima (0) continuará alta $(0)$ continuará alta $(0)$ suscep. -> máxima (2) continuará máxima (0) continuará alta $(0)$ continuará alta (0) continuará máxima (0) insusceptível - $>$ alta (2) suscep. -> máxima (2) máxima -> alta $(-1)$ tinuará alta (0) continuará máxima (0) continuará alta (0) continuará máxima (0) continuará alta (0) máxima -> insuscep. (-3) máxima $->$ insuscep. $(-3)$ máxima -> alta (-1) continuará máxima (0) continuará alta (0) continuará máxima (0) continuará máxima (0) continuará alta (0) máxima -> alta (-1) máxima -> alta $(-1)$ continuará alta (0) máxima -> alta (-1) continuará alta (0)

continuará alta (0)

continuará insuscep. (0) continuará alta (0)

máxima -> alta (-1) continuará máxima (0) continuará máxima (0) continuará alta (0) continuará alta (0) máxima -> alta (-1) continuará alta (0)

continuará máxima (0) máxima -> alta (-1) máxima -> alta $(-1)$ continuará alta (0) continuará insuscep. (0) máxima -> alta $(-1)$ suscep. -> máxima (2)

continuará máxima (0) máxima -> alta $(-1)$ continuará alta (0)

continuará máxima (0) continuará máxima (0) continuará alta (0) continuará insuscep. (0) continuará máxima (0) máxima -> alta $(-1)$ continuará máxima (0)

máxima -> susceptível $(-2)$ continuará alta (0) continuará alta $(0)$ continuará alta (0) continuará alta (0) suscep. -> insuscep. (-1) continuará máxima (0) continuará suscep. (0) continuará máxima (0) continuará alta (0) continuará insuscep. (0) continuará insuscep. (0) continuará alta (0) máxima -> alta (-1) máxima -> alta (-1) máxima -> alta (-1) continuará alta $(0)$ continuará alta $(0)$ continuará alta (0) máxima -> alta (-1) continuará alta (0) máxima -> alta $(-1)$ continuará máxima (0) máxima -> alta (-1) 


\begin{tabular}{|c|c|c|c|c|}
\hline 149 & Feliz - RS & 0.68 & 0.97 & 0.90 \\
\hline 150 & Flores da Cunha - RS & 0.54 & 0.91 & 0.75 \\
\hline 151 & Forquetinha - RS & 0.94 & 0.73 & 0.70 \\
\hline 152 & Forquilhinha - SC & 0.90 & 0.77 & 0.55 \\
\hline 153 & Fraiburgo - SC & 0.62 & 0.76 & 0.75 \\
\hline 154 & Frei Rogério - SC & 0.60 & 0.85 & 0.60 \\
\hline 155 & Garibaldi - RS & 0.63 & 0.96 & 0.75 \\
\hline 156 & Garuva - SC & 0.46 & 0.42 & 0.40 \\
\hline 157 & Gaspar-SC & 0.68 & 0.77 & 0.55 \\
\hline 158 & General Câmara - RS & 0.90 & 0.72 & 0.55 \\
\hline 159 & Glorinha - RS & 0.81 & 0.86 & 0.40 \\
\hline 160 & Gramado-RS & 0.49 & 0.97 & 0.80 \\
\hline 161 & Grão Pará-SC & 0.87 & 0.87 & 0.45 \\
\hline 162 & Gravatai - RS & 0.81 & 0.86 & 0.80 \\
\hline 163 & Guabiju - RS & 0.47 & 0.84 & 0.50 \\
\hline 164 & Guabiruba - SC & 0.66 & 0.81 & 0.20 \\
\hline 165 & Guaiba - RS & 0.78 & 0.85 & 0.70 \\
\hline 166 & Guapiara - SP & 0.90 & 0.70 & 0.80 \\
\hline 167 & Guaporé - RS & 0.63 & 0.96 & 0.85 \\
\hline 168 & Guaramirim - SC & 0.49 & 0.49 & 0.40 \\
\hline 169 & Guaraqueçaba-PR & 0.25 & 0.00 & 0.45 \\
\hline 170 & Guaratuba - PR & 0.37 & 0.32 & 0.10 \\
\hline 171 & Harmonia - RS & 0.71 & 0.91 & 0.55 \\
\hline 172 & Herval-RS & 0.99 & 0.59 & 0.55 \\
\hline 173 & Hulha Negra - RS & 1.00 & 0.58 & 0.70 \\
\hline 174 & Ibiaçá - RS & 0.51 & 0.70 & 0.60 \\
\hline 175 & Ibiraiaras - RS & 0.44 & 0.76 & 0.75 \\
\hline 176 & Ibirama-SC & 0.74 & 0.82 & 0.60 \\
\hline 177 & Içara -SC & 0.90 & 0.75 & 0.70 \\
\hline 178 & Igrejinha - RS & 0.71 & 1.00 & 0.65 \\
\hline 179 & Ilhota - SC & 0.69 & 0.67 & 0.40 \\
\hline 180 & Ilópolis - RS & 0.57 & 1.00 & 0.70 \\
\hline 181 & Imbé - RS & 0.76 & 0.66 & 0.10 \\
\hline 182 & Imbuia - SC & 0.74 & 0.95 & 0.60 \\
\hline 183 & Imigrante-RS & 0.85 & 0.85 & 0.80 \\
\hline 184 & Indaial -SC & 0.65 & 0.87 & 0.55 \\
\hline 185 & Ipê-RS & 0.50 & 0.89 & 0.80 \\
\hline 186 & Iporanga -SP & 0.54 & 0.58 & 0.60 \\
\hline 187 & Itaiópolis - SC & 0.82 & 0.87 & 0.70 \\
\hline 188 & Itaóca - SP & 0.66 & 0.61 & 0.45 \\
\hline 189 & Itaperuçu-PR & 0.82 & 0.76 & 0.35 \\
\hline 190 & Itapeva-SP & 0.74 & 0.63 & 0.80 \\
\hline 191 & Itapirapuã Paulista - SP & 0.85 & 0.83 & 0.45 \\
\hline 192 & Itati-RS & 0.68 & 0.73 & 0.65 \\
\hline 193 & Ituporanga -SC & 0.81 & 0.86 & 0.70 \\
\hline 194 & Ivoti-RS & 0.71 & 1.00 & 0.55 \\
\hline 195 & Jacinto Machado - SC & 0.93 & 0.87 & 0.45 \\
\hline 196 & Jaguarão - RS & 0.99 & 0.49 & 0.75 \\
\hline 197 & Jaguariaiva - $P R$ & 0.94 & 0.73 & 0.60 \\
\hline 198 & Jaquirana - $R S$ & 0.56 & 0.97 & 0.30 \\
\hline 199 & Jaraguá do Sul - SC & 0.69 & 0.80 & 0.40 \\
\hline 200 & Joinville - SC & 0.76 & 0.58 & 0.50 \\
\hline 201 & José Boiteux - SC & 0.78 & 0.85 & 0.25 \\
\hline 202 & Lages - SC & 0.79 & 0.91 & 0.55 \\
\hline 203 & Lagoa Vermelha-RS & 0.47 & 0.81 & 0.85 \\
\hline 204 & Lajeado - RS & 0.91 & 0.75 & 0.80 \\
\hline 205 & Lapa-PR & 0.94 & 0.91 & 0.90 \\
\hline 206 & Laurentino-SC & 0.78 & 0.83 & 0.45 \\
\hline 207 & Lauro Muller - SC & 0.85 & 0.86 & 0.45 \\
\hline 208 & Lauras do Sul-RS & 0.03 & 0.83 & 0.75 \\
\hline 209 & Lebon Régis - SC & 0.68 & 0.73 & 0.50 \\
\hline 210 & Leoberto Leal-SC & 0.74 & 0.90 & 0.30 \\
\hline 211 & Lindolfo Collor - RS & 0.68 & 1.00 & 0.65 \\
\hline 212 & Linha Nova - RS & 0.62 & 0.99 & 0.85 \\
\hline 213 & Lontras - SC & 0.76 & 0.82 & 0.60 \\
\hline 214 & Luiz Alves - SC & 0.56 & 0.68 & 0.45 \\
\hline 215 & Mafra-sC & 0.93 & 0.89 & 0.70 \\
\hline 216 & Major Gercino - SC & 0.74 & 0.72 & 0.20 \\
\hline 217 & Major Vieira - SC & 0.81 & 0.85 & 0.30 \\
\hline 218 & Mampituba-RS & 0.59 & 0.82 & 0.60 \\
\hline 219 & Mandirituba - $P R$ & 0.94 & 0.87 & 0.75 \\
\hline 220 & Maquiné - RS & 0.72 & 0.56 & 0.50 \\
\hline 221 & Maracajá - SC & 0.91 & 0.72 & 0.10 \\
\hline 222 & Maratá-RS & 0.74 & 0.91 & 0.80 \\
\hline 223 & Mariana Pimentel - RS & 0.79 & 0.94 & 0.50 \\
\hline 224 & Marques de Souza - RS & 0.91 & 0.81 & 0.75 \\
\hline 225 & Massaranduba-SC & 0.68 & 0.66 & 0.40 \\
\hline 226 & Mato Leitão - RS & 0.93 & 0.76 & 0.45 \\
\hline 227 & Meleiro - SC & 0.93 & 0.74 & 0.25 \\
\hline 228 & Minas do Leão-RS & 0.88 & 0.70 & 0.25 \\
\hline 229 & Mirim Doce - SC & 0.76 & 0.87 & 0.30 \\
\hline 230 & inte Aleare dos Camoos - & 0.57 & 0.95 & 0.6 \\
\hline
\end{tabular}

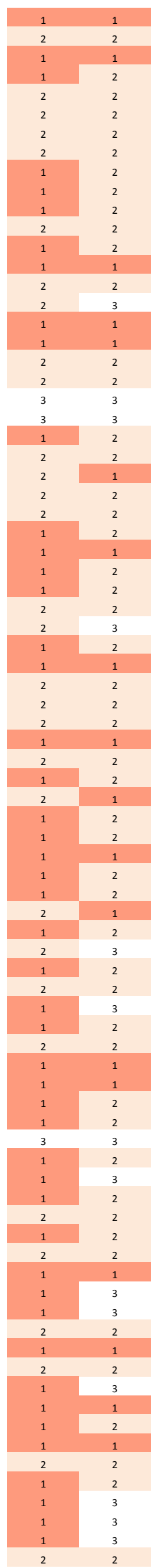
máxima -> alta $(-1)$ máxima -> insuscep. $(-3)$ máxima -> alta (-1) alta -> susceptível (-1) alta -> susceptível (-1) máxima -> alta (-1) insuscep. -> suscep.(1) continuará alta (0) máxima -> alta $(-1)$ continuará alta $(0)$ continuará alta (0) máxima -> alta $(-1)$ continuará alta (0) continuará alta (0) continuará alta (0) continuará alta $(0)$ máxima -> insuscep. (-3) continuará alta (0) continuará alta (0) continuará insuscep. (0) insuscep. $\rightarrow>$ suscep.(1)

continuará alta (0) continuará máxima (0) continuará máxima (0) continuará alta (0) continuará alta (0) máxima -> alta $(-1)$ máxima -> alta $(-1)$ continuará alta (0) continuará alta (0) continuará alta (0) máxima -> alta $(-1)$ máxima -> alta $(-1)$

máxima -> alta (-1) continuará alta (0) continuará alta $(0)$

continuará insuscep. (0) máxima -> insuscep. (-3) continuará insuscep. (0) insusceptivel $>$ alta (2) continuará insuscep. (0) continuará insuscep. (0) continuará alta (0) máxima -> alta (-1) continuará alta (0) máxima -> alta $(-1)$ continuará máxima (0) continuará insuscep. (0) continuará alta (0) continuará alta (0) insusceptivel -> alta (2) continuará alta (0) máxima -> alta $(-1)$ continuará alta $(0)$

máxima -> alta (-1) máxima -> insuscep. (-3) continuará alta (0)

insuscep. -> suscep.(1) susceptivel -> alta (1) continuará alta (0) continuará alta (0) continuará alta (0) continuará alta (0) máxima -> alta (-1) continuará alta (0) máxima -> insuscep. (-3) continuará alta (0) máxima -> insuscep. (-3) continuará alta (0) continuará máxima (0) continuará alta (0) máxima -> alta (-1) continuará alta (0) continuará alta (0) máxima -> alta $(-1)$ continuará alta $(0)$ máxima $>>$ alta $(-1)$ máxima -> alta (-1) máxima -> alta (-1) insuscep. -> suscep.(1) continuará alta (0) máxima -> alta (-1) máxima $>$ insuscep. $(-3)$ máxima -> alta (-1) alta $\rightarrow$ insusceptivel $(-2)$ alta $\rightarrow$ insusceptivel (-2) máxima -> alta (-1) insusceptível -> alta (2) continuará alta (0) máxima -> alta $(-1)$ continuará alta (0) continuará alta (0) máxima -> alta (-1) continuará alta (0) continuará alta (0) continuará alta (0) continuará alta (0)

continuará máxima (0) continuará alta (0) continuará alta (0)

insuscep. $\rightarrow$ suscep.(1) insusceptivel -> alta (2) continuará alta $(0)$ continuará máxima (0) continuará máxima (0) continuará alta (0) continuará alta (0) máxima -> alta $(-1)$ máxima -> alta (-1) continuará alta (0) continuará alta $(0)$ continuará alta (0) máxima -> alta $(-1)$ máxima -> alta $(-1)$ máxima -> alta (-1) continuará alta (0) continuará alta (0) insuscep. -> máxima (3) continuará máxima (0) continuará insuscep. (0) insuscep. -> máxima (3) continuará insuscep. (0) continuará insuscep. (0) continuará alta (0) máxima -> alta (-1) continuará alta (0) máxima -> alta (-1) continuará máxima (0) continuará insuscep. (0) continuará alta (0) alta -> máxima (1)

insusceptível -> alta (2) continuará alta (0) máxima -> alta $(-1)$ continuará alta (0)

máxima -> insuscep. $(-3)$ máxima -> insuscep. $(-3)$ continuará alta (0)

continuará insuscep. (0) suscep. -> insuscep. (-1) alta $\rightarrow$ insusceptível $(-2)$ continuará alta (0) continuará alta (0) continuará alta (0) máxima -> alta $(-1)$ alta -> máxima (1) máxima -> insuscep. (-3) continuará alta (0) máxima -> insuscep. (-3)

continuará alta (0) continuará máxima (0) continuará alta (0) máxima -> alta $(-1)$ continuará alta $(0)$ continuará alta (0)

máxima -> insuscep. (-3) alta -> máxima (1) máxima -> insuscep. (-3) máxima $->$ alta $(-1)$

máxima -> alta (-1) insuscep. $\rightarrow$ suscep.(1) 


\begin{tabular}{|c|c|c|c|c|}
\hline 231 & Monte Belo do Sul - RS & 0.65 & 0.90 & 0.65 \\
\hline 232 & Monte Carlo - SC & 0.56 & 0.78 & 0.15 \\
\hline 233 & Monte Castelo - SC & 0.79 & 0.85 & 0.45 \\
\hline 234 & Montenegro - RS & 0.74 & 0.84 & 0.90 \\
\hline 235 & Morretes - PR & 0.62 & 0.45 & 0.55 \\
\hline 236 & Morrinhos do Sul-RS & 0.81 & 0.40 & 0.65 \\
\hline 237 & Morro da Fumaça - SC & 0.87 & 0.78 & 0.40 \\
\hline 238 & Morro Grande - SC & 0.88 & 0.85 & 0.10 \\
\hline 239 & Morro Redondo - RS & 0.96 & 0.86 & 0.80 \\
\hline 240 & Morro Reuter-RS & 0.56 & 1.00 & 0.85 \\
\hline 241 & Mostardas - RS & 0.15 & 0.57 & 0.90 \\
\hline 242 & Muçum - RS & 0.76 & 0.87 & 0.70 \\
\hline 243 & Muitos Capões - RS & 0.50 & 0.90 & 0.40 \\
\hline 244 & Muliterno - RS & 0.43 & 0.73 & 0.50 \\
\hline 245 & Nova Araçá - RS & 0.47 & 0.84 & 0.55 \\
\hline 246 & Nova Bassano - RS & 0.54 & 0.90 & 0.85 \\
\hline 247 & Nova Bréscia - RS & 0.85 & 0.83 & 0.65 \\
\hline 248 & Nova Campina - SP & 0.85 & 0.81 & 0.60 \\
\hline 249 & Nova Hartz - RS & 0.69 & 1.00 & 0.70 \\
\hline 250 & Nova Pádua - RS & 0.54 & 0.93 & 0.70 \\
\hline 251 & Nova Petrópolis - RS & 0.60 & 0.95 & 0.90 \\
\hline 252 & Nova Prata - RS & 0.47 & 0.91 & 0.70 \\
\hline 253 & Nova Roma do Sul - RS & 0.56 & 0.94 & 0.65 \\
\hline 254 & Nova Santa Rita - RS & 0.69 & 0.81 & 0.75 \\
\hline 255 & Nova Trento - SC & 0.78 & 0.76 & 0.40 \\
\hline 256 & Nova Veneza -SC & 0.90 & 0.86 & 0.30 \\
\hline 257 & Novo Hamburgo - RS & 0.72 & 0.89 & 0.85 \\
\hline 258 & Orleans - SC & 0.87 & 0.81 & 0.70 \\
\hline 259 & Osório-RS & 0.75 & 0.66 & 0.70 \\
\hline 260 & Otacilio Costa - SC & 0.75 & 0.89 & 0.30 \\
\hline 261 & Painel-SC & 0.96 & 0.85 & 0.20 \\
\hline 262 & Palmares do Sul - RS & 0.79 & 0.65 & 0.45 \\
\hline 264 & Palmeira-SC & 0.76 & 0.93 & 0.10 \\
\hline 264 & Palmeira - PR & 0.75 & 0.93 & 0.75 \\
\hline 265 & Pantano Grande-RS & 0.78 & 0.83 & 0.60 \\
\hline 266 & Papanduva - SC & 0.79 & 0.88 & 0.55 \\
\hline 267 & Paraí-RS & 0.50 & 0.89 & 0.80 \\
\hline 268 & Pareci Novo-RS & 0.71 & 0.79 & 0.75 \\
\hline 269 & Parobé-RS & 0.74 & 0.95 & 0.55 \\
\hline 270 & Passo de Torres - SC & 0.76 & 0.06 & 0.10 \\
\hline 271 & Passo do Sobrado - RS & 0.93 & 0.81 & 0.80 \\
\hline 272 & Paverama - RS & 0.88 & 0.86 & 0.65 \\
\hline 273 & Pedras Altas - RS & 1.00 & 0.39 & 0.35 \\
\hline 274 & Pedro Osório - RS & 0.99 & 0.68 & 0.45 \\
\hline 275 & Pelotas - RS & 0.97 & 0.77 & 1.00 \\
\hline 276 & Petrolândia -SC & 0.81 & 0.87 & 0.50 \\
\hline 277 & Picada Café - RS & 0.65 & 0.99 & 0.75 \\
\hline 278 & Piên - PR & 0.85 & 0.87 & 0.50 \\
\hline 279 & Pinhais - PR & 0.82 & 0.94 & 0.35 \\
\hline 280 & Pinhal da Serra-RS & 0.51 & 0.85 & 0.75 \\
\hline 281 & Pinheiro Machado - RS & 0.94 & 0.79 & 0.55 \\
\hline 282 & Piraí do Sul - PR & 0.87 & 0.81 & 0.65 \\
\hline 283 & Piraquara - $P R$ & 0.69 & 0.87 & 0.70 \\
\hline 284 & Piratini-RS & 0.97 & 0.82 & 0.75 \\
\hline 285 & Poço das Antas - RS & 0.75 & 0.90 & 0.35 \\
\hline 286 & Pomerode-SC & 0.68 & 0.84 & 0.35 \\
\hline 287 & Ponta Grossa - PR & 0.75 & 0.83 & 0.70 \\
\hline 288 & Ponte Alta - SC & 0.76 & 0.86 & 0.35 \\
\hline 289 & Ponte Alta do Norte - SC & 0.87 & 0.75 & 0.20 \\
\hline 290 & Portão - RS & 0.72 & 0.90 & 0.85 \\
\hline 291 & Porto Alegre - RS & 0.82 & 0.72 & 0.80 \\
\hline 292 & Porto Amazonas - PR & 0.82 & 0.89 & 0.50 \\
\hline 293 & Pouso Novo - RS & 0.84 & 0.83 & 0.60 \\
\hline 294 & Pouso Redondo - SC & 0.81 & 0.87 & 0.55 \\
\hline 295 & Praia Grande - SC & 0.79 & 0.78 & 0.30 \\
\hline 296 & Presidente Getúlio - SC & 0.79 & 0.83 & 0.50 \\
\hline 297 & Presidente Lucena - RS & 0.69 & 0.96 & 0.70 \\
\hline 298 & Presidente Nereu - SC & 0.75 & 0.93 & 0.35 \\
\hline 299 & Protásio Alves - RS & 0.50 & 0.91 & 0.60 \\
\hline 300 & Putinga - RS & 0.72 & 0.87 & 0.50 \\
\hline 301 & Quatro Barras - PR & 0.72 & 0.77 & 0.65 \\
\hline 302 & Quitandinha - PR & 0.94 & 0.89 & 0.80 \\
\hline 303 & Rancho Queimado - SC & 0.78 & 0.73 & 0.75 \\
\hline 304 & Relvado-RS & 0.78 & 0.83 & 0.55 \\
\hline 305 & Ribeira - SP & 0.85 & 0.78 & 0.45 \\
\hline 306 & Ribeirão Branco - SP & 0.87 & 0.80 & 0.65 \\
\hline 307 & Ribeirão Grande - SP & 0.91 & 0.65 & 0.75 \\
\hline 308 & Rio Branco do Sul - PR & 0.68 & 0.80 & 0.70 \\
\hline 309 & Rio do Campo - SC & 0.75 & 0.84 & 0.50 \\
\hline 310 & Rio do Oeste - SC & 0.79 & 0.84 & 0.25 \\
\hline 311 & Rio do Sul-SC & 0.78 & 0.84 & 0.80 \\
\hline 312 & Rio dos Cedros - SC & 0.76 & 0.89 & 0.30 \\
\hline
\end{tabular}

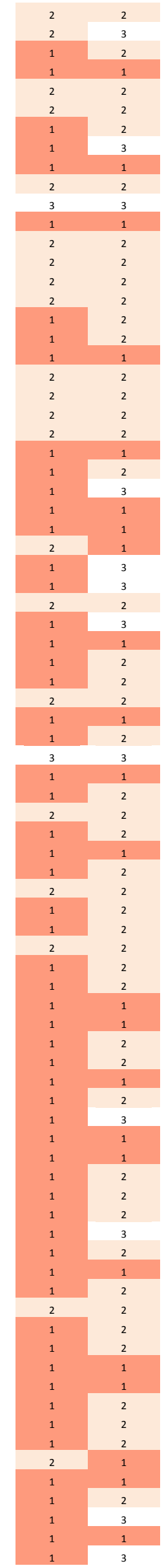
alta -> susceptivel (-1) máxima -> insuscep. (-3) continuará alta (0) continuará insuscep. (0) continuará máxima (0) insusceptível -> alta (2)

máxima -> alta (-1)

continuará máxima (0) continuará alta (0) continuará máxima (0) continuará alta (0) continuará alta (0) continuará alta $(0)$ continuará alta (0) continuará alta (0) máxima -> alta (-1)

continuará insuscep. (0) continuará alta (0) continuará alta $(0)$ continuará alta (0) continuará alta (0) continuará alta (0) continuará alta (0) continuará alta $(0)$ insuscep. -> suscep.(1) continuará alta (0)

máxima -> alta (-1) máxima -> alta $(-1)$ continuará máxima (0) continuará máxima (0)

máxima -> alta (-1) continuará máxima (0) insuscep. - > suscep.(1) continuará alta (0) máxima -> insuscep. (-3) continuará alta (0) continuará alta (0) continuará alta (0) máxima -> alta $(-1)$ máxima -> alta (-1)

máxima -> alta (-1) continuará máxima (0) continuará máxima (0) continuará máxima (0) máxima -> alta (-1) continuará alta (0) continuará máxima (0) continuará máxima (0) continuará alta (0) continuará máxima (0) continuará insuscep. (0) insusceptível -> alta (2) continuará máxima (0) continuará alta (0)

continuará alta (0)

insuscep. $\rightarrow$ suscep.(1) máxima -> alta $(-1)$

máxima -> alta (-1)

continuará alta (0)

máxima -> alta $(-1)$

insuscep. $\rightarrow>$ suscep.(1)

máxima -> alta (-1)

susceptível -> alta (1) máxima -> alta $(-1)$

continuará alta $(0)$

continuará alta (0)

máxima -> alta (-1)

continuará alta (0)

continuará alta (0)

insusceptível -> alta (2)

continuará máxima (0)

continuará alta (0)

máxima -> alta $(-1)$ continuará insuscep. (0)

continuará insuscep. (0) continuará insuscep. (0) susceptível -> alta (1) máxima -> insuscep. (-3)

continuará alta (0)

continuará alta (0) máxima -> alta (-1) continuará alta (0)

alta $\rightarrow$ insusceptivel $(-2)$ continuará máxima (0)

ntinuará alta (0) insusceptível -> alta (2) continuará máxima (0) insusceptível -> alta (2)

máxima -> alta (-1) continuará máxima (0) continuará alta (0)

continuará máxima (0) continuará alta (0) continuará alta (0) continuará alta $(0)$ continuará alta $(0)$ continuará alta (0) máxima -> alta (-1)

continuará insuscep. (0) continuará alta (0) continuará alta (0) continuará alta (0) continuará alta (0) continuará alta (0) continuará alta (0) continuará alta (0) máxima -> alta $(-1)$ continuará alta (0) máxima -> alta (-1) máxima -> alta (-1) continuará máxima (0) continuará máxima (0)

máxima -> alta (-1) continuará máxima (0) continuará insuscep. (0) continuará alta (0) máxima -> insuscep. (-3) continuará alta $(0)$ continuará alta (0)

continuará alta (0) continuará máxima (0) máxima -> insuscep. $(-3)$

máxima -> alta $(-1)$

continuará máxima (0) continuará máxima (0) continuará máxima (0) máxima -> alta $(-1)$ continuará alta (0) continuará máxima (0) continuará máxima (0) continuará alta (0) continuará máxima (0) continuará insuscep. (0) insusceptivel -> alta (2) continuará máxima (0) continuará alta (0)

continuará alta (0)

insusceptível -> alta (2) continuará máxima (0) continuará alta (0) máxima -> alta (-1) insuscep. $\rightarrow>$ suscep.(1) máxima -> alta (-1) susceptível -> alta (1) máxima -> alta $(-1)$ continuará alta (0) continuará alta (0) máxima -> alta (-1) continuará alta $(0)$ continuará alta (0) insusceptível -> alta (2) continuará máxima (0) continuará alta (0) máxima -> alta (-1) continuará insuscep. (0) insuscep. -> máxima (3) insuscep. $\rightarrow>$ máxima (3) susceptível $->$ alta (1) máxima -> insuscep. (-3)

continuará alta (0) continuará alta (0) continuará máxima (0) 


\begin{tabular}{|c|c|c|c|c|}
\hline 313 & Rio Fortuna - SC & 0.90 & 0.88 & 0.55 \\
\hline 314 & Rio Grande - RS & 1.00 & 0.58 & 0.80 \\
\hline 315 & Rio Negrinho - SC & 0.82 & 0.86 & 0.50 \\
\hline 316 & Rio Negro - PR & 0.93 & 0.91 & 0.85 \\
\hline 317 & Rio Pardo - RS & 0.88 & 0.77 & 0.90 \\
\hline 318 & Rio Rufino - SC & 0.94 & 0.87 & 0.55 \\
\hline 319 & Riozinho - RS & 0.53 & 0.96 & 0.75 \\
\hline 320 & Roca Sales - RS & 0.82 & 0.85 & 0.75 \\
\hline 321 & Rodeio - SC & 0.66 & 0.84 & 0.25 \\
\hline 322 & Rolante - $R S$ & 0.76 & 0.98 & 0.85 \\
\hline 323 & Salete - SC & 0.76 & 0.90 & 0.55 \\
\hline 324 & Salvador do Sul-RS & 0.66 & 0.92 & 0.75 \\
\hline 325 & Sananduva - RS & 0.51 & 0.71 & 0.75 \\
\hline 326 & Santa Cecilia - SC & 0.85 & 0.73 & 0.45 \\
\hline 327 & Santa Clara do Sul-RS & 0.94 & 0.73 & 0.75 \\
\hline 328 & Santa Cruz do Sul - RS & 0.91 & 0.79 & 0.95 \\
\hline 329 & Santa Maria do Herval - RS & 0.53 & 0.99 & 0.85 \\
\hline 330 & Santa Rosa de Lima -SC & 0.81 & 0.81 & 0.45 \\
\hline 331 & Santa Rosa do Sul -SC & 0.88 & 0.62 & 0.30 \\
\hline 332 & Santa Tereza - RS & 0.76 & 0.90 & 0.65 \\
\hline 333 & Santa Terezinha - SC & 0.81 & 0.90 & 0.50 \\
\hline 334 & Santa Vitória do Palmar-RS & 0.99 & 0.64 & 0.80 \\
\hline 335 & Santana da Boa Vista - RS & 0.81 & 0.92 & 0.75 \\
\hline 336 & Santo Antônio da Patrulha - RS & 0.75 & 0.87 & 0.70 \\
\hline 337 & São Bento do Sul - SC & 0.81 & 0.90 & 0.60 \\
\hline 338 & São Cristovão do Sul - SC & 0.90 & 0.74 & 0.15 \\
\hline 339 & São Domingos do Sul - RS & 0.50 & 0.84 & 0.75 \\
\hline 340 & São Francisco de Paula - RS & 0.41 & 0.96 & 0.70 \\
\hline 341 & São Jerônimo - RS & 0.79 & 0.90 & 0.65 \\
\hline 342 & São João do Sul - SC & 0.75 & 0.13 & 0.45 \\
\hline 343 & São Joaquim - SC & 0.94 & 0.83 & 0.65 \\
\hline 344 & São Jorge - RS & 0.46 & 0.83 & 0.60 \\
\hline 345 & São José do Cerrito - SC & 0.62 & 0.89 & 0.60 \\
\hline 346 & São José do Hortêncio - RS & 0.68 & 0.94 & 0.75 \\
\hline 347 & São José do Norte - RS & 1.00 & 0.52 & 0.80 \\
\hline 348 & São José do Ouro - RS & 0.56 & 0.75 & 0.80 \\
\hline 349 & São José do Sul - RS & 0.72 & 0.92 & 0.70 \\
\hline 350 & São José dos Ausentes - RS & 0.91 & 0.82 & 0.40 \\
\hline 351 & São José dos Pinhais - PR & 0.87 & 0.89 & 0.80 \\
\hline 352 & São Leopoldo - RS & 0.75 & 0.86 & 0.35 \\
\hline 353 & São Lourenço do Sul - RS & 0.96 & 0.77 & 0.80 \\
\hline 354 & São Marcos - RS & 0.53 & 0.90 & 0.80 \\
\hline 355 & São Pedro da Serra - RS & 0.66 & 1.00 & 0.35 \\
\hline 356 & São Sebastião do Caí-RS & 0.69 & 0.82 & 0.90 \\
\hline 357 & São Valentim do Sul - RS & 0.65 & 1.00 & 0.60 \\
\hline 358 & São Vendelino - RS & 0.62 & 0.94 & 0.10 \\
\hline 359 & Sapiranga-RS & 0.66 & 1.00 & 0.70 \\
\hline 360 & Sapucaia do Sul - RS & 0.76 & 0.82 & 0.40 \\
\hline 361 & Schroeder-SC & 0.56 & 0.74 & 0.40 \\
\hline 362 & Sengés - $P R$ & 0.90 & 0.72 & 0.30 \\
\hline 363 & Sentinela do Sul - RS & 0.85 & 0.80 & 0.65 \\
\hline 364 & Serafina Corrêa - RS & 0.56 & 0.93 & 0.60 \\
\hline 365 & Sério-RS & 0.93 & 0.76 & 0.80 \\
\hline 366 & Sertão Santana - RS & 0.81 & 0.96 & 0.60 \\
\hline 367 & Siderópolis - SC & 0.90 & 0.87 & 0.25 \\
\hline 368 & Sinimbu -RS & 0.91 & 0.85 & 0.65 \\
\hline 369 & Sombrio - SC & 0.84 & 0.69 & 0.45 \\
\hline 370 & Tabai - RS & 0.85 & 0.82 & 0.45 \\
\hline 371 & Taió - SC & 0.78 & 0.87 & 0.50 \\
\hline 372 & Tapes - RS & 0.84 & 0.66 & 0.35 \\
\hline 373 & Taquara - RS & 0.76 & 0.96 & 0.90 \\
\hline 374 & Taquari - RS & 0.88 & 0.72 & 0.80 \\
\hline 375 & Taquarivaí-SP & 0.79 & 0.64 & 0.55 \\
\hline 376 & Tavares - RS & 0.18 & 0.53 & 0.65 \\
\hline 377 & Terra de Areia - RS & 0.68 & 0.34 & 0.60 \\
\hline 378 & Teutônia - RS & 0.85 & 0.82 & 0.75 \\
\hline 379 & Tijucas do Sul - PR & 0.81 & 0.94 & 0.70 \\
\hline 380 & Timbé do Sul - sC & 0.84 & 0.87 & 0.15 \\
\hline 381 & Timbó - sc & 0.66 & 0.83 & 0.50 \\
\hline 382 & Timbó Grande - SC & 0.71 & 0.82 & 0.25 \\
\hline 383 & Torres - RS & 0.75 & 0.07 & 0.50 \\
\hline 384 & Tramandaí-RS & 0.76 & 0.54 & 0.40 \\
\hline 385 & Travesseiro - RS & 0.90 & 0.80 & 0.60 \\
\hline 386 & Três Barras - SC & 0.87 & 0.91 & 0.70 \\
\hline 387 & Três Cachoeiras - RS & 0.76 & 0.43 & 0.55 \\
\hline 388 & Três Coroas - RS & 0.59 & 0.99 & 0.75 \\
\hline 389 & Três Forquilhas - RS & 0.60 & 0.72 & 0.55 \\
\hline 390 & Treviso - SC & 0.85 & 0.87 & 0.20 \\
\hline 391 & Triunfo- $R S$ & 0.75 & 0.77 & 0.60 \\
\hline 392 & Trombudo Central -SC & 0.79 & 0.83 & 0.60 \\
\hline 393 & Tunas do Paraná - PR & 0.78 & 0.91 & 0.55 \\
\hline 394 & Tupanci do Sul - RS & 0.46 & 0.77 & 0.30 \\
\hline
\end{tabular}

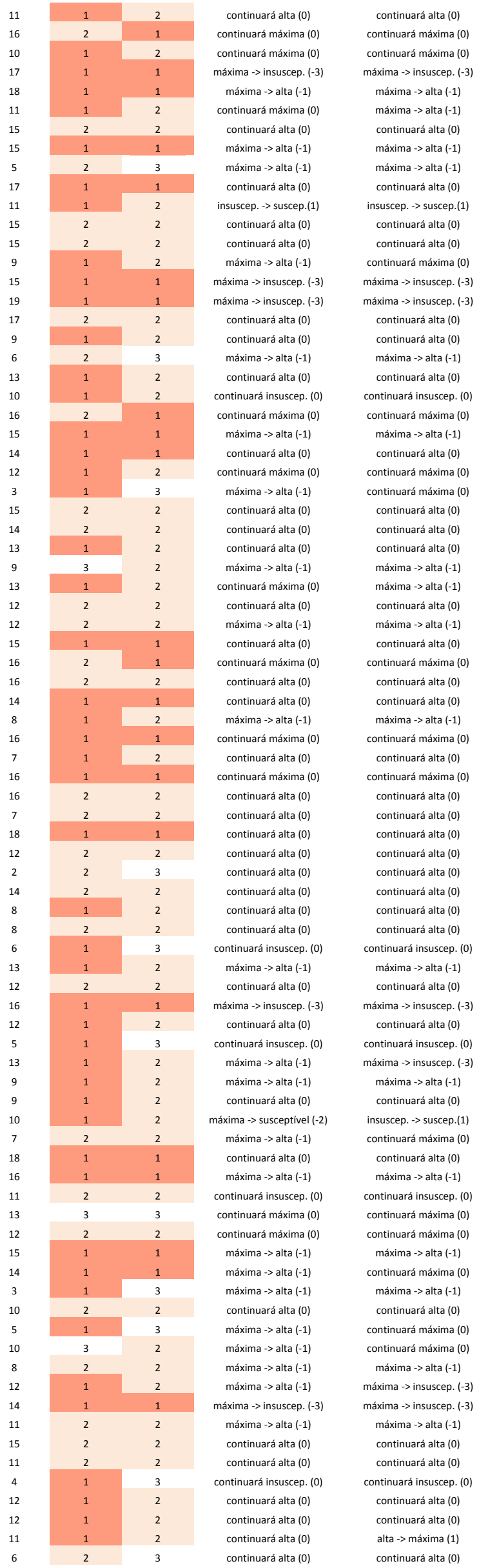




\begin{tabular}{|c|c|c|c|c|}
\hline 395 & Tupandi - RS & 0.72 & 0.94 & 0.45 \\
\hline 396 & Turuçu-RS & 0.97 & 0.71 & 0.65 \\
\hline 397 & Turvo - SC & 0.91 & 0.81 & 0.55 \\
\hline 398 & União da Serra-RS & 0.60 & 0.93 & 0.45 \\
\hline 399 & Urubici - SC & 1.00 & 0.70 & 0.80 \\
\hline 400 & Urupema-sC & 0.94 & 0.77 & 0.30 \\
\hline 401 & Urussanga - SC & 0.85 & 0.85 & 0.60 \\
\hline 402 & Vacaria - RS & 0.56 & 0.93 & 0.60 \\
\hline 403 & Vale Real-RS & 0.63 & 0.94 & 0.65 \\
\hline 404 & Vale Verde - RS & 0.93 & 0.84 & 0.65 \\
\hline 405 & Vanini - RS & 0.46 & 0.79 & 0.20 \\
\hline 406 & Vargem - SC & 0.54 & 0.86 & 0.40 \\
\hline 407 & Venâncio Aires - RS & 0.93 & 0.77 & 0.90 \\
\hline 408 & Vera Cruz - RS & 0.90 & 0.80 & 0.75 \\
\hline 409 & Veranópolis - RS & 0.62 & 0.95 & 0.95 \\
\hline 410 & Vespasiano Correa - RS & 0.63 & 0.97 & 0.45 \\
\hline 411 & Viamão - RS & 0.79 & 0.73 & 0.90 \\
\hline 412 & Vidal Ramos - SC & 0.74 & 0.93 & 0.60 \\
\hline 413 & Vila Flores - RS & 0.51 & 0.95 & 0.55 \\
\hline 414 & Vista Alegre do Prata - RS & 0.59 & 0.94 & 0.65 \\
\hline 415 & Vitor Meireles - SC & 0.79 & 0.88 & 0.45 \\
\hline 416 & Westfalia - RS & 0.78 & 0.82 & 0.60 \\
\hline 417 & Witmarsum - SC & 0.78 & 0.87 & 0.35 \\
\hline 418 & Xangri-lá - RS & 0.72 & 0.23 & 0.00 \\
\hline
\end{tabular}

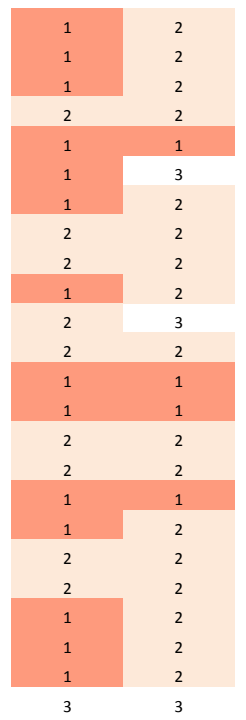

\begin{tabular}{|c|c|}
\hline continuará alta $(0)$ & continuará alta (0) \\
\hline continuará máxima (0) & continuará máxima (0) \\
\hline máxima -> alta $(-1)$ & máxima -> alta $(-1)$ \\
\hline continuará alta (0) & continuará alta (0) \\
\hline máxima -> alta $(-1)$ & máxima -> alta $(-1)$ \\
\hline continuará máxima (0) & máxima -> alta $(-1)$ \\
\hline insuscep. $\rightarrow>$ suscep.(1) & continuará insuscep. (0) \\
\hline continuará alta (0) & continuará alta (0) \\
\hline continuará alta (0) & continuará alta (0) \\
\hline máxima -> alta $(-1)$ & máxima -> alta $(-1)$ \\
\hline continuará alta (0) & continuará alta (0) \\
\hline continuará alta (0) & continuará alta $(0)$ \\
\hline náxima -> insuscep. $(-3)$ & máxima -> insuscep. $(-3)$ \\
\hline máxima -> alta $(-1)$ & máxima $->$ alta $(-1)$ \\
\hline continuará alta (0) & continuará alta (0) \\
\hline continuará alta (0) & continuará alta (0) \\
\hline máxima -> alta $(-1)$ & máxima $>$ alta $(-1)$ \\
\hline máxima -> alta $(-1)$ & máxima -> alta $(-1)$ \\
\hline continuará alta (0) & continuará alta (0) \\
\hline continuará alta (0) & continuará alta (0) \\
\hline insuscep. -> suscep.(1) & insuscep. $>>$ suscep.(1) \\
\hline continuará alta $(0)$ & continuará alta (0) \\
\hline insuscep. -> suscep.(1) & suscep. -> suscep.(1) \\
\hline & \\
\hline
\end{tabular}

Anexo C6-1. Aranha da família Thomisidae (Misumena vatia) predando Bombus terrestris. Fonte: http://www.summitpost.org/users/bazz/

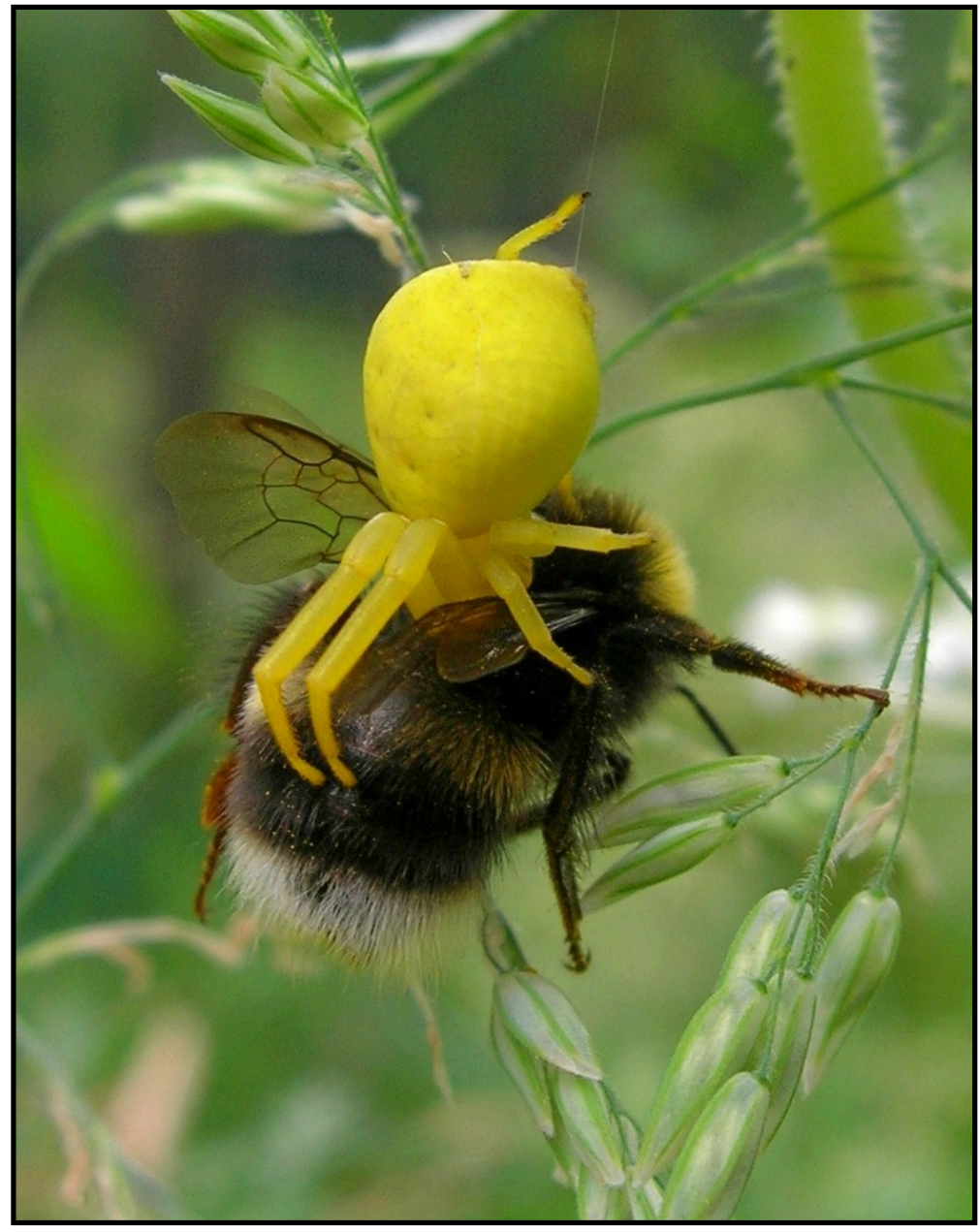



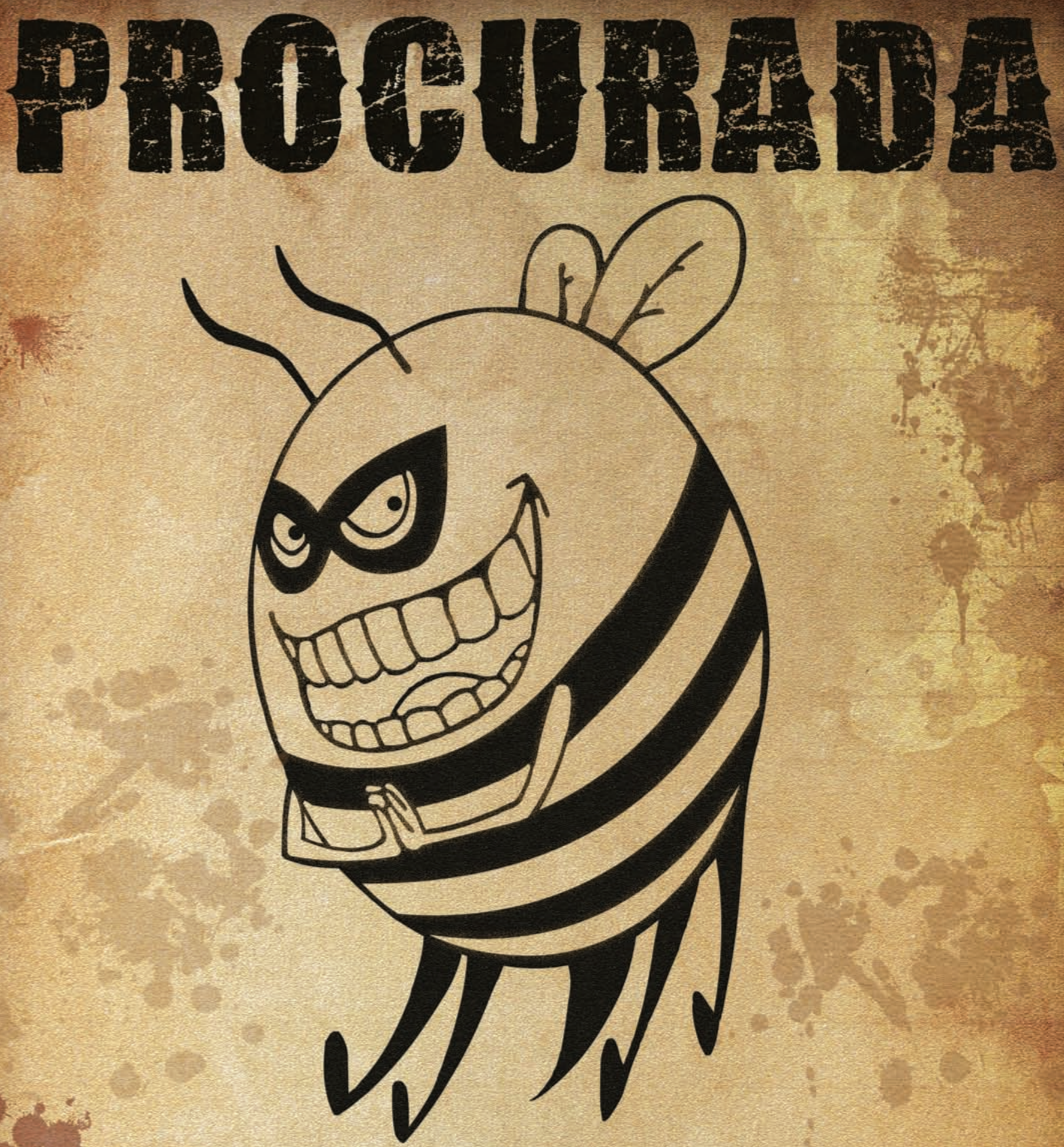

\section{ABELHA INVASORA}

\section{ABILHA IUROPIIA $\star P R O C U R A D A$ VIVA $\star$ BOMBOS TIRR RSTRIS}

Sahemos que esta ahelha europeia entrou na Imérica do Sul pelo Chile, invadinilo este pais. Os íltimos relatos indicam que tamhém invadiu a Irg̣entina e segue em direc,ão ao Urựuai, país que já poile ter sillo invadililo por ela, mas ainla não encontramos informacỏes seguras. Eviilências surgerem que ela poilerá chenar ao Brasil em hreve, mas nós já estamos preparailos! I invasao no Brasil polerá acontecer no Rio Granile do Sul, cruzanilo a tronteira Uruguaia. Se avistá-la, não a mate, nẫo a capture, apenas tire totos e nos envie com sua localização. WWW.ahelhaprocuraila.com.hr - ahelhaprocuraila 0 gmail.com 


\section{Pesquisadores descobriram mais uma espécie invasora na América do Sul: uma abelha.}

Tudo começou quando colônias foram importadas da Europa para o Chile durante a década de 70 para polinização de tomateiros cultivados dentro de estufas, mas as abelhas escaparam do confinamento das estudas e começaram a invadir ambientes naturais naquele país.

A invasão é tão veloz que em 2006 esta abelha já tinha chegado na Argentina, depois de ocupar vastas áreas no Chile. Hoje, sabemos que a espécie expande rapidamente sua invasão sobre o território argentino, inclusive seguindo em direção ao Uruguai.

Existem suspeitas não confirmadas de que ela já chegou ao Uruguai e vem em direção ao Brasil. Nossa preocupação está em detectá-la tão logo chegar ao nosso país. Análises indicam que ela poderá entrar através de cidades do sudeste do Rio Grande do Sul.

O nome científico desta abelha é Bombus terrestris, mas popularmente é conhecida como Mamangava da Cauda Branca. Este nome decorre da sua cauda bastante clara destacandose do restante de seu corpo, que é todo listrado com tons alaranjados e preto.

Abelhas invasoras podem representar riscos ambientais, tanto para a agricultura, trazendo doenças e prejudicando a polinização, quanto para as espécies nativas. Mas não podemos afirmar que danos ocorrerão no Brasil quando ela invadir, por isso precisamos estudá-la VIVA, interagindo com outras abelhas e com as plantas nativas e agrícolas.

Precisamos de sua colaboração apenas para fotografá-la pousada e nos enviar com a localização do avistamento, portanto, a abelha NÃO deve ser capturada ou morta. Quando a abelha procurada for encontrada, os pesquisadores poderão ir até ela para estudá-la.

Acesse a página da internet para mais detalhes sobre a abelha, sobre a invasão e as formas de nos avisar quando avistá-la; ainda, poderá verificar se sua cidade está na rota da invasão. Sua participação é essencial para encontrarmos e estudarmos esta abelha tão logo ela entrar no Brasil, assim poderemos avaliar as repercussões para nossa agricultura e biodiversidade.

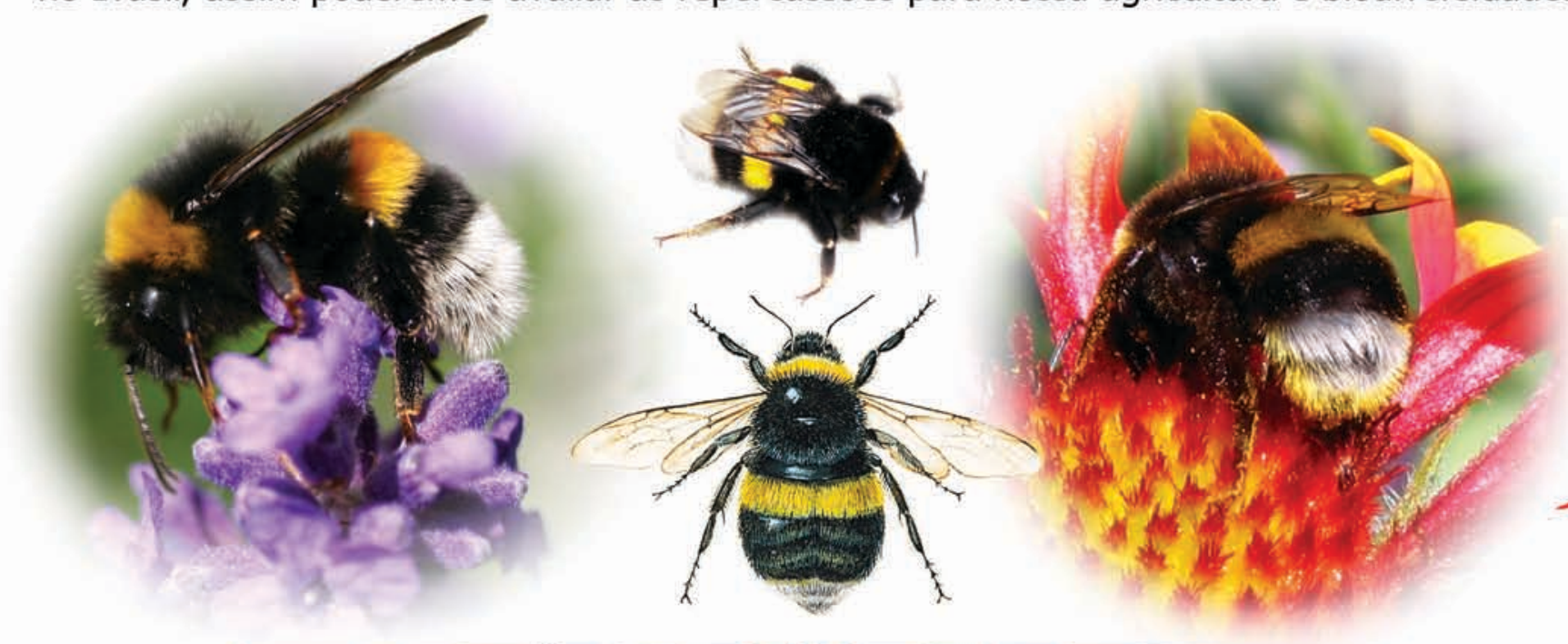

ww w.abelhaprocurada.com.br

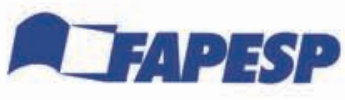

๒EMATER/RS
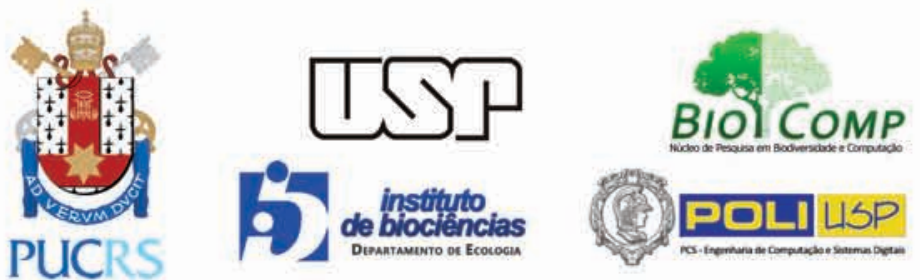
Publicações Relevantes

As publicações elencadas foram desenvolvidas durante o doutoramento do autor desta Tese e com a sua participação. Embora estes trabalhos não abordem o caso da Bombus terrestris, abordam os métodos analíticos aplicados nesta pesquisa, e podem contribuir com informações complementares.

GIANNINI, T. C. ; TAMBOSI, L.R. ; ACOSTA, A.L. ; JAFFÉ, R. ; SARAIVA, A.M. ; IMPERATRIZ-FONSECA, V.L. ; METZGER, J.P. (em publicação) Safeguarding ecosystem services: A methodological framework to buffer the joint effect of habitat configuration and climate change. Plos One 10(6): e0129225, 2015.

SANTOS, C. F. ; ACOSTA, A. L. ; NUNES-SILVA, P. ; SARAIVA, A. M. ; BLOCHTEIN, B. Climate Warming May Threaten Reproductive Diapause of a Highly Eusocial Bee. Environmental Entomology, v. 44, p. 1-10, 2015.

VERSIEUX, L. M. ; ACOSTA, A. L. ; JORDAO, A. L. ; ZIDKO, A. ; MAIA, U. M. Floral biology, morphology and ecological niche modelling of Caraipa grandifolia (Calophyllaceae), an important Amazonian floodplain tree. Boletim do Museu Paraense Emílio Goeldi. Ciências Naturais, v. 9, p. 621-638, 2014.

GIANNINI, T. C. ; PINTO, C. E. ; ACOSTA, A. L. ; TANIGUCHI, M. ; SARAIVA, A. M. ; ALVES DOS SANTOS I. Interactions at large spatial scale: The case of Centris bees and floral oil producing plants in South America. Ecological Modelling, v. 258, p. 74-81, 2013.

GIANNINI, T. C. ; ACOSTA, A. L. ; SILVA, C. I ; OLIVEIRA, P.E.A.M. ; IMPERATRIZFONSECA, V. L. ; SARAIVA, A. M. Identifying the areas to preserve passion fruit pollination service in Brazilian Tropical Savannas under climate change. Agriculture, Ecosystems \& Environment, v. 171, p. 39-46, 2013.

GIANNINI, T. C. ; SIQUEIRA, M. F. ; ACOSTA, A. L. ; BARRETO, F. C. C. ; SARAIVA, A. M. ; ALVES DOS SANTOS I. Desafios atuais da modelagem preditiva de distribuição de espécies. Rodriguésia (Online), v. 63, p. 733-749, 2012.

GIANNINI, T. C. ; ACOSTA, A. L. ; GARÓFALO, C. A. ; SARAIVA, A. M. ; ALVES DOS SANTOS I. ; IMPERATRIZ-FONSECA, V. L. Pollination services at risk: bee habitats will decrease owing to climate change in Brazil. Ecological Modelling, v. 244, p. 127-131, 2012.

GIANNINI, T.C.; GARIBALDI, L.A.; ACOSTA, A.L.; SILVA, J.S.; MAIA, K.P.; SARAIVA, A.M.; GUIMARÃES JR., P.R.; KLEINERT, A.M.P. (em publicação) Native and non-native supergeneralist bee species have different impacts on plant-bee networks. Plos One. (Submetido)

JAFFÉ, R; POPE, N; GIANNINI, T.C.; ACOSTA, A.L.; ALVES, D.A.; ARIAS, M.C.; FRANCISCO, F.O.; GONZALEZ, A.; IMPERATRIZ-FONSECA, V.L.; JHA, S.; DE LA RÚA, P.; TAVARES, M.G.; CARVALHEIRO, L.G. Gene flow in stingless bees is determined by geographic distance and beekeeping practices. (Em preparação) 